\title{
Long-term activity of shear zones in the Dom Feliciano Belt and associated terranes (South America)
}

\author{
Dissertation \\ zur Erlangung des mathemathisch-naturwissenschaftlichen Doktorgrades \\ „Doctor rerum naturalium“ \\ der Georg-August-Universität Göttingen \\ im Promotionsprogramm Geowissenschaften \\ der Georg-August University School of Science (GAUSS) \\ vorgelegt von \\ Mathias Hueck \\ aus São Paulo, Brasilien
}

Göttingen 2018 


\section{Betreuungsausschuss}

Prof. Dr. Siegfried Siegesmund

Abteilung Strukturgeologie und Geodynamik

Geowissenschaftliches Zentrum der Georg-August-Universität Göttingen

Prof. Dr. Miguel Angelo Stipp Basei

Centro de Pesquisas Geocronológicas

Instituto de Geociências da Universidade de São Paulo

\section{Mitglieder der Prüfungskommission}

\section{$\underline{\text { Referent }}$}

Prof. Dr. Siegfried Siegesmund

Abteilung Strukturgeologie und Geodynamik

Geowissenschaftliches Zentrum der Georg-August-Universität Göttingen

\section{Korreferent}

Prof. Dr. Miguel Angelo Stipp Basei

Centro de Pesquisas Geocronológicas

Instituto de Geociências da Universidade de São Paulo

Weitere Mitglieder der Prüfungskommission

Prof. Dr. Pedro Oyhantçabal

Departamento de Geología

Facultad de Ciencias, Universidad de la República

Prof. Dr. Bernd Lammerer

Fakultät für Geowissenschaften

Ludwig-Maximilians-Universität München

Dr. Klaus Wemmer

Abteilung Isotopengeologie

Geowissenschaftliches Zentrum der Georg-August-Universität Göttingen

Dr. Florian Heidelbach

Bayerisches Geoinstitut

Universität Bayreuth

Tag der mündlichen Prüfung: 23.07.2018 


\section{ACKNOWLEDGEMENTS}

It is impossible to get a PhD without (a lot of) help. During the last years I was lucky to work with amazing people, and ended up making new friends.

I would like to thank my advisors, Siegfried Siegesmund and Miguel Basei, for the opportunity of coming to Germany, for the trust they put on me, for the patient orientation and for the generosity on helping advance my career.

On a personal note, I am very grateful for Siggi's effort for a smooth landing on my arrival in Göttingen, and for being so welcoming, together with Brigitte, on many barbecue evenings. Thank you also for the fantastic geology in various field excursions, and for the general knowledge on Bratwurst, Riesling terroir and curious parts of the German culture.

Many thanks go to Miguel for the tranquility and reassurance, for the productive geological discussions and for the hospitality in Barra Velha. Thank you also for introducing me to the world of research, for presenting me to the Dom Feliciano Belt and for the many good times over the last ten years. I would also like to thank Ivani for the patience and technical help during communication.

I'm very thankful to Klaus Wemmer for joining the field works and for the shared knowledge and discussions on K-Ar dating and illite analysis. Thank you also for the constant help and clever solutions in the lab, and for the excellent company.

To István Dunkl, thank you for the generous and patient orientation on (U-Th)/He analysis, thermochronology and thermal modelling. I would also like to thank Judit for the big help in the pickpack and He measurements, and both for the hospitality in the department and at their home.

I am extremely grateful to the constant help and encouragement from Sebastián Oriolo during the entire work, contributing from the field to the lab to many, many discussions, not to mention shared beers and laughs.

I would like to thank Pedro Oyhantçabal for the advice in the field, for the constructive suggestions and for the big help during the short stay in Uruguay.

Ruy Paulo Philipp generously shared his knowledge and was an excellent guide to the geology of Rio Grande do Sul. I am very grateful for the collaboration.

Florian Heidelbach is thankfully acknowledged for the quartz CPO analyses and helpful suggestions. 
Beatrix Heller offered great advice for the analyses of radiation damage and in the translation of the abstract. I am also very thankful for our globetrotting friendship during these years.

I am really grateful for the help and company of Caio Santos (Fofona), Vinícius Zacatei (Sinistro) and Jéssica Lima (Exu) during field campaigns in Brazil. Special thanks for Fofona for digging up references in São Paulo and for constant geological discussions. Thanks also to Leonardo Aguiar and Luana Florisbal for facilitating references, and to Pedro Rosa for lending his sledgehammers.

Claudia Passarelli is acknowledged for generously sharing thin sections from the Major Gercino Shear Zone. Thanks also to Andre Steenken, Manuela Morales and Thilo Hartung for providing additional samples. Keno Lünsdorf is acknowledged for help with Raman spectroscopy and spectra evaluation with IFORS. Max Schanofski is thanked for the illite analyses of samples from the Sierra Ballena Shear Zone, and Anna Schönberg for help with the evaluation of XRD results for illite polytypes. Thank you also to both of them and to Sandra Balmer for help with sample preparation for illite. Brigitte Dietrich and Sabrina Metje are acknowledged for the support during K-Ar analyses, Harald Tonn, Maxim Bogdanowitsch and Falko Malis for the assistance in the confection of thin sections, and Kerstin Techmer for the help with sample preparation for EBSD. I would also like to thank Vasco, Samuca, Gabriel and Solange for the great support during sample preparation in São Paulo.

Thanks to all members of the Department of Structural Geology and Geodynamics for the inspiring discussions, and to Marie-France Hesse for the administrative support. Thanks also to my PhD "brothers" and to the TecLab group for the good times: Amanda Menezes, Christopher Pötzl, Johanna Menningen, Wanja Wedekind, Sofia Pascual, Maxim Bogdanowitsch, Malte Teipel, Falko Malis, Enrico Sassoni and Orsolya Farkas. Special thanks for the many shared lunches and company to Jan Peter Duda, Elco Luijendijk and Filiz Afsar. Outside of the university, I would like to thank all of the friends I made in Göttingen, with whom I shared laughs, food, drinks, and many, many dances. Thank you also to my friends from Brazil, who were always there for me and are always missed.

The same is true for my family, who offered constant support from afar and great happiness when near.

Finally, I cannot imagine being here were it not for the endless encouragement, love and patience of my wife Carolina. Thank you so much for sharing your life with me.

This PhD research was supported by the CNPq, in partnership with CAPES and DAAD, with a long-term scholarship through the Ciências sem Fronteiras Programm. 


\section{$\underline{\text { ABSTRACT }}$}

The Dom Feliciano Belt in southern Brazil and Uruguay records the superposed tectonic events that led to the assembly of southwestern Gondwana during the Neoproterozoic Brasiliano-Pan-African orogenic cycle. During the course of the orogeny, the belt and associated Precambrian domains were affected by widespread crustal deformation, leading to a complex set of shear zones. This thesis investigates the tectono-thermal history of the main shear zones in the Dom Feliciano Belt and associated terranes. Deformation conditions and the evolution of the shear zones are characterized using structural and microstructural observations, combined with quartz CPO textural analyses. New K-Ar data and a review of the literature are used to constrain this evolution in the geochronological timescale. In addition, the Phanerozoic thermal history of the study area is investigated combining (U-Th)/He analyses on zircon and apatite, thermal modelling, and K-Ar dating of fault gouges. In this way, it is possible to examine the impact of the main Neoproterozoic structures as preferential sites for reactivation.

The oldest terrane boundary in the region is the Ibare Shear Zone, which records the accretion of the Tonian juvenile São Gabriel Terrane to the Archean-Paleoproterozoic Nico Pérez Terrane as a dextral lateral ramp during SW-verging thrusting. New-K-Ar analyses suggest that it was established at $c a .760$ to $740 \mathrm{Ma}$, and reactivated in the Cryogenian-Ediacaran in narrow sinistral shear zones at cooler conditions, during the formation of the Dom Feliciano Belt. The belt was formed during oblique collision between the Congo and Río de la Plata cratons, together with the Nico Pérez and Luís Alves Terranes, resulting in widespread transpression. This process was probably diachronic, with onset of transcurrent structures being recorded between ca. 650 and $620 \mathrm{Ma}$ in different sectors of the belt, and led to the formation of its main terrane boundary, the Major Gercino-Dorsal do Canguçu-Sierra Ballena lineament. This shear zone system records an intense amount of pure shear and contrasting kinematics along its extension, suggesting local variations to the main horizontal compression and partitioning into different transcurrent vectors. After $600 \mathrm{Ma}$ there is a decrease in wide-scale regional compression, transitioning to localized strike-slip deformation along the main shear zones, suggesting a post-collisional stage. Late ductile reactivations were active until ca. 540-530 Ma.

With the cessation of the orogenic processes, the study area stabilized and achieved an intracratonic position inside Gondwana, experiencing a protracted evolution during the Phanerozoic. Exhumation during the early Paleozoic probably exposed much of the present-day crystalline basement to nearsurface conditions, and was followed by regional subsidence during the sedimentation of the Paraná Basin. For most of the belt's extension, final exhumation was achieved at the latest during the rift stage 
of the South Atlantic in the Lower Cretaceous, but its northernmost portion records up to $2 \mathrm{~km}$ of postrift exhumation. While recurrent brittle reactivation of Neoproterozoic structures is recorded by the dating of fault gouges, this process is not reflected in the study area's thermal history. Instead, the main structural control is by transecting fault systems, oriented perpendicular to the South Atlantic coastline. Along the south-southeastern South American passive margin, major reactivation of the inherited structures is predominantly recorded in strongly uplifted regions. 


\section{ZUSAMMENFASSUNG}

Im Dom Feliciano Gürtel in Südbrasilien und Uruguay sind die Spuren der überlappenden tektonische Ereignisse erhalten, die zur Bildung Südwest-Gondwanas während des neoproterozoischen BrasilianoPan-Afrikanischen orogenetischen Zyklus führten. Im Laufe der Orogenese wurden der Gürtel und die angrenzenden präkambrischen Domänen durch weit verbreitete Krustendeformation überprägt, was zur Bildung eines komplexen Netzes von Scherzonen führte. In dieser Dissertation wird die tektonothermische Geschichte der Haupt-Scherzonen im Dom Feliciano Gürtel und den umliegende Krustenblöcken untersucht. Makro- und mikrostrukturelle Beobachtungen werden mit Gefügeanalysen kombiniert, um Verformungsbedingungen und die strukturelle Entwicklung der Scherzonen zu erläutern. Neue K-Ar Alter werden mit Literaturdaten verglichen, um diese Evolution in den geochronologischen Kontext zu setzen. Des Weiteren wird die phanerozoische thermische Entwicklung des Studiengebietes anhand von (U-Th)/He Analysen von Zirkon und Apatit, thermischer Modellierung und K-Ar Datierung von Störungsletten untersucht. Auf diese Weise wird der Einfluss der neoproterozoischen Hauptstrukturen als bevorzugte Reaktivierungsstellen erforscht.

Die älteste Terrangrenze im Gebiet ist die Ibaré-Scherzone, die während der Akkretion des im Tonium entstandene juvenilen São Gabriel Terran mit dem archaisch-paläoproterozischen Nico Pérez Terran bei SW gerichteter Überschiebung als dextrale seitliche Rampe fungierte. Neue K-Ar Alter deuten an, dass die Scherzone sich schon um ca. 760 bis 740 Ma bildete und später im Cryogenium-Ediacarum in schmalen sinistralen Scherzonen bei der Bildung des Dom Feliciano Gürtels reaktiviert wurde. Der Gürtel entstand durch schräge Kollision zwischen Congo und Río de la Plata Kraton, zusammen mit den Nico Pérez und Luís Alves Terranen, welches zur weitverbreiteten Transpression führte. Diese Entwicklung war wahrscheinlich diachron, mit erstmaligen auftritt Blattverschiebung in unterschiedlichen Bereichen des Gürtels zwischen ca. 650 und 620 Ma, und führte zur Bildung von dessen Hauptstruktur, dem Major Gercino-Dorsal do Canguçu-Sierra Ballena Lineament. Dieses Scherzonensystem hat einen großen Anteil reine Scherung und zum Teil gegensätzliche Kinematik, was auf lokale Variationen der horizontalen Hauptkompressionsrichtung und Aufteilung in unterschiedliche Seitenverschiebungsrichtungen hindeutet. Ab ca. $600 \mathrm{Ma}$ nahm die regionale Kompression ab und verlagerte sich auf seitliche Verschiebungen entlang der Haupt-Scherzonen, was auf ein post-kollisionales Setting hindeutet. Späte duktile Reaktivierungen waren bis ca. 540-530 Ma aktiv.

Mit dem Niedergang des orogenetischen Prozesses stabilisierte sich das Studiengebiet und erreichte eine intrakratonische Position innerhalb Gondwanas, wo es im Laufe des Phanerozoikums eine langwierige 
geologische Entwicklung erlebte. Exhumierung im frühen Paläozoikum brachte viel des heutigen Basements in Oberflächennähe. Daraufhin folgte regionale Absenkung im Zuge der Sedimentation des Paraná-Beckens. In den meisten Bereichen des Gürtels wurde die finale Exhumierung spätestens während der Öffnung des Südatlantiks in der Unterkreide erreicht. Lediglich im nördlichsten Bereich des Gürtels gab es bis zu 2 km post-rift Exhumierung. Obwohl die Datierung von Störungsletten wiederholte spröde Reaktivierungen der Neoproterozoischen Strukturen andeutet, spiegelt die thermischen Geschichte des Gebietes diesen Prozess nicht wider. Stattdessen waren querstreichende Störungssyteme, senkrecht zur atlantischen Küste, die strukturelle Hauptkontrolle. Entlang des südsüdostlichen passiven Kontinentalrandes Südamerikas ist die starke Reaktivierung der Neoproterozoischen Strukturen nur in stark gehobenen Gegenden zu erkennen. 


\section{TABLE OF CONTENTS}

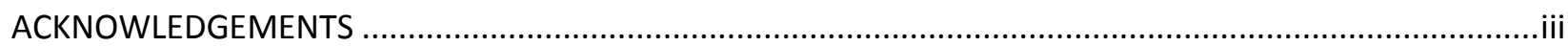

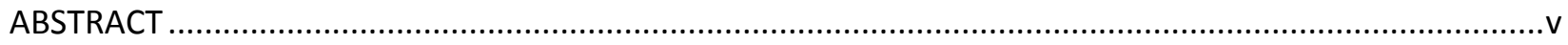

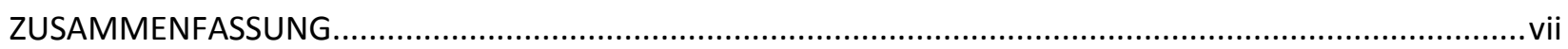

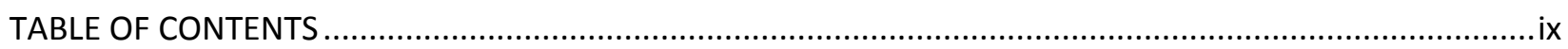

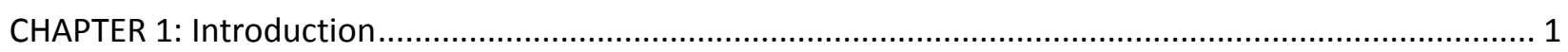

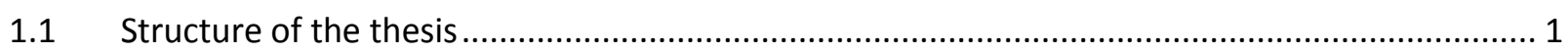

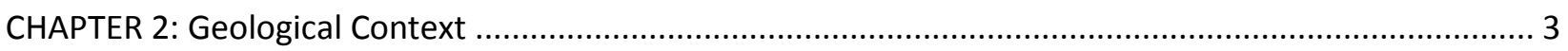

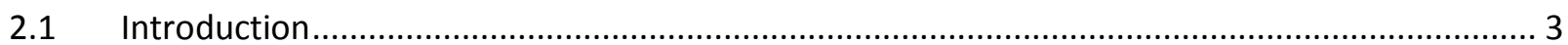

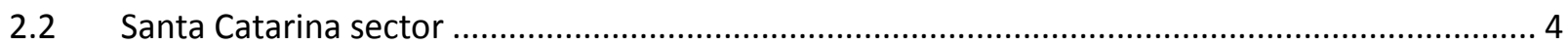

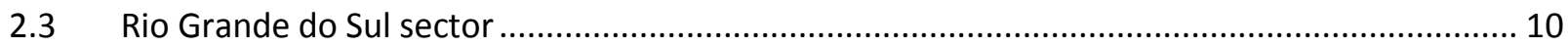

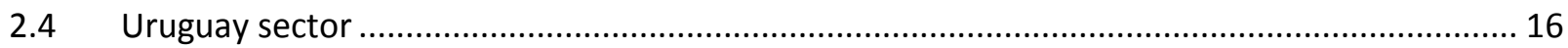

2.4.1 Structural characterization of the Uruguayan Shield and main shear zones ..................... 21

$2.5 \quad$ Phanerozoic evolution of the southern South American Platform ........................................ 23

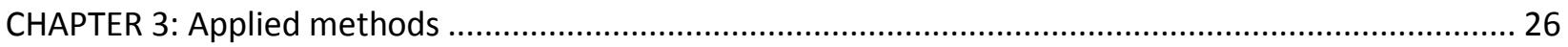

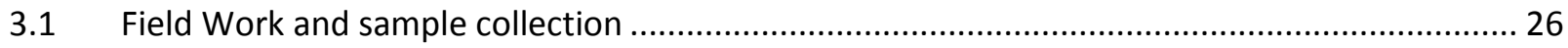

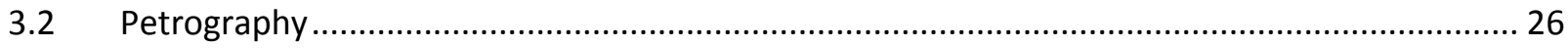

3.3 Quartz crystallographic preferred orientation analyses ..................................................... 26

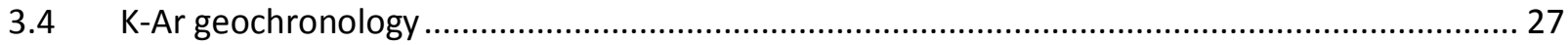

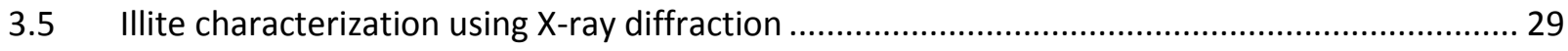

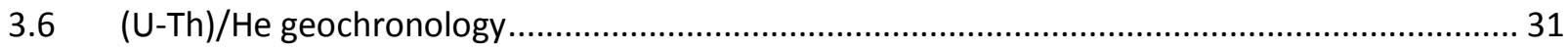

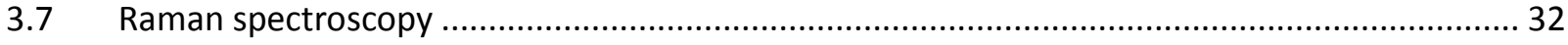

CHAPTER 4: Evolution of Neoproterozoic shear zones in the Sul-rio-grandense Shield........................... 34

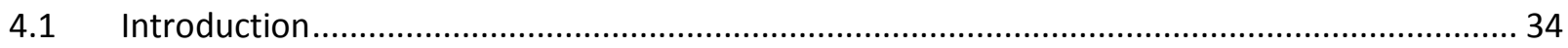

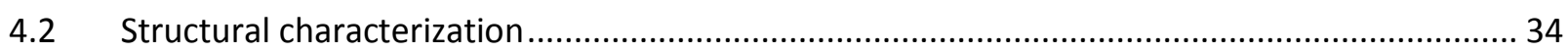

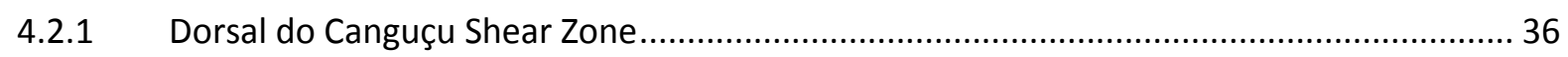

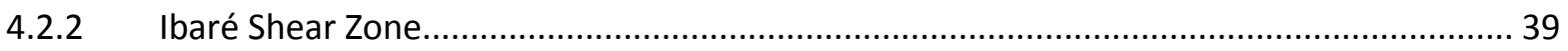

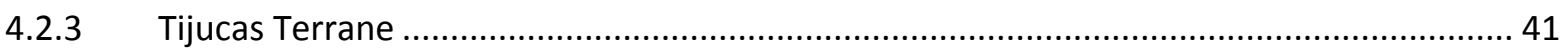

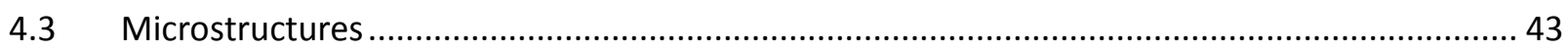

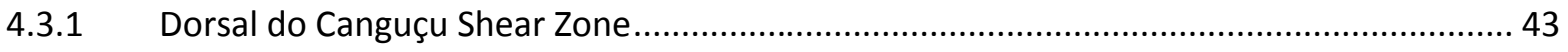

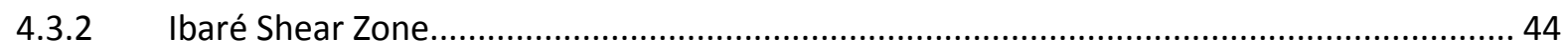

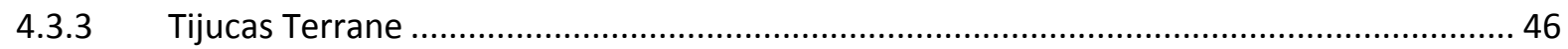

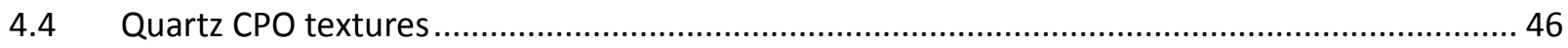

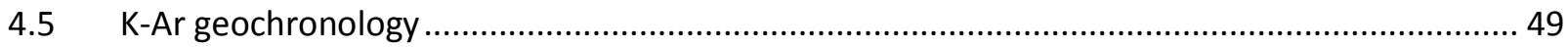

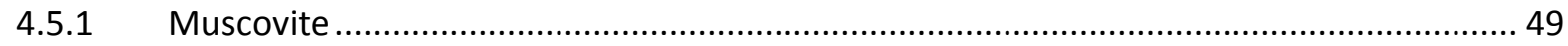




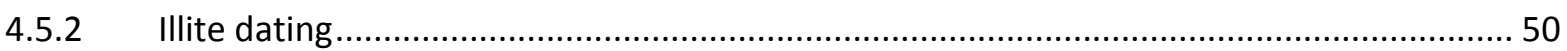

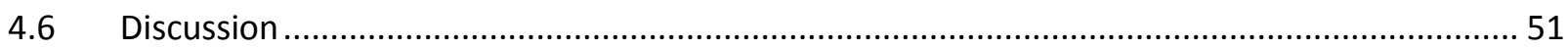

4.6.1 The Ibaré Shear Zone and accretion of the São Gabriel Terrane ...................................... 51

4.6.2 Deformation history and geochronological constraints of shear zones in the Dom Feliciano Belt 54

4.6.3 Evolution of the Dom Feliciano Belt in Rio Grande do Sul .............................................. 58

4.7 Conclusions

CHAPTER 5: Evolution of the Major Gercino Shear Zone .................................................................. 61

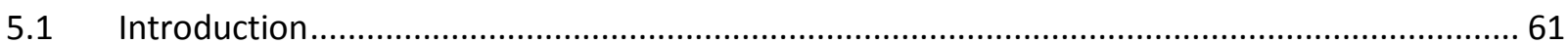

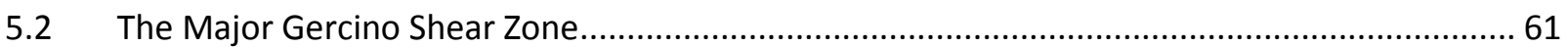

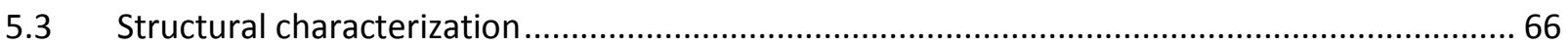

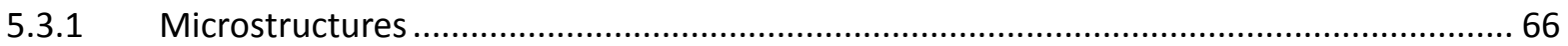

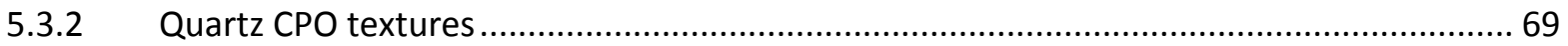

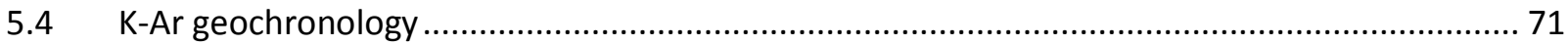

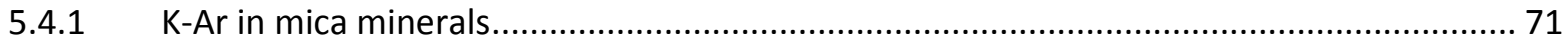

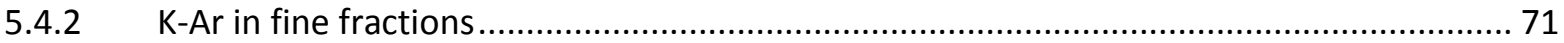

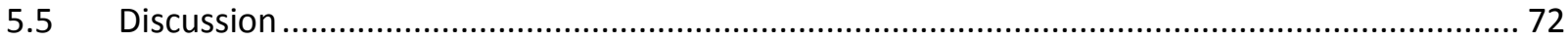

5.5.1 Deformation of the Major Gercino Shear Zone .......................................................... 73

5.5.2 Geochronological constraints and the evolution of the Major Gercino Shear Zone and the

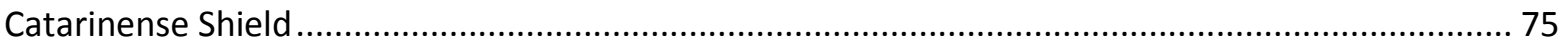

5.5.3 Illite ages and the Phanerozoic history of the Major Gercino......................................... 75

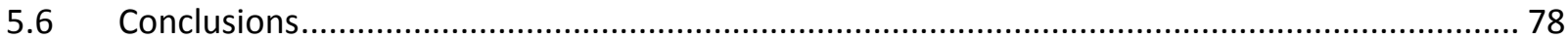

CHAPTER 6: Phanerozoic low-temperature evolution of the Uruguayan Shield ..................................... 82

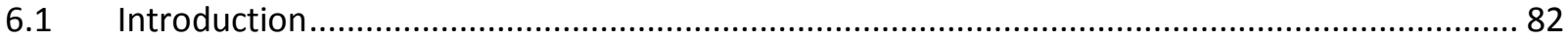

6.2 Geomorphological aspects of the Uruguayan Shield .......................................................... 84

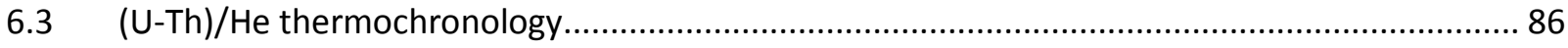

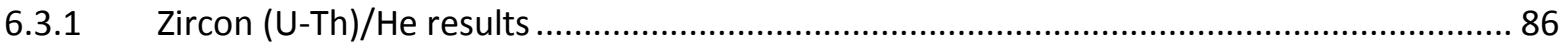

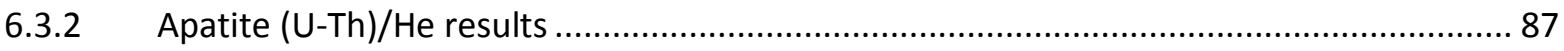

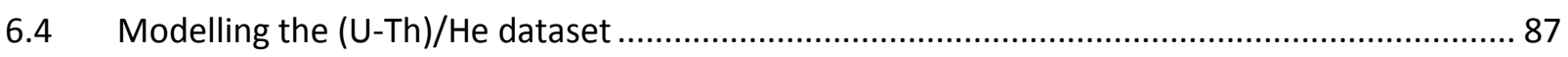

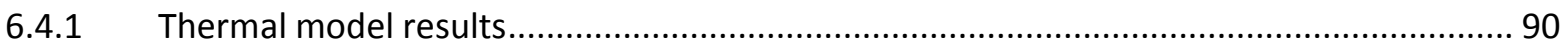

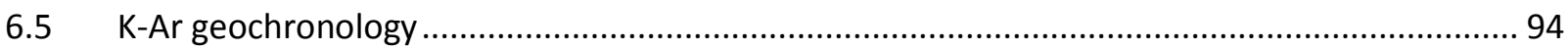

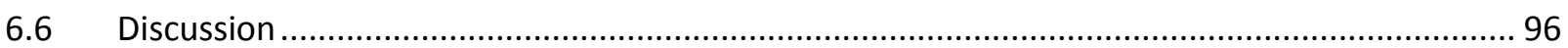

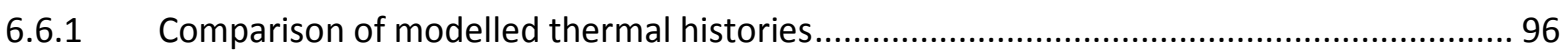

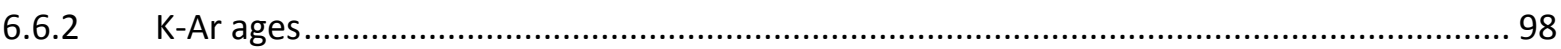

6.6.3 Low-temperature evolution of the Uruguayan Shield .................................................. 99

6.6.4 Influence and reactivation of Brasiliano structures during the Phanerozoic.................... 105 


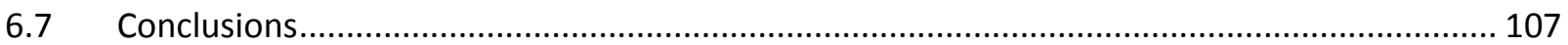

CHAPTER 7: Phanerozoic low-temperature evolution of the Sul-rio-grandense Shield .......................... 110

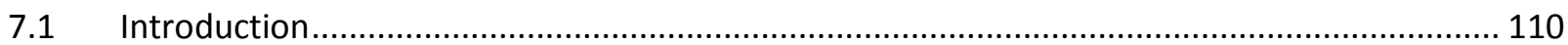

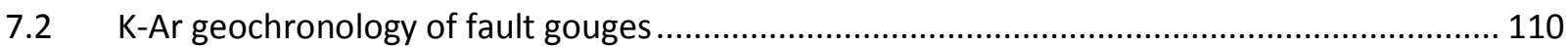

7.3 Apatite and Zircon (U-Th)/He thermochronology ............................................................. 115

7.3.1 Zircon (U-Th)/He results and initial interpretation ......................................................... 115

7.3.2 Apatite (U-Th)/He results and initial interpretation....................................................... 117

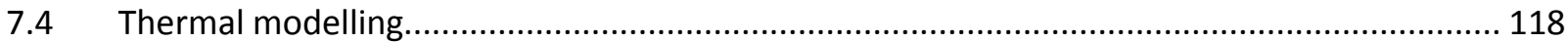

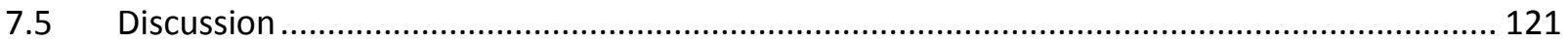

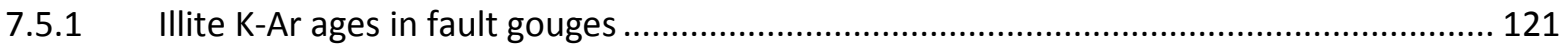

7.5.2 (U-Th)/He thermochronology and the thermal history of the Sul-rio-grandense Shield.. 123

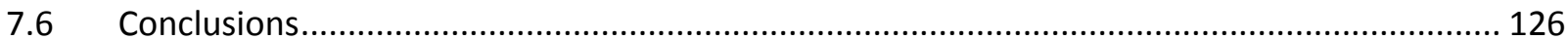

CHAPTER 8: Phanerozoic low-temperature evolution of the Catarinense Shield.................................. 128

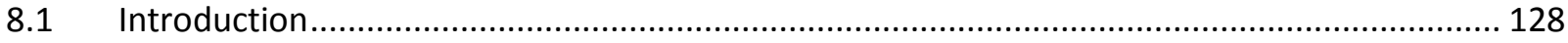

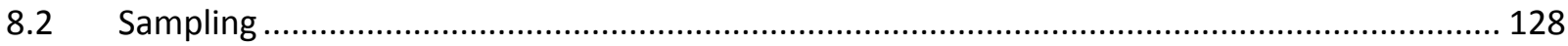

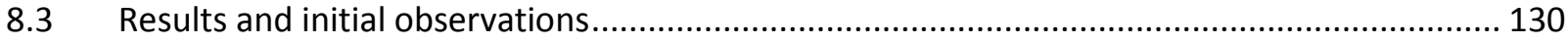

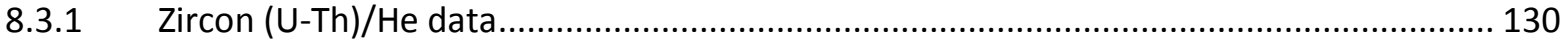

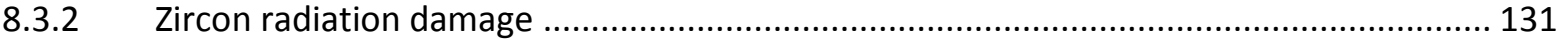

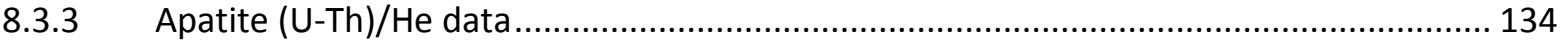

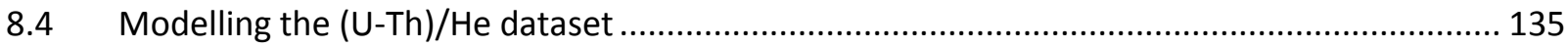

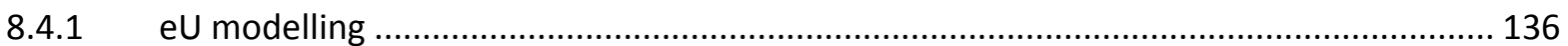

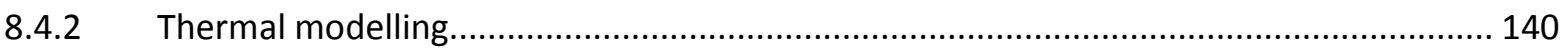

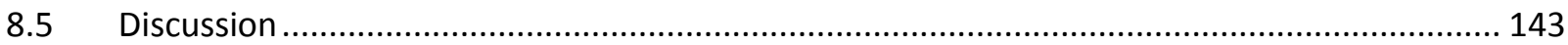

8.5.1 Thermochronological control of the zircon and apatite He ages ................................... 143

8.5.2 Phanerozoic evolution of the Catarinense Shield ............................................................ 144

8.5.3 Comparing zircon radiation damage ages and the ZHe ages ......................................... 146

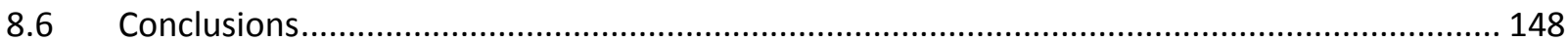

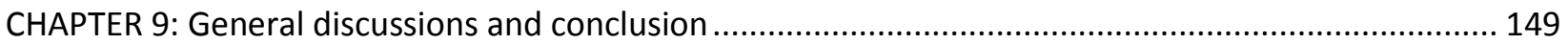

9.1 Shear zone activity and the evolution of the Dom Feliciano Belt ........................................ 149

9.1.1 Structural evolution of the main shear zones ............................................................... 149

9.1.2 Deformation history of the Dom Feliciano Belt ............................................................ 150

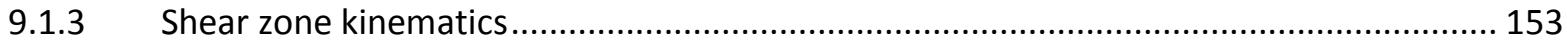

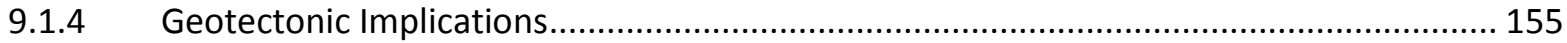

9.2 Phanerozoic evolution of the South Atlantic passive margin along the Dom Feliciano Belt .... 158

9.2.1 The effect of radiation damage in the (U-Th)/He dataset.............................................. 158

9.2.2 Phanerozoic evolution of the studied areas................................................................... 159 
9.2.3 Integrated exhumation history of the Dom Feliciano Belt .............................................. 162

9.2.4 Reactivation of Brasiliano structures in the Phanerozoic ................................................ 164

9.2.5 Structural controls on the exhumation of the South American passive margin ............... 166

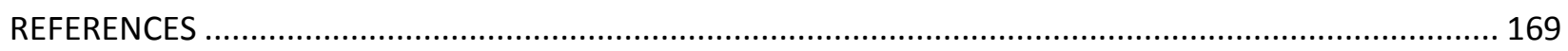

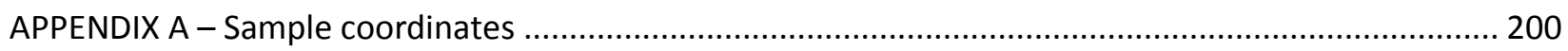

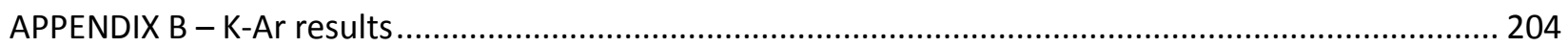

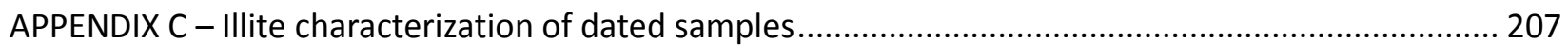

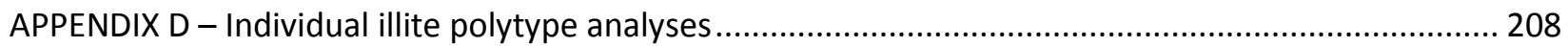

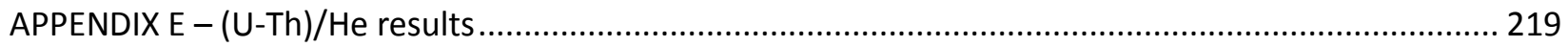

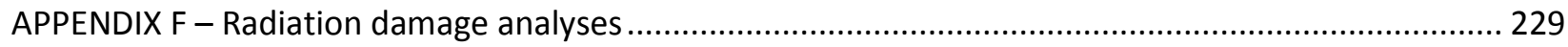




\section{CHAPTER 1: Introduction}

The crystalline basement in southern Brazil and Uruguay holds important magmatic, metamorphic, structural and geotectonic records of the superposed orogenic events that occurred during the late Neoproterozoic. Such records reflect the collage of distinct terranes that led to the assembly of the Gondwana supercontinent during the Brasiliano-Pan-African orogenic cycle.

The Dom Feliciano Belt is the main tectonic feature in the region, stretching for about $1,100 \mathrm{~km}$ with a maximum width of $c a .200 \mathrm{~km}$ along a NNE trend approximately parallel to the Atlantic coast, in association with other Precambrian terranes that acted as foreland during the orogenic cycle. It is crosscut by a complex set of shear zones, resulting from the juxtaposition of different continental sectors.

The aim of this thesis is to characterize the tectono-thermal history of the main shear zones in the Dom Feliciano Belt and adjacent Precambrian domains, in order to better understand the evolution of the major terranes that compose the region. In addition, it aims to evaluate the impact these structures had as preferential sites for brittle reactivation during the opening of the South Atlantic and the fragmentation of Gondwana.

\subsection{Structure of the thesis}

The different individual contributions that compose this thesis are divided into chapters. After this short introduction, Chapter 2 presents the geological context of the research, exposing the geology of the Dom Feliciano Belt and associated Precambrian domains with a review of the literature. It is based, on a shortened version, on two book chapters (Hueck et al. 2018a and Oriolo et al. 2018a) of a recently edited review on the Geology of Southwestern Gondwana (Siegesmund et al. 2018, Springer). Chapter 3, on the other hand, details the different methods used during the research.

The results obtained during this research are presented and discussed in Chapters 4 to 8 . They are organized according to the main methods used and to the geographical disposition of the Dom Feliciano Belt, which is exposed in three structural windows in the Brazilian states of Santa Catarina and Rio Grande do Sul, and in Uruguay. Chapters 4 and 5 are focused on the Neoproterozoic evolution of major shear zones in Rio Grande do Sul and Santa Catarina, respectively. In it, structural and microstructural observations are combined with quartz crystallographic preferred orientation (CPO) textural analyses in order to characterize the deformational conditions and structural evolution of the structures. In addition, new K-Ar geochronology and a review of the available geochronological data are used to reconstruct 
their evolution through time. Both chapters are structured as research papers intended for publication, with Chapter 5 already published (Hueck et al. 2018b, International Journal of Earth Sciences) and chapter 4 currently in preparation.

Chapters 6, 7 and 8, on the other hand, are concentrated in the Phanerozoic low-temperature evolution of the three basement expositions that comprise the Dom Feliciano Belt: Uruguay, Rio Grande do Sul and Santa Catarina, respectively. This is achieved by combining an extensive dataset of new (U-Th)/He analyses on zircon and apatite, modelling of this dataset, and K-Ar dating of fault gouges formed during brittle deformation. Once more, each chapter represents an individual manuscript, two of which have been published (Chapter 5, Hueck et al. 2017, Journal of the Geological Society of London and Chapter 8 , Hueck et al. 2018c, Tectonics), while the remaining one is intended for submission in the near future (Chapter 7).

Finally, Chapter 9 integrates the results and discussions from the previous chapters, addressing the main implications for the Neoproterozoic evolution of the Dom Feliciano Belt and an integrated model for the Phanerozoic exhumation history of the area. 


\section{CHAPTER 2: Geological Context}

\subsection{Introduction}

The Mantiqueira Province is the biggest mobile belt association in Brazil, extending for over 3,000 km with a NE-SW direction parallel to its southern and eastern coast and into Uruguay (Almeida et al. 1973, 1981). It was formed in the Neoproterozoic during the Brasiliano-Pan-African orogenic cycle, and was one of the most significant orogenic systems during the assembly of southwestern Gondwana (Fig. 2.1). It is divided into three orogenic belts, from north to south: Araçuaí, Ribeira and Dom Feliciano (e.g.: Heilbron \& Machado 2003; Silva et al. 2005a; Basei et al. 2010). At the African side of the Atlantic, its counterparts are the West Congo, Kaoko, Damara and Saldania-Gariep belts (Porada 1989; Basei et al. 2005, 2008; Heilbron et al. 2008; Oyhantçabal et al. 2011a).

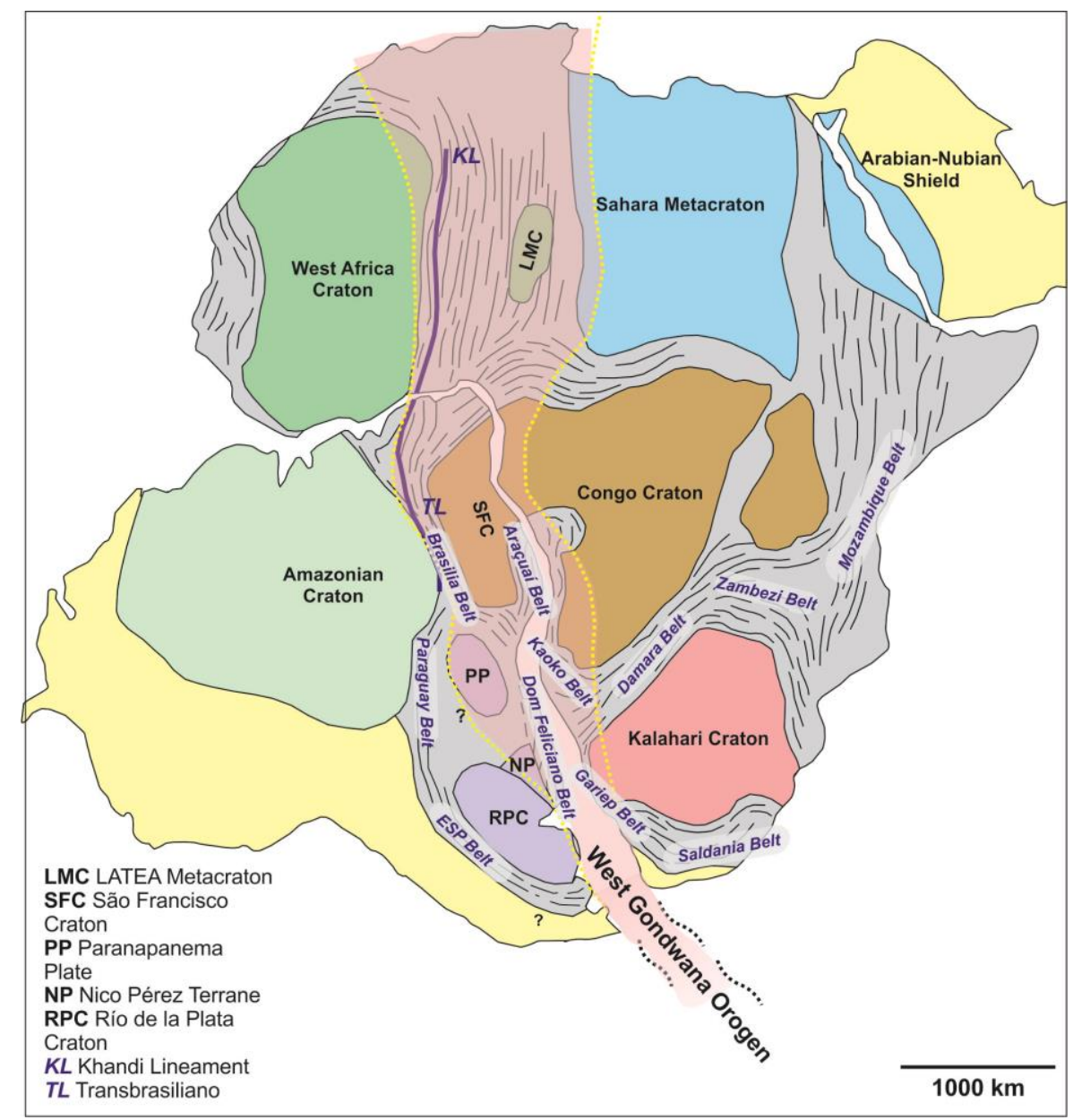

Figure 2.1: Position of the Dom Feliciano Belt in relation to the surrounding cratons and other orogenic belts in Gondwana. ESP Belt-Eastern Sierras Pampeanas Belt. Modified from Oriolo et al. (2017) 
In the southernmost portion of the Mantiqueira Province, the Dom Feliciano Belt (Fragoso César et al. 1980) extends for more than $1100 \mathrm{~km}$, striking NE-SW to NNE-SSW, roughly following the coastline and with a maximum width of $c a$. $200 \mathrm{~km}$ (Fig. 2.2). It is limited to the north by the cratonic Luís Alves Terrane, to the east by the shore of the South Atlantic Ocean and associated marine sediments, and to the south by the Río de la Plata estuary between Uruguay and Argentina. To the west, it is commonly covered by the Paleo- to Mesozoic sedimentary succession of the Paraná Basin, but locally it is in contact with foreland basement blocks such as the Nico Pérez Terrane. The belt is exposed in three structural windows, also known as shields, which are, from north to south, in the Brazilian states of Santa Catarina and Rio Grande do Sul, and in Uruguay. Each sector has its own particularities and has been the focus of recurrent research.

This chapter offers a short introduction to the geological context of the Dom Feliciano Belt, with a description of each sector and its main units. It is based on a careful review of the extensive bibliography accumulated in the last decades around the Dom Feliciano Belt. An exposition of the main shear zones and of the deformation history of the Uruguayan Shield is also presented. For the Rio Grande do Sul and Santa Catarina sectors, these aspects will be discussed in detail in Chapters 4 and 5, respectively, in light of the new findings of the thesis.

\subsection{Santa Catarina sector}

The northernmost occurrence of the Dom Feliciano Belt is exposed in the Brazilian state of Santa Catarina (Figs. 2.3 and 2.4). It constitutes a ca. $60 \mathrm{~km}$ wide corridor along the South Atlantic coastline, south of the city of Penha, covered to the west and to the south by Phanerozoic sediments of the Paraná Basin. The orogenic belt is limited, to the north, by the Luís Alves Terrane, a cratonic block that acted as a foreland during the Neoproterozoic orogenic event in this sector. In Santa Catarina, the architecture of the Dom Feliciano Belt is especially clear, and since its original recognition (Basei 1985) it has been extended to the remaining portions of the belt (Basei et al. 2000). It is divided into three domains: southeastern (internal), central and northwestern (external). Each domain has a characteristic lithological association and is separated from the bordering terrane by major shear zones.

The largest of the three domains in Santa Catarina is the southeastern, comprising a large granitic association, the Florianópolis Batholith. This unit is divided into distinct plutonic suites with geochemical signatures trending from early calc-alkaline to late alkaline magmatism (Bitencourt \& Nardi 2000; Silva et al. 2002a, 2005b, Florisbal et al. 2009). Metasedimentary rocks occur sporadically overlying the 
Florianópolis Batholith, grouped into the Queçaba Formation (Basei 1985; Zanini et al. 1997). They correspond to quartzites associated with mica schists, quartz schist and phyllites, tectonically juxtaposed with the granites.

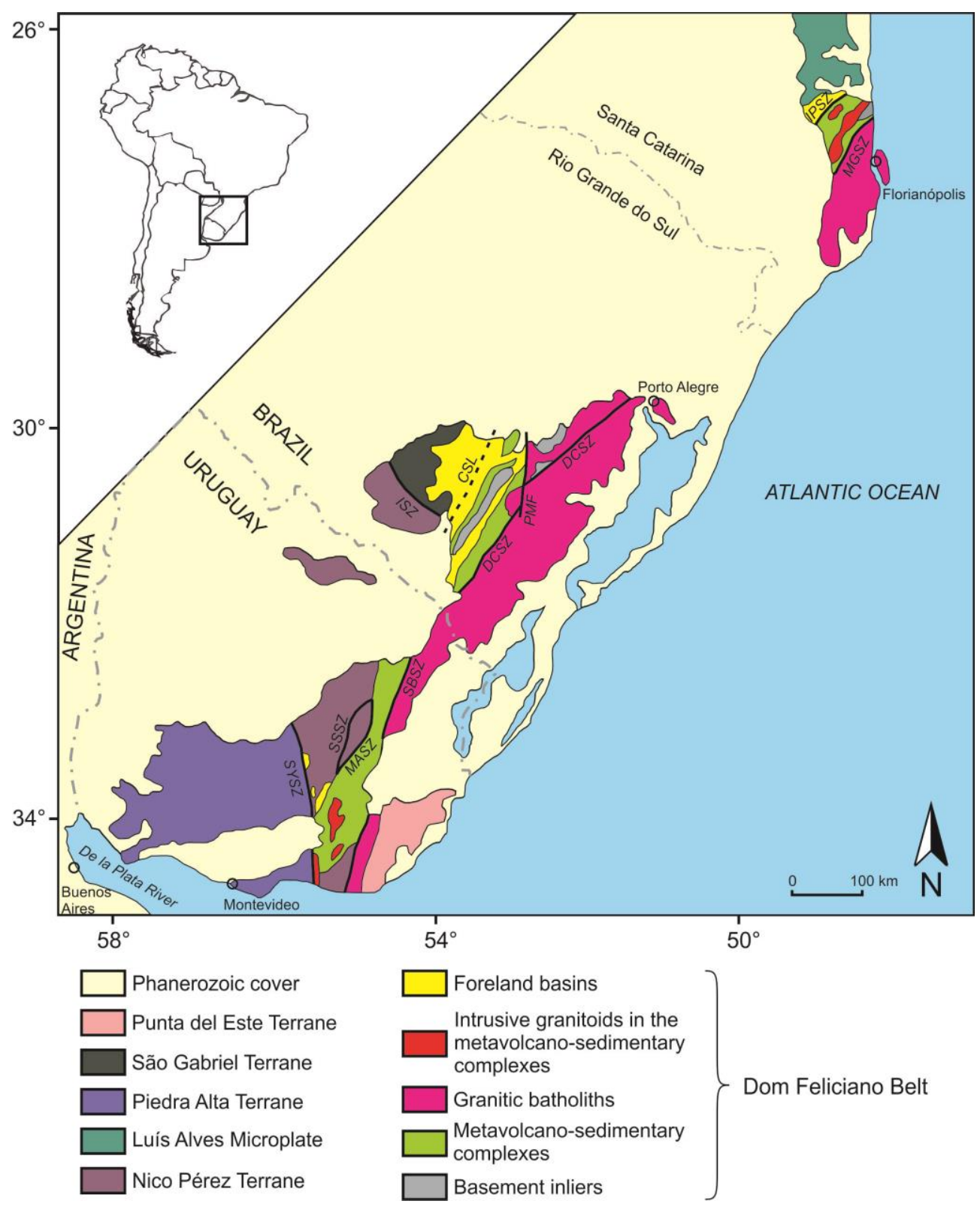

Figure 2.2: Tectonic map of the Dom Feliciano Belt and main structures (Modified from Basei et al. 2000; Hueck et al. 2016). IPSZ - Itajaí-Perimbó Shear Zone; MGSZ - Major Gercino Shear Zone; DCSZ - Dorsal do Canguçu Shear Zone; PMF - Passo do Marinheiro Shear Zone; CSSZ - Caçapava do Sul Lineament; ISZ - Ibaré Shear Zone; SBSZ Sierra Ballena Shear Zone; MASZ - Maria Albina Shear Zone; SSSZ - Sierra de Sosa Shear Zone; SYSZ - Sarandí del Yí Shear Zone 
The earliest association in the batholith is the Águas Mornas Suite (Basei et al. 2000, 2006), which includes widespread xenoliths and restites from the Paleoproterozoic basement protolith with ages between 2.20 and $1.75 \mathrm{Ga}$, and is associated with intense migmatitization (Basei et al. 2000; Silva et al. $2000,2002 a, 2005 b)$. Granites of this suite record the interaction of mantle-derived mafic magmas with abundant crustal contaminants (Bitencourt et al. 2008; Florisbal et al. 2009). Following this unit, calcalkaline granodiorites and monzogranites are grouped into the São Pedro de Alcântara Suite (Basei et al. $2000,2006)$. They mostly comprise gray to pink rocks which usually show a slight deformation. Finally, the Pedras Grandes Suite corresponds to the last stage of magmatism in the Florianópolis Batholith, and includes alkaline isotropic gray to pink/red leucocratic granites (Fig. 2.5a) (Basei et al. 2000, 2006). Volcanic rocks associated to this suite, sometimes divided into the Cambirela Suite (e.g., Zanini et al. 1997; Bitencourt et al. 2008), include rhyolitic flows and tuffs, besides numerous dykes. In addition, granites from the northern part of the batholith, associated with the Major Gercino Shear Zone, are commonly addressed separately from the rest of the batholith, owing to their close relationship to the development of this structure (Basei et al. 2000, 2006; Bitencourt \& Kruhl 2000; Passarelli et al. 2010; Florisbal et al. 2012a, b, c, Chapter 5). Nonetheless, the isotopic signature of these rocks is compatible to that of the remaining Florianópolis Batholith, instead of the bordering units of the central domain (Basei et al. 2000; Passarelli et al. 2010; Florisbal et al. 2012b, c; Hueck et al. 2016). Geochronological data of the granites from the Florianópolis Batholith constrain the magmatism mostly between 625 and $580 \mathrm{Ma}$, with early crustal anatexis dated at ca. 650 Ma (Silva et al. 2002a, 2003, 2005b; Passarelli et al. 2010; Chemale Jr. et al. 2012; Florisbal et al. 2012c).

The central domain of the Dom Feliciano Belt in Santa Catarina is a complex association of metamorphic rocks, crystalline basement and granitic intrusions. The main unit is the Brusque Group, a polyphasedeformed metavolcano-sedimentary sequence characterized by low-pressure regional metamorphism coupled with high-temperature contact metamorphism (Basei 1985; Silva 1991; Basei et al. 2000, 2008, 2011a; Philipp et al. 2004). It is divided into three formations, from the oldest to the youngest: Rio Oliveira, Botuverá and Rio da Areia (Basei et al. 2000, 2006, 2011a). The predominant metasedimentary units are mica-schists to phyllites, quartzites, metacarbonates and paraconglomerates, while metavolcanic rocks in the basal and top units include amphibolite, metaultramafites and turmanilites (Silva 1991; Basei et al. 2000, 2006, 2011a; Philipp et al. 2004; Campos \& Philipp 2007; Campos et al. 2012a; Garda et al. 2013). The main surface of the metavolcano-sedimentary sequence is a transposition foliation (S2), developed during thrusting accompanied by regional metamorphism (Philipp et al. 2004; Basei et al. 2011a). This was followed by the intrusion of numerous granitic bodies, 
associated with the thermal apex, and two more deformational events, D3 and D4 (Fig. 2.5b). Detrital zircon crystals in the metasediments have predominant ages of $2.0-2.2 \mathrm{Ga}$, with subordinated populations at 1.7-2.0 Ga and 1.1-1.5 Ga (Hartmann et al. 2003a; Basei et al. 2008, 2011a). The best estimate for the age of the regional metamorphism (syn-S2) of the Brusque Group is given by the interval between the crystallization of syn-depositional acid volcanism (ca. 640 Ma, Silva 1991; Silva et al. 2002b; Basei et al. 2011a) and the intrusion of basic rocks cutting the main foliation (ca. 620, Campos et al. 2012b).
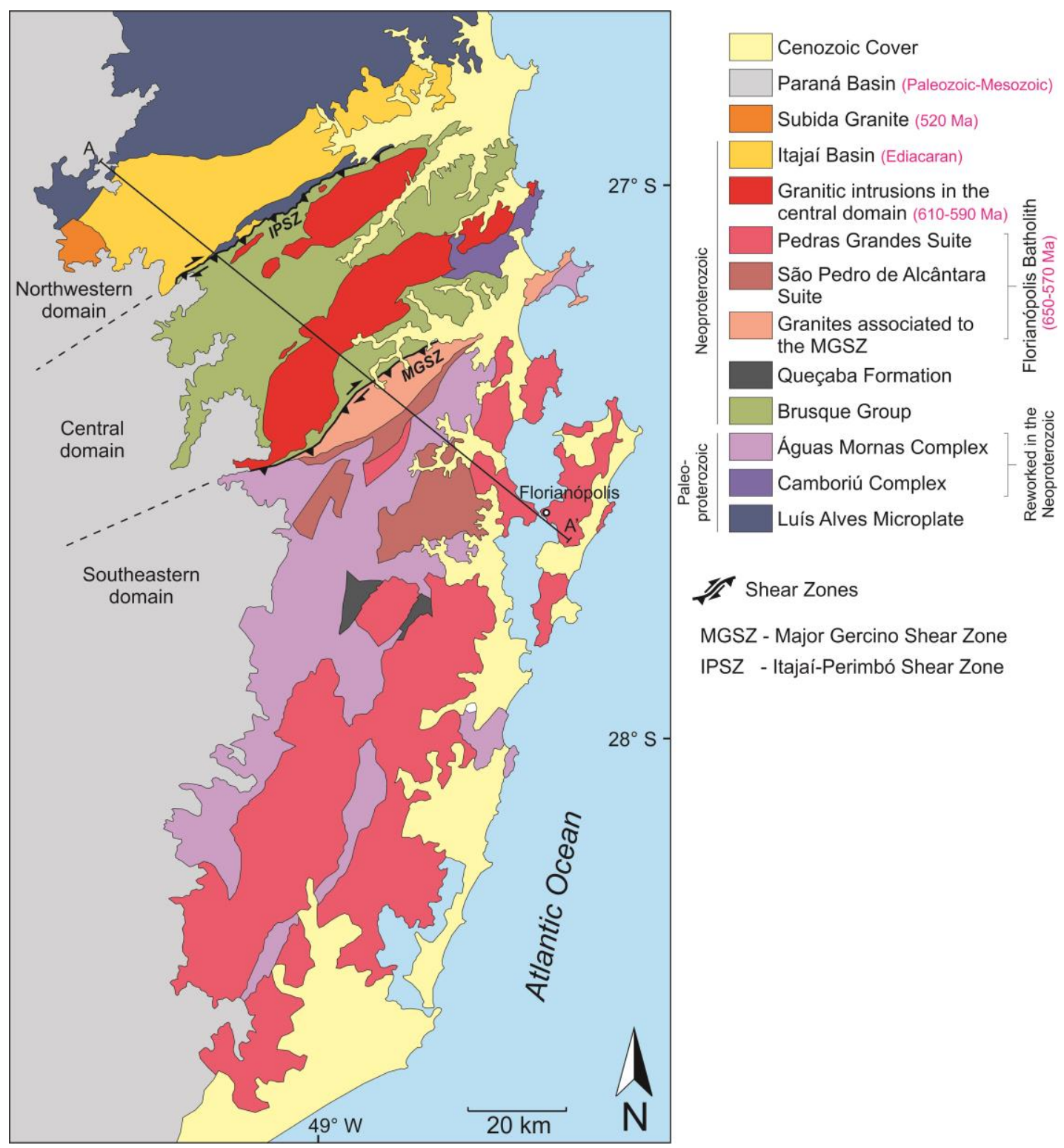

MGSZ - Major Gercino Shear Zone IPSZ - Itajaí-Perimbó Shear Zone

Figure 2.3: Simplified geological map of the Santa Catarina sector of the Dom Feliciano Belt. Profile A-A' is presented in Fig. 2.4. Modified from Basei et al. (2000, 2006), Silva et al. (2005b), and Wildner et al. (2014) 
The basement of the Brusque metavolcano-sedimentary sequence is exposed on the northeastern portion of the Central Domain in Santa Catarina, and is known as the Camboriú Complex. It is mostly composed of banded gneisses and migmatites (Fig. 2.5c), cross-cut by more than one generation of neosome and granitic injections (Basei et al. 2000, 2013a; Hartmann et al. 2003a; Peternell et al. 2010; Florisbal et al. 2012a). These metamorphic rocks were intruded by a large granitic body concordant to its main foliation and characterized by abundant mafic xenoliths, which is named Ponta do Cabeço or Itapema Granite (Hartmann et al. 2003a; Bitencourt \& Nardi 2004; Basei et al. 2013a). The Camboriú Complex has a long-spanning geological evolution, with most crust-forming events having taken place in the Archean and Paleoproterozoic, but was ultimately reworked and migmatized in the Neoproterozoic Brasiliano event (Silva et al. 2005b; Basei et al. 2013a; Martini et al. 2015).

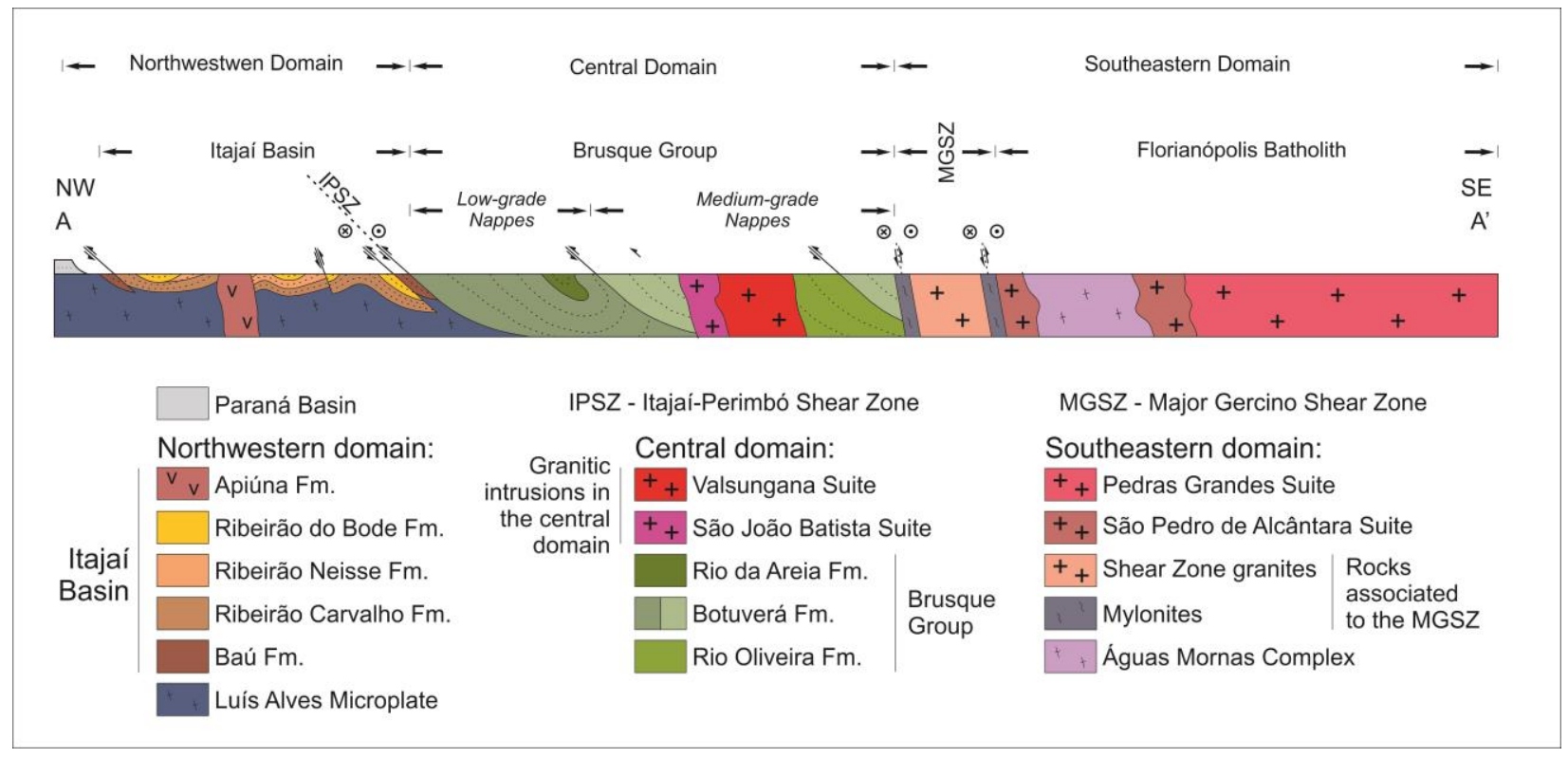

Figure 2.4: Schematic geological profile of the Dom Feliciano Belt in the Santa Catarina sector. Details of the stratigraphy of the Brusque Group and Itajaí Basin presented in this figure were omitted from Fig. 2.3 in order to comply with the scale of the map. Modified from Basei et al. (2006, 2011a, b)

Both the Brusque Group and the Camboriú Complex are intruded by numerous granitic plutons during the regional thermal climax. The intrusions are grouped into three different suites, from the oldest to the youngest: the peraluminous São João Batista Suite, the porphyritic Valsungana Suite, and the mostly equigranular Nova Trento Suite (Basei et al. 2000, 2011a; Hueck et al. 2016). All suites are slightly peraluminous and have high-K calc-alkaline affinity (Castro et al. 1999; Florisbal et al. 2012a; Hueck et al. 2016). They present a strong crustal signature indicating multiple sources within the central domain of the Dom Feliciano Belt, with little mantellic input limited to the Valsungana Suite (Fig. 2.5d). The 
relative stratigraphy of the suites is based on field criteria, but most U-Pb zircon ages overlap between 610-590 Ma (Silva et al. 2002a, 2003, 2005b; Vlach et al. 2009; Basei et al. 2011a; Florisbal et al. 2012c; Hueck et al. submitted).

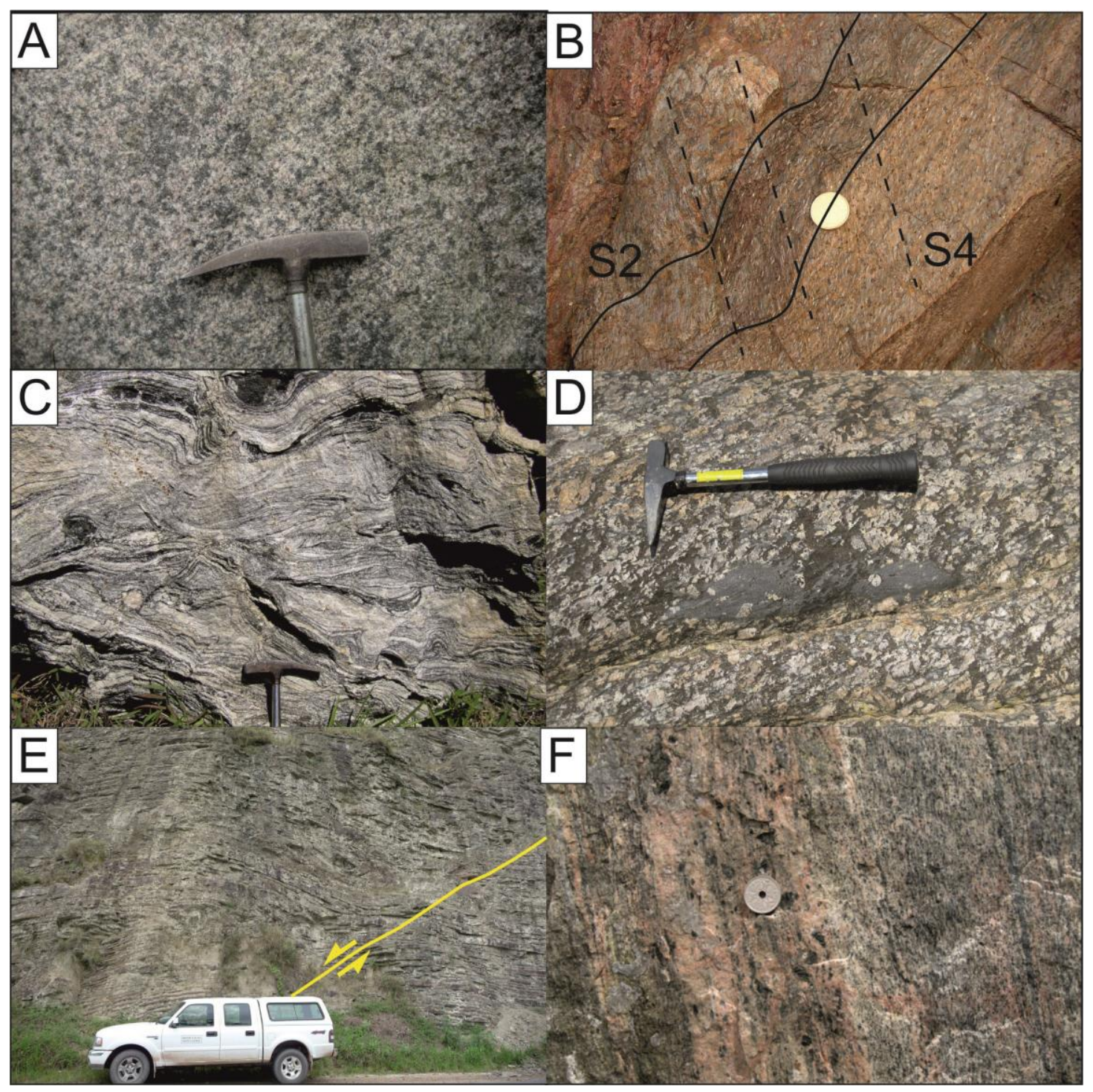

Figure 2.5: Some field aspects of rocks from the Santa Catarina sector of the Dom Feliciano Belt: a: Late isotropic leucogranite of the Pedras Grandes Suite; b: Metapelitic rocks from the Botuverá Formation, Brusque Group. Note that the compositional layering (S2) is transposed by a pervasive crenulation foliation (S4); c: Folded migmatites of the Morro do Boi unit, Camboriú Complex; d: Mafic enclave in the porphyritic southern Valsungana Batholith, part of the granitic intrusions in the Brusque Group. Note $\mathrm{cm}$-sized K-feldspar megacrysts within a coarse, biotite-rich matrix; e: Turbidites of the Ribeirão Carvalho Formation, Itajaí Basin. Note the normal fault in the lower right corner of the picture; f: Granulitic rocks overprinted by retrograde metamorphism, Luís Alves Complex 
Finally, the northwestern domain of the Dom Feliciano Belt in Santa Catarina is the foreland Itajaí Basin, a volcano-sedimentary package up to $5 \mathrm{~km}$ thick. According to Basei et al. (2011b), the sedimentary rocks are divided into four formations: Baú, Ribeirão Carvalho, Ribeirão Neisse and Ribeirão do Bode, recording a transition from continental deposits to a marginal setting. The two uppermost units are intruded by rhyolitic dykes and domes of the Apiúna Formation, while in the eastern portion of the basin is limited by the late Subida Granite. The stratigraphy of the Itajaí Basin has been affected by two deformational phases recording thrust tectonics and extension (Fig. 2.5e), respectively, which caused local folding and numerous repetitions (Basei 1985; Rostirolla et al. 1992, 1999; Schroeder 2006; Basei et al. 2011b; Raposo et al. 2014; Costa \& Nascimento 2015). Geochronological constraints to the deposition of the Itajaí Basin place it almost entirely in the Ediacaran, between 586 and $550 \mathrm{Ma}$ (Guadagnin et al. 2010; Basei et al. 2011b). The late Subida Granite is dated at 520 Ma (Basei et al. 2011b).

The Itajaí Basin is deposited on top of the Luís Alves Terrane. This terrane is mostly composed of banded ortogneiss with TTG compositions (Fig. 2.5f), with subordinated presence of quartzites, migmatites and banded iron formations, intruded in its eastern border by the Neoproterozoic Paranaguá Batholith. An Archean accretion is suggested for most of the terrane, based on the U-Pb SHRIMP dating of zircon cores and $\mathrm{Nd} \mathrm{T}_{\mathrm{DM}}$ model ages, but it was strongly reworked in the Paleoproterozoic by two high-grade metamorphic events (Basei 1985; Basei et al. 2000, 2009; Hartmann et al. 2000, 2001, 2003a; Passarelli et al. 2018).

\subsection{Rio Grande do Sul sector}

The Dom Feliciano Belt in Rio Grande do Sul is part of the Precambrian Sul-rio-grandense Shield, an association of terranes juxtaposed in the Brasiliano-Pan-African orogenic cycle and composed of various geotectonic units. This wide area is bounded to the north and to the west by the Paleozoic sequences of the Paraná Basin, resting in sedimentary contact over the shield rocks, while to the east it is covered by the Cenozoic coastal sediments close to the South Atlantic shore. In its southern extremity, it crops out across the national border into the Uruguay sector of the Dom Feliciano Belt.

The Sul-rio-grandense Shield is traditionally divided into four geotectonic units (Figs. 2.6 and 2.7), namely the Taquarembó, São Gabriel and Tijucas terranes, and the Pelotas Batholith, which are overlain by the Ediacaran to Cambrian Camaquã Basin (Chemale Jr. 2000; Philipp et al. 2016a). Each domain is separated from its neighbor by large shear zones, although not all are exposed. Both the Taquarembó and São 
Gabriel Terranes acted locally as foreland domains to the Ediacaran evolution of the Dom Feliciano Belt in the Ediacaran, while the remaining domains roughly correspond to those recognized in the threefold division of the belt (Basei et al. 2000): eastern domain (Pelotas Batholith); central domain (Tijucas Terrane) and western domain (Camaquã Basin).

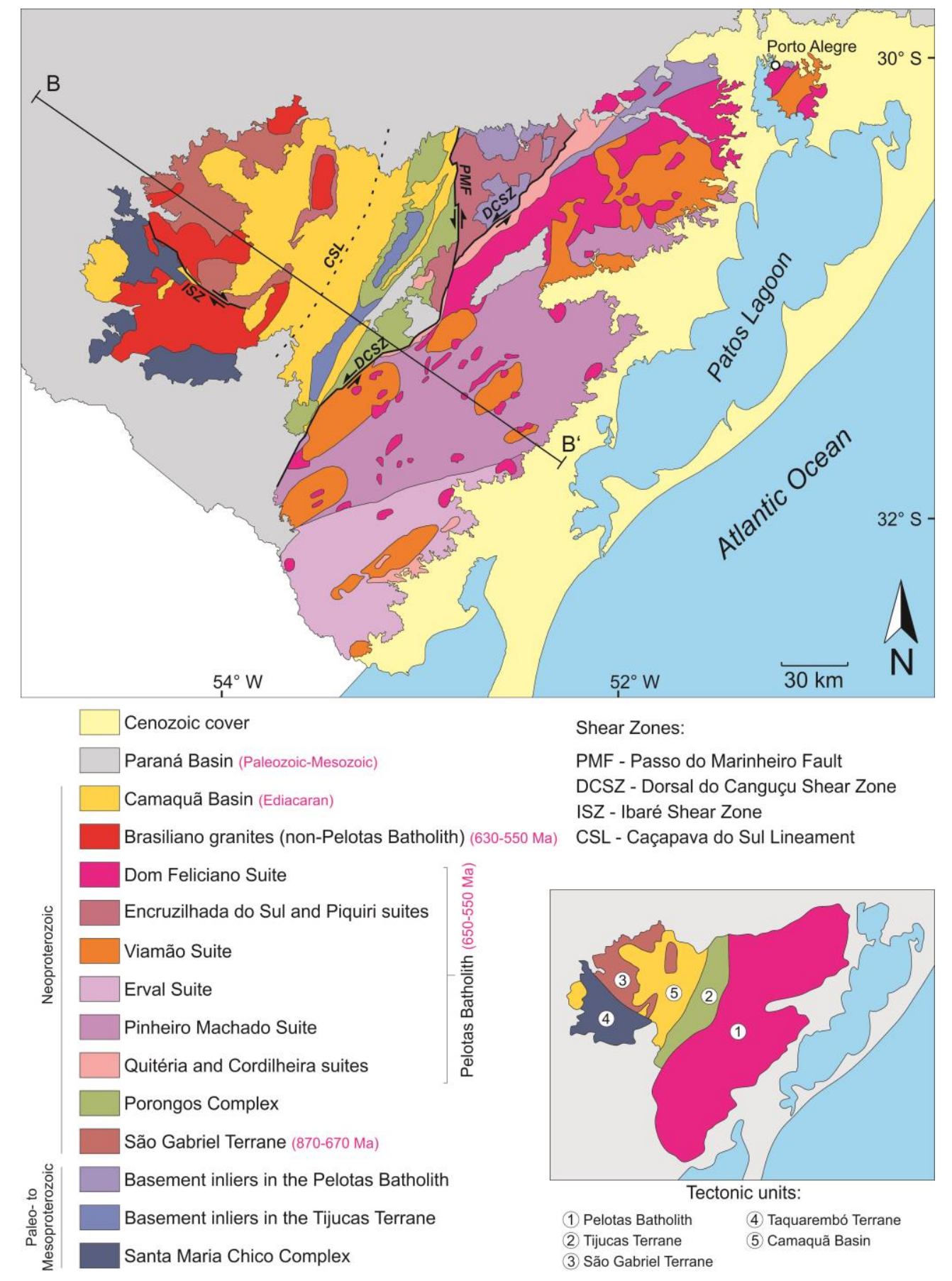

Figure 2.6: Simplified geological map of the Rio Grande do Sul sector of the Dom Feliciano Belt. Profile B-B' is presented in Fig. 2.7. Modified from Wildner et al. (2006), Saalmann et al. (2011) and Philipp et al. (2016a) 
On the eastern part of the shield, the Pelotas Batholith comprises a large association of granitic intrusions that is the largest unit in the Precambrian shield, corresponding to almost half of its area. It is limited to the Tijucas Terrane to the north by the Dorsal do Canguçu Shear Zone, which is transacted by the brittle Passo do Marinheiro Fault. The numerous intrusions roughly record a transition from high- $\mathrm{K}$ calc-alkaline magmatism to alkaline and then peralkaline compositions that is interpreted to represent the evolution from syn- to post-collisional stages of the orogenic event (Babinski et al. 1997; Silva et al. 1997; Koester et al. 2001a, b; Frantz et al. 2003; Philipp et al. 2002, 2008, 2013, 2016a; Philipp \& Machado 2005; Nardi \& Bitencourt 2009; Oliveira et al. 2015a). The lithostratigraphic sequence of the batholith is divided into numerous suites, many of which had their generation and emplacement controlled by high-angle ductile transcurrent shear zones (Fernandes et al. 1992; Bitencourt \& Nardi 1993; Philipp et al. 1993, 2002, 2003; Nardi \& Frantz 1995; Koester et al. 2001a, b). The earliest associations are identified along the Dorsal do Canguçu Shear Zone, and correspond to the I-type Quiteria Granite and the peraluminous Cordilheira Suite (Fig. 2.8a), mostly yielding ages between 658 and $625 \mathrm{Ma}$ (Koester et al. 2001a, b; Frantz et al. 2003; Philipp et al. 2013). Following this early magmatism, the Pinheiro Machado Complex and Viamão Suite include large syn-tectonic intrusions associated with compressional deformation, and are mostly constrained between 630 and $620 \mathrm{Ma}$, interpreted to correspond to the orogenic peak of the Dom Feliciano Belt (Babinski et al. 1997; Silva et al. 1997; Philipp et al. 2002, 2003). Late- to post-collisional reactivation of the shear zones resulted in the generation of the alkaline and peralkaline Piquiri and Encruzilhada do Sul suites, and high-K calc-alkaline to alkaline granites of the Dom Feliciano Suite (Philipp \& Machado 2005; Philipp et al. 2002, 2003, 2016a). The subvolcanic component associated with this late stage is separated into the Itapuã Suite, including rhyolitic to basaltic dyke swarms with alkaline to peralkaline affinity (Oliveira et al. 2001, 2015a). All of these late suites yield ages between ca. 610 and 550 Ma (Babinski et al. 1997; Koester et al. 2001c; Philipp et al. 2002, 2016a; Oliveira et al. 2015a).

Large crustal xenoliths and roof pendants up to several kilometers across represent the basement inliers of the Pelotas Batholith. The main exposures are within granites of the Encruzilhada do Sul Suite in its northern portion, and are grouped into paragneisses of the Várzea do Capivarita Complex (Fig. 2.8b), orthogneisses of the Arroio dos Ratos Complex and the Capivarita Meta-anorthosite (Fernandes et al. 1992; Leite et al. 1998; Lima et al. 1998; Tickyj et al. 2004; Philipp \& Campos 2004; Gross et al. 2006; Philipp et al. 2010, 2013, 2016b; Gregory et al. 2011, 2015; Martil et al. 2011, 2017). The orthogneisses of the Arroio dos Ratos Complex have magmatic ages spreading around ca. 2.2-2.0 Ga and juvenile signatures (Leite et al. 2000; Silva et al. 2005b; Gregory et al. 2015) while the intrusion of the 
Capivarita Meta-anorthosite is constrained by magmatic zircon crystals dated at $1.57 \mathrm{Ga}$. (Chemale Jr. et al. 2011). In addition, all basement units record Neoproterozoic metamorphic overprint between 650 and $600 \mathrm{Ma}$ (Silva et al. 2005b; Chemale Jr. et al. 2011; Philipp et al. 2016b). These associations have been correlated with the basement rocks of the Tijucas and Nico Pérez Terranes elsewhere in Rio Grande do Sul and in Uruguay (Philipp et al. 2016a; Oyhantçabal et al. 2018).

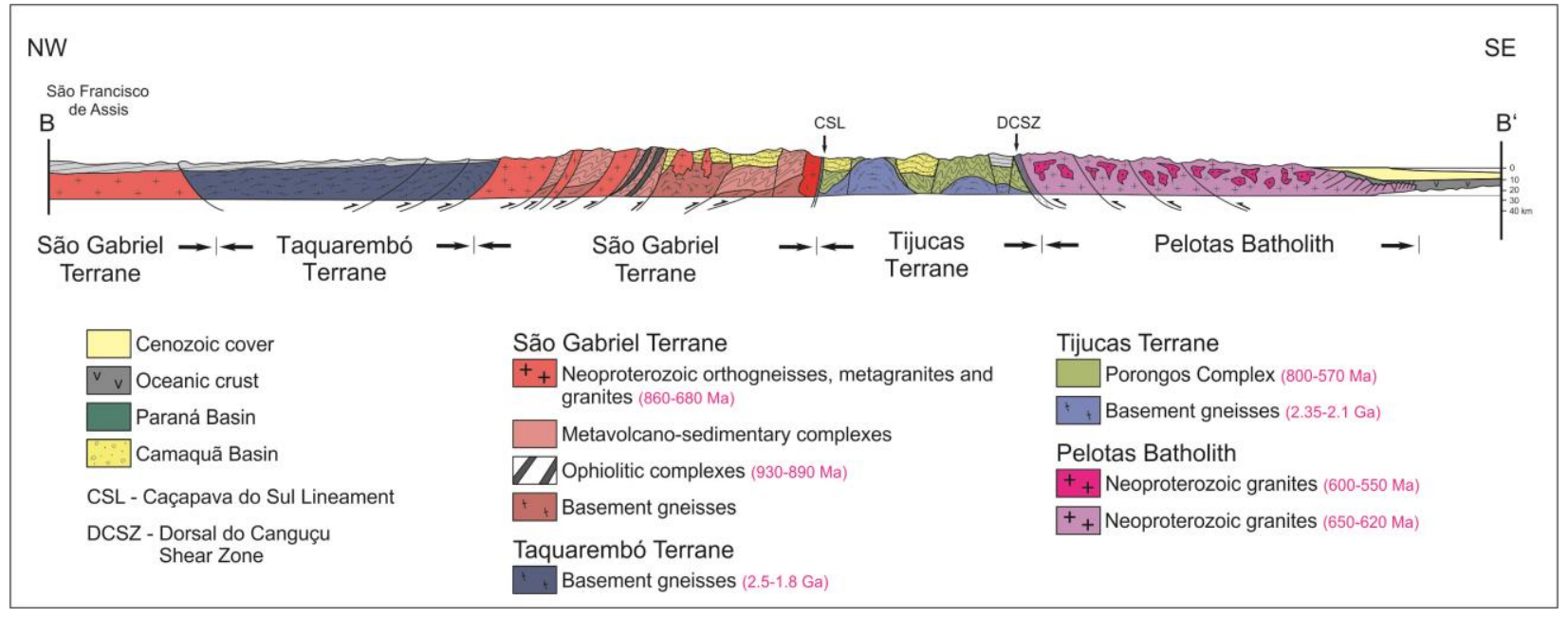

Figure 2.7: Schematic geological profile of the Dom Feliciano Belt in the Rio Grande do Sul sector

The Tijucas Terrane represents the central domain of the Dom Feliciano Belt in Rio Grande do Sul, and is composed of a metavolcano-sedimentary complex associated with basement inliers exposed in structural domes (Jost 1981). It's eastern limit to the São Gabriel is covered by sediments of the Camaquã Basin and corresponds to the Caçapava do Sul Lineament. The main basement units are the Paleoproterozoic gneissic Encantadas and Vigia complexes. The Encantadas Complex is exposed in the central portion of the terrane, in the Santana da Boa Vista dome, and includes tonalitic gneisses (Fig. 2.8c) with magmatic zircon ages between 2.35 and $2.1 \mathrm{Ga}$, intruded by mylonitic gneisses dated at 2.17-2.15 Ga, and metamorphosed at 2.06-2.02 Ga (Hartmann et al. 2003b; Saalmann et al. 2011; Camozzato et al. 2013; Philipp et al. 2016a). The Vigia complex, on the other hand, comprises the basement in the southern portion of the terrane, and comprises dioritic, tonalitic and trondhjemitic gneisses with zircon crystallization ages between 2.05 and $2.0 \mathrm{Ga}$ (Camozzato et al. 2013). This metamorphic complex is intruded by the Statherian (1.78 -1.76 Ga) Seival Metagranite and by the Tupi Silveira Amphibolite, dated at $1.57 \mathrm{Ga}$ (Camozzato et al. 2013; Philipp et al. 2016a, b). All units were affected by regional metamorphism under granulite facies between $c a .650$ and $630 \mathrm{Ma}$ 


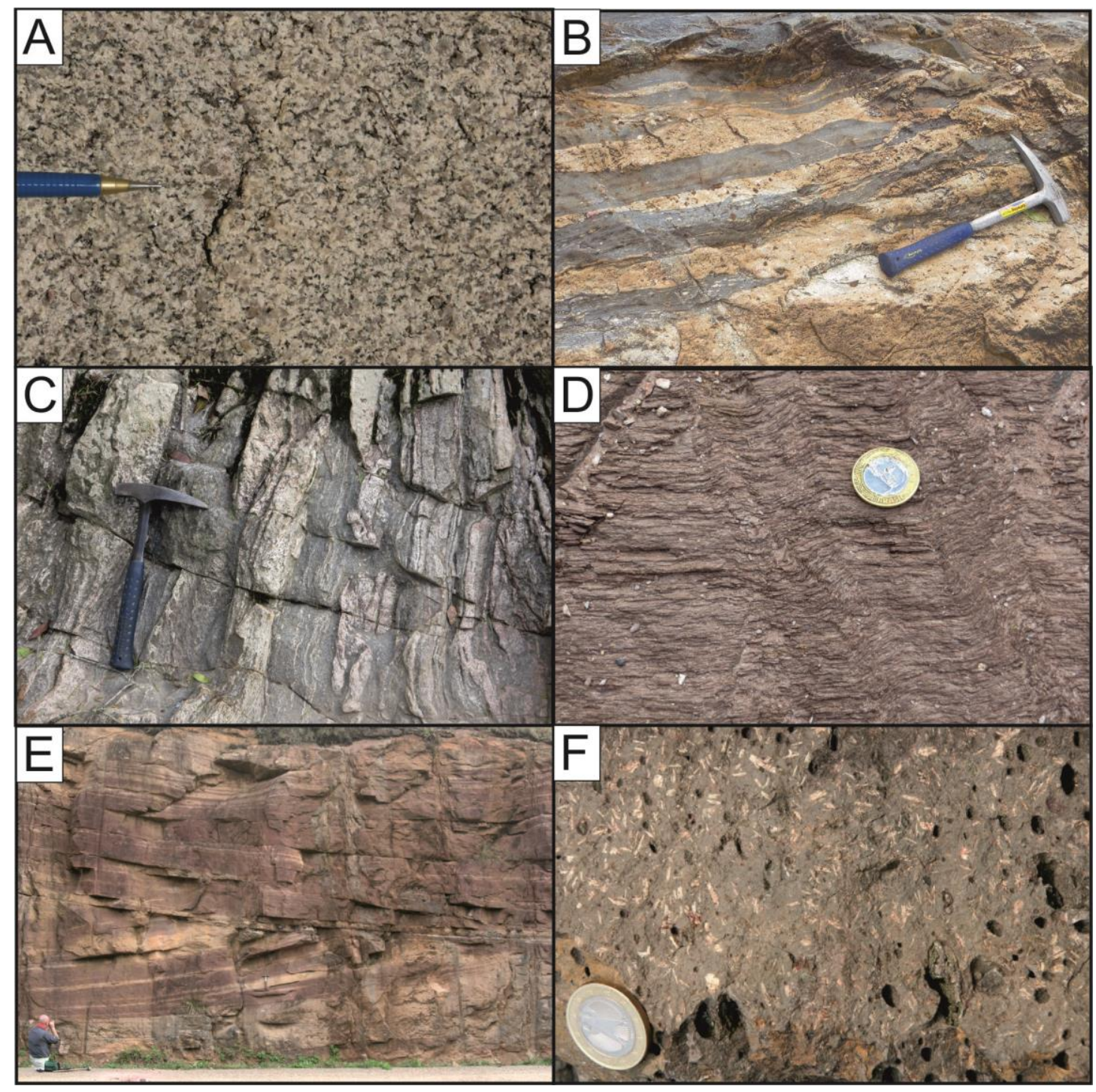

Figure 2.8: Some field aspects of rocks from the Rio Grande do Sul sector of the Dom Feliciano Belt: a: Fine- to medium-grained granite of the peraluminous Cordilheira Suite; b: Migmatitic paragneiss of the Várzea do Capivarita Complex; c: Banded gneiss of the Encantadas Complex; d: Finely laminated phyllite of the Porongos Complex. Note the presence of kink bands representing late-stage deformation; e: Arenites with metric cross-beddings of the Pedra Pintada Formation, Guaritas Group, Camaquã Basin; f: Andesite of the Hilário Formation, Bom Jardim Group, Camaquã Basin

Supracrustal rocks of the Tijucas Terrane comprise poli-deformed metavolcano-sedimentary sequences that underwent regional metamorphism, and are grouped into the Porongos Complex. The main association is exposed in the southern and central portions of the terrane and comprises quartzite, pelitic schists (Fig. 2.8d) and marble lenses, interlayered with Tonian metarhyolites, metadacites and meta-andesites, with subordinate ultramafic rocks (Jost 1981; Chemale Jr. 2000; Saalmann et al. 2006a, 
2007, 2011; Pertille et al. 2015a, b, 2017; Philipp et al. 2016a). Detrital zircon inheritances for this association suggest predominantly Archean, Paleo- and Mesoproterozoic sources with ages between 2.9 and 2.0 Ga, and between 1.6 and 1.0 Ga (Hartmann et al. 2004; Basei et al. 2008; Gruber et al. 2011; Pertille et al. 2015a, b). The northern sequence, on the other hand, is exposed in the Capane area, and consists of metapelites and quartzites intercalated with Ediacaran fine-grained crystal metatuffs and metadacites intruded by alkaline granites (Marques et al. 1998a, b; Gollmann et al. 2008; Saalmann et al. 2011; Zvirtes et al. 2017; Höfig et al. 2018). Detrital zircon ages of the Capané area range from Mesoproterozoic to Neoproterozoic, with strong similarity with the magmatism of the Pelotas Batholith (Pertille et al. 2015a, b, 2017; Höfig et al. 2018). For these reasons, these authors suggest that this part of the Porongos Complex represents a foreland basin that was deformed and metamorphosed during the formation of the Dom Feliciano Belt.

Overlying the Brasiliano configuration of the Sul-rio-grandense Shield, the Camaquã Basin comprises sediments and volcanic rocks, deposited between 600-535 Ma. The basin was initiated with the deposition of the Maricá Group in a marine environment. It is interpreted to correspond to a retro-arc foreland basin during the evolution of the Dom Feliciano Belt (Borba et al. 2006, 2008). This was followed by a transition between marine and lacustrine conditions during the deposition of the Bom Jardim and Santa Bárbara Groups. The former was associated with transpressive tectonics (Paim et al. 2000), while the latter marks the transition to the upper stage of the Camaquã Basin evolution, under a transtensional rift context developed after the amalgamation of the shield was already completed (Bicca et al. 2013; Oliveira et al. 2014). In this context, the last sedimentary sequence, the Guaritas Group, was deposited in fluvial and lacustrine environments with Aeolian facies (Fig. 2.8e). In the last three sequences, activity of the main shear zones and extensional faults reached the mantle and lower crust levels to generate volcanic rocks corresponding to the high-K calc-alkaline to shoshonitic Hilário Formation (Fig. 2.8f), tholeiitic to sodic alkaline Acampamento Velho Formation, and alkaline basaltic Rodeio Velho Formation (Wildner et al. 2002; Sommer et al. 2005; Janikian et al. 2012). Granitic intrusions with high-K calc-alkaline to alkaline signatures accompanied this magmatism.

The terranes that acted as foreland to the Ediacaran formation of the Dom Feliciano Belt in the Sul-riograndense Shield are the Taquarembó and São Gabriel terranes. The Taquarembó Terrane is situated in the southwestern portion of the shield, and is a continuation of the Nico Pérez Terrane in Uruguay, which was accreted to the Rio de la Plata Craton in the Neoproterozoic (Rapela et al. 2011; Oriolo et al. 2015, 2016a, b, c; Philipp et al. 2016a; Oyhantçabal et al. 2018). It mostly comprises Paleoproterozoic granulites of the Santa Maria Chico Complex, dated at ca. $2.0 \mathrm{Ga}$ with possible protolith ages between 
2.55 and $2.36 \mathrm{Ga}$ (Hartmann et al. 1999, 2008). These units are intruded by late- to post tectonic granites associated with the Dom Feliciano event (Camozzato et al. 2012, 2016; Laux et al. 2012; Philipp et al. 2016a).

North of the Ibaré Shear Zone, in the northwestern portion of the Shield, the São Gabriel Terrane is unique in the context of the southern Mantiqueira Province for representing the remains of TonianCryogenian orogenic events with juvenile signatures (Babinski et al. 1997; Leite et al. 1998; Hartmann et al. 2011; Lena et al. 2014; Lopes et al. 2015; Philipp et al. 2016a, 2018). It comprises two magmatic arcs, numerous ophiolitic complexes and metamorphosed marginal deposits, intruded by late-tectonic granites. The ophiolitic complexes occur as elongated slabs of metaultramafic rocks, interpreted to have been emplaced around 930-890 Ma (Leite et al. 1998; Hartmann and Chemale Jr. 2003; Arena et al. 2017). The first arc association comprises tonalitic and trondhjemitic gneisses attributed to an island arc formed during the Passinho Event, between 890 and $860 \mathrm{Ma}$, while the second involved the development of a continental arc between 770 and $680 \mathrm{Ma}$ in the São Gabriel Event (Leite et al. 1998; Saalman et al. 2005, 2006b, 2011; Hartmann et al. 2011; Lena et al. 2014; Philipp et al. 2016a, 2018). Metavolcano-sedimentary rocks occur throughout the terrane and represent sequences deposited both in passive margins and in arc-related basins (Lopes et al. 2015; Gubert et al. 2016; Vedana et al. 2018). Finally, the whole sequence was intruded by granitic magmatism during the Dom Feliciano Event (Laux et al. 2012; Camozzato et al. 2016; Philipp et al. 2016a).

\subsection{Uruguay sector}

The southernmost outcrops of the Dom Feliciano Belt are exposed in eastern Uruguay over more than $300 \mathrm{~km}$. The belt probably continues in the continental shelf up to the Mar del Plata Terrane, in Argentina, where it has been identified below the Paleozoic cover in the Punta Mogotes drill hole (Rapela et al. 2011). The belt is in tectonic contact to the west with the Archean-Paleoproterozoic Nico Pérez Terrane (e.g. Oyhantçabal et al. 2018) representing its cratonic foreland, while to the east the outcrops continue up to the Atlantic Ocean coastline.

The belt can be divided into two main domains, western and eastern (Figs. 2.9 and 2.10), bounded by the Sierra Ballena Shear Zone (Oriolo et al. 2016b). The western domain comprises the metavolcanosedimentary association, basement inliers from the Nico Pérez Terrane and widespread Ediacaran granite intrusions. The eastern domain (also known as Punta del Este Terrane, Basei et al. 2011c) includes the Aiguá Batholith, the Cerro Olivo Complex and the Rocha and Sierra de Aguirre formations. 
The latter three units constitute a peculiarity of the Dom Feliciano Belt in Uruguay, as they are the only wide exposures of rocks to the east of the granite batholith. Widespread transcurrent shear zones are a common feature of both domains, as well as relics of foreland basin deposits. In contrast to the other sections of the Dom Feliciano Belt, however, these deposits do not constitute a single continuous domain. In this way, the Uruguay sector differs from the traditional threefold division of the belt (Basei et al. 2000).
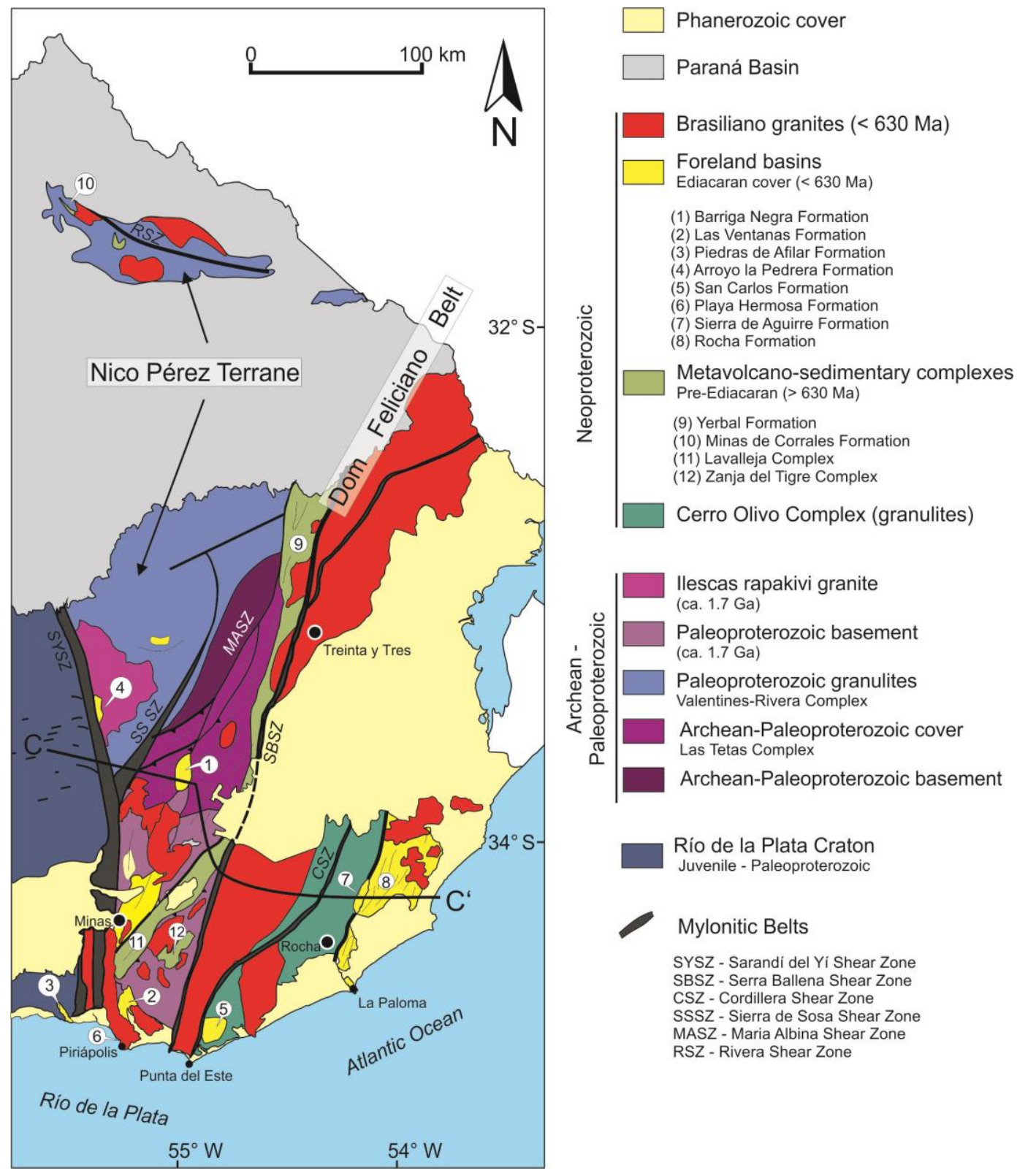

Figure 2.9: Simplified geological map of the Uruguay sector of the Dom Feliciano Belt. Modified from Oyhantçabal et al. 2009 and Oriolo et al. 2016b, c. Profile C-C' is presented in Fig. 2.10. Shear zones: SYSZ: Sarandí del Yí Shear Zone; SSSZ - Sierra de Sosa Shear Zone; MASZ: Maria Albina Shear Zone; RSZ: Rivera Shear Zone 
In the easternmost portion of the Uruguayan Shield, the Punta del Este Terrane comprises gneissic crystalline basement rocks and metavolcano-sedimentary units, intruded by Neoproterozoic granites. The basement association is known as the Cerro Olivo Complex (Masquelin et al. 2012), and consists of high-grade metamorphic ortho- and paraderived granulites and migmatites (Fig. 2.11a). The orthoderived rocks yield protolith ages between ca. 820 and $770 \mathrm{Ma}$, with a minor populaton of zircons with ages from 1.3 to $1.0 \mathrm{Ga}$, and records metamorphic overprint at $c a .650 \mathrm{Ma}$ that constrain the age of the granulite-facies event (Oyhantçabal et al. 2009; Basei et al. 2011c; Lenz et al. 2011; Masquelin et al. 2012; Konopásek et al. 2018). Detrital zircons in the paragneisses record main peaks at ca. 1.45-1.50 Ga, 1.75 Ga and 2.00-2.05 Ga (Konopásek et al. 2018). Two metasedimentary sequences are recognized in the region: the Rocha Formation (Fig. 2.11b) is a turbiditic sequence composed by sandstones, wackestones and mudstones deformed and affected by metamorphism in greenschist facies conditions (Sánchez-Bettucci \& Burgueño 1993; Basei et al. 2011c; Blanco et al. 2014), with deposition constrained between the youngest detrital zircons (630-670 Ma, Basei et al. 2005) and the intrusion of the Santa Teresa Granite (Fig. 2.11c) (ca. 543 Ma, Basei et al. 2013b). On the other hand, the Sierra de Aguirre Formation is a volcano-sedimentary succession that comprises felsic pyroclastic rocks, and lavas of basaltic to rhyolitic composition interbedded with siliciclastic sediments (Campal \& Schipilov 2005; Fantin 2003). The volcanic component is dated at ca. 571 Ma age (Hartmann et al. 2002).

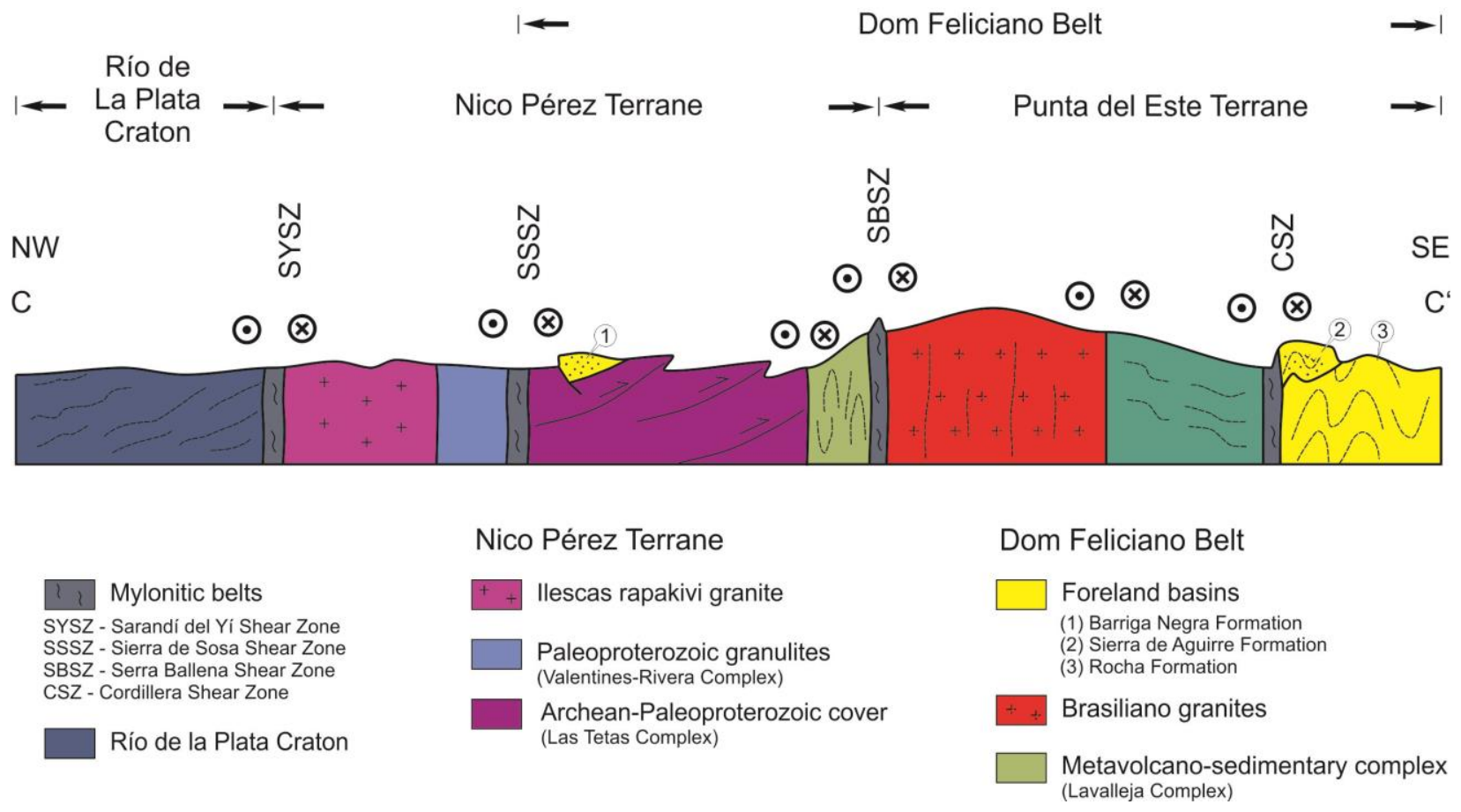

Figure 2.10: Schematic geological profile of the Dom Feliciano Belt in the Uruguay Sector 
The Aiguá Batholith is the southernmost occurrence of the granitic batholiths that comprise the eastern domain of the Dom Feliciano Belt (Basei et al. 2000). Its eastern border to the Nico Pérez Terrane is marked by the Sierra Ballena Shear Zone. The batholith includes several plutons such as Maldonado, Aiguá, Florencia, Valdivia, Puntas del Arroyo de Rocha and Cerrillos (Masquelin 1990; Spoturno et al. 2012). The predominant lithology comprises equigranular to porphyritic biotite granites, commonly with titanite. Many of the plutons, such as the Florencia and Maldonado granites, had their emplacement controlled by shear zones, as indicated by protomylonitic foliations parallel to the strike of the main regional structures (Fig. 2.11d). Crustal sources are interpreted for the association intrusions, as indicated by negative $\varepsilon N d$ signatures and Nd $T_{D M}$ model ages between 2.1 and 1.4 Ga (Basei et al. 2000; Peel et al. 2015). U-Pb geochronological data for the Aiguá Batholith range from 625 to 564 Ma (Basei et al. 2000; Oyhantçabal et al. 2007; Peel et al. 2015; Lara et al. 2016).

Located in the central portion of the Uruguayan Shield, between the Sierra Ballena and Sarandí del Yí Shear Zones, the Nico Pérez Terrane acted as the cratonic foreland for the generation of the Dom Feliciano Belt in the region (e.g. Oyhantçabal et al. 2018). The main unit in the terrane is the ValentinesRivera Complex, an association of Paleoproterozoic gneiss and granulite which extends through the Isla Cristalina de Rivera region and connects to the Santa Maria Chico Complex in the Brazilian Taquarembó Block (Hartmann et al. 2008; Oyhantçabal et al. 2011a, 2012; Oriolo et al. 2016c). It is intruded on its western border by the large Statherian Illescas Rapakivi Granite (Campal and Schipilov 1995), whereas on the east it is juxtaposed by means of the Sierra de Sosa Shear Zone to the La Chinas Complex, an Archean block consisting of metamorphosed mafic to ultramafic rocks and gneisses (Hartmann et al. 2001; Oyhantçabal et al. 2011a). During the Neoproterozoic, the Nico Pérez Terrane was intensely reworked by its interaction with the Dom Feliciano Belt, as evidenced by regional K-Ar cooling ages, widespread granitic magmatism and the development of several internal shear zones, such as the Maria Albina and Rivera shear zones (Oyhantçabal et al. 2007, 2011a, b, 2012; Oriolo et al. 2015, 2016b, c).

Metavolcano-sedimentary complexes in the Uruguay sector of the Dom Feliciano Belt include different Mesoproterozoic to Cryogenian successions affected by Brasiliano deformation and metamorphism, and are commonly grouped in the Lavalleja Complex (e.g. Masquelin et al. 2017). Taken together, the association has a width of up to $40 \mathrm{~km}$, along a NNE-SSW strike for more than $250 \mathrm{~km}$. The oldest units are grouped in the Mesoproterozoic Zanja del Tigre Formation and include metapelites, dolomitic marbles, metamarls and metatuffs, interbedded with metagabbros and mafic to felsic metavolcanic rocks (Fig. 2.11e) dated at ca. 1.43-1.46 Ga (Sánchez-Bettucci \& Ramos 1999; Poiré et al. 2003; Oyhantçabal et al. 2005; Basei et al. 2008; Chiglino et al. 2008, 2010; Poiré \& Gaucher 2009; Gaucher et 
al. 2014). In addition, Neoproterozoic metasediments interbedded with basic volcanic rocks have deposition ages between 1,000 and $650 \mathrm{Ma}$, constrained by detrital zircon data and intrusive granites (Pecoits et al. 2016). South of the main expositions of the Lavalleja Complex, the Campanero Unit corresponds to a local basement inlier, and comprises an association of orthogneisses, calc-silicatic gneisses, amphibolites, mica schists, banded iron formations and migmatites (Oyhantçabal 2005). Both the Nico Pérez Terrane and the metavolcano-sedimentary sequences are intruded by numerous high- $\mathrm{K}$ calc-alkaline to shoshonitic granitic bodies with ages ranging from ca. 634 to $575 \mathrm{Ma}$ and strong crustal signatures with Paleoproterozoic to Archean Nd T $\mathrm{D}_{\mathrm{DM}}$ model ages (Oyhantçabal et al. 2007; Gaucher et al. 2008; Rapalini et al. 2015; Lara et al. 2016, 2017; Fort et al. 2016; Gallardo et al. 2016).

The Uruguay sector of the Dom Feliciano Belt distinguishes itself for not having a single, wide sedimentary foreland basin, such as the Itajaí and Camaquã successions in Santa Catarina and Rio Grande do Sul. Instead, the Ediacaran cover occurs as relicts covering different units throughout the Uruguayan Shield, leading to difficulties in the chronostratigraphical correlating of these sequences. The main units are the Playa Hermosa, Barriga Negra, Las Ventanas and San Carlos formations (Fig. 2.11f). Most are characterized by clastic sediments intercalated with volcanic and volcanoclastic rocks, with detrital zircon inheritances with peaks in the upper Neoproterozoic, Paleoproterozoic and occasionally in the Archean, indicating sources within the Uruguayan Shield (Midot 1984; Masquelin \& Sánchez-Bettucci 1993; Fambrini et al. 2005; Pazos et al. 2003, 2011; Blanco \& Gaucher 2005; Pecoits et al. 2008, 2016; Blanco et al. 2009; Sánchez-Bettucci et al. 2009; Gaucher et al. 2010; Rapalini et al. 2015; Nuñez et al. 2016).

In the westernmost portion of the Uruguayan Shield, the Piedra Alta Terrane is dominated by a Paleoproterozoic association which comprises a large granitic-gneiss area associated with metavolcanosedimentary belts, which were in turn intruded by late- to post-tectonic granitic intrusions (Oyhantçabal et al. 2011b). the terrane is correlated with the Tandilia Belt in Argentina (Cingolani 2011), forming the Rio de la Plata Craton (Almeida et al. 1973). This tectonic unit is largely covered by Phanerozoic sediments and thus most of its margins are concealed, but in Uruguay its eastern border to the Nico Pérez Terrane is well characterized by the Sarandí del Yí Shear Zone. 


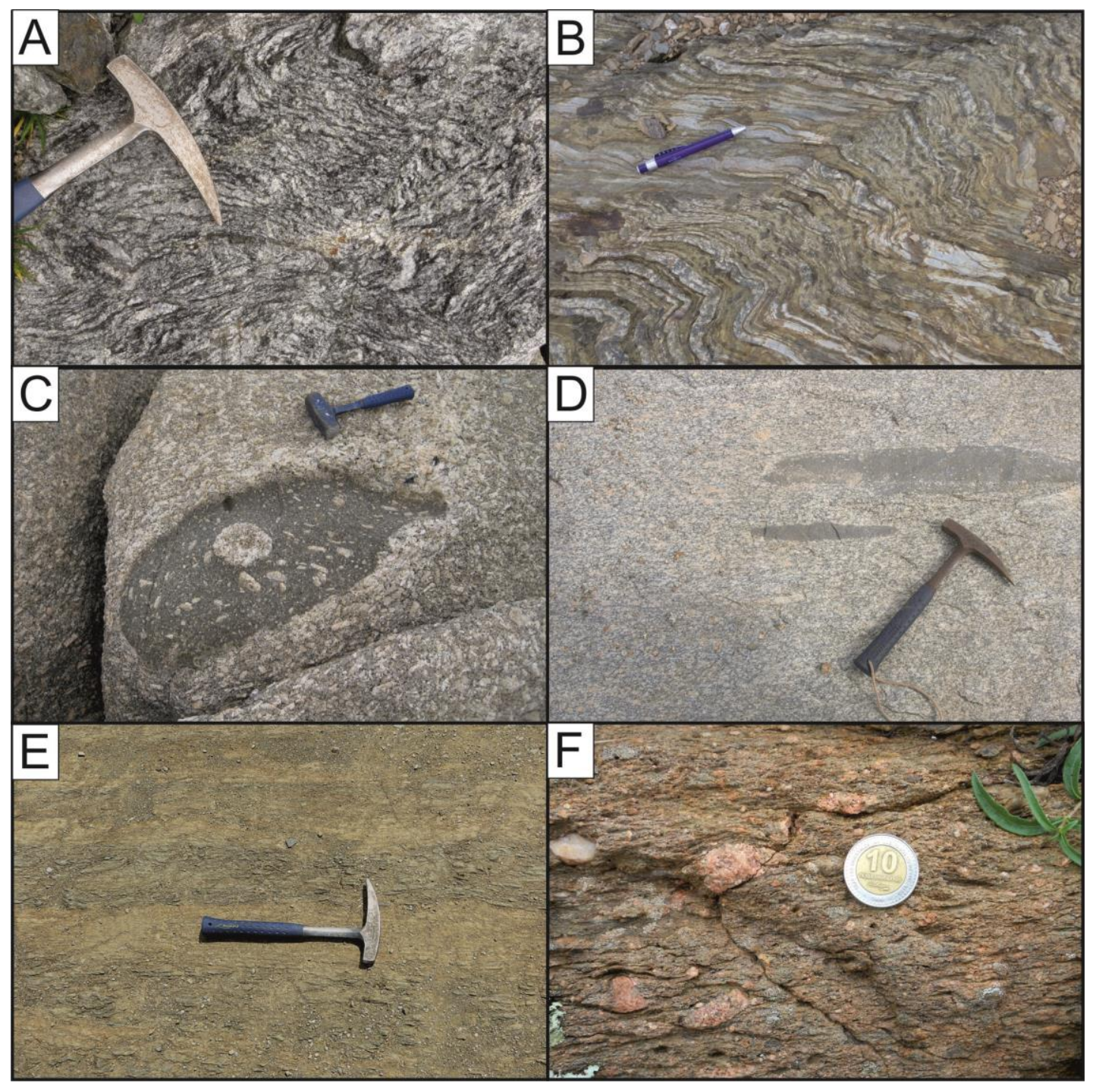

Figure 2.11: Some field aspects of rocks from the Uruguay sector of the Dom Feliciano Belt: a: Folded orthogneiss of the Cerro Olivo Complex; b: Folded metasediments of the Rocha Formation; c: Double enclave in the post-tectonic Santa Teresa Granite; d: Stretched mafic enclaves in the syn-tectonic Maldonado Granite, of the Aiguá Batholith; e: Compositional layering of metasediments and metabasic rocks of the Lavalleja Complex; note the strong foliation in the rock; f:Conglomerate of the San Carlos Formation

\subsubsection{Structural characterization of the Uruguayan Shield and main shear zones}

Most authors acknowledge two main deformation events associated with characteristic structures in the Uruguay sector of the orogen (Oyhantçabal et al. 2009; Oriolo et al. 2015, 2016a, b; Masquelín et al. 2017). The older structures include NW-verging NE-SW trending thrusts (Campal \& Schipilov 1999; Oyhantçabal et al. 2009). These occur as recumbent folds with subhorizontal mylonitic foliation and a flat-lying stripped foliation, recognized in the Archean orthogneisses of the La China Complex (Masquelin 
et al. 2017), in the Paleoproterozoic orthogneisses of the Campanero Unit (Oyhantçabal et al. 2009) and in the quartzites and metaconglomerates of the Las Tetas Complex (Fig. 2.10). This event does not affect the late Ediacaran foreland basins, and available geochronological data from several isotopic systems allow a rough constraint on the period of 630-600 Ma (Oriolo et al. 2016a, b). This event can be correlated with the collision between the Río de la Plata and Congo cratons, leading to the reworking of the Nico Pérez cratonic foreland and the closure of the Lavalleja Complex basin.

The final architecture of the belt is controlled by younger structures including NW-verging thrusts and NNE-striking sinistral transcurrent shear zones, with subhorizontal stretching lineation parallel to the fold axis of the metasediments in the low-strain domains (Oyhantçabal et al. 2009; Oriolo et al. 2016b). This event affects the late Ediacaran foreland basin sequences (Figs. 2.10 and 2.11e), and is well constrained by different isotopic systems in multiple minerals between 600 and $550 \mathrm{Ma}$ (Oyhantçabal et al. 2009, 2011a; Oriolo et al. 2016b). It is probably related to the convergence of the Kalahari Craton and the Río de la Plata-Congo cratons.

As in the entire extension of the Dom Feliciano Belt, the Uruguayan Shield is cut by numerous shear zones, both along terrane boundaries and within individual tectonic domains. The Sarandí del Yí Shear Zone represents the eastern boundary of the Río de la Plata Craton, separating it from the Nico Pérez Terrane (Oyhantçabal et al. 2011b; Oriolo et al. 2015). It has a N-S to NNW-SSE orientation and is exposed for over $200 \mathrm{~km}$. Its initial stage is characterized by dextral shear, as recorded in S- $\mathrm{C}^{\prime}$ shear bands in mylonites and protomylonites and in the bending of the structural framework in the Piedra Alta Terrane (Bossi \& Campal 1992; Oriolo et al. 2015; Sánchez-Bettucci et al. 2016). This stage is constrained by multiple geochronological methods at $630-600 \mathrm{Ma}$, under deformation conditions of $c a .650-600^{\circ} \mathrm{C}$ (Oriolo et al. 2015, 2016a, c). Subsequent deformations in the shear zone record pure-shear dominated sinistral shear, as recorded in tight to isoclinal symmetrical folds and shear indicators such as S-C' shear bands and $\sigma$-type feldspar mantled porphyroclasts (Oriolo et al. 2015). This event is constrained between 600 and $570 \mathrm{Ma}$, and took place under deformation conditions of $550-450^{\circ} \mathrm{C}$ (Oriolo et al. 2015, 2016a, c). Subsequent low-temperature deformation is suggested by pseudotachylite veins, phyllonites and cataclasites.

Separating the Aiguá Batholith from the Nico Pérez Terrane and metavolcano-sedimentary sequences, the Sierra Ballena Shear Zone has a NNE strike and is exposed for hundredths of $\mathrm{km}$. It is correlated with the Dorsal de Canguçú and Major Gercino shear zones in Rio Grande do Sul and Santa Catarina, respectively (Fernandes et al. 1992; Fernandes \& Koester 1999; Basei et al. 2000, 2005, 2008; 
Oyhantçabal et al. 2009, 2011a; Passarelli et al. 2010, 2011a). It is characterized by subvertical mylonites with subhorizontal stretching lineations, indicating sinistral sense of shear in such structures as S-C shear bands, $\sigma$ - and $\delta$-type feldspar mantled porphyroclasts and deflection of passive markers (Oyhantçabal et al. 2009). An important pure shear component is indicated by the common presence of tight to isoclinal folds with show axes parallel to the stretching lineation and textural analyses (Oyhantçabal et al. 2009). Deformation conditions are constrained at $\mathrm{ca} .550-400^{\circ} \mathrm{C}$ between at least 585 and $550 \mathrm{Ma}$ (Oyhantçabal 2005; Oyhantçabal et al. 2009, 2011a).

The main shear zones internal to the Nico Pérez Terrane are the NE-striking Sierra de Sosa Shear Zone, which separates Paleoproterozoic rocks of the Valentines-Rivera Granulitic Complex from the Archean La China Complex, and the NE- to NNE-striking María Albina Shear Zone, which separates the La China Complex from metasedimentary rocks of the Las Tetas Complex. Both record predominant sinistral shearing at ca. $600 \mathrm{Ma}$ with maximum deformation conditions of $c a .550^{\circ} \mathrm{C}$ (Oriolo et al. 2016b). Other subordinated NE- to NNE-striking shear in the western Dom Feliciano Belt include the sinistral Arroyo Corrales and Zapicán shear zones, which predominantly affect the schist belt (Oriolo et al. 2016b). A few oblique shear zones, such as the WNW Rivera Shear Zone and the ENE Tupambaé Shear Zone, affect the Nico Pérez Terrane in the Isla Cristalina de Rivera region (Oyhantçabal et al. 2012). They record sinistral and dextral shear, respectively, and were active between 600 and $550 \mathrm{Ma}$.

Finally, internal shear zones in the eastern Dom Feliciano Belt comprise several NE- to NNE-striking structures, including the Cordillera, Punta de las Palmas, Paso de los Talas, Cañada del Sauce and Cerro Amaro shear zones (Oyhantçabal et al. 2009; Spoturno et al. 2012; Oriolo et al. 2016b). They mostly indicate sinistral shear, but dextral displacements are also recognized. K-Ar data indicate shearing at $c a$. 632 and $615 \mathrm{Ma}$ for the Cordillera and Cerro Amaro shear zones, respectively (Oriolo et al. 2016b).

\subsection{Phanerozoic evolution of the southern South American Platform}

During the Phanerozoic, most of the southern portion of the South American Platform was covered by the large intracratonic Paraná Basin (known in Uruguay as the Norte Basin). During its sedimentary history, it experienced numerous cycles of subsidence and sedimentary gaps that are commonly associated with the far-flung influence of orogenetic processes in the southwestern margin of Gondwana (e.g. Zalán et al. 1990; de Santa Ana 2004; Rocha Campos et al. 2007). This process began with restricted rift deposition in the Ordovician and the Silurian. The main sedimentary stage, however, took place towards the end of the Paleozoic, with two supersequences deposited in large internal seas connected to 
the ocean in the Devonian and Permian (Assine et al. 1994; Milani et al. 2007; Holz et al. 2010). The Mesozoic was characterized by the deposition of thee more cycles in continental settings, with a restricted Triassic sedimentation and two larger cycles in the Cretaceous (Riccomini 1997; Zerfass et al. 2004).

The geodynamic context of the Paraná Basin was spectacularly disrupted in the early Cretaceous with the eruption of massive continental flood basalts, culminating in the extrusion of up to $2 \mathrm{~km}$ of volcanic rocks over an area above of 1 million $\mathrm{km}^{2}$ with remnants in Namibia and Angola. Most volcanic activity took place in a relatively short period, between 135 and 131 Ma (Renne et al. 1992; Ernesto et al. 1999; Thiede \& Vasconcelos 2010; Janasi et al. 2011). This association, known as the Paraná Large Igneous Province (Paraná LIP), also includes intrusive units such as dyke swarms interpreted as feeding systems (Piccirillo et al. 1990; Valente et al. 2007). In Santa Catarina, these associations are represented by the Florianópolis Dyke Swarm, comprising numerous doleritic dykes with a NNE-SSW direction (e.g. Florisbal et al. 2014). The continental magmatism was followed by the rifting and opening of the South Atlantic Ocean from the Hauterivian to the Albian, which progressed from south to north (Contreras et al. 2010; Moulin et al. 2010; Stica et al. 2014).

One particularity of the rifting event in the Uruguayan Shield is the installation of a rift corridor along the Santa Lucia-Aiguá-Merin Lineament (Rossello et al. 2000, 2007), which culminated in the onset of two pull-apart basins: the Laguna Merin in the northeast, and Santa Lucia in the southwest. The former is ca. 2,000 $\mathrm{m}$ thick and has a predominantly sedimentary infill, whereas the latter comprises up to a thousand meters of basaltic rocks coeval with the Paraná lava flows, later intruded by gabbro and trachyte complexes (Cernuschi et al. 2014). According to Rossello et al. $(2000,2007)$, the Santa Lucia-Aiguá-Merin Lineament began as an aborted rift during the opening of the South Atlantic Ocean and developed into a dextral transcurrent corridor, which helped expand the basins. The same authors points to the influence of Brasiliano-related structures on the lineament. Although the lineament cuts through shear zones of the crystalline basement in Uruguay, the boundaries of both basins are determined by the Sierra Ballena and Sarandí del Yí shear zones, creating a central domain on which only vestiges of the volcanosedimentary infill are preserved.

After the opening of the South Atlantic Ocean, the passive South American margin experienced intense exhumation, culminating in the uplift of coast-parallel ridges in south and southeast Brazil that frequently surpass $2,000 \mathrm{~m}$ in elevation. Those areas were traditionally the focus of most thermochronological studies, and major exhumation cycles were recognized in the Upper Cretaceous- 
Paleocene and later in the Paleogene (Tello Saenz et al. 2003; Hackspacher et al. 2004, 2007; Hiruma et al. 2010; Cogné et al. 2011, 2012). Most studies correlate such cycles to episodes of alkaline magmatism and pronounced tectonic activity in the Andean system (e.g. Cobbold et al. 2001; Hiruma et al. 2010; Cogné et al. 2011, 2012; Franco-Magalhães et al. 2014; Karl et al. 2013). Most of the Dom Feliciano Belt, however, has a less pronounced topography, mostly restricted to elevations below $500 \mathrm{~m}$. Recent research on such areas have revealed more detailed pre-rift exhumations stories (Oliveira et al. 2015b; Kollenz et al. 2016).

Previous thermochronological studies in the Dom Feliciano Belt suggest a long exhumation history during most of the Phanerozoic (Borba et al. 2002, 2003; Bicca et al. 2013; Karl et al. 2013; Kollenz 2015; Oliveira et al. 2015b, 2017). Evidences of syn- to post-rifting exhumation are restricted to the Catarinense Shield, and virtually absent on the Sul-rio-grandense and Uruguayan shields. 


\section{CHAPTER 3: Applied methods}

\subsection{Field work and sample collection}

Field work carried out for this thesis had the main objective of gathering structural data in outcrop scale and collecting samples both for structural and geochronological analyses. In total, a period of approximately two months was spent in the field, divided into three campaigns between 2014 and 2017.

During the acquisition of structural data in the field, special attention was given to detailed investigations of the main shear zones, in particular the Major Gercino Shear Zone in the Catarinense Shield and the Dorsal do Canguçu and Ibaré shear zones in the Sul-rio-grandense Shield, besides smaller intra-terrane structures. Oriented samples were collected for structural analyses in the laboratory, namely microstructural petrography and quartz crystallographic preferred orientation (CPO) analyses.

Sampling for K-Ar geochronology also focused on the main shear zones, and was applied to estimate the timing of middle- to low-temperature. In addition, sampling of representative units of the main lithostratigraphic units of the Dom Feliciano Belt and associated domains was carried out throughout the basement shields in order to evaluate the (U-Th)/He thermochronometers on a regional scale.

The material gathered in these field campaigns was complemented with a selection of samples available from previous researches in the study areas, culminating in a collection of over 150 samples which were treated for the various applied methods.

\subsection{Petrography}

Thin sections were predominantly confectioned from the XZ plane of the sampled rocks (parallel to the lineation and perpendicular to the foliation), and were analyzed with a polarizing microscope. Petrographic characterization focused on such features as mineralogical composition, critical metamorphic parageneses, and microstructural analysis aimed at estimating deformation mechanisms and conditions. Representative features were photographed with an attached digital camera for illustration.

\subsection{Quartz crystallographic preferred orientation analyses}

The development of preferential orientation of a specific mineral crystallographic geometry is a common result of rock deformation. This principle can be used as a powerful tool for analyzing texture and the mechanisms by which they were formed. Its most common application is on quartz, for its widespread 
geological occurrence and extensively studied deformational behavior. In combination with the traditional microstructural petrography, quartz CPO patterns are useful for estimating the mineral's slip systems that were activated during deformation, which are temperature-dependent, providing insights into the crystallization conditions of the analyzed rocks (e.g. Lister \& Hobbs 1980; Schmid \& Casey 1986; Stipp et al. 2002; Passchier \& Trouw 2005). In addition, they can be used as shear sense indicators by analyzing their asymmetry (Schmid \& Casey 1986), although such assumptions should be taken with care (e.g. Killian et al. 2011).

The electron backscatter diffraction (EBSD) technique detects the cloud of backscattered electrons when the beam from an electron microscope hits a crystalline structure and is refracted, reflecting the atom organization of the targeted crystalline structure (e.g. Lloyd et al. 1991; Prior et al. 1999). The analysis is performed by scanning a stationary polished surface with a tilted electron beam and examining the obtained diffraction patterns. This allows for a single-grain determination of the lattice orientation for every scanned crystal. The data is then organized in fabric diagrams, usually pole figures in which the horizontal axis is adjusted parallel to the rocks lineation, a similar procedure to that traditionally applied to optical U-stage measurements, but with a much higher resolution and in less time. In fact, the results from both techniques agree quite well, and are the most indicated to investigate a rocks' local texture and the mechanisms by which it was formed (Ullemeyer et al. 2000).

Samples of mylonites from the main shear zones were selected for analysis of their quartz CPO patterns with EBSD in the Bayerisches Geoinstitut of the Bayreuth University. Sections with an area of about 40 $\mathrm{mm}^{2}$ parallel to the lineation and perpendicular to the foliation were polished using a high $\mathrm{pH}$ silica solution (40-nm particle size) in order to remove damage from previous polishing steps. Samples were then analyzed with a Leo (now Zeiss) Gemini 1530 SEM with a Schottky emitter, and EBSD patterns were recorded with a Nordlys 2 camera and indexed with the Channel software package from Oxford Instruments. Mapping with a step size of $10 \mu \mathrm{m}$ yielded between 15,000 and 300,000 indexed points for quartz, depending on the sample. Discrete orientations were smoothed with Gaussian of $15^{\circ} \mathrm{FWHM}$ for pole figure analysis.

\subsection{K-Ar geochronology}

Dating of individual minerals by the $\mathrm{K}-\mathrm{Ar}$ and $\mathrm{Ar}-\mathrm{Ar}$ methods are among the most commonly used geochronological tools, and its long history of utilization has been transmitted into high-developed techniques with reliable results. 
Furthermore, the possibility of application of these methods for a wide array of minerals with different closure temperatures, such as hornblende $\left(530 \pm 40^{\circ} \mathrm{C}\right.$, Harrison 1982$)$, muscovite $\left(350-425^{\circ} \mathrm{C}\right.$, Purdy \& Jäger 1976; Harrison et al. 2009) and biotite (310 $\pm 40^{\circ} \mathrm{C}$, Harrison et al. 1985) can be used to obtain a detailed thermal history in the middle-temperature range. The dating of muscovite is particularly interesting for the investigation of shear zones, since common deformation processes in mylonitic rocks occur within its thermal range (e.g. Stipp et al. 2002; Passchier \& Trouw 2005).

$\mathrm{K}$-Ar dating of illite crystals falls within the low-temperature geochronological range, as illite crystallization begins under temperature conditions below that of the methods closure even for very fine-grained crystals (Purdy \& Jäger 1976; Harrison et al. 2009; Duvall et al. 2011). When used for the dating of the crystallization age of low metamorphic fine fractions, this method can set a limit age to the end of the mylonitization processes along shear zones. Another application is on the dating of illite clays in fault gouges, allowing the direct dating of brittle faulting, such as in the reactivation of older structures.

Sample preparation was carried out at the Georg-August-Universität Göttingen and at the Centro de Pesquisas Geocronológicas of the São Paulo University (CPGeo - USP). Coarse-grained mineral separation was performed by standard procedures, beginning with the crushing of the samples in a jaw crusher and sewing of the obtained material into different granulometric fractions, so as to obtain concentrated materials. An additional enrichment technique known as mica-jet was performed, which consists of passing a specific granulometric fraction through an upwards-streaming water jet, in order to separate floating sheet minerals from sinking isometric ones (Wemmer 1991).

Samples prepared for fine fractions were pulverized in a ring mill only for a short period of time, in order to prevent contamination of the finest fractions by means of a complete disintegration of coarsergrained sericitic crystals. The obtained material was sieved, and the $<63 \mu \mathrm{m}$ fraction was selected for granulometric separation. Fault gauge samples, on the other hand, were directly sieved to $<63$ um after being dispersed in water. For both types of samples, three grain-size fractions were extracted and measured for each sample: $2-6 \mu \mathrm{m},<2 \mu \mathrm{m}$ and $<0.2 \mu \mathrm{m}$. The first two fractions were obtained by means of differential setting in water using the Atterberg method, whilst the latter was enriched using ultracentrifugation.

Potassium and Argon were measured independently for the dating. The Ar isotopic concentrations were obtained with an Argus VI (Thermo Fisher) noble gas mass spectrometer coupled to a glass extraction and purification vacuum line. Radiogenic ${ }^{40} \mathrm{Ar}$ concentrations were determined by isotope dilution 
method using an enriched ${ }^{38} \mathrm{Ar}$ spike (Schumacher 1975), calibrated against the biotite standard HD-B1 (Fuhrmann et al. 1987). Flame photometry was used to determine the amount of $\mathrm{K}$ in samples dissolved in a mixture of $\mathrm{HF}$ and $\mathrm{HNO}_{3}$ using an BWB-XP flame photometer.

\subsection{Illite characterization using X-ray diffraction}

All dated fractions were characterized using X-ray diffraction (XRD) of both air-dried and ethylene glycolsolvated preparations in order to estimate their mineralogical content, the crystallinity of the measured illite and the relative content of the different illite polytypes. The latter two are useful for inferring the temperature conditions on which the illite was formed.

Illite crystallinity is derived from the peak width at half height of the $10 \AA$ illite peak, measured on oriented samples (Kübler Index). Boundaries set by Kübler (1967) on specific widths are used to separate the zones of very low grade metamorphism, which are, from the lowest to the highest, the diagenetic zone, the anchizone and the epizone. The temperatures that set the boundaries between the diagenetic zone and the anchizone and between the anchizone and the epizone correspond approximately to $200^{\circ} \mathrm{C}$ and $300^{\circ} \mathrm{C}$, respectively (Merriman \& Frey 1999).

Illite polytype analysis corresponds to the relative concentration of three main illite polytypes in the analyzed material, $1 M_{d}, 1 M$ and $2 M_{1}$. Since illite suffers irreversible polytype transformation from the $1 \mathrm{M}_{\mathrm{d}}$ polytype to the $1 \mathrm{M}$ and then $2 \mathrm{M}_{1}$ varieties with increasing temperature and pressure (Hunziker et al. 1986), it is assumed that the presence of $1 \mathrm{M}_{\mathrm{d}}$ and $1 \mathrm{M}$ polytype indicates diagenetic conditions, whereas in the anchizone there is a mixture between $1 M$ and $2 M_{1}$, and in epizone conditions solely $2 M_{1}$ illite remains (Środoń \& Eberl 1984). This is quantified using XRD patterns from randomly oriented samples. For this analysis, the concentration of the $2 \mathrm{M}_{1}$ polytype is determined by comparing peaks specific to it with peaks common to all illite polytypes (method after Grathoff \& Moore 1996, following techniques from Ksienzyk et al. 2016). Evaluation of the XRD spectra was done using the software IFORS (Lünsdorf \& Lünsdorf 2016), which modelled the signal into pseudo-Voigt functions with a maximum width of $0.3^{\circ} 2 \theta$, approximating a baseline using a second order polynomial. $2 \mathrm{M}_{1}$ percentages were calculated dividing the height of five polytype-specific peaks by the height of the $2.58 \AA$ band using coefficients of Grathoff \& Moore (1996). For each sample, an average $2 \mathrm{M}_{1}$ percentage was calculated, and standard deviation was used as the uncertainty of the analysis. Fig. 3.1 exemplifies one such polytype analysis. 


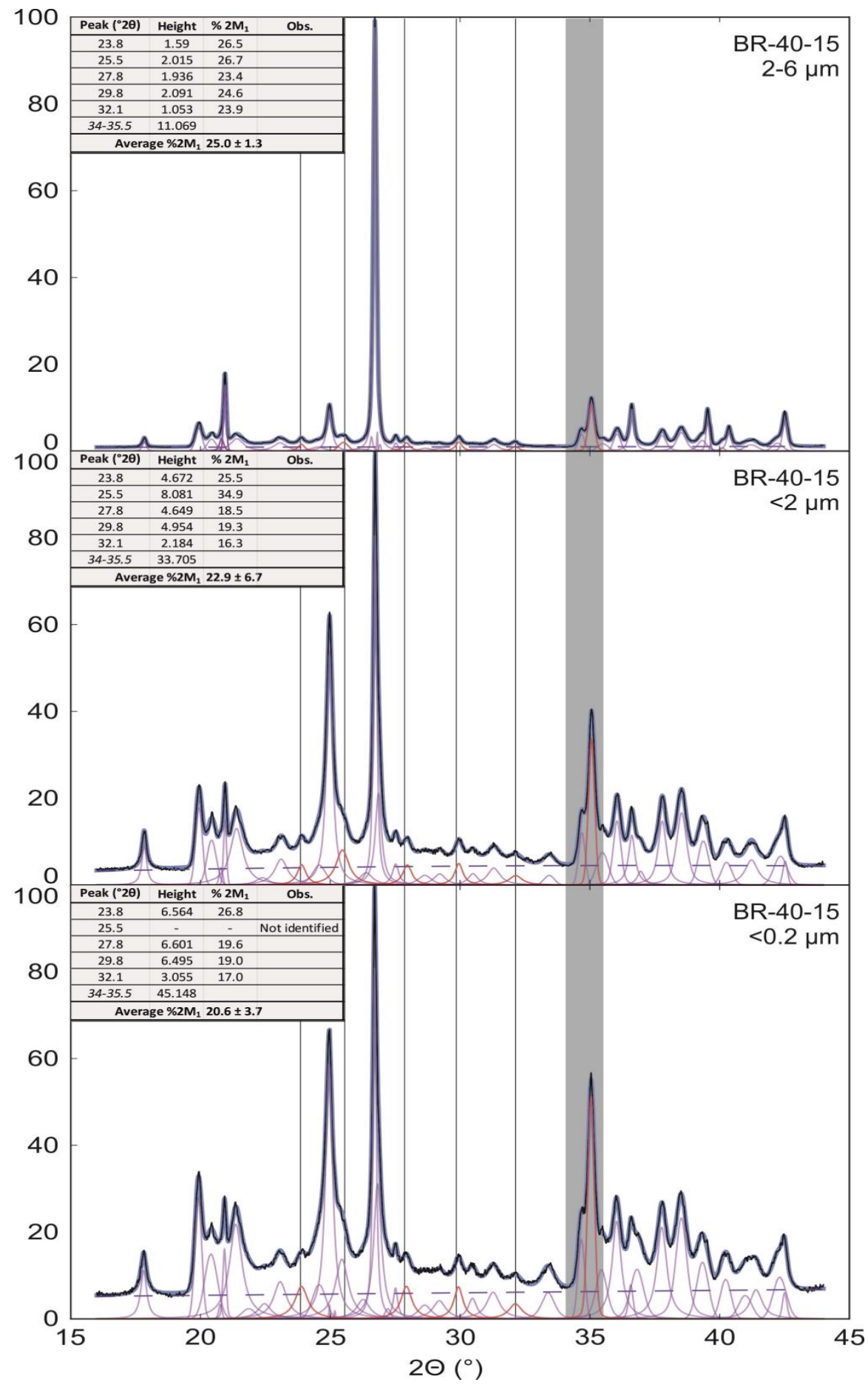

Figure 3.1: Example of $2 \mathrm{M}_{1}$ illite polytype quantification on the three dated fractions of Sample BR-40-15 (results are discussed in Chapter 7). The XRD patterns were obtained from randomly oriented samples. For determination of the amount of $2 \mathrm{M}_{1}$, the height of the polytype-specific peaks at $23.8,25.5,27.8,29.8$ and $32.1^{\circ} 2 \theta$ is compared to the height of the 34-35.5 band common to all polytypes. In the case of this specific analysis, the peak at $25.5^{\circ} 2 \Theta$ of fraction $<0.2 \mu \mathrm{m}$ is partially covered by the much higher kaolinite peak at $c a .25^{\circ} 2 \Theta$ and could not be properly identified. Method after Grathoff \& Moore (1996), following techniques from Ksienzyk et al. (2016). 


\section{6 (U-Th)/He geochronology}

The radioactive decay of ${ }^{238} \mathrm{U},{ }^{235} \mathrm{U}$, and ${ }^{232} \mathrm{Th}$, long used for determining radiogenic ages of minerals and rocks, produces ${ }^{4} \mathrm{He}$ by means of alpha emission. This principle was tentatively used to determine geological meaningful ages since the first developments with radiation, but only after the 1980's, with a better comprehension of He diffusion in minerals, did researchers begin to use this method to obtain closure ages of very low temperatures (Farley 2002).

With the definition of ranges for the partial retention zone (PRZ) of a number of minerals, most notably Apatite (ca. $40-80^{\circ} \mathrm{C}$, Farley 2002) and Zircon (ca. 160-200 ${ }^{\circ} \mathrm{C}$, Reiners et al. 2004), and a surge in research focused on understanding the factors that impact the diffusion of He in these minerals (e.g. Flowers et al. 2009; Spiegel et al. 2009; Flowers \& Kelley 2011; Ault \& Flowers 2012; Gautheron et al. 2013; Guenthner et al. 2013), (U-Th)/He dating has been successfully applied to a variety of topics, such as the interpretation of uplift and orogenic building, basin evolution, denudation and landscape development and near surface tectonics.

An important development of the method in recent years is the understanding of the influence of a crystal's radioactive content in its He diffusivity, and how it can lead to varying closure temperatures within a same geological context (Flowers et al. 2009; Guenthner et al. 2013). This is particularly important in old stable areas with prolonged residence in near-surface conditions, on which the long accumulation of radiation damage amplifies this effect (Ault et al. 2009; Flowers \& Kelley 2011; Murray et al. 2016; Orme et al. 2016; Powell et al. 2016; Guenthner et al. 2017; Johnson et al. 2017). In these cases, it is possible to use the concentration of radioactive elements in each measured crystal, expressed in its effective uranium content $(\mathrm{eU}, \mathrm{U}+0.235 * \mathrm{Th}$, in $\mathrm{ppm})$, as a tool for constraining detailed thermal histories.

Work on the mineral separation was divided between laboratories in the Georg-August-Universität Göttingen and at the Centro de Pesquisas Geocronológicas of the São Paulo University (CPGeo - USP). For the process of mineral concentration, each sample was crushed in a jaw crusher with an opening of about a millimeter. The obtained material was sieved with a $250 \mu \mathrm{m}$ net and the smaller fraction was separated in a wet vibration table. The heaviest aliquot was bathed in weak acetic acid for three days in order to eliminate carbonates, and later washed in acetone and left to dry, thus preventing oxidation of the material. After extracting ferromagnetic minerals with a hand magnet, the remaining fraction was submitted to a magnetic separation with a lateral and longitudinal tilts of $20^{\circ}$ in an 1.0 Ampere field. The 
non-magnetic portion underwent a gravimetric separation utilizing a heavy lithium metatungstate liquid with the commercial name LST, with a density of $c a$. 2.9. The resulting heavy-mineral fraction concentrated both zircon and apatite.

Having obtained mineral concentrates from a big number of samples, it was possible to carefully select the most relevant samples for the low-temperature geochronology study. Priority was given to rocks which yielded both quality zircon and apatite, as they have the potential of revealing more detailed geological evolutions. For the analytical phase, three individual mineral aliquots of both zircon and apatite were handpicked for each sample using binoculars and petrologic microscope. Only euhedral, clear, inclusion- and fissure-free crystals with a minimum diameter of $60 \mu \mathrm{m}$ were selected, preferentially with presence of both pyramidal terminations. Crystal measurements like width, total length and length of the prismatic section were taken from calibrated microphotographs for the calculation of $\alpha$-ejection correction ("Ft-correction", Farley et al. 1996).

For the extraction of Helium, each crystal was wrapped in platinum capsules and heated in high vaccum with an infrared laser. The extracted gas was purified at $450^{\circ} \mathrm{C}$ with a SAES Ti-Zr getter, and the remaining inert gases were measured in a HidenR triple-filter quadrupole mass spectrometer equipped with a positive-ion-counting detector. In order to control the efficiency of the gas extraction, a reextraction was performed for each crystal.

After the He extraction, crystals were spiked with calibrated ${ }^{230} \mathrm{Th}$ and ${ }^{233} \mathrm{U}$ solutions and dissolved in acid. For zircon, this process used distilled $48 \% \mathrm{HF}+65 \% \mathrm{HNO}_{3}$ solutions in pressurized teflon bombs at $220^{\circ} \mathrm{C}$ during 5 days, while apatite was dissolved using $4 \% \mathrm{HNO}_{3}+0.05 \% \mathrm{HF}$ at room temperature in an ultrasonic bath. Parent isotopes were measured with a Thermo iCAP Q ICP-MS or using a Perkin Elmer Elan DRC II mass spectrometer with a MicroFlow nebulizer. The isotope dilution method was used for $U$ and Th, and external calibration was applied for $\mathrm{Sm}, \mathrm{Ca}$ and $\mathrm{Zr}$. The obtained data was reduced using the MASsoft (Hiden) and PEPITA (Dunkl et al. 2008) software.

\subsection{Raman spectroscopy}

The amount of alpha-radiation damage a zircon crystal has experienced influences its He retentivity, and can be expressed as a function of the concentrations of $U$, Th and of the time during which damage was accumulated. Raman spectroscopy can be used as a proxy for estimating the alpha-radiation damage density, using the width of the v3 $\left(\mathrm{SiO}_{4}\right)$ Raman band at ca. $1000 \mathrm{~cm}^{-1}$ (Nasdala et al. 2001; Palenik et al. 2003). 
Measurements were made using two systems. The first consists of a Horiba Jobin-Yvon Labram HR800UV with a red unpolarized laser $(633 \mathrm{~nm})$, a $2400 \mathrm{l} / \mathrm{mm}$ grid and a CCD detector, coupled to a Olympus BX41microscope. The second is a Horiba XPloRa Plus system, equipped with a 532nm green excitation laser (20-25 mW maximum output power) and an Olympus BX41 microscope coupled to a 200 $\mathrm{mm}$ focal length spectrograph with a four-grating turret (2400 I/mm; $1800 \mathrm{l} / \mathrm{mm} ; 1200 \mathrm{l} / \mathrm{mm} ; 600 \mathrm{l} / \mathrm{mm})$. This system has a Multi-Pinned-Phase (MPP) open-electrode CCD detector.

Each zircon crystal was measured in one to two spot, using a $2400 \mathrm{l} / \mathrm{mm}$ grid for $2 * 15 \mathrm{sec}$ at $100 \%$ laser energy with a $20 x$ objective. The spectral resolution is approximately 1 pixel, corresponding to $\sim 1.0 \mathrm{~cm}-1$ for the used setting. Evaluation of the spectra was done using the software IFORS (Lünsdorf \& Lünsdorf 2016). Fitted peak widths were corrected for the apparatus function after Irmer (1985) and Nasdala et al. (2001). For crystals measured more than once, mean values were used for subsequent analyses. 


\section{CHAPTER 4: Evolution of Neoproterozoic shear zones in the Sul-rio-grandense Shield}

\subsection{Introduction}

Shear zones are structures of particular importance in the crust, in which they act as terrane boundaries, juxtapose unrelated lithostratigraphic units and accommodate deformation in all kinds of settings (e.g. Cosca et al. 1995; Ghosh et al. 2004; Fossen \& Cavalcante 2017). An effect of strain localization in shear zones during orogenic processes is that such structures become preferential sites for reactivation, which can lead to multiple deformation events throughout long geological periods in different tectonic settings. This geological evolution can be explored by applying different geochronological techniques and reconstructing the structure thermal evolution, thus offering insights into their tectonic and geodynamic significance (van der Pluijm et al. 1994; de Wit et al. 2001; Streepey et al. 2001; Oriolo et al. 2016a, b, 2018b; Egli et al. 2017).

In this chapter, the tectonic evolution of the Sul-rio-grandense Shield (Fig. 4.1) is examined by interpreting the evolution of its major shear zones. New structural observations in macro- to microscale, associated with quartz crystallographic preferred orientation (CPO) textural analyses are used to interpret the deformation conditions of the main structures. This is evolution is correlated with the available geochronological dataset and complemented with new $\mathrm{K}-\mathrm{Ar}$ analyses focusing on the main ductile crystallization events, and including illite analyses for characterizing the transition into brittle deformation conditions.

\subsection{Structural characterization}

Three areas of the Sul-rio-grandense Shield were selected for detailed study in order to investigate the role of shear zones during the Neoproterozoic tectonic events. These include the two major ductile terrane boundaries that are exposed, the Dorsal do Canguçu and Ibaré shear zones, and the central expositions of the Tijucas Terrane in the Santana da Boa Vista and Capané regions. Each area will be detailed in the following sections. Field photographs of the main structural aspects of each area are presented in Fig. 4.2. 

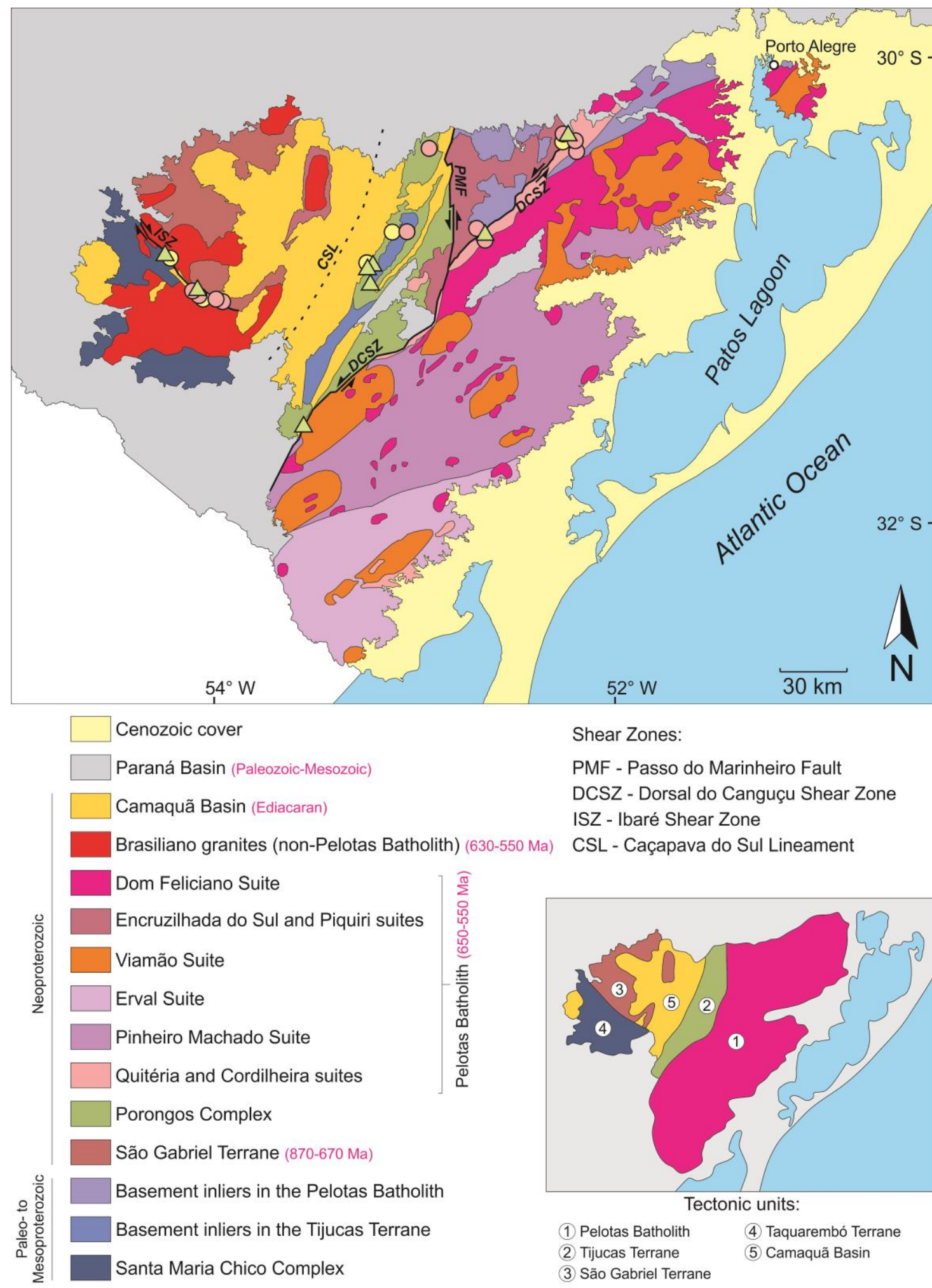

Shear Zones:

PMF - Passo do Marinheiro Fault DCSZ - Dorsal do Canguçu Shear Zone ISZ - Ibaré Shear Zone

CSL - Caçapava do Sul Lineament

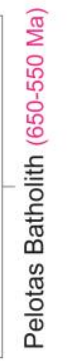

\section{Samples: $\triangle \mathrm{EBSD}$}

$\mathrm{K}-\mathrm{Ar}$ in $\mathrm{Ms}$

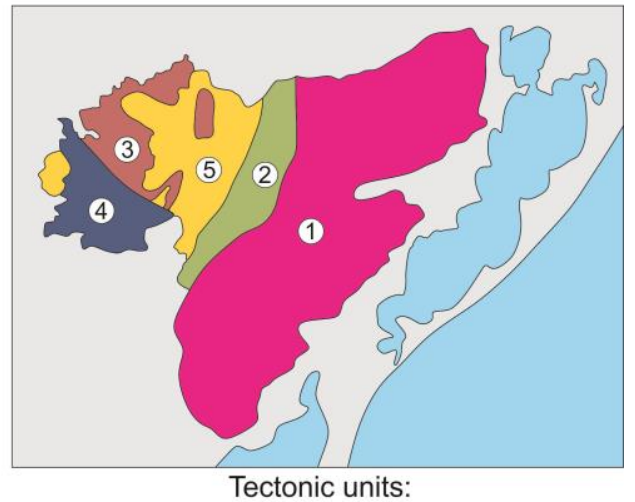
(1) Pelotas Batholith
(4) Taquarembó Terrane
(2) Tijucas Terrane
(5) Camaquã Basin
(3) São Gabriel Terrane

Figure 4.1: Geological map of the Sul-rio-grandense Shield with location of the analyzed samples. Modified from Wildner et al. (2006), Saalmann et al. (2011) and Philipp et al. (2016a) 


\subsubsection{Dorsal do Canguçu Shear Zone}

The Dorsal do Canguçu Shear Zone is the largest tectonic boundary in the Sul-rio-grandense Shield, separating the Pelotas Batholith from the Tijucas Terrane with a NE-SW direction for ca. $200 \mathrm{~km}$. Its position in the shield is correlated to that of the Major Gercino and Sierra Ballena shear zones in Santa Catarina and Uruguay, respectively, constituting a lineament over 1,000 km long through the entire Dom Feliciano Belt (Mantovani et al. 1989; Basei et al. 2000, 2005, 2008; Oyhantçabal et al. 2007, 2010; Passarelli et al. 2011a; Oriolo et al. 2016b). This lineament is interpreted to represent a Neoproterozoic suture associated with the closure of the Adamastor Ocean (e.g. Basei et al. 2000, 2005, 2008, 2018; Passarelli et al. 2011a). In its central portion, the shear zone is transversed by the brittle Passo do Marinheiro Fault. It should be noted that the structure is sometimes referred to as Cordilheira Shear Zone in the literature.

Sin-kinematic emplacement of granites accompanied the evolution of the Dorsal do Canguçu Shear Zone, affecting rocks mostly grouped into the Cordilheira and Quiteria suites. While the former includes porphyritic granodiorites with strong mantellic input, the latter comprises S-type granites (Nardi \& Frantz 1995; Fernandes \& Koester 1999; Koester et al. 2001a, b; Philipp \& Machado 2005; Philipp et al. 2013). Dating of these intrusions constrains the evolution of the shear zone between 658 and $605 \mathrm{Ma}$ (Frantz et al. 2003; Philipp et al. 2016a), establishing a remarkably long intrusive history. The old ages correspond to the earliest pulses of granitic magmatism within the Pelotas Batholith.

Macro- and microstructures record a transition from magmatic conditions, which contributed for most of the strain accommodation, to solid-state deformation during transcurrence under a cooling trajectory (Fernandes et al. 1993; Tommasi et al. 1994). The latter is responsible for the formation of extensive mylonite belts. Besides granitic mylonites, quartz-mylonites and phyllites occur sporadically along the shear zone's extension (Figs. 4.2a, 4.2b). Locally the quartz-mylonites have thicknesses of up to a few tens of meters (Fig. 4.2a), forming small aligned ridges that stand out in the geomorphology.

The mylonitic foliation is predominantly subvertical or has steep dips to NW, with strikes mostly between $\mathrm{N} 85^{\circ} \mathrm{E}$ to $\mathrm{N} 45^{\circ} \mathrm{E}$ (Fig. 4.3). These are accompanied by stretching lineations mostly subhorizontal and strike-parallel, with some low plunges (up to $20^{\circ}$ ) to SW. Isoclinal intrafolial folds are present locally (Fig. 4.2b), with subhorizontal fold axes that are mostly parallel to the stretching lineation. Shear sense indicators such as shear bands and rotated mantled porphyroclasts predominantly indicate sinistral displacement. 


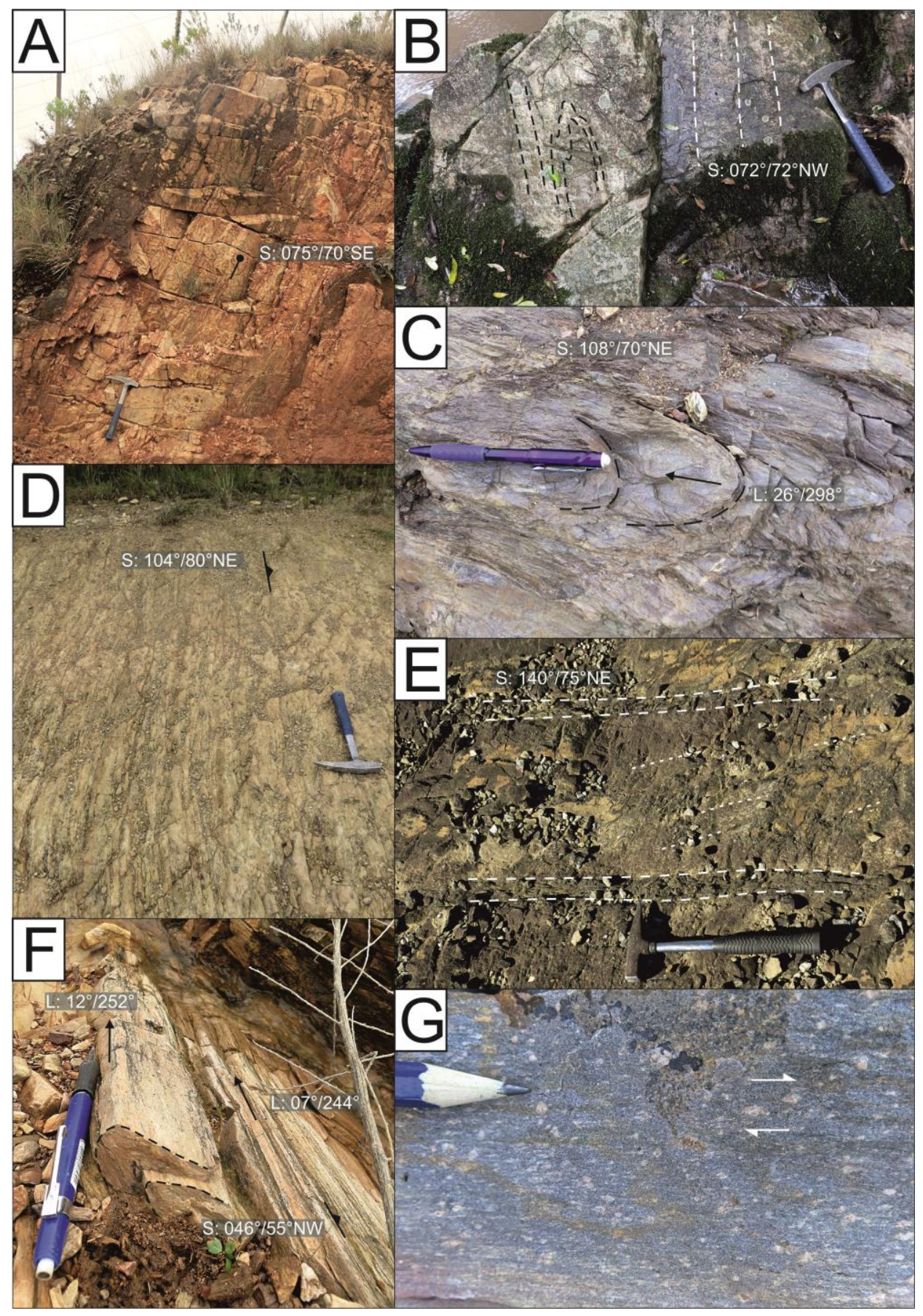

Figure 4.2: Field photographs of rocks and structures of the main shear zones and mylonites of the Sul-riograndense Shield: a: Quartz mylonites on the Dorsal do Canguçu Shear Zone; b: Mylonites associated with synkinematic intrusion along the Dorsal do Canguçu Shear Zone. Note the presence of intrafolial fold; c: Metapelites along the Ibaré Shear Zone with recumbent folds; d: Subvertical mylonitic band on metapelite of the Ibaré Shear Zone; e: Centimetric shear bands on metapsamite of the Ibaré Shear Zone. Note the original reworked foliation; f:

Folded quart-mylonites of the Tijucas Terrane with fold axis subparallel to the stretching lineation; g: Granitic mylonite of the syn-kinematic Capané Granite, in the Tijucas Terrane 


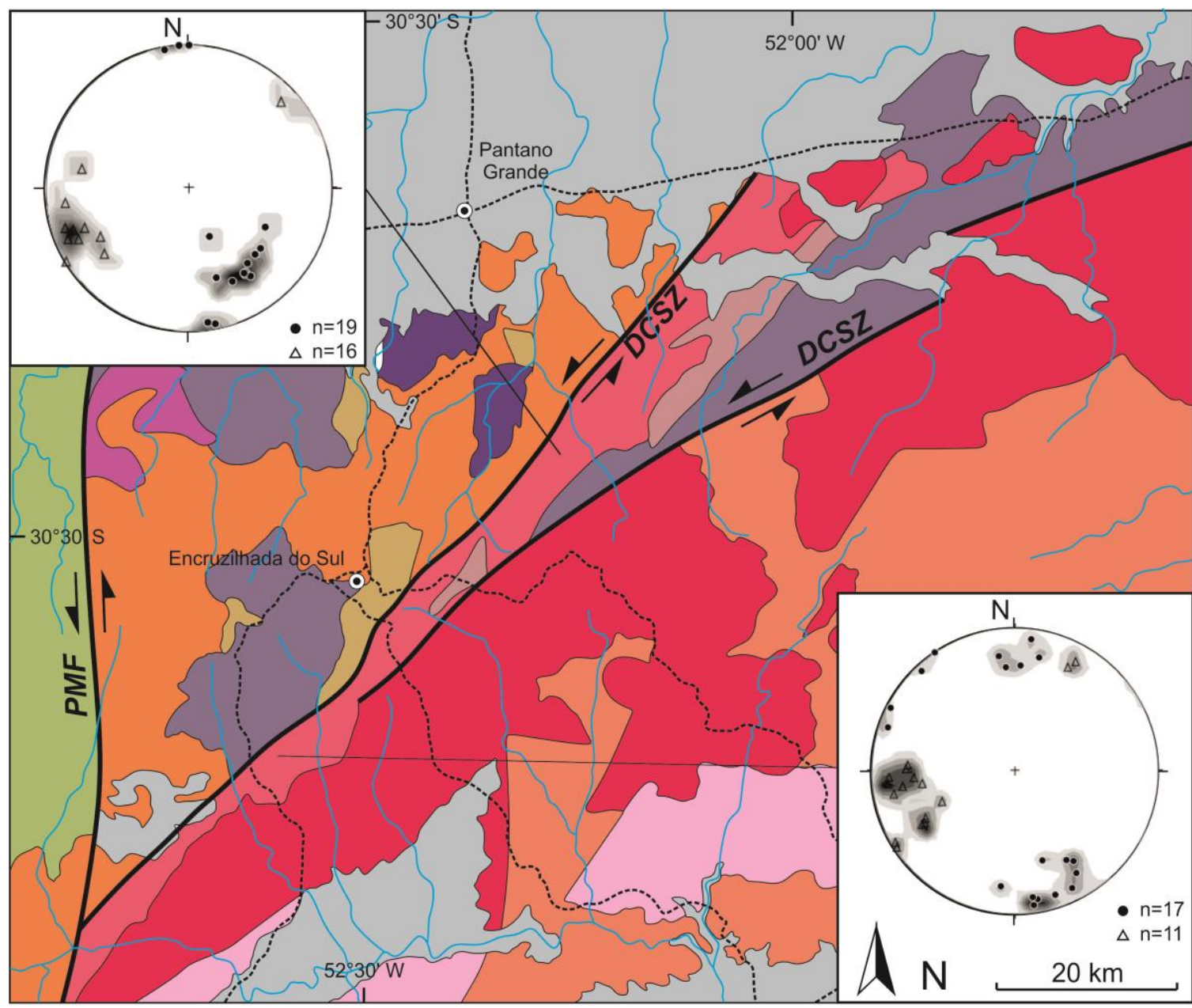

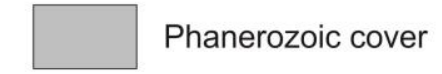

\section{Pelotas Batholith}
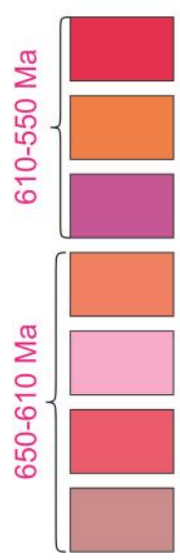

Dom Feliciano Suite

Encruzilhada do Sul Suite

Piquiri Suite

Viamão Suite

Pinheiro Machado Suite

Cordilheira Suite

Quitéria Suite
Porongos Complex Neoproterozoic

\section{Basement inliers}

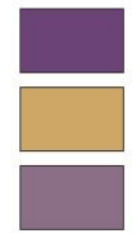

Capivarita Anorthosite $1,57 \mathrm{Ga}$

Várzea do Capivarita Complex

Arroio dos Ratos Complex 2.2 - 2.0 Ga

Figure 4.3: Geological map and structural data of the northeastern portion of the Dorsal do Canguçu Shear Zone. Black circles: mylonitic foliation, hollow black triangles: stretching lineation. Modified from Wildner et al. (2006) and Philipp et al. (2016a). DCSZ: Dorsal do Canguçu Shear Zone; PMF: Passo do Marinheiro Fault 


\subsubsection{Ibaré Shear Zone}

Despite constituting an important terrane boundary between the São Gabriel and Nico Pérez (Taquarembó) terranes, the Ibaré Shear Zone has been relatively little studied in detail. This is in part due to the fact that large portions of its original lineament are masked by the intrusion of later granites and by the deposition of sediments both from the Ediacaran Camaquã Basin and from the Paleozoic Paraná Basin. The structure is unique in the context of the Sul-rio-grandense Shield for having a NW-SE orientation, striking mostly between $\mathrm{N}^{\circ} \mathrm{W}$ and $\mathrm{N} 50^{\circ} \mathrm{W}$ for almost $100 \mathrm{~km}$. It is interpreted to represent an escape shear zone along a lateral ramp during the SW-verging accretion of the São Gabriel Terrane to the Nico Pérez (Taquarembó) Terrane (Philipp et al. 2016a, 2018).

The shear zone is exposed predominantly in areas dominated by metasedimentary rocks, mapped as part of the Arroio Marmeleiro, Ibaré and Coxilha do Batovi complexes (Camozzato et al. 2012; Laux et al. 2012; Philipp et al. 2016a, 2018). Philipp et al. (2016a, 2018) correlate these units to the Passo Feio Complex and interpreted them as Neoproterozoic metavolcano-sedimentary sequences deposited during the early stages of the evolution of the São Gabriel Terrane. For the sequences along the Ibaré Shear Zone, its conspicuous position along the terrane border might indicate that they were deposited on the passive margin of the Nico Pérez (Taquarembó) Terrane (e.g. Philipp et al. 2018). The entire region is also intruded by a post-tectonic multi-suite granitic association with ages between 635 and 570 Ma (Philipp et al. 2016a; Camozzato et al. 2016).

The dominant lithologies within the Ibaré Shear Zone are phyllites, metapelites and metapsamites (Figs. $4.2 \mathrm{c}, 4.2 \mathrm{~d}, 4.2 \mathrm{e}$ ). Locally, mylonites to ultra-mylonites with stretched feldspar porphyroclasts might indicate the juxtaposition of sheared gneiss-granitic rocks or metagraywackes within the structure. Phyllites are composed essentially by sericite, quartz and/or chlorite. Coarser-grained rocks include muscovite-quartz schists, occasionally with graphite, quartz-mylonites with sericite, and quartz-feldspatic mylonites with muscovite. The metasediments record a polyphase deformational history that might not represent a single evolution for all units contained along the structure (Fig. 4.2c). The main foliation is a transposition of at least one previous deformation phase, but primary sedimentary structures are preserved locally (e.g. Camozzato et al. 2012; Laux et al. 2012). It mostly strikes with a NW-SE orientation but can be inflected to E-W and even slightly to NE-SW (Fig. 4.4). It typically has gentle to moderate dips, predominantly to N, that is, towards the São Gabriel Terrane, but locally also in the opposite direction. 


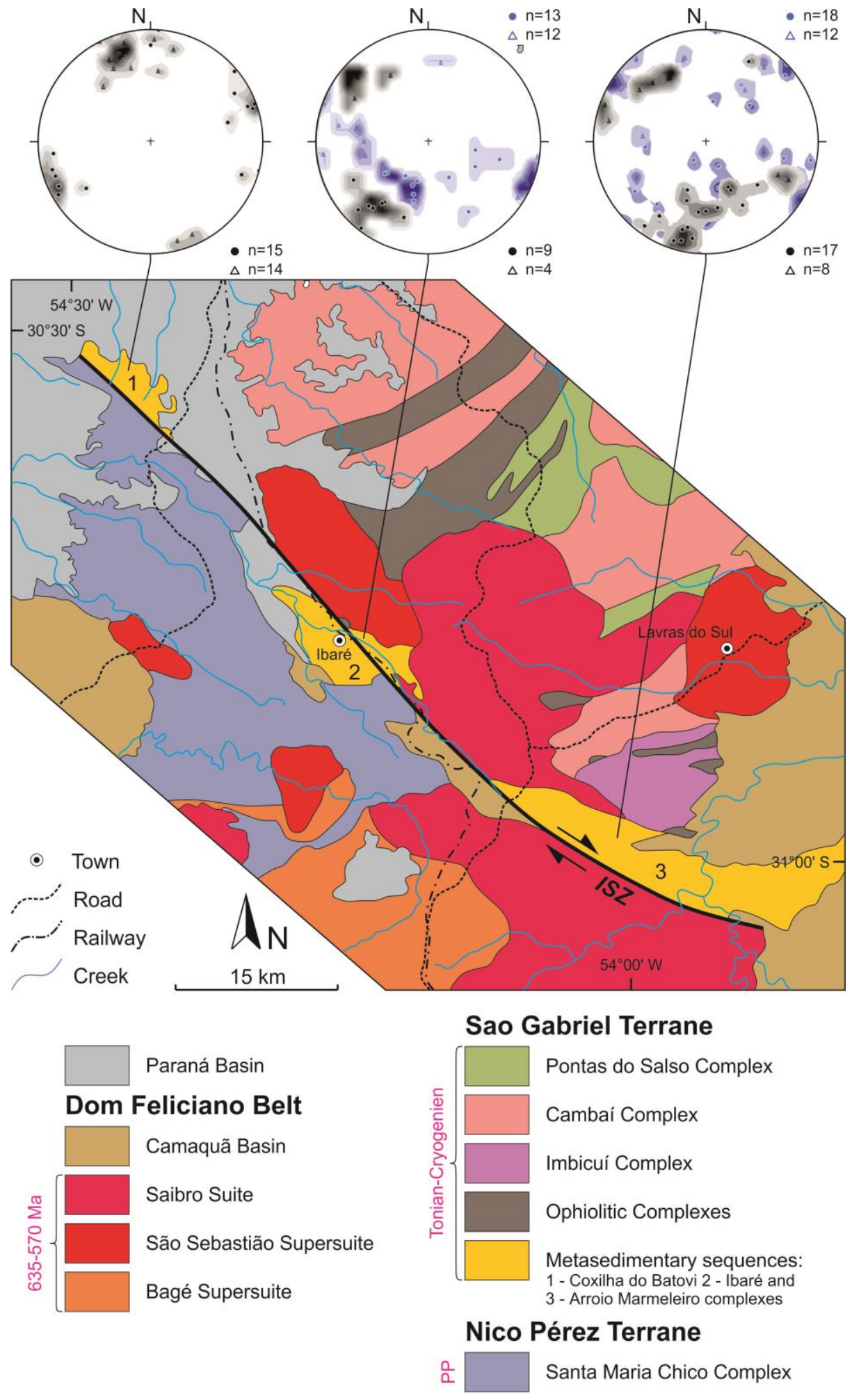

Figure 4.4: Geological map and structural data of the Ibaré Shear Zone. Black circles: mylonitic foliation, hollow black triangles: stretching lineation, blue circles: non-mylonitic foliation, blue hollow triangles: non-mylonitic lineations and fold axes. Modified from Wildner et al. (2006), Laux et al. (2012) and Philipp et al. (2016a, 2018). ISZ: Ibaré Shear zone; PP: Paleoproterozoic 
These structures are reworked in high-strain belts with widths from a few decimeters to several meters, on which the predominant lithologies are mylonites and phyllites (Fig. 4.2e). They have a systematic variation from subvertical NW-SE strikes within the NW part of the structure to high-angle dips to NE in the central portion to moderate dips to $\mathrm{N}$ in the SE extremity (Fig. 4.4). Shear sense indicators are fairly rare within the structure, and conflicting shear senses have been reported (Luzardo et al. 1990; Camozzato et al. 2012; Laux et al. 2012). Based on the inflection of the internal structural framework of the São Gabriel Terrane closest to the shear zone, the terrane boundary is mostly interpreted as having accommodated dextral displacement (Philipp et al. 2016a, 2018).

The entire region is cut by numerous brittle faults, parallel to the main lineament. They have controlled the deposition and preservation of sediments from the Camaquã Basin and from the Paleozoic sequences of the Paraná Basin in graben-like structures. In addition, many of the later granitic intrusions, posterior to the main deformation along the shear zone, are limited by the shear zone's lineament on both sides of the structure, such as the Santa Rita, Saibro and Jaguari granites (Camozzato et al. 2012; Laux et al. 2012; Philipp et al. 2016a). These intrusions are affected by widespread cataclastic domains and narrow ductile-brittle deformation bands.

\subsubsection{Tijucas Terrane}

The Tijucas Terrane is characterized by a polyphasic structural evolution, reflecting the association of crystalline basement, such as the Encantadas Gneiss, with overlying metavolcano-sedimentary sequences grouped into the Porongos Complex. While the Encantadas Gneiss has been deformed multiple times still in the Paleoproterozoic, the deformation of the Porongos Complex is associated with the Neoproterozoic São Gabriel and Dom Feliciano events (Saalmann et al. 2006a, 2007, 2011; Philipp et al. 2008, 2016a). The main expression of this event is the development of a transposition foliation under greenschist to amphibolite conditions, in association with NW-verging thrusting and stacking, folding the sequence into regional-scale structures (Jost 1981).

Mylonitic rocks are common throughout the Tijucas Terrane, and occur in a complex relationship with its surrounding units. The most common lithotypes are fine-grained quartz mylonites and mylonitic to ultramylonitic granites, commonly occurring between the Paleoproterozoic basement inliers and metapelites of the Porongos Complex (Figs. 4.2f, 4.2g). The basement exposition in the Santana da Boa Vista region includes an extensive unit of ultra-mylonitic granites (e.g. Philipp et al. 2016a), associated with quartz-mylonites that are interpreted to represent Paleoproterozoic units predating the main Porongos Complex (Pertille et al. 2015a, b, 2017). This assemblage has been correlated with rocks in the 
Capané region, where quartz-mylonites and quartz-feldspatic mylonites in the central portion of the dome yielded exclusively Paleoproterozoic signatures, in contrast to juxtaposed schists with abundant Ediacaran zircon populations (Höfig et al. 2018). In the same region, mylonitic granites are concordant with the metasediments (Fig. 4.2g) and were dated at ca. $605 \mathrm{Ma}$ (Philipp et al. 2016a; Zvirtes et al. 2017).

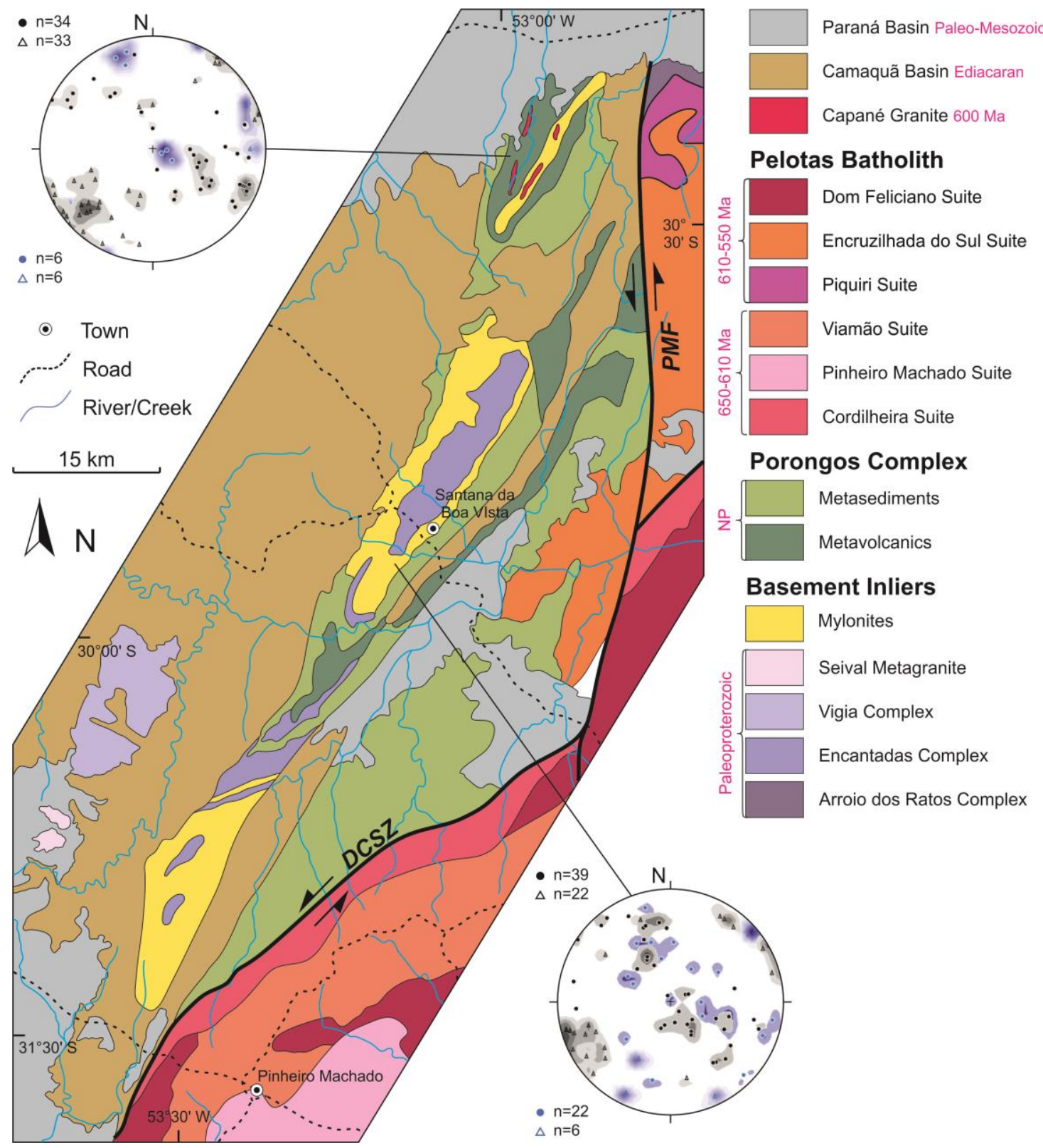

Figure 4.5: Geological map and structural data of the Tljucas Terrane. Black circles: mylonitic foliation, hollow black triangles: stretching lineation, blue circles: non-mylonitic foliation, blue hollow triangles: non-mylonitic lineations and fold axes. Modified from Wildner et al. (2006), Camozzatto et al. (2013), Philipp et al. (2016a) and Höfig et al. (2018). DCSZ: Dorsal do Canguçu Shear Zone; PMF: Passo do Marinheiro Fault; NP: Neoproterozoic 
The main mylonitic units of the Tijucas Terrane are structurally concordant with the deformation of the Porongos Complex proper. Foliations in all units are sub-parallel and folded into regional-scale structures striking NE-SW (Figs. 4.2f, 4.5). Dips range from sub-horizontal to moderate and steep, forming a girdle perpendicular to the axes of the large-scale folds. Stretching lineations trend from horizontal and subparallel to the strike of the foliation to intermediate plunges (up to $50^{\circ}$ ), mostly to SSW. These are mostly parallel to fold axes and crenulation lineations in metasediments. The pre-folding shear sense is interpreted to have been dextral, with top displaced to SW (Saalmann et al. 2006a, 2011). Sin-kinematic intrusions such as the Capané Granite (Zvirtes et al. 2017) are also concordant with the foliation of the metamorphic rocks, and also record top to SW shear sense. Basement rocks of the Tijucas Terrane record earlier stages of deformation from the Paleoproterozoic, but localized high-strain mylonitic belts parallel to the main Neoproterozoic structure are interpreted as the result of Brasiliano reworking (Saalmann et al. 2006a, 2011).

\subsection{Microstructures}

\subsubsection{Dorsal do Canguçu Shear Zone}

Within little-deformed portions of the shear zone, in particular within the core of the syn-kinematic granitic intrusions, magmatic structures are well preserved, characterized by the orientation of euhedral feldspar crystals within idiomorphic fabrics. Sub-magmatic structures such as filled microfractures in feldspar and chessboard extinction in large quartz crystals are still present in protomylonites. Solid-state deformation, however, is dominant in the structure, generating mylonites and ultramylonites.

Granitic mylonites are characterized by the presence of stretched and mantled K-feldspar and, subordinately, plagioclase (Fig. 4.6a). Muscovite and/or biotite are commonly concentrated in bands parallel to the main mylonitic foliation, occasionally indicating the development of S-C shear bands. Quartz-mylonites are characteristically fine-grained and commonly present muscovite fishes (Fig. 4.6b). On both lithologies, quartz is dynamically recrystallized into fine granulations by means of grain boundary migration (Fig. 6b) and/or sub-grain rotation (Fig. 4.6c). In quartz-mylonites, in particular, the intense recrystallization of quartz may lead to a homogeneous granulation and the development of foliations oblique to the main mylonitic structure (Fig. 4.6c). Late-stage deformation is occasionally recognizable in thin sections, localized in narrow fine-grained bands parallel to the main foliation (Fig. 4.6d). Microstructures such as rotated mantled porphyroclasts, shear bands, mica fishes and oblique foliations evidence a predominant sinistral sense of shear. 


\subsubsection{Ibaré Shear Zone}

The metasedimentary rocks along the Ibaré Shear Zone have varied structural characteristics. Most metapelites are muscovite-quartz schists on which the main foliation is a transposition of a previous metamorphic surface, indicated by the presence of statically healed intrafolial folds (polygonal arcs). Metapsamites commonly have foliations parallel to primary structures, such as levels with the accumulation of opaque minerals. Parallel to these rocks, mylonites to ultramylonites occur locally that suggest the shearing of gneiss-granitic rocks or metagraywackes. These are characterized by stretched plagioclase and K-feldspar porphyroclasts with well-developed recrystallization mantles surrounded by a matrix with quartz and muscovite/sericite (Figs. 4.6g, 4.6h, 4.6i). Their foliation is more pervasive and consistent than that of the mylonites in the metapelites, and rare asymmetric porphyroclasts mostly suggest dextral displacement (Fig. 4.6h).

The regional foliation is reworked within mylonites and phyllites, on which there is a predominance of dynamic recrystallization of the minerals. Phyllites occur mostly within high-strain deformation bands in metapelites. They are typically fine-grained, and mostly consistent of quartz, sericite and/or chlorite (Fig. 4.6e). Within quartz-dominated portions of the rocks, dynamic recrystallization was predominantly controlled by sub-grain rotation and bulging commonly leading to uniform grain sizes. Protomylonites are common in mylonites within the metapsamitic units and are characterized by quartz and feldspar clasts with little mantling, enveloped in a fine-grained recrystallized matrix (Fig. 4.6f). Shear sense indicators are quite scarce and not entirely reliable, but mostly include rotated porphyroclasts with littledeveloped mantles, oblique foliations, and asymmetrically folded quartz veins in phyllites (Fig. 4.6e). They predominantly suggest sinistral shear. On the quartz-feldspatic mylonites parallel to the predominant metasedimentary rocks, the main foliation is commonly superposed by a later deformation, leading to asymmetric folding (Fig. 4.6g), dynamic recrystallization of quartz in the matrix mainly by subgrain rotation and bulging, and very fine-grained ductile-brittle shear concentrated in narrow bands (Fig. 4.6i). Most structures also suggest a sinistral shear sense for this later stage. On the other hand, closest to the main post-tectonic granitic intrusions, both the metasedimentary associations and granitic mylonites are affected by static recrystallization, leading to sutured grain boundaries (Fig. 4.6j). 


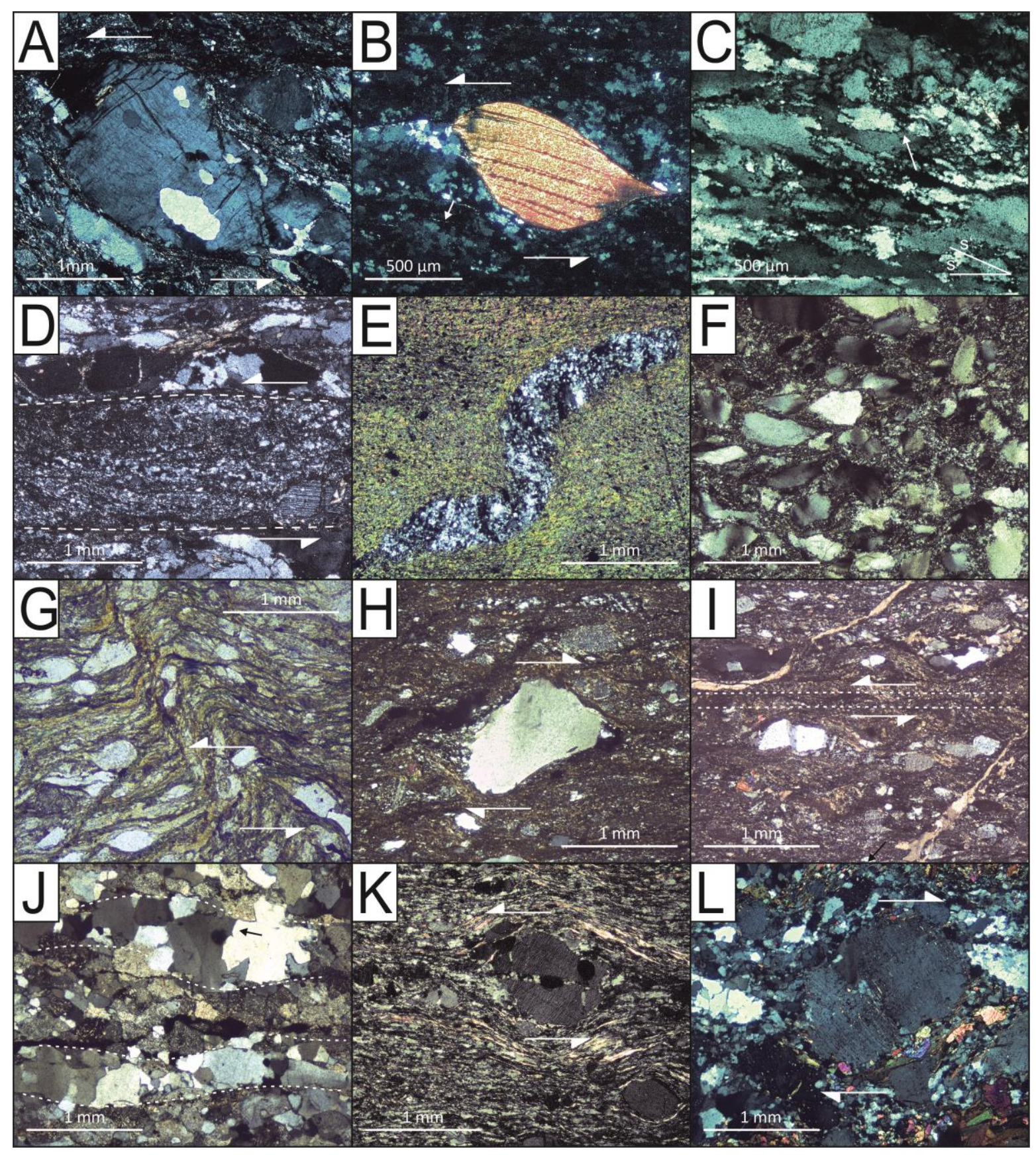

Figure 4.6: Photomicrographs of microstructures of the main shear zones and mylonites of the Sul-rio-grandense

Shield: a: Mantled porphyroclast indicating sinistral shear sense in granitic protomylonite of the Dorsal do Canguçu

Shear Zone; b: Muscovite-fish indicating sinistral shear sense in quartz-mylonite of the Dorsal do Canguçu Shear Zone; c: Dynamic recrystallization in a quartz-mylonite of the Dorsal do Canguçu Shear Zone. Quartz was mostly recrystallized by bulging and the neoformed crystals are oriented according to a direction $\left(S^{\prime}\right)$ that is oblique to the main foliation (S), indicating sinistral shear sense; d: Fine-grained recrystallization concentrated in millimetric band in mylonite of the Dorsal do Canguçu Shear Zone. The band evolved late in the rock's deformation history, as it displaces earlier structures; e: Folded quartz vein in sericite phyllite from the Ibaré Shear Zone. The rock was 
affected by a high-angle shear band, and the asymmetry in the fold indicates sinistral displacement; $f$ : Deformed metapsamite of the Ibaré Shear Zone. Note that the fine-grained matrix is intensively recrystallized while the original clasts are mostly undeformed; g: Quartz-feldspatic mylonite of the Ibaré Shear Zone with stretched porphyroclasts. The mylonitic foliation is asymmetrically folded, suggesting sinistral displacement; h: Mantled Kfeldspar porphyroclast indicating dextral shear in quartz-feldspatic mylonite of the Ibaré Shear Zone; i: Late submillimetric shear band displacing a carbonate vein in quartz-feldspatic mylonite of the Ibaré Shear Zone. The displacement is sinistral; j: Quartz-feldspatic mylonite of the Ibaré Shear Zone which has experienced static recrystallization, as indicated by granoblastic crystals; k: Mantled K-feldspar porphyroclast indicating sinistral shear sense in quartz-feldspatic mylonite of the Tijucas Terrane; I: Basement gneiss of the Tijucas Terrane affected by late transcurrent deformation. The mantled K-feldspar porphyroclast in the center of the image indicates dextral shear sense

\subsubsection{Tijucas Terrane}

Most mylonites in the Tijucas Terrane are refolded together with the metasedimentary rocks of the Porongos Complex. They include fine grained quartz-mylonites and quartz-feldspatic ultramylonites, probably with granitic protoliths. Quartz-mylonites are characteristically fine-grained and may contain up to $15 \%$ of muscovite and/or sericite, mostly in bands parallel to the mylonitic foliation. Quartz commonly has a homogeneous granulation due to pervasive dynamic recrystallization, on which both grain boundary migration and sub-grain rotation were active. This is often accompanied by the development of an oblique foliation in the neoformed crystals. Quartz-feldspatic rocks are predominantly ultramylonitic, with less than $10 \%$ of porphyroclasts. These are usually K-feldspar crystals with well-developed recrystallization mantles (Fig. 4.6k). Sin-kinematic granitic intrusions, such as the Capané Granite, have variable degrees of solid-state deformation, and locally preserve igneous structures. Due to the folding of the mylonites during regional NW-trending deformation in the Tijucas Terrane, they can present conflicting shear senses (Fig. k.6k, 4.6I). Most indicators, such as rotated mantled feldspar porphyroclasts and oblique foliations, however, suggest an original top-to-SW displacement.

\subsection{Quartz CPO textures}

In total, eight samples of mylonites from the selected areas were collected in order to assess their quartz CPO patterns with electron backscatter diffraction (EBSD). Coordinates of the samples are presented in Fig. 4.1 and Appendix A. The pole figures of c- and a- axes of all analyzed samples are presented in Fig. 4.7, together with reference orientations of the foliation poles $(\mathrm{Z})$ and stretching lineation $(X)$. 


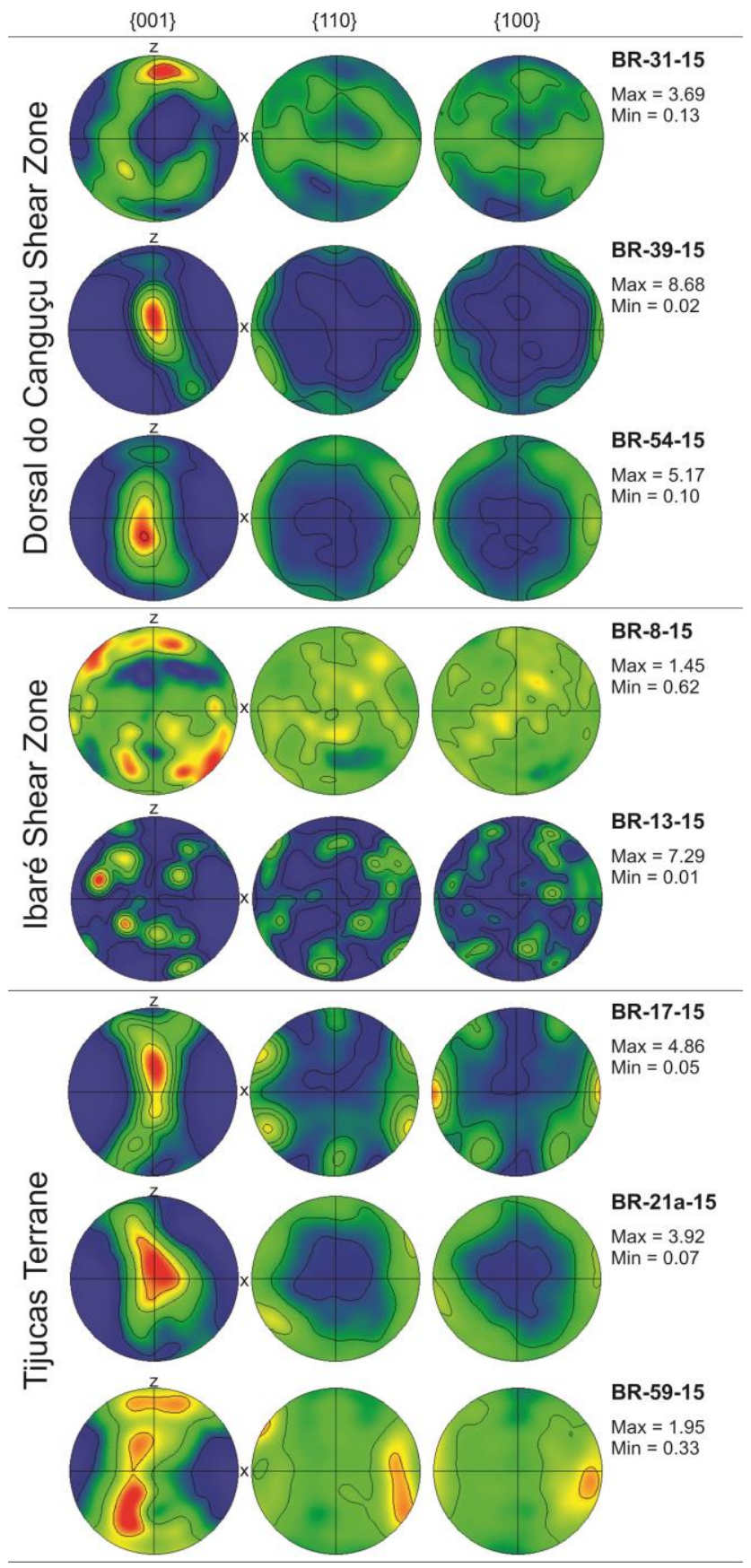

Figure 4.7: Quartz CPO pole figures from mylonite samples of the Sul-rio-grandense Shield. Pole of the foliation (Z) and the lineation $(\mathrm{X})$ are marked. Color scaling is from blue (minimum) to red (maximum)

Three samples represent mylonites from the Dorsal do Canguçu Shear Zone. Samples BR-31-15 and BR39-15 are from muscovite-bearing quartz mylonites, while sample BR-54-15 is a mylonite of granitic origin with $30-40 \%$ of feldspatic porphyroclasts. Quartz CPO patterns in sample BR-31-15 seem to be slightly rotated along the $\mathrm{Z}$ and $\mathrm{X}$ directions, which might be the result of an oblique preparation of the sample. Nonetheless, [c]-axes are distributed along a single girdle approximately parallel to the YZ plane, 
with a maximum parallel to the $Z$ direction, while [a]-axes are arranged perpendicular to the $Z$ direction, forming a girdle parallel to the $X Y$ plane. This indicates that the predominant deformation mechanism in quartz was basal <a> slip, with only limited rhomb and prism <a> slip. Although the described pattern presents a slight external asymmetry indicating dextral shear, this sample is particularly unreliable, due to the possible rotation during preparation. On the other hand, [c]-axes of samples BR-39-15 and BR-5415 also form single girdles parallel to the YZ plane, but with a clear maximum parallel to the $\mathrm{Y}$ direction, indicating a dominance of prism <a> slip. Accordingly, the [a]-axes in both samples are aligned along the XY plane. While the external asymmetry of sample BR-39-15 indicates a sinistral shear sense, sample BR54-15 is quite symmetrical, rather suggesting a large component of coaxial deformation.

Two quartz-feldspatic mylonites from the Ibaré Shear Zone yielded very different quartz CPO patterns. Sample BR-8-15 has [c]-axes concentrated along the XZ plane, with maxima rotated $c a .45^{\circ}$ from the Z direction, presenting a strong asymmetry that indicates sinistral shear, with [a]-axes forming a girdle perpendicular to the [c]-axes' maximum. This pattern suggests an overwhelming predominance of basal $<$ a s slip as the main slip system, possibly under flattening strain. Sample BR-13-15, on the other hand, was collected close to the border of the Ediacaran Jaguari Granite, and in thin section records the effect of static recrystallization, with coarse-grained sutured quartz ribbons. Accordingly, the quartz CPO pattern of this sample is very disperse and effectively untextured, and is not characteristic of the mylonitic deformation experienced by the rock.

Samples BR-17-15, BR-21a-15 and BR-59-15 are mylonites internal to the Tijucas Terrane and were collected in the Santana da Boa Vista region, where they are folded, together with the metasediments of the Porongos Complex, into regional-scale structures. The first two samples are fine-grained muscovitequartz ultramylonites, while the latter has up to $15 \%$ of plagioclase and K-feldspar porphyroclasts, suggesting a granitic protolith. Samples BR-17-15 and BR-21a-15 have [c]-axes that present Type I crossed girdles with well-defined maxima parallel to the $Y$ direction and [a]-axes parallel to the XZ plane. Basal and minor rhomb <a> slip are thus interpreted as the main slip systems. While patterns from the first sample are quite symmetrical, indicating coaxial deformation, the latter's asymmetry indicate a sinistral shear sense. Although sample BR-59-15 also presents a poorly defined type I girdle, its maxima are distributed along the entire girdle, indicating that all <a> slip systems, basal, rhomb and prism, were active during deformation. Poorly defined [a]-axes maxima perpendicular to the $Y$ direction and close to the $X$ direction also evidence the effect of the prism <a> slip system. In contrast to sample BR-21a-15, however, these patterns present slight asymmetries suggestive of dextral shear. 


\subsection{K-Ar geochronology}

K-Ar geochronology was applied to estimate the timing of middle- to low-temperature deformation of the shear zones. 12 samples were collected for muscovite dating and six for illite dating in fine fractions of mylonites, totalizing 24 individual analyses, including different grain size fractions for the illite samples. Coordinates of the samples and all analytical results are presented in Appendices A and B.

\subsubsection{Muscovite}

Results for all muscovite K-Ar analyses are presented in Appendix B. Six samples were collected from the Dorsal do Canguçu Shear Zone. Three are typical examples of mylonites associated with intrusions of the peraluminous Cordilheira granitic suite. Samples BR-30-15 and BR-39a-17 are fine-grained quartzmylonites with muscovite fishes, while sample BR-32-15 is a granitic mylonite that also includes muscovite parallel to the mylonitic foliation in the deformed matrix. The first two produced ages of 648.0 \pm 6.8 and $585.1 \pm 6.2 \mathrm{Ma}$, respectively, while the latter has an age of $619.3 \pm 9.3 \mathrm{Ma}$. These ages are interpreted as representative of the crystallization that took place during mylonitization. Samples BR-2917 and BR-43b-17, on the other hand, correspond to undeformed granites of the Cordilheira Suite, characterized by the presence of abundant magmatic muscovite. They yielded ages of $639.4 \pm 6.5 \mathrm{Ma}$ and $608.2 \pm 7.5 \mathrm{Ma}$, respectively, interpreted as cooling ages of the granitic intrusions. The last sample associated with the Dorsal do Canguçu Shear zone corresponds to a sheared pyroxene-bearing gneiss, interpreted to correspond to a basement inlier correlated to the Arroio dos Ratos Complex (Gregory et al. 2015). Muscovite in this sample is mostly restricted to syn-deformational mica fishes, and produced an age of $618.8 \pm 6.4 \mathrm{Ma}$, interpreted as a syn-deformational age.

Four samples correspond to rocks associated with the Ibaré Shear Zone. Muscovite in these samples is predominantly oriented parallel to the metamorphic foliation, but some degree of post-kinematic crystallization is also recognized. Two samples, BR-12-15 and BR-16-17, correspond to quartz-feldspatic mylonites from the eastern portion of the shear zone, and yielded Tonian ages of 757.7 \pm 11.4 and 747.1 \pm 9.2 Ma. Samples BR-14b-17 and BR-15a-17 were taken from metasedimentary rocks along the Ibaré Shear Zone. They represent also muscovite-quartz schists associated with the regional low-angle NWdipping structural configuration of most metapelites along the region. They yielded ages of $662.7 \pm 7.1$ $\mathrm{Ma}$ and $743.5 \pm 10.2 \mathrm{Ma}$, respectively. All ages obtained in these samples are interpreted as representative of the metamorphic growth or subsequent cooling and closure of the K-Ar system. 
Samples collected from the mylonites of the Tijucas Terrane did not produce enough muscovite with quality for dating. K-Ar analyses, therefore, were restricted to associated lithologies. Sample BR-64-15 is a muscovite-bearing gneiss from the Encantadas complex, collected from the basement core of the Santana da Boa Vista region, and produced an age of $551.3 \pm 5.6 \mathrm{Ma}$. Sample BR-51b-17, on the other hand, corresponds to a garnet-staurolite-muscovite schist of the Porongos Complex in the Capané region, and yielded an age of $556.1 \pm 9.5 \mathrm{Ma}$. Both ages can be interpreted as recording metamorphic growth or subsequent cooling.

\subsection{2 llite dating}

Illite dating was applied to fine fractions extracted from mylonites $(<2 \mu \mathrm{m}$ and $<0.2 \mu \mathrm{m})$, in order to date the last illite crystallization event and to estimate the timing of the transition from ductile to brittle deformation conditions. All dated fractions were additionally analyzed by X-ray diffraction (XRD) in order to estimate their mineralogical content, the crystallinity of the measured illite and the relative content of the different illite polytypes. Results are summarized in Appendix C, while individual illite polytype analyses are presented in appendix D.

The new K-Ar ages of illite in fine-fraction materials exhibits grain-size dependency, a common feature of this kind of analyses that is sometimes referred to in the literature as inclined age spectra. When analyzing fractions extracted from whole-rock samples, this behavior is mostly interpreted as the result of mixing between inherited illite/muscovite crystals and new crystals formed under low-temperature conditions (e.g. Pevear 1992; Grathoff et al. 1998, 2001). The inherited crystals can come either from coarser-grained metamorphic crystals within a cooling trajectory or from detrital components in rocks that only experienced low-grade metamorphism. On dating fine fractions extracted from mylonites, a consequence of this effect is that the coarsest dated fractions are the most susceptible to contamination from coarse grained muscovite crystallized during the ductile stage of the shear zone. As such, the ages obtained from the $<2 \mu \mathrm{m}$ fractions in the newly dated samples can be interpreted as maximum ages constraining the end of mylonitic activity on the respective shear zones.

Fine fractions from six samples were analyzed, two each of mylonites from the Dorsal do Canguçu and Ibaré shear zones and two of the mylonites from the Tijucas Terrane. The obtained results show internal consistency, with samples from similar contexts producing well-constrained ages that mostly overlap, and are restricted to the late Ediacaran to the Middle Ordovician. Samples BR-10-15 and BR-12-15 were taken from mylonites on the Ibaré Shear Zone and produced the oldest set of ages, with mostly overlapping analyses between 580 and 560 Ma. Mylonites from the Dorsal do Canguçu Shear Zone 
produced two distinct sets of results. Sample BR-30-15 yielded very similar ages at 525-523 Ma, while sample BR-32-15 produced grain-size-dependent ages of $495.9 \pm 7.7 \mathrm{Ma}(<2 \mu \mathrm{m})$ and $468.8 \pm 6.2 \mathrm{Ma}$ $(<0.2 \mu \mathrm{m})$. Similar results were obtained in mylonites from the Tijucas Terrane. Both samples BR-58-15 and BR-60-15 yielded very similar grain-size-dependent ages that correspond to those obtained in the samples from the Dorsal do Canguçu Shear Zone. The oldest set, taken from the $<2 \mu \mathrm{m}$ fraction, produced ages between 523 and $520 \mathrm{Ma}$, while the youngest set, corresponding to the $<0.2 \mu \mathrm{m}$ fraction, yielded ages between 496 and $487 \mathrm{Ma}$.

As a general, quantification of the illite polytypes identified the presence of the $2 M_{1}$ polytype in all analyzed samples, with values between and 20 and 50\%, identifying at least anchizone conditions for these materials. The Kübler Indexes suggest somewhat more elevated conditions, with values characteristic of the epizone for all samples except of the $<2 \mu \mathrm{m}$ fraction of sample BR-58-15, which produced values corresponding to the upper anchizone.

\subsection{Discussion}

By integrating structural analyses in macro- and microscale with textural data, a range of different deformation conditions and mechanisms can be inferred for the mylonites of the Sul-rio-grandense Shield. These conditions vary not only between different shear zones, but also within a same structure, indicating a long deformational history with frequent reactivation. When coupled with geochronological analyses, including both new data and that from the literature, the evolution of the different structures can be better constrained.

\subsubsection{The Ibaré Shear Zone and accretion of the São Gabriel Terrane}

The Ibaré Shear Zone is characterized by the superposition of different deformation stages. The regional structural configuration along the shear zone is characterized by low-angle to moderate dips to $\mathrm{N}$, interpreted to represent the result of SW-verging juxtaposition along a lateral ramp during accretion to the Nico Pérez (Taquarembó) Terrane (Philipp et al. 2016a, 2018). This structure is better preserved in the metasedimentary rocks that comprise the majority of metamorphic rocks along the shear zone. Few associated quartz-feldspatic ultramylonites record ductile shearing under high-temperature conditions, as indicated by the dynamic recrystallization of feldspar. A dextral displacement is inferred for this stage from the inflection of the original NE-striking structural configuration of the São Gabriel Terrane along the lineament of the Ibaré Shear Zone, which is in accordance with the accommodation of SW-verging 
thrust tectonics. Shear sense indicators preserved from this stage which were not affected by later overprint are very rare, but seem to support dextral shear sense.

This original association, however, has mostly been reworked both by means of static recrystallization, probably associated with the intrusion of granites along the structure, and by further deformation under progressively cooler conditions. The latter is most evident in relatively narrow bands of ultramylonites and phyllites associated with the metasedimentary rocks (e.g. Camozzato et al. 2012; Laux et al. 2012), usually oriented parallel to the strike of the shear zone but with moderate to subvertical dips. Deformation in this stage took place under low-temperature conditions of the ductile deformation spectrum, as indicated by brittle microfractures of feldspar and quartz recrystallization mostly by subgrain rotation and bulging (Pryer 1993; Stipp et al. 2002; Sinha et al. 2010). This observation is also supported by the quartz CPO patterns of sample BR-8-15, on which [c]-axes are predominantly oriented parallel to the $Z$ direction and [a]-axes form a perpendicular girdle, indicating a predominance of basal <a> slip. In a few samples, late-stage deformation is concentrated on narrow fine-grained shear bands with cataclastic characteristics. Most shear sense indicators for this later shearing, such as oblique foliations, microfaulting, asymmetrical folds and external asymmetry in the quartz CPO patterns, suggest sinistral displacement. This suggests, therefore, that there was an inversion of the shear sense during the duration of the shear zone evolution.

Geochronological constraints to the structural history of the Ibaré Shear Zone are mostly indirect, and relate to the original formation of the main involved units (Fig. 4.8). The metasedimentary rocks oriented along the structure are interpreted as passive margin associations correlated with the Passo Feio Complex (Philipp et al. 2016a, 2018), which were deposited early on in the history of the São Gabriel Terrane, based on the absence of detrital zircon U-Pb ages younger than ca. $800 \mathrm{Ma}$ (Lopes et al. 2015). Another constraint is the intrusion of an association of post-kinematic granitic intrusions from $635 \mathrm{Ma}$ onwards (Camozzato et al. 2016; Philipp et al. 2016a, 2018). Three new K-Ar ages obtained in this study correspond to metamorphic crystals extracted from mylonites and from metasedimentary rocks associated with the main low- to moderate-dipping structural conformation of the shear zone. They yielded Late Tonian ages between 760 and $740 \mathrm{Ma}$, and set a minimum age for the initial shear along the terrane boundary, corresponding either to direct crystallization ages or subsequent cooling below $c a$. $425^{\circ} \mathrm{C}$ (Harrison et al. 2009). This period corresponds to the initial stages of the São Gabriel Event and accretion of the São Gabriel juvenile association to the northwestern margin of the Nico Pérez Terrane, in associated with the development of a continental magmatic arc (Hartmann et al. 2011; Lena et al. 2014; Philipp et al. 2016a, 2018). In this context, the formation of the Ibaré Shear Zone is interpreted as 
a lateral ramp formed during the SE- verging accretion. The new ages are slightly younger than the age interpreted for the final closure of the Charrua Ocean associated with regional metamorphism (ca. 720$710 \mathrm{Ma}$, Remus et al. 1999; Hartmann et al. 2011; Philipp et al. 2018), which may represent a continuation of the process further away from the continental foreland and suture zone.

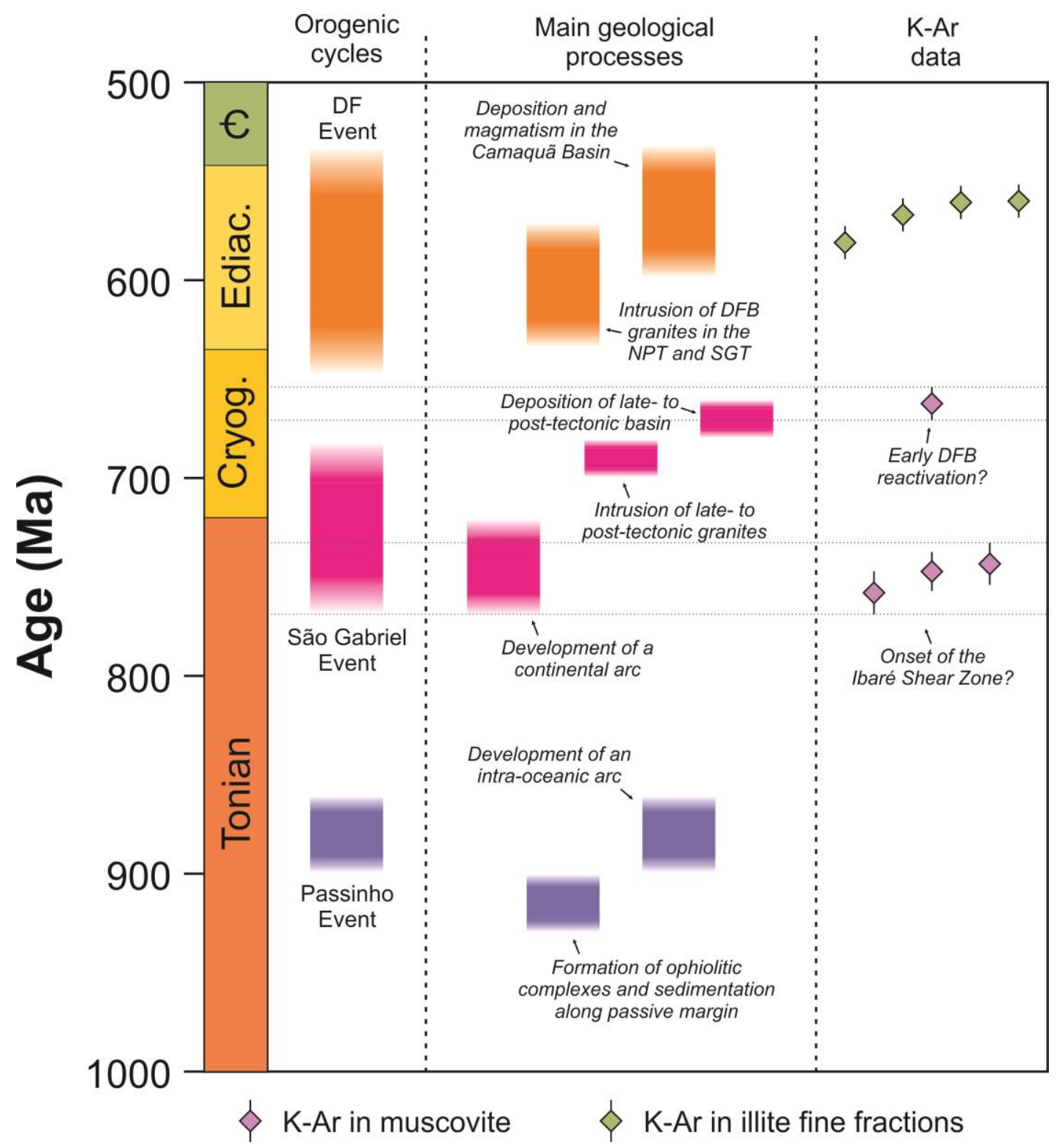

Figure 4.8: New K-Ar dataset of rocks from the Ibaré Shear Zone and main geological events in the São Gabriel Terrane (after Philipp et al. 2018). DF Event: Dom Feliciano Event; DFB: Dom Feliciano Belt; NPT: Nico Pérez Terrane; SGT: São Gabriel Terrane

Dating the reactivation of mylonitic activity in the Ibaré Shear zone is more elusive, however, because of its limited occurrence. Within this context, an additional K-Ar age was obtained from a metapelite 
sample from the shear zone that, at $662.7 \pm 7.1 \mathrm{Ma}$, is considerably younger than the remaining $\mathrm{K}-\mathrm{Ar}$ ages. This could either represent a ductile reactivation accompanied by the resetting of the K-Ar system and crystallization of new muscovite crystals, or it could be caused by the thermal effect of postcollisional magmatism of the São Gabriel Terrane (Lagoa da Meia Lua Suite, e.g. Philipp et al. 2016a, 2018). As this particular sample is not associated with any known intrusions of the period, the interpretation of a metamorphic age during ductile reactivation is favored. Despite the presence of postkinematic granites along the structure, it is possible that limited reactivation took place after their intrusion, as the granites are frequently affected by ductile-brittle deformation bands and cataclastic domains. These indications imply in a restricted reactivation of the Ibaré Shear Zone during the Dom Feliciano Event, and might be responsible for the observed change in the sense of shear, from initial dextral to later sinistral. A minimum age limit for the cessation of metamorphic activity on the mylonites of the structure can be interpreted from the dating of fine-grained illite crystals at ca. 580-560 Ma. As indicated by their degree of crystallinity, crystallization of the oldest dated fractions took place under temperatures corresponding to the epizone (above $c a .300^{\circ} \mathrm{C}$ ), which corresponds on first order to the transition from ductile to brittle deformation in quartz (Passchier \& Trouw 2005).

\subsubsection{Deformation history and geochronological constraints of shear zones in the Dom Feliciano Belt}

The Dorsal do Canguçu Shear Zone is mostly restricted to the border of intrusions from the earliest granitic suites of the Pelotas Batholiths, namely Cordilheira and Quitéria (Fernandes \& Koester 1999; Koester et al. 2001a, b; Philipp \& Machado 2005; Philipp et al. 2013). Emplacement of the granites was synchronic to the deformation along the shear zone, as indicated by a gradational transition from magmatic conditions to submagmatic deformation to solid-state deformation (Fernandes et al. 1993; Tommasi et al. 1994). Microstructural and textural analyses of the mylonites indicate distinct deformation conditions. Dynamic recrystallization of feldspar with development of mantled porphyroclasts, in association with grain boundary migration as the main deformation mechanism in quartz, indicate temperature conditions above ca. $500^{\circ} \mathrm{C}$ (Jessell 1987; Pryer 1993; Stipp et al. 2002; Passchier \& Trouw 2005). This observation is supported by the quartz CPO patterns from samples BR-3915 and BR-54-15, on which the concentration of [c]-axes along single girdles parallel to the YZ plane with a clear concentration parallel to the $\mathrm{Y}$ direction indicate prism $<a>$ slip and subordinately rhomb $<a>$ slip as the main deformation mechanism. A few samples, however, indicate lower temperature conditions (ca. $350-450^{\circ} \mathrm{C}$ ), as suggested by the brittle microfracturing of feldspar crystals and quartz recrystallization by means of sub-grain rotation and bulging (Pryer 1993; Stipp et al. 2002; Passchier \& Trouw 2005). In the textural analyses, this is exemplified by the quartz CPO patterns of sample BR-31-15, 
on which the concentration of [c]-axes parallel to the $Z$ direction and [a]-axes forming a girdle along the $\mathrm{XY}$ plane indicate basal <a> slip as the main slip system.

The presence of mylonites formed under distinct temperature conditions evidences that the cooling trajectory continued during solid-state deformation. This is further supported by the observation of strain localization in narrow bands recording a transition to cataclastic conditions, even in microscale. Despite the occasional presence of conflicting indicators, most diagnostic structures evidence a predominant of sinistral displacement throughout the shear zone's history, regardless of the inferred deformation conditions.

Geochronological evidences also indicate a long period of activity for the Dorsal do Canguçu Shear Zone (Fig. 4.9). Granitic emplacement along the structure is interpreted to have been controlled by transcurrent activity and started as early as $658 \mathrm{Ma}$, lasting until ca. $600 \mathrm{Ma}$ (Frantz et al. 2003; Philipp et al. 2013). New K-Ar ages in muscovite yielded ages that span much of the same period. This includes both magmatic crystals extracted from undeformed samples, on which the results are interpreted as cooling ages for the granitic intrusions, and crystals from mylonite samples that are interpreted as syndeformational. The first group yielded ages of $639.4 \pm 6.5$ and $608.2 \pm 7.5 \mathrm{Ma}$, while the second group has disperse ages $(648.0 \pm 6.8,619.3 \pm 9.3,618.8 \pm 6.4$ and $585.1 \pm 6.2 \mathrm{Ma})$ that span most of the emplacement history, reinforcing the notion that solid-state deformation and the formation of mylonites was synchronic with the emplacement of the granitic magma. The oldest age, in particular, evidences that this process began together with the earliest intrusions along the shear zone. The K-Ar results also extend beyond the period dominated by the emplacement of the granites. The age of $585.1 \pm 6.2$ is $c a$. 20 Myr younger than the last granite dated from the Cordilheira Granite, indicating that mylonitic deformation continued even after the end of syn-transcurrent magmatism. Similar K-Ar ages were obtained from granites of the same suite in muscovite crystals interpreted as both primary and secondary (Koester et al. 1997). As a constraint for the youngest possible cessation of mylonitization along the shear zone, $\mathrm{K}$-Ar illite dating produced ages of $c a .520 \mathrm{Ma}$. Finer fractions still were crystallized until ca. $470 \mathrm{Ma}$ under epizone temperature conditions $\left(300-350^{\circ} \mathrm{C}\right)$, as indicated by illite crystallinity. Very similar age spectra (535-465 Ma) were obtained from fine fractions in the Sierra Ballena Shear Zone, in Uruguay (Chapter 6), suggesting similar thermal paths in the southernmost portion of the Dom Feliciano Belt. Illite fine fractions extracted from mylonites of the Major Gercino Shear Zone in the northern extremity of the orogenic belt, however, yielded significantly younger ages (500-330 Ma). Those are also associated with lower crystallization conditions (anchizone and diagenetic conditions), and might represent hydrothermal activity during fault reactivation in the Paleozoic (Chapter 8). 


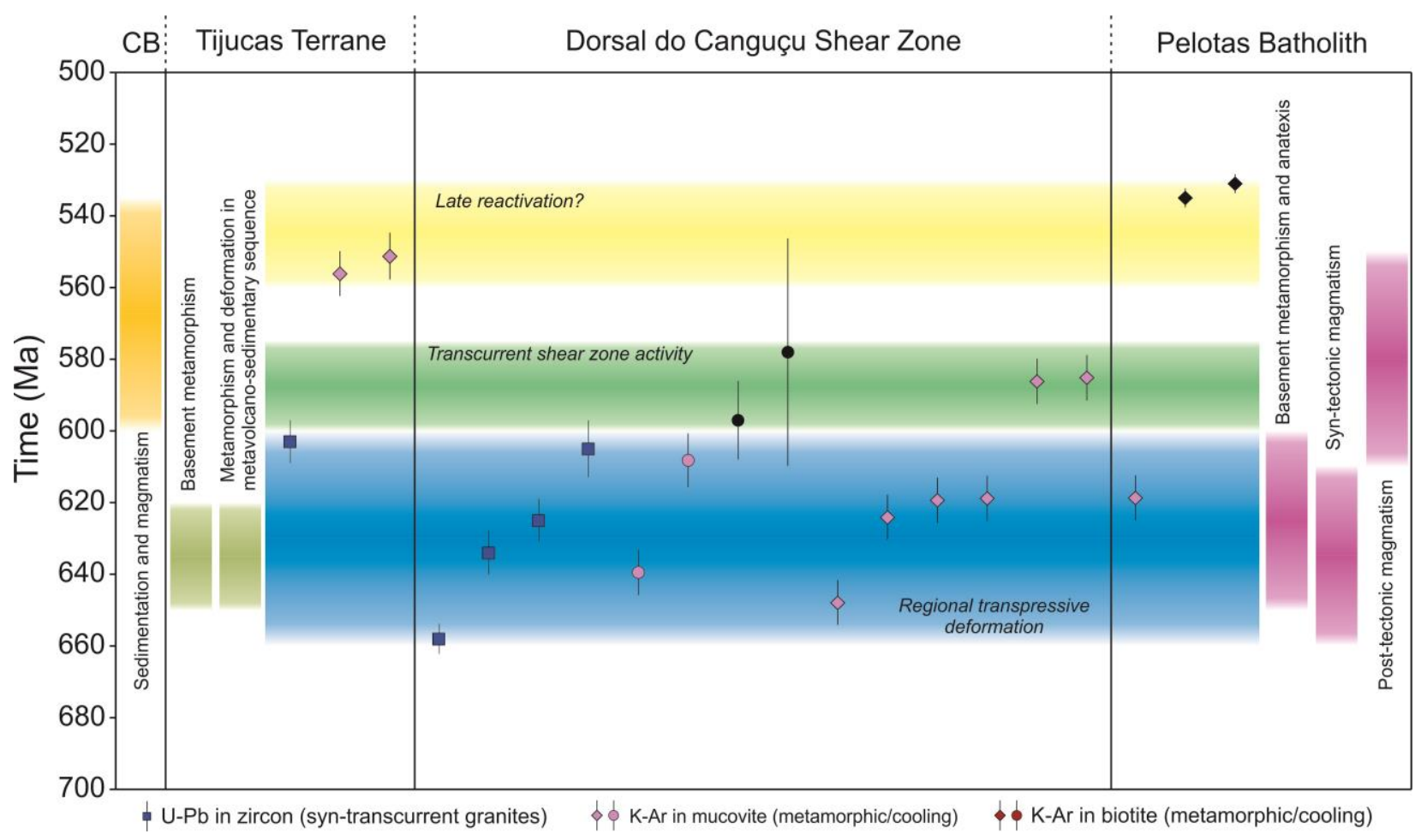

Figure 4.9: Summary of new and published geochronological data of the Dorsal do Canguçu and associated rocks in the Dom Feliciano Belt. U-Pb ages are from Frantz et al. (2003), Bitencourt et al. (2015) and Zvirtes et al. 2017. Previously published K-Ar an Ar-Ar data are from Koester et al. (1997) and Philipp et al. (2002). CB: Camaquã Basin

On the other hand, the main mylonitic units in the Tijucas Terrane are distinguished from the remaining structures discussed above as they are not linked to a clear shear zone, being deformed together with the metasedimentary units of the Porongos Complex into regional-scale structures (Jost 1981).They mostly comprise fine-grained ultramylonites, characterized by the presence of recrystallization mantles in feldspar and quartz recrystallization developed by means of both grain boundary migration and subgrain rotation. Quartz CPO patterns show [c]-axes predominantly concentrated along single girdles parallel to the $Y Z$ plane, sometimes with maxima parallel to the $Y$ direction. Taken together, these evidences suggest that deformation took place under upper greenschist to lower amphibolite temperature conditions, between 450 and $550^{\circ} \mathrm{C}$ (Jessell 1987; Pryer 1993; Stipp et al. 2002; Passchier and Trouw 2005). As the mylonitic foliation was subsequently deformed into open folds, shear sense indicators are conflicting according to its position in the larger structure, but generally suggest a top-toSW movement (Saalmann et al. 2006a, 2011; Zvirtes et al. 2017).

The geological significance of the mylonites is not entirely clear. Granitic mylonites more closely associated with the gneisses of the Encantadas Complex are generally interpreted as part of the 
Paleoproterozoic basement (e.g. Philipp et al. 2016a). Quartz mylonites, however, have been alternatively interpreted as part of the same association or as quartzitic units of the Porongos Complex, in which case the mylonitic deformation would correspond to the main foliation of the sequence, developed during peak metamorphic conditions (e.g. Saalmann et al. 2006a, 2011). The former interpretation is supported by the apparent Paleoproterozoic formation of these rocks, as indicated by the conspicuous absence of Neoproterozoic zircons (e.g. Pertille et al. 2015a, b, 2017; Höfig et al. 2018). As such, the deformation that led to the formation of these mylonites might be the result of preBrasiliano tectonism, refolded during the Dom Feliciano event into the general framework of the orogenic belt. This deformational event itself involved the generation of smaller strike-slip structures, in particular during the late stages following the NW-verging stacking of the Porongos Complex. These structures are characteristically narrow and have steep to subvertical foliations. Similar structures also affect the crystalline basement of the Tijucas Terrane, which is not folded into the reginal deformation that affected the metavolcano-sedimentary sequences (Saalmann et al. 2006a, 2011). Further evidences of transcurrent shear zone activity in the Tijucas Terrane during the generation of the Dom Feliciano Belt is the presence of syn-kinematic intrusions, in particular the Capané Granite, dated at ca. 600 Ma (e.g. Philipp et al. 2016a; Zvirtes et al. 2017; Höfig et al. 2018). The granites have varied degrees of deformation and record a continuous deformation under cooling conditions, culminating in a predominance of solid-state deformation and development of a mylonitic foliation under medium-grade conditions concordant with that of its metasedimentary host rocks (Zvirtes et al. 2017).

New muscovite K-Ar ages from samples of the Tijucas Terrane produced very similar ages between 555 and $550 \mathrm{Ma}$ and can be interpreted in more than one way. The samples represent distinct units; a muscovite-bearing gneiss with intense solid-state deformation associated with the Encantadas Gneiss in the Santana da Boa Vista region; and a schist of the Porongos Group in the Capané Region. The first sample records Brasiliano reworking of the Paleoproterozoic crystalline basement, whether by active recrystallization during deformation or through resetting of the isotopic system following regional metamorphism. Conversely, the second sample can also be attributed to ductile reactivation or to regional cooling. In any case, both hypotheses register the late-stage trajectory of the Dom Feliciano Belt. It should be noted that late-stage shear activity has been recognized in the Pelotas Batholith at $c a$. $535 \mathrm{Ma}$ by the Ar/Ar dating of biotite (Philipp et al. 2003). New illite fine fractions K-Ar ages from the mylonites of the Tijucas Terrane are very similar to those analyzed from the Dorsal do Canguçu Shear Zone, indicating similar brittle-ductile conditions achieved during the Lower Paleozoic. 


\subsubsection{Evolution of the Dom Feliciano Belt in Rio Grande do Sul}

The main orogenic episode in the Sul-rio-grandense Shield, and the one responsible for its present tectonic configuration, was the Dom Feliciano Event during the Brasiliano orogenic cycle. It is directly involved in the formation of the Pelotas Batholith and in the reworking of the Tijucas Terrane, and to a lesser extent, also had an effect in the Taquarembó and São Gabriel terranes, besides being responsible for the initiation of the Camaquã Basin.

The individual syn-tectonic granitic intrusions that comprise the Pelotas Batholith are mostly controlled by two structural patterns (e.g. Fernandes et al. 1992; Philipp \& Machado 2005). The first pattern comprises low-angle structures, with gentle dips to the SE. The second pattern is dominated by the emplacement of granites along subvertical strike-slip shear zones associated with extensive solid-state deformation and the formation of mylonitic belts, best exemplified by the Dorsal do Canguçu Shear Zone, but also occurring to a minor extent throughout the batholith (Fernandes et al. 1993; Tommasi et al. 1994; Nardi \& Frantz 1995; Fernandes \& Koester 1999; Philipp \& Machado 2005). This dual configuration was originally interpreted as the result of the evolution from convergent tectonics during collision to strike-slip orogenic collapse. This interpretation, however, is contradicted by the geochronological evidence, as granites associated with transcurrent shear zones consistently yield the oldest crystallization ages of the Pelotas Batholith (Frantz et al. 2003; Philipp et al. 2013, 2016). This observation implies that strike-slip deformation and shear zone nucleation were active from the early stages of the Dom Feliciano event in the Sul-rio-grandense Shield, beginning at $658 \mathrm{Ma}$. This is further supported by the new K-Ar dating of syn-mylonitic muscovite between 650 and $620 \mathrm{Ma}$. In this context, both structural patterns (low-angle thrusting and subvertical transcurrent shearing) developed synchronically during partitioned transpressive deformation, with strike-slip deformation concentrated in shear zones while the remaining intrusions are mostly characterized by compressive structures. This process is mirrored in other portions of the Dom Feliciano Belt (e.g. Oyhantçabal et al. 2010, 2011a; Oriolo et al. 2016b, Chapter 5). Magmatic emplacement under transpressive conditions is also suggested for the coeval peraluminous Butiá Granite in the northern portion of the Pelotas Batholith (ca. 629 Ma, Bitencourt et al. 2015), as evidenced by its magnetic fabric (Lyra et al. 2017). This intrusion is interpreted by the authors as the result of a shear system conjugated with the Dorsal do Canguçu Shear Zone.

At the same time, in the Tijucas Terrane, the main expression of the Dom Feliciano Event is the deformation and regional metamorphism of the Porongos Complex and its associated crystalline basement, mostly constrained to $650-620 \mathrm{Ma}$, based on zircon recrystallization in the basement rocks 
(Camozzato et al. 2013; Philipp et al. 2016a). During this stage, the structural evolution of the Tijucas Terrane is predominantly characterized by the NW-verging thrusting of the Porongos Complex, being thus comparable to the low-dipping NW-verging syn-tectonic intrusions in the Pelotas Batholith. This stage involved the folding of the mylonites into regional-scale structures (Jost 1981). The formation of the mylonites present in the Tijucas Terrane is not necessarily associated with this event, but it is also not discarded. The crystalline basement of the Tijucas Terrane is not folded into the same large-scale structures, and the latest evidences of deformation are mostly restricted to narrow subvertical NE-SW mylonitic bands, probably generate during the Dom Feliciano Event (e.g. Saalmann et al. 2006a, 2011). The divergent responses to this stage of deformation in the Tijucas Terrane are another indication of transpression, with rocks reacting differently according to their mechanical anisotropy and ability to accommodate strain into localized shear zones or regional fold belts (e.g. Carreras 2001). The latest intrusions of syn-kinematic granitic magmatism in the Sul-rio-grandense Shield are located in the Tijucas Terrane, represented by the Capané Granite, with a crystallization age of $603 \pm 6$ Ma (Philipp et al. 2016a; Zvirtes et al. 2017). This age corresponds roughly with the cessation of magmatic emplacement along the Dorsal do Canguçu Shear Zone (Frantz et al. 2003).

After this point, magmatism in the Pelotas Batholith is marked by the emplacement of isotropic intrusions and associated volcanic rocks interpreted as post-tectonic (e.g. Philipp \& Machado 2005; Oliveira et al. 2015a; Philipp et al. 2016a). Reactivation of the Dorsal do Canguçu Shear Zone is dated in the new K-Ar data at $585.1 \pm 6.2 \mathrm{Ma}$ and is further recognized in interior structures in the Tijucas Terrane and Pelotas Batholith until ca. $535 \mathrm{Ma}$, as constrained by new and published mica ages (Philipp et al. 2003). Though this process might have played a role in promoting magma migration (Philipp et al. 2016a), it was not an important emplacement mechanism. In the Porongos Complex, deformation posterior to the main thrusting event is restricted to open folding and kinking in association with narrow strike-slip shear zones (Saalmann et al. 2006a, 2011). Taken together, these evidences suggest that after $600 \mathrm{Ma}$, deformation in the Dom Feliciano Belt was less pervasive, characterized by local shear zone activity and coeval open folding and kinking.

\subsection{Conclusions}

Shear zones played an important role during the evolution of the Sul-rio-grandense Shield in the Brasiliano orogenic cycle. By examining the structural evolution of key structures together with a revision of new and available geochronological data, aspects of the Neoproterozoic assembly of this portion of the southern Mantiqueira Province are revealed. 
The earliest evidence of shear zone activity in the studied area is the development of the Ibaré Shear Zone in the Tonian. New-K-Ar analyses suggest an age of $c a .760$ to $740 \mathrm{Ma}$ for the development of SWverging structure, interpreted as a lateral ramp formed during accretion of juvenile crust to the Paleoproterozoic Nico Pérez Terrane. This period correlates with the earliest stages of the São Gabriel Event, associated with the generation of a continental arc. The structure was later reactivated in narrow shear zones at lower grade ductile conditions, probably due to the influence of the Dom Feliciano Event. This event was also responsible for assembling the Sul-rio-grandense Shield into its present configuration, forming the Pelotas Batholith and strongly reworking the Tijucas Terrane. Transcurrent shear zone activity is recognized in the Dorsal do Canguçu Shear zone from the early onset of the Brasiliano orogenic cycle, with syn-tectonic intrusion of granites along the structure accompanied by coeval solid-state deformation in mylonitic belts. This process took place during transpression, associated with regional metamorphism and NW-verging thrust tectonics, besides widespread granitogenesis. During this stage, mylonites in the Tijucas Terrane were folded into regional-scale structures, though the exact meaning of these rocks is unclear. This stage of the orogenic cycle took place until ca. $600 \mathrm{Ma}$, when there is a cessation of regional-scale deformation and intrusion of syntectonic granites. After this, strike- slip shear zones continued to be reactivated until ca. 550-530 Ma, and though they might have played a role in magma migration, they were not relevant mechanisms during emplacement of the post-tectonic magmatism of the Pelotas Batholith. 


\section{CHAPTER 5: Evolution of the Major Gercino Shear Zone}

\subsection{Introduction}

The Major Gercino Shear Zone, located in the southern Brazilian state of Santa Catarina, is the northernmost continuation of the over $1,000 \mathrm{~km}$ long lineament that includes the Dorsal do Canguçu and Sierra Ballena shear zones in Rio Grande do Sul and Uruguay, respectively. As such, it is one of the key structures of the Neoproterozoic Dom Feliciano Belt. In this chapter, the structural evolution of the Major Gercino Shear Zone is reviewed using new structural and microstructural observations and quartz crystallographic preferred orientation (CPO) textural analysis. In addition, the thermochronological history of the region is reconstructed by combining the available geochronological data with new $\mathrm{K}-\mathrm{Ar}$ analyses. Finally the evolution of the shear zone is integrated with the tectonic history of the Dom Feliciano Belt.

\subsection{The Major Gercino Shear Zone}

The Major Gercino Shear Zone is the most important tectonic structure in the Catarinense Shield, separating the eastern and central domain of the Dom Feliciano Belt (Basei et al. 2000). The lithological contrast between the Florianópolis Batholith, to southeast, and the metamorphic Brusque Group, to northwest, is a feature that has been observed since early geological mappings in the 1960's and 70's (Caldasso et al. 1995 a, b and references therein), but the shear zone itself and its tectonic significance have received more attention from the 1990's onwards (e.g. Passarelli et al. 1993, 2010, 2011a, b; Bitencourt \& Kruhl 2000; Bitencourt \& Nardi 2000; Chemale Jr. et al. 2012; Florisbal et al. 2012a).

The structure is exposed along ca. $70 \mathrm{~km}$, from the South Atlantic coastline to the limit of the Paraná Basin, with a NE strike (Fig. 5.1, 5.2). In its central portion it controls the valley of the Tijucas River, close to the town of Major Gercino, where the shear zone has a width of up to $10 \mathrm{~km}$, with two km-wide mylonitic belts separated by elongated granitic cores (Passarelli et al. 1993, 2010, 2011a). This configuration is less clear in the northeastern sector of the structure, where mylonite belts are thinner and are mostly restricted to shear bands within and around the borders of granitic intrusions (Bitencourt \& Kruhl 2000; Florisbal et al. 2012b). 

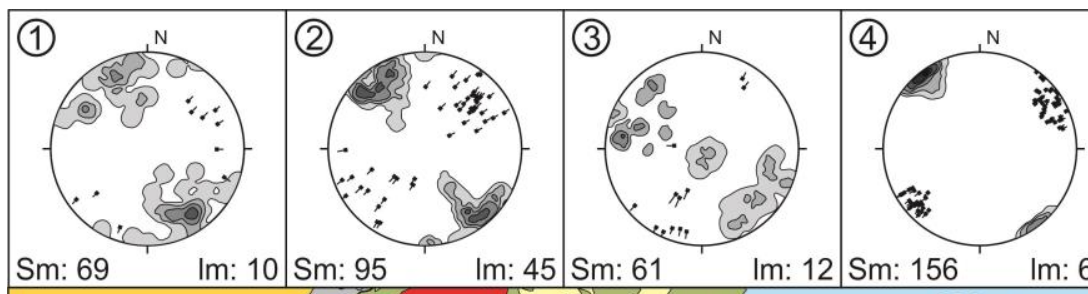

Im: 45 Sm: 61

Im: 12 Sm: 156

Im: 64
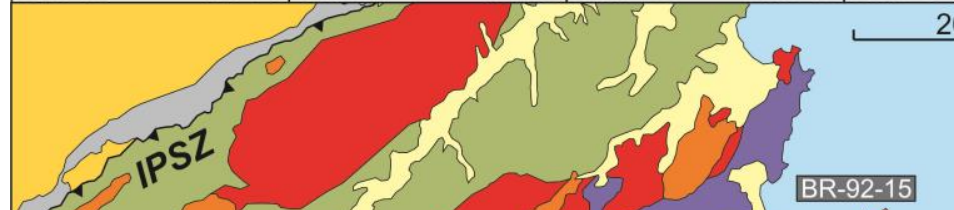

$20 \mathrm{~km}$

$27^{\circ} \mathrm{S}$

Atlantic

Ocean

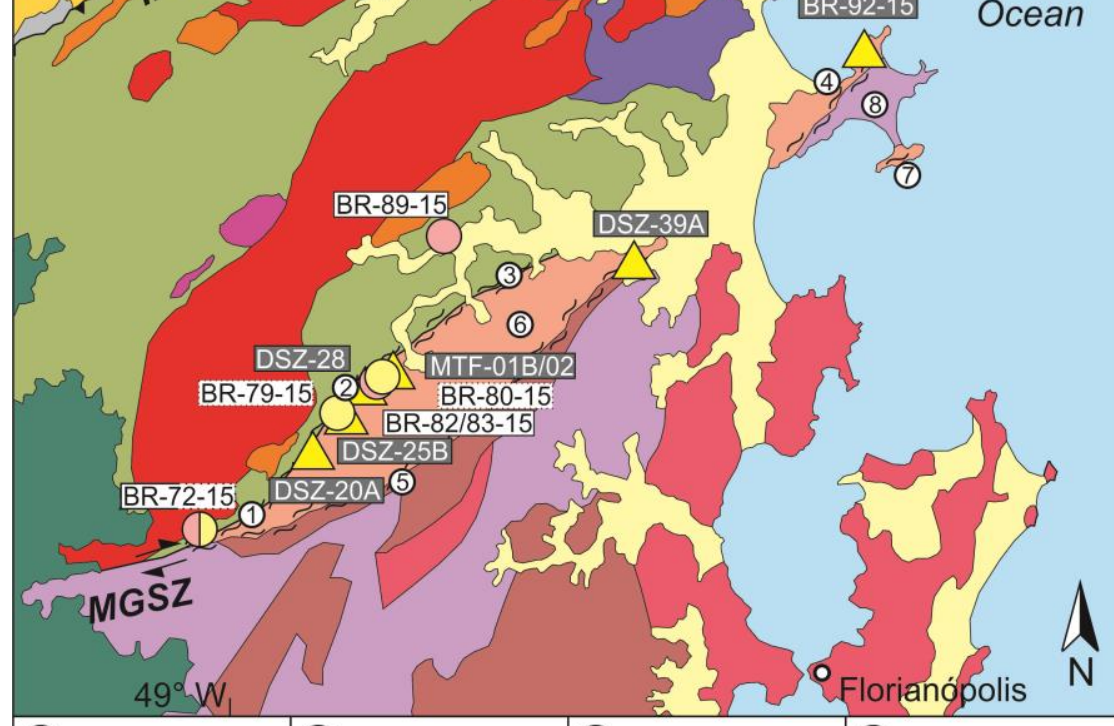

(5)

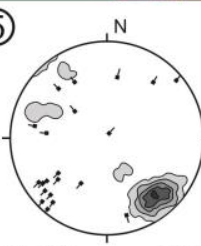

Sm: 59

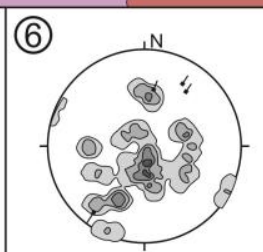

10: 4

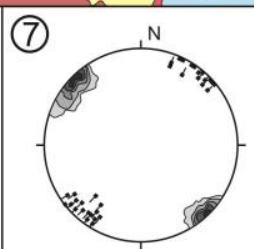

Im: 33

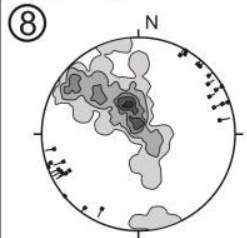

10: 25

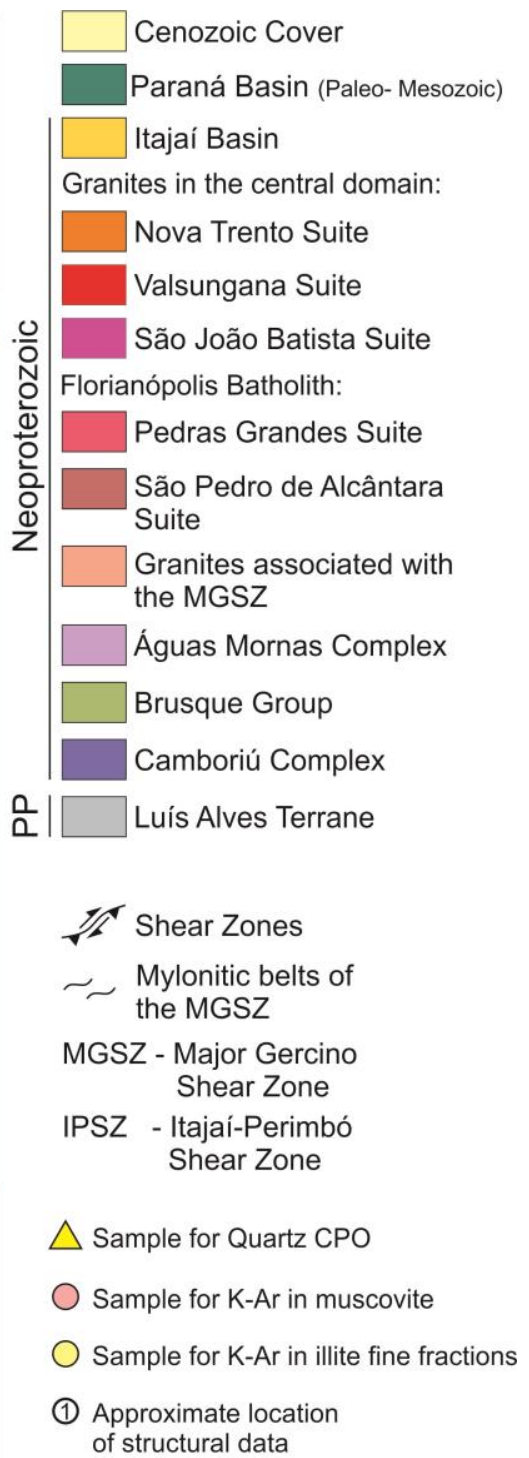

Paraná Basin (Paleo- Mesozoic)

Nova Trento Suite

rianópolis Batholith:

Pedras Grandes Suite

São Pedro de Alcântara

Suite the MGSZ

Figure 5.1: Geological map of the Major Gercino Shear Zone, with location of the analyzed samples and main structural features. Sm and Im refer to mylonitic foliations and lineations, while SO and lo refer to primary magmatic lineations. PP - Paleoproterozoic. Modified from Basei et al. (2006); Passarelli et al. (2010), with structural data from Bitencourt (1996) and Passarelli et al. (2010)

Granites formed the protolith of most mylonites of the shear zone, which encompass from coarsegrained protomylonites with porphyroclasts of a few centimeters to finer-grained ortho- and ultramylonites (Fig. 5.3a, 5.3b).They are mostly composed of K-feldspar, plagioclase, quartz, biotite and muscovite. Less frequent are very fine-grained phyllonites, usually constituted mainly of sericite, chlorite and quartz. Quartz mylonites are rare and have widths of up to a few meters, and are interpreted as the result of quartz segregation during deformation (Passarelli et al. 2010), and composed only of very thingrained stretched quartz and muscovite (Fig. 5.3c). 
Throughout the structure, most mylonitic rocks have subvertical to steeply dipping foliations with strikes that oscillate between $\mathrm{N} 65^{\circ} \mathrm{E}$ and $\mathrm{N} 20^{\circ} \mathrm{E}$ (Fig. 5.1). There is a slight predominance of NW-dipping highangle foliations on the southwestern mylonites of the structure. The stretching lineation is commonly subhorizontal with shallow plunges to the NE or SW, though moderate plunges to the SW and NE are also observed, particularly in the central portion of the shear zone. Locally, the mylonites present isoclinal and intrafolial folds (Fig. 5.3b, 5.3d), typically with fold axes sub-parallel to the stretching lineation. The most common macroscopic shear sense indicators are asymmetric porphyroclasts (Fig. 5.3a), predominantly composed of stretched K-feldspar. They usually indicate dextral shearing, although numerous symmetrical and even sinistral (reverse) indicators occur locally as well (e.g. Passchier \& Trouw 2005; Fossen \& Cavalcante 2017; Mukherjee 2017). In low-strain portions of the structure, on which mylonitization was less pervasive, deformation is commonly concentrated in $\mathrm{cm}$-thick shear bands (Fig. 5.3e). Cataclastic reworking is observed throughout the Major Gercino Shear Zone (Fig. 5.3f), affecting mylonites and undeformed granitic rocks.

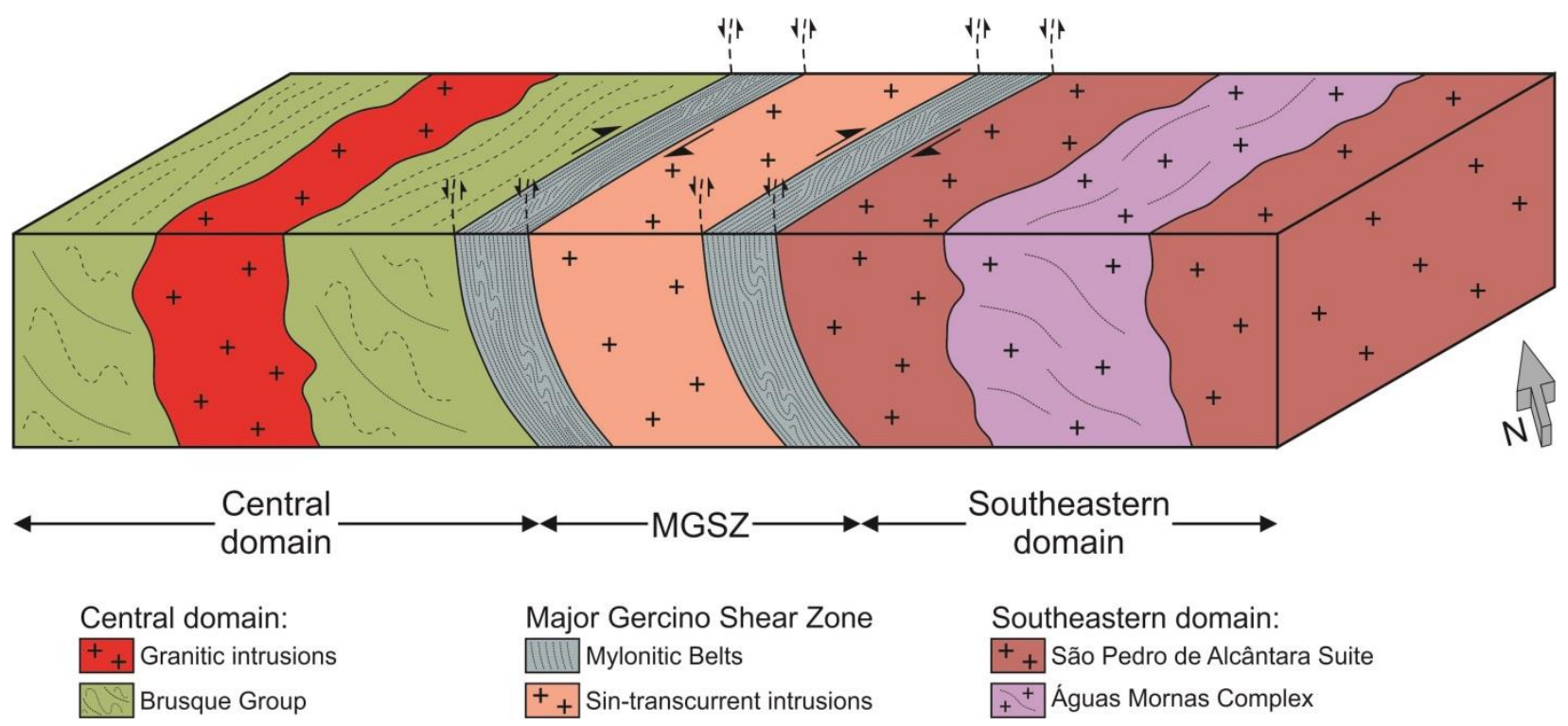

Figure 5.2: Schematic structural profile representing the structure of the Major Gercino Shear Zone

The evolution of the Major Gercino Shear Zone was accompanied by the emplacement of numerous granitic intrusions (referred to as granites associated with the Major Gercino Shear Zone in Fig. 5.1). These are divided, in the central portion, into the Rolador and Fernandes Suites (Passarelli et al. 2010, 2011b), while in the coastal portion they comprise the Quatro Ilhas, Mariscal, Estaleiro and Zimbros associations (Bitencourt \& Kruhl 2000; Florisbal et al. 2012a, b). Continuous deformation is registered in these rocks throughout their cooling process (Bitencourt \& Kruhl 2000; Passarelli et al. 2010; Florisbal et 
al. 2012b). The primary magmatic foliation is characterized by the shape-preferred orientation of euhedral feldspar crystals within an undeformed matrix. This foliation is predominantly preserved in the central portion of most intrusions, and commonly records a transition from subhorizontal to low dips to SW-NE (Fig. 5.1). These intrusions vary from calc-alkaline to alkaline granites, and have petrological, isotopic and geochronological signatures that are similar to those of the Florianópolis Batholith (Passarelli et al. 2010, 2011b; Florisbal et al. 2012a, b; Hueck et al. 2016).

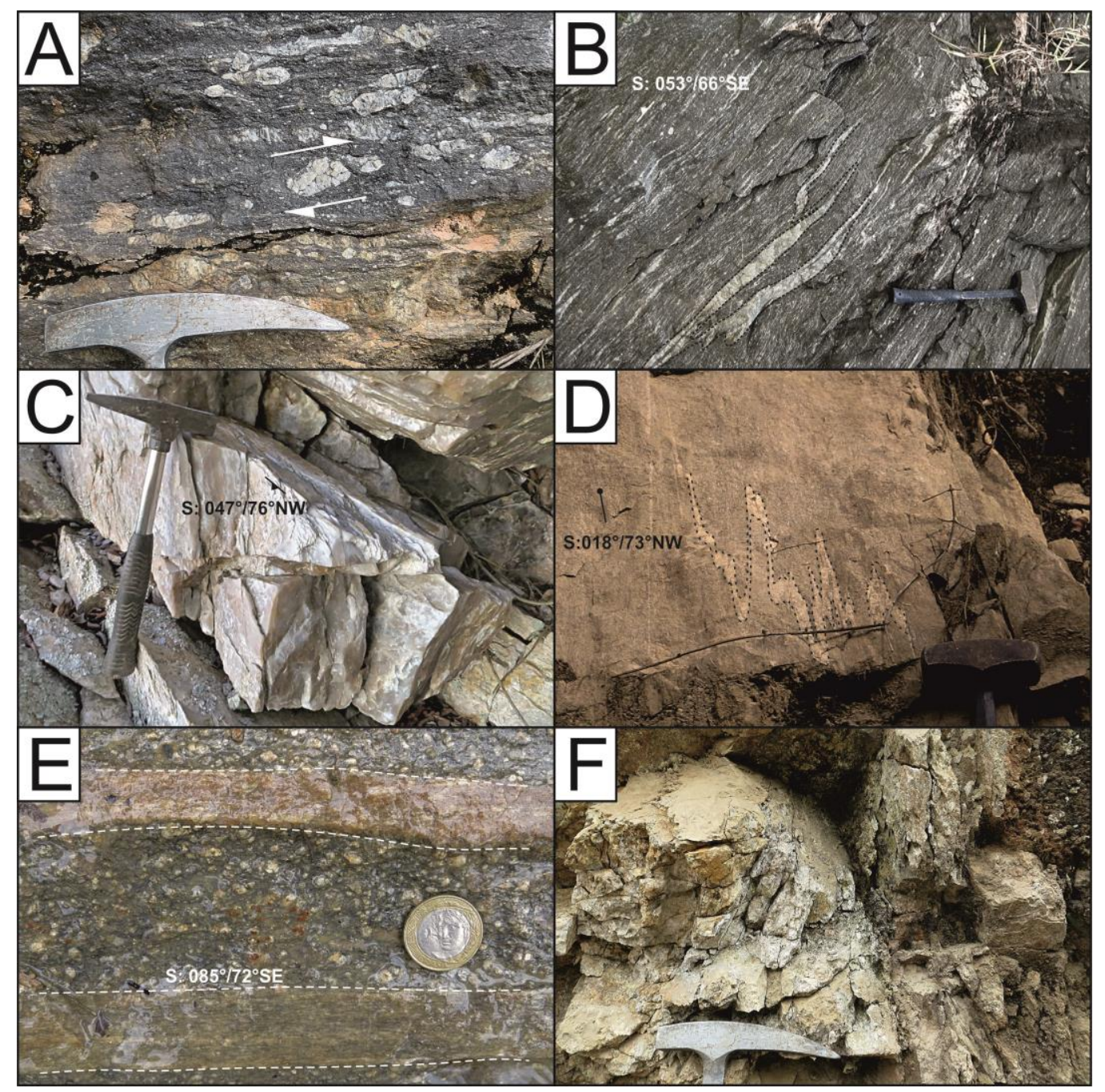

Figure 5.3: Field photographs of rocks and structures of the Major Gercino Shear Zone. a: Mylonite with $\sigma$-type feldspar porphyroclasts, in some cases with boudinage, indicating dextral shear. b: Typical ultramylonite with steeply-dipping foliation. Note the presence of intrafolial folds. c: quartz-mylonite, part of an outcrop 4 to $5 \mathrm{~m}$ wide. d: Intrafolial fold in ultramylonite with subvertical foliation, seen perpendicular to the shear direction. e: $\mathrm{cm}$ wide protomylonitic shear zones, in contact with slightly deformed host rocks. f: Cataclastic reworking of granitic rocks emplaced along the shear zone 
A number of geochronological methods have been applied to the Major Gercino Shear Zone (Table 5.1), to which new data are added in this study. The applied methods for new and available data and their closure temperatures are: $\mathrm{U}-\mathrm{Pb}$ in zircon $\left(>900^{\circ} \mathrm{C}\right.$; Cherniak \& Watson 2000$)$; K-Ar in muscovite (425$350^{\circ}$ C; Purdy \& Jäger 1976; Harrison et al. 2009); K-Ar in biotite (330-300 $\mathrm{C}$; Purdy \& Jäger 1976); and KAr in illite fine fractions $\left(250-350^{\circ} \mathrm{C}\right.$; Hunziker et al. 1986; Wemmer \& Ahrendt 1997; Duvall et al. 2011; Oriolo et al. 2018b; Süssenberger et al. 2018).

Table 5.1: Summary of published geochronological data in the Major Gercino Shear Zone (MGSZ). FF refers to illite fine fractions

\begin{tabular}{|c|c|c|c|}
\hline Geological Unit & Method & Age (Ma) & Reference \\
\hline Partial melt in the Porto Belo Complex & U-Pb LA-ICPMS in zircon & $649 \pm 9.7$ & Chemale Jr. et al. 2012 \\
\hline Partial melt in the Porto Belo Complex & U-Pb TIMS in zircon & $646 \pm 15$ & Chemale Jr. et al. 2012 \\
\hline Quatro Ilhas Meta-granite & U-Pb LA-ICPMS in zircon & $625.1 \pm 6.5$ & Florisbal et al. 2012c \\
\hline Quatro Ilhas Meta-granite & U-Pb LA-ICPMS in zircon & $623 \pm 6.2$ & Chemale Jr. et al. 2012 \\
\hline Quatro Ilhas Meta-granite & U-Pb LA-ICPMS in zircon & $619 \pm 22$ & Chemale Jr. et al. 2012 \\
\hline Quatro Ilhas Dykes & U-Pb LA-ICPMS in zircon & $617 \pm 5.6$ & Chemale Jr. et al. 2012 \\
\hline Quatro Ilhas Dykes & U-Pb LA-ICPMS in zircon & $617 \pm 5.2$ & Chemale Jr. et al. 2012 \\
\hline Quatro Ilhas Dykes & U-Pb TIMS in zircon & $615 \pm 7$ & Chemale Jr. et al. 2012 \\
\hline Quatro Ilhas Meta-granite & U-Pb LA-ICPMS in zircon & $613.7 \pm 3.9$ & Florisbal et al. 2012c \\
\hline Mariscal Meta-granite & U-Pb LA-ICPMS in zircon & $620 \pm 31$ & Chemale Jr. et al. 2012 \\
\hline Mariscal Meta-granite & U-Pb LA-ICPMS in zircon & $609 \pm 8.3$ & Florisbal et al. 2012c \\
\hline Fernandes Granite & U-Pb TIMS in zircon & $614 \pm 2$ & Passarelli et al. 2010 \\
\hline Rolador Granite & U-Pb TIMS in zircon & $609 \pm 16$ & Passarelli et al. 2010 \\
\hline Estaleiro Granite & U-Pb TIMS in zircon & $602 \pm 4.2$ & Chemale Jr. et al. 2012 \\
\hline Morro dos Macacos Granite & U-Pb TIMS in zircon & $588 \pm 3.3$ & Chemale Jr. et al. 2012 \\
\hline Zimbros Dyke & U-Pb LA-ICPMS in zircon & $587 \pm 7.5$ & Chemale Jr. et al. 2012 \\
\hline Zimbros Granite & U-Pb SHRIMP in zircon & $586.9 \pm 8.7$ & Chemale Jr. et al. 2012 \\
\hline MGSZ mylonites & $\mathrm{K}-\mathrm{Ar}$ in Muscovite & $569 \pm 14$ & Passarelli et al. 2010 \\
\hline MGSZ mylonites & K-Ar in Muscovite & $539 \pm 13$ & Passarelli et al. 2010 \\
\hline MGSZ mylonites & $\mathrm{K}-\mathrm{Ar}$ in Biotite & $569 \pm 10$ & Passarelli et al. 2010 \\
\hline Fernandes Granite & $\mathrm{K}-\mathrm{Ar}$ in Biotite & $584 \pm 25$ & Passarelli et al. 2010 \\
\hline Rolador Granite & K-Ar in Biotite & $575 \pm 12$ & Passarelli et al. 2010 \\
\hline Fernandes Granite & K-Ar in Biotite & $572 \pm 10$ & Passarelli et al. 2010 \\
\hline Fernandes Granite & K-Ar in Biotite & $561 \pm 18$ & Passarelli et al. 2010 \\
\hline Brusque Group near MGSZ & $\mathrm{K}-\mathrm{Ar}$ in $\mathrm{FF}<2 \mu \mathrm{m}$ & $532 \pm 13$ & Passarelli et al. 2010 \\
\hline MGSZ mylonites & $\mathrm{K}-\mathrm{Ar}$ in $\mathrm{FF}<2 \mu \mathrm{m}$ & $377 \pm 9$ & Passarelli et al. 2010 \\
\hline Brusque Group & $\mathrm{K}-\mathrm{Ar}$ in $\mathrm{FF}<2 \mu \mathrm{m}$ & $359 \pm 9$ & Passarelli et al. 2010 \\
\hline MGSZ mylonites & $\mathrm{K}-\mathrm{Ar}$ in $\mathrm{FF}<2 \mu \mathrm{m}$ & $230 \pm 6$ & Passarelli et al. 2010 \\
\hline MGSZ mylonites & $\mathrm{K}-\mathrm{Ar}$ in $\mathrm{FF}<2 \mu \mathrm{m}$ & $206 \pm 5$ & Passarelli et al. 2010 \\
\hline
\end{tabular}


The granitic suites occurring in the central portion of the shear zone have yielded ages between ca. 615$610 \mathrm{Ma}$ (Passarelli et al. 2010), and are interpreted by the authors as recording the onset of transpressive shear in the shear zone during collision between the Florianópolis Batholith and the central domain of the Dom Feliciano Belt. On the other hand, U-Pb ages from rocks of the coastal domain of the shear zone are significantly more dispersed, spanning from ca. 650 to $585 \mathrm{Ma}$ (Chemale Jr et al. 2012; Florisbal et al. 2012a). Ages from 650 to $645 \mathrm{Ma}$ are the oldest crystallization ages within the context of the Florianopolis Batholith, and were obtained from anatectic melts in migmatites with low-angle foliations that predate the onset of the shear zone itself. Later ages, from 625 to $615 \mathrm{Ma}$, are interpreted to record a transition from a flat-lying SE-dipping structures to shear zone-controlled magma emplacement. Finally, the syn-to late-transcurrent stage of the Major Gercino Shear Zone is recorded in magmatic rocks controlled solely by the shear zone fabrics, which were dated between 615 and $585 \mathrm{Ma}$.

Regional medium-T geochronology in the shear zone is so far poorly constrained by K-Ar ages obtained by Passarelli et al. (2010), mostly corresponding to biotite cooling ages in the granites associated with the shear zone. They span from 585 to $560 \mathrm{Ma}$ and register the cooling that took place immediately after the end of granitic emplacement along the shear zone. Only a few ages were obtained in micas from the mylonites themselves. They correspond to one analysis in muscovite and one in biotite, both yielding ages of ca. $570 \mathrm{Ma}$, and an age of $539 \pm 13 \mathrm{Ma}$ in muscovite. These ages document late-stage shearing along the Major Gercino Shear Zone and reveal that further mylonitization followed the emplacement of granites in the structure. It should be noted, however, that no metamorphic crystallization ages had yet been recorded in the mylonites corresponding to the main period of shearing as constrained by the emplacement of the granitic intrusions, that is, between 615 and $585 \mathrm{Ma}$ (Passarelli et al. 2010; Chemale Jr et al. 2012; Florisbal et al. 2012a). Finally, subsequent brittle deformation of the shear zone is recorded throughout the Paleozoic by the neocrystallization of fine illite fractions. These samples record Devonian and Triassic ages (Passarelli et al. 2010).

\subsection{Structural characterization}

\subsubsection{Microstructures}

Most mylonites in the Major Gercino Shear Zone are the product of mylonitization of granitic protoliths. This is indicated by their mineralogy, predominantly composed of quartz, plagioclase and K-feldspar, in which feldspar porphyroclasts, mostly $\sigma$ - and $\phi$-types, are usually enveloped in a fine-grained felsic 
matrix. Muscovites are accessory mineral phases, rarely composing more than $1-2 \%$ of the rocks, except in the sericitic phyllonites, where abundant white mica usually marks the foliation. The predominant mafic mineral is biotite, which represents as much as $15 \%$ of some samples, either dispersed in the matrix or forming narrow monomineralic bands. Both biotite and muscovite are usually concentrated in bands, occasionally form mica fish, and have higher abundancies in the mylonites than in the granitic protoliths, indicating recrystallization during the shear zone activity. Igneous accessory phases such as zircon, allanite and apatite are usually present, as well as later metamorphic minerals such as epidote and chlorite.

Microstructures throughout the shear zone record the presence of submagmatic deformation in the granites emplaced during the development of the structure. They include features such as bent plagioclase, chessboard extinction of quartz and extensional microfractures in feldspars filled with matrix minerals (Fig. 5.4a). These structures can occasionally be found preserved in protomylonites which were only slightly reworked during later solid-state deformation.

Two assemblages of microstructures indicating solid-state ductile deformation are recognized. The first association is relatively uncommon and is characterized by sutured grain boundaries in quartz indicating grain boundary migration (Fig. 5.4b), and by the presence of well-developed recrystallization mantles in feldspar porphyroclasts (Fig. 5.4c). The second association occurs much more frequently, and is characterized by recrystallization of quartz by means of sub-grain rotation and, subordinately, bulging (Fig. 5.4d). This is accompanied by microfracturing of feldspars associated with limited recrystallization along the rim of the crystals. Rocks of this association commonly present some degree of chloritization of biotite and can also contain epidote.

Common shear sense indicators include mantled feldspar porphyroclasts, S-C and S-C' shear bands (Fig. 5.4e), oblique foliation in quartz bands (Fig. 5.4d) and muscovite fish. As observed at the macroscopic scale, although there is a predominance of structures indicating a dextral sense of shear, there are numerous examples of symmetric structures and of left-lateral displacement, particularly mantled porphyroclasts. This indicates a significant pure shear component during deformation (Passchier \& Trouw 2005; Fossen \& Cavalcante 2017; Mukherjee 2017). 


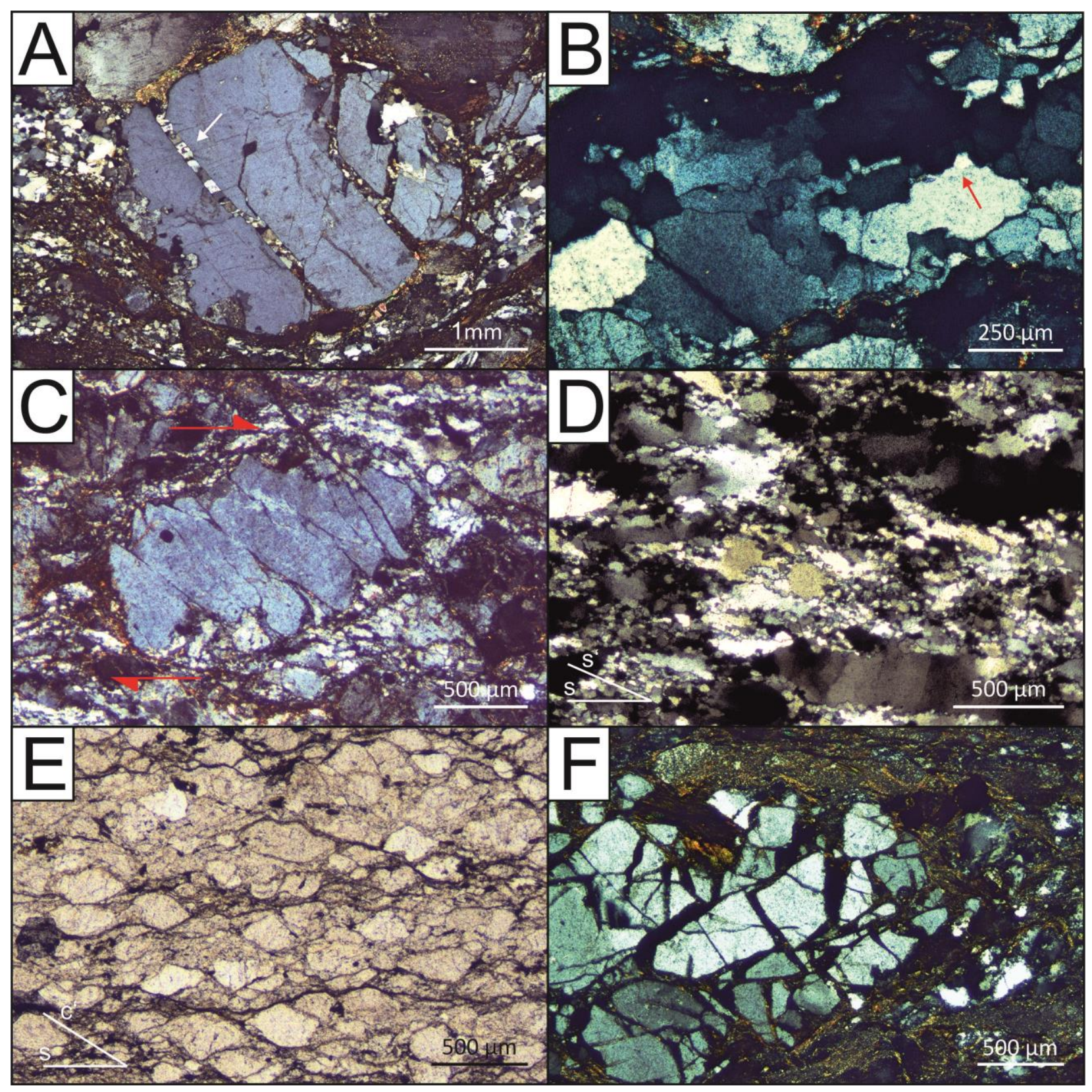

Figure 5.4: Photomicrographs of microstructures from the Major Gercino Shear Zone. a: mantled K-feldspar porphyroclast. The white arrow points to an extensional microfracture filled with undeformed magmatic quartz, indicating deformation in sub-magmatic state. b: Interlobated contact between quartz crystals, indicating dynamic recrystallization controlled by grain boundary migration. c: mantled rotated K-feldspar porphyroclast with $\sigma$ geometry, indicating dextral shear sense. $d$ : dynamic recrystallization in a quartz vein. The larger crystals are aligned parallel to the foliation $(S)$ while neoformed crystals have an oblique direction ( $S^{\prime}$ ), indicating sinistral shearing. Quartz was recrystallized by a combination of bulging and sub-grain rotation. e: General aspect of a protomylonite. Note the formation of S-C' shear bands oblique to the main foliation (S), indicating dextral shear. $\mathrm{f}$ : cataclastic microfracturing of K-feldspar porphyroclast 
Mylonitic features described above are frequently overprinted by cataclastic reworking, characterized by the presence of a very fine-grained matrix involving angular fragments of the original rock (Fig. 5.4f). Such deformation affects both the mylonites of the shear zone and previously undeformed rocks of the associated granitic intrusions. When mylonites are affected by cataclasis, it is common to identify ductile structures still preserved in the bigger fragments.

\subsubsection{Quartz CPO textures}

Texture analyses of the mylonites of the Major Gercino Shear Zone have so far been restricted to quartz c-axis analyses by means of U-stage (Passarelli \& Basei 1995; Passarelli et al. 2010). In order to expand on the existing data, seven samples of mylonites from the shear zone were selected for analysis of their quartz crystallographic preferred orientation (CPO) patterns with electron backscatter diffraction (EBSD) at the Bayerisches Geoinstitut of the Bayreuth University. Sections with an area of about $40 \mathrm{~mm}^{2}$ parallel to the lineation and perpendicular to the foliation were polished using a high $\mathrm{pH}$ silica solution (40-nm particle size) in order to remove damage from previous polishing steps. Samples were then analyzed with a Leo (now Zeiss) Gemini 1530 SEM with a Schottky emitter, and EBSD patterns were recorded with a Nordlys 2 camera and indexed with the Channel software package from Oxford Instruments. Mapping with a step size of $10 \mu \mathrm{m}$ yielded between 30,000 and 300,000 indexed points for quartz, depending on the sample. Discrete orientations were smoothed with Gaussian of $15^{\circ} \mathrm{FWHM}$ for pole figure analysis. The location of the samples is given in Fig. 5.1 and in Appendix A. Fig. 5.5 presents the pole figures of cand a- axes of all analyzed samples, along with the reference orientation of the poles of the foliation (Z) and the lineation (X). In general, the EBSD results are in agreement with the available c-axes fabrics and their interpretation (Passarelli \& Basei 1995; Passarelli et al. 2010), but the new data reveals more defined patterns, probably due to the much larger number of data points measured by the EBSD method.

Different quartz CPO patterns were obtained for the mylonites of the Major Gercino Shear Zone. The most common pattern is characterized by the distribution of [c]-axes maximum close to the $Z$ direction, with [a]-axes forming perpendicular girdles. From this group, samples MTF-01B, DSZ-25B and DSZ-28 are symmetric to slightly asymmetric, and the girdles formed by their [a]-axes are contained in the x-y plane. Samples MTF-02 and DSZ-20A, on the other hand, are strongly asymmetric. These patterns indicate a predominance of basal <a> slip as the main deformation mechanism, and the symmetric patterns point to a certain degree of flattening within coaxial deformation (Schmid \& Casey 1986; Passchier \& Trouw 2005). Regarding the microstructural characterization of these samples, they correspond to the majority 
of rocks on which quartz is predominantly recrystallized by means of sub-grain rotation, and often experienced chloritization of biotite. Besides the presence of a maximum close to $Z$, [c]-axes from sample DSZ-39a form a girdle in the z-y plane, indicating the activation of the rhomb <a> slip systems. Sample BR-92-15, on the other hand, displays [c]-axes along a girdle in the $x-y$ plane and a maximum close to $y$, with [a]-axes distributed along the $x-z$ plane. This pattern indicates the activation of prism <a> slip (Lister \& Hobbs 1980; Schmid \& Casey 1986; Passchier \& Trouw 2005). Both samples correspond to rocks which show no indication of chloritization, and on which grain boundary migration was recognized in addition to sub-grain rotation.

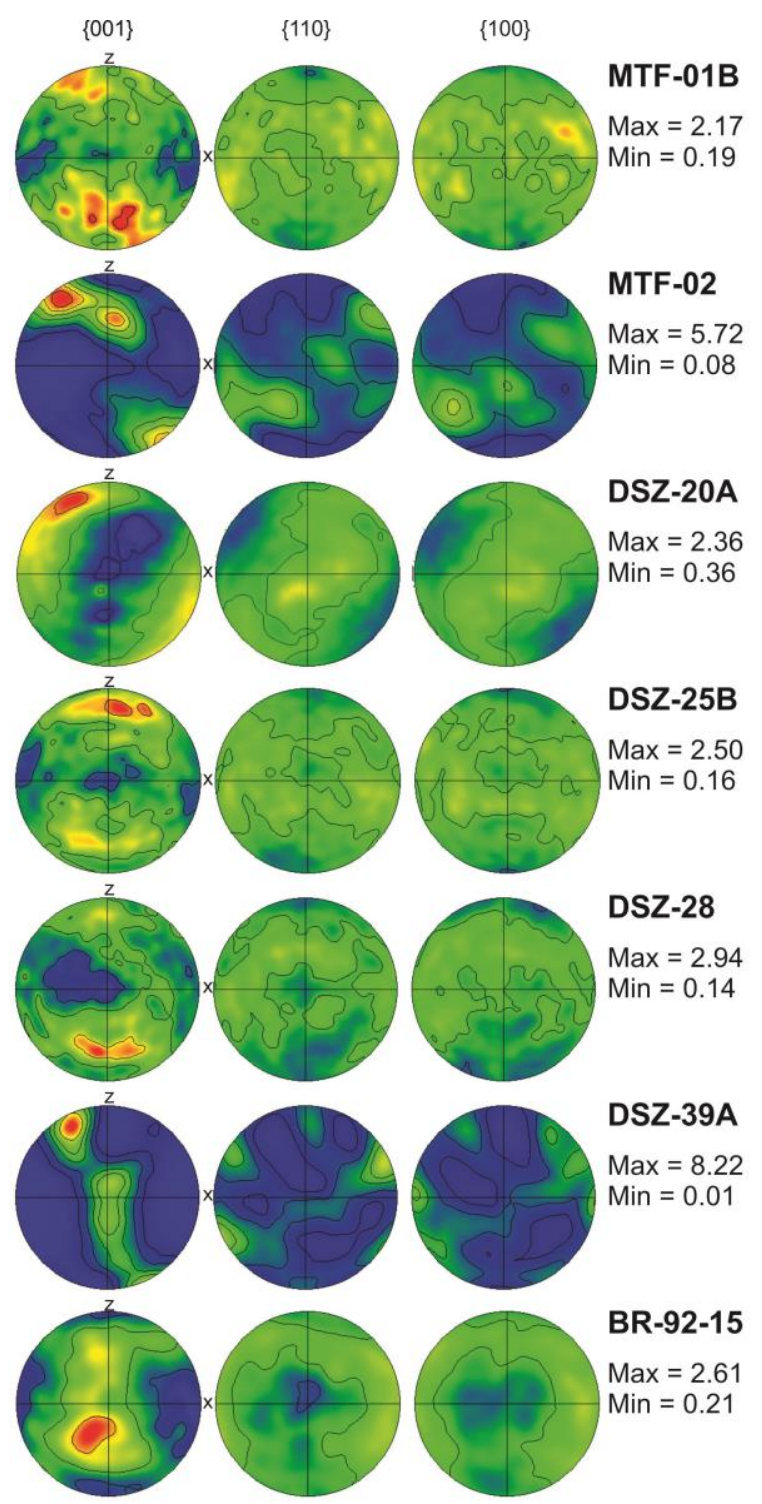

Figure 5.5: Quartz CPO pole figures from mylonite samples of the Major Gercino Shear Zone. Pole of the foliation ( $\mathrm{Z}$ ) and the lineation $(\mathrm{X})$ are marked. Color scaling is from blue (minimum) to red (maximum) 
Although quartz CPO patterns are not the most reliable criteria for determining shear sense (Killian et al. 2011), the new data diverge from the macro- and microstructural observation as the strongest asymmetries indicate a sinistral shear sense (samples MTF-02, DSZ-20a, DSZ-39A). The data, however, reflect the common ambiguity of shear sense indicators in the structure, presenting in addition some fairly symmetrical patterns (MTF-01B, DSZ-28) and slightly asymmetrical with a dextral sense (DSZ-25B, BR-92-15), indicating a significant pure shear component.

\subsection{K-Ar geochronology}

Geochronological analyses using the K-Ar method were performed in samples from selected rocks of the Major Gercino Shear Zone. The location of the samples is presented in Fig. 5.1 and in Appendix A. The main objective of this set of analyses is to better explore the evolution of the shear zone within the middle- to low-temperature range that the method offers. In particular, sampling was aimed at obtaining more ages of metamorphic crystallization during shearing in mylonites; comparing the cooling of the structure to that of its country rocks; and acquiring low-temperature ages by dating illite fine fractions coupled with a characterization of the dated material using X-ray diffraction.

\subsection{1 $\quad$ K-Ar in mica minerals}

Four samples were selected for K-Ar dating of coarse-grained muscovite. In order to determine ages for metamorphic crystallization during shear, two samples were selected from one of the best-exposed mylonitic outcrops in the central portion of the structure with abundant neocrystallized muscovite along the main foliation. They correspond to typical varieties of granitic mylonites that compose the majority of the shear zone. Petrographic analyses of the samples indicate that they display the characteristic greenschist-facies assemblage that dominates the structure (see Section 5.5.1). Two additional samples were collected from non-mylonitic metamorphic and igneous rocks outside of the structure, in order to characterize the thermal trajectory of the regional units and compare those to that of the shear zone. These comprise a mica-schist of the Brusque Group and an undeformed sample of the S-type São João Batista Granite, intrusive in the metavolcano-sedimentary sequence (Hueck et al. 2016).

Coarse-grained mica K-Ar ages are given in Appendix B. Muscovites from both mylonites samples yielded ages of $603.9 \pm 6.7$ and $597.8 \pm 7.5 \mathrm{Ma}$. These results are comparable within error and likely represent the same event, which is expected, as both samples were taken from the same outcrop. Considering the presence of muscovite fish in the sampled rocks and deformation of the mylonites under greenschist metamorphic conditions, these ages probably reflect syn-kinematic crystallization. 
The muscovite crystals obtained from the country rocks north of the Major Gercino Shear Zone yielded ages that are a little younger. Crystals from the Brusque Group mica-schist were dated at $588.1 \pm 6.1 \mathrm{Ma}$, while muscovites from the peraluminous São João Batista Granite produced an age of $576.4 \pm 6.3$ Ma. The latter ages correspond to cooling ages, and record a cooling from magma emplacement to temperatures below $425-350{ }^{\circ} \mathrm{C}$ within at least $15 \mathrm{Myr}$, as crystallization ages for these granites are between 610 and $590 \mathrm{Ma}$ (Silva et al. 2002a, 2005b; Basei et al. 2011a; Florisbal et al. 2012). The significance of the ages obtained for samples from the Brusque Group metasedimentary rocks are less clear, as they might represent either cooling ages from the sequence's thermal apex, related to the intrusion of the same granitic suites, or later stages of crystallization. Both new muscovite ages for country rocks are comparable with biotite and muscovite K-Ar ages obtained from the shear zone itself, reported by Passarelli et al. (2010).

\subsection{2 $\underline{\text { K-Ar in fine fractions }}$}

Three samples were selected for dating of fine illite fractions: two mylonites from the best-exposed outcrops of the shear zone (BR-79-15 and BR-80-15), and one mica-schist from the Brusque Group (BR72-15), in order to compare the activity in the shear zone with country rocks within the same thermal range. The latter sample corresponds to the same rock, from which muscovites were dated. All ages are presented in Appendix B.

Concerning results from the mlonitic samples, sample BR-79-15 produced grain-size-dependent ages of $345.2 \pm 4.9 \mathrm{Ma}$ and $336.8 \pm 4.3 \mathrm{Ma}$ for fractions $<2 \mu \mathrm{m}$ and $<0.2 \mu \mathrm{m}$, respectively, while sample BR-80-15 yielded ages of $438.9 \pm 4.9 \mathrm{Ma}$ and $353.3 \pm 5.4 \mathrm{Ma}$ for the same grain-size fractions. Both ages from sample BR-79-15 are somewhat within error, and it is probable that both record the same event. Sample BR-80-15, on the other hand, clearly records two ages with distinct significances, the younger of which is quite similar to both ages obtained on the first sample.

Determination of the illite crystallization conditions of the mylonite samples indicates low-temperature environments. Most measured X-ray diffraction spectrums yielded rather broad $10 \AA$ illite peaks, with Kübler Indexes ranging between 0.432 and 0.518 , indicating thermal conditions around the transition from the diagenetic-zone to anchizone (ca. $150-200^{\circ} \mathrm{C}$, Kübler 1967; Merriman \& Frey 1999). Those results are in accordance with a qualitative analysis of the samples' illite polytypes. In the evaluated spectra, obtained from untextured samples, none of the diagnostic peaks were recognized for polytypes $1 \mathrm{M}$ and $2 \mathrm{M}_{1}$, indicating that the dominating crystal polytype is of the low-temperature $1 \mathrm{M}_{d}$ variety. 
On the other hand, results from the fine fractions extracted from the metasediments of the Brusque Group (Sample BR-72-15) record older and less clear ages. The ages are also grain-size-dependent, but exhibit an inverted pattern, that is, in which the finest fraction produced older ages (497.4 $\pm 3.8 \mathrm{Ma})$ than the coarser fraction $(436.3 \pm 6.7 \mathrm{Ma})$. Another distinction between the results of this sample and those from the mylonites is the apparent higher-temperature crystallization conditions of the measured illites. This is indicated by Kübler indexes consistently below 0.25 , and by the presence of characteristic illite peaks between 29 and $33^{\circ} 20$ in the X-ray diffraction spectra of untextured analyses, which are typical of $2 \mathrm{M}_{1}$-variety illite polytypes. All of these evidences suggest crystallization under conditions upwards of $300^{\circ} \mathrm{C}$.

\subsection{Discussion}

\subsubsection{Structure and deformation of the Major Gercino Shear Zone}

The ductile history of the Major Gercino Shear Zone can be reconstructed by identifying the different deformation stages that affect it and constraining the conditions in which they were developed. A wellestablished approach for characterizing these conditions is by combining microstructural and textural analyses in order to constrain the deformation mechanisms that were active during the shearing.

One of the main aspects of the shear zone is that it developed during the emplacement of granitic intrusions, which form the protoliths of most of the mylonites. Magmatic fabrics, predominantly recorded by the shape-preferred orientation of euhedral feldspar crystals, are locally preserved in rocks that were little affected by solid-state deformation, commonly restricted to the core of the intrusions. Sub-magmatic deformation structures (e.g. Bouchez et al. 1992; Paterson et al. 1998), such as feldspars with microfractures filled with magmatic matrix minerals and chessboard extinction in quartz, are common and have been recognized by numerous authors (Bitencourt \& Kruhl 2000; Passarelli et al. 2010; Florisbal et al. 2012b).

Coeval with the emplacement of the intrusions, strain localization during solid-state deformation culminated in the formation of the mylonitic belts that characterize the shear zone. Two main microstructural assemblages were recognized in these mylonites. The first assemblage is marked by the presence of localized recrystallization in feldspar, forming continuous mantles around porphyroclasts, associated with dynamic recrystallization in quartz by means of grain boundary migration and, subordinately, sub-grain rotation. This assemblage corresponds to the minority of samples, for which quartz CPO patterns (Fig. 5.5) indicate the activation of rhomb and prism <a> slip as slip systems, 
suggested by a concentration of [c]-axes within the z-y plane (sample DSZ-39A) and, in one sample with a maximum approximately parallel to the y direction (BR-92-15). Together, these evidences point to maximum deformation conditions between 450 and $550{ }^{\circ} \mathrm{C}$, between the lower amphibolite and upper greenschist metamorphic facies (Jessell 1987; Pryer 1993; Stipp et al. 2002; Passchier and Trouw 2005).

Most samples, however, show feldspar porphyroclasts with poorly developed recrystallization mantles and a predominance of microfracturing and mechanical twinning as main deformation mechanisms. Dynamic recrystallization in quartz in these samples is mostly driven by sub-grain rotation, associated with bulging. This assemblage corresponds to the majority of CPO patterns (Fig. 5.5), in which basal <a> slip is the main slip system, as evidenced by [c]-axes concentrated close to the $Z$ direction and [a]-axes forming perpendicular girdles. All of these evidences indicate temperature conditions lower than those of the first assemblage, predominantly between 350 and $450{ }^{\circ} \mathrm{C}$ (Pryer 1993; Stipp et al. 2002; Passchier and Trouw 2005). Greenschist-facies conditions are in accordance with the common presence of chlorite in the samples of this assemblage, replacing biotite due to retrograde metamorphism. The microstructural and textural assemblages described above characterize a progression of shearing under a cooling trajectory within low-grade metamorphic conditions, predominantly in the greenschist facies. Both solid-state assemblages seem to have developed during a single tectonic event until cooling was reached, as they share the same structural characteristics.

Shear sense indicators such as rotated porphyroclasts, shear bands, oblique foliations and mica fish predominantly indicate dextral shearing, though a significant number of structures show symmetrical and even sinistral geometries. Despite the inherent problems in inferring shear sense from quartz CPO patterns (e.g. Killian et al. 2011), new data also present ambivalent asymmetries, with the best and clearest indicators suggesting sinistral shear, in contrast to most macro- and microstructures. The dominance of dextral together with the presence of symmetrical and even sinistral kinematic indicators thus suggests a significant pure shear component (Passchier \& Trouw 2005; Fossen \& Cavalcante 2017 and references therein). This is further supported by strain analysis data of Passarelli et al. (2010) and by the symmetric geometry of intrafolial folds with axes parallel to the stretching lineation. Altogether, data indicate pure-shear-dominated dextral shearing for the MGSZ.

Finally, the widespread presence of cataclasis records the transition of the shear zone into cooler conditions, already within the brittle deformation regime. They might represent either the final stages of displacement within the ceasing tectonic event responsible for the ductile shear or posterior reactivations of the structure within the Phanerozoic. Medium to low-temperature geochronology 
indicate a long-term geological history within this thermal range, as will be discussed below (Section 5.5.3).

\subsubsection{Geochronological constraints and the evolution of the Major Gercino Shear Zone and the Catarinense Shield}

By integrating the structural observations with the new and available geochronological data, the geological evolution of the Major Gercino Shear Zone can be reconstructed (Fig. 5.6, Fig. 5.7) and compared with that of other tectonostratigraphic units of the Catarinense Shield during the same period.

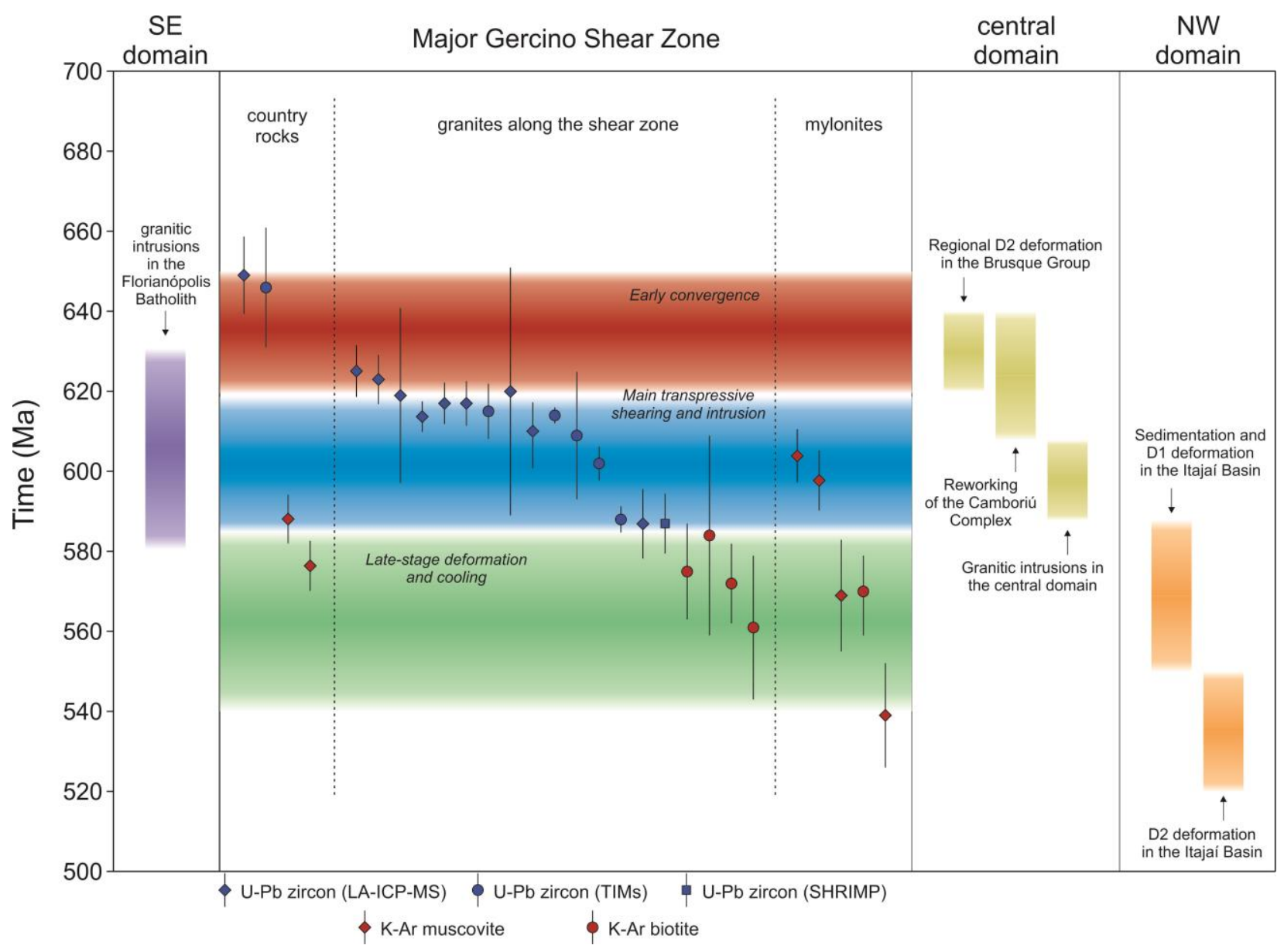

Figure 5.6: Summary of new and published geochronological data of the Major Gercino Shear Zone with an indication of the main stages of deformation, and regional events in the Catarinense Shield. U-Pb data in zircon are from Passarelli et al. (2010); Chemale et al. (2012) and Florisbal et al. (2012c). Previously available K-Ar data are from Passarelli et al. (2010)

The initial structural configuration of the rocks within the Dom Feliciano Belt in Santa Catarina is predominantly recognized in the regional events that affect the Brusque Group and gneissic basement 
inliers between 650 and $620 \mathrm{Ma}$ (Fig. 5.7a), and was dominated by regional thrusting and folding with NW-vergence (Silva et al. 2002b; Philipp et al. 2004; Basei et al. 2011b, 2013; Campos et al. 2012; Chemale Jr. et al. 2012; Florisbal et al. 2012a; Chapter 2). This stage predates the onset of the Major Gercino Shear Zone itself, and can only be observed locally within the oldest rocks associated with the Florianópolis Batholith (Chemale et al. 2012), which were almost entirely reworked by strike-slip shearing related to the mylonites. Granites dated between 625 and 615 Ma record a transition from this first structural stage to subvertical foliations parallel to that of the mylonites, constraining the end of this stage (Chemale et al. 2012; Florisbal et al. 2012a, b).

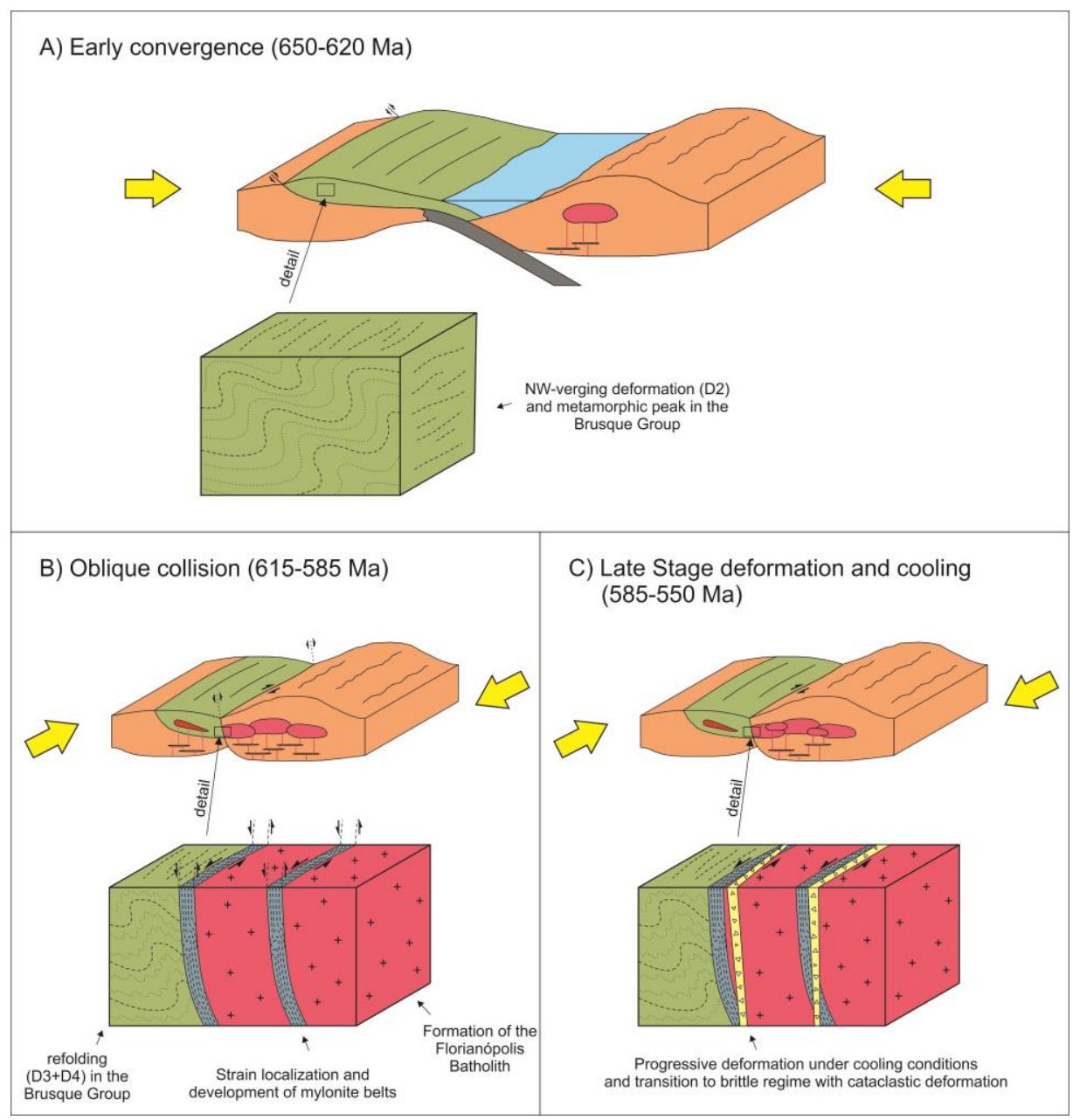

Figure 5.7: Schematic model showing the evolution of the Major Gercino Shear Zone in the context of the $S$ Catarinense Shield. Early convergence is recognized regionally. Installation of the shear zone is marked by the onset of transpression and was accompanied by the intrusion of syn-kinematic granites and intense mylonitization, gradually changing into transcurrent-dominated deformation. Late-stage deformation is recorded by dominant greenschist facies ductile deformation in mylonites and transition to brittle deformation 
The installment of the Major Gercino Shear Zone as a strike-slip structure marks the juxtaposition of the southern and central domains of the Dom Feliciano Belt in Santa Catarina along the former suture zone between both domains. This is constrained by the intrusion of syn-kinematic granitic magmatism between 615 and $585 \mathrm{Ma}$ (Passarelli et al. 2010; Chemale et al. 2012; Florisbal et al. 2012a). During this pure-shear-dominated strike-slip stage of the shear zone, the continued emplacement of granitic magma triggered strain softening, favoring strain localization within the intrusions (Tommasi et al. 1994; Vauchez et al. 1997). Cooling of these intrusions led to a transition to solid-state deformation, in particular along intrusion margins, which was responsible for the formation of the extensive mylonitic belts of the shear zone (Fig. 5.7b). As recognized in the new microstructural and textural observations presented in this contribution, continuous evolution from lower amphibolite to greenschist metamorphic facies is recorded in the mylonites, with the latter being predominant in the shear zone. New K-Ar dating of synkinematic muscovite yielded ages (604-598 Ma) within the time span of the granitic intrusions, i.e., 615$585 \mathrm{Ma}$. Considering that the closure temperature of the K-Ar system in muscovite lies within the greenschist-facies conditions estimated for the deformation of these rocks (Purdy and Jäger 1976; Harrison et al. 2009), these results can be interpreted as the timing of syn-kinematic crystallization. Hence, the new ages set, for the first time, a strong indication that the emplacement of the granitic magmatism was coeval with the mylonitization. Another consequence of these ages is that the intrusion of the granites along the shear zone took place at middle- to upper-crust conditions. Similar ages obtained for muscovites from a metasedimentary sample of the Brusque Group indicate comparable temperature conditions for the country rocks.

By this time, the Major Gercino Shear Zone was an active tectonic boundary between the southern and central domains of the Dom Feliciano Belt in Santa Catarina. The granitic magmatism emplaced around the structure was not confined to it, as it shares petrographic, isotopic and geochronological signatures with the abundant isotropic granitogenesis in the contemporaneous Florianópolis Batholith (Passarelli et al. 2010, 2011b; Florisbal et al. 2009, 2012a, b). These signatures, on the other hand, are in strong contrast with those of the rocks from central domain (Basei et al. 2000; Passarelli et al. 2010, 2011b; Florisbal et al. 2012a, b; Hueck et al. 2016), indicating that the magmatism along the Major Gercino Shear Zone should be predominantly regarded as product of this southern domain evolution.

The transition from an early convergent setting to pure-shear dominated strike-slip deformation is in accordance with a context of regional transpressive regime caused by the oblique collision that generated the Dom Feliciano Belt (e.g. Oyhantçabal et al. 2009; Oriolo et al. 2015, 2016a, 2018a; Basei et al. 2018). In this sense, the early stage would correspond to the convergence between the adjacent 
crustal blocks. With the onset of the Major Gercino Shear Zone, strain partitioning led to localized strikeslip deformation along the former suture zone. At the same time, contraction and dip-slip deformation were predominant in the Brusque Group, leading to the refolding of the regional foliation locally evolving to strike-slip shear zones (Philipp et al. 2004; Basei et al. 2011a).

Deformation along the mylonitic belts did not cease after the emplacement of granitic magmatism, as recorded in $\mathrm{K}-\mathrm{Ar}$ ages from 570 to $540 \mathrm{Ma}$, obtained both in muscovite and biotite from mylonites of the shear zone (Passarelli et al. 2010). These ages are interpreted to correspond to crystallization ages during further solid-state deformation as they were obtained from samples with low-grade metamorphic conditions, similarly to the new ages obtained in this work.

Muscovite and biotite K-Ar ages in rocks from the Brusque Group and Florianópolis Batholith between 584 to 561 Ma (Passarelli et al. 2010; Section 5.4.1) indicate that both the Major Gercino Shear Zone and its country rocks were at comparable temperature conditions during this period, and suggest regional cooling, possibly associated with post-collisional exhumation. There is a moderate concentration of biotite $\mathrm{K}-\mathrm{Ar}$ ages around 585-540 Ma, in contrast with a predominance of muscovite K-Ar ages combined with granite crystallization between 615-585 Ma. This cooling trajectory suggests that the beginning of brittle activity along the shear zone probably took place after ca. $540 \mathrm{Ma}$ (Fig. 5.7c), marking the end of the high- to medium-temperature deformation of the structure.

\subsubsection{Illite ages and the Phanerozoic history of the Major Gercino}

Illite crystallization ages from mylonites of the Major Gercino Shear Zone evidence recurrent deformation throughout the Phanerozoic (Fig. 5.8). The ages obtained in this study are restricted to the Silurian and the Carboniferous, adding to previous ages from Passarelli et al. (2010) confined to the Upper Devonian and Upper Triassic. Estimation of the temperature conditions during illite crystallization for the newly dated samples indicate low-temperature conditions, predominantly around the diageneticzone to anchizone transition (ca. $150-200^{\circ} \mathrm{C}$, Merriman \& Frey 1999). Such conditions are in accordance with the thermochronological data of the area (Chapter 8), which indicate at least partial closure of the zircon (U-Th)/He system (and, consequently, temperatures below $180^{\circ} \mathrm{C}$ ) from the early Paleozoic on. 


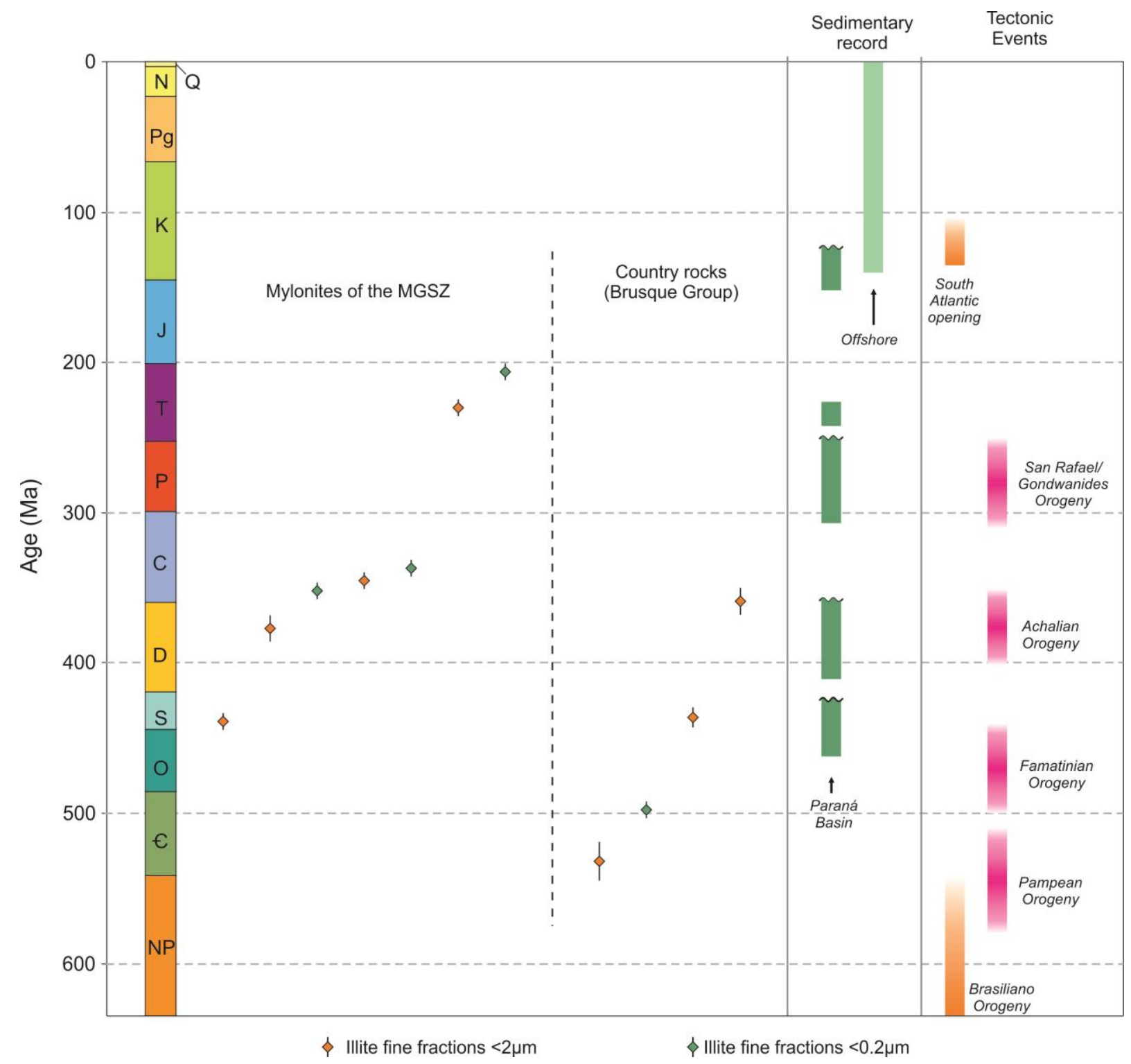

Figure 5.8: Summary of K-Ar ages in illite fine fractions of the Major Gercino Shear Zone, compared to the main sedimentary sequences in the region and tectonic events ins southwestern Gondwana. Previously available data are from Passarelli et al. 2010. Error bars represent $2 \sigma$ error

This pattern of multiple illite crystallization events during most of the Paleo- and Mesozoic suggest recurrent reactivation of the fault zone under brittle conditions. Upper Paleozoic faulting has been linked to the sedimentary evolution of the Paraná Basin, and has commonly been associated with far-field effects of the active southwestern margin of Gondwana (Zalán et al. 1990; Rostirolla et al. 2000; Holz et al. 2006; Rocha Campos et al. 2007; Milani et al. 2007; Oriolo et al. 2018a; Chapter 6). A concentration of ages on the early Carboniferous (359-337 Ma), in particular, are coeval with a discontinuity of the Paraná basin in the top of the Devonian, leading to a deposition gap of over $60 \mathrm{Myr}$. 
When compared to ages obtained within the shear zone, newly dated fine fractions in the metasediments of the Brusque Group show overall older ages. Furthermore, the evaluation of the illite crystallization conditions of the new measured sample indicate higher temperature conditions than those experienced by illites crystallized along the shear zone (probably above $300^{\circ} \mathrm{C}$ ). This sets an upper limit for the cooling of regional conditions in the country rocks north of the Major Gercino Shear Zone below ca. $300^{\circ} \mathrm{C}$ to $500-435 \mathrm{Ma}$. As noted above, however, regional conditions in the study area were likely below $180^{\circ} \mathrm{C}$ by the early Ordovician (Chapter 8 ), suggesting that the estimated temperatures are not representative of the entire region. A possible interpretation for this could be the upward percolation of hydrothermal fluids during local fault reactivation (e.g. Tagami 2012). Similar rocks also dated for illite fine fractions by Passarelli et al. (2010) yielded distinctly younger ages of $359 \pm 9 \mathrm{Ma}$. This dating, however, was not accompanied by analysis of the crystallization conditions of the material, and might represent lower temperatures conditions, more akin to those estimated for the newly dated samples of the shear zone itself. Considering that low-crystallinity illites start crystallizing from rearrangement of smectites already in temperatures within the early diagenesis range (Środoń \& Eberl 1984), this age might represent regional reheating due to burial of the Paleozoic sediments of the Paraná Basin.

\subsection{Conclusions}

A revision of new and published structural, microstructural, textural and geochronological data of the Major Gercino Shear Zone was used to reconstruct the geological evolution of the shear zone and situate it within the geodynamic context of the Brasiliano-Pan-African orogenic system. An early stage of deformation coeval with the regional metamorphic peak in the Catarinense Shield between 650-615 Ma produced NW-vergent folds and thrust and was almost entirely reworked afterwards in the area of the shear zone. The onset of the Major Gercino Shear Zone took place during the juxtaposition of granitic rocks from the Florianópolis Batholith with metavolcano-sedimentary sequences from the Brusque Group. This stage was characterized in the shear zone by pure-shear dominated strike-slip deformation, and was accompanied by the continuous intrusion of granites between 615 and $585 \mathrm{Ma}$. These granites favored strain softening during emplacement, and strain localization along their borders generated wide mylonitic belts, predominantly under greenschist metamorphic conditions. This evolution is interpreted in the context of regional transpression during and after oblique collision. Late-stage deformation continued along the shear zone until ca. $550 \mathrm{Ma}$, probably accompanying exhumation. After the stabilization of the Catarinense Shield and cooling below brittle-ductile transition conditions, reactivation 
of the structure occurred sporadically and might reflect far-field effects of the ongoing active southwestern margin of Gondwana. 


\section{CHAPTER 6: Phanerozoic low-temperature evolution of the Uruguayan Shield}

\subsection{Introduction}

The eastern coast of the South American continent has long been the subject of thermochronology studies which have focused on the rift and post-rift evolution of its "passive" margin, especially on its steep coastal ranges (e.g. Tello Saenz et al. 2003; Hackspacher et al. 2004; Franco-Magalhães et al. 2010, 2014; Cogné et al. 2011, 2012; Karl et al. 2013; Jelinek et al. 2014). Older ages recording pre-rift exhumation, however, are usually restricted to a few samples which were not as strongly overprinted by the intense uplift during the Cretaceous and Cenozoic (Hiruma et al. 2010; Karl et al. 2013; Jelinek et al. 2014).

There is, however, evidence of the influence of far-reaching tectonic processes from the Gondwanan active margin into the interior part of the supercontinent, as recorded in its long sedimentary history (Zalán et al. 1990; Lopez-Gamundi \& Rossello 1993; Zerfass et al. 2004; Milani et al. 2007). With the recent extension of the low-temperature investigations to study areas less affected by the rift and postrift uplift, this complex history is now being identified in the thermochronological record (Oliveira et al. 2015b; Kollenz 2015).

One such area is the crystalline basement of Uruguay, which occupies much of the south and east of the country (Fig. 6.1). In this Chapter a multi-method low-temperature study of the Uruguayan Shield is presented, combining (U-Th)/He ages from both zircon and apatite, T-t modelling and K-Ar dating of fine illite fractions and fault gouge clays. The results reveal a protracted exhumation history spanning almost the entire Phanerozoic, from the post-collisional phase of the Brasiliano orogenic cycle to the rifting of the South Atlantic Ocean. The new data are discussed considering the sedimentary and geomorphological record in the area, and compared to the few local pre-existing low-temperature data and regional constraints. Finally, the influence of the inherited structural framework after the end of the orogenic process and during the sedimentary evolution of the area is discussed in light of the new data. 


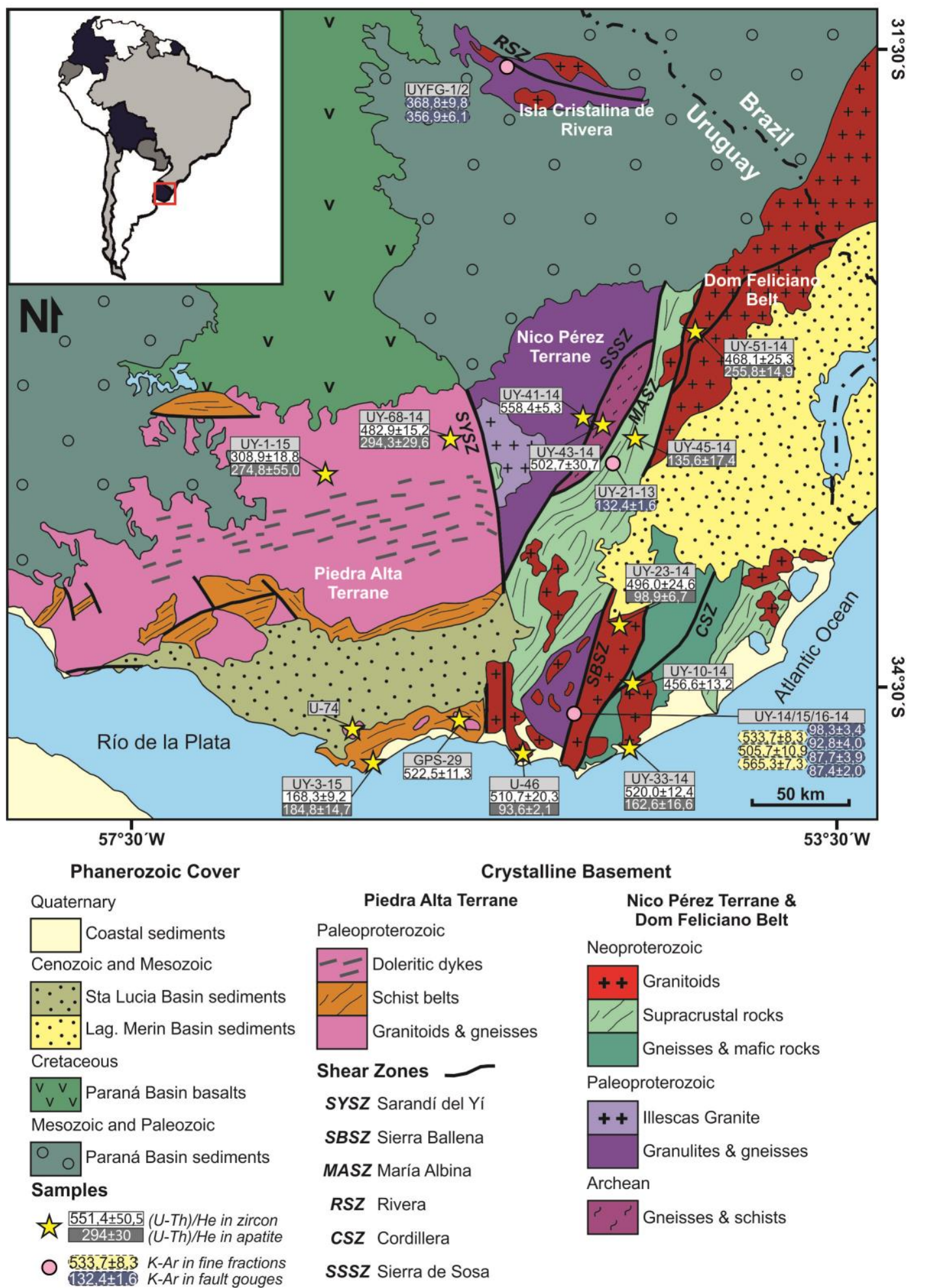

Figure 6.1: Geological map of the Uruguayan Shield with sample localities and (U-Th)/He and K-Ar results. Modified after Oyhantçabal et al. (2011b) and Oriolo et al. (2015) 


\subsection{Geomorphological aspects of the Uruguayan Shield}

The Uruguayan Shield is generally flat and its modest ranges hardly exceed $500 \mathrm{~m}$ in altitude, thus differing from the passive Atlantic margin further north in south and southeast Brazil, in which the highest peaks exceed $2000 \mathrm{~m}$. The most elevated areas within Uruguay form a watershed dividing the country with an approximate $\mathrm{N}-\mathrm{S}$ orientation, and are referred to as the geomorphological Eastern Hills Region by Panario et al. (2014).

Geologically, these areas correspond to rocks associated with the Dom Feliciano Belt and the Nico Pérez Terrane. Its prominence is especially accentuated in the southern portion of Uruguay, between the Santa Lucia-Aiguá-Merin Lineament and the coastal shoreline. With the notable exception of the Carapé Massif, a part of the Granitic Belt that sustains the culminating peak in the country (Cerro Catedral), this topographically elevated domain is almost entirely bound to the east by the Sierra Ballena Shear Zone and to the west by the Sarandí del Yí Shear Zone (Fig. 6.2a). An extreme example of the topographic contrast along the Nico Pérez Terrane, enhanced by differential erosion caused by lithological differences, is the western flank of the Sierra de las Animas located in the southern extent of the Sarandí del Yí Shear Zone (Fig. 6.3a). This contrast, however, is not uniform along the length of the structure.

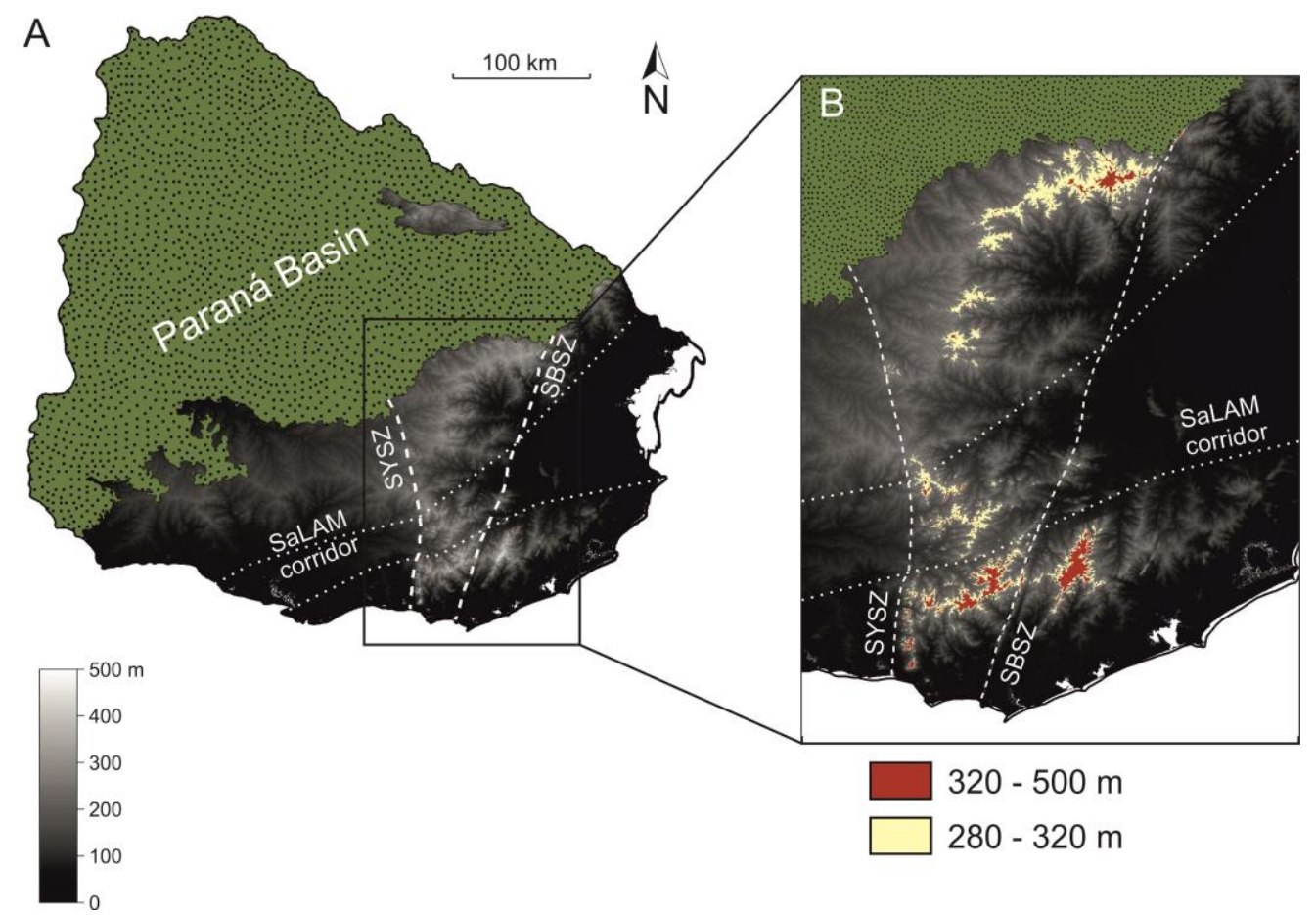

Figure 6.2: Digital elevation model of the Uruguayan Shield (a) with indication of the shear zones that separate the main terranes and detail of the extension of the main paleosurfaces (b) 


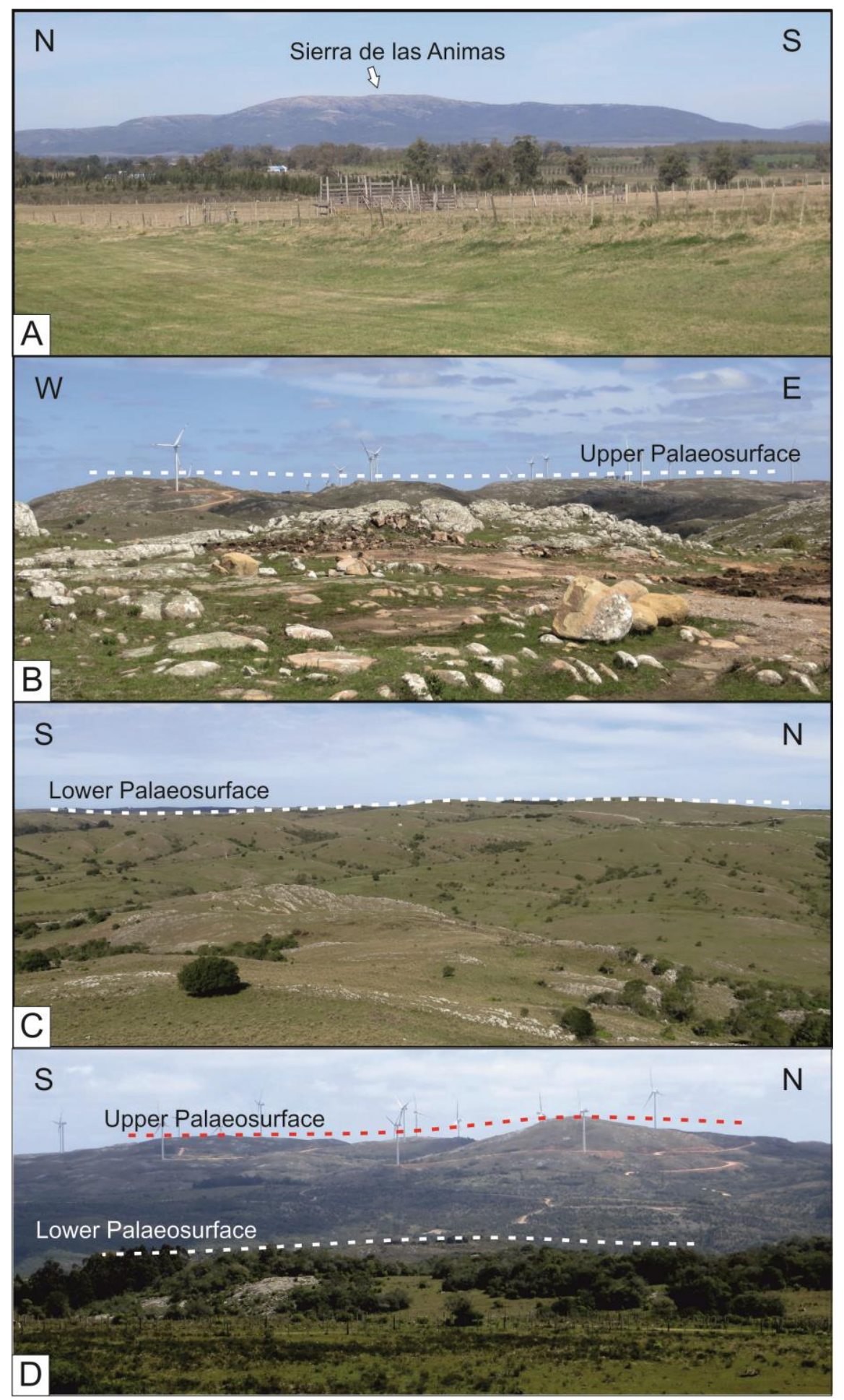

Figure 6.3: Typical landscapes of the Uruguayan Shield: a) strong topographic contrast on the western flank of the Sierra de las Animas, along the Sarandi del Yi Shear Zone; b) upper paleosurface visible as flat hilltops close to the Cerro Catedral (elevation ca. $480 \mathrm{~m}$ ); c) lower planation surface, strongly dissected with the formation of valleys along main drainage paths (elevation ca. $280 \mathrm{~m}$ ); d) view to the upper paleosurface from the lower paleosurface (elevation: ca. $310 \mathrm{~m}$ ) 
Restricted vestiges of elevated paleosurfaces occur in the Eastern Hills Region. Panario et al. (2014) identifies two distinct levels (Fig. 6.2b). The upper surface comprises elevations between 320 and $500 \mathrm{~m}$ and is particularly well exposed on flat weathering fronts preserved on the Cerro Catedral (Fig. 6.3b). The lower paleosurface, situated between 280 and $320 \mathrm{~m}$ and exposed in such ranges as the Aiguá and Yerbal Sierras, displays better developed soil horizons (Figs. 6.3c, 6.3d). Both surfaces are interpreted to have a Mesozoic origin by Panario et al. (2014), and correlate well with the geomorphology of the coastal Tandilia range in the Argentinian portion of the Rio de la Plata Craton (Demoulin et al. 2005).

\section{3 (U-Th)/He thermochronology}

Sampling for the (U-Th)/He method focused mostly on granitoids and gneisses. A total of 29 samples were treated for mineral concentration, of which 11 were selected for zircon analysis and nine for apatite, comprising all of the main tectonic blocks on the Uruguayan Shield. Seven of these samples yielded both minerals, with the potential of revealing more detailed thermal paths during modelling. Coordinates for all analyzed samples are presented in Appendix A.

\subsubsection{Zircon (U-Th)/He results}

Zircon (U-Th)/He (ZHe) ages are presented in Fig. 6.1, and in Appendix E. A few outlier ages were discarded as unrealistic within the regional context, probably biased by high radiation damage density and the strong core-rim zoning of the actinide elements. These results are neither considered for the calculation of average ages nor reported in the following sections. Additional analyses using Raman spectroscopy of zircons from a discarded sample indicated a low degree of "crystallinity", probably caused by the accumulated radiation damage (e.g. Nasdala et al. 2001, Chapter 8 ).

Nonetheless, the effect of radiation damage is of little consequence in the measured dataset. Effective uranium content $(\mathrm{eU}, \mathrm{U}+0.235 * \mathrm{Th}$, in $\mathrm{ppm}$ ) values are wide-ranging, with most crystals bearing values between 30 and $600 \mathrm{ppm}$. There is, however, no evident intra-sample correlation pattern between the obtained ZHe ages and either eU or crystal size, and even samples from a same domain that yielded similar ages have different and non-linear patterns. This behavior unfortunately prevents any attempt to further enhance thermal modelling by applying eU as a criterion (e.g. Guenthner et al. 2015; Orme et al. 2016, Chapter 8).

The sample average ZHe ages are consistent throughout the Uruguayan Shield (Fig. 6.1), covering an interval of ca. $100 \mathrm{Myr}$ (560 to $460 \mathrm{Ma}$ ), i.e. from the end of the Ediacaran to the Ordovician. These ages 
extend continuously throughout this time span, not converging to any given episode. The only exception is sample UY-1-15, collected in the interior part of the Piedra Alta Terrane. It produced an age of $309 \pm 19$ Ma, which is almost 150 Myr younger than the time interval set by the remaining samples.

Concerning the obtained ages, with the exception of sample UY-1-15, no regional trend is discernible, not even along the main Brasiliano shear zones. Relatively old ages occur close to young ones, and even the most significant geological structures may lie between samples displaying age differences of only 10 or $20 \mathrm{Myr}$, such as in the southern part of the study area. The oldest recorded age (558 \pm 5$) \mathrm{Ma}$, was obtained in a gneiss sample from the granulitic basement of the Nico Pérez Terrane, while the youngest (457 $\pm 13 \mathrm{Ma}$ ) comes from mylonitic rocks along the Cordillera Shear Zone. In addition, there is no significant correlation between ZHe ages and sample altitudes.

\subsection{2 $\quad$ Apatite (U-Th)/He results}

Apatite (U-Th)/He (AHe) ages are presented in Fig. 6.1, and in Appendix E. Only a few of the ages contradict geological evidence, as clarified in the footnote in Appendix E. As with the ZHe results, no significant pattern was identified when comparing single-crystal He ages from a given sample to the corresponding eU or crystal size (e.g. Flowers et al. 2009; Murray et al. 2016).

In contrast to the zircon results, however, the sample average apatite ages are much more dispersed, and can be clustered into three groups (Fig. 6.1). The three oldest samples yielded Permian ages, followed by a triplet of Jurassic-Cretaceous ages and, finally, two mid-Cretaceous ages. Age uncertainties overlap for samples within a same group, but do not extend from one group to another.

Another difference between the ZHe and AHe datasets is that the latter displays variability as a function of sample location. In general, samples collected in the hills of the northern section of the Uruguayan Shield, close to the border of the Paraná Basin, yielded the oldest (Permian) cooling ages. In contrast, the youngest ages, i.e. from the Jurassic to the Cretaceous, were obtained almost exclusively in samples collected in the southern portion of the study area. Nonetheless, correlation between the apparent AHe age and altitude is only moderate $(r=0.71)$.

\subsection{Modelling the (U-Th)/He dataset}

Cooling trajectories were modelled using HeFTY 1.8.3 software (Ketcham 2005) for every sample in which both zircon and apatite (U-Th)/He ages were obtained. Results from samples UY-43-14 and UY-4514 were modelled together, assuming a combined geological evolution. Calibration models for zircon 
(Guenthner et al. 2013) and apatite (Flowers et al. 2009) considered U, Th and Sm concentrations for every crystal, as well as their dimensions. Within the model, calculated ages were corrected for alpha ejection age according to Ketcham et al. (2011). Obtained fits were categorized as either good or acceptable matches, according to general recommendations by Ketcham (2005). Samples were modelled using all measured crystals, but results failing to produce acceptable fits were recalculated on the basis of only two crystals of each mineral.

Initially, all samples went through an unsupervised model, in which only starting and ending points were fixed. Regional muscovite cooling ages were represented by a time-temperature constraint at 350$425^{\circ} \mathrm{C}$ (after Purdy \& Jäger 1976 and Harrison et al. 2009), centered at 600 Ma for basement units and of 580 Ma for Dom Feliciano Belt granitic intrusions (Oyhantçabal et al. 2009; Oriolo et al. 2016a, b), and annual mean surface temperatures of $17 \pm 2{ }^{\circ} \mathrm{C}$ were assumed. For samples of the Piedra Alta Terrane, in which muscovite cooling ages are Paleoproterozoic (Oyhantçabal et al. 2011b), a temperature interval was fixed shortly before the oldest single-crystal ZHe age at $160-200{ }^{\circ} \mathrm{C}$, beyond the limit of the ZHe method.

Following this first approach, each sample was tested for a set of four independent hypotheses, based on the sedimentary record covering the Uruguayan Shield. Hypothesis 1 assumes an exhumation shortly after the Brasiliano orogenic cycle and pre-dating the first Phanerozoic sediments in the Paraná Basin, i.e. the Devonian Durazno Group (part of the Paraná Sequence after Milani et al. 2007). This scenario was modelled by fixing time-temperature constraints for the modelling below $60{ }^{\circ} \mathrm{C}$ during the $440-420$ Ma interval, in the Silurian. The reburial event caused by the Paleozoic sedimentation of the Paraná Basin did not exceed $90^{\circ} \mathrm{C}$, a value independently provided by organic maturation data detected close to the study area (Silva \& Cornford 1985). This estimation also considers the strong likelihood of sample locations at the edge of the basin, and assumes that the basement was little affected by the intrusion of basic rocks associated with the Cretaceous magmatism, responsible for the most intense maturations recorded in this sequence (Zalán et al. 1990; Hurter \& Pollack 1994; Souza et al. 2008). Hypothesis 2 postulates a similar exhumation with exposure to surface conditions after the Brasiliano orogenic cycle, during or after the Devonian sedimentation, but before the onset of Permian Gondwana I deposition in the Paraná Basin (Milani et al. 2007). This hypothesis would allow the sampled area to act as a possible provenance source for the Durazno Group as postulated by Uriz et al. (2016), and was modelled by placing a time-temperature constraint below $60^{\circ} \mathrm{C}$ during the Devonian and early Carboniferous (420$320 \mathrm{Ma}$ ). As with Hypothesis 1, the maximum temperature assumed as a result of the Paleozoic deposition was $90^{\circ} \mathrm{C}$. Hypothesis 3 adopts an exposure to surface conditions during the early and middle 
Jurassic, shortly before the onset of the Paraná volcanism. This was constrained by means of a timetemperature constraint below $60^{\circ} \mathrm{C}$ from 200-160 Ma. The maximum temperature associated with the reheating events was limited only by the thermal limits of the (U-Th)/He method, since it is entirely dependent on the effect of the volcanic rocks. Furthermore, this hypothesis was rejected for samples UY68-14 and UY-51-14, which bear AHe ages older than the Jurassic. Lastly, Hypothesis 4 works under the assumption that the sampled rocks were never exposed to near-surface conditions prior to their apparent AHe age. This was constrained by preventing the tested thermal trajectories from reaching temperatures below $60^{\circ} \mathrm{C}$ before the AHe apparent age. The hypotheses described above are summarized in Table 6.1.

Table 6.1: Summary of the hypotheses tested during thermal modelling.

\begin{tabular}{|c|c|c|}
\hline Hypothesis & Assumption & Constraints \\
\hline 1 & $\begin{array}{l}\text { Currently exposed basement } \\
\text { surface was at a shallow } \\
\text { crustal depth during the } \\
\text { Silurian before subsequent } \\
\text { burial followed by exhumation }\end{array}$ & $\begin{array}{c}\text { Temperatures below } 60^{\circ} \mathrm{C} c a \\
440-420 \mathrm{Ma} \text {, reburial event did } \\
\text { not exceed } 90^{\circ} \mathrm{C}\end{array}$ \\
\hline 2 & $\begin{array}{l}\text { Currently exposed basement } \\
\text { surface was at a shallow } \\
\text { crustal depth during the } \\
\text { Devonian/Carboniferous } \\
\text { before subsequent burial } \\
\text { followed by exhumation }\end{array}$ & $\begin{array}{c}\text { Temperatures below } 60^{\circ} \mathrm{C} c a \text {. } \\
420-320 \mathrm{Ma} \text {, reburial event did } \\
\text { not exceed } 90^{\circ} \mathrm{C}\end{array}$ \\
\hline 3 & $\begin{array}{l}\text { Currently exposed basement } \\
\text { surface was at a shallow } \\
\text { crustal depth during the } \\
\text { Jurassic before subsequent } \\
\text { burial followed by exhumation }\end{array}$ & $\begin{array}{l}\text { Temperatures below } 60^{\circ} \mathrm{C} c a \text {. } \\
200-160 \mathrm{Ma} \text {, reheating event did } \\
\text { not exceed the detection limits of } \\
\text { the zircon }(\mathrm{U}-\mathrm{Th}) / \mathrm{He} \text { partial } \\
\text { retention zone (PRZ) }\end{array}$ \\
\hline 4 & $\begin{array}{l}\text { Currently exposed basement } \\
\text { never experienced surface } \\
\text { conditions prior to the (U- } \\
\text { Th)/He cooling ages }\end{array}$ & $\begin{array}{l}\text { Temperatures above } 60^{\circ} \mathrm{C} \text { prior } \\
\text { to the }(\mathrm{U}-\mathrm{Th}) / \mathrm{He} \text { cooling ages }\end{array}$ \\
\hline
\end{tabular}

All samples were tested for 100,000 independent trajectories, or until the 100th good fit. With the exception of the constraints determining the age of exhumation, the configuration of the models was kept as similar as possible for all hypotheses in order to minimize the effect in the obtained results of variations of the tested areas of the diagrams. It should also be noted that while hypotheses 1 to 3 fix a 
determined period in which the sample was close to the surface, the modelling was unconstrained and allowed additional exhumation and burial events in other time intervals.

Sample UY-1-15 could not be tested for these four hypotheses because, unlike the other samples, its ZHe and AHe error margins overlap. This implies a rather straightforward thermal history, which was therefore simulated by using the simple unconstrained model.

\subsubsection{Thermal model results}

Thermal modelling performed remarkably well for the obtained (U-Th)/He dataset with the assumed constraints. Usually data from three dated crystals were considered, but two of the models (sample UY69-14 and the combination of samples UY-43-14 and UY-45-14) rendered too few matching paths and had to be calculated on the basis of only two apatite and zircon crystals each. Such a positive output from models considering as much as six crystals at the same time is an indication of consistency in the dataset.

The same dataset was submitted to models with distinct configurations in order to test the validity of different hypotheses (summarized in Table 6.1) and compare among the trajectories which responded best to the measured parameters.

The exhumation events identified by the thermal models mostly reflect the periods within which the majority of (U-Th)/He ages are concentrated (Fig. 6.4). Based on the mean fits of all tested models, the ZHe temperature range is characterized by steep cooling trajectories mostly between 550 and $450 \mathrm{Ma}$. Cooling events constrained by the AHe dataset, in contrast, are divided into two distinct time intervals, the first from $\mathrm{ca}$. 160 to $120 \mathrm{Ma}$ and the second from 100 to $80 \mathrm{Ma}$ approximately. Their presence among all models tested with different configurations indicates that these periods most likely correspond to actual cooling events. A third set of AHe results, corresponding to ages around the PermoTriassic boundary, obtained a less conspicuous confirmation from the T-t modelling, having been identified only in some of the tested hypotheses.

All four of the tested hypotheses produced model temperature trajectories with at least acceptable fits to the measured data. As a result, none of the hypotheses can be ruled out as unrealistic geological trajectories. Some of the models, however, performed better than others. Their relative performance was initially tested on the basis of goodness of fit (GOF) values given by the software. A comparison of 
the GOF values among the best fits obtained for each model, however, proved to be of little diagnostic value for models with large numbers of path counts. Under all four hypotheses, increasing the numbers of model runs tended to raise GOF values until they stabilized around optimal values. Adding more model runs beyond this cutoff point failed to gain in diagnostic model quality.
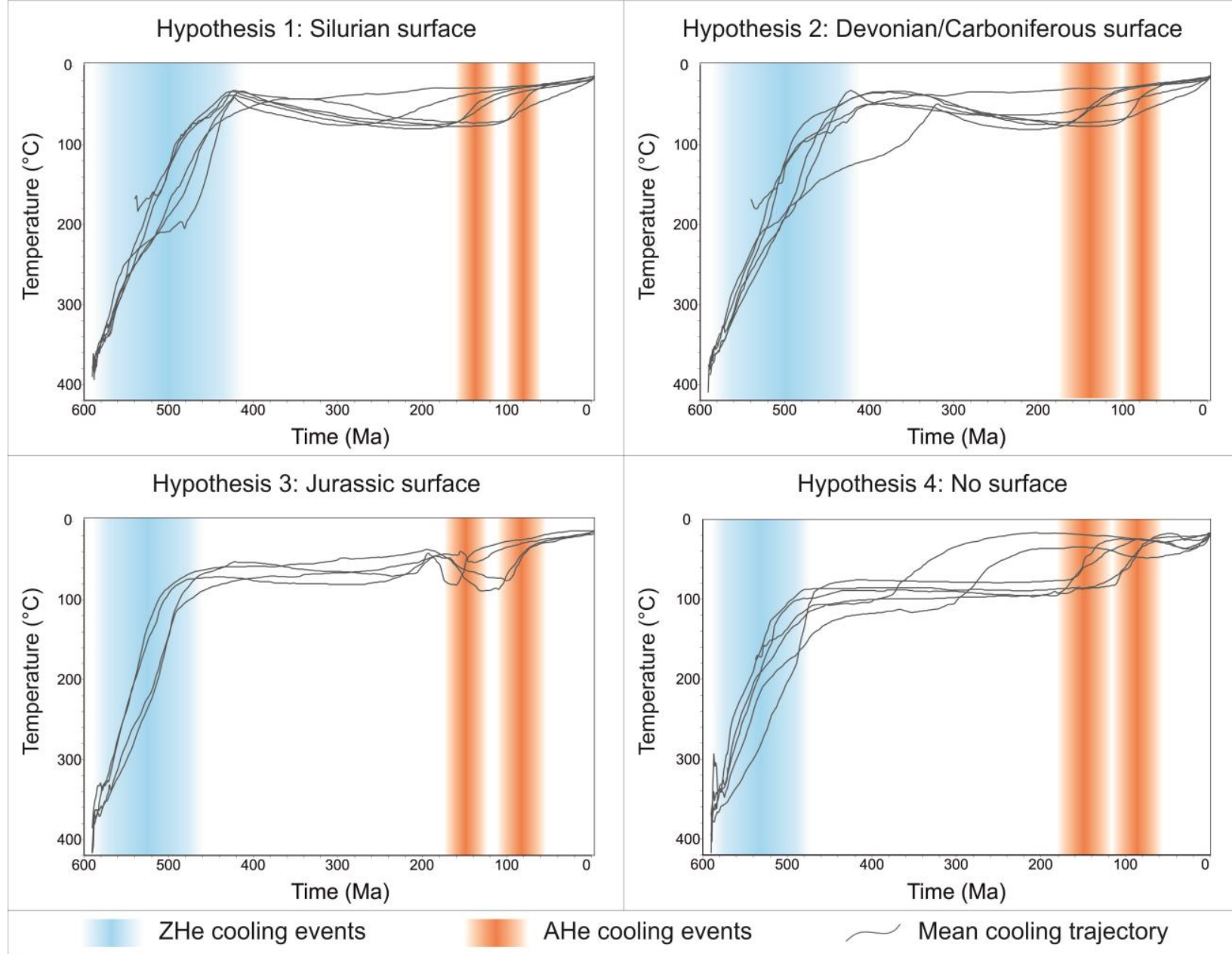

Figure 6.4: Mean T-t trajectories of the paths qualified as good fits for the four tested hypotheses, with indication of the main exhumation events identified. Models were run 100,000 times or until obtaining the 100th good fit, and with the exception of the specific constraints to every hypothesis configurations were kept as similar as possible for comparison purposes

Given this limitation, a second criterion was used in order to compare the four hypotheses. For each model, the number of good trajectories was divided by the total number of tested paths. Direct comparison of these ratios was made possible by standardizing the constraints on the models under different configurations, thereby reducing the variability of parameters other than those specific to each 
hypothesis. This second criterion was found to exhibit much larger dispersion than the overall GOF values, and was thus deemed better suited to assessing the different scenarios.

A comparison of the overall values for all models shows that hypotheses 1 and 2 consistently yielded the most elevated ratios (Fig. 6.5a). Hypothesis 3 clearly produced the lowest values, with results that are at least one order of magnitude below the remaining models. Finally, Hypothesis 4 maintained an intermediate position. The consistent underperformance of Hypothesis 3 indicates that, although this hypothesis cannot be rejected, it is less likely to correspond to the actual geological evolution of the study area. The relationship between results from the remaining hypotheses is presented more clearly by comparing the results for each modelled sample (Fig. 6.5b). This representation clarifies that the results yielded by Hypothesis 4 are of a significantly lower quality than those of scenarios 1 and 2, with ratios varying from 2.5 to 30 times lower than those of the best-performing hypothesis. Although hypotheses 1 and 2 produced comparable values for almost all modelled samples, it should be pointed out that even among them there is a consistent difference, with Hypothesis 1 producing the highestperforming ratios in all but one of the tested samples.

A few samples stand as exceptions to the overall pattern established above. UY-43-14 and UY-45-14, which were treated together, are the only samples for which Hypothesis 1 is not the highest performing scenario. Instead, Hypothesis 2 yielded a good/total-paths ratio that is $c a .20 \%$ higher than in the case of Hypothesis 1. Although it forms an outlier in the dataset, this relative ratio for both hypotheses is completely within the range of most modelled samples. Sample UY-51-14, in contrast, is the only sample where Hypothesis 2 was the lowest-performing scenario among all tested configurations. In fact, its good/total paths ratio is about three times lower than that of the second-to-last low-performing model, Hypothesis 4, and almost 30 times smaller than the results from Hypothesis 1. Such an outlier strongly indicates that, unlike the other samples, a geological evolution compatible with Hypothesis 2 is unlikely for this sample.

In summary, the comparison of the ratio of good/total modelled paths seems to be a useful diagnostic parameter for the modelled dataset, allowing for a direct comparison of different scenarios. Although the successful modelling of all tested configurations prevents a simple dismissal of any given hypothesis, the consistent relations between the obtained results strongly suggest that Hypothesis 1 most likely describes the geological evolution of the Uruguayan Shield, followed by Hypothesis 2, which also constitutes a realistic model. Hypothesis 4, and particularly Hypothesis 3, on the other hand, underperformed consistently. Accordingly, they can be interpreted as less likely descriptions of the 
thermal evolution of the (U-Th)/He dataset. Variations to the regional pattern recorded at restricted locations, however, suggest that the study area did not always act as a homogeneous entity.

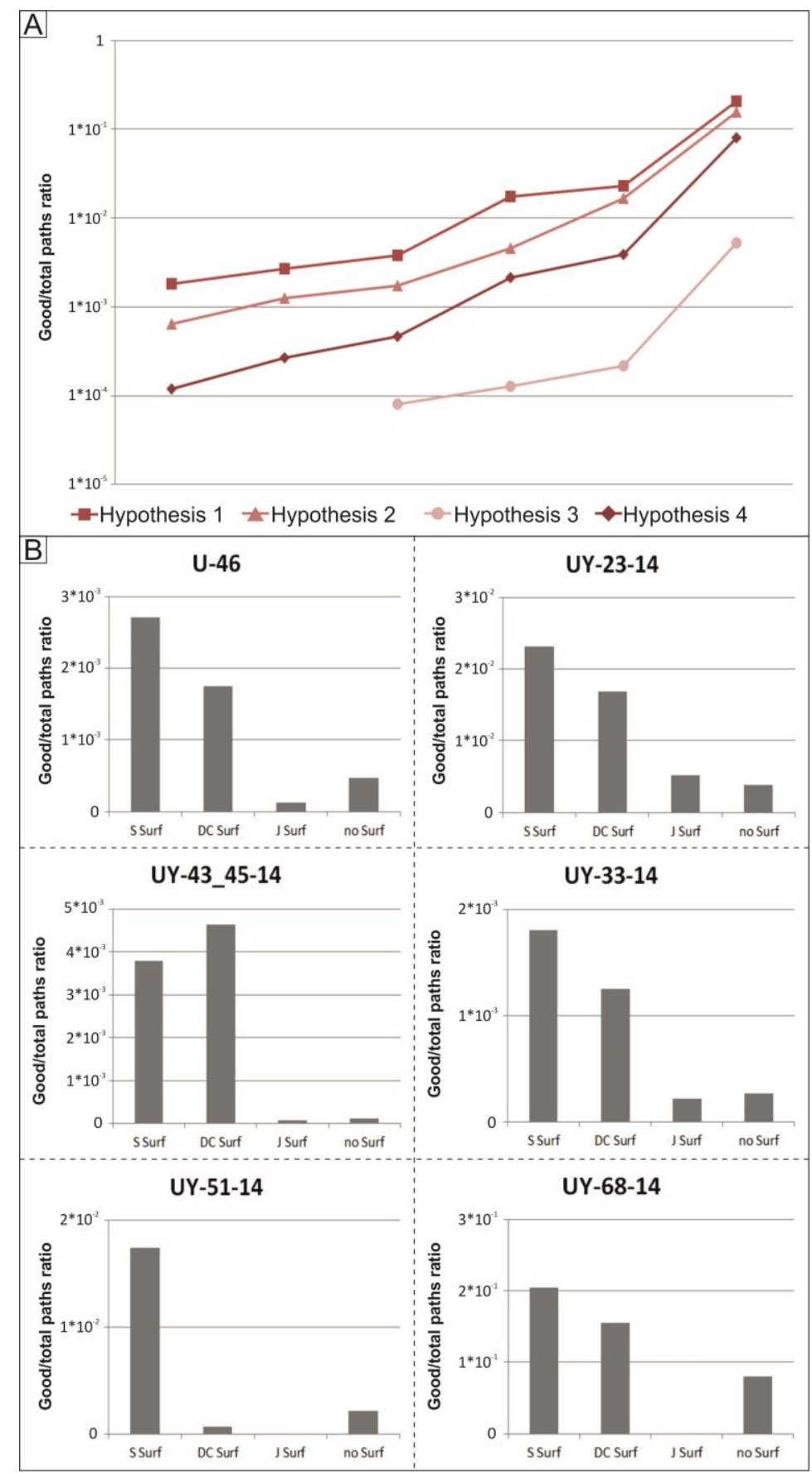

Figure 6.5: Variation of the good fits/total tested paths ratios of the modelled dataset: a: Comparison of ratios for all samples under the four tested hypotheses, arranged from the lowest-performing sample to the highest. Note that the vertical scale is logarithmic; b: Ratios from all tested hypotheses for each modelled sample. Vertical scale is linear. All models were run 100,000 times or until obtaining the 100th good fit. With the exception of the few constraints specific to each hypothesis, configurations were kept as similar as possible for comparison purposes 


\subsection{K-Ar geochronology}

Fault gouge samples were collected in outcrops associated with significant shear zones of the crystalline basement. When possible, duplicates of gouge material exhibiting different aspects on a same fault were collected in order to obtain age controls. The sampled fault gouge along the Sierra Ballena Shear Zone has a thickness of several tens of $\mathrm{cm}$ and is comprised of yellow clay without lithic fragments. The main mineral is kaolinite, with subsidiary proportions of illite. The fault gouge associated to the Maria Albina Shear zone is less than $10 \mathrm{~cm}$ thick and is composed of slightly textured dark-grey clay. Again, illite occurs as an accessory for a material mostly composed of kaolinite. The samples associated with the Rivera Shear Zone were collected on a gouge less than $1 \mathrm{~cm}$ thick, light grey to green in color and with abundant lithic fragments. All sampled faults were parallel to host rock foliation and to the direction of the shear zones. Illite fine fractions extracted from the mylonitic host rock alongside the sampled gouge in the Sierra Ballena Shear Zone were also dated by K-Ar in order to estimate the age of the brittleductile transition in the shear zone. The coordinates of all analyzed samples are presented in the supplementary data, and their location is shown in Fig 6.1. K-Ar ages are presented in Fig. 6.1, and the analytical data are available in Appendix B. Double-sampled and double-measured gouge materials show excellent reproducibility, with results that mostly overlap within error. In all samples, K-Ar ages are grainsize dependent, increasing from finer to coarser fractions, a characteristic commonly referred to as inclined age spectra (Fig. 6.6).

As a maximum age to the faulting event recorded in the fault gouge samples from the Sierra Ballena Shear Zone, fine fractions of the mylonites hosting the sampled rock were analyzed (sample UY-14-14). The three grain-size aliquots produced K-Ar ages that range approximately from 535 to $465 \mathrm{Ma}$. Illite crystallinity analyses were performed on these samples so as to infer the metamorphic conditions under which they crystallized. Kübler Index values ranged between 0.139 and 0.185 , pointing to temperatures above $300{ }^{\circ} \mathrm{C}$, i.e. within the epizone (Kübler 1967).

Fault-gouge ages can roughly be divided into those from the Paleozoic and those from the Mesozoic. Samples collected in the Isla Cristalina region, associated to the Rivera Shear Zone, yielded exclusively Paleozoic ages, ranging from ca. 440 to $360 \mathrm{Ma}$. These materials have very high $\mathrm{K}_{2} \mathrm{O}$ contents, with values as high as 8 wt. \%, indicating a mineral composition with abundant highly-evolved K-rich illite, pointing to crystallizing conditions in excess of $250{ }^{\circ} \mathrm{C}$. Explicit analytical data on the clay mineralogy of this sample are not available. 


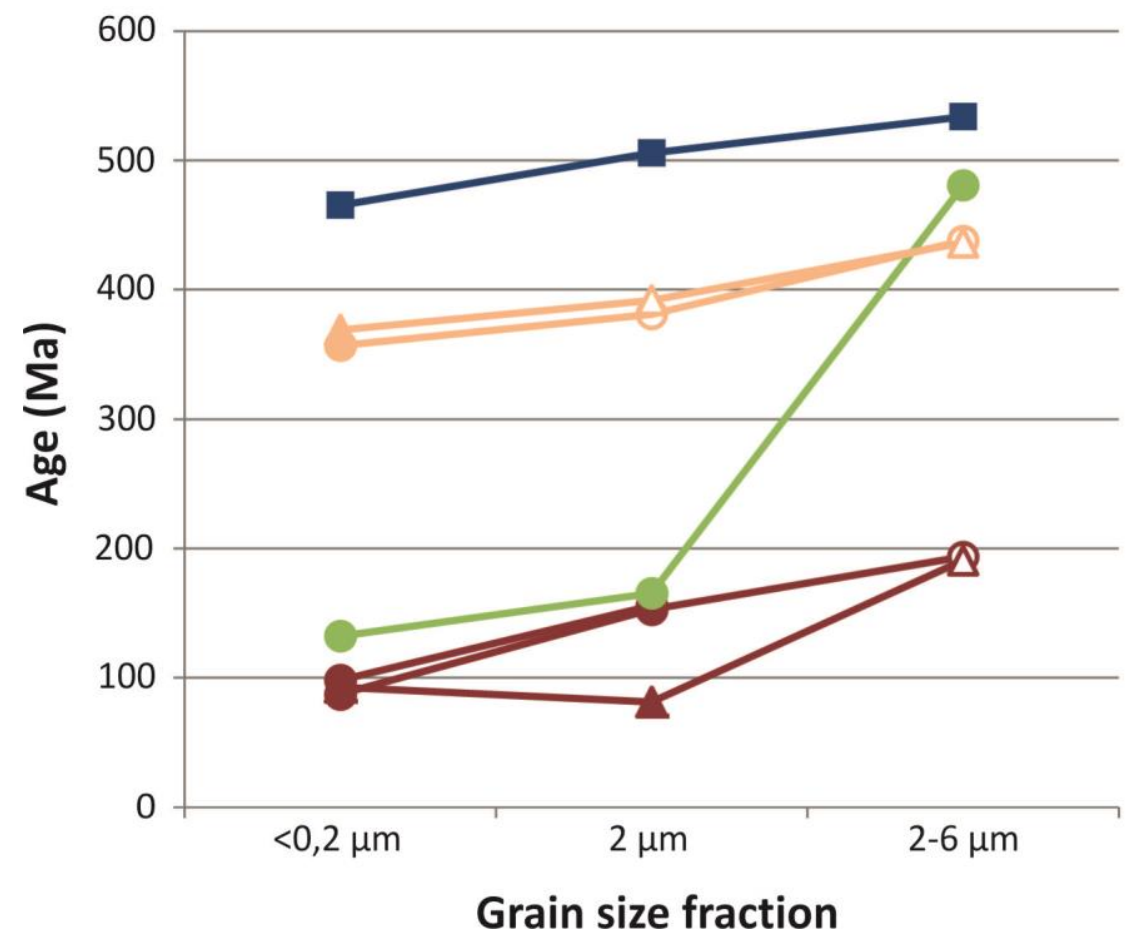

Fine fractions from mylonite from the SBSZ:

$\rightarrow$ UY-14-14

Fault gouge associated to the RSZ:

- UYFG 1

- UYFG 2

Fault gouge associated to the MASZ:

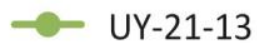

Fault gouge associated to the SBSZ:

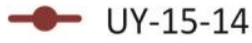

$\rightarrow$ UY-16-14

Figure 6.6: K-Ar ages obtained on fine fractions and fault gouge of the Uruguayan Shield, arranged according to the dated grain-size fraction. Empty symbols represent ages that could not be correlated to other geochronological methods or geological evidence. RSZ - Rivera Shear Zone, MASZ - Maria Albina Shear Zone, SBSZ - Sierra Ballena Shear Zone

Mesozoic ages were recorded on the fault gouge samples associated with the Sierra Ballena and Maria Albina shear zones. These materials yielded results that mostly span from 195 to 80 Ma. They can roughly be divided into three groups. Two Lower Jurassic ages (190-195 Ma) were obtained from the 2$6 \mu \mathrm{m}$ fractions of both samples collected on the Sierra Ballena Shear Zone. They are followed by a set of results clustering around the Jurassic-Cretaceous boundary, spanning from 165 to $130 \mathrm{Ma}$, obtained from the $<2 \mu \mathrm{m}$ fraction of the fault gouge from the Sierra Ballena Shear Zone and at both the $<2$ and $<0.2 \mu \mathrm{m}$ fractions from the fault associated to the Maria Albina Shear Zone. Lastly, the $<0.2$ fractions of the gouge from the Sierra Ballena Shear Zone yielded Upper Cretaceous ages, ranging from 80 to 100 Ma. Standing out from these results, the $<6 \mu \mathrm{m}$ grain fraction of the gouge associated to the Maria Albina Shear Zone produced a K-Ar age of $481 \pm 5 \mathrm{Ma}$.

Despite this consistent set of results, the set of samples that yielded Mesozoic ages show a very low $\mathrm{K}_{2} \mathrm{O}$ content, close to the detection limit of the method. X-ray diffraction (XRD) mineral identification analyses indicate that most of the measured material consists of kaolinite, whereas illite is only an accessory mineral (ca. $5 \mathrm{wt}$. \%). This low mineral concentration on both samples prevented the 
performance of analyses focused on determining the temperature conditions in which the analyzed material was formed, such as illite crystallinity (Kübler Index) and polytypes.

It is possible to roughly estimate strain axes associated with the sampled faults during their activity based on preliminary kinematic data collected during the field investigation. These include the orientation of the fault surface, striae, and the displacement of its passive markers or " $R$ " shears. This investigation was possible on the faults sampled along the Maria Albina Shear Zone and the Sierra Ballena Shear Zone, indicating a NE-SW principal stress orientation and a transtensional strain during the Mesozoic faulting events.

\subsection{Discussion}

\subsubsection{Comparison of modelled thermal histories}

The thermal modelling of the analyzed samples produced successful results for all tested hypotheses (outlined in Table 6.1), suggesting that none of the tested configurations can be rejected as unrealistic descriptions of the thermal history of the Uruguayan Shield. However, a comparison of the performance of each hypothesis has shown that some of the configurations have consistently produced better results than others.

The best-fitting thermal paths were obtained by the constraints imposed in hypotheses 1 and 2 . Both scenarios consistently yielded more paths that could be classified as good fits with the modelled dataset and clearly outperformed the competing models in almost all tested samples. They share some of their assumptions, proposing early post-orogenic exhumation and exposure to surface conditions during the early and middle Paleozoic. As such, it is strongly suggested that initial exhumation after the Brasiliano orogenic cycle during the early Paleozoic was responsible for exposing the analyzed samples to nearsurface conditions. This agrees well with previous geochronological data in the region, which indicate late-stage low-degree deformation immediately before the onset of the cooling event defined by the ZHe ages (Oyhantçabal et al. 2011a; Oriolo et al. 2015, 2016 a, b), as well as with the K-Ar dating of fine illite fractions presented in this work. In addition, provenance studies of the earliest sediments of the Paraná Basin in Uruguay suggest that most Precambrian terranes in Uruguay acted as source areas during the Devonian (Uriz et al. 2016), which implies that the studied rocks should have been exposed to the surface by then. 
Another implication of the high performance of hypotheses 1 and 2 is that initial exposure of the Uruguayan Shield to near-surface conditions was followed by reheating during the Paleozoic, resetting the AHe system. This heating event was probably caused by deposition of the sedimentary sequences of the Paraná Basin, and affected rocks currently cropping out in the landscape. It is therefore likely that the basin previously extended beyond its current boundaries, with some of its sedimentary strata covering portions of the crystalline basement that are now exposed. This agrees well with evidence that a considerable portion of the sedimentary packages was eroded from the margins of the basin (e.g. de Santa Ana 2004; Milani et al. 2007; Strugale et al. 2007). This is also in accordance with other recent thermal modelling data from basement areas in Uruguay and southern Brazil (Kollenz 2015; Oliveira et al. 2015b). This cycle of deposition and erosion probably preceded the onset of flood-basalt eruption, and may have been controlled by the onset of NW-SE trending deformation of the basin (e.g. Rostirolla et al. 2000; Strugale et al. 2007).

The relatively poor performance of Hypothesis 3, which assumed exposure to surface conditions during the Jurassic, suggests that the thick Cretaceous volcanism did not have a decisive impact on the thermal evolution of the analyzed samples. In this sense, the coeval ages obtained with both the (U-Th)/He and $\mathrm{K}-\mathrm{Ar}$ methods probably record the occurrence of tectonic displacement and exhumation accompanying the rifting of the South Atlantic Ocean and of the Santa Lucia-Aiguá-Merin Lineament, rather than the resetting of the geochronological system by the thermal effect of the Paraná Large Igneous Province (Paraná LIP). As such, the extrusive event was probably confined to its present occurrence, as exemplified on the lineament, in which the disposition of the volcanic rocks has been restricted to the basins hosted by the rift corridor. While these areas experienced subsidence from the Cretaceous onwards, their surroundings have since been exhumed (Rossello et al. 2007).

Somewhat more surprising is the bad performance of Hypothesis 4 among the tested models. As such, it argues against a straightforward assumption that the Uruguayan Shield went through a simple exhumation trajectory, without the effect of previous exposure of the current terrain to surface conditions or to a reheating event.

Some of the models yielded results that differ from the general pattern established by most samples. The clearest example is sample UY-1-15, which experienced a final exhumation during the transition from the Carboniferous to the Permian. This implies a vertical displacement considerably larger than in the rest of the study area. This is indicative that the Uruguayan Shield did not behave uniformly, having on occasions involved strong contrasts in the magnitudes of crustal displacements in contiguous areas. 
The timing of final exhumation to current crustal depths is variable across the study area, as indicated by the variability in apparent AHe ages.

\subsection{2 $\underline{\text { K-Ar ages }}$}

Samples dated by the K-Ar method have shown to be grain-size dependent, i.e. they produce inclined age spectra (Fig. 6.6). This pattern is commonly identified in the literature for pelitic rocks, and is usually interpreted as mixing of detrital muscovite with the neoformation of illite crystals. Nonetheless, a similar pattern has also been recognized in fault gouge (e.g. van der Pluijm et al. 2001; Clauer et al. 2012; Bense et al. 2014; Torgersen et al. 2015; Ksienzyk et al. 2016). The most credited interpretation for this behavior is also related to a mixing of different age components, either because of the crushing of hostrock minerals or because of an inheritance of illite from older generations of fault reactivation. It is generally assumed that the finest fractions of the fault gouge are less affected by the contamination of host rocks (Torgersen et al. 2015; Ksienzyk et al. 2016), making their ages the most reliable when dating brittle faulting events.

The inclined age spectrum obtained for the fine fractions of the mylonitic wall-rock to the fault associated to the Sierra Ballena Shear Zone might be interpreted as similar, in origin, to that of pelitic rocks. In this case, the 2-6 $\mu \mathrm{m}$ fraction might represent inherited muscovite crystals crystallized during the ductile stage of the shear zone. As such, assuming that this grain fraction is the most susceptible to contamination, its age of $534 \pm 8 \mathrm{Ma}$ can be admitted as an age limit for the end of mylonitization on this shear zone. This age happens to be less than $20 \mathrm{Myr}$ younger than the last $\mathrm{U}-\mathrm{Pb}$ zircon age for a porphyritic mylonite along this structure (Oyhantçabal et al. 2011a). The generation of the finer and younger illites at $506 \pm 11$ and $465 \pm 7$ Ma should represent stages of tectonic displacement along the shear zone following the mylonitic phase of the structure within the ductile-brittle transition. Nonetheless, the crystallization conditions above $300^{\circ} \mathrm{C}$ indicated by its degree of illite crystallinity (Kübler Index 0.139-0.185) are distinctly warmer than those indicated by the coeval ZHe data for the undeformed shield. They might, therefore, be related to the upward percolation of hydrothermal fluids along the fault zone during reactivation, as argued by Tagami (2012).

The Paleozoic fault gouge associated with the Rivera Shear Zone produced ages that range from 360 to $440 \mathrm{Ma}$. The $<0.2 \mu \mathrm{m}$ fraction yielded ages that are close to the Devonian-Carboniferous boundary, which is recognized in most basins in SW Gondwana as a regional angular unconformity (López-Gamundi \& Rossello 1993). In the Paraná Basin, specifically, it marks the top of the Paraná Supersequence, which is followed by a sedimentation gap that spans most of the Carboniferous (Milani et al. 2007). Coarser 
fractions from the same gouge provide ages which have a less clear interpretation, and might have been affected by some degree of contamination from the host rock.

The Mesozoic set of K-Ar results was recorded on both the Maria Albina and Sierra Ballena shear zones, and is distinctively dependent on the grain size of the dated fraction. Three groups of ages were recognized: a Lower Jurassic, a Jurassic-Cretaceous, and an Upper Cretaceous. The last two sets, corresponding to results obtained in the $<0.2 \mu \mathrm{m}$ and $<2 \mu \mathrm{m}$ fractions of gouges samples associated with both shear zones, have ages that correspond well to time periods recorded by the AHe dataset. They correlate well with the pre-, syn- and post-rift phases of the South Atlantic Ocean. The 2-6 $\mu \mathrm{m}$ fractions from both faults produced results which, in contrast, have a less clear geological interpretation. The material dated from the gouge related to the Maria Albina Shear Zone stands out for having a very old age of $c a .480 \mathrm{Ma}$. This age is well within the range of fine fractions dated for the wall-rock of another structure, the Sierra Ballena Shear Zone, and is probably the result of contamination from crystals from the host rock. As such, it should not be interpreted as representative of a brittle event in this shear zone. Similarly, the pair of ages of $c a$. 190-195 Ma from the 2-6 $\mu \mathrm{m}$ fraction of the gouge associated to the Sierra Ballena Shear Zone cannot be correlated to other low-temperature data and have no clear relation to known geological events. As this fraction is the most susceptible to contamination from minerals from the host rock, they are not considered in this study to be representative of faulting events.

In summary, the new K-Ar ages obtained can be correlated with other low-temperature geochronological methods and regional geological events. The inclined age spectra obtained in the fault gouge samples probably result either from contamination of the host rock (in the case of outlying ages) or from recurrent reactivation of the geological structures - in this case generating more than one geologically meaningful age in the same sample.

\subsubsection{Low-temperature evolution of the Uruguayan Shield}

By combining different low-temperature geochronological methods, the new dataset reveals more than $450 \mathrm{Myr}$ of late- to post-orogenic tectonic evolution since the beginning of the Paleozoic. Fig. 6.7 presents a graphic summary of the new ages and illustrates their temporal relation to the Uruguayan sedimentary record and the regional tectonic events in western Gondwana, alongside previous mediumand low-temperature geochronological data. 


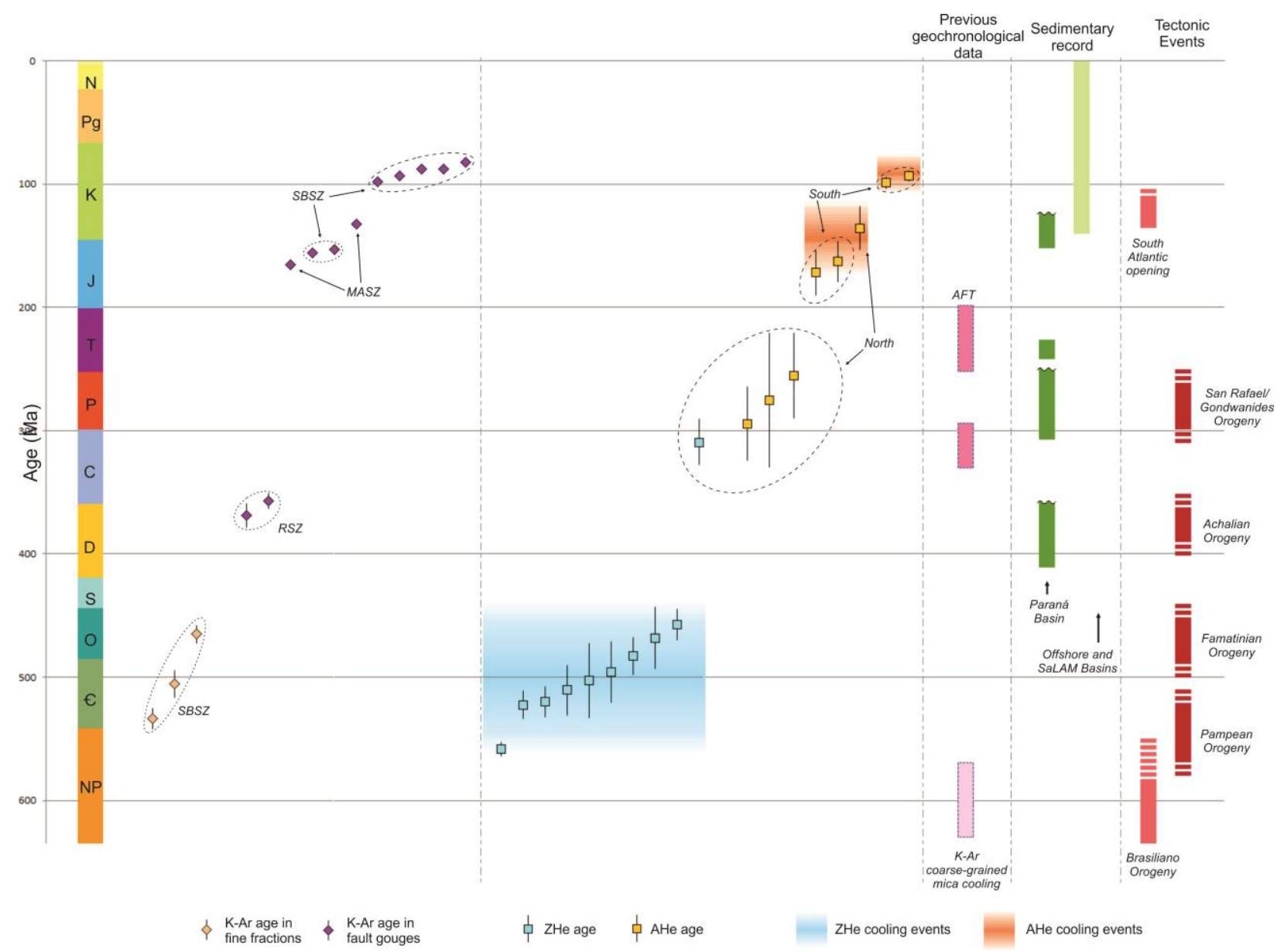

Figure 6.7: Temporal distribution of low-temperature geochronological data in relation to main sedimentary and tectonic events. Error bars represent $2 \sigma$ imprecision. Time constraints for the apatite fission track (AFT) method is from Kollenz (2015) and K-Ar cooling ages of coarse-grained mica are from Oyhantçabal et al. $(2010,2011 \mathrm{~b})$ and Oriolo et al. (2016a, b). RSZ - Rivera Shear Zone, MASZ - Maria Albina Shear Zone, SBSZ - Sierra Ballena Shear Zone; SaLAM: Santa Lucía-Aiguá-Laguna Merín Lineament

Formerly published apatite fission track (AFT) ages (Kollenz 2015) mostly cluster between 245 and 200 $\mathrm{Ma}$, but there are also considerable older apparent ages of $\mathrm{ca}$. $300 \mathrm{Ma}$ and $325 \mathrm{Ma}$. The AFT ages are usually between the ZHe and AHe ages, attesting to the consistency of the database in the region.

The widespread distribution of ZHe ages between 560 to 460 Ma within a large-scale area differs from previous studies in southern and southeast Brazil for similar temperature ranges, such as zircon fission track (ZFT) and ZHe ages. Such old signatures, if present at all, are usually limited to a few samples within generally younger domains (e.g. Karl et al. 2013). This is probably a reflection of the significant uplift experienced in these areas during the post-rift opening phases of the South Atlantic Ocean, as evidenced by its coastal ranges and numerous thermochronology studies (e.g. Tello Saenz et al. 2003; Hackspacher 
et al. 2004; Franco-Magalhães et al. 2010, 2014; Cogné et al. 2011, 2012). This new pattern points to the relevance of applying such techniques to regions of lower relief such as Uruguay, leading to a more detailed Phanerozoic history (e.g. Oliveira et al. 2015b).

The continuous distribution of Paleozoic ZHe ages between 560 to 460 Ma suggest that they are not related to single events but rather to a period during which the sampled crystals crossed the system's partial retention zone. As such, the Uruguayan Shield probably behaved as a consolidated unit already during the beginning of the Paleozoic and underwent significant exhumation since the Ediacaran, driving the analyzed samples to relatively shallow depths. This is corroborated by the thermal modelling of the $(\mathrm{U}-\mathrm{Th}) / \mathrm{He}$ dataset, which shows steep cooling trajectories for this period. Further indication of early Paleozoic tectonic activity is given by the K-Ar ages for the fine illite fractions of the Sierra Ballena Shear Zone mylonite.

This event extends into the border of the Piedra Alta Terrane, with sample UY-68-14 recording the first Paleozoic cooling ages in this geological unit. Since muscovite K-Ar cooling ages are restricted to the Paleoproterozoic Era within this unit (Oyhantçabal et al. 2011b), these rocks are expected to have been exposed to surface conditions much sooner than the recorded ZHe ages. Therefore, the new results indicate a gentle Brasiliano-aged thermal overprint of the border of the Rio de la Plata Craton, which did not, however, reach temperatures high enough to affect the muscovite K-Ar system. Such burial conditions match the shallow emplacement interpreted for the only Neoproterozoic intrusion in the Piedra Alta Terrane, the La Paz Granite (587 $\pm 8 \mathrm{Ma}$, Cingolani et al. 2012). Further into the center of the Rio de la Plata Craton, sample UY-1-15 yielded an apparent ZHe age of $309 \pm 19$ Ma, which is almost 140 Myr younger than the remaining ZHe results, breaking away from the pattern of continuous postcollisional ages established above.

In terms of the thermal range and, as a consequence, crustal depth, the new geochronological data set a distinctive contrast between the Dom Feliciano Belt in Uruguay and the orogenic belts on the African side of the Atlantic. The new ZHe data are coeval with regional K-Ar and Ar-Ar muscovite-cooling ages for the Kaoko, Damara, Gariep and Saldania belts, which have consistently been dated as younger than 530 Ma (Goscombe et al. 2005; Gray et al. 2006; Foster et al. 2009 and references therein). They were interpreted to represent the last phases of the Brasiliano-Pan-African orogenic cycle on the African continent, particularly the late stages of interaction between the Congo and Kalahari Cratons.

This relation suggests a common tectonic drive, causing concurrent exhumation processes in adjacent areas of the Gondwana supercontinent during the last phases of its assembly, but at distinct crustal 
depths. It can be interpreted as an immediate effect of the final phases of the Brasiliano orogenic cycle itself, with tectonic exhumation associated to post-collisional extension of the thick continental crust (e.g. Consentius 1996; Çemen et al. 2006; Fossen 2010). This is corroborated by the fact that the new set of ages is only a few tens of Myr younger than the late stages of deformation and magmatism in the Dom Feliciano Belt and Nico Pérez Terrane (Hartmann et al. 2002; Basei et al. 2005, 2013b; Campal \& Schipilov 2005; Oyhantçabal et al. 2011a; Oriolo et al. 2016a, b). Furthermore, effects of extensional tectonics have been recognized along the Dom Feliciano Belt as early as 600 Ma (Almeida et al. 2010, 2012).

Another possible influence on the early Paleozoic thermal history on the Uruguayan Shield is the continuous orogenic history along the active SW Gondwana margin. The late phases of the Pampean and early Famatinian events (Steenken et al. 2011 and references therein), in particular, are coeval with the bulk of ZHe and fine fraction K-Ar data. This coincidence, however, is unlikely to entirely explain the data from this study because it does not account for the lack of low-temperature ages corresponding to the later events of this orogenic association.

The bulk of the ZHe dataset is followed by approximately 140 Myr during which no (U-Th)/He cooling ages were recorded. Rather than uplift, this period is better characterized by subsidence and reheating, as recorded by the onset of Paraná Basin deposition. The thermal modelling performed with the new (UTh)/He dataset corroborates this suggestion, indicating a reheating responsible for resetting the AHe system. At least during the early Paleozoic, parts of the basement might have been exposed and acted as a source area for these sediments, in agreement with provenance studies (Uriz et al. 2016). Tectonic activity was only recorded locally at the end of the Devonian, based on the K-Ar ages of two fault-gouge samples associated with the Rivera Shear Zone in the Isla Cristalina Block and with regional angular unconformities and a gap in the sedimentary record (López-Gamundi \& Rossello 1993; Milani et al. 2007).

The late Paleozoic and Mesozoic in the Uruguayan Shield are recorded predominantly by the AHe data. Unlike the ZHe method, AHe results are much more varied and location-dependent. There is a striking difference between the northernmost and southernmost ages, which are separated by as much as 200 Myr.

Considered together, the three oldest AHe ages and the youngest ZHe age define an interval from the end of the Carboniferous throughout the Permian (ca. 310-250 Ma). They are much older than the subsequent AHe results, and are clearly associated with the northern part of the Uruguayan Shield, i.e. 
along the present border of the Paraná Basin. The two oldest AFT ages recorded in Uruguay (Kollenz 2015), also obtained from the northern part of the shield, are approximately contemporaneous.

Among these results, sample UY-1-15 is an outlier. Besides having a much younger ZHe age, it is the only sample for which both the ZHe and the AHe ages are almost identical, overlapping at the transition from the Carboniferous to the Permian. Unlike the other samples, this implies a faster and steadier exhumation to present conditions, without multiple events or burial periods. Consequently, there should be a fault separating the inner portion of the Piedra Alta Terrane from its boundary, at least in the north. The coeval exhumation of rock units under contrasting temperature conditions was probably accommodated by this fault.

It should be noted, however, that this time interval was not constrained by the T-t models as precisely as the later events (Mesozoic AHe ages). Likewise, the Permo-Triassic set of ages is not always represented by cooling trajectories in the thermal models. This suggest that the ages do not necessarily correspond to sharp exhumation events, and might be related instead to only partial resetting of the AHe isotopic system. This is also suggested by the fact that this period corresponds to the deposition of the thickest Paleozoic sedimentary package in this basin (Gondwana I Supersequence, Milani et al. 2007).

There seems to be, however, a correlation between these localized ages and the presence of angular unconformities in this sedimentary package (Rocha Campos et al. 2007; Milani et al. 2007). These have been interpreted as resulting from far-field propagation of compressional deformation into the continent (Rostirolla et al. 2000; de Santa Ana 2004; Pángaro et al. 2015), linked to the development of the Gondwanides/San Rafael Orogeny along the active margin of the supercontinent (von Gosen et al. 1990; Kleiman \& Japas 2009; Sato et al. 2015). Similar effects have been reported, for example, from the Sierras Pampeanas in Argentina (Löbens et al. 2011; Bense et al. 2014).

All factors considered, the set of oldest AHe ages is not necessarily linked to exhumation of the Uruguayan Shield, but the presence of local cooling events cannot be ignored. These would indicate that, despite covering a large intracratonic area, subsidence in Uruguay was not spatially uniform and may have coexisted with local exhumation, especially in the north.

The transition to the Triassic is recorded in Uruguay by the bulk of the AFT results of Kollenz (2015), indicating a more regional exhumation. It correlates with the extensional tectonics that characterize this period in South America, recorded in the Paraná Basin by the development of restricted grabens (Zerfass et al. 2004). 
The remaining ages, including the Mesozoic set of K-Ar results in fault gouge samples, are mostly restricted to the southern portions of the Uruguayan Shield. They span from the Upper Jurassic to the Cretaceous and are linked to the opening of the South Atlantic Ocean. Three main episodes are the most distinctive: a Late Jurassic, an early Cretaceous, and a mid-Cretaceous event, corresponding to the doming, syn-, and post-rift phases, respectively. The first is recorded by a couple of AHe and K-Ar ages (illite fractions from fault gouge) associated with the Maria Albina and Sierra Ballena shear zones. These ages range from 175 to $150 \mathrm{Ma}$, and represent early exhumation in response to the thermal anomaly that led to continental rifting.

The phase of rifting itself, coeval with the extensive basaltic magmatism in the Paraná and Laguna Merin basins, is recorded by one AHe age and by the K-Ar dating of a fault gouge related to the Maria Albina Shear Zone. Of the new results, the AHe age stands out for being the only one north of the Santa LuciaAiguá-Merin Lineament younger than Paleozoic, and may be related to a slight exhumation of the lineament's northern border, as recognized by Rossello et al. (2007). These ages are contemporaneous with the ca. 135-130 Ma old Paraná LIP (Renne et al. 1992; Janasi et al. 2011; Cernushi et al. 2015). Thermal modelling suggests that this extrusive event had little effect on rocks from the crystalline basement, and that the flood basalts were probably confined to the areas where they presently occur.

A younger and larger set of data, spanning from 100 to $85 \mathrm{Ma}$, is represented by two AHe ages and by the K-Ar ages of the finest fractions of fault gouge samples associated with the Sierra Ballena Shear Zone. These data correlate well with the beginning of the main exhumation process that culminated in the uplift of the coastal ranges in south and southeast Brazil (Franco-Magalhães et al. 2010; Cogné et al. 2011, 2012; Karl et al. 2013 and references therein). In contrast to these results obtained in the latter areas, however, there is a notable absence of Cenozoic AHe data in Uruguay. This can be explained by the low denudation rates mirrored by the gentle topography of the region.

Thermal modelling of the (U-Th)/He dataset identified two main stages of cooling during the Mesozoic, strengthening the interpretation that the combined $\mathrm{AHe}$ and $\mathrm{K}-\mathrm{Ar}$ ages correspond to actual exhumation events. The first phase broadly corresponds to the pre- and syn-rift ages, while the second is associated with the post-rift event. In this regard, these events are compatible with the two paleosurfaces identified by Panario et al. (2014), which the authors interpret to have a Mesozoic origin. 


\subsubsection{Influence and reactivation of Brasiliano structures during the Phanerozoic}

One of the main characteristics of orogenic events is the assembly of a complex structural configuration, combining fault zones at all crustal levels with variable rock fabrics. The result is a highly anisotropic crust, in which the influence of weaknesses along preferential orientations has a significant control on subsequent deformation. As such, an inherited structural framework has a lasting influence on the tectonic evolution of the newly formed terrane long after the cessation of the orogenic cycle itself, an aspect which has received much scientific interest in the last decades.

The effect of the reactivation of old discontinuities on rifting processes cannot be understated. It is a prominent mechanism in the formation of basins of all sizes and in all geotectonic contexts, with the potential for influencing the basins' location, shape and evolution (e.g. Milani \& Davison 1988; Morley et al. 2004; Riccomini et al. 2004; Autin et al. 2013; Peron-Pinvidic et al. 2013; Figueiredo et al. 2015). Thermochronological techniques have recently started to be widely applied to such contexts, not only in order to date the faulting events but also in order to identify relative displacements (e.g. FrancoMagalhães et al. 2010; Cogné et al. 2011; Tremblay et al. 2013; Fossen et al. 2016).

One of the major aspects that control the influence of previously formed structures during rifting is the angle formed between the older fabric and the direction of the subsequent regional extension in the area. As has been shown both in natural examples and in models, pre-existing faults with angles as high as $45-60^{\circ}$ to the orientation of the extension vectors tend to be reactivated with oblique displacements, accommodating extension along old weaknesses instead of creating new discontinuities (Morley 1995; Morley et al. 2004; Henza et al. 2011). Even along structures with less favorable orientations, i.e. orientations that are not decisive during strain concentration, minor reactivation can still influence rift evolution by creating domain boundaries (Fossen et al. 2016).

The recurrent reactivation of Brasiliano-related shear zones during the Phanerozoic evolution of the Uruguayan Shield is distinctively evidenced by the dating of multiple brittle events on fault gouge materials generated along them. These ages correlate chronologically with the rest of the lowtemperature dataset and can be linked to regional events that probably influenced its evolution. Kinematic analysis of structural data associated with faults that yielded early- and mid-Cretaceous ages indicate transtensional strain with principal stress orientated NE-SW. This observation is in accordance with the orientation of syn- and post-rift stress fields at the time in south and southeast Brazil (Salomon et al. 2015 and references therein). 
Nevertheless, how exactly the Neoproterozoic shear zones influenced the exhumation history in Uruguay is not clear from the (U-Th)/He record. Since they do not divide blocks with consistently distinct ages in either of the analyzed minerals, it is inferred that the vertical displacements of these events might not have been sufficient to be detected by these methods. The main geographical pattern observed in the new low-temperature dataset is the $\mathrm{N}-\mathrm{S}$ difference observed among the AHe results. This finding is no surprise given the presence of ENE-WSW and WNW-ESE-striking structures that were very active in the southern and southeast portion of the South American Platform since the early stages of Atlantic opening. Effects of this tectonic control include the deformation of intracratonic basins, segmentation of the passive margin, and conditioning of the emplacement of basic dykes (Zalán et al. 1990; Rostirolla et al. 2000; Meisling et al. 2001; Strugale et al. 2007; Masquelin et al. 2009; Franco-Magalhães et al. 2010; Salomon et al. 2015). Their influence on late stages of exhumation has been shown to go back to more than 200 Myr in southern Brazil (Karl et al. 2013). It has also been shown to be a more dominant system in the southern portion of the Atlantic margin than further north, which is more affected by the reactivation of NE-trending Brasiliano structures (Riccomini et al. 2004; Cogné et al. 2011, 2012, 2013; Franco-Magalhães et al. 2014).

In Uruguay, the most remarkable expression of this phase of deformation is the installation of the Santa Lucia-Aiguá-Merin Lineament, controlling an aborted rift during the Jurassic-Cretaceous transition. This corridor has been affected by the reactivation of basement structures inherited from the Brasiliano deformation. The orientation of the lineament is favored by the foliation directions and subordinate shear zones within the eastern Dom Feliciano Belt (NE-SW, Oyhantçabal et al. 2009; Oriolo et al. 2016b) and the Piedra Alta Terrane (E-W, Oriolo et al. 2015), which have been interpreted as influential aspects of the rift's development (Rossello et al. 2007).

This corridor is further influenced by the Sierra Ballena and Sarandí del Yí shear zones, the major terrane boundaries of the Uruguayan Shield, which act as internal limits to the basins deposited along the corridor. Although their orientation, which is parallel to the main extension vectors during rifting of the basement, means that they probably did not accommodate much of the extension, they separate an elevated internal domain, corresponding to the Nico Pérez Terrane, on which only disconnected Cretaceous metasedimentary remnants occur. The progress of the rifting process within this terrane was probably hindered by a less favorable, inherited structural framework (NNE-WSW, Oriolo et al. 2016b, c) preventing a connection of the Laguna Merin and Santa Lucia basins (Rossello et al. 2007). The multiple exhumation events identified in this study emphasize the importance of these structures during the syn- 
sedimentary evolution of the basins, acting as domain boundaries (e.g. Fossen et al. 2016) and possibly leading to some uplift, which would explain the relative elevation of the Nico Pérez Terrane.

\subsection{Conclusions}

The application of low-temperature geochronological methods across the crystalline shield of Uruguay reveals an eventful geological history throughout the Phanerozoic, revealing up to 550 Myr of residence time in the upper crust. This study identifies with rare detail the discrete tectonic activity that has affected the interior of Gondwana and is connected with various independent clues in the sedimentary record. The reconstructed geological history is the result of low-intensity events compared to the uplift which characterizes the thermal record of much of the South American eastern passive margin. This study thus shows the advantages of applying thermochronological research to areas with less dramatic topography than along the Brazilian passive margin, where Cenozoic events have overprinted much of the low-intensity and much older signal recorded by the present dataset.

As shown by the new data, all of the different crustal blocks that compose the Uruguayan Shield reached shallow burial conditions between 550 and $450 \mathrm{Ma}$. Therefore, the terrane amalgamation was completed during the Ediacaran. The post-collisional period was marked by intense exhumation and tectonic activity, and thermal modelling strongly suggests that currently outcropping rocks were exposed to near-surface conditions by early to mid-Paleozoic times (Fig. 6.8a). Multiple subsidence cycles promoted the Paraná Basin sedimentation, which began in the Devonian, during which the crystalline basement acted as a source area (Fig. 6.8b). The middle and late Paleozoic were characterized by the further burial of the basement and resetting of the (U-Th)/He system until the Permian, when the thickest sedimentary package of the basin was deposited. The record of local exhumation indicates, however, that subsidence was not uniform in Uruguay (Fig. 6.8c).

During the Mesozoic, the basement rocks of Uruguay went through multiple cycles of exhumation, accompanied by restricted sedimentation. The Triassic was marked by general exhumation of the crystalline shield, and sedimentation was confined to portions of the Paraná Basin (Fig. 6.8d). After this event, the basement areas closest to the border of this basin were essentially in their present conditions. The southern portion of the study area went through additional phases of exhumation associated with the opening of the South Atlantic Ocean, accompanied by the installation of an aborted rift along the Santa Lucia-Aiguá-Merin Lineament in the early Cretaceous (Fig. 6.8e). This event was recorded by the exhumation of rocks close to the lineament's margin and by the reactivation of the main Neoproterozoic 
shear zones, dated by the K-Ar method in fault gouge samples. The last event detected in Uruguay is a post-rift phase of upheaval registered in the Lower to Upper Cretaceous transition. It is probably responsible for the uplift of the Nico Pérez Terrane and southeastern Dom Feliciano Belt, accompanied by more fault reactivation (Fig. 6.8f). In contrast to most areas along the southeast Brazilian coast, a shorter post-rift geological evolution in Uruguay implied little exhumation during the Cenozoic.

a) Early Palaeozoic (550 - $450 \mathrm{Ma})$

- General post-Brasiliano exhumation

- Activity along shear zones

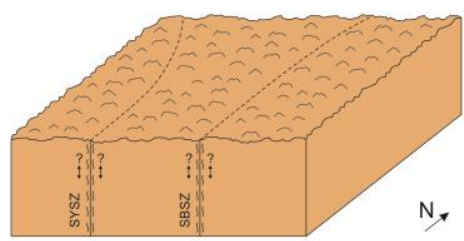

d) Permo-Triassic (250 - $220 \mathrm{Ma})$

- General exhumation of the Uruguayan Shield

- Regional extension on the Norte Basin with restricted sedimentation
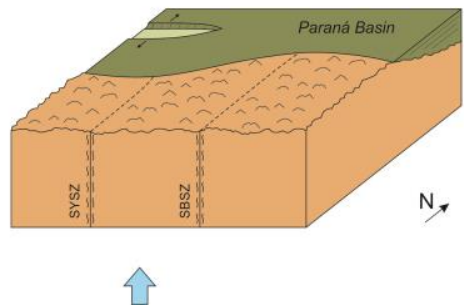

b) Devonian (420 - $360 \mathrm{Ma}$ )

- General subsidence

- Beginning of deposition in the Norte Basin

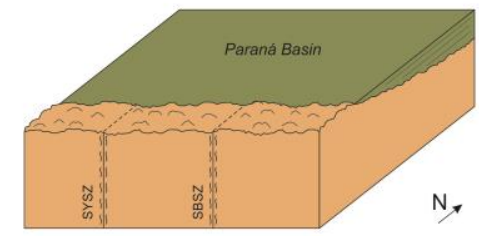

e) Lower Cretaceous ( $135 \mathrm{Ma})$

- Opening of the South Atlantic Rift

- Paraná Volcanism

- Rifting and subsidence along the SaLAM corridor

- Reactivation of shear zones and local exhumation

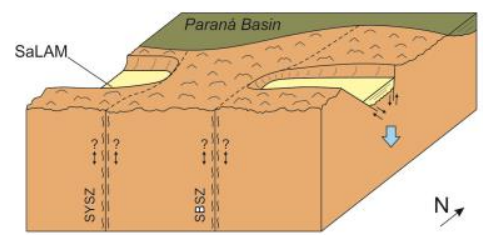

仓ิ c) Permian (300 - $250 \mathrm{Ma}$ )

- General subsidence

- Deposition in the Norte Basin

- Localized exhumation

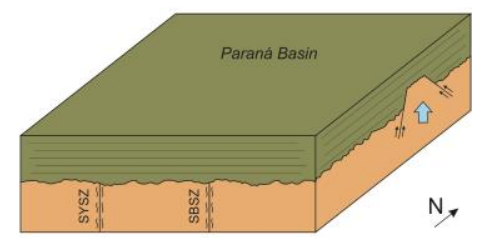

f) Upper Cretaceous (100 - $85 \mathrm{Ma}$ )

- Subsidence and deposition in SaLAM corridor

- Reactivation of shear zones

- Uplift in the south and probably in the NPT

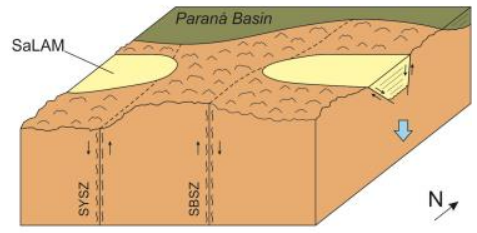

仓ิ 仓ิ

Figure 6.8: Schematic evolutionary model of the Uruguayan Shield and associated sedimentary record during the

Phanerozoic

The tectonic forces driving this evolution varied throughout time. Initial exhumation was coeval with the final stages of the Brasiliano-Pan-African orogenic cycle, and followed late deformation of the Dom Feliciano Belt in Uruguay. From the Devonian to the early Mesozoic, the thermochronological record is less well constrained, and was probably controlled by the far-reaching tectonic influence of the southwestern active margin of Gondwana, leading to the development of the Paraná Basin. The last regional tectonic drive was the opening of the South Atlantic Ocean and its associated rifts, which dominated the final exhumation and uplift of the Uruguayan Shield. 
Thermal modelling of the new dataset suggests that the Paraná Basin once covered much of the nowexposed crystalline basement, which had already been exposed to near-surface conditions prior to burial by the Paraná sequences. This resulted in resetting the basement AHe system, with the reheating most likely accomplished by the deposition of the Paleozoic sedimentary sequences, in particular by the Devonian and Permian sediments. The thick flood basalts, still present in the Paraná and Laguna Merin basins, had little influence over the studied rock's thermal histories. Unlike the older Paleozoic sedimentary rocks, the paleogeography of the basalts was probably confined to their present occurrence.

Inherited Neoproterozoic structures played an important role in the post-Brasiliano history. Although the major shear zones do not define the boundaries observed in the (U-Th)/He age pattern, the last phases of exhumation are clearly coeval with $\mathrm{K}$-Ar-dated fault reactivation. The rifting and subsidence pattern of the Santa Lucia-Aiguá-Merin Lineament were strongly conditioned by the legacies of crustal anisotropy, and likewise segmented by the main Brasiliano shear zones despite the fact that these probably did not accommodate much of the extension. This activity is possibly related to differential exhumation during the final stage of uplift, which has shaped the modern landscape of Uruguay. 


\section{CHAPTER 7: Phanerozoic low-temperature evolution of the Sul-rio-grandense Shield}

\subsection{Introduction}

After the stabilization of the Gondwanan supercontinent and throughout the Phanerozoic, the southern South American Platform experienced a long history of intra-cratonic evolution and basin development, until the rifting of the South Atlantic Ocean in the Lower Cretaceous (Zalán et al. 1990; Milani et al. 2007; Contreras et al. 2010; Moulin et al. 2010; Stica et al. 2014). The Sul-rio-grandense Shield is one of the southernmost expositions of the Neoproterozoic basement, and comprises a complex association of tectonic terranes juxtaposed along crustal-scale shear zone systems (Fig. 7.1, Chapter 2).

In this chapter, the Phanerozoic evolution of the Sul-rio-grandense Shield is investigated using multiple low-temperature geochronological methods, including fault gouge clays K-Ar dating and zircon and apatite (U-Th)/He thermochronology, along with thermal modelling. Special attention is given to the influence of the structural framework inherited from the Brasiliano-Pan-African orogenic cycle. The results reveal a long exhumation history between the cessation of orogenic activity and the opening of the South Atlantic Ocean.

\subsection{K-Ar geochronology of fault gouges}

Six fault gouge samples associated with four large-scale structures were selected for dating, totalizing 18 individual analyses, considering the different granulometric fractions measured for each sample. Coordinates of the outcrops on which the samples were collected are listed in Appendix $A$, and their location is presented in Fig. 7.1. Three samples come from a same outcrop along the Dorsal do Canguçu Shear Zone and represent distinct faults affecting quartz-mylonites (which were also analyzed for muscovite, sample BR-39-15). Samples BR-37-15 and BR-40-15 represent faults parallel to the mylonitic foliation, while sample BR-38-15 was taken from a transversal fault that cuts the remaining structures (Fig. 7.2a). Two samples were collected from within the Pelotas Batholith. Sample BR-43-15 was taken from an outcrop of post-tectonic granites in a section affected by the brittle Passo do Marinheiro Fault. The outcrop is affected by numerous faults and fractures, mostly with a N-S direction, and is intruded by a basalt dyke associated with the opening of the South Atlantic Ocean in the Cretaceous. The sampled fault is approximately parallel to the dyke. Sample BR-45-16, on the other hand, was collected from a fault in an outcrop close to the city of Canguçu, on which the granites of the Pelotas Batholith are crosscut by numerous shear structures parallel to the main Dorsal do Canguçu Shear Zone (Fig. 7.2b). Finally, 
sample BR-62-15 represents a fault transversal to quartz-mylonites from the Tijucas Terrane (Fig. 7.2c), discussed in chapter 4.

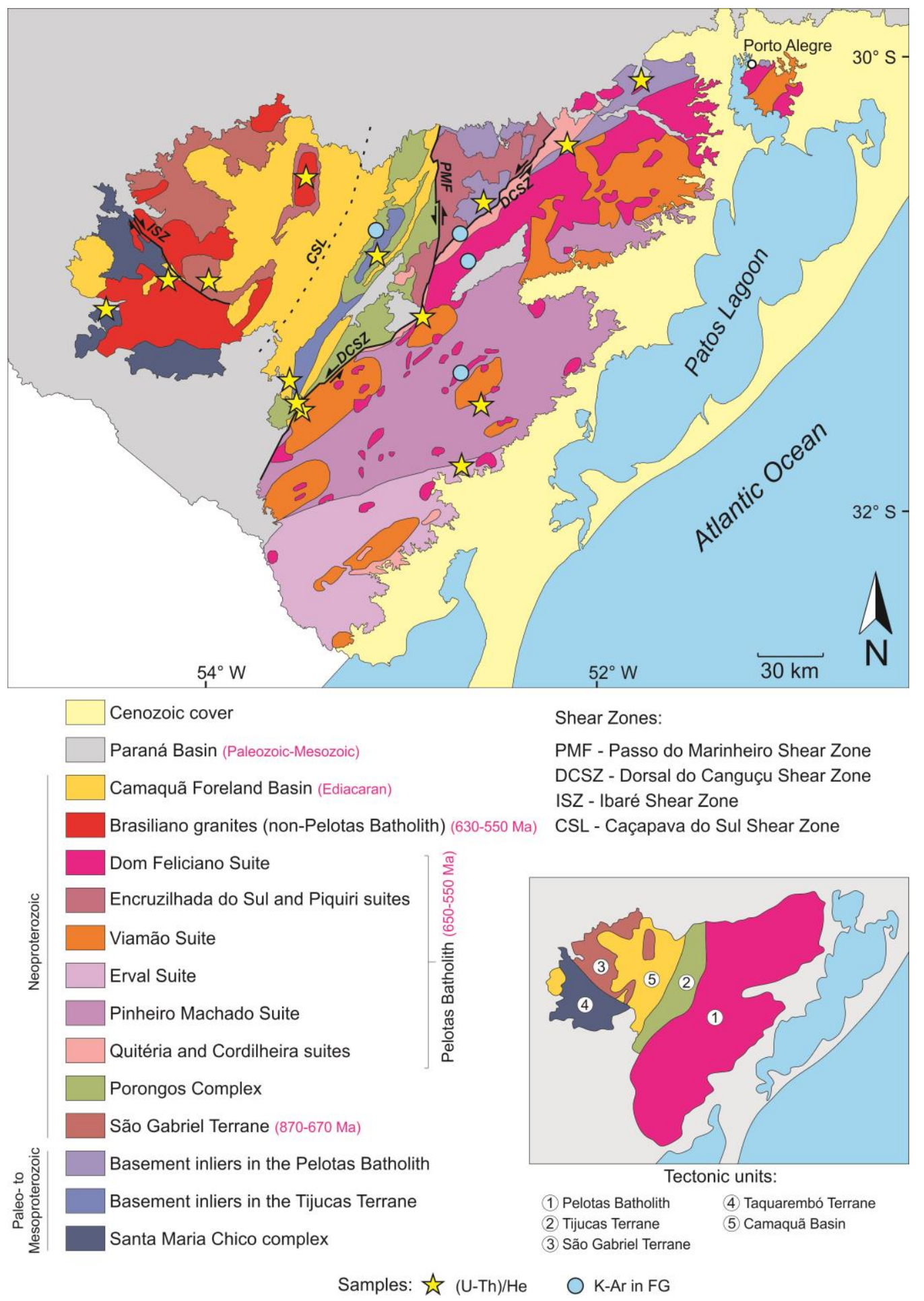

Figure 7.1: Simplified geological map of the Sul-rio-grandense Shield with location of the analyzed samples.

Modified from Wildner et al. (2006), Saalmann et al. (2011) and Philipp et al. (2016a) 


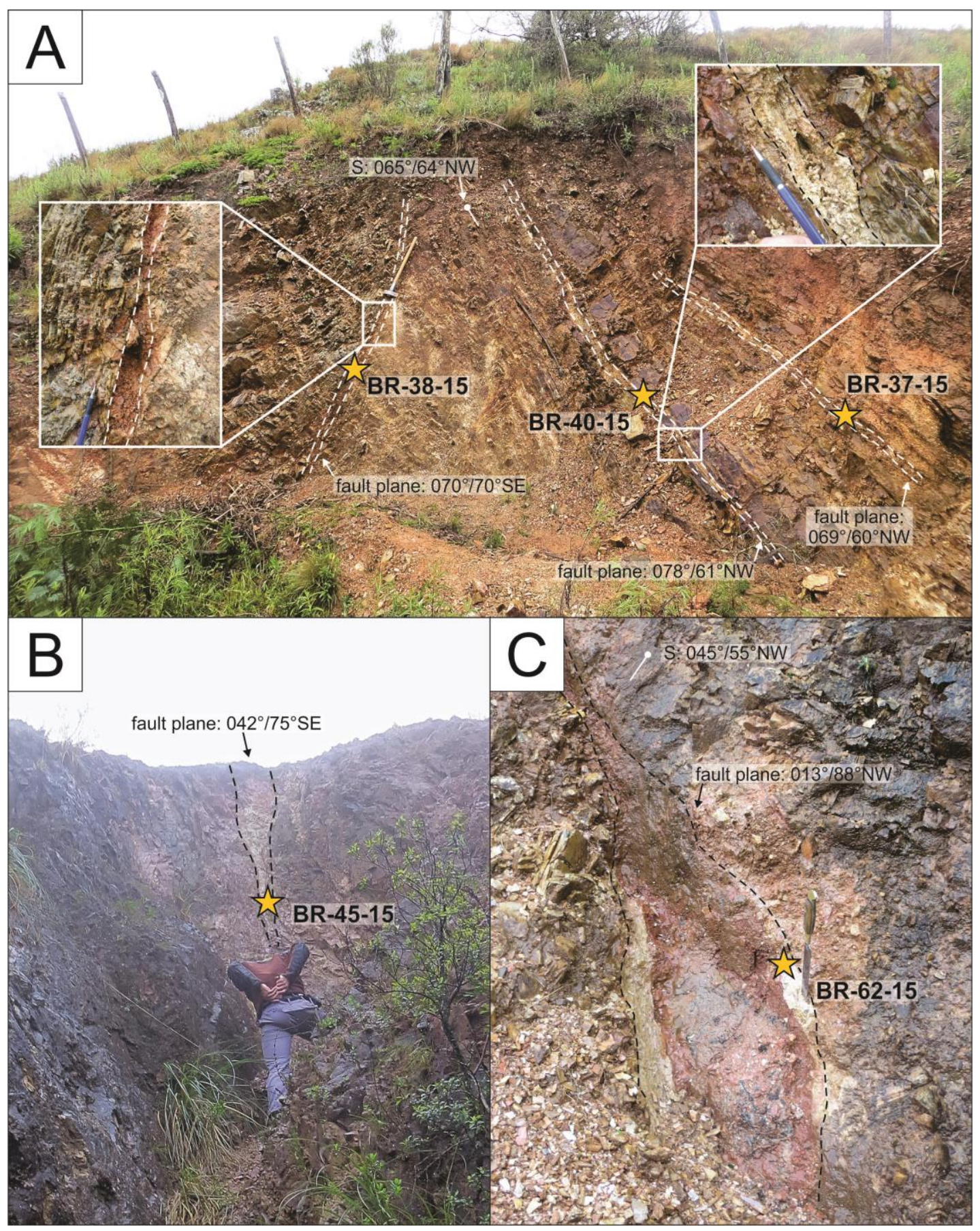

Figure 7.2: Field photographs of dated fault gouges: a: Outcrop of mylonites from the Dorsal do Canguçu Shear

Zone cut by three faults. Note that two of the faults are sub-parallel to the rock foliation and one is transverse; $b$ :

Fault along shear zone internal to the Pelotas Batholith; c: Sampled gouge from fault affecting mylonites from the Tijucas Terrane. Note that the structure is wide and has materials with different colors. The dated type corresponds to the white variety 
With the exception of sample BR-43-15, the dated fault gouges produced ages almost entirely restricted to the Paleozoic and are strongly grain-size dependent (Fig. 7.3a). Three main age populations were recognized: Cambrian-Ordovician, Silurian-Devonian and late Carboniferous. Individual fractions from the samples associated with the Dorsal do Canguçu Shear Zone yield ages between 568 and $422 \mathrm{Ma}$. As expected, the youngest age was obtained from the finest dated fraction of the transecting fault that cross-cuts the other dated gouges (sample BR-38-15). This Silurian age (422.2 $\pm 8.6 \mathrm{Ma})$ is almost $50 \mathrm{Myr}$ younger than the remaining results, which include three Lower Ordovician fractions (470-481 Ma) and five Cambrian to late Neoproterozoic ages (506-563 Ma). These ages overlap broadly with the results obtained from the fine fractions extracted from the same unit of mylonitic rocks (Chapter 4), indicating that this period marks a transition to temperature conditions dominated by brittle deformation. The fault associated with internal shear zones in the Pelotas Batholith (sample BR-45-15) yielded ages comparable to the youngest dated material in the Dorsal do Canguçu Shear Zone, corresponding to the Devonian and Silurian (377-437 Ma). Sample BR-62-15, collected from a fault associated with the mylonites of the Tijucas Terrane, produced a remarkably wide spectrum of ages, strongly dependent on the grain size. The youngest fraction $(<0.2 \mu \mathrm{m})$ yielded a late Carboniferous age $(305.8 \pm 5.1 \mathrm{Ma})$ that is unique among the dated gouges, while the remaining results correspond to the main periods identified in the other samples, Devonian-Silurian (357.9 \pm 4.9 ) and Ordovician-Cambrian (476.1 $\pm 5.1 \mathrm{Ma})$. Standing strongly apart from the remaining analyses, sample BR-43-15, yielded much younger Cretaceous ages (107-115 Ma), which are little dependent on the measured grain size fraction. This sample is also unique within the dated set for consisting almost entirely of smectite, as indicated by their XRD spectra and reflected in the exceptionally low values of $\mathrm{K}_{2} \mathrm{O}(0.1-0.5 \%)$.

As a general, quantification of the illite polytypes identified the presence of the $2 M_{1}$ polytype in all analyzed samples with the exception of sample BR-43-15, identifying at least anchizone conditions for these materials. However, despite presenting a considerable internal consistency, the polytype values do not indicate much variety within the analyzed samples, repeatedly yielding values between 10 and $50 \%$ of $2 M_{1}$, which is not in accordance with the Illite crystallinity measured for the same samples. This little variation prevents the extrapolation of ages for "pure" end-members of $0 \%$ and $100 \% 2 \mathrm{M}_{1}$ illite (e.g. Grathoff \& Moore, 1996). This might be a consequence of the polymineralic nature of the analyzed materials, which influences the obtained spectra. For these reasons, the degree of illite crystallinity is assumed to be more diagnostic of the temperature conditions of illite formation in the analyzed samples then the polytype analyses, and will be used as the main criteria. 


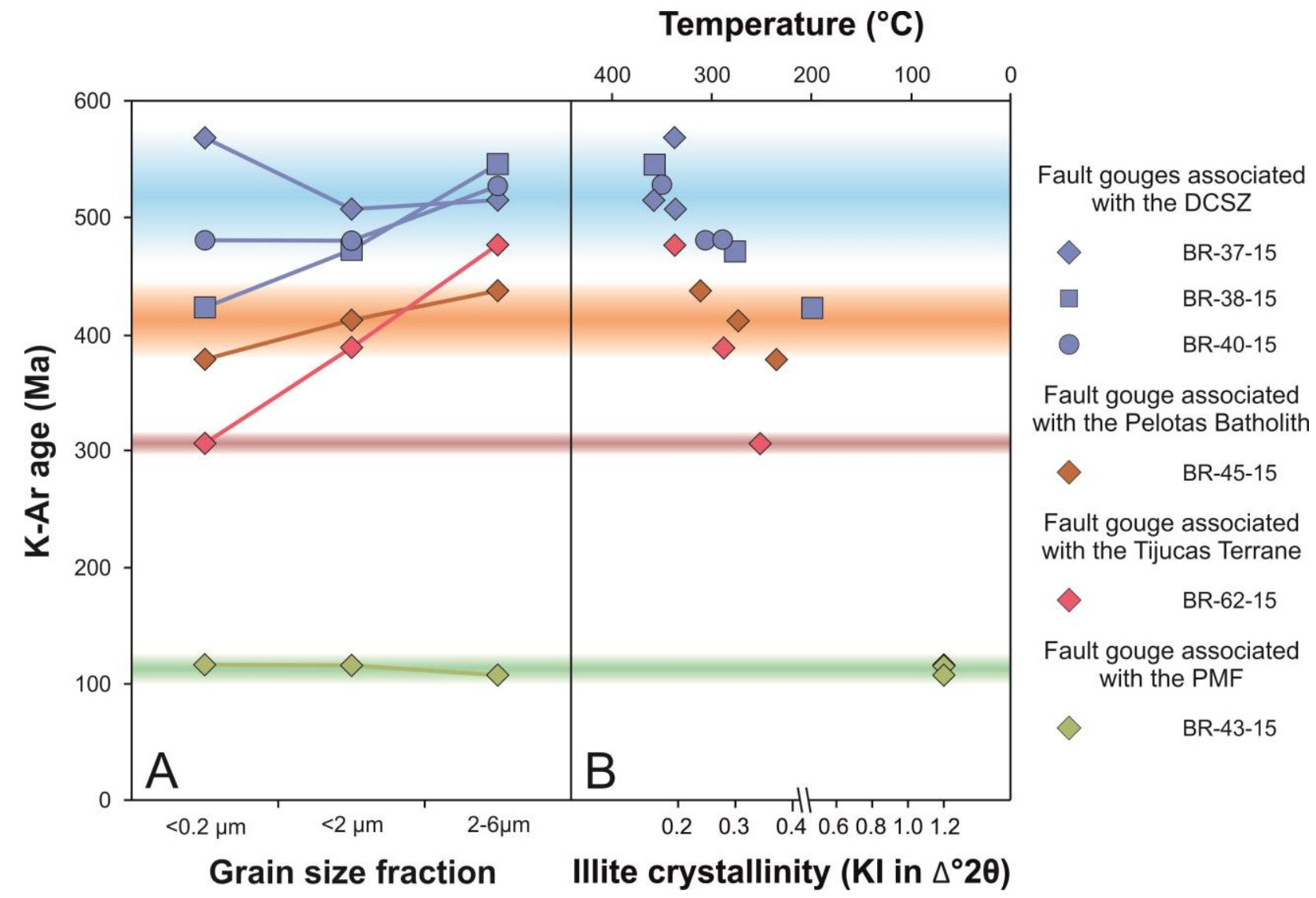

Figure 7.3: a: K-Ar ages obtained on the dated fault gouge, arranged according to the dated grain-size fraction, with main activity periods highlighted; b: Age distribution vs. Kübler index of all grain size fractions of the dated fault gouges. Illite crystallinity values of sample BR-43-15 are assumed, as its mineralogy composed exclusively of smectite prevents this analysis, but suggests conditions within the diagenetic zone $\left(<100^{\circ} \mathrm{C}\right)$. DCSZ: Dorsal do Canguçu Shear Zone, PMF: Passo do Marinheiro Fault

Illite crystallinity from the analyzed fault gouges varies from values characteristic of the epizone to results associated with the boundary between anchizone and the diagenesis zone. Most sets of samples show a clear trend from lower Kübler Indexes in the coarsest fractions to higher values in the finest fractions, indicating that the continuous crystallization of finer illite crystals was accompanied by cooling conditions. This trend is also evident when comparing the Kübler index of all analyzed fractions with the corresponding ages (Fig. 7.3b), also corroborating a pattern of cooling conditions during the dated brittle deformation. It should be noted that sample BR-43-15, which produced the youngest ages, consists almost exclusively of smectite. Though this prevents the characterization of the illite crystallinity in the analyzed material, it is in itself indicative of very low-temperature conditions, well within the diagenetic zone. 


\subsection{Apatite and Zircon (U-Th)/He thermochronology}

Samples were collected from the crystalline basement of the Sul-rio-grandense Shield along three profiles oriented approximately E-W to NE-SW, covering all tectonic terranes. Sampling was focused on gneisses and granites for the common presence of zircon and apatite in these lithologies, but was not restricted to them. More than thirty individual samples were treated for mineral concentration, of which 13 were selected for (U-Th)/He dating. Three single-crystal aliquots were selected for each sample and mineral phase according to their quality, including an evaluation of radiation damage to zircon crystallinity with Raman spectroscopy prior to He extraction. All (U-Th)/He results for zircon (ZHe) and Apatite $(\mathrm{AHe})$ are presented in Appendix $\mathrm{E}$.

\subsubsection{Zircon (U-Th)/He results and initial interpretation}

A total of 38 crystals were measured from 13 samples. All of them produced ZHe ages that are younger than the emplacement or stratigraphic age of the sampled units. The individual crystals yielded a wide spread of ages, between 580 and $60 \mathrm{Ma}$. The results have no apparent correlation with such influencing factors as altitude or grain size, and the different ages are not arranged geographically into blocks with similar ages. There is, however, a moderate negative correlation between individual ages and the concentration of radioactive elements in the measured crystals, expressed in its effective uranium content (eU $=U+0.235 * T h$, in ppm). This correlation (Fig. 7.4a) is a common feature of the (U-Th)/He thermochronological method for both zircon and apatite, and is caused by the fact that the accumulation of radiation damage on the crystal lattice has an influence on its He retentivity (e.g. Flowers et al. 2009; Guenthner et al. 2013). Given enough time for the accumulation of radiation damage, such as in areas with a long exposition to near-surface conditions, it will effectively lead to distinct closure temperatures for individual crystals, even if they experienced the same thermal history. Under appropriate conditions, this feature can be used for constraining detailed thermal histories by modelling an expected distribution of eU content vs. age and comparing it to the measured dataset (Ault et al. 2009; Flowers \& Kelley 2011; Murray et al. 2016; Orme et al. 2016; Powell et al. 2016; Guenthner et al. 2017; Johnson et al. 2017). In the new dataset, however, this correlation is quite broad along a wide extension of eU contents ( 0 to $1,600 \mathrm{ppm}$ ), varying from apparent ages of ca. $500 \mathrm{Ma}$ to ca. $200 \mathrm{Ma}$, and with variations of up to 100 Ma for a given eU value. As such, it does not correspond to a single thermal history shared by all analyzed samples, preventing its use as a modelling tool. 


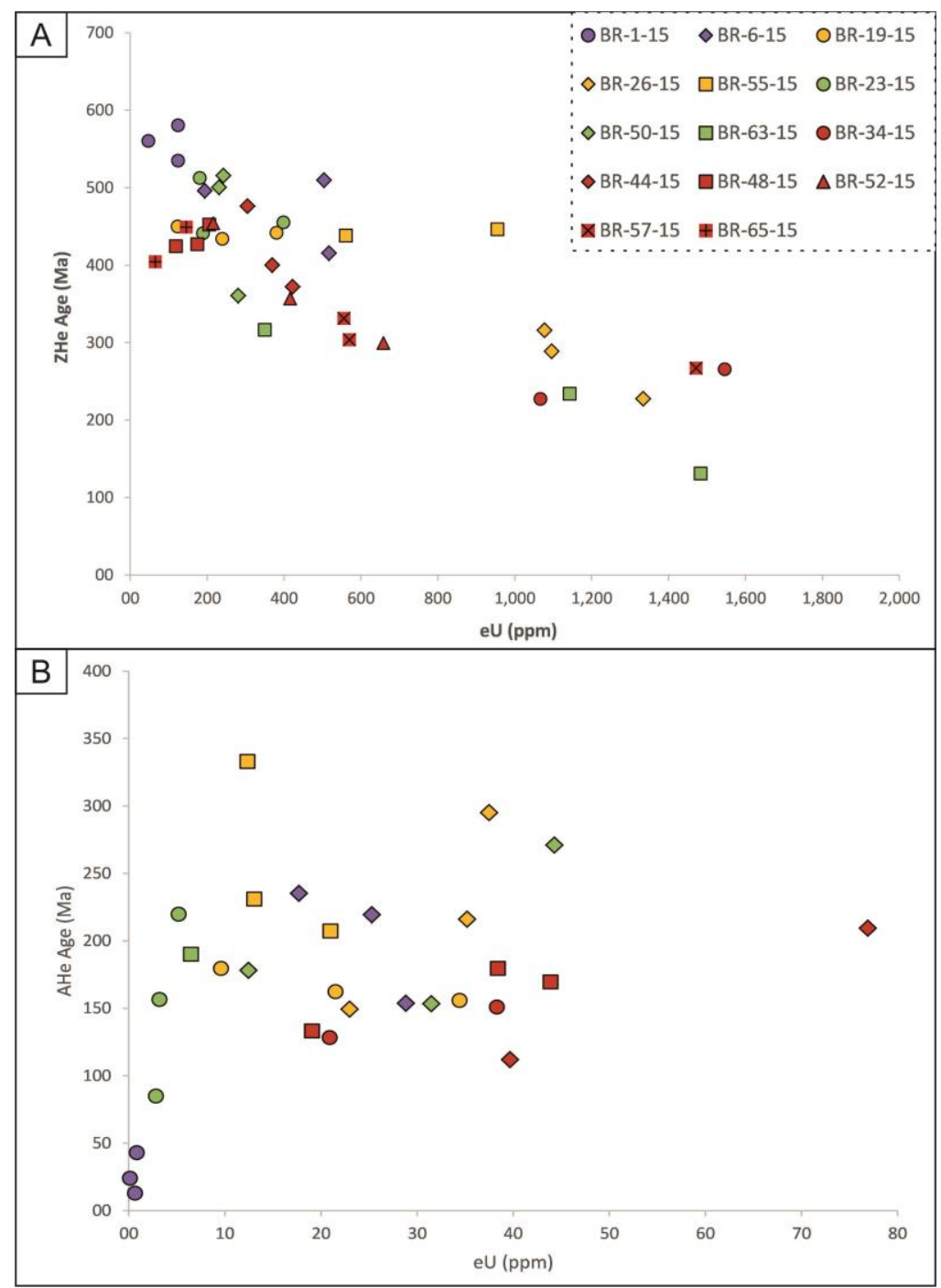

Figure 7.4: Single-crystal zircon (a) and apatite (b) (U-Th)/He age versus eU content for the entire measured dataset, with the exclusion of obvious outliers. Symbols are color-coded according to the tectonic units of each of the samples: Purple - Nico Pérez (Taquarembó) Terrane; Orange - São Gabriel Belt; Green: Tijucas Terrane; Red:

Pelotas Batholith

Nonetheless, it can be used as a criterion for identifying the most reliable ages within the dataset. Based on the eU content of all measured crystals, two groups can be roughly identified. The first one comprises the majority of crystals (27) and is characterized by eU values below 700 ppm and ZHe ages between 580 and $300 \mathrm{Ma}$. On the other hand, the second group corresponds to 10 crystals with eU values between 950 and 6,100 ppm which produced consistently younger apparent ages, almost all of them below 300 Ma. These ages are already well in the range of the AHe dataset (mostly 330-100 Ma) and published apatite fission track (AFT) results for the same region (Borba et al. 2002, 2003; Bicca et al. 2013; Oliveira et al. 2015b). A similar pattern was observed in the northern part of the Dom Feliciano Belt, on which 
ZHe ages from crystals with eU contents above 1,000 ppm yielded ages comparable to AHe results in the same samples (Chapter 8). The data obtained on the low eU crystals are assumed to be more reliable as in the high eU -more damaged- crystals the collapse of the crystal lattice took place heterogeneously (e.g. Danišík et al. 2017). Therefore only the data measured on low damage-density crystals will be considered in subsequent analyses. The results are restricted to Pre-Permian ages, with a concentration of ages between 550 and $400 \mathrm{Ma}$.

These ages, however, are older than previously reported zircon fission track (ZFT) ages from the study area (Oliveira et al. 2015b), which is unexpected. Although this thermochronometer is traditionally interpreted to represent higher reset temperatures, the reported ages are distributed between 386 and $210 \mathrm{Ma}$, which are predominantly younger than the accepted ZHe dataset. In fact, most ZFT apparent ages are comparable to the oldest AFT and AHe ages in the region (Borba et al. 2002, 2003; Bicca et al. 2013; Oliveira et al. 2015b). This inconsistency might be the result of the analytical method, as fission track counting for old zircons with high densities of spontaneous tracks is not without subjectivity (Wagner \& van den Hute 1992). In addition, the apparent contradictory results might reflect a distinction in the sampling strategy between the available ZFT and new AHe data. Despite focusing on the same study area, all ZFT measurements were obtained from samples of sedimentary rocks of the Camaquã Basin, while the new (U-Th)/He ages represent crystalline units from the Sul-rio-grandense Shield. Due to the relative consistency of the new ZHe dataset throughout a larger sampling area, and added to the fact that the eU content was used as an internal control of the apparent ages, the ZHe results are considered representative of cooling below $140-180^{\circ} \mathrm{C}$ for the crystalline basement. The ZFT data, on the other hand, is probably more representative of the local thermal evolution of the Camaquã Basin. This observation is supported by the remaining thermochronological data in the shield and it's continuation to Uruguay (Chapter 6, see discussion in section 7.5.2). Future studies applying ZHe thermochronology to the basin may help address this particular problem.

\subsubsection{Apatite (U-Th)/He results and initial interpretation}

32 apatite crystals from 11 samples were analyzed, resulting in a wide array of apparent AHe ages. A few of the results yielded outlying and/or imprecise results, and are not considered representative (see footnotes in Appendix E). Excluding the outlying crystals, the measured AHe ages do not correlate with possible influencing factors such as altitude, grain size or eU content (Fig. 7.4b), and are not distributed according to geographical location. Notwithstanding, they cover a wide range of possible apparent ages between 333 and $85 \mathrm{Ma}$, with a majority of results concentrated between 235 and $110 \mathrm{Ma}$. Within this 
time interval, the individual ages show a continuous distribution, without the presence of apparent age gaps or concentration into given periods. The lack of individual controlling factors that might explain the distribution of the AHe dataset lead to the conclusion that they cannot be resolved with a single thermal history, and that the analyzed samples probably underwent at least slightly different T-t trajectories. Furthermore, the continuous spread of ages throughout a long period of time also indicates a prolonged permanence under temperature conditions at or close to the systems partial retention zone (PRZ), without indication of fast heating or cooling.

The apparent AHe age interval is in accordance with previous thermochronological studies performed in the Sul-rio-grandense Shield. A number of AFT ages have been reported in the past, and have produced a wide range of ages, between 360 and $75 \mathrm{Ma}$ (Borba et al. 2002, 2003; Bicca et al. 2013; Oliveira et al. 2015b), with most ages concentrated between 310 and $135 \mathrm{Ma}$.

\subsection{Thermal modelling}

Thermal modelling was applied in order to test viable geological evolutions for the Sul-rio-grandense Shield and evaluate their compatibility with the measured U-Th)/He dataset. This was done using the HeFTy program (Ketcham 2005) and following the zircon diffusion model of Guenthner et al. (2013) and apatite diffusion model of Flowers et al. (2009). Individual crystal ages were corrected for alpha ejection age according to Ketcham et al. (2011). For each modelled scenario, random T-t paths were tested within the boundaries of assumed constraints, yielding crystal diffusion curves that were on their turn compared with the ones calculated from the input data. According to their goodness of fit, satisfactory results were categorized into acceptable and good paths (see Ketcham 2005 for more details). All samples that provided both acceptable $\mathrm{ZHe}$ and $\mathrm{AHe}$ ages were modelled, totalizing seven samples. As discussed above, the damaged zircons with eU content above $700 \mathrm{ppm}$ were not considered for thermal modelling. Up to three individual crystals each for both zircon and apatite were used for calculations in all models, and simulations which failed to reproduce good paths when considering all measured crystals were repeated using two crystals for each mineral.

Initially, all samples were submitted to an unsupervised model, for which only initial and final conditions were fixed. Initial conditions were constrained at a middle-temperature range corresponding to the cooling of the muscovite K-Ar system (350-425 ${ }^{\circ} \mathrm{C}$, Purdy \& Jäger 1976; Harrison et al. 2009), set between 570 and $530 \mathrm{Ma}$, representative of the crystalline basement of the Sul-rio-grandense Shield (Chapter 4). Present-day annual mean temperatures were set to $20 \pm 5^{\circ} \mathrm{C}$. 
Following this step, two main viable thermal paths were tested for each of the basement samples, based on the geological evidence for the Phanerozoic history of the Sul-rio-grandense Shield. Both scenarios correspond to $\mathrm{T}-\mathrm{t}$ paths that are in accordance with the range of possibilities obtained in the unsupervised models (Fig. 7.5). The first one assumes that the basement has not experienced exposure to near-surface conditions, and only went through long-term cooling since the end of the Dom Feliciano Event. For this scenario, the only limiting factor was to keep temperature above $60^{\circ} \mathrm{C}$ until each sample's mean AHe age.

The second hypothesis assumes an initial exhumation to near-surface conditions during the early Paleozoic, after the end of orogenic activity in the Dom Feliciano Belt. This hypothesis allows the basement to be exposed prior to the onset of regional subsidence in the Paraná Basin, starting in the Devonian (Milani et al. 2007). It was constrained by fixing temperatures below $60^{\circ} \mathrm{C}$ in the Silurian, between 440-420 Ma. After this, the model allowed for reheating, in order to simulate the deposition of the Paraná Basin. Temperatures from the Devonian onwards were limited at $100^{\circ} \mathrm{C}$. This value is a conservative maximum, and was estimated using maturation studies from sediments within the basin (Silva \& Cornford 1985) and assuming higher temperatures for the buried basement. The constraints imposed by this latter scenario are in agreement with the majority of the reliable ZHe ages, which are predominantly older than $420 \mathrm{Ma}$. However, there are a few samples on which the mean ZHe age is as young as ca. $320 \mathrm{Ma}$. This is the case for only one of the samples that provided enough results as to be modelled, sample BR-44-15, which has a mean age of $416 \pm 31 \mathrm{Ma}$. Therefore, this scenario was not modelled for this sample.

Finally, it should be noted that the impact of considerable thermal influence from the Lower Cretaceous volcanism of the Paraná Large Igneous Province (Paraná LIP) was not taken into account during thermal modelling, as an overwhelming majority of AHe ages are older than $135 \mathrm{Ma}$ and indicate that this thermochronometer was already closed at onset of magmatism and remained so afterwards.

100,000 trajectories were tested for each simulation, or the simulation was interrupted after 100 good fits were found. The thermal modelling yielded successful results for the (U-Th)/He dataset, with all tested scenarios identifying numerous acceptable and good paths, most of which reaching 100 good paths before testing 100,000 possible trajectories. On a first order, this indicates that both tested hypotheses represent viable geological histories for the measured (U-Th)/He dataset. 


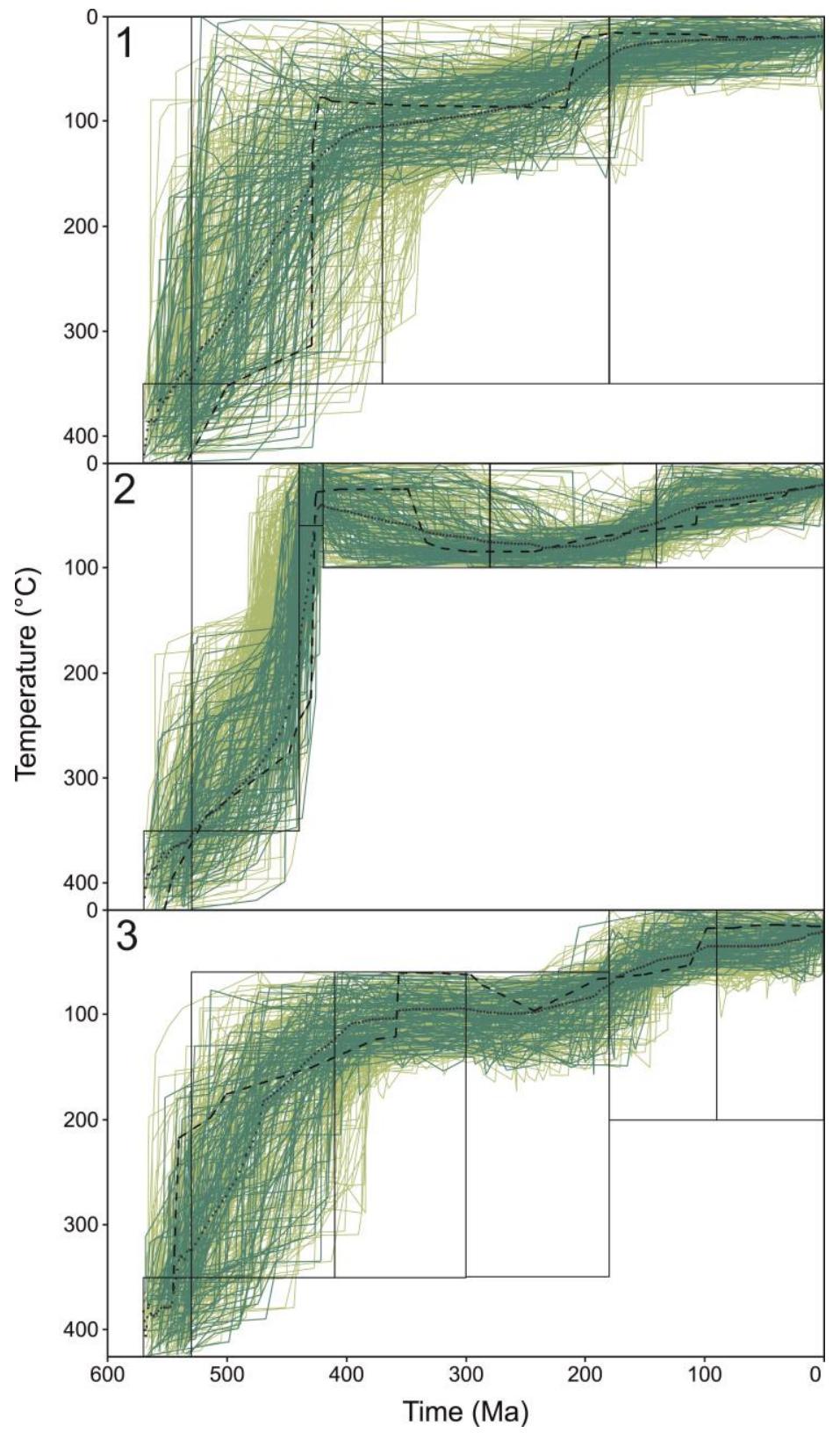

Figure 7.5: Example of the thermal modelling applied to the (U-Th)/He dataset, with results from sample BR-55-15. The model tested in Hypothesis 1 corresponds to an unsupervised model, on which only initial and final constraints are fixed. Hypothesis 2 and 3 test distinct realistic geological scenarios, simulating an exposition to near-surface conditions in the Silurian and a thermal evolution with no exposition to near-surface conditions prior to the sample's mean AHe age, respectively. Note that both scenarios 2 and 3 were successfully reproduced in the unsupervised model. Light and dark green paths correspond to acceptable and good paths, respectively, and black boxes represent the thermal constraint assumed for the simulations.

There is, however, a noticeable difference between the success rates of the different tested hypotheses. When comparing the number of good paths in relation to the total paths tried for each simulation of a 
same sample, Hypotheses 2 consistently outperforms both Hypothesis 1 and the unsupervised models, suggesting a better compatibility with the modelled dataset (Fig. 7.6). In addition, in most cases, Hypothesis 1 yielded a performance considerably below that of the unsupervised models. Altogether, this indicates that the assumption of exposition to near-surface conditions prior to the sedimentation of the Paraná Basin associated with reheating of the basement units is a more realistic depiction of the thermal evolution of the Sul-rio-grandense Shield, in the modelled samples. On the other hand, the possibility of a long-term exhumation without the necessity of a Phanerozoic reburial is also a possibility, in particular for the samples that yielded ZHe ages that overlap with the deposition of the Paraná Basin.

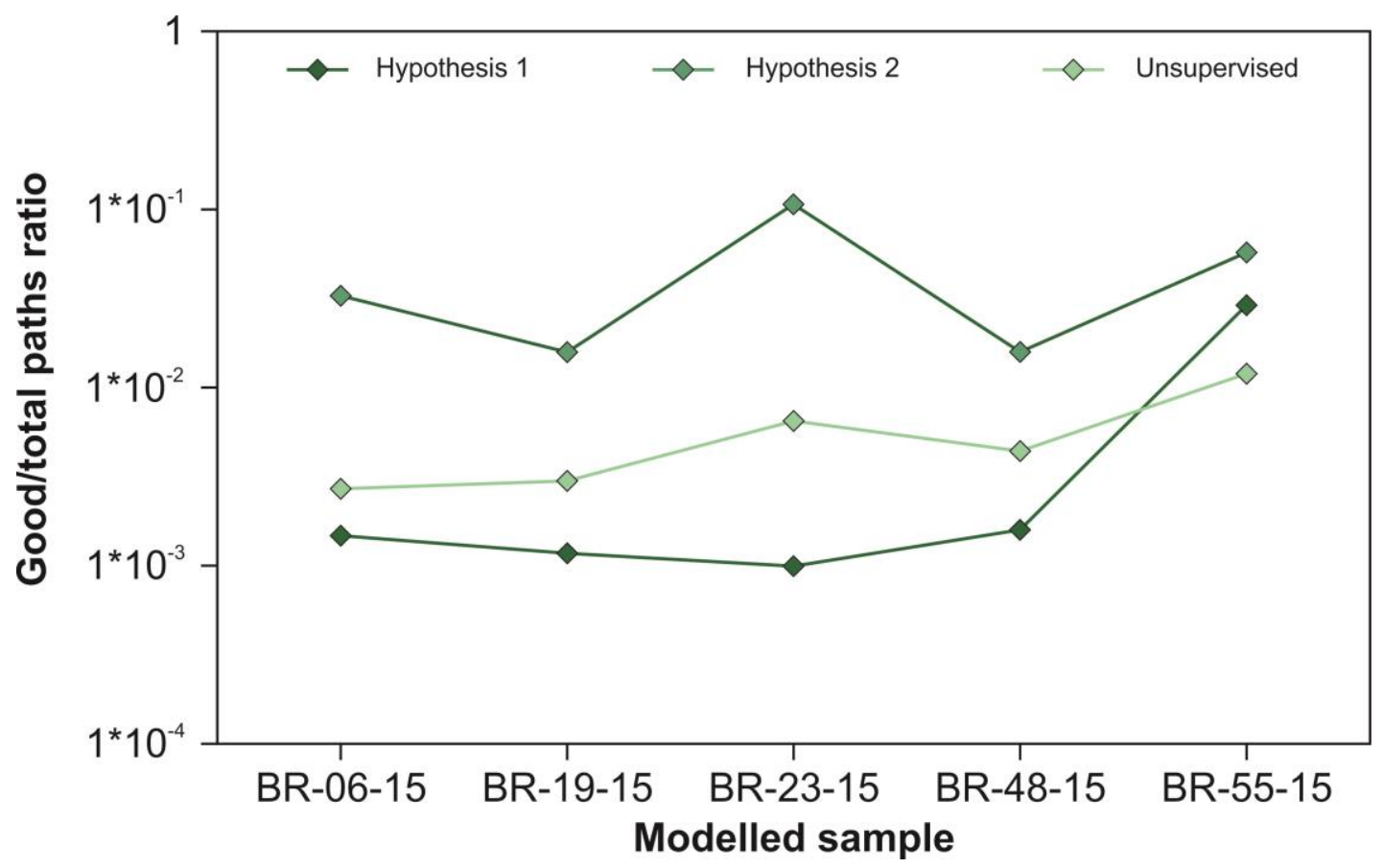

Figure 7.6: Variation of the good fits/total tested paths ratios for all modelled scenarios. All models were run 100,000 times or until obtaining the 100 th good fit. Note that the vertical scale is logarithmic

\subsection{Discussion}

\subsubsection{Illite K-Ar ages in fault gouges}

Illite fractions dated from fault gouges collected along the Dom Feliciano Belt in the Sul-rio-grandense Shield have the advantage of recording brittle activity directly. Four sets of Phanerozoic ages were obtained. The first group is mostly constrained to the Cambrian and Ordovician (545-475 Ma), and corroborates the transition from ductile to brittle conditions between 520 and $470 \mathrm{Ma}$ in mylonites from the belt, as discussed above. This is particularly clear in the case of gouges collected from two faults 
parallel to the mylonitic foliation in one outcrop of the Dorsal do Canguçu. Even if part of the material in the coarsest fractions (e.g. the 2-6 $\mu \mathrm{m}$ fraction) is contaminated by inherited crystals from the host rock, the youngest ages confirm the onset of brittle activity during this period.

The second set of ages was collected from three individual faults, associated with the Dorsal do Canguçu Shear Zone, the mylonites from the Tijucas Terrane and an internal shear zone within the Pelotas Batholith. These faults are not parallel to the main mylonitic foliation, but have NE-SW orientations and steep to subvertical dips, parallel to the general strike of the Dom Feliciano Belt. They produced Silurian and Devonian ages, between 437 and $378 \mathrm{Ma}$. A similar range of results was obtained from fault gouges associated with the Rivera Shear Zone in Uruguay (ca. 430-370 Ma, Chapter 6). Taken together, these ages may indicate a period of fault activity in a larger regional context, roughly coincident with the deposition of the Devonian Paraná Supersequence of the Paraná Basin (Milani et al. 2007).

A single late Carboniferous age (of $305.8 \pm 5.1 \mathrm{Ma}$ ) was extracted from a fault gouge associated with the mylonites in the Tijucas Terrane. It was obtained from the finest fraction $(<0.2 \mu \mathrm{m})$ on a sample with strong grain-size dependency. The remaining fractions produced ages comparable to the first two age sets (Cambro-Ordovician and Silurian-Devonian). Although this age is not corroborated by other fractions, the overall pattern provided by this fault suggests a continuous history of fault reactivation throughout the Paleozoic.

Finally, a set of Cretaceous ages (116-107 Ma) was obtained for one fault gouge along the strike of the brittle Passo do Marinheiro Fault. This fault is semi-parallel to a basaltic dyke associated with the Cretaceous magmatism that accompanied the opening of the South Atlantic Ocean. Although this age is ca. 20 Myr younger than the bulk of the continental flood magmatism that affected the Paraná Basin around 135-130 Ma (e.g. Renne et al. 1992; Ernesto et al. 1999; Thiede \& Vasconcelos 2010; Janasi et al. 2011), dyke intrusion persisted after the continental stage of the magmatism and during the initial rifting and spreading of oceanic crust (Florisbal et al. 2014; Stica et al. 2014). The subvertical, NW-SE striking orientation of the dated structure is in accordance with widespread dyke intrusion in the Sul-riograndense Shield during the initial continental drifting (Salomon et al. 2015, 2017), which is attributed to extension associated with rotation of the South American continent. Deformation along this fault occurred under diagenetic conditions $\left(<100^{\circ} \mathrm{C}\right)$, as indicated by a mineralogy almost exclusively comprised of smectite.

The widespread range of fault gouge ages indicate that the main Neoproterozoic structures of the Sulrio-grandense Shield experienced recurrent reactivation after the culmination of the orogenic event and 
stabilization of the South American Platform. This process has been interpreted to have influenced the sedimentation and deformation of the Paleozoic sequences of the Paraná Basin (e.g. Rostirolla et al. 2000; Holz et al. 2006). This is also commonly reflected in basement-cover relationships of the shield, as sedimentary sequences from the Camaquã and Paraná basins are commonly preserved along grabens following the major structures. This is particularly evident the central portion of the Ibaré Shear Zone and the southern termination of the Dorsal do Canguçu Shear Zone (Wildner et al. 2006; Laux et al. 2012).

\subsection{2 (U-Th)/He thermochronology and the thermal history of the Sul-rio-grandense Shield}

The new (U-Th)/He dataset produced a wide range of apparent ages, which hinder straightforward interpretations and should be interpreted with care. There is a moderate correlation between ZHe ages and eU content in the new ages, probably as a result of accumulated radiation damage in the measured crystals, leading to effectively variable closure temperatures (Guenthner et al. 2013, 2015, 2017; Orme et al. 2016; Powell et al. 2016; Johnson et al. 2017). This correlation cannot be modelled into a single coherent thermal history that satisfies the ZHe age distribution, indicating that the Sul-rio-grandense did not behave in a singular fashion during the exhumation through the ZHe PRZ. Nonetheless, the singlecrystal eU content can be used as an internal criterion for selecting the most reliable analyses, resulting in ages consistently older than $300 \mathrm{Ma}$, a majority of which are concentrated between 550 and $400 \mathrm{Ma}$. This suggests that considerable exhumation followed the late stages of the Dom Feliciano Event by the early Paleozoic (Chapter 6). The lack of a unified thermal history for the shield in this period might be a consequence of block tectonics bound by fault activity, leading to slightly variations in the exhumation process throughout the study area. This is further supported by the new illite K-Ar analyses. Not only is recurrent fault activity indicated by these ages between 540 and $380 \mathrm{Ma}$, during which the bulk of exhumation is proposed for the region, but the degree of illite crystallinity in the measured samples indicates that a progressive cooling accompanied this history of reactivation (Fig. 7.7). This cooling is somewhat slower than in the majority of the shield, as indicated by the higher temperatures assumed from degree of illite crystallinity than from the thermal modelling. This might be the result of the percolation of hydrothermal fluids along the fault zones during brittle displacement (e.g. Tagami 2012).

This assumption is further supported by thermal modelling of the dataset, which recognizes an initial period of exhumation responsible for the closing of the ZHe thermochronometer. In most modelled samples, a comparative analysis between different thermal histories suggests that parts of the shield probably were exposed to near-surface in the early Paleozoic and reheated during the deposition of the 
Paraná Basin (Fig. 7.6). This assumption also satisfies geological evidence, as it is in accordance with the sedimentary contact between the crystalline basement and sediments from the Paraná Basin deposited by regional subsidence from the Devonian onwards. Similar T-t trajectories characterized by initial exhumation to near-surface conditions followed by reheating during the Paleozoic were recognized for other expositions of crystalline basement rocks along the Dom Feliciano Belt, such as in Uruguay and Santa Catarina (Chapters 6, 8).

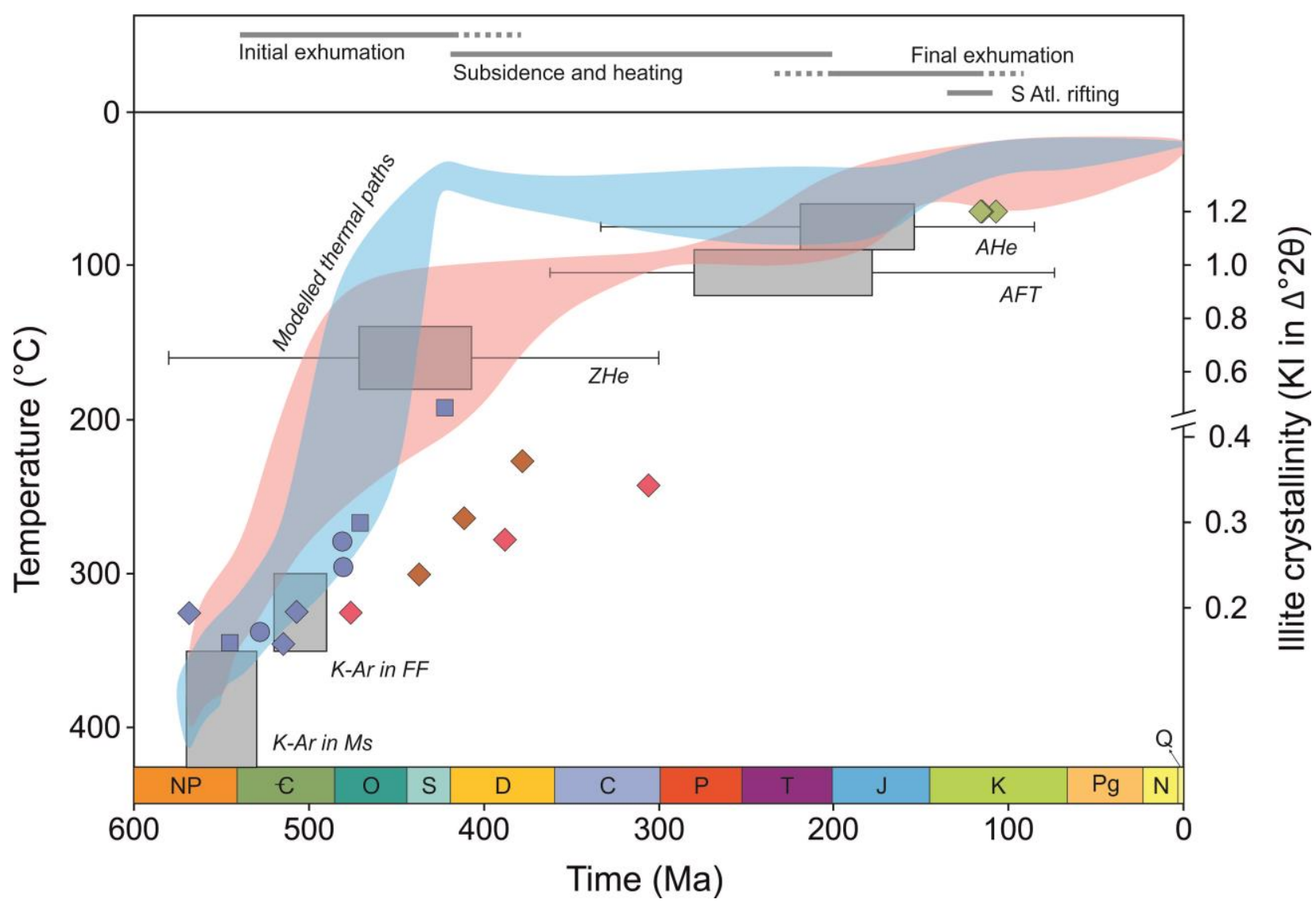

Figure 7.7: Summary of the low-temperature thermochronological data in the Sul-rio-grandense Shield and dominant tectonic processes. AFT ages are from Borba et al. (2002, 2003), Bicca et al. (2013) and Oliveira et al. (2015), and K-Ar ages in muscovite (Ms) and illite fine fractions (FF) are presented and discussed in Chapter 4. Blue and red thermal paths correspond to the mean trajectories for all samples modelled for hypotheses 2 and 3 , respectively, as exemplified in Fig. 7.5. Diamonds correspond to dated fault gouges, arranged according to their age and Kübler Index, as in Fig. 7.3, using the same symbol notation

There are, however, a few samples which produced consistent ZHe ages younger than 420 Ma from crystals with $\mathrm{eU}$ values within the accepted eU range (<700 ppm). This is indicative that a few portions of the Sul-rio-grandense Shield probably remained covered before the onset of Devonian subsidence, only 
being exposed later, during the Devonian and Carboniferous. These concurrent events of exhumation during deposition cycles are another indication of the importance of block segmentation during the Paleozoic, which is also suggested by the sedimentary record (e.g. Holz et al. 2006). It should be noted, however, that the new dataset produced no coherent distribution of samples with conflicting thermal evolutions that can be attributed to known or hypothetical faults, as has been recognized previously in the study area (e.g. Borba et al. 2002).

Similarly to the ZHe data, the AHe results have a widespread span of ages between 333 and $85 \mathrm{Ma}$, but mostly concentrated between 235 and $110 \mathrm{Ma}$. Individual crystal ages are distributed continuously during this period, suggesting a lack of pronounced exhumation events. Instead, a long-term residence in the systems PRZ was probably promoted by the thermal effect of the accumulated deposition of the Paraná Basin. As in the case of the ZHe system, the AHe age distribution cannot be modelled into a single thermal history, indicating that the different analyzed samples probably experienced slightly distinct T-t evolutions. This could be a consequence of variable thickness in the sedimentary cover for each analyzed sample, leading to different thermal evolutions. AHe ages consistently older than 135-110 Ma indicate that final exhumation to near-surface conditions was acquired at the latest by the syn-rifting stage of the South Atlantic Ocean (Contreras et al. 2010; Moulin et al. 2010; Stica et al. 2014). Extrusion of the voluminous Paraná LIP left no discernible impact on the dataset, indicating that, if the studied area was ever covered by flood basalts, they were not as thick as in the central portions of the basin, as they did not cause a resetting of the AHe system. The evolution exposed above is reproduced in the most successful models, on which the wide spread of AHe apparent ages can be reproduced by variable thermal paths simulating the heating promoted by the Paleozoic sediments of the Paraná Basin.

The lack of AHe ages younger than 135-110 Ma indicates that the Sul-rio-grandense Shield experienced no significant exhumation posterior to the extrusion of the Paraná LIP and the opening of the South Atlantic Ocean. This is in clear contrast with the central portion of the Brazilian Atlantic margin, on which elevated coast-parallel ridges are interpreted to have been uplifted in the Upper Cretaceous/Paleogene after the initial rifting phase (Tello Saenz et al. 2003; Hackspacher et al. 2004, 2007; Hiruma et al. 2010; Cogné et al. 2011, 2012; Karl et al. 2013). In this sense, the studied area is more similar to other lowtopography portions of the South Atlantic margin, for which the last substantial exhumation period coincides with the initial stages of rifting, such as in Uruguay or Argentina (Kollenz et al. 2016, Chapter 6). The segmentation of the passive margin into blocks with different exhumation histories is influenced by the presence of a system of coast-perpendicular transverse faults, which not only had an impact on the differential uplift, but also influenced the segmentation of offshore basins and the intrusion of dykes 
during the onset of the Paraná LIP (Zalán et al. 1990; Rostirolla et al. 2000; Meisling et al. 2001; Strugale et al. 2007; Masquelin et al. 2009; Torsvik et al. 2009; Franco-Magalhães et al. 2010; Karl et al. 2013; Salomon et al. 2015, 2017).

Despite evidence of episodic reactivation and the possibility that block segmentation played an important role in the thermal evolution of the shield during the Paleozoic, the Neoproterozoic structural framework inherited from the Brasiliano orogenic cycle is not reflected in the available thermochronological dataset. Somewhat surprisingly, this is also true for the Ibaré Shear Zone, despite being the only major Brasiliano shear zone in the shield oriented parallel to the direction of the main structural control in southern Brazil (NW-SE) during the later Phanerozoic events.

\subsection{Conclusions}

With the cessation of the orogenic process that led to the formation of the Dom Feliciano Belt in the late Ediacaran, the Sul-rio-grandense Shield stabilized and achieved an intracratonic position in the recently assembled Gondwanan supercontinent. Throughout the Phanerozoic, however, the area underwent several tectonic events, including cycles of exhumation and reburial. During this process, the structural framework inherited from the Neoproterozoic evolution was frequently reactivated, as indicated by the direct dating of illite crystallization in fault gouges parallel to important shear zones, though it was not the main driving factor controlling the segmentation during exhumation and reburial of the crystalline basement.

After the late stages of the Brasiliano orogenic cycle, intense exhumation during the early Paleozoic exposed much of the present-day crystalline basement to near-surface conditions, as recorded in the majority of ZHe apparent ages. Fault activity had the likely effect of preventing a single comprehensive exhumation history, but with the exception of a few samples, similar thermal histories in the early Paleozoic can be modelled for most of the crystalline basement. Starting in the Devonian, regional subsidence promoted significant sedimentation in the Paraná Basin, causing a reheating of the basement. The new AHe dataset suggests that reburial from the sedimentary deposits of the Paraná Basin promoted a continued residence of the crystalline basement in the system's PRZ. This continued until the syn-rifting stage of the South Atlantic Ocean at the latest, after which no significant exhumation was recorded. Similarly, the onset of the magmatism related to the Paraná LIP did not affect the AHe thermochronometer. After the initial rifting of the South Atlantic Ocean, the Sul-rio-grandense Shield did not experience pronounced uplift as in other segments of the Brazilian passive margin, as is reflected by 
its relatively modest topography. During these later stages of crustal evolution in the Meso-Cenozoic, the main structural control of the southern portion of the South Atlantic passive margin was through transect fault systems, oriented perpendicular to the coastline. 


\section{CHAPTER 8: Phanerozoic low-temperature evolution of the Catarinense Shield}

\subsection{Introduction}

(U-Th)/He thermochronology is one of the most used methods for investigating low-temperature thermal histories. An important development of the method in recent years is the understanding of the influence of a crystal's radioactive content in its He diffusivity, and how it can lead to varying closure temperatures within a same geological context (Flowers et al., 2009; Guenthner et al., 2013). This is particularly important in old stable areas with prolonged residence in near-surface conditions, on which the long accumulation of radiation damage amplifies this effect (Ault et al., 2009; Flowers \& Kelley, 2011; Murray et al., 2016; Orme et al., 2016; Powell et al., 2016; Guenthner et al., 2017; Johnson et al., 2017). In these cases, it is possible to use the concentration of radioactive elements in each measured crystal, expressed in its effective uranium content (eU, $U+0.235 * T h$, in ppm), as a tool for constraining detailed thermal histories.

In this chapter, the Phanerozoic history of a portion of the Catarinense Shield is investigated using zircon and apatite $(\mathrm{U}-\mathrm{Th}) / \mathrm{He}$ dating and taking into account the impact of radiation damage into the thermochronometers. Thermal and eU-based modelling is successfully applied to reconstruct the area's Phanerozoic history and investigate the thermal imprint of the Paraná Large Igneous Province (Paraná LIP). The chosen study area comprises Neoproterozoic units of the Dom Feliciano Belt, and includes the Major Gercino Shear Zone, a prominent crustal discontinuity (Basei et al. 2000; Passarelli et al. 2010). One of the aims of the chapter is to identify the impact this structure had in the low-temperature geochronological record (e.g. Ault et al. 2009; Cogné et al. 2011; Sueoka et al. 2012; Tagami 2012; Schultz et al. 2017). Finally, the potential of applying zircon radiation damage assessment by Raman spectroscopy as a companion for the mineral's (U-Th)/He investigation is also explored.

\subsection{Sampling}

Samples were collected from the main basement units on both sides of the MGSZ along three crosssections (Fig. 8.1, coordinates in Appendix A). The majority of samples comprise the widespread granitic magmatism mainly intruded between 625 and 570 Ma. Over thirty samples were processed for zircon and apatite; after grinding and sieving, standard gravity and magnetic separation techniques were applied. According to the quality of the crystals, 16 samples were selected for thermochronologic analysis. All but two provided crystals from both mineral phases with the necessary quality for the (UTh)/He analyses. The two remaining samples only had one of the minerals with a satisfactory quality. 


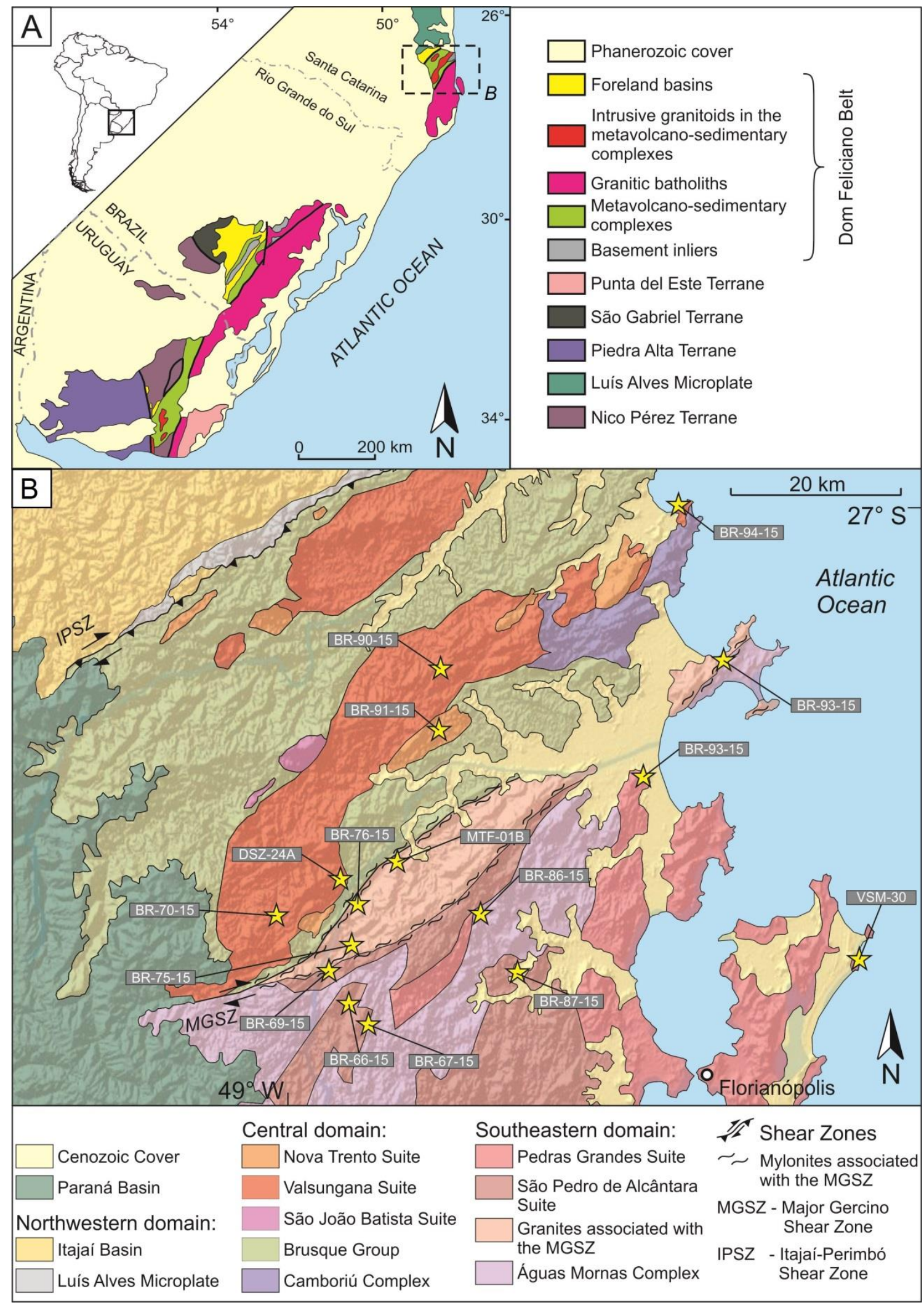

Figure 8.1: Geological map of the Major Gercino Shear Zone, with location of the analyzed samples (modified from Basei et al. 2000, 2006, and Passarelli et al. 2010) 
Three single-crystals aliquots were measured at the GÖochron Laboratory of the University of Göttingen for each sample, totalizing $45 \mathrm{He}$ analyses each for zircon and apatite. In addition, Raman spectroscopy was applied to all measured zircon crystals prior to the He measurement, as a control of the radiation damage. On many of the figures in this chapter, results are divided into three groups in order to provide a better visualization. They correspond to samples collected in the central and southeast domain of the DFB, and to samples from the MGSZ itself (Fig. 8.1).

\subsection{Results and initial observations}

\subsubsection{Zircon (U-Th)/He data}

The measured zircon (U-Th)/He (ZHe) ages are all younger than the emplacement/ stratigraphic age of the sampled units. Single-crystal apparent ages show a large spread from 472 to $26 \mathrm{Ma}$ (Appendix E). These ages do not correlate with elevation or grain size, and are not dependent on location relative to the shear zone. However, there is a strong correlation between the ZHe ages and the eU content of corresponding crystals (Fig. 8.2a). Crystals with eU content below 1,000 ppm have a strongly negative correlation, while the youngest ages are restricted from 67 to $27 \mathrm{Ma}$, forming a long tail with eU contents between 1,000 and 5,200 ppm.

We assume that the wide spread of acquired ages is mainly controlled by their eU content. As such, the apparent ages probably do not represent geologically meaningful events, but rather variable eUcontrolled closure temperatures within a partially reset ZHe system. The relative little intra-sample variation, with most samples yielding multiple-crystal ages with in uncertainties ( $2 \mathrm{SE}$ ) between $6 \%$ and $20 \%$, are the consequence of crystals from the same sample having similar eU contents.

The oldest ZHe age indicates that this thermochronometer has been partially closed since at least 472 Ma (Ordovician) in the study area. The combined results of crystals from all samples form a uniform coherent trend, and can thus be assumed to record the same thermal history, representative for the entire study area. These assumptions will be used at the modeling of data, and an important approach will be to try to replicate the age distribution in relation to their eU content as predicted by the zircon radiation damage accumulation and annealing model (ZRDAAM, Guenthner et al., 2013). 

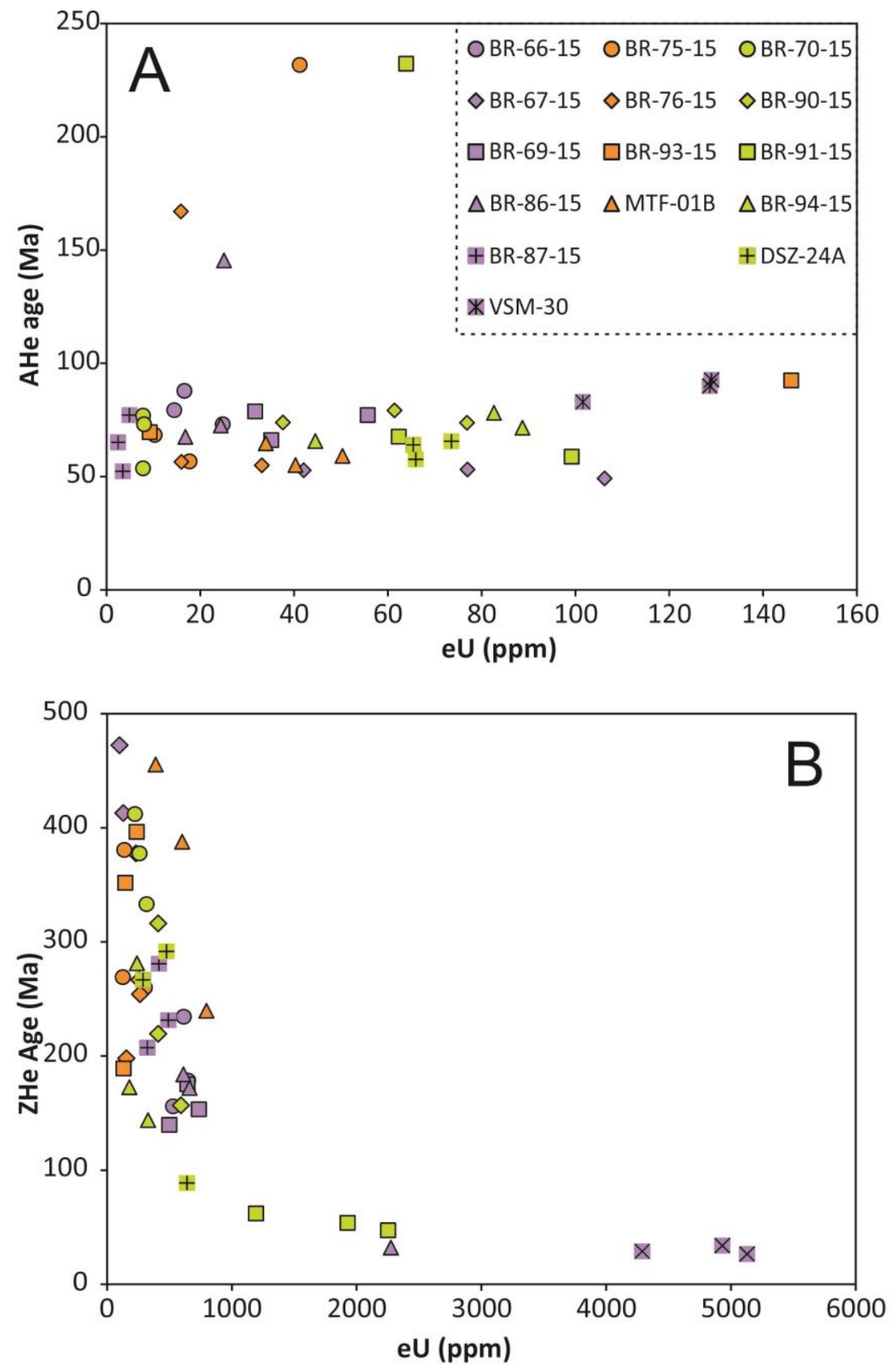

Figure 8.2: Single-crystal apatite (a) and zircon (b) (U-Th)/He age versus eU content for the entire dataset. Different colors are used for different domains of the studied area in relation to the Major Gercino Shear Zone; purple, orange and green symbols correspond to samples collected south of the shear zone, along its strike and north of it, respectively (as shown in Fig. 8.1). Note that, despite this distinction, all samples form a single coherent trend line

\subsubsection{Zircon radiation damage}

The retentivity of $\mathrm{He}$ in zircon crystals is influenced by the damage inflicted in its crystalline lattice due to self-irradiation, which ultimately has an impact in the closure temperature of the ZHe method. 
Therefore, it is useful to develop companion techniques to examine the quality of a crystals internal structure prior to the (U-Th)/He analysis. Raman spectroscopy offers such an opportunity, using the width of the v3 (SiO4) Raman band at ca. $1000 \mathrm{~cm}-1$ as a proxy for estimating the alpha-radiation damage (Nasdala et al., 2001; Palenik et al., 2003). Crystals with elevated damage will have broader peaks, which are expressed by the full width at half maximum (FWHM). The analyzed crystals have FWHM values that range from 2.3 to $21.7 \mathrm{~cm}-1$, but most crystals typically have values below $13 \mathrm{~cm}-1$ (Appendix F).

Special care has to be taken when comparing results from the Raman and ( $\mathrm{U}-\mathrm{Th}$ )/He analyses, as there is a significant difference in the spatial resolution of these methods. While He ages and element concentrations are obtained from entire crystals, the Raman spots have diameters of only a few $\mu \mathrm{m}$ and depths of up to $20 \mu \mathrm{m}$, and may therefore not be representative of the crystal as a whole. Nonetheless, despite of these issues, there is a moderate correlation between the FWHM values and the eU content of individual zircon crystals in our dataset (Fig. 8.3a). This is an indication that the Raman analyses are overall descriptive of the measured crystals, as the amount of alpha-radiation damage a zircon crystal has experienced is an expression of accumulation time and the content of $\mathrm{U}$ and Th. As $\mathrm{eU}$ and ZHe are strongly correlated in our dataset, there is also a moderate negative correlation between FWHM and individual ZHe ages (Fig 8.3b).
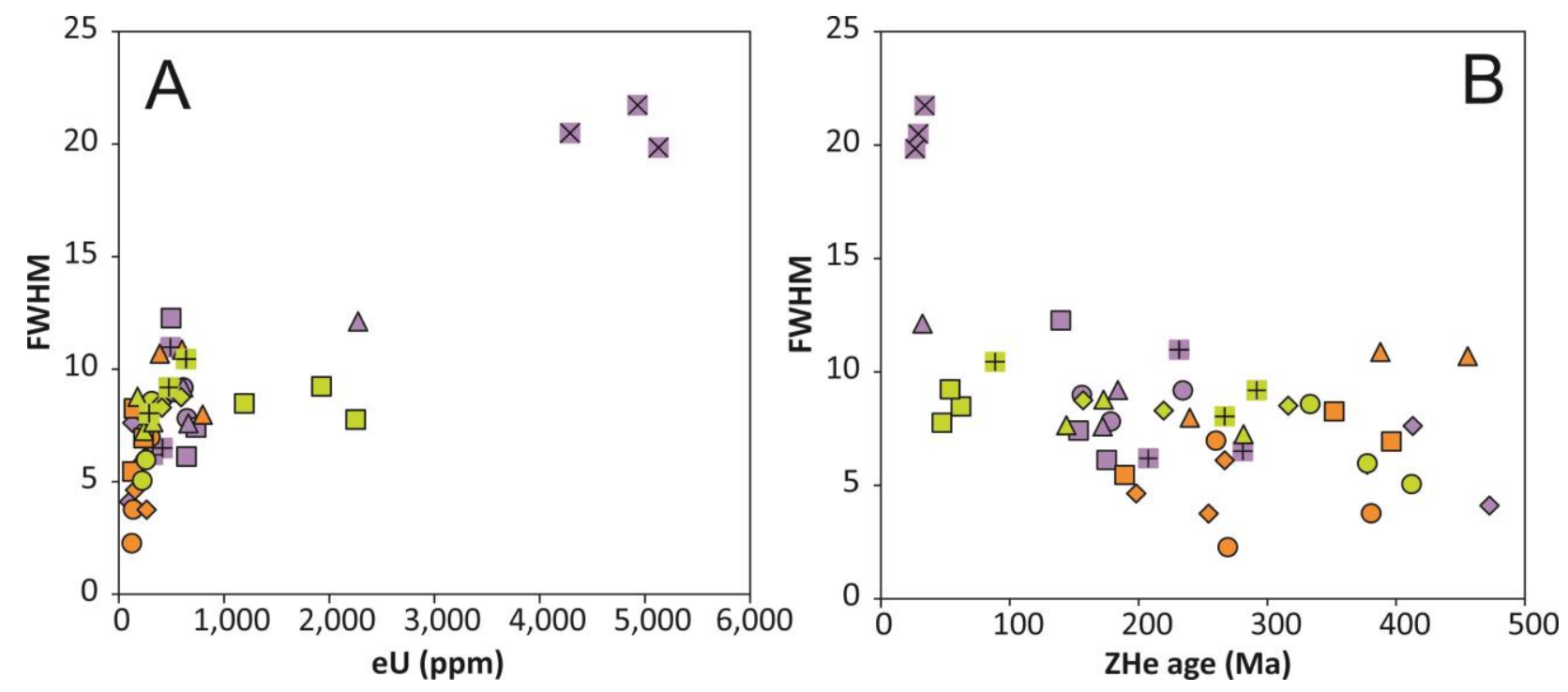

Figure 8.3: Full width at half maximum (FWHM) of the ca. 1000 band in zircon vs. (a) single-crystal eU value and (b) single crzstal ZHe age. Symbols used are the same as in Fig. 8.2 
In order to further explore these relationships, Fig. 8.4 shows the correlation between FWHM values and eU content for each crystal, together with modelled radiaton damage isochrones spaced regularly at 100 Myr steps from $600 \mathrm{Ma}$ to $100 \mathrm{Ma}$. These isochrones were obtained using the empirical calibration curve of Palenik et al., (2003) and alpha-radiation damages calculated for each accumulation period and a range of eU concentations. Almost all measured zircons have FWHM values that correspond to the effect of the accumulation of 100 to $600 \mathrm{Ma}$ of alpha-radiation damage.

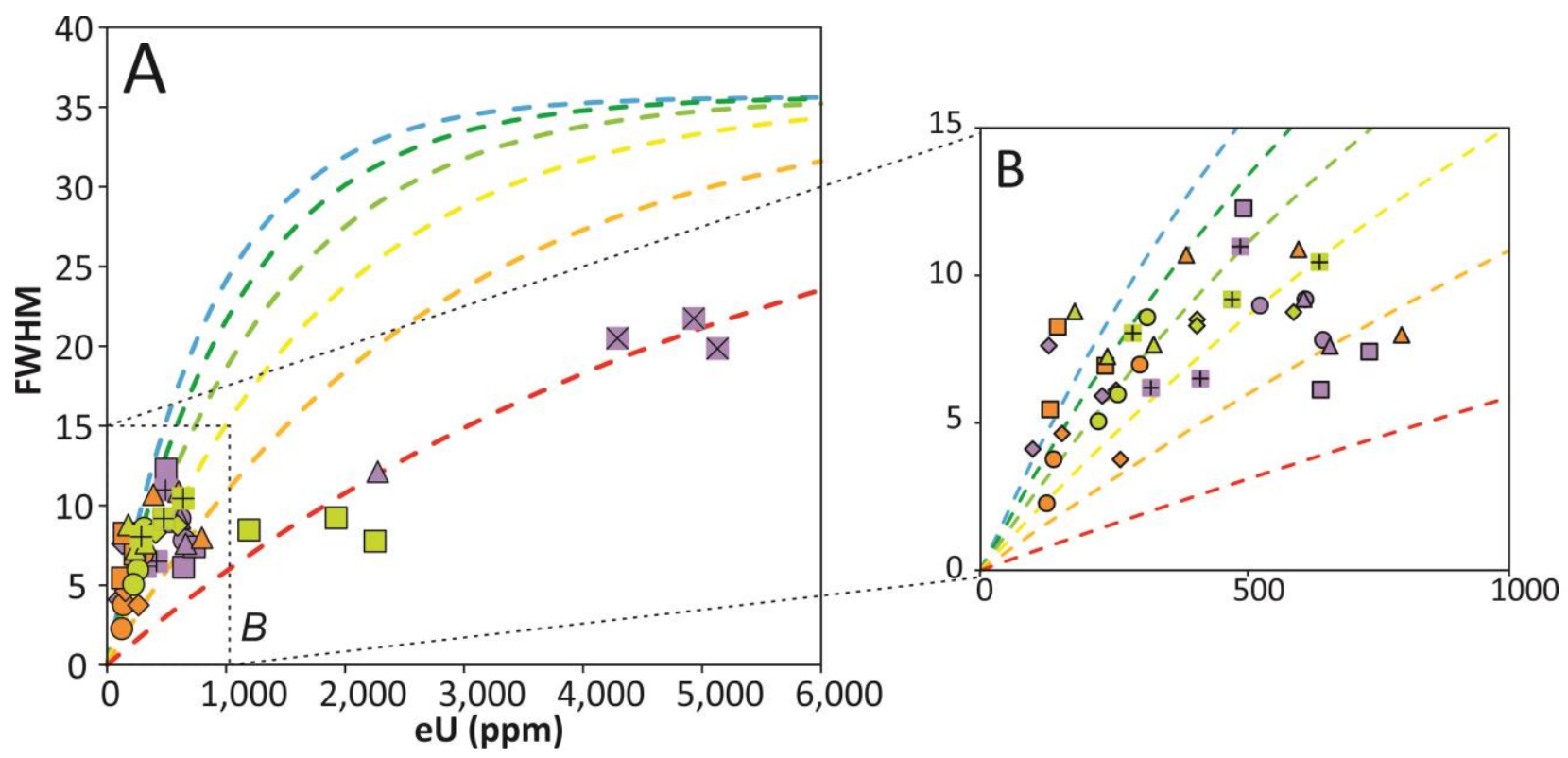

Figure 8.4: Full width at half maximum (FWHM) of the ca. $1000 \mathrm{~cm}-1$ band in zircon vs. single-crystal eU value and radiaton damage isochrones obtained using the empirical calibration curve of Palenik et al., (2003) spaced regularly at 100 Myr steps from $600 \mathrm{Ma}$ (blue) to $100 \mathrm{Ma}$ (red). Detail of (a) is presented in (b). Symbols used are the same as in Fig. 8.2

Following this reasoning, zircon radiation damage ages can be calculated from the FWHM and $\mathrm{U}$ and Th concentrations (e.g. Pidgeon, 2014). The calculated ages vary from 61 to $957 \mathrm{Ma}$, but except for 5 of the 45 measured crystals, all values are younger than 510 Ma (Appendix F). The outlying ages are unrealistic, as they are older than the crystallization age of the sampled rocks.

To first order, the calculated ages correspond to the possible range of ages on which the zircons could have started accumulating radiation damage (Fig. 8.5). Furthermore, they lie within an age interval that is very similar to the one obtained by the ZHe ages. It should also be noted that a clear majority of ages calculated from the radiation damage are older than the corresponding (U-Th)/He ages, evidencing a systematic difference between the thermal sensitivity of these systems. Additionally, there is a 
correlation between the radiation damage ages and the corresponding crystal's eU values, with crystals with more elevated actinide contents generally yielding the youngest ages.

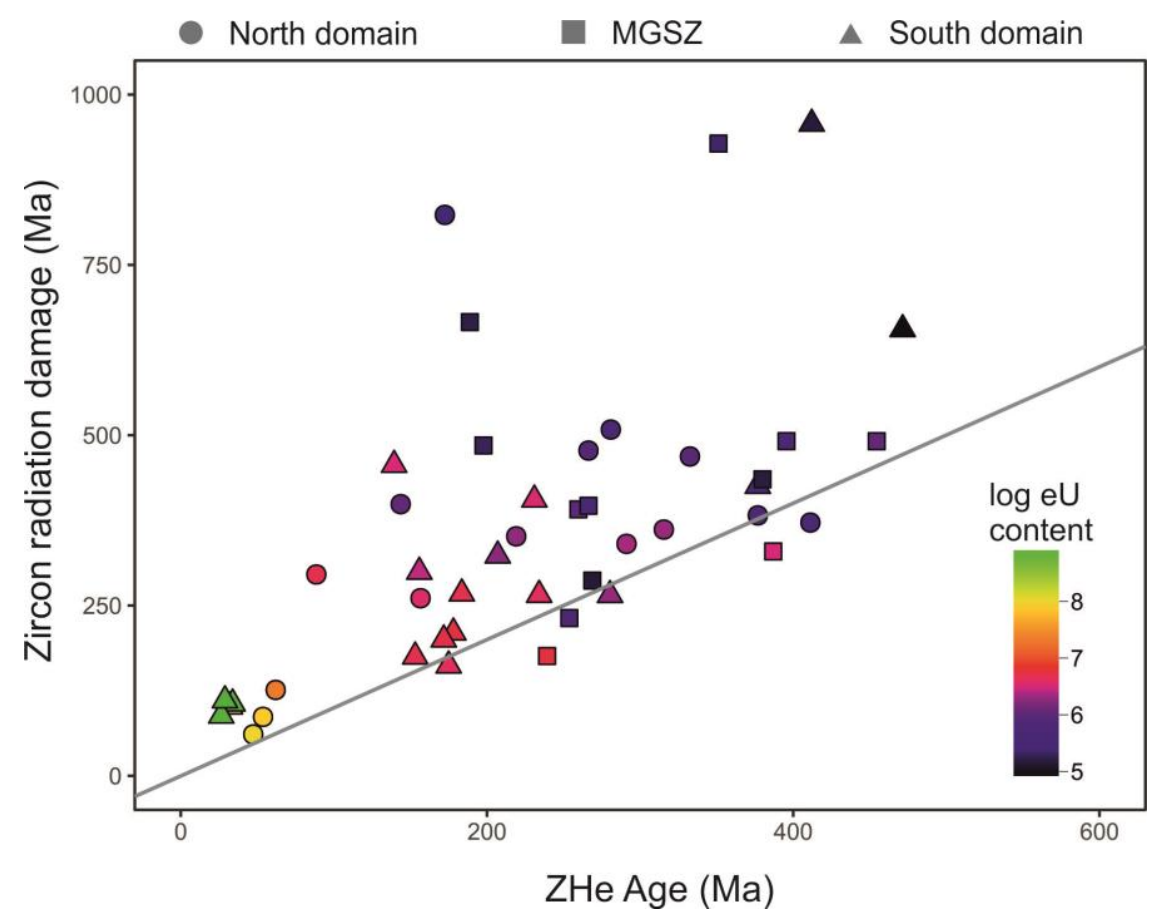

Figure 8.5: Single-crystal radiation damage ages versus measured zircon (U-Th)/He ages. Radiation damage ages were calculated after Pidgeon (2014) based on the measured peak width of the ca. 1000 band in zircon and the empirical calibration curve from Palenik et al. (2003). In a simplified way, the ages correspond to the relative position of each crystal in relation to the radiation damage isochrones presented in Fig. 8.4. Different symbols are used for different domains of the studied area in relation to the Major Gercino Shear Zone (MGSZ). The solid line represents a one-to-one correlation between the methods. Symbol colors correspond to the eU content of the analyzed crystals, as indicated by the legend

\subsubsection{Apatite (U-Th)/He data}

Apatite (U-Th)/He (AHe) ages have a much smaller dispersion than the ZHe results. With the exception of a few outliers, single-crystal ages are tightly constrained between 93 and 49 Ma (Appendix E). Single crystals ages have little intra-sample variation. Mean ages range from 89 to $52 \mathrm{Ma}$, and most uncertainties (2 SE) are within $6 \%$, with only four samples surpassing $10 \%$. The well-restrained dataset indicates that all samples experienced a similar thermal history within the AHe thermal range, which can be considered as representative of the studied area.

There is no apparent correlation between AHe ages and other possible criteria, such as altitude, geographic position, crystal size or eU content (Fig. 8.2b). Nonetheless, the dataset includes crystals with 
a wide range of sizes (equivalent sphere radius between 31 and $94 \mu \mathrm{m}$ ) and eU contents (ranging from 2 to $146 \mathrm{ppm}$ ). Crystals with outlying AHe ages are well within the range of all measured parameters (e.g. grain size, eU content) and probably represent small and unaccounted for inclusions. Therefore, these ages were considered unrealistic and were discarded for all subsequent evaluations. The relatively short range of apparent AHe ages, combined with a lack of correlation with crystal size or eU content, suggest that measured crystals have not experienced prolonged residence in the partial retention zone (PRZ) of the AHe thermochronometer. Had this been the case, the impact of these factors in the AHe system would be reflected in a larger spread of apparent ages. Instead, the dataset suggests a relatively quick cooling to near-surface temperatures from conditions under which the AHe system was completely open (above $60-80^{\circ} \mathrm{C}$ ) between 90 and $50 \mathrm{Ma}$, as constrained by the single-crystal ages.

\subsection{Modelling the (U-Th)/He dataset}

This section aims to investigate how the thermochronologic dataset can be explained with geologically reasonable thermal trajectories. Any possible history has to be able to replicate both the spread of the ZHe dataset and the relative constraint of the AHe results. For this, we applied a combination of eUbased and inverse thermal modeling with the HeFTy program (Ketcham, 2005) using the zircon ZRDAAM (Guenthner et al., 2013) and apatite RDAAM diffusion models (Flowers et al. 2009).

Modeling of the dataset followed a two-step approach. The first step consisted of "eU modeling", that is, using forward modeling for testing different thermal histories and comparing the calculated eU content vs. ZHe age patterns to the measured dataset (Orme et al., 2016; Powell et al., 2016; Guenthner et al., 2017; Johnson et al., 2017). Initially, a variety of possible thermal histories were tested in order to see what ZHe distributions would be generated. Subsequently, we tested variations of the most successful (and geologically most meaningful) T-t paths. This step was not applied to the apatite results, due to the relatively young apparent ages and the lack of age-eU correlation, which indicates a history of quick cooling between 90 and 50 Ma (e.g. Ault et al., 2009).

In the second step, inverse thermal modeling was used to evaluate how successfully the trajectories obtained in the eU models can be reproduced when testing both the ZHe and AHe results. For this, the simulations had a relative degree of freedom to explore for thermal paths, fixing only the necessary constraints in order to test a given scenario.

Four significant regional geological events were taken into account during modeling as constraint or as tested hypotheses. First, initial cooling from middle-temperature range (e.g. cooling temperatures of K- 
Ar system in muscovite) in the region happened between 600 and $500 \mathrm{Ma}$. Most dated samples are granites dated by U-Pb predominantly between 625 and $570 \mathrm{Ma}$ (Passarelli et al. 2010; Basei et al. 2011a; Chemale et al. 2012; Florisbal et al. 2012), and mica K-Ar ages spread from $600 \mathrm{Ma}$ to $540 \mathrm{Ma}$ (Passarelli et al. 2010, Chapter 5). Second, deposition of Devonian and Permian sediments of the Paraná Basin may have covered the studied area. Based on the maturation of organic material, this burial did not impose temperature increases above $80-100^{\circ} \mathrm{C}$ (Silva \& Cornford 1985). Third, we acknowledged the extrusion of the Paraná LIP, mostly constrained between 135 and 131 Ma (Renne et al. 1992; Thiede \& Vasconcelos 2010; Janasi et al. 2011). Heating associated to intrusion of feeding dykes and sills is interpreted as responsible for most of the over-matured organic material in the Paraná Basin (e.g. Zalán et al. 1990). Finally, surface temperatures for the present day were set at $20 \pm 5^{\circ} \mathrm{C}$.

\subsection{1 eU modelling}

In this step, forward modeling was used for testing different thermal histories with the zircon ZRDAAM diffusion model, in order to attempt to reproduce the range of measured apparent ZHe ages and its relation to the crystals' eU content. Input data used were the radius of a crystal's equivalent sphere, $U$ and Th concentrations equivalent to a eU content spectrum between 100 to 5,000 ppm, and a given T-t path. For each tested scenario, we modelled three curves assuming three crystal sizes. The first one used a sphere radius corresponding to the mean value for all dated crystals (ca. $50 \mu \mathrm{m}$ ), while the remaining comprise inner and outer envelopes by adding or subtracting two standard deviations to the mean (ca. $20 \mu \mathrm{m})$. The resulting pattern was then compared to the entire ZHe dataset.

On a first approach, the models aimed to test thermal trajectories corresponding to end-member crustal histories for the studied area, in order to see how the calculated eU curves react to paths controlled purely by each of the main geological event that affected the region (Fig. 8.6a). First, we tested a simple exhumation to surface conditions shortly after cooling from mid-range temperatures in the end of the Neoproterozoic. Secondly, sedimentary burial promoted by the Paraná Basin was simulated by adding to the first scenario a monotonic heating between 430 and $250 \mathrm{Ma}$ up to $120^{\circ} \mathrm{C}$, corresponding to a conservative maximum thermal imprint of the Paleozoic sediments from the Paraná Basin (Silva \& Cornford 1985). On a third hypothesis, the onset of the Paraná LIP was simulated by fixing a heating event with maximum temperatures of $200^{\circ} \mathrm{C}$ and total duration of $10 \mathrm{Myr}$ starting from surface conditions at $140 \mathrm{Ma}$. This simulation considers that most of the LIP was extruded between 135 and 130 Ma (Renne et al. 1992; Thiede \& Vasconcelos 2010; Janasi et al. 2011), and assumes maximum temperatures that could result in a partial reset of the ZHe system, as is suggested by our data. This 
hypothesis also assumes that the extrusion of the LIP resulted in the addition of up to $2 \mathrm{~km}$ of volcanic rocks in the area, simulated by setting the temperature after the onset of the LIP at $100^{\circ} \mathrm{C}$ and adding a last stage of exhumation between 90 and $50 \mathrm{Ma}$ as constrained by the AHe data. Finally, a history of prolonged residence in the ZHe PRZ was modelled by fixing an initial cooling in the end of the Neoproterozoic to $140^{\circ} \mathrm{C}$ and keeping this temperature until $80 \mathrm{Ma}$, after which we imposed a cooling to surface conditions by $50 \mathrm{Ma}$. This last cooling step is well constrained by the apparent AHe ages.

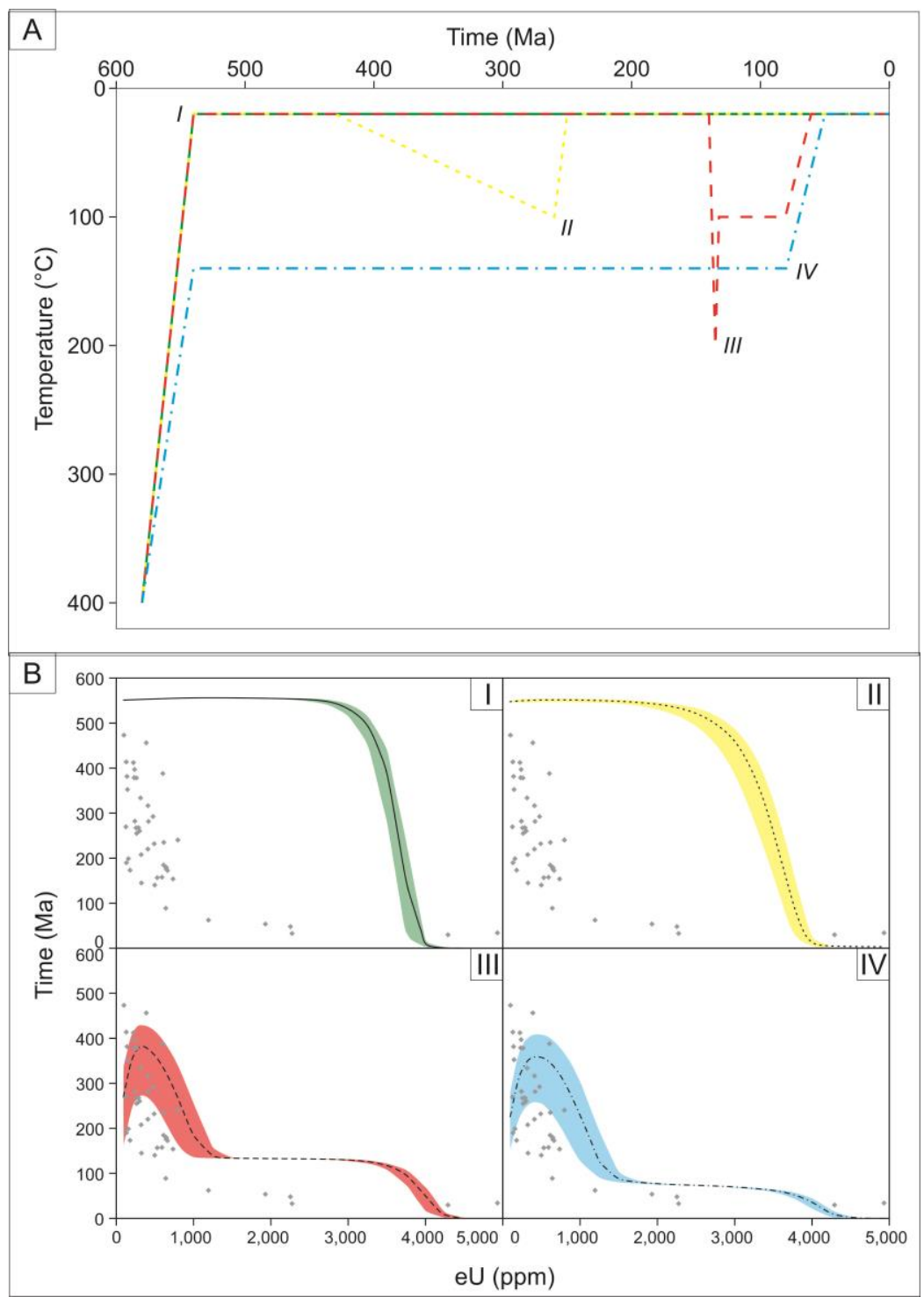

Figure 8.6: Diagram summarizing the results of thermal modelling considering all dated zircon crystal and calculated ZHe ages according to their eU content. A: tested end-member thermal scenarios. B: modelled zircon (U-Th)/He ages. Central lines were calculated for crystals with a corresponding sphere radius of $50 \mu \mathrm{m}$, while the envelope represents variations of $20 \mu \mathrm{m}$. The colors of the envelops correspond to the colors of the assumed thermal paths 
The first two scenarios yield eU distributions evidently incompatible with the tested dataset (Fig. 8.6b). Exhumation to surface condition in the early Cambrian would generate uniformly old ages throughout most of the tested eU spectrum, and would need a later thermal overprint in order to generate the spread in ZHe ages measured. In the next scenario tested, it is clear that this partial reset cannot be reached alone by the effect of the Paleozoic sedimentation of the Paraná Basin, since its maximum overprint only slightly resets crystals with relatively high eU contents (2,000 to 3,500 ppm).

On the other hand, the remaining hypotheses yield curves that are much closer to the general trend of the ZHe dataset (Fig. 8.6b). Both a rapid thermal imprint of the Paraná LIP in the Cretaceous and a prolonged period in the system's PRZ during the Paleo- to Mesozoic are successful in generating apparent age patterns that are similar to the measured dataset. In particular, they are characterized by markedly old ages within the $\mathrm{eU}$ range of 100 to $1,000 \mathrm{ppm}$, which is one of the main characteristics of the measured results.

In order to explore how well these two thermal histories replicate the measured ZHe dataset, both scenarios were submitted to a sensitivity test. This consisted of varying the fixed temperatures assumed for simulating the geological events tested in the end-member scenarios (Fig. 8.7). In the first case, four different maximum temperatures ranging between 180 and $220^{\circ} \mathrm{C}$ were tested for the short Cretaceous thermal pulse, while in the second case the long Paleo-Mesozoic residence in the PRZ was simulated with four different temperatures between 120 and $180^{\circ} \mathrm{C}$. The resulting patterns envelop almost the entirety of measured data. In other words, the range of apparent ages in the new data can mostly be reproduced only by adding or subtracting $20^{\circ} \mathrm{C}$ from the central temperatures tested in the end-member scenarios. It should be noted that in order to keep the diagrams clear, Fig. 8.6 only displays the curves for crystals with equivalent sphere radii corresponding to the mean measured value $(50 \mu \mathrm{m})$. The same models with the entire range of measured radii would lead to an envelopment of the measured data with even smaller variations in the experienced temperature.

Despite the good agreement between the most successful models and the measured dataset, none of the tested scenarios was able to capture the trend of crystals with eU contents $>1,000 \mathrm{ppm}$. The measured ages of crystals with eU contents between 1,000 and 4,000 ppm are younger than those predicted by the models, and are in fact comparable to those obtained for the AHe system. Considering the maximum possible time of damage accumulation for the sampled rocks, our models would only predict such comparable ages for crystals with eU contents, between 3,000 and 3,500 ppm. The inverse 
effect happens for crystals with eU contents $>4,000 \mathrm{ppm}$, for which the modelled ages tend to zero, which is in disagreement with measured ages of a few tens of Myr.
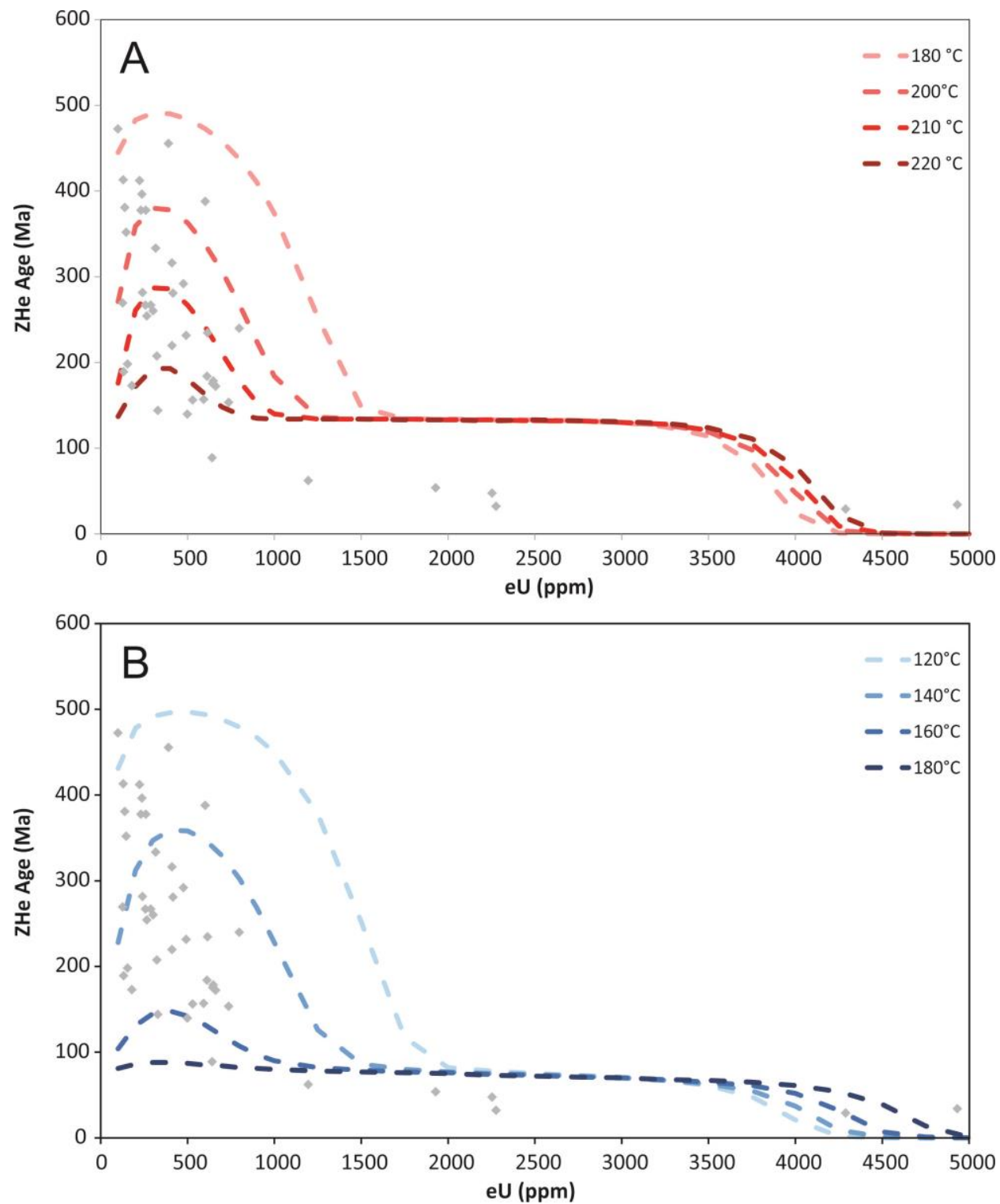

Figure 8.7: Sensitivity tests for scenarios III and IV of Fig. 8.6. A: Effect on the ZHe ages versus eU content distribution patterns of the variation of the maximum temperature of the short Cretaceous thermal pulse simulated in scenario III. For the sake of clarity, the final phase of exhumation in the Cretaceous simulated in Fig. 5 is not included in this simulation. Tested temperatures range from 180 to $220^{\circ} \mathrm{C}$. B: Effect on the ZHe ages versus $\mathrm{eU}$ content distribution patterns of the variation of the temperature of the prolonged exposure to Partial Retention Zone (PRZ) conditions simulated in scenario IV. Tested temperatures range from 120 to $180^{\circ} \mathrm{C}$. All curves were calculated for crystals with sphere radius of $50 \mu \mathrm{m}$ 


\subsubsection{Thermal modelling}

The next step in modeling the dataset consisted of inverse thermal modeling. In it, random T-t paths were tested and the resulting crystal diffusion curves were compared with the ones calculated from the input data. Satisfactory results were then categorized as acceptable or good paths (see Ketcham et al., 2005 for more details). In this way we tested the most successful scenarios constrained in the first step (i.e. short Cretaceous thermal pulse and long Paleo-Mesozoic residence in the PRZ) are reproduced by the measured dataset including both zircon and apatite results.

The tested models were designed with a certain degree of freedom, so as not to force the simulations to follow a tight T-t path. An initial constraint was set for both models corresponding to the age of cooling from mid-range temperatures around 540-500 Ma (Passarelli et al., 2010, Chapter 5). For the scenario of a partial reset caused by the thermal overprint of the Paraná LIP magmatism (scenario III in Fig. 8.5b), exhumation to near-surface conditions $\left(0-60^{\circ} \mathrm{C}\right)$ was constrained for the early Paleozoic, before the onset of sedimentation in the Paraná Basin. Temperatures were then limited below $120^{\circ} \mathrm{C}$ for much of the Paleo- and Mesozoic, corresponding to the maximum possible heating promoted by the Paleozoic Sequences. Higher temperatures (up to $220^{\circ} \mathrm{C}$ ) were only allowed around the age of the magmatic event, between 140 and $130 \mathrm{Ma}$, after which the thermal range was again limited to below $120^{\circ} \mathrm{C}$. In the second scenario tested, considering a long residence in the ZHe PRZ (scenario IV in Fig. 8.5B), the only constrain set was that the tested paths were not allowed to achieve temperatures below $60^{\circ} \mathrm{C}$ until ca. $80 \mathrm{Ma}$.

Each simulation tested 100,000 different trajectories, or was interrupted after achieving 100 good paths. Three representative samples were tested for this simulation, one for each of the main tectonic units in the study area (southeast domain, along the MGSZ, and central domain). Each model considered the results of two crystals from each mineral phase. In addition, we tested a synthetic simulation combining the dataset for the entire study area. The advantage of using such an approach is that it can be used to test different portions of the eU content spectrum obtained for each mineral, thus constraining thermal trajectories that better represent the complexity of the dataset (e.g. Ault et al., 2009; Johnson et al., 2017). In our model, we separated the ZHe data by eU content into two bins that correspond to most of the measured crystals (less than 350 ppm and between 350 and 700 ppm), generating two synthetic crystal populations of which we used the average values of $U$ and Th concentrations, and the mean radius of the equivalent sphere. Similarly, mean apatite results were selected for two eU ranges, of less than 20 ppm and between 60 and 100 ppm. 
The tested models performed very well with the described inputs, generating numerous acceptable and good paths. Most scenarios provided 100 good paths before testing 100,000 individual trajectories. In this regard, none of the tested hypothesis clearly outperformed the other, and both represent viable geological histories for the measured (U-Th)/He dataset. Furthermore, the different samples tested all provided similar results (Fig. 8.8). Models simulating a short Cretaceous thermal pulse associated to the Paraná LIP resulted in good paths that reach up to the imposed limit of $220^{\circ} \mathrm{C}$ for this event. As expected, this scenario constrains a last cooling event from ca. $60-110^{\circ} \mathrm{C}$ to near-surface conditions between the end of the Cretaceous and the beginning of the Paleogene, corresponding to the complete reset of the AHe system. The models which simulated a prolonged residence in the PRZ yielded good paths that initially spread through the entire possible range of T-t trajectories before converging to temperatures between 80 and $160^{\circ} \mathrm{C}$ in the Mesozoic. The most significant variation in the models is recorded in sample BR-86-15, from the southeast domain, in which a cooling event to temperatures below $180^{\circ} \mathrm{C}$ was constrained at ca. $180 \mathrm{Ma}$, corresponding to the sample's apparent ZHe ages. The models using the averaged crystal populations as input have results that are entirely in accordance with those for the real samples, and did not produce a more constrained thermal evolution.

A last round of modeling tested only the AHe dataset, aiming to explore the system's full eU range. For this step, the input considered the mean values for four crystal populations with ranges of <20; 20-60; 60-100; and >100 ppm. In this simulation, the only constrain was a fixed starting point corresponding to temperatures and ages little above those constrained by the AHe data (90-100 Ma, $80-100^{\circ} \mathrm{C}$ ). This simulation then tested random T-t paths until achieving 1,000 good trajectories. The resulting good paths (Fig. 8.9) define a more constrained age window for the cooling of the AHe system between 75 and $55 \mathrm{Ma}$, thus narrowing the broader time range obtained by the apparent ages (ca. 50-90 Ma). 


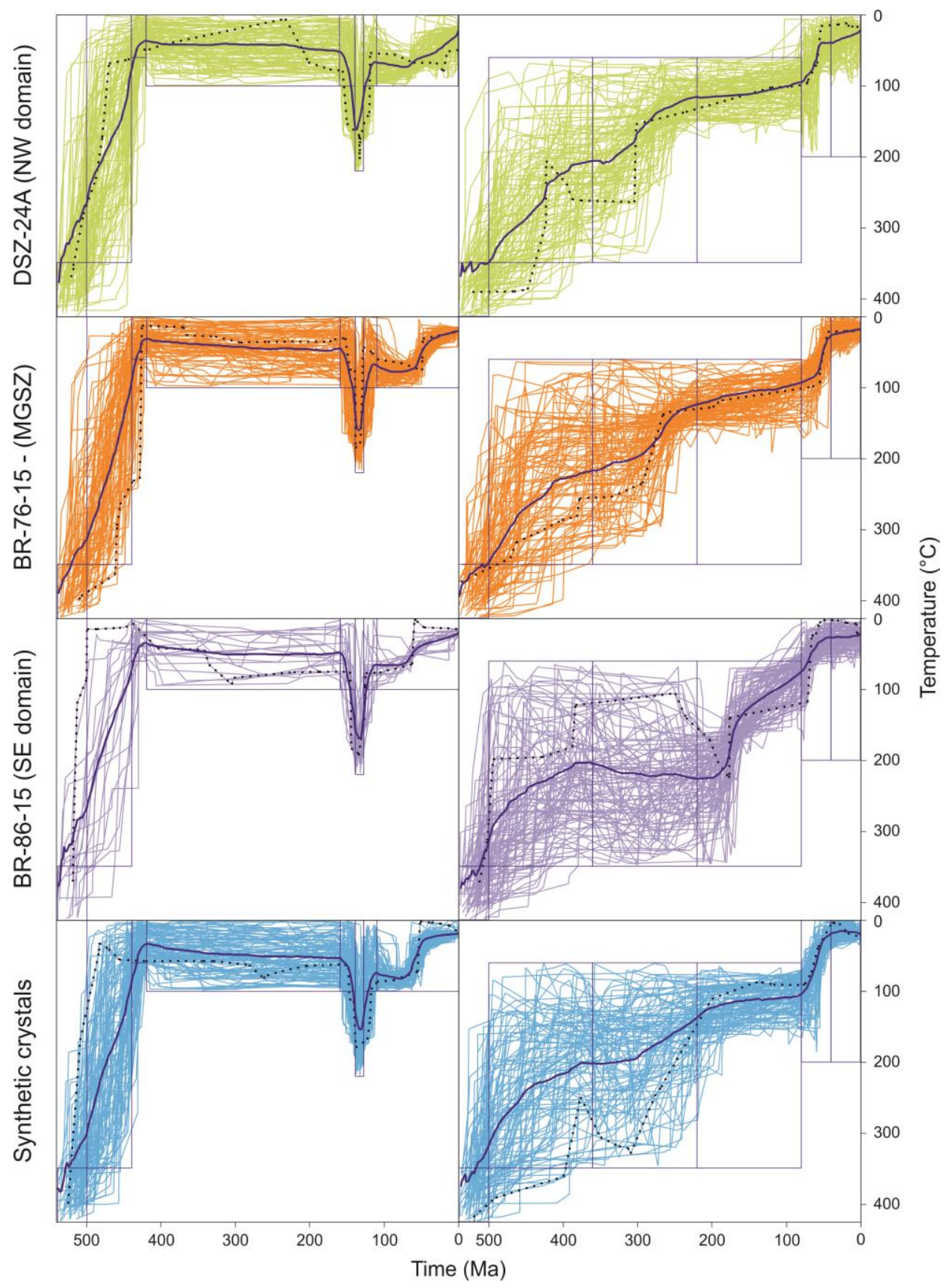

Figure 8.8: Thermal modeling results of the most likely histories, corresponding roughly to scenarios III and IV of

Fig.8.6. Models were tested for three representative samples and for average values from a combination of synthetic crystal populations representative of the entire dataset. Only paths classified as good fits by the program are displayed. Boxes represent the thermal constrained used in the simulations 


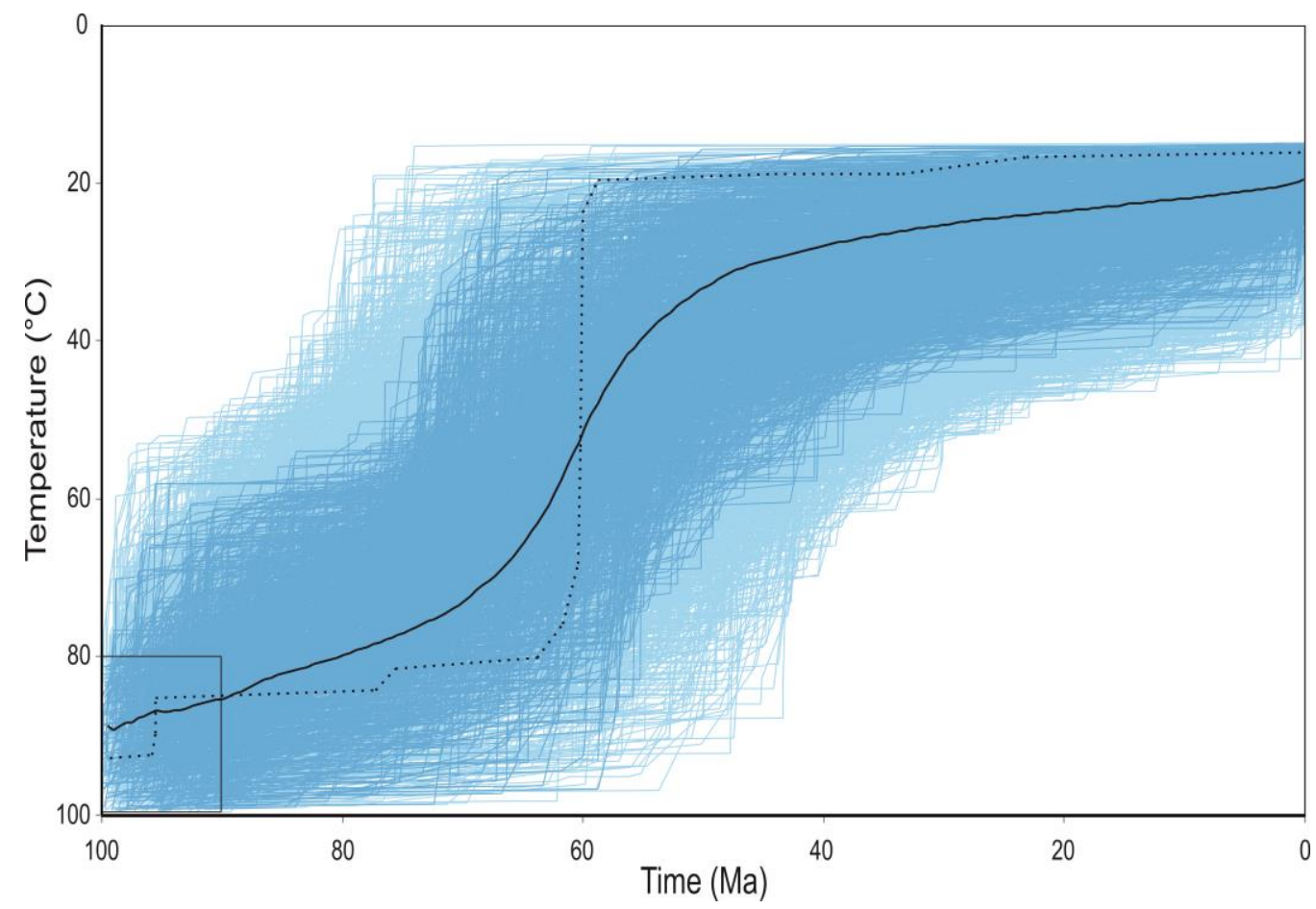

Figure 8.9: Unconstrained thermal modeling results of the AHe dataset. Light and dark blue curves are paths classified as acceptable and good fits respectively. Continuous line is the mean calculated trajectory and pointed line is the tested path with the best fit

\subsection{Discussion}

\subsubsection{Thermochronologic control of the zircon and apatite He ages}

The eU-based models show that the significant spread of apparent ZHe ages observed in the study area is strongly controlled by the eU content of individual crystals. As such, instead of expressing geologically meaningful events, the apparent ages represent crystals with variable closure temperatures exposed to a same thermal history that cause partial reset of the ZHe system (e.g. Guenthner et al., 2015, 2017; Orme et al., 2016; Powell et al., 2016; Johnson et al., 2017). The eU content vs. ZHe age pattern was successfully reproduced by testing geologically reasonable scenarios with the ZRDAAM model (Guenthner et al., 2013). These scenarios were, in turn, reproduced by inverse thermal modeling of the measured dataset, further strengthening our interpretation. However, our models were not successful in predicting the ages of the more radioactive crystals. Crystals with eU content between 1,000 and 2,500 have $\mathrm{ZHe}$ ages similar to those of the AHe system and therefore probably represent similar closure temperatures. However, the ZRDAAM model only predicts such an effect for crystals with eU contents between 3,000 and 3,500 ppm. On the other hand, ZHe ages for crystals with eU>4,000 ppm still retain 
enough He to yield ages of some tens of Myr, although the predicted apparent ages should tend to zero, similar to that observed by Johnson et al. (2017). This could be the result of eU zonation causing "pockets" of He-retentive crystal lattices in overall highly radioactive zircon crystals (e.g. Danišík et al., 2017).

Together with the latest research focused on the potential of modeling the control of eU content on the ZHe system, the results presented here caution against the over-interpretation of apparent (U-Th)/He ages without a proper assessment of how He diffusivity has been affected by the crystals characteristics. This is particularly true to areas with ancient geological history, as the accumulation of radiation damage over time amplifies the influence of such features. Sampling strategies in such cases should therefore focus in measuring more crystals from a same sample, even at the expense of enlarging the possible study area. The acquisition of datasets with a wide range of crystal sizes and eU contents is particularly helpful.

The AHe dataset, on the other hand, yielded results with the opposite behavior, producing ages that do not seem to be controlled by the expected crystal features, such as eU or crystal size (Flowers \& Kelley, 2011; Murray et al., 2016; Guenthner et al., 2017). This indicates that the study area has probably not experienced a prolonged time in the system's PRZ (e.g. Ault et al., 2009). Thermal modeling was able to reproduce this interpretation, and define a cooling event between 75 and $55 \mathrm{Ma}$ that would have caused a complete reset of the thermochronometer. The age spread surpassing this time period is probably caused by non-quantified crystal features such as internal zonation, implantation of He from radioactive neighboring minerals (so-called "bad neighbors"), Cl content and micro-inclusions (Spiegel et al., 2009; Flowers \& Kelley, 2011; Ault \& Flowers, 2012; Gautheron et al., 2013).

\subsubsection{Phanerozoic evolution of the Catarinense Shield}

The measured (U-Th)/He dataset is best explained by a shared geological history, as evidenced by the uniform coherent trends observed in the eU content vs. ZHe/AHe age diagrams. Consequently, despite evidences of episodic Phanerozoic reactivation of shear zones in the Dom Feliciano Belt (Chapter 5; Oriolo et al. 2018a), the MGSZ has not caused enough differential exhumation in order to leave a regional impact in the low-T thermochronometers.

The wide dispersion of apparent ZHe ages indicates that this system was partially reset, with He diffusion being controlled by the crystals' radiation damage densities. By applying eU and inverse thermal modeling, two viable scenarios can satisfy the regional geological context and the measured dataset. The 
first one begins with exhumation to near-surface conditions before the sedimentation in the Paraná Basin, followed by a long period with temperatures below $120^{\circ} \mathrm{C}$, and only disrupted by the onset of the Paraná LIP around ca. $135 \mathrm{Ma}$. This event caused the partial reset recognized in the ZHe system, and was later followed by a final stage of cooling between 75 and $55 \mathrm{Ma}$. Alternatively, the dispersion in the ZHe ages could be explained by a prolonged residency in the system's PRZ, particularly during most of the Mesozoic, later followed by an equivalent cooling event in the Late Cretaceous-early Paleogene.

Both hypotheses are possible considering the thermochronologic dataset. However, a surface exposure of the crystalline basement during the Paleozoic is very likely, as the base of the Devonian sediments of the Paraná basin is situated less than $10 \mathrm{~km}$ to the west of the studied area, with no significant fault system known in between. Consequently, the study area has probably been exposed to near-surface conditions in the past, and had to experience a later thermal overprint in order to justify its ZHe data. Although Paleozoic burial is certainly possible, and even likely given the reasons just discussed, our models show that this alone could not have promoted enough He loss so as to induce the dispersion in the zircon ages.

As a consequence, partial reset caused by the thermal imprint from the Paraná LIP seems to be the most likely cause of the ZHe scatter. This observation is somewhat surprising, as thermal simulations suggest that the flood basalts should not have left a significant thermal imprint in rocks not within close range, due to fast cooling within hundreds of kyr (Hurter \& Pollack, 1994). The identified thermal overprint, however, could be explained by the existence in the region of an important feeding dyke system of the Paraná LIP in the Catarinense Shield, the Florianópolis Dyke Swarm, (e.g. Florisbal et al., 2014). We propose that the continuous intrusion of basaltic dykes in the crystalline basement throughout the duration of the LIP could have provided the necessary thermal gradients in order to affect the ZHe system. It has been suggested that the coast-parallel orientation of dyke swarm, perpendicular to most of the dykes recognized in southern Brazil, might be an evidence of its proximity to the South Atlantic rift center or even to the head of the megaplume suggested by some authors as responsible for the Paraná LIP (Salomon et al., 2017 and references therein). Such a position would further contribute to elevated geothermal gradients in the region.

The extrusion of the Paraná LIP probably left a cover of massive basaltic floods in the study area, such as those preserved in other parts of the basin. This is evidenced by the fact that the AHe system remained open after the magmatic event, only closing by the Late Cretaceous-early Paleogene, when the volcanic cover, probably associated with remaining sedimentary sequences of the Paraná Basin, were eroded. 
The existence of the Florianópolis Dyke Swarm has also been argued as evidence that the Catarinense Shield should have been covered by basaltic floods, connecting the remains of the Paraná LIP in South America to its counterparts in Africa (Florisbal et al., 2014). Thermal modeling considering the AHe dataset constrain this exhumation event between 75 and $55 \mathrm{Ma}$, when most successful thermal simulations suggest a cooling from ca. $80^{\circ} \mathrm{C}$ to approximately $30^{\circ} \mathrm{C}$. Assuming geothermal gradients between 20 and $30^{\circ} \mathrm{C} / \mathrm{km}$, this would imply in a denudation of rock covers with thicknesses between 1.6 and $2.5 \mathrm{~km}$.

The onset of this late Cretaceous to early Paleogene exhumation is recorded through most of the passive margin in southeast Brazil, particularly in its central portion, where it is associated with the uplift of the elevated coast-parallel ridges (Tello Saenz et al., 2003; Hackspacher et al., 2004, 2007; Hiruma et al., 2010; Cogné et al., 2011, 2012). It postdates the rifting of the South Atlantic opening by at least 40 Myr and, as such, cannot be assigned to the early development stages of the passive margin (Green et al. 2017). In fact, this event is most commonly associated with the intrusion of alkaline magmatism and/or pronounced tectonic activity in the Andean system (Cobbold et al. 2001; Cogné et al. 2011, 2012). The latter hypothesis is commonly interpreted to have been controlled by the normal reactivation of Neoproterozoic shear zones during uplift. This, however, is not the case in the study area, which recorded no significant vertical displacement along the main inherited structural feature.

\subsubsection{Comparing zircon radiation damage ages and the ZHe ages}

Most zircon radiation ages calculated in this study have a range that corresponds to the reasonable time interval expected from the geological context. Few crystals yielded outlying ages that are probably a reflection of the limitations of assuming that punctual Raman analyses are representative of the entire crystal. Unrealistic old ages, in part older than the crystallization age of the sampled rocks, were probably obtained from crystal zones with elevated $U$ and Th concentration. The inverse can be assumed for exceedingly young ages, in particular those younger than the age of the onset of the Paraná LIP, which is the last important heating event in the study area. Future research exploring this method should use a statistical approach to Raman measurements in order to define values that are more representative of the entire crystal, so as to allow for more confident direct comparisons with the (UTh)/He method.

Nonetheless, the new dataset produces some important correlations between the two systems. The apparent ZHe ages have similar ranges that appear to be geologically consistent, but lack a direct correlation. The radiation damage ages mirror the ZHe results in the sense that they present a wide 
range of ages, which is unexpected for samples that are interpreted to have experienced a similar thermal evolution. Both systems also produced ages that are mostly restricted between ca. 500 and 130 Ma. Therefore, it may be hypothesized that the radiation damage ages also represent a system that has been allowed to accumulate since ca. $500 \mathrm{Ma}$ and was partially rest at ca. $130 \mathrm{Ma}$, due to the onset of the Paraná LIP.

A consequence of this observation is that the measured zircons must have been subjected to some degree of healing of its crystalline lattices, and that this process took place under temperature conditions between ca. 180 and $220^{\circ} \mathrm{C}$, as constrained by the eU-based modeling of the ZHe ages. These temperature conditions are lower than expected, as the annealing of radiation damage in zircon is commonly interpreted to occur at temperatures similar to those of fission track annealing, which are usually estimated between 200 and $250^{\circ} \mathrm{C}$ (Yamada et al. 1995; Bernet 2009). However, single crystal He ages do not correlate with corresponding radiation damage ages, probably as an expression of the considerable imprecision of both methods, including the question of representability of the Raman spot analyses. As such, it is not possible to estimate the temperatures involved in the annealing of individual zircon crystals. Nonetheless, radiation damage ages in our study are consistently older than those obtained from the (U-Th)/He system, which probably has a systematic significance. This indicates that, in our study area, the diffusion of He in zircon crystals was more effective than the annealing of radiation damage during the Cretaceous thermal overprint. Both processes are not only dependent of the temperature to which the systems were exposed to, but also of the duration of the thermal event. As our results are interpreted to represent the impact of elevated heating during a short period, it would be interesting to investigate the relationship between both methods in areas which experienced long exposures to temperatures close to the ZHe PRZ.

A final interesting observation in our dataset is the correlation between radiation damage ages and eU content (Fig. 8.5). This is somewhat unexpected, as the ages are calculated from a calibration curve that already expresses the effect of radioactive concentration in the crystals (Nasdala et al., 2001; Pidgeon 2014). As such, this correlation may suggest that the annealing of radiation damage is susceptible to the degree of damage already experienced by the crystal, which would implicate that different healing mechanism are active for crystals with different damage densities. The younger radiation damage ages in crystals with more elevated eU contents, which are expected to have accumulated more damage, indicate they were more effectively annealed during the thermal overprint. 
In summary, the results in this dataset illustrate how the dynamics of radiation damage healing and its applicability for dating are still poorly understood (e.g. Pidgeon 2014 and references therein). However, the degree of concordance with the ZHe system presented in our dataset is promising and deserves to be further explored as a companion for more established thermochronologic methods. At the very least, Raman spectroscopy can be used to quickly estimate radiation damage and consequently select less disturbed crystals for (U-Th)/He dating, when the aim is to obtain more significant individual apparent ages.

\subsection{Conclusions}

New thermochronologic data reveal a well-constrained Phanerozoic thermal history for a segment of the South American passive margin, thanks to modeling contrasting patterns of eU versus He age for zircon and apatite. Widespread apparent ZHe ages span most of the Phanerozoic and are strongly eUdependent, indicating a partially reset system which has experienced relative low temperatures since at least the early Paleozoic. Exposition to surface conditions prior to the sedimentation of the intracratonic Paraná Basin is probable, but modeling of the ZHe dataset indicate that this burial had relatively little impact on the basement. The most likely cause for its partial reset is the onset of the Paraná LIP in the Lower Cretaceous. After this event, the study area was probably covered by up to $2 \mathrm{~km}$ of basaltic floods, keeping the AHe system open until rapid post-rift cooling between 75 and $55 \mathrm{Ma}$, as constrained by thermal modeling. Despite the presence of the Major Gercino Shear Zone, an important crustal discontinuity, the thermochronologic dataset does not appear to have experienced differential exhumation, and whichever reactivations of the shear zone happened during the Phanerozoic were not enough to leave an imprint in the new dataset. The thermal imprint revealed by the dataset and attributed to the Paraná LIP is interesting, as the volcanic floods are not expected to have contributed with heat for enough time to affect the ZHe system of the strata below. We propose that the longer-lived elevated geothermal gradient suggested by our dataset was caused by the intrusion of the Florianópolis Dyke Swarm, an important feeder system of the LIP that may be related to its central ridge. The successful modeling of the widespread ZHe dataset into a coherent geological history evidences the risks of over-interpretation of apparent (U-Th)/He ages in a context where radiation damage accumulation may lead to variable closure temperatures. For this reason, it is important to develop companion systems that can act as independent validation. As shown in this work, the assessment of zircon radiation damage by Raman spectroscopy is a promising method that should be better developed. 


\section{CHAPTER 9: General discussions and conclusion}

In this chapter, the discussions and conclusions presented in the previous chapters are integrated. It is divided into two sections, covering the different aspects of the thesis. The first deals with the tectonic evolution of the Dom Feliciano during the Brasiliano orogenic cycle as constrained by its main shear zones. The second part covers the Phanerozoic exhumation history of the belt and associated terranes, and how this process was influenced by the main Neoproterozoic structures. In each section, the main findings of this thesis's research are shortly summarized for each of the three basement expositions (shields) of the belt: Santa Catarina, Rio Grande do Sul and Uruguay. This is followed by general discussions resulting from the integration of the conclusions from the different contributions.

\subsection{Shear zone activity and the evolution of the Dom Feliciano Belt}

\subsubsection{Structural evolution of the main shear zones}

A combination of structural and microstructural observations, quartz crystallographic preferred orientation (CPO) analyses and new and available geochronological data was used to reconstruct the evolution of the main shear zones in the Dom Feliciano Belt and associated Precambrian domains, focusing on the two expositions of the belt in southern Brazil: Santa Catarina and Rio Grande do Sul.

The earliest terrane border in the area is the NW-SE trending Ibaré Shear Zone in Rio Grande do Sul (Chapter 4), which separates the Tonian juvenile São Gabriel Terrane from the Archean-Paleoproterozoic Nico Pérez Terrane. It is characterized by low-angle to moderate $\mathrm{N}$-dipping sheared metasediments, locally associated with quartz-feldspatic ultramylonites recording ductile shearing under hightemperature conditions. It probably originated as the result of SW-verging juxtaposition along a dextral lateral ramp during subduction of the Charruas Ocean and accretion of the São Gabriel Terrane to the Nico Pérez Terrane. New K-Ar ages at 760-740 Ma suggest a younger age limit for the metamorphosis accompanying the accretion, which correlates with the generation of a continental magmatic arc until 720-710 Ma, during final closure of the ocean. The structure was later reactivated in narrow moderateto steep-dipping sinistral transcurrent shear zones, at temperature conditions close to the brittle-ductile transition. $\mathrm{K}-\mathrm{Ar}$ ages in muscovite ( $c a .660 \mathrm{Ma}$ ) and illite fine fractions (580-560 Ma) suggest that the reactivation was due to the influence of the Dom Feliciano Event.

The main structural feature of the Dom Feliciano Belt is the Major Gercino-Dorsal do Canguçu- Sierra Ballena Shear Lineament, which acts as a terrane border for over 1,000 km. In Santa Catarina, the Major 
Gercino Shear Zone, separates the Florianópolis Batholith from the Brusque Group along a NE-SW strike (Chapter 5). It is mostly confined to syn-kinematic granitic intrusions, which were continuously deformed during emplacement and cooling. This led to the formation of wide mylonitic belts predominantly under greenschist metamorphic conditions. Deformation was transpressive, leading to dextral movements with a significant pure shear component that later transitioned to predominantly strike-slip displacements. New K-Ar ages of $603.9 \pm 6.7$ and 597.8 $\pm 7.5 \mathrm{Ma}$ in syn-kinematic muscovite crystals record that mylonite deformation was coeval with the magmatic crystallization of the granites, mostly emplaced between 615 and $585 \mathrm{Ma}$. The intrusion of these granites constrains the onset of the shear zone and of the oblique collision that formed it. Late-stage ductile deformation continued along the shear zone until ca. $550 \mathrm{Ma}$, probably accompanying exhumation.

The continuation of this structure in Rio Grande do Sul is the Dorsal do Canguçu Shear Zone, which separates the Pelotas Batholith from the Tijucas Terrane, characterized by metavolcano-sedimentary sequences (Porongos Complex) associated with basement cores (Chapter 4). As in the Major Gercino Shear Zone, the evolution of this shear zone is also linked to the intrusion of syn-kinematic intrusions, and led to the formation of mylonites under upper greenschist facies temperature conditions. In contrast to the former shear zone, however, the Dorsal do Canguçu Shear Zone mostly records sinistral shear, although also with an important pure shear component. Another distinction is that this process began considerably earlier in Rio Grande do Sul, as the first granites emplaced along the structure are dated at ca. $655 \mathrm{Ma}$. Coeval transcurrent deformation is indicated by new muscovite K-Ar ages beginning at ca. $648 \mathrm{Ma}$, thus recording a much older onset of transpression, compared to the Major Gercino Shear Zone. This was accompanied by regional metamorphism and NW-verging thrusting, folding quartz mylonites in the Tijucas Terrane into mega-folds that are concordant with the deformation of the Porongos Complex metasediments. Regional transpression continued until at least 620-610 Ma, as recorded in the intrusion of syn-tectonic granites in the Pelotas Batholith and metamorphic overprint of the Tijucas Terrane. After $600 \mathrm{Ma}$, however, deformation is mostly confined to strike-slip activity along the main shear zones, as indicated by new and published K-Ar mica ages. Similar analyses record late-stage ductile deformation in these structures until ca. 540-530 Ma.

\subsubsection{Deformation history of the Dom Feliciano Belt}

The compilation and revision of structural and geochronological data carried out in the individual chapters of this thesis can be used for tracing the structural evolution and deformational history of the Dom Feliciano Belt (Fig. 9.1). 


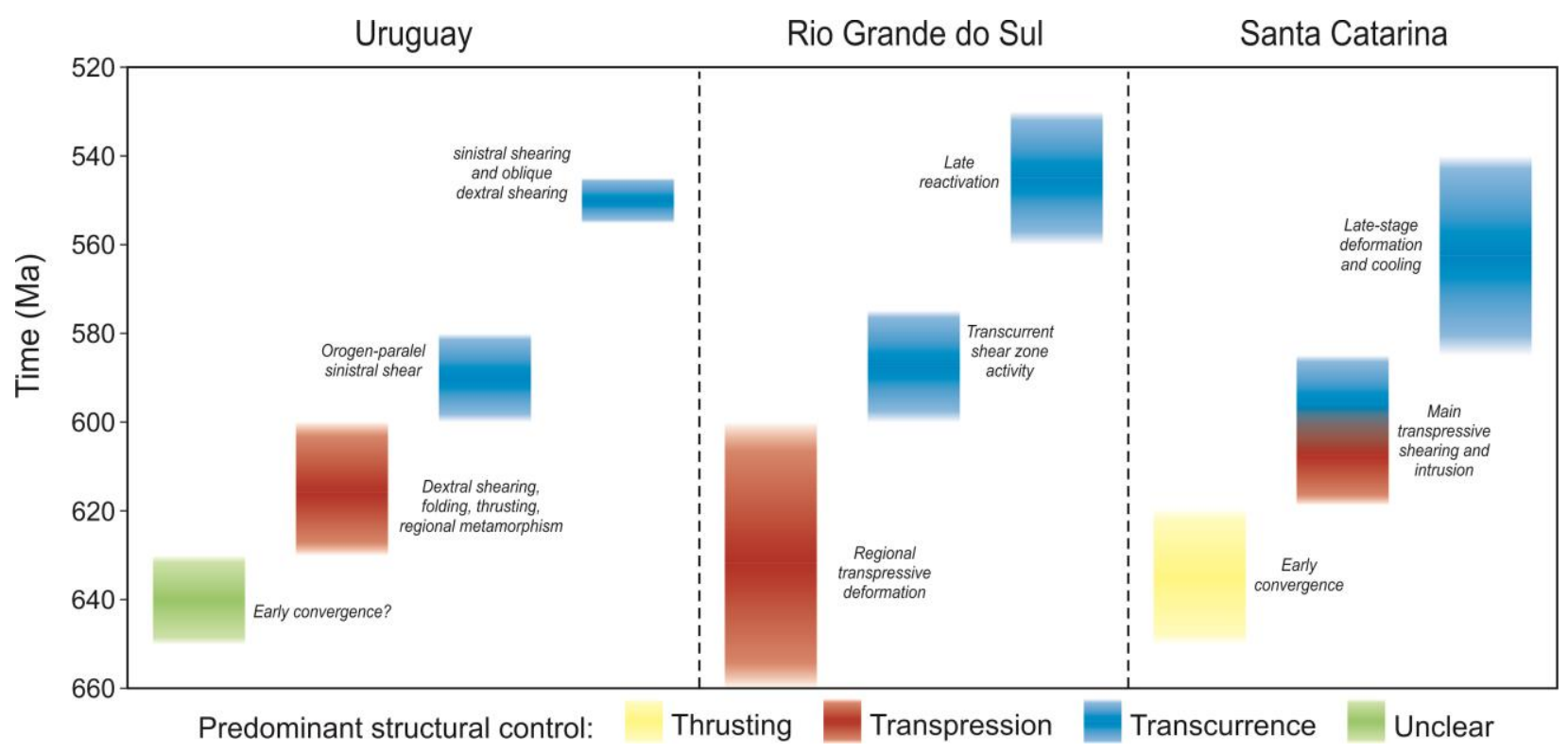

Figure 9.1: Evolution of the deformation stages and predominant structural control in the three sectors of the Dom Feliciano Belt. Data for the Uruguayan Shield is modified from Oriolo et al. (2016b), and the remaining sectors are detailed in chapters 4 and 5.

Early evidences of orogenic activity begin at ca. 660-630 Ma, and are best recognized in the reworking and migmatitization of basement units and generation of the first granitic intrusions along the Dorsal do Canguçu Shear Zone (Frantz et al. 2003; Silva et al. 2002a, 2005b; Lenz et al. 2011; Chemale Jr. et al. 2012; Masquelin et al. 2012; Basei et al. 2013a; Philipp et al. 2013). In all sectors of the belt, initial deformation is usually associated with thrust tectonics and development of a NW-verging low-dipping structural configuration, a process which is also interpreted to be responsible for the regional metamorphism affecting the metasupracrustal sequences (Philipp et al. 2004, 2016a; Basei et al. 2011a; Oyhantçabal et al. 2009; Oriolo et al. 2016b).

While in Rio Grande do Sul the oldest evidences of orogenic activity are accompanied by the generation of the transcurrent Dorsal do Canguçu Shear Zone, the first evidences so far of transpression in Santa Catarina and Uruguay were recorded at ca. 625-615 Ma (Florisbal et al. 2012c, Chapter 5), and ca. 630 Ma (Oriolo et al. 2016b), respectively. This diachronism might suggest either a lack of evidence in the preserved geological record, or it may have a tectonic significance. In the case of the latter, the transpressive event is commonly interpreted to have evolved during an oblique collision that formed the Dom Feliciano Belt, being responsible for the regional metamorphism and widespread granitogenesis (Basei et al. 2000, 2005, 2008; Oyhantçabal et al. 2009, 2011b; Oriolo et al. 2016a, b, c; Philipp et al. 2016a, Chapter 2). The indication of transpression already in the early orogenic stages of the Sul-rio- 
grandense Shield in comparison to the rest of the belt might therefore reflect an early docking the different terranes that led to the development of the orogen, which would from that point on have migrated to the remaining portions of the belt. This model is somewhat counterintuitive, as initial docking would be expected to take place at one of the extremities of the belt, but might be reflective of irregular continental margins. On the other hand, alternative interpretations of the orogen's evolution place the onset of the collision later, at ca. $600 \mathrm{Ma}$ (e.g. Basei et al.2018).

In any case, it is evident that transpression is an important characteristic of the Dom Feliciano Belt at least between 650 and 600 Ma (e.g. Saalmann et al. 2007, 2011; Oyhantçabal et al. 2009; Philipp et al. 2013, 2016a; Oriolo et al. 2015, 2016a, b) This is also true for the African counterparts of the West Gondwana Orogen, the Kaoko and Gariep belts (Goscombe et al. 2003, 2005, 2017a; Konopásek et al. 2005; Goscombe \& Gray 2007, 2008; Frimmel et al. 2011). In fact, it is one of the most important characteristics of the system, and is responsible for generating the network of crustal-scale transcurrent shear zones both within terranes and along their borders during the oblique collision.

After $600 \mathrm{Ma}$, the deformation pattern of the Dom Feliciano Belt is mostly characterized by a decrease in wide-scale regional deformation, with deformation localizing along transcurrent shear zones. Sinistral strike-slip shear zones are active in Uruguay, including the Sarandí del Yí Shear Zone, which during earlier stages had accommodated dextral displacement (Oriolo et al. 2015, 2016a). In Rio Grande do Sul, this transition is marked by the end of syn-kinematic emplacement of granitic intrusions along the Dorsal do Canguçu Shear Zone and Tijucas Terrane (Frantz et al. 2003; Philipp et al. 2016a; Zvirtes et al. 2017), while in the Pelotas Batholith the later intrusions are characteristically isotropic, and interpreted as posttectonic (Philipp \& Machado 2005). In Santa Catarina this transition is gradual and is recorded during the main period of shear activity accompanied by granitic emplacement in the Major Gercino Shear Zone (615-585 Ma), towards the end of which strike-slip deformation is dominant.

Ductile reactivation of the main shear zones extends until ca. 540-530 Ma t, constrained by K-Ar and ArAr dating of syn-kinematic mica in mylonites in Santa Catarina and Rio Grande do Sul (Philipp et al. 2003; Passarelli et al. 2010, Chapters 4, 5). Mylonites of late-stage intrusive rocks in Uruguay, dated at ca. 550 $\mathrm{Ma}$, also record this stage of the belts evolution (Oyhantçabal et al. 2011b; Oriolo et al. 2016b). The latter rocks evidence that shear zone reactivation might be associated with the migration of the latest magmatic events of the Dom Feliciano Belt (550-540 Ma), including the volcanic rocks of the foreland basins (Guadagnin et al. 2010; Basei et al. 2011b; Janikian et al. 2012; Oliveira et al. 2015a; Matté et al. 2016; Philipp et al.2016a). 


\subsubsection{Shear zone kinematics}

The kinematic relations between the main shear zones of the Dom Feliciano Belt and adjacent Precambrian domains present a few inconsistencies. In contrast to the orogen-parallel structures that are predominant along the belt's extension, the main terrane boundaries separating the terranes that acted as forelands have oblique orientations, from NNW-SSE, to NW-SE. These are the Ibaré Shear Zone in Rio Grande do Sul and the Sarandí del Yí Shear Zone in Uruguay. Both structures also have in common the fact that they experienced an inversion in their shear sense during their evolution. In the case of the Ibaré Shear Zone, the structure was first established as a dextral lateral ramp accommodating a SEverging accretion of the São Gabriel Terrane to the Taquarembó Block in the late Tonian (Chapter 4). Later reactivation during the Brasiliano orogenic cycle inverted this displacement, however, evidencing a transition of the main horizontal compression to an E-W orientation (Fig. 9.2). The Sarandí del Yí Shear Zone, on the other hand, represents the later collision between the Rio de la Plata Craton and the Nico Pérez Terrane, and was first established at $c a .630 \mathrm{Ma}$ as a dextral transpressional structure, but after $600 \mathrm{Ma}$ records mostly sinistral strike-slip deformation (Oriolo et al. 2015, 2016a, b, c). This is interpreted as the result of a local reorientation of the main horizontal shortening direction, from NE-SW to approximately WNW-ESE (Fig. 9.2).

Another matter, however, is the kinematic inconsistency observed along the shear zones that comprise main lineament of the Dom Feliciano Belt, the Major Gercino, Dorsal do Canguçu and Sierra Ballena shear zones. This lineament is the most conspicuous structural feature of the belt, and has an orogenparallel NE-SW orientation throughout the belts extension. Nonetheless, while the southern extremity of the structure, represented by the dorsal do Canguçu and Sierra Ballena shear zones record sinistral shear, the Major Gercino Shear Zone in the northern extremity records predominant dextral. Passarelli et al. (2011a) attribute this contrast to the effect of the irregular margins of the involved continental masses, and partitioning of the convergence into locally different transcurrent vectors. An important component of pure shear and coaxial deformation is recognized throughout the lineament (e.g. Oyhantçabal et al. 2009; Passarelli et al. 2010, Chapters 4 and 5), suggesting that only slight local variations of the main horizontal compression along the extension of the belt might be enough to cause contrasting transcurrent displacements.

One consequence of this opposing shear vectors is the possibility of local development of NW-SE extension west of the lineament as local responses to the overall transpressive to transcurrent regional deformation. The influence of extension in these basins has been proposed by Almeida et al. (2010, 
2012), though the main tectonic drive behind their evolution is associated with compression or transtension (Paim et al. 2000; Borba et al. 2006, 2008; Basei et al. 2011b; Guadagnin et al. 2011).

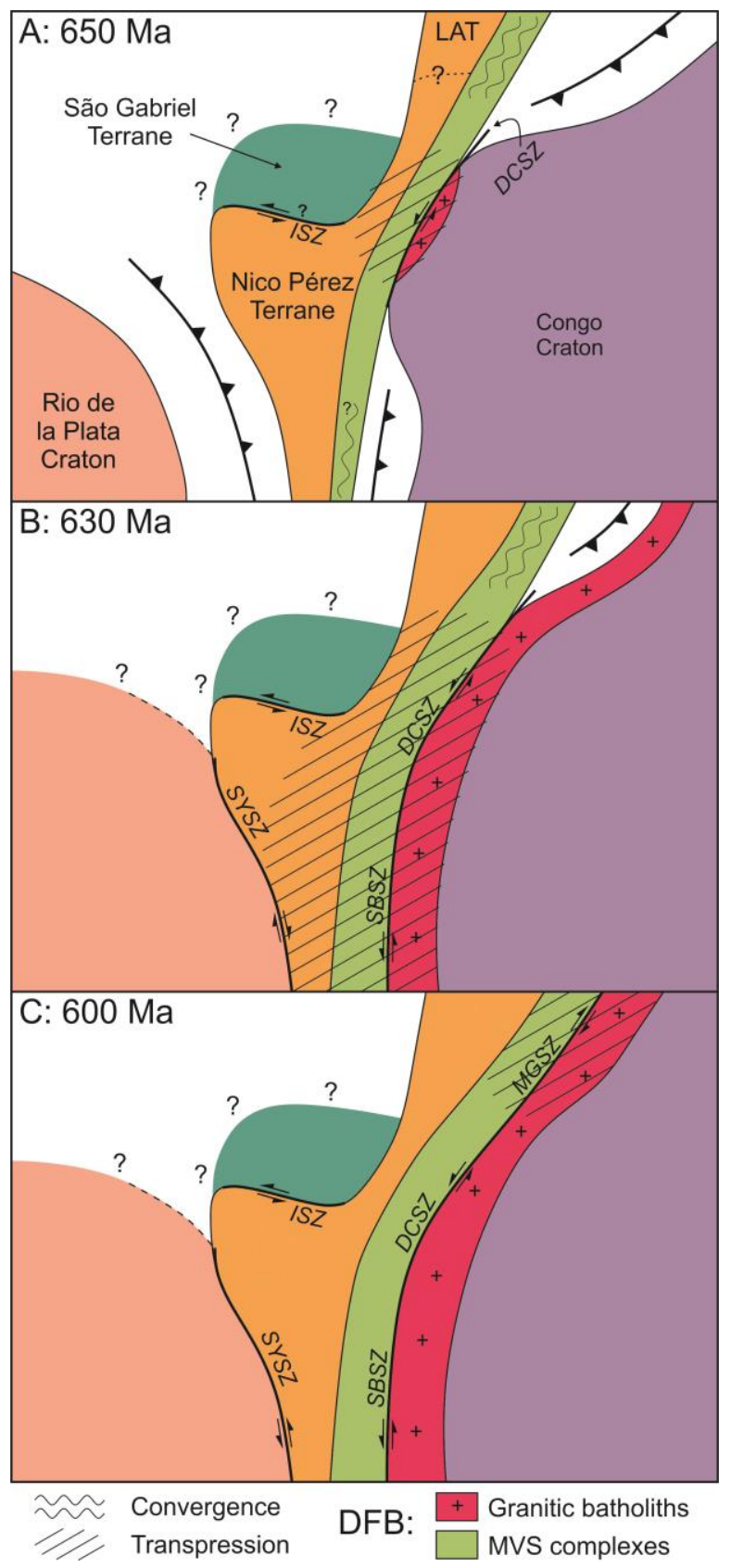

Figure 9.2: schematic representation of the evolution of the Dom Feliciano Belt, including the generation of the main units, shear zone activity and regional structural controls. Conflicting kinematics between different shear zones and shear inversion through time in some structures are caused by partitioning of compression into locally different transcurrent vectors along irregular margins during progressive accommodation of the regional tectonic drive. LAT: Luís Alves Terrane; DFB: Dom Feliciano Belt; MGSZ: Major Gercino Shear Zone; DCSZ: Dorsal do Canguçu Shear Zone; ISZ: Ibaré Shear Zone; SYSZ: Sarandí del Yí Shear Zone; SBSZ: Sierra Ballena Shear Zone. 


\subsubsection{Geotectonic Implications}

The São Gabriel Terrane and Tonian activity in southern South America

Tonian associations have been recognized in most Neoproterozoic Provinces of the South American Platform in the last decades (e.g. Philipp et al. 2018 and references therein). The São Gabriel Terrane records the earliest Neoproterozoic tectonic events in the southern South American Platform, comprising Ophiolitic sequences and the remains of an island arc that represent intra-oceanic activity in the Charrua Ocean between 930 and 860 Ma (Leite et al. 1998; Hartmann \& Chemale Jr. 2003; Lena et al. 2014; Philipp et al. 2016a, 2018; Arena et al. 2017). Subduction of the oceanic crust and accretion of this juvenile association along the margin of the Nico Pérez Terrane is recorded in the lbare Shear Zone between 760-740 Ma and $c a$. $710 \mathrm{Ma}$, when final closure of the Charrua Ocean is recorded by regional metamorphism in the central São Gabriel Terrane (Remus et al. 1999; Hartmann et al. 2011). As with the São Gabriel Terrane, the Goiás Arc in the Tocantins Belt in central Brazil is characterized by juvenile units developed in an oceanic setting (Pimentel et al. 1997, 2011). It is associated with the Transbrasiliano Lineament, one of the most significant suture zones of western Gondwana, separating the large Amazonian and São Francisco-Congo cratons along the former Goiás-Pharusian Ocean (Cordani et al. 2003, 2014; Brito Neves \& Fuck 2014; Ganade de Araújo et al. 2014). Philipp et al. (2018) propose a correlation between both juvenile Tonian associations, in which case the Charrua and Goiás oceans would be linked along an active continental margin.

Another group of Tonian rocks is recognized in the eastern portion of the Dom Feliciano Belt, in basement inliers in Rio Grande do Sul and Uruguay (Lenz et al. 2011, 2013; Masquelin et al. 2012; Koester et al. 2016; Martil et al. 2017). Differently from the main events associated with the Transbrasiliano Lineament, however, these associations are not characterized by juvenile signatures, and varied settings have been proposed, from extensional magmatism to subduction-related arc association.

Based on the temporal and paleogeographic correlation, it has been suggested that both Tonian associations in the southern South American Platform share a tectonic origin (Oriolo et al. 2017; Konopásek et al. 2018). In this interpretation, the Tonian association in the eastern domains of the Dom Feliciano Belt would represent the onset of extension and rifting of the Congo and Kalahari Cratons, as a result of subduction along the active continental margin represented by the São Gabriel Terrane (Fig. 9.3). This process would then lead to the formation of an attenuated rift, and, eventually, the Adamastor Ocean (Basei et al. 2018). This scenario is in accordance with the affinity between the African Cratons and the basement inliers east of the Major Gercino-Dorsal do Canguçu-Sierra Ballena Lineament, in 
particular the Nico Pérez Terrane in Uruguay (Oriolo et al. 2016c). The same tectonic affinity is extended by some authors to the Tijucas Terrane (Philipp et al. 2016a; Oyhantçabal et al. 2018) and even to the Luís Alves Terrane (Konopásek et al. 2018).

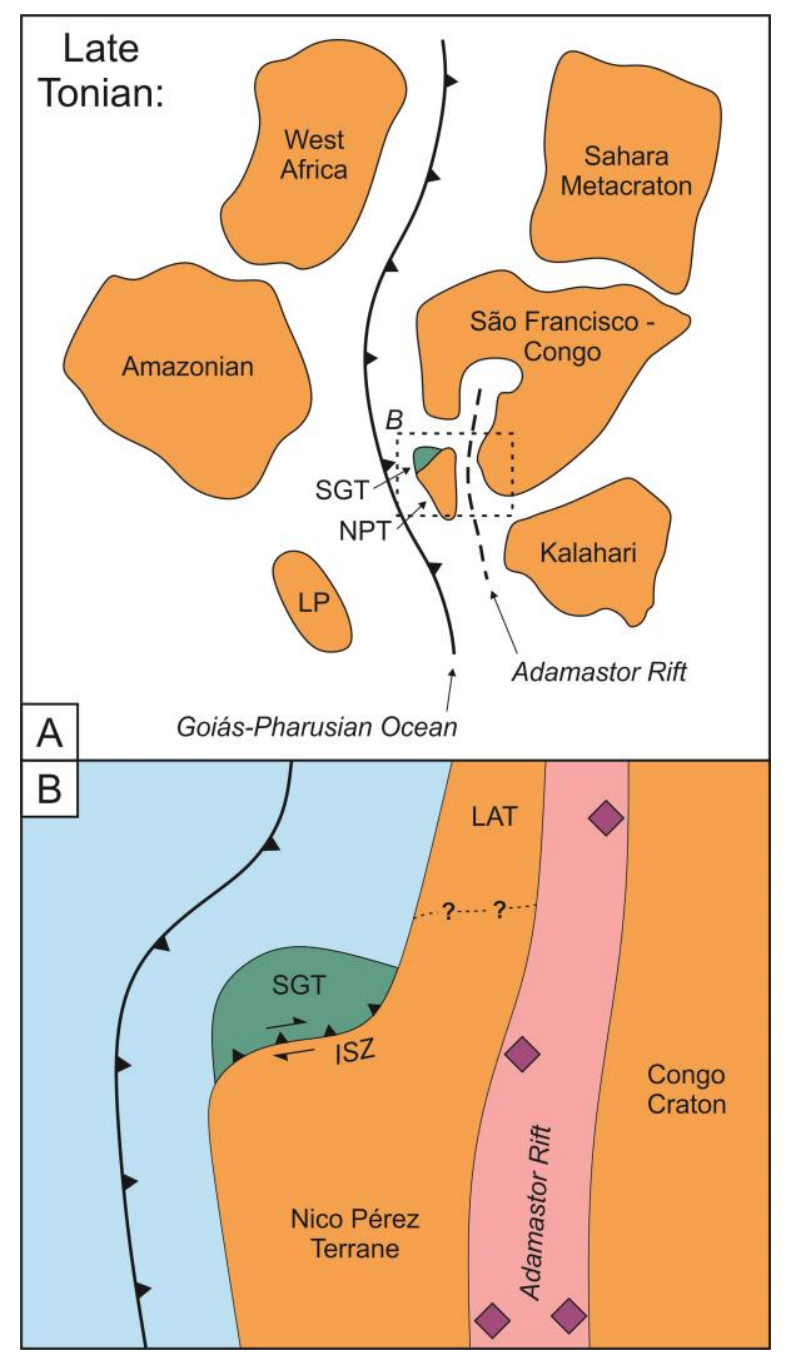

Figure 9.3: Schematic geodynamic interpretation of the southern South American Platform within Western Gondwana in the Late Tonian. A: correlation between subduction along the Goiás-Pharusian Ocean and extension along the Adamastor Rift. After Oriolo et al. (2017) with elements from Cordani et al. (2014), Ganade de Araújo et al. (2014), Basei et al. (2018) and Philipp et al. (2018). B: Detail of A along the terranes associated with the Dom Feliciano Belt, after Konopásek et al. (2018). In this conception, the Adamastor rift represents areas affected by late Tonian magmatism (ca. 780-710 Ma), as symbolized by purple diamond, corresponding to events in the Coastal Terrane in the Kaoko Belt (Konopásek et al. 2008, 2018), in the Pelotas Batholith, Tijucas Terrane and Punta del Este Terrane the Dom Feliciano belt (Basei et al. 2011 c; Lenz et al. 2011; Saalmann et al. 2011; Masquelin et al. 2012; Koester et al. 2016; Martil et al. 2017) and in the Gariep Belt (Frimmel et al. 1996). SGT: São Gabriel Terrane; NPT: Nico Pérez Terrane; LAT: Luís Alves Terrane; ISZ: Ibaré Shear Zone. 
A final implication of the evolution of the Ibaré Shear Zone and accretional history of the Nico Pérez Terrane involves the position of the Rio de la Plata Craton in relation to the major continental masses in the South American Platform and the Transbrasiliano Lineament. While the accretion along the Ibaré Shear Zone took place still in the Tonian with the closure of the Charrua Ocean (Philipp et al. 2018, Chapter 7), the final amalgamation between the Nico Pérez Terrane and Rio de la Plata Craton only took place at ca. $630 \mathrm{Ma}$, culminating in the Sarandí del Yí Shear Zone in southern Uruguay (Oriolo et al. 2015, $2016 a, b, c)$. In this context, it is possible that the accretional processes along the margin of the Nico Pérez Terrane represents a continued history of subduction and convergence, in which case the terrane border represented by the Sarandí del Yí Shear Zone might once have been connected to the Charrua and Goiás-Pharusian oceans and the remaining Transbrasiliano Lineament. Although this interpretation is still speculative and requires further investigation, it is in contrast to most paleogeographic reconstructions, which place the Transbrasiliano Lineament along the western border of the Rio de la Plata Craton (e.g. Cordani et al. 2003, 2014; Brito Neves \& Fuck 2014; Ganade de Araújo et al. 2014).

\section{The Major Gercino-Dorsal do Canguçu-Sierra Ballena Lineament}

The tectonic significance of the Major Gercino-Dorsal do Canguçu-Sierra Ballena Lineament has wider implications for the evolution of the Dom Feliciano Belt and its role during the assembly of southwestern Gondwana. The system has traditionally been interpreted as the main Brasiliano suture of the orogen, juxtaposing terranes of South American and African affinity (Basei et al. 2000, 2005, 2008; Goscombe et al. 2003, 2005, 2017a; Bossi \& Gaucher 2004; Gaucher et al. 2009; Passarelli et al. 2010, 2011a; Frimmel et al. 2011, 2013). In the latest versions of this model, east-dipping subduction of the Adamastor Ocean led to the formation of the granitic arc association on the eastern (African) side of the system, eventually leading to the collision of both terranes. This interpretation is supported by the presence of a crustalscale shear zone extending for over 1,000 km, coupled with contrasting isotopic signatures and zircon inheritance patterns on both sides of the lineament, recorded in Santa Catarina (Basei et al. 2000, 2005, 2008, 2011a; Passarelli et al. 2010, 2011a; Florisbal et al. 2012c; Hueck et al. 2016) and in Uruguay (Basei et al. 2000; Peel et al. 2015; Lara et al. 2016, 2017). The overall width of the Adamastor Ocean is not clear in the literature, with some authors considering it to be a rather restricted ocean, in particular when compared to the Goiás-Pharusian Ocean (e.g. Cordani et al. 2003, 2014), leading some authors to instead consider it as an attenuated rift (e.g. Konopásek et al. 2018). This scenario is supported by the strong predominance of overall continental signatures along the Mantiqueira Province, suggesting that metacratonization played an important part in the Brasiliano orogenic cycle (e.g. Meira et al. 2015; Oriolo et al. 2017). 
Alternatively, a number of authors consider both strike-slip shearing along the system and associated granitogenesis as the result of post-collisional processes during the Dom Feliciano Belt evolution. (Fernandes et al. 1993, 1995; Fernandes \& Koester 1999; Bitencourt \& Kruhl 2000; Koester et al. 2001a, b; Oyhantçabal et al. 2007, 2009; Philipp \& Machado 2005; Saalman et al. 2011; Chemale Jr. et al. 2012; Florisbal et al. 2012a, b, c; Philipp et al. 2013, 2016a; Lara et al. 2017). Arguments for this model include similarities on the crystallization ages and geochemical signature of granites on both side of the lineament. In this context, it is argued that, if the shear system once acted as a suture zone, this event predated the timing of shearing and crystallization ages of granitoids.

To some extent, the different interpretations described above may be the result of the diachronic deformational history observed along the Dom Feliciano Belt (Figs. 9.1, 9.2). If the onset of transpression identified in each sector of the orogen is interpreted to represent the oblique collision along the Major Gercino-Dorsal do Canguçu-Sierra Ballena Lineament, lithological associations in similar geological contexts may have developed within different tectonic stages. As an example, while in Santa Catarina the period between ca. 650 and $620 \mathrm{Ma}$ is mostly dominated by convergence and would correspond to the pre-collisional state of the orogenic cycle, in Rio Grande do Sul the onset of transpression at $650 \mathrm{Ma}$ implies that the same period would correspond to the syn- to post-collisional stage. In any case, the transition to predominantly strike-slip deformation following widespread transpression, recognized through most of the orogen by ca. $600 \mathrm{Ma}$, may be used as a minimum age for constraining the postcollisional stage for the entire system.

\subsection{Phanerozoic evolution of the South Atlantic passive margin along the Dom Feliciano Belt}

\subsubsection{The effect of radiation damage in the (U-Th)/He dataset}

Before presenting the main findings of the thermochronological evolution the study area, it is important to address how the new (U-Th)/He dataset was influenced by the effect of radiation damage, a topic which has only recently started to be widely recognized. Damages to the crystalline lattice due to radioactive emissions directly affects a crystal's He diffusivity, leading to varying closure temperatures within a same thermal history for both zircon and apatite (Flowers et al. 2009; Guenthner et al. 2013). In the Dom Feliciano Belt, as in other areas which have experienced a long-term stability in the upper crust, this effect is amplified due to the prolonged residence in near-surface temperature conditions, and consequent accumulation of radiation damage. 
One positive consequence of this effect is its application as a modelling tool to constrain more detailed thermal history (Ault et al. 2009; Flowers \& Kelley 2011; Murray et al. 2016; Orme et al. 2016; Powell et al. 2016; Guenthner et al. 2017; Johnson et al. 2017). This approach uses the concentration of radioactive elements in each measured crystal, expressed in its effective uranium content $(e U, U+0.235$

* Th, in ppm), in order to estimate the predicted apparent He ages. This can be demonstrated along the Major Gercino Shear Zone in the Catarinense Shield (Chapter 8), where the complex pattern of widespread Zircon (U-Th)/He (ZHe) ages vs. eU content was successfully reproduced, offering a more reliable reconstruction of the area's Phanerozoic history.

Unfortunately, this kind of treatment is not possible when the studied area went through a complex or heterogeneous evolution, as it cannot be presumed that all samples experienced the same thermal path. Nonetheless, it still can be used as a control for the selection of the most reliable apparent ages. This is the case of the Uruguayan and Sul-rio-grandense Shield (Chapters 6 and 7), where zircon crystals with elevated eU contents (e.g. upwards of 700-1000 ppm) consistently yielded excessively young apparent ages, which are not representative of the thermal evolution of the crystalline basement. For the same reasons, it is also important to develop companion systems that can act as independent validation. Such an experiment was conducted in the Major Gercino region (Chapter 8), applying Raman spectroscopy as a proxy for the radiation damage of zircons and using it to calculate the accumulation period (e.g. Nasdala et al. 2001; Palenik et al. 2003; Pidgeon 2014). The results indicate that this method produced results that are comparable to the ZHe system, yielding independent ages that are not correlated, but cover the same time range and are geologically reasonable. Therefore, the assessment of zircon radiation damage by Raman spectroscopy is a promising method that should be better developed.

\subsubsection{Phanerozoic evolution of the studied areas}

The new low-T geochronological data presented in this thesis, in association with the available data from the literature, reveal the Phanerozoic exhumation history along the extension of the Dom Feliciano Belt and adjacent Precambrian domains (Fig. 9.4).

All of the different crustal blocks that compose the Uruguayan Shield reached shallow burial conditions between 550 and $450 \mathrm{Ma}$, as recorded in the ZHe ages, indicating intense exhumation and tectonic activity shortly after the end of the Pan-African-Brasiliano orogenetic cycle (Chapter 6). Thermal modelling suggests that most of the currently outcropping rocks were exposed to near-surface conditions by early to mid-Paleozoic times, being subsequently reheated during the subsidence cycles that led to the sedimentation of the Paraná Basin in the Paleozoic. Variations in the (U-Th)/He dataset 
indicate that subsidence was not uniform in Uruguay, being coeval with local exhumation. Final exhumation and cooling below the temperatures of the apatite (U-Th)/He ( $\mathrm{AHe})$ thermochronometer was achieved during the Triassic in the northern portion of the Shield, while the southern areas experienced an additional exhumation during opening of the South Atlantic Ocean in the early Cretaceous. This process was accompanied by the installation of an ENE-WSW aborted rift corridor, segmenting the crystalline basement. Brittle activity along the main shear zones is recognized throughout the Phanerozoic, as recorded in the K-Ar dating of fault gouges, with ages coinciding with the main exhumation events. Nonetheless, fault reactivation did not lead to significant vertical displacement, as it is not reflected in the (U-Th)/He dataset.

Post-orogenic exhumation is also recorded in the ZHe dataset in Rio Grande do Sul during the early Paleozoic (Chapter 7). Dating of illite crystallization in fault gouges parallel to important shear zones indicate that these structures were recurrently reactivated in the Paleozoic. As an effect, no single comprehensive thermal history can be modelled for the ZHe dataset, but individual modelling of most dated samples suggest that after a pre-Devonian exposition to near-surface conditions, regional subsidence and the sedimentation in the Paraná Basin caused a reheating of the basement. AHe ages indicate that final exhumation was achieved at the latest by the syn-rifting stage of the South Atlantic Ocean throughout the Sul-rio-grandense Shield. The area was not affected by significant post-rifting uplift in the late Cretaceous and Cenozoic, as reflected by its gentle topography.

The (U-Th)/He dataset obtained along the Major Gercino Shear Zone in Santa Catarina is characterized by widespread apparent ZHe ages that are strongly eU-dependent (Chapter 8). This suggests a partially reset system which has experienced relative low temperatures since at least the Ordovician. While exposition to surface conditions and subsequent burial by the Paleozoic sedimentation of the Paraná Basin is likely, modelling of the ZHe dataset indicate that the area must have been affected by a more pronounced heating event. The most likely cause for this is the onset of the Paraná Large Igneous Province (Paraná LIP) in the Lower Cretaceous, which in the area was accompanied by the intrusion of the Florianópolis Dyke Swarm, an important feeder system of the LIP. Subsequently, the area was probably covered by up to $2 \mathrm{~km}$ of basaltic floods, which were eroded during rapid post-rift exhumation between 75 and $55 \mathrm{Ma}$, as constrained by thermal modelling. For the entire area, the (U-Th)/He dataset is best explained by a shared geological history, indicating that the Major Gercino Shear Zone did not cause significant differential exhumation. 


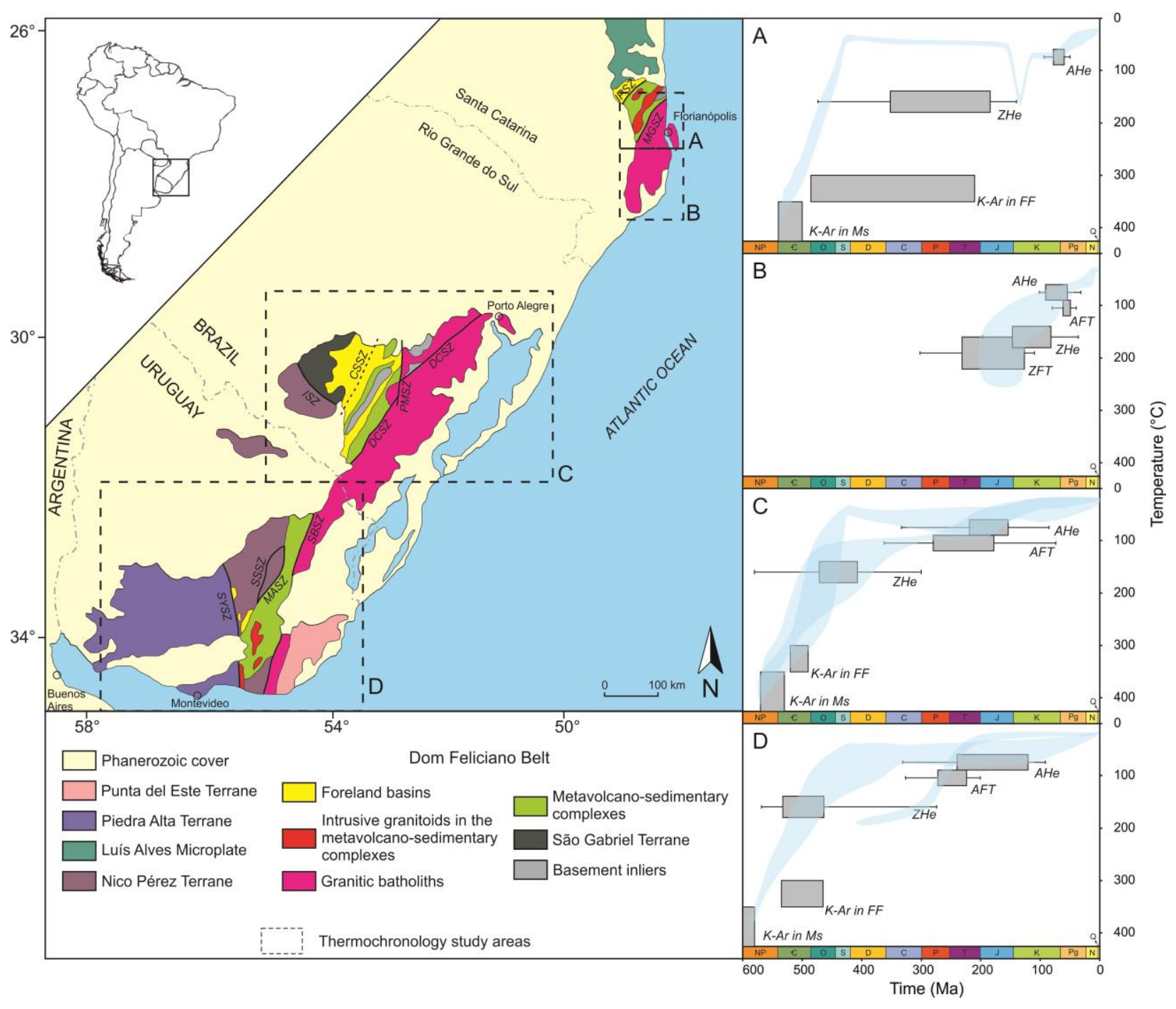

Figure 9.4: Summary of thermochronological data and T-t evolution along the Dom Feliciano Belt and associated

Precambrian domains. The light blue belts correspond to the envelope of the mean paths yielding good fit at thermal modelling. The distinct envelopes in $C$ and $D$ correspond to sets of samples modelled with distinct constraints in Uruguay and Rio Grande do Sul, simulating exposure to surface conditions prior to subsidence in the Paraná Basin and prolonged residence in the ZHe partial retention zone (see chapters 6 and 7 for more details). Apatite fission track (AFT) constraints in Uruguay are from Kollenz (2015), and in Rio Grande do Sul from Borba et al. (2002, 2003), Bicca et al. (2013) and Oliveira et al. (2015b). Data from the southern part of the Santa Catarina sector of the Dom Feliciano Belt (Area B) are from Jelinek et al. (2003) and Karl et al. (2013). Muscovite (Ms) K-Ar constraints in Uruguay are from Oyhantçabal et al. (2009) and Oriolo et al. (2016b), and additional illite fine fractions (FF) K-Ar ages data in Santa Catarina are from Passarelli et al. (2010).

The thermal event responsible for the partial reset of the ZHe ages in the northern portion of the Catarinense Shield may have also affected the southern portion of the shield, on which the few available 
zircon fission track (ZFT) and ZHe ages have quite young and widespread values (Karl et al. 2013). While most ZFT ages are older than the Paraná LIP event, and may have been partially reset by it, a few of the reported ZHe ages are very young, with ages comparable to that of the Apatite fission track (AFT) and AHe methods in the same area. As observed throughout this thesis, however, most very young crystals are characterized by elevated eU values (> $700 \mathrm{ppm}$ ). Thermal modelling based on AFT and AHe ages in the same area (Jelinek et al. 2003; Karl et al. 2013) indicate that final exhumation in the mid- to late Paleogene took place after the last events recorded along the Major Gercino Shear Zone. This contrast was probably controlled by the presence of coast-perpendicular fracture zones, as will be discussed in more detail in section 9.2.5.

\subsubsection{Integrated exhumation history of the Dom Feliciano Belt}

A comparison of the estimated thermal histories for each of the three studied basement shields reveals some interesting trends. ZHe data in all areas reveal that intense exhumation in the early Paleozoic followed the end of the Brasiliano orogenic cycle, with most analyzed samples achieving near-surface conditions prior to regional subsidence in the Paraná Basin. This is an important observation, because this process is usually poorly recorded in most thermochronological studies along the elevated central portion of the South Atlantic passive margin, which were masked by intense post-rift exhumation and uplift (Gallagher et al. 1994; Tello Saenz et al. 2003; Hackspacher et al. 2004, 2007; Hiruma et al. 2010; Cogné et al. 2011, 2012; Karl et al. 2013; Jelinek et al. 2014).

However, when comparing the ZHe dataset from the three studied areas (Fig. 9.5), the apparent ages reveal a progression from older to younger ages accompanying the extension of the orogen from south to north. These suggest that initial exhumation following the Brasiliano orogenic cycle was more intense in Uruguay than elsewhere in the belt. This could possibly be an expression of the proximity to the active orogenic front of the late stages of the Brasiliano-Pan-African orogenic system, which migrated to the southern portions of the system in what is now the African continent, as exemplified by the <560 Ma evolution of the Damara and Gariep Belts (e.g. Gray et al. 2006, 2008; Frimmel et al. 2011, 2018; Goscombe et al. 2017a, b, 2018). In addition, the southern extremity of the Dom Feliciano Belt is closer to the active continental margin in south and southwest Gondwana, stretching from the Saldania Belt in South Africa to the Eastern Sierras Pampeanas in South America (e.g. Kisters \& Belcher 2018; Lópes de Luchi et al. 2018 and references therein).

Another significant difference is recorded in the final exhumation of the studied areas, as recorded by the AHe dataset. Both in Uruguay and in Rio Grande do Sul, AHe ages cluster around the Mesozoic and 
are mostly younger than $130 \mathrm{Ma}$. This indicates that final exhumation was achieved during pre-rift doming in both shields by the time of the Paraná LIP onset (135-130 Ma, Renne et al. 1992; Ernesto et al. 1999; Thiede \& Vasconcelos 2010; Janasi et al. 2011) and subsequent opening of the South Atlantic. The occasional occurrence of basaltic lavas of the Paraná LIP over Precambrian basement rocks, such as in the central portion of the Uruguayan Shield (Rossello et al. 2000, 2007), further supports this interpretation.

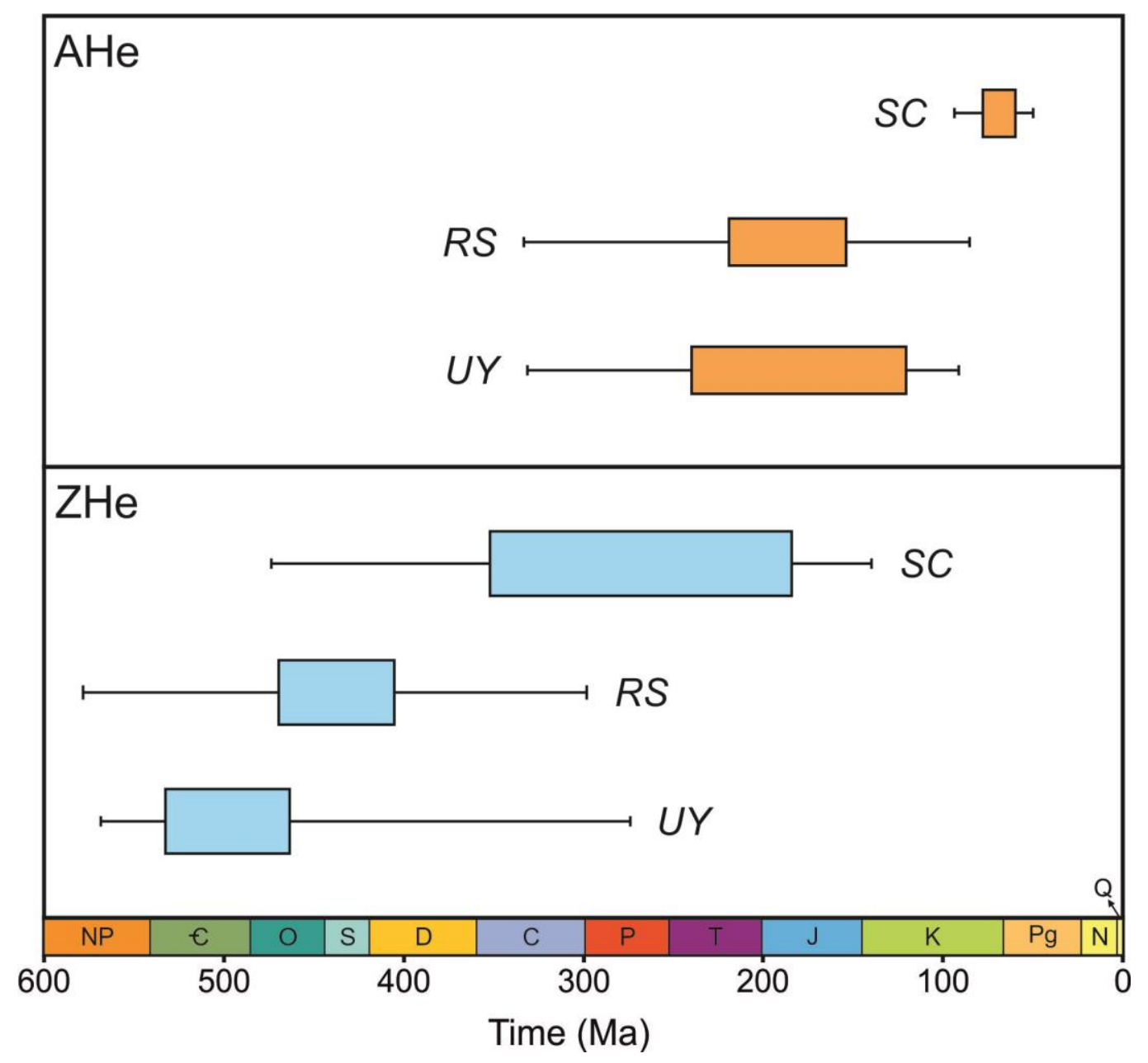

Figure 9.5. (U-Th)/He ages of the three sector of the Dom Feliciano Belt studied in this thesis.

On the other hand, final exhumation in Santa Catarina was mostly achieved after the rifting of the South Atlantic Ocean. AHe data around the Major Gercino Shear Zone is quite well constrained, and indicate a fast exhumation of up to $2 \mathrm{~km}$ between 75 and $55 \mathrm{Ma}$. Is this sense, the thermal evolution of the Catarinense Shield was more similar to that of the central portion of the South Atlantic passive margin in southeastern Brazil, which experienced intense post-rift uplift (Gallagher et al. 1994; Tello Saenz et al. 
2003; Hackspacher et al. 2004, 2007; Hiruma et al. 2010; Cogné et al. 2011, 2012; Karl et al. 2013; Jelinek et al. 2014).

\subsubsection{Reactivation of Brasiliano structures in the Phanerozoic}

Evidences of reactivation of Neoproterozoic Brasiliano structures are recorded in all study areas. K-Ar dating of illite clays from fault gouges formed during brittle activity yield ages that span most of the Phanerozoic and coincide with the main exhumation events recorded in the (U-Th)/He dataset (Chapters 6 and 7). This is complemented by the dating of illite on fine fractions extracted from mylonites, which constrain an upper limit for the end of ductile recrystallization, and, occasionally, post-orogenic hydrothermal recrystallization (Chapters 5, 6 and 7)

Paleozoic K-Ar ages are widespread in fault gouges in the Uruguayan and Sul-rio-grandense shields. A number of foliation-parallel fault gouges yielded ages that are coeval with the fine fractions obtained in mylonites in both shields (predominantly 560-440 Ma), recording the transition of the crystalline basements from ductile- do brittle-deformation conditions. The remaining ages are mostly in the Late Paleozoic (420 to $360 \mathrm{Ma}$ and ca. $300 \mathrm{Ma}$ ), coinciding with the main period of regional subsidence and deposition of the Paraná Basin. Similar ages were recognized in illite fine fractions extracted from mylonites of the Major Gercino Shear Zone, indicating that this structure was partially affected by the percolation of hydrothermal fluids during the period.

This recurrent Paleozoic reactivation suggests that block segmentation played an important role during the period in both the Uruguayan and Sul-rio-grandense shields. This is in accordance with the (U-Th)/He dataset, as thermal modelling in both shields were not able to provide a unified exhumation history that satisfied the entire dataset (discussed in sections 9.2.1 and 9.2.2). Another evidence for the activity of block segmentation in both shields is the overlap between the youngest ZHe ages and the oldest AHe and AFT ages in the late Paleozoic, (Borba et al. 2002, 2003; Bicca et al. 2013; Kollenz 2015; Oliveira et al. 2015b), which suggests contrasting temperature conditions throughout the basement. Taken together, all of these evidences record how the area experienced distinct responses to the same large-scale regional tectonic process, namely, the main sedimentation cycle of the Paraná Basin. In this way, it reflects the evolution of the basin itself, which was affected by structural controls during sedimentation (e.g. Rostirolla et al. 2000; Holz et al. 2006). 
Finally, Mesozoic K-Ar ages in fault gouges in Uruguay and Rio Grande do Sul (165 to $130 \mathrm{Ma}$ and 110 to $80 \mathrm{Ma}$ ) record the tectonism related to the opening of the South Atlantic Ocean, and are probably associated with the final exhumation events recorded in the AHe dataset.

Nonetheless, despite these evidences of recurrent reactivation, the main Neoproterozoic are not recognized as particular boundaries for the new (U-Th)/He dataset, not even on a detail-scale approach, such as on the Major Gercino Shear Zone (Chapter 8). In this sense, the Dom Feliciano Belt and associated Precambrian domains are in contrast with high-elevation areas along the Mantiqueira Range in southeastern Brazil, where major shear zones separate areas with distinct thermal histories during post-rift exhumation and uplift (Tello Saenz et al. 2003; Hiruma et al. 2010; Cogné et al. 2011, 2012; Franco-Magalhães et al. 2014). Consequently, the (U-Th)/He suggests that the Brasiliano structures accommodated limited vertical displacements during final exhumation in this section of the South American passive margin. This observation is somewhat unexpected, as the reactivation of Brasiliano structures is interpreted to have been a driving process during the rifting of the South Atlantic Ocean (e.g. Almeida \& Carneiro 1998, Zalán 2004; Moulin et al. 2010). A possible consequence is that this process, if present in this section of the passive margin, was restricted to structures currently offshore.

In fact, throughout the studied area, the most significant contrast in terms of thermal history occur along the extension of the Dom Feliciano Belt and associated basement blocks, as indicated by the stark contrasting thermal histories between Santa Catarina and the rest of the study area. This suggests that the final exhumation on this stretch of the South American passive margin was predominantly controlled by NW-SE structures transverse to the coastline and to the main Brasiliano framework. The effect of this coast-perpendicular control is not restricted to the exhumation history, but has been an influential factor in the South American Platform since at least the Mesozoic, as recorded in the deformation of the Paraná Basin, the emplacement of volcanic dykes during the Paraná LIP event and the segmentation of the passive margin, among others (Piccirillo et al. 1990; Zalán et al. 1990; Rostirolla et al. 2000; Meisling et al. 2001; Strugale et al. 2007; Masquelin et al. 2009; Salomon et al. 2015, 2017). The formation of this system has been associated with clockwise rotation of the South American Continent during rifting of the South Atlantic (Szatmari \& Milani 2016; Salomon et al. 2017), eventually, linking to transfer zones of the mid-ocean ridge and the segmentation of the oceanic crust (Cobbold et al. 2001; Franke et al. 2007; Torsvik et al. 2009; Stica et al. 2014). One good example of the influence of this system within the study area is in the Uruguayan Shield. There, the Neoproterozoic basement configuration is affected by a Cretaceous aborted rift (Rossello et al. 2000, 2007), which also acts as a boundary to the oldest AHe ages, restricted to the north of the structure. The influence of this system in the thermochronological 
record of the South American passive margin extends further north, at least to the Ponta Grossa Arch (Franco-Magalhães et al. 2010; Karl et al. 2013).

\subsubsection{Structural controls on the exhumation of the South American passive margin}

By integrating the available literature on thermochronology of the southern South American, the causes for the distinction between the predominant structural controls along the Mantiqueira Province can be investigated. On a compilation of AFT and AHe data for the entire region (Fig. 9.6a, b), the Catarinense Shield is revealed to be the southernmost portion of the South Atlantic passive margin where final exhumation was attained predominantly during the South Atlantic post-rift stage. Although there is no direct correlation between apparent AFT and AHe ages and the elevation of the analyzed samples (Fig. 9.7), when comparing the distribution of apparent ages with an elevation model of the same area (Fig. 9.6c), it is evident that young exhumation is dominant in coast segments with elevated coast-parallel ridges.

This correlation demonstrates how post-rift exhumation was responsible for the final uplift of the central portion of the South American passive margin. The uplift has commonly been attributed to the impact of a cycle of alkaline magmatism, recorded in to numerous intrusions (Fig. 9.6d) in the Late Cretaceous and Paleogene (Cobbold et al. 2001; Hiruma et al. 2010; Cogné et al. 2011, 2012; Franco-Magalhães et al. 2014). Traditionally, this alkaline magmatic event was interpreted as the result of the drifting of the South American Platform over a mantle plume (Gibson et al. 1995; Thompson et al. 1998). However, the presence of this plume has been somewhat discredited more recently, based on the lack of a correct correlation between geochronological data and the alignment of the main intrusion belts (Riccomini et al. 2005). Instead, some authors suggest that the post-rift intrusions along the passive margin are controlled mainly by the coast-perpendicular NW-SE trending fault systems, possibly in association with the reactivation of Neoproterozoic structures (Almeida et al. 1991; Riccomini et al. 2005).

In this regard, reactivation of the inherited structural framework is commonly attributed as the cause for the post-rift exhumation, triggered by phases of pronounced tectonic activity in the Andean system (Cobbold et al. 2001; Cogné et al. 2011, 2012; Karl et al. 2013). The presence of the NE-SW-trending Brasiliano structures on its own, however, cannot be accounted as a significant factor for pronounced exhumation of the passive margin. This is well demonstrated in the Dom Feliciano Belt, where the main Neoproterozoic structural framework is subparallel to the main shear zones in the central and uplifted portion of the passive margin (Fig. 9.6d). Nonetheless, while the latter experienced significant reactivation in the Upper Cretaceous and Paleogene (Tello Saenz et al. 2003; Hiruma et al. 2010; Cogné 
et al. 2011, 2012; Franco-Magalhães et al. 2014), the former left no particular imprint on the thermochronological record (discussed in section 9.2.4).

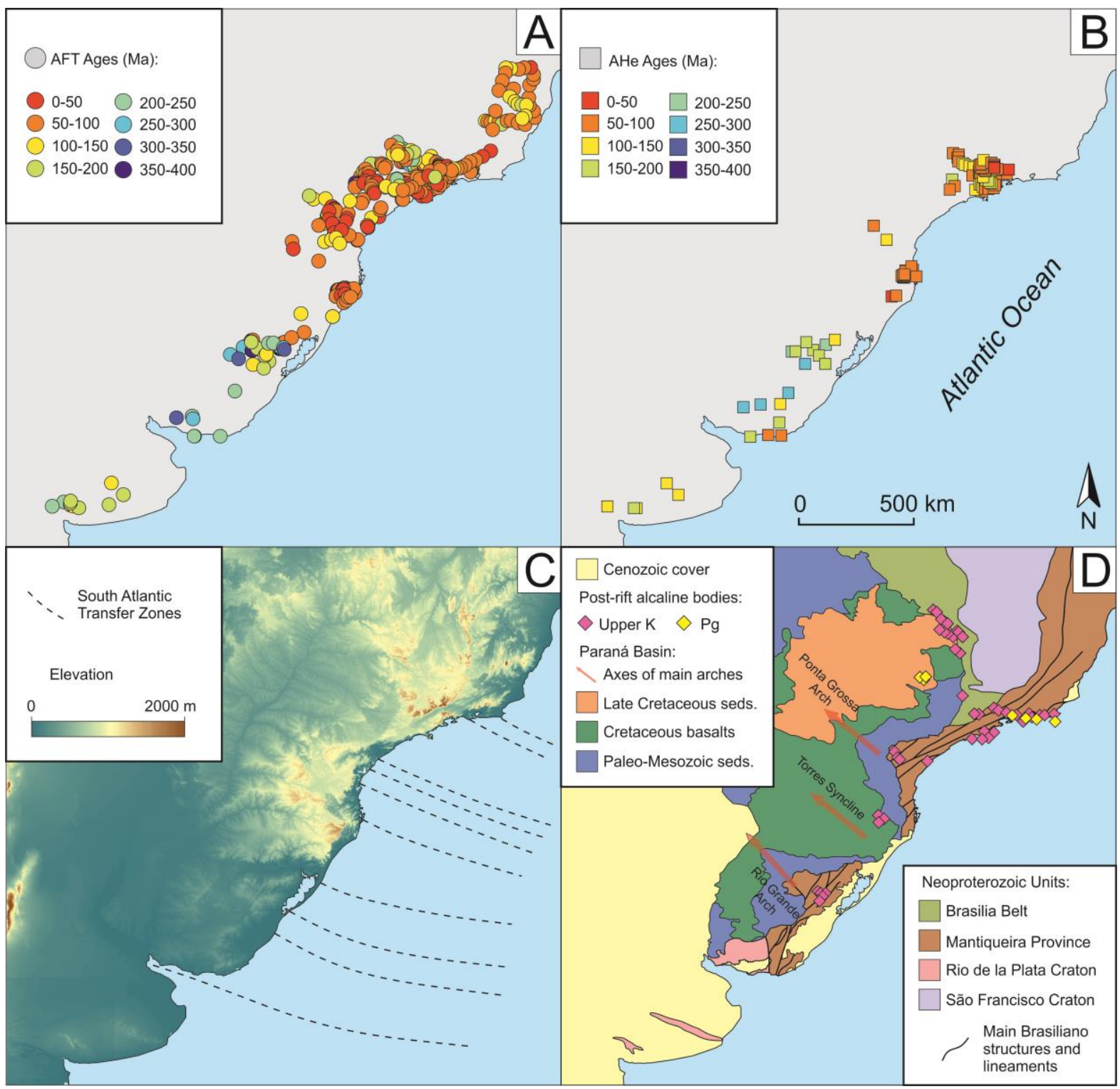

Figure 9.6: Compilation of thermochronological data and factors influencing post-rift exhumation in the southsoutheastern portion of the South American passive margin. A and B: Summary of published AFT and AHe ages along the Mantiqueira Province and neighboring basins and cratonic forelands. Modified from Oliveira \& Jelinek 2017 with data from Gallagher et al. (1994), Oliveira et al. (2000, 2015b, 2016), Borba et al. (2002, 2003), Jelinek et al. (2003, 2014), Tello Saenz et al. (2003), Hackspacher et al. (2004, 2007), Franco et al. (2005): Ribeiro et al. (2005, 2011), Franco-Magalhães et al. (2010, 2014): Hiruma et al. (2010), Cogné et al. (2011, 2012), Bicca et al. (2013), Karl et al. (2013), Souza et al. (2014), Kollenz (2015), Kollenz et al. (2016) and this work. AHe ages correspond to average ages from single-crystal results for a same sample. C: Digital elevation model of the south-southeastern 
portion of the South American passive margin. The elevation color ramp is limited at 2,000 $\mathrm{m}$, but peaks in the highest areas can reach altitudes of up to $2,800 \mathrm{~m}$. The location of the main South Atlantic transfer Zones follows Meisling et al. (2001), Franke et al. (2007), Torsvik et al. (2009) and Stica et al. (2014). D: Simplified geological map of the area, with Neoproterozoic domains, main structural features of the Mantiqueira Province, principal units of the Paraná Basin and location of the main post-rift alkaline bodies along the passive margin. Modified from Assine et al. (1994), Heilbron et al. (2004, 2008), Riccomini et al. (2005), Cingolani (2011), Passarelli et al. (2011a) and

Oriolo et al. (2016b)

Hence, it is most likely that the same thermal anomaly which led to the initiation of the alkaline magmatism left the central section of the passive margin susceptible to uplift and reactivation of inherited structures due to thermal weakening (e.g. Cogné et al. 2011, 2012). It is possible that the significant vertical displacements observed along the main structures in these areas are a result of isostatic compensation after regional uplift. Such a scenario would also be in accordance with the lack of a direct correlation between individual sample ages and elevation (Fig. 9.7).

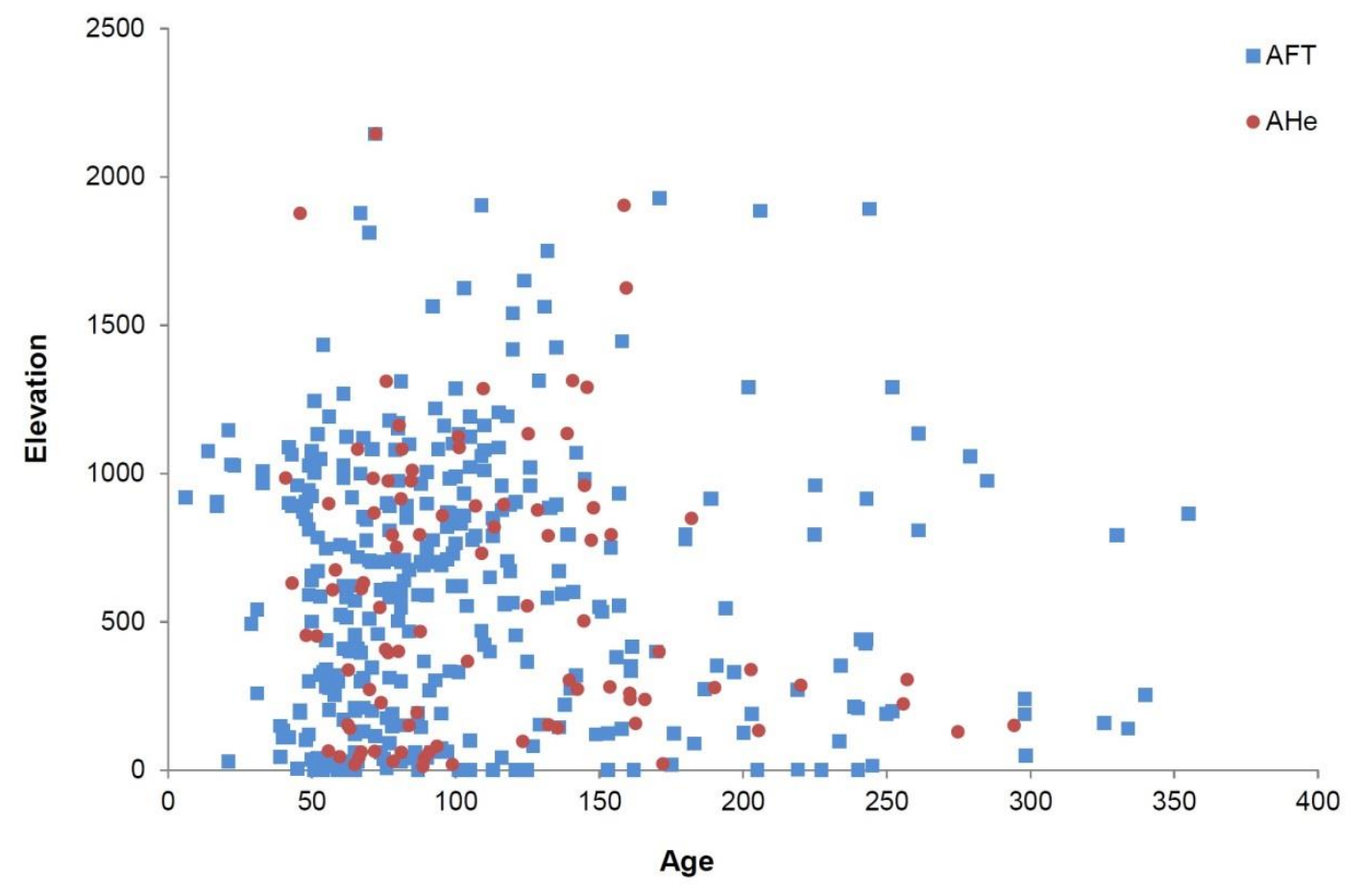

Figure 9.7: Distribution of apatite fission-track (AFT) and (U-Th)/He (AHe) ages versus elevation of the measured sample. Modified from Oliveira \& Jelinek 2017 using the same database as in Fig. 9.6 ( $a$ and b) 


\section{REFERENCES}

Almeida, F.F.M., 1991. O alinhamento magmatico de Cabo Frio. In: $2^{\circ}$ Simposio de Geologia do Sudeste, Sao Paulo. Abstracts, 423-428.

de Almeida, F.F.M., Carneiro, C.D.R., 1998. Origem e evolução da Serra do Mar. Revista Brasileira de Geociências 28(2), 135-150.

Almeida, F.F.M., Amaral, G., Cordani, U.G., Kawashita, K., 1973. The precambrian evolution of the South American cratonic margin, South of Amazonas River. In: Nairn ACM, Kanes WH, Stehli FG (Eds.) The Ocean basins and margins. Plenum, New York, 411-446.

Almeida, F.F.M., Hasui, Y., de Brito Neves, B.B., Fuck, R.A., 1981. Brazilian structural provinces; an introduction. Earth-Science Reviews 17 (1/2), 1-29.

Almeida, R.P., Janikian, L., Fragoso-Cesar, A.R., Fambrini, G.L., 2010. The Ediacaran to Cambrian rift system of Southeastern South America: tectonic implications. Journal of Geology 118, 145-161.

Almeida, R.P., Santos, M.G.M., Fragoso-Cesar, A.R., Janikian, L., Fambrini, G.L., 2012. Recurring extensional and strike-slip tectonics after the Neoproterozoic collisional events in the southern Mantiqueira province. Annals of the Brazilian Academy of Sciences 84 (2), 347-376.

Arena, K.R., Hartmann, L.A., Lana, C., 2017. Tonian emplacement of ophiolites in the southern Brasiliano Orogen delimited by U-Pb-Hf isotopes of zircon from metasomatites. Gondwana Research 49, 296332.

Assine, M.L., Soares, P.C., Milani, E.J., 2017. Sequências tectono-sedimentares mesopaleozóicas da Bacia do Paraná, Sul do Brasil. Revista Brasileira de Geociências 24(2), 77-89.

Ault, A.K., Flowers, R.M., 2012. Is apatite U-Th zonation information necessary for accurate interpretation of apatite (U-Th)/He thermochronometry data?. Geochimica et Cosmochimica Acta 79, 60-78.

Ault, A.K., Flowers, R.M., Bowring, S. A., 2009. Phanerozoic burial and unroofing history of the western Slave craton and Wopmay orogen from apatite $(\mathrm{U}-\mathrm{Th}) / \mathrm{He}$ thermochronometry. Earth and Planetary Science Letters 284(1), 1-11.

Autin, J., Bellahsen, N., Leroy, S., Husson, L., Beslier, M.O. d'Acremont, E., 2013. The role of structural inheritance in oblique rifting: Insights from analogue models and application to the Gulf of Aden. Tectonophysics 607: 51-64.

Babinski, M., Chemale, F., Hartmann, L.A., Van Schmus, W.R., da Silva, L.C., 1997. U-Pb and Sm-Nd geochronology of the Neoproterozoic granitic-gneissic Dom Feliciano belt, southern Brazil. Journal of South American Earth Sciences 10 (3-4), 263-274.

Basei, M.A.S., 1985. O Cinturão Dom Feliciano em Santa Catarina. PhD Thesis, Universidade de São Paulo.

Basei, M.A.S., Siga Jr., O., Masquelin, H., Harara, O.M., Reis Neto, J.M., Preciozzi, F., 2000. The Dom Feliciano Belt of Brazil and Uruguay and its Foreland Domain the Rio de la Plata Craton: framework, tectonic evolution and correlation with similar provinces of Southwestern Africa. In: Cordani, U.G., Milani, E.J., Thomaz Filho, A., Campos, D.A. (Eds.), Tectonic Evolution of South America, IGC 31, Rio de Janeiro, 311-334. 
Basei, M.A.S., Frimmel, H.E., Nutman, A.P., Preciozzi, F., Jacob, J., 2005. The connection between the Neoproterozoic Dom Feliciano (Brazil/Uruguay) and Gariep (Namibia/South Africa) orogenic belts. Precambrian Research 139, 139-221.

Basei, M.A.S., Campos Neto, M.C., Castro, N.A., Santos, P.R., Siga Jr., O., Passarelli, C.R., 2006. Mapa Geológico 1:100,000 das Folhas Brusque e Vidal Ramos, SC, Convênio USP-CPRM. In: XLII Congresso Brasileiro de Geologia, Aracaju, SE.

Basei, M.A.S., Frimmel, H.E., Nutman, A.P., Preciozzi, F., 2008. West Gondwana amalgamation based on detrital zircon ages from Neoproterozoic Ribeira and Dom Feliciano belts of South America and comparison with coeval sequences from SW Africa. In: Pankhurst, R.J., Trouw, R.A.J., de Brito Neves, B.B., de Wit, M.J. (Eds.), West Gondwana: Pre-Cenozoic Correlations Across the South Atlantic Region, London. Geological Society London, Special Publication 294, 239-256.

Basei, M.A.S., Nutman, A., Siga Jr, O., Passarelli, C.R., Drukas, C.O., 2009. The evolution and tectonic setting of the Luis Alves Microplate of Southeastern Brazil: an exotic terrane during the assembly of Western Gondwana. In: Gaucher, C., Sial, A.N., Halverson, G.P., Frimmel, H.E. (Eds.), Neoproterozoic-Cambrian tectonics, global change and evolution: a focus on southwestern Gondwana. Developments in Precambrian Geology 16, 273-291.

Basei, M.A.S., Neves, B.B.B., Junior, O.S., Babinski, M., Pimentel, M.M., Tassinari, C.C.G., Hollanda, M.H.B., Nutman, A., Cordani, U. G., 2010. Contribution of SHRIMP U-Pb zircon geochronology to unravelling the evolution of Brazilian Neoproterozoic fold belts. Precambrian Research 183(1), 112-144.

Basei, M.A.S., Campos Neto, M.C., Castro, N.A., Nutman, A.P., Wemmer, K., Yamamoto, M.T., Hueck, M., Osako, L., Siga, O., Passarelli, C.R., 2011a. Tectonic evolution of the Brusque group, Dom Feliciano belt, Santa Catarina, Southern Brazil. Journal of South American Earth Science 32 (4), 324-350.

Basei, M.A.S., Drukas, C.O., Nutman, A., Wemmer, P.K., Dunyi, L., Santos, P.R., Passarelli, C.R., CamposNeto, M.C., Siga Jr., O., Osako, L., 2011b. The Itajaí foreland basin: a tectono-sedimentary record of the Ediacaran period, Southern Brazil. International Journal of Earth Sciences 100, 543-569.

Basei, M.A.S., Peel, E., Sánchez Bettucci, L., Preciozzi, F., Nutman, A.P., 2011c. The basement of the Punta del Este Terrane (Uruguay): an African Mesoproterozoic fragment at the eastern border of the South American Río de la Plata craton. International Journa of Earth Sciences 100, 289-304.

Basei, M.A.S., Campos Neto, M.C., Lopes, A.P., Nutman, A.P.,Liu, D., Sato, K. 2013a. Polycyclic evolution of Camboriú Complex migmatites, Santa Catarina, Southern Brazil: integrated $\mathrm{Hf}$ isotopic and U-Pb age zircon evidence of episodic reworking of a Mesoarchean juvenile crust. Braz. J. Geol., São Paulo 43, 427-443.

Basei, M.A.S., Sánchez Bettucci, L., Peel, E., Muzio, R., 2013b. Geocronología U-Pb LA-ICP-MS en circones del Complejo Granítico Santa Teresa, Terreno Punta del Este. VII Congreso Uruguayo de Geología, Montevideo, Proceedings, 30-31.

Basei, M.A.S.,Frimmel, H., Campos Neto,M.C., Araújo, C.A., Castro,N.A., Passarelli, C.R., 2018. The Tectonic History of the Southern Adamastor Ocean Based on a Correlation of the Kaoko and Dom Feliciano Belts. In: Siegesmund, S., Oyhantçabal, P., Basei, M.A.S., Oriolo, S. (Eds.) Geology of Southwest Gondwana. Regional Geology Reviews, Springer, Heidelberg, 63-85. 
Bense, F.A., Wemmer, K., Löbens, S., Siegesmund, S., 2014. Fault gouge analyses: K-Ar illite dating, clay mineralogy and tectonic significance - a study from the Sierras Pampeanas, Argentina. International Journal of Earth Sciences 103, 189-218.

Bicca, M.M., Chemale Jr., F., Jelinek, A.R., Oliveira, C.H.E., Guadagnin, F., Armstrong, R., 2013. Tectonic evolution and provenance of the Santa Bárbara Group, Camaquã Mines region, Rio Grande do Sul, Brazil. Journal of South American Earth Sciences 48, 173-192.

Bitencourt, M.F., Kruhl, J.H., 2000. Crustal-scale shearing, magmatism and the development of deformation structures: an example from Santa Catarina (Southern Brazil). Zeitschrift für Angewandte Geologie SH1/2000, 229-236.

Bitencourt, M.F., Nardi, L.S., 1993. Late-to post-collisional Brasiliano magmatism in southernmost Brazil. Anais da Academia Brasileira de Ciências 65(1), 3-6.

Bitencourt, M.F., Nardi, L.V.S., 2000. Tectonic setting and sources of magmatism related to the Southern Brazilian shear Belt. Revista Brasileira de Geociências 30, 186-189.

Bitencourt, M. F., Nardi, L. V. S., 2004. The role of xenoliths and flow segregation in the genesis and evolution of the Paleoproterozoic Itapema Granite, a crustally derived magma of shoshonitic affinity from southern Brazil. Lithos 73(1), 1-19.

Bitencourt, M.F., Bongiolo, E., Philipp, R.P., Morales, L.F., Ruber, R.R., Melo, C.L., Luft Jr., J.L., 2008. Estratigrafia do Batólito Florianópolis, Cinturão Dom Feliciano, na Região de Garopaba-Paulo Lopes, SC. Pesquisas em Geociências 35, 109-136.

Bitencourt, M.F., Nardi, L.V.S., Florisbal, L.M., Heaman, L., 2015. Geology, geochronology and petrogenesis of a Neoproterozoic, syntectonic sillimanite-muscovite-biotite granite from southernmost Brazil. In: Eighth Hutton Symposium on Granites and Related Rocks, Florianópolis, Brazil, Abstracts p. 176

Blanco, G., Gaucher, C., 2005. Estratigrafia, paleontologia y edad de la Formacion Las Ventanas (Neoproterozoico, Uruguay). Latin American journal of sedimentology and basin analysis 12(2), 109-124.

Blanco, G., Rajesh, H.M., Gaucher, C., Germs, G.J.B., Chemale Jr, F., 2009. Provenance of the Arroyo del Soldado Group (Ediacaran to Cambrian, Uruguay): Implications for the paleogeographic evolution of southwestern Gondwana. Precambrian Research 171, 57-73.

Blanco, G., Abre, P., Cabrera, J., Gaucher, C., 2014. Formación Rocha. in: Bossi, J., Gaucher, C. (Eds.) Geología del Uruguay - Tomo 1: Predevónico. DIRAC, Montevideo, 401-408.

Borba, A.W., Vignol-Lelarge, M.L.M., Mizusaki, A.M.P., 2002. Uplift and denudation of the Caçapava do Sul granitoids (southern Brazil) during Late Paleozoic and Mesozoic: constraints from apatite fission-track data. Journal of South American Earth Sciences 15(2), 683-692.

Borba, A.W., Lima, E.F., Vignol-Lelarge, M.L.M., Mizusaki, A.M.P., Sparrenberg, I., Barros, C.E., 2003. Significance of Late Paleozoic fission-track ages in volcanic rocks from the Lavras do Sul region, southernmost Brazil. Gondwana Research 6(1), 79-88. 
Borba, A.W., Mizusaki, A.M.P., Silva, D.R.A., Noronha, F.L., Casagrande, J., 2006. Provenance of the Neoproterozoic Maricá Formation (Sul-rio-grandense Shield, Southern Brazil): petrographic and Sm- Nd isotopic constrains. Gondwana Research 9, 464-474.

Borba, A.W., Mizusaki, A.M.P., Santos, J.O.S., Mc Naughton, N.J., Onoe, A.T., Hartmann, L.A., 2008. U-Pb zircon and 40Ar-39Ar K-feldspar dating of syn-sedimentary volcanism of the Neoproterozoic Maricá Formation: constraining the age of foreland basin inception and inversion in the Camaquã Basin of southern Brazil. Basin Research 20, 359-375.

Bossi, J., Campal, N., 1992. Magmatismo y tectónica transcurrente durante el Paleozoico inferior del Uruguay. In: Gutiérrez J et al. (Eds.) Paleozoico Inferior de Ibero-América. Universidad de Extremadura, Alicante, 343-356.

Bossi, J., Gaucher, C., 2004. The Cuchilla Dionisio Terrane, Uruguay: an allochthonous block accreted in the Cambrian to SW-Gondwana. Gondwana Research 7, 661-674.

Bouchez, J.-L., Delas, C., Gleizes, G., Nedelec, A., Cuney, M., 1992. Submagmatic microfractures in granites. Geology 20, 35-38.

Brito Neves, B.B., Fuck, R.A., 2014. The basement of the South American platform: Half Laurentian (NNW) + half Gondwanan (E-SE) domains. Precambrian Research 244, 75-86.

Caldasso, A.L.S., Krebs, A.S.J., da Silva, M.A.S., Camozzato, E., Ramgrab, G.E., 1995. Programa de Levantamentos Geológicos Básicos 1: 100,000; Folha Brusque (SG-22-Z-D-II-1), SC. CPRM, Brasília.

Caldasso, A.L.S., Krebs, A.S.J., da Silva, M.A.S., Camozzato, E., Ramgrab, G.E., 1995. Programa de Levantamentos Geológicos Básicos 1: 100,000; Folha Botuverá (SG-22-Z-D-I-2), SC. CPRM, Brasília.

Camozzato E., Lopes R.C., Philipp R.P., 2012. Mapa Geológico da Folha Hulha Negra (SH.22.Y-C-1), escala 1:100.000. Rio de Janeiro, Programa Levantamentos Geológicos, CPRM. v.1, 128 p.

Camozzato E., Philipp R.P., Chemale Jr. F., 2013. Evolução Tectônica e Geocronologia U-Pb em zircão da terminação sul do Terreno Tijucas (RS, Brasil). In: VII Congreso Uruguayo de Geología, Montevideo, Resúmenes Extendidos, 7.

Camozzato, E., Philipp, R.P., Laux, J.H., Chemale Jr., F., Iglesias, C.M. da F., 2016. O Batólito Torquato Severo e a colagem dos terrenos Taquarembó e São Gabriel, RS. In: Congresso Brasileiro de Geologia, 48, Porto Alegre, Boletim de Resumos.

Campal, N., Schipilov, A., 1995. The Illescas bluish quartz rapakivi granite (Uruguay-South America): some geological features. In: Symposium Rapakivi granites and related rocks, Belem, Abstracts, 18.

Campal, N., Schipilov, A., 1999. The eastern edge of the Rio de la Plata Craton: a history of tangential collisions. Basement Tectonics 13, 33-48

Campal, N., Schipilov, A., 2005. La Formación Cerros de Aguirre: evidencias de magmatismo Vendiano en el Uruguay. Latin American Journal of Sedimentology and Basin Analysis 12, 161-174.

Campos, R.S. de, Philipp, R.P., 2007. Petrografia e geoquímica das rochas metavulcânicas máficas e ultramáficas do Complexo Metamórfico Brusque, região da Serra da Miséria, Itapema, SC. Revista Brasileira de Geociências 37(4), 705-726. 
Campos, R.S. de, Philipp, R.P., Massonne, H.J., Chemale Jr, F., Theye, T., 2012a. Petrology and isotope geology of mafic to ultramafic metavolcanic rocks of the Brusque Metamorphic Complex, southern Brazil. International Geology Review 54(6), 686-713.

Campos, R.S. de, Philipp, R.P., Massonne, H.J., Chemale, F., 2012b. Early post-collisional Brasiliano magmatism in Botuverá region, Santa Catarina, southern Brazil: Evidence from petrology, geochemistry, isotope geology and geochronology of the diabase and lamprophyre dikes. Journal of South American Earth Sciences 37, 266-278 .

Carreras, J., 2001. Zooming on Northern Cap de Creus shear zones. Journal of Structural Geology 23(9), 1457-1486.

Castro, N.A., Basei, M.A.S., Crósta, A.P., 1999. The W(Sn-Mo) specialized Catinga and other intrusive granitoids in the Brusque group, Neoproterozoic of the state or Santa Catarina, southern Brazil. RBG 29 (1), 17-26.

Çemen, I., Catlos, E.J., Gögus, O., Özerdem, C., 2006. Postcollisional extensional tectonics and exhumation of the Menderes massif in the Western Anatolia extended terrane, Turkey. Geological Society of America, Special Paper 409, 353-379.

Cernuschi, F., Dilles, J.H., Kent, A.J.R., Schroer, G., Raab, A.K., Conti, B., Muzio, R., 2014. Geology, geochemistry and geochronology of the Cretaceous Lascano East intrusive complex and magmatic evolution of the Laguna Merín basin, Uruguay. Gondwana Research 28 (2), 837-857.

Chemale Jr. F., 2000. Evolução Geológica do Escudo Sul-Rio-Grandense. In: Holz M., De Ros L.F. (Eds.) Geologia do Rio Grande do Sul. Editora UFRGS, Porto Alegre, 13-52.

Chemale Jr. F., Philipp R.P., Dussin I., Formoso M.L.L., Kawashita K., Berttotti A.L., 2011. Lu-Hf and U-Pb age determination of the Capivarita Anorthosite, Dom Feliciano belt, Brazil. Precambriam Research $186,117-126$.

Chemale, F., Mallmann, G., Bitencourt, M.F., Kawashita, K., 2012. Time constraints on magmatism along the Major Gercino Shear Zone, southern Brazil: implications for West Gondwana reconstruction. Gondwana Research 22 (1), 184-199.

Cherniak, D.J., Watson, E.B., 2001. Pb diffusion in zircon. Chemical Geology 172(1), 5-24.

Chiglino, L., Gaucher C., Sial A.N., Bossi J., Ferreira V.P., 2008. Chemostratigraphy of Mesoproterozoic carbonates in the Nico Pérez Terrane (Río de la Plata Craton). $33^{\circ}$ International Geological Congress, Oslo, Abstracts.

Chiglino, L., Gaucher C., Sial A.N., Bossi J., Ferreira V.P., Pimentel, M.M., 2010. Chemostratigraphy of Mesoproterozoic and Neoproterozoic carbonates of the Nico Pérez Terrane, Río de la Plata Craton, Uruguay. Precambrian Research 182, 313-336.

Cingolani, C.A., 2011. The Tandilia system of Argentina as a southern extension of the Río de la Plata craton: an overview. International Journal of Earth Sciences 100, 221-242.

Cingolani, C.A., Basei, M.A.S., Bossi, J., Piñeiro, D., Uriz N.J., 2012. U-Pb (LA-ICP-MS) zircon age of the La Paz Granite (Pando Belt, Uruguay): an Upper Neoproterozoic magmatic event in the Río de la Plata Craton. 8th South American Symposium on Isotope Geology, Medellin, abstracts. 
Clauer, N., Zwingmann, H., Liewig, N., Wendling, R., 2012. Comparative 40Ar/39Ar and K-Ar dating of illite-type clay minerals: A tentative explanation for age identities and differences. Earth-Science Reviews 115, 76-96.

Cobbold, P.R., Meisling, K.E., Mount, V.S., 2001. Reactivation of an obliquely rifted margin, Campos and Santos Basins, Southeastern Brazil. AAPG Bulletin 85, 1925-1944.

Cogné, N., Gallagher, K., Cobbold, P.R., 2011. Post-rift reactivation of the onshore margin of southeast Brazil: evidence from apatite (U-Th)/He and fission-track data. Earth and Planetary Science Letters 309, 118-130.

Cogné, N., Gallagher, K., Cobbold, P.R., Riccomini, C., Gautheron, C., 2012. Post-breakup tectonics in southeast Brazil from thermochronological data and combined inverse-forward thermal history modelling. Journal of Geophysical Research B: Solid Earth 117 (11), doi:10.1029/2012JB009340

Cogné, N., Cobbold, P.R., Riccomini, C., Gallagher, K., 2013. Tectonic setting of the Taubaté Basin (Southeastern Brazil): Insights from regional seismic profiles and outcrop data. Journal of South American Earth Sciences 42, 194-204.

Constenius, K.N., 1996. Late Paleogene extensional collapse of the Cordilleran foreland fold and thrust belt. Geological Society of America Bulletin 108, 20-39.

Contreras, J., Zühlke, R., Bowman, S., Bechstädt, T., 2010. Seismic stratigraphy and subsidence analysis of the southern Brazilian margin (Campos, Santos and Pelotas basins). Marine and Petroleum Geology 27(9), 1952-1980.

Cordani, U.G., D'Agrella-Filho, M.S., Brito-Neves, B.D., Trindade, R.I.F.. 2003. Tearing up Rodinia: the Neoproterozoic palaeogeography of South American cratonic fragments. Terra Nova 15(5), 350359.

Cordani, U. G., Pimentel, M. M., de Araújo, C. E. G., \& Fuck, R. A. (2013). The significance of the Transbrasiliano-Kandi tectonic corridor for the amalgamation of West Gondwana. Brazilian Journal of Geology 43(3), 583-597.

Cosca, M.A., Essene, E.J., Mezger, K., van der Pluijm, B.A., 1995. Constraints on the duration of tectonic processes: Protracted extension and deep-crustal rotation in the Grenville orogen. Geology 23(4), 361-364.

Costa, M.S., Nascimento, M.S., 2015. Tratos deposicionais e arquitetura estratigráfica de sucessões sedimentares da Bacia do Itajaí (Neoproterozoico), nordeste de Santa Catarina, Brasil. Geologia USP, série científica 15(2), 111-134.

Danišík, M., Mclnnes, B.I., Kirkland, C.L., McDonald, B.J., Evans, N.J., Becker, T., 2017. Seeing is believing: Visualization of He distribution in zircon and implications for thermal history reconstruction on single crystals. Science Advances 3(2), e1601121.

de Santa Ana, H., 2004. Análise Tectono-estratigráfica das Sequëncias Permotriassica e Jurocretácea da Bacia Chacoparanense Uruguaia (“Cuenca Norte”). PhD Thesis, State University of São Paulo.

de Wit, M.J., Bowring, S.A., Ashwal, L.D., Randrianasolo, L.G., Morel, V.P., Rambeloson, R.A., 2001. Age and tectonic evolution of Neoproterozoic ductile shear zones in southwestern Madagascar, with implications for Gondwana studies. Tectonics 20(1), 1-45. 
Demoulin, A., Zarate, M., Rabassa, J., 2005. Long-term landscape development: a perspective from the southern Buenos Aires ranges of east central Argentina. Journal of South American Earth Sciences 19, 1963-204.

Dunkl, I., Mikes, T., Simon, K., von Eynatten, H., 2008. Brief introduction to the Windows program Pepita: data visualization, and reduction, outlier rejection, calculation of trace element ratios and concentrations from LAICPMS data. Mineralogical Association of Canada, Short Course 40, 334340 .

Duvall, A.R., Clark, M.K., van der Pluijm, B.A., Li, C., 2011: Direct dating of Eocene reverse faulting in northeastern Tibet using Ar-dating of fault clays and low-temperature thermochronometry. Earth and Planetary Science Letters 304, 520-526.

Egli, D., Mancktelow, N., Spikings, R., 2017. Constraints from 40Ar/39Ar geochronology on the timing of Alpine shear zones in the Mont Blanc-Aiguilles Rouges region of the European Alps. Tectonics 36(4), 730-748.

Ernesto, M., Raposo, M.I.B., Marques, L.S., Renne, P.R., Diogo, L.A., de Min, A., 1999. Paleomagnetism, geochemistry and 40Ar/39Ar dating of the North-eastern Paraná Magmatic Province: tectonic implications. Journal of Geodynamics 28 (4-5), 321-340.

Fambrini, G.L., Fragoso-Cesar, A.R.S., Almeida, R.P., Riccomini, C., 2005. A Formaçao Barriga Negra (Ediacarano do Uruguai): caracterizaçao estratigráfica e correlaçao com unidades do estado do Rio Grande do Sul, Brasil. Revista Brasileira de Geociências 35, 515-524.

Fantin, M., 2003, Geología de la Sierra de Aguirre, Departamento de Rocha, Uruguay. Graduation dissertation, Universidad de Buenos Aires, 92 pp.

Farley K.A., 2002. (U-Th)/He Dating: Techniques, Calibrations, and Applications. Reviews in Mineralogy and Geochemistry 47(1), 819-844.

Farley, K.A., Wolf, R.A., Silver, L.T., 1996. The effects of long alpha-stopping distances on (U-Th)/He ages. Geochimica et Cosmochimica Acta 60(21), 4223-4229.

Fernandes, L.A.A, Koester, E., 1999. The Neoproterozoic Dorsal de Canguqii strike-slip shear zone: its nature and role in the tectonic evolution of southern Brazil. Journal of African Earth Sciences 29 (1), 3-24.

Fernandes, L.A.D., Tommasi, A., Porcher, C.C., 1992. Deformation Patterns in the southern Brazilian branch of the Dom Feliciano Belt: A reappraisal. Journal of South American Earth Sciences 5, 7796.

Fernandes, L.A.D., Tommasi, A., Vauchez, A., Percher, C.C., Menegat, R., Koester, E., 1993. Zona de cisalhamento transcorrente Dorsal de Canguçu: Caracterizacão e importancia na compartimentação tectônica do Cinturão Dom Feliciano. Revista Brasileira de Geociencias 23, 110.

Fernandes, L.A.D., Menegat, R., Costa, A.F.U., Koester, E., Porcher, C.C., Tommasi, A., Kramer, G., Ramgrab, G.E., Camazzoto, E., 1995. Evolução Tectônica do Cinturão Dom Feliciano no Escudo Sulriograndense: Parte I- Uma Contribuição a partir do registro geológico. Revista Brasileira de Geociências 25, 351-374. 
Figueiredo, F.T., Almeida, R.P., Freitas, B.T., Marconato, A., Carrera, S.C., Turra, B.B., 2015. Tectonic activation, source area stratigraphyand provenance changes in a rift basin: the Early CretaceousTucano Basin (NE-Brazil). Basin Research 1-13, doi: 10.1111/bre.12115.

Florisbal, L.M., Bitencourt, M.F., Nardi, L.V.S., Conceição, R.V., 2009. Early postcollisional granitic and coeval mafic magmatism of medium- to high-K tholeiitic affinity within the Neoproterozoic Southern Brazilian Shear Belt. Precambrian Research 175, 135-148.

Florisbal, L.M., Janasi, V.A., Bitencourt, M.F., Nardi, L.V.S., Heaman, L.M., 2012. Contrasted crustal sources as defined by whole-rock and $\mathrm{Sr}-\mathrm{Nd}-\mathrm{Pb}$ isotope geochemistry of Neoproterozoic early post-collisional granitic magmatism within the Southern Brazilian Shear Belt, Camboriú, Brazil. Journal of South American Earth Science 39, 24-43

Florisbal, L.M., Janasi, V.A., Bitencourt, M.F., Heaman, L.M., 2012. Space-time relation of post-collisional granitic magmatism in Santa Catarina, southern Brazil: U-Pb LAMC-ICP-MS zircon geochronology of coeval mafic-felsic magmatism related to the Major Gercino Shear Zone. Precambrian Research 216-219, 132-151

Florisbal, L.M., Bitencourt, M.F., Janasi, V.A., Nardi, L.V.S., Heaman, L.M., 2012. Petrogenesis of syntectonic granites emplaced at the transition from thrusting to transcurrent tectonics in postcollisional setting: whole-rock and $\mathrm{Sr}-\mathrm{Nd}-\mathrm{Pb}$ isotope geochemistry in the Neoproterozoic Quatro Ilhas and Mariscal granites, southern Brazil. Lithos 153, 53-71

Florisbal, L.M., Heaman, L.M., de Assis Janasi, V., Bitencourt, M.F., 2014. Tectonic significance of the Florianópolis Dyke Swarm, Paraná-Etendeka Magmatic Province: A reappraisal based on precise $\mathrm{U}-\mathrm{Pb}$ dating. Journal of Volcanology and Geothermal Research 289, 140-150.

Flowers, R.M., Kelley, S.A., 2011. Interpreting data dispersion and inverted dates in apatite (U-Th)/He and fission-track datasets: an example from the U.S. mid-continent. Geochimica et Cosmochimica Acta 75 (18), 5169-5186.

Flowers, R., Ketcham, R.A:, Shuster, D.L., Farley, K.A., 2009. Apatite (U-Th)/He thermochronometry using a radiation damage accumulation and annealing model. Geochimica et Cosmochimica Acta 73, 2347-2365.

Flowers, R.M., Kelley, S.A., 2011. Interpreting data dispersion and "inverted" dates in apatite (U-Th)/He and fission-track datasets: an example from the US midcontinent. Geochimica et Cosmochimica Acta 75(18), 5169-5186.

Fort, S., Peel, E., Gallardo, P., 2016. Caracterización geoquímica de los Granitos Guazunambí, Policlínica y Yerbal. VIII Congreso uruguayo de Geología, Montevideo, Actas.

Fossen, H., 2010. Extensional tectonics in the North Atlantic Caledonides: a regional view. In: Law, R.D., Butler, R.W.H., Krabbendam, M. \& Strachan, R.A., (Eds.), Continental Tectonics and Mountain Building: The Legacy of Peach and Horne. Geological Society, London, Special Publications 335, 767-793.

Fossen, H., Cavalcante, G.C.G., 2017. Shear zones-A review. Earth-Science Reviews 171, 434-455.

Fossen, H., Khani, H.F., Faleide, J.I., Ksienzyk, A.K., Dunlap, W.J., 2016. Post-Caledonian extension in the West Norway-northern North Sea region: the role of structural inheritance. In: Childs, C., 
Holdsworth, R.E., Jackson, C.A.-L., Manzocchi, T., Walsh, J.J., Yielding, G., (Eds.), The Geometry and Growth of Normal Faults. Geological Society, London, Special Publications 439, SP 439-6.

Foster, D.A., Goscombe, B.D., Gray, D.R., 2009. Rapid exhumation of deep crust in an obliquely convergent orogeny: the Kaoko Belt of the Damara Orogen. Tectonics. doi:10.1029/2008TC002317.

Fragoso César, A.R.S., 1980. O Cráton do Rio de La Plata e o Cinturão Dom Feliciano no Escudo UruguaioSul e Riograndense. In: XXXI Congresso Brasileiro de Geologia, Camboriú, Santa Catarina, Brazil. Anais, 2879-2892

Franco, A.O.B., Hackspacher, P.C., Godoy, D.F., Ribeiro, L.F.B., Guedes, S., 2005. História térmica do Maciço Alcalino de Poços de Caldas (SP/MG) e adjacências através da análise de datação por traços de fissão em apatitas. Revista Brasileira de Geociências 35(3), 351-358.

Franco-Magalhães, A.O.B., Hackspacher, P.C., Glasmacher, U.A., Saad, A.R., 2010. Rift to post-rift evolution of a "passive" continental margin: the Ponta Grossa Arch, SE Brazil. International Journal of Earth Sciences 99, 1599-1613.

Franco-Magalhaes, A.O.B., Cuglieri, M.A.A., Hackspacher, P.C., Saad, A.R., 2014. Long-term landscape evolution and post-rift reactivation in the southeastern Brazilian passive continental margin: Taubaté basin. International Journal of Earth Sciences 103, 441-453.

Franke, D., Neben, S., Ladage, S., Schreckenberger, B., Hinz, K., 2007. Margin segmentation and volcanotectonic architecture along the volcanic margin off Argentina/Uruguay, South Atlantic. Marine Geology 244(1-4), 46-67.

Frantz, J.C., McNaughton, N.J., Marques, J.C., Hartmann, L.A., Botelho, N.F., Caravaca, G., 2003. SHRIMP $\mathrm{U}-\mathrm{Pb}$ zircon ages of granitoids from southernmost Brazil: constrains on the temporal evolution of the Dorsal de Canguçu transcurrent Shear Zone and Eastern Dom Feliciano Belt. In: IV South American Symposium on Isotope Geology, Salvador, Short Papers 174-177.

Frimmel, H.E., Klötzli, U.S., Siegfried, P.R., 1996. New Pb-Pb single zircon age constraints on the timing of Neoproterozoic glaciation and continental break-up in Namibia. The Journal of Geology 104(4), 459-469.

Frimmel, H.E., Fölling, P.G., Eriksson, P., 2002. Neoproterozoic tectonic and climatic evolution recorded in the Gariep Belt, Namibia and South Africa. Basin Research 14, 55-67.

Frimmel, H.E., Basei, M.A.S., Gaucher, C., 2011. Neoproterozoic geodynamic evolution of SW-Gondwana: a southern African perspective. International Journal of Earth Sciences 100, 323-54.

Frimmel, H.E., Basei, M.A., Correa, V.X., Mbangula, N., 2013. A new lithostratigraphic subdivision and geodynamic model for the Pan-African western Saldania Belt, South Africa. Precambrian Research 231, 218-235.

Fuhrmann, U., Lippolt, H.J., Hess, J.C., 1987. Examination of some proposed K-Ar standards: 40Ar/39Ar analyses and conventional K-Ar-data. Chemical Geology 66, 41-51.

Gallagher, K., Hawkesworth, C.J., Mantovani, M.S.M., 1994. The denudation history of the onshore continental margin of SE Brazil inferred from apatite fission track data. Journal of Geophysical Research: Solid Earth 99(B9), 18117-18145. 
Gallardo, P., Peel, E., Fort, S., 2016. Geoquímica del Complejo Granítico Polanco (Ediacárico-Cámbrico). VIII Congreso uruguayo de Geología, Montevideo, Actas

Ganade e Araujo, C.E. Rubatto, D., Hermann, J., Cordani, U.G., Caby, R., Basei, M.A.S., 2014. Ediacaran 2,500-km-long synchronous deep continental subduction in the West Gondwana Orogen. Nature communications 5, 5198.

Garda, G.M., Brentan, F., Basei, M.A.S., 2013. Turmalinitos do Grupo Brusque na região entre São João Batista e Tijucas, Santa Catarina, Brasil. Geologia USP - Série Científica 13(1), 73-94.

Gaucher, C., 2000. Sedimentology, palaeontology, and stratigraphy of the Arroyo del Soldado Group (Vendian to Cambrian, Uruguay). Beringeria 26, 1-120.

Gaucher, C., Finney, S.C., Poiré, D.G., Valencia, V.A., Grove, M., Blanco, G., Pamoukaghlián, K., Gómez Peral, L., 2008. Detrital zircon age of Neoproterozoic sedimentary successions of Uruguay and Argentina: Insights into the geological evolution of the Río de la Plata Craton. Precambrian Research 167, 150-170.

Gaucher, C., Frimmel, H.E., Germs, G. J., 2009. Tectonic events and palaeogeographic evolution of Southwestern Gondwana in the Neoproterozoic and Cambrian. In: Gaucher, C., Sial, A.N., Halverson, G.P., Frimmel, H.E. (Eds.), Neoproterozoic-Cambrian tectonics, global change and evolution: a focus on southwestern Gondwana. Developments in Precambrian Geology 16, 295316.

Gaucher, C., Frei, R., Frei, D., 2010. Detrital zircon U-Pb ages of the San Carlos Formation (latest Neoproterozoic, Uruguay) and the allochthonous nature of Arachania. In: VII South American Symposium on Isotope Geology, Brasília. Extended Abstracts, 556-559.

Gautheron, C., Barbarand, J., Ketcham, R.A., Tassan-Got, L., van der Beek, P., Pagel, M., Pinna-Jamme, R., Couffignal, F., Fialin, M., 2013. Chemical influence on $\alpha$-recoil damage annealing in apatite: Implications for (U-Th)/He dating. Chemical Geology 351, 257-267.

Ghosh, J.G., de Wit, M.J., Zartman, R.E., 2004. Age and tectonic evolution of Neoproterozoic ductile shear zones in the Southern Granulite Terrain of India, with implications for Gondwana studies. Tectonics 23(3). doi:10.1029/2002TC001444

Gibson, S.A., Thompson, R.N., Leonardos, O.H., Dickin, A.P., Mitchell, J.G., 1995. The Late Cretaceous impact of the Trindade mantle plume: evidence from large-volume, mafic, potassic magmatism in SE Brazil. Journal of Petrology 36(1), 189-229.

Gollmann, K., Marques, J.C., Frantz, J.C., Chemale Jr., F., 2008. Geoquímica e isótopos de Nd de rochas metavulcânicas da antiforme Capané, complexo metamórfico Porongos, RS. Pesquisas em Geociências 35(2), 83-95.

Gómez Rifas, C., 1995. A Zona de Cisalhamento Sinistral "Sierra Ballena" no Uruguai. PhD thesis, Universidade de São Paulo, 243 pp.

Goscombe, B., Gray, D.R., 2007. The Coastal Terrane of the Kaoko Belt, Namibia: outboard arc-terrane and tectonic significance. Precambrian Research 155(1), 139-158. 
Goscombe, B., Gray, D.R., 2008. Structure and strain variation at mid-crustal levels in a transpressional orogen: a review of Kaoko Belt structure and the character of West Gondwana amalgamation and dispersal. Gondwana Research 13(1), 45-85.

Goscombe, B., Hand, M., Gray, D., Mawby, J., 2003. The metamorphic architecture of a transpressional orogen: the Kaoko Belt, Namibia. Journal of Petrology 44(4), 679-711.

Goscombe, B., Gray, D., Armstrong, R., Foster, D.A., Vogl, J., 2005. Event geochronology of the PanAfrican Kaoko Belt, Namibia. Precambrian Research 140, 103.e1-103.e41.

Goscombe, B., Foster, D.A., Gray, D., Wade, B., Marsellos, A., Titus, J., 2017a. Deformation correlations, stress field switches and evolution of an orogenic intersection: the Pan-African Kaoko-Damara orogenic junction, Namibia. Geoscience Frontiers 8(6), 1187-1232.

Goscombe, B., Foster, D.A., Gray, D., Wade, B., 2017b. Metamorphic response and crustal architecture in a classic collisional orogen: The Damara Belt, Namibia. Gondwana Research 52, 80-124.

Goscombe, B., Foster, D.A., Gray, D., Wade, B., 2018. The Evolution of the Damara Orogenic System: A Record of West Gondwana Assembly and Crustal Response. In: Siegesmund, S., Oyhantçabal, P., Basei, M.A.S., Oriolo, S. (Eds.) Geology of Southwest Gondwana. Regional Geology Reviews, Springer, Heidelberg, 303-352.

Grathoff, G.H., Moore, D.M., 1996. Illite polytype quantification using Wildfire calculated x-ray diffraction patterns. Clays and Clay Minerals 44(6), 835-842.

Grathoff, G.H., Moore, D.M., Hay, R.L., Wemmer, K., 1998. Illite Polytype Quantification and K/Ar Dating of Paleozoic Shales: A Technique to Quantify Diagenetic and Detrital Illite. In: Schieber, J., Zimmerle, W., Sethi, P.S. (Eds.): Shales and Mudstones II - Petrography, Petrophysics, Geochemistry, and Economic Geology. Schweizerbart'sche Verlagsbuchhandlung, Stuttgart, Germany, pp. 161-175.

Grathoff, G.H., Moore, D.M., Hay, R.L., Wemmer, K., 2001. Origin of illite in the lower Paleozoic of the Illinois basin: Evidence for brine migrations. Geological Society of America Bulletin 113, 10921104.

Gray, D.R., Foster, D.A., Goscombe, B., Passchier, C.W., Trouw, R.A.J., 2006. 40Ar/39Ar thermochronology of the Pan-African Damara Orogen, Namibia with implications for tectonothermal and geodynamic evolution. Precambrian Research 150, 49-72.

Gray, D.R., Foster, D.A., Meert, J.G., Goscombe, B.D., Armstrong, R., Trouw, R.A.J., Passchier, C.W., 2008. A Damara orogen perspective on the assembly of southwestern Gondwana. Geological Society, London, Special Publications 294(1), 257-278.

Gregory, T.R., Bitencourt, M.A.F.S., Nardi, L.V.S., 2011. Caracterização estrutural e petrológica de metatonalitos e metadioritos do Complexo Arroio dos Ratos na sua seção-tipo, região de Quitéria, RS. Pesquisas em Geociências 38(2), 85-108.

Gregory T.R., Bitencourt M.A.F.S., Nardi L.V.S., Florisbal L.M., Chemale Jr. F., 2015. Geochronological data from TTG-type rock associations of the Arroio dos Ratos Complex and implications for crustal evolution of southernmost Brazil in Paleoproterozoic times. Journal of South American Earth Sciences 57, 49-60. 
Gross, A.O.M.S, Porcher, C.C., Fernandes, L.A.D., Koester, E., 2006. Neoproterozoic low-pressure/hightemperature colisional metamorphic evolution in the Varzea do Capivarita Metamorphic Suite, SE Brazil: Thermobarometric and Sm/Nd evidence. Precambrian Research 147, 41-64.

Gruber L., Porcher C.C., Lens C., Fernandes L.A.D., 2011. Proveniência dos metassedimentos das seqüências Arroio Areião, Cerro Cambará e Quartzo Milonitos no Complexo Metamórfico Porongos, Santana da Boa Vista, RS. Pesquisas em Geociências 38(3), 205-223.

Guadagnin F., Chemale Jr. F., Dussin I.A., Jelinek A.R., Santos M.N., Borba, M.L., Justino D., Bertotti A.L., Alessandretti L., 2010. Depositional age and provenance of the Itajaí Basin, Santa Catarina State, Brazil: Implications for SW Gondwana correlation. Precambrian Research 180, 156-182.

Gubert, M.L., Philipp, R.P., Basei, M.A.S., 2016. The Bossoroca Complex, São Gabriel Terrane, Dom Feliciano Belt, southernmost Brazil: UPb geochronology and tectonic implications for the neoproterozoic São Gabriel Arc. Journal of South American Earth Sciences 70, 1-17.

Guenthner W.R., Reiners, P.W., Ketcham, R.A., Nasdala, L., Giester, G., 2013. Helium diffusion in natural zircon: radiation damage, anisotropy, and the interpretation of zircon (U-Th)/He thermochronology. American Journal of Science 313, 145-198.

Guenthner W.R., Reiners, P.W., DeCelles, P.G., Kendall, J., 2015. Sevier belt exhumation in central Utah constrained from complex zircon (U-Th)/He data sets: Radiation damage and He inheritance effects on partially reset detrital zircons. Geological Society of America Bulletin 127, doi: 10.1130/B31032.1

Guenthner, W.R., Reiners, P.W., Drake, H., Tillberg, M., 2017. Zircon, titanite, and apatite (U-Th)/He ages and age-eU correlations from the Fennoscandian Shield, southern Sweden. Tectonics 36, 12541274.

Hackspacher, P.C., Ribeiro, L.F.B., Ribeiro, M.C.S., Fetter, A.H., Hadler Neto, J.C.., Tello Saenz, C.A., Dantas, E.L., 2004. Consolidation and break-up of the South American platform in southeastern Brazil: tectonothermal and denudation histories. Gondwana Research 1, 91-101.

Hackspacher, P.C., Godoy, D.F., Ribeiro, L.F.B., Neto, J.C.H., Franco, A.O.B., 2007. Modelagem térmica e geomorfologia da borda sul do Cráton do São Francisco: termocronologia por traços de fissão em apatita. Revista Brasileira de Geociências 37(4), 76-86.

Harrison, T. M., 1982. Diffusion of 40Ar in hornblende. Contributions to Mineralogy and Petrology 78(3), 324-331.

Harrison, T.M., Duncan, I., McDougall, I., 1985. Diffusion of 40Ar in biotite: Temperature, pressure and compositional effects. Geochimica et Cosmochimica Acta 49, 2461-2468.

Harrison, T.M., Célérier, J., Aikman, A.B., Hermann, J., Heizler, M.T., 2009. Diffusion of 40Ar in muscovite. Geochimica et Cosmochimica Acta 73, 1039-1051.

Hartmann, L. A., Chemale Jr., F., 2003. Mid amphibolite facies metamorphism of harzburgites in the Neoproterozoic Cerro Mantiqueiras Ophiolite, southernmost Brazil. Anais da Academia Brasileira de Ciências 75(1), 109-128.

Hartmann, L.A., Leite, J.A.D., Mcnaughton, N.J., Santos, J.O.S., 1999. Deepest exposed crust of Brazil SHRIMP establishes three events. Geology 27, 947-950. 
Hartmann, L.A., Leite, J.A.D., Silva, L.C., Remus, M.V.D., McNaughton, N.J., Groves, D.I., Fletcher, I.R., Santos, J.O.S., and Vasconcellos, M.A.Z., 2000. Advances in SHRIMP geochronology and their impact on understanding the tectonic and metallogenic evolution of southern Brazil: Australian Journal of Earth Sciences 47, 829-844.

Hartmann, L.A., Campal, N., Santos, J.O.S., McNaughton, N.J., Bossi, J., Schipilov, A., Lafon, J.-M., 2001. Archean crust in the Río de la Plata Craton, Uruguay - SHRIMP U-Pb zircon reconnaissance geochronology. Journal of South American Earth Sciences 4, 557-570.

Hartmann, L.A., Santos, J.O.S., Bossi, J., Campal, N., Schipilov, A., McNaughton, N.J., 2002. Zircon and titanite U-Pb SHRIMP geochronology of Neoproterozoic felsic magmatism on the eastern border of the Río de la Plata Craton, Uruguay. Journal of South American Earth Sciences 15, 229-236.

Hartmann, L.A., Bitencourt, M.F., Santos, J.O.S., McNaughton, N.J., Rivera, C.B., Betiollo, L., $2003 a$. Prolonged Paleoproterozoic magmatic participation in the Neoproterozoic Dom Feliciano belt, Santa Catarina, Brazil, based on zircon U-Pb SHRIMP geochronology. Journal of South American Earth Sciences 16, 477-492.

Hartmann, L.A., Santos, J.O.S., Leite, J.A.D., Porcher, C.C., McNaughton, I., Neal, J., 2003b. Metamorphic evolution and U-Pb zircon SHRIMP geochronology of the Belizário ultramafic amphibolite, Encantadas Complex, southernmost Brazil. Anais Academia Brasileira de Ciências 75(3), 393-403.

Hartmann, L.A., Philipp, R.P., Liu, D., Wan, Y., Wang, Y., Santos, J.O.S., Vasconcellos, M.A.Z., 2004. Paleoproterozoic provenance of detrital zircon, Porongos Complex quartzites, southern Brazilian Shield. International Geology Review 46, 127-157.

Hartmann, L.A., Liu, D., Wang, Y., Massonne, H.J., Santos, J. dos, 2008. Protolith age of Santa Maria Chico granulites dated on zircons from an associated amphibolite-facies granodiorite in southernmost Brazil. Annals of the Brazilian Academy of Sciences 80(3), 543-551.

Hartmann, L.A., Philipp, R.P., Santos, J.O.S., McNaughton, N.J., 2011. Time frame of 753-680 Ma juvenile accretion during the São Gabriel orogeny, southern Brazil. Gondwana Research 19, 84-99.

Heilbron, M., Machado, N., 2003. Timing of terrane accretion in the Neoproterozoic-Eopaleozoic Ribeira orogen (SE, Brazil). Precambrian Research, 125(1-2), 87-112.

Heilbron, M., Pedrosa-Soares, A.C., Campos Neto, M.D.C., Silva, L.D., Trouw, R.A.J., Janasi, V.D.A., 2004. Província Mantiqueira. In: Mantesso-Neto, V., Bartorelli, A., Carneiro C.D.R., Brito Neves, B.B. (Eds.) Geologia do continente sul-americano: evolução da obra de Fernando Flávio Marques de Almeida. Beca, São Paulo, 203-235.

Heilbron, M., Valeriano, C.M., Tassinari, C.C.G., Almeida, J., Tupinambá, M., Siga, O., Trouw, R., 2008. Correlation of Neoproterozoic terranes between the Ribeira Belt, SE Brazil and its African counterpart: comparative tectonic evolution and open questions. Geological Society, London, Special Publications 294(1), 211-237.

Henza, A.A.,Withjack, M.O., Schlische, R.W., 2011. How do the properties of a pre-existing normal-fault population influence fault development during a subsequent phase of extension? Journal of Structural Geology 33, 1312-1324.

Hiruma, S.T., Riccomini, C., Modenesi-Gauttieri, M.C., Hackspacher, P.C., Hadler Neto, J.C., FrancoMagalhães, A.O.B., 2010. Denudation history of the Bocaina Plateau, Serra do Mar, Southeastern 
Brazil: relationships to Gondwana breakup and passive margin development. Gondwana Research $18,674-687$.

Höfig, D.F., Marques, J.C., Basei, M.A.S., Giusti, R.O., Kohlrausch, C., Frantz, J.C., 2017. Detrital zircon geochronology (U-Pb LA-ICP-MS) of syn-orogenic basins in SW Gondwana: new insights into the Cryogenian-Ediacaran of Porongos Complex, Dom Feliciano Belt, southern Brazil. Precambrian Research 306, 189-208.

Holz, M., Küchle, J., Philipp, R.P., Bischoff, A.P., Arima, N., 2006. Hierarchy of tectonic control on stratigraphic signatures: base-level changes during the early Permian in the Paraná Basin, southernmost Brazil. Journal of South American Earth Sciences 22(3), 185-204.

Holz, M., França, A.B., Souza, P.A., lannuzzi, R., Rohn, R., 2010. A stratigraphic chart of the Late Carboniferous/Permian succession of the eastern border of the Paraná Basin, Brazil, South America. Journal of South American Earth Sciences 29(2), 381-399.

Hueck, M., Basei, M.A.S., de Castro, N.A., 2016. Origin and evolution of the granitic intrusions in the Brusque Group of the Dom Feliciano Belt, south Brazil: Petrostructural analysis and wholerock/isotope geochemistry. Journal of South American Earth Sciences 69, 131-151.

Hueck, M., Oriolo, S., Dunkl, I., Wemmer, K., Oyhantçabal, P., Schanofski, M., Basei, M.A.S., Siegesmund, S., 2017. Phanerozoic low-temperature evolution of the Uruguayan Shield along the South American passive margin. Journal of the Geological Society of London 174, 609-626.

Hueck, M., Oyhantçabal, P., Philipp, R.P., Basei, M.A.S., Siegesmund, S., 2018. The Dom Feliciano Belt in Southern Brazil and Uruguay. In: Siegesmund, S., Oyhantçabal, P., Basei, M.A.S., Oriolo, S. (Eds.) Geology of Southwest Gondwana. Regional Geology Reviews, Springer, Heidelberg, 267-302.

Hueck, M., Basei, M.A.S., Wemmer, K., Oriolo, S., Heidelbach, F., Siegesmund, S., 2018b. Evolution of the Major Gercino Shear Zone in the Dom Feliciano Belt, South Brazil, and Implications for the Assembly of Southwestern Gondwana. International Journal of Earth Sciences, DOI: 10.1007/s00531-018-1660-4

Hueck, M., Dunkl, I., Heller, B., Basei, M.A.S., Siegesmund, S., 2018c. (U-Th)/He thermochronology and zircon radiation damage in the South American passive margin: Thermal overprint of the Paraná LIP? Tectonics, DOI: 10.1029/2018TC005041

Hueck, M., Basei, M.A.S., Castro, N.A. Tracking the sources and the emplacement of the Neoproterozoic granitic intrusions in the Brusque Group, Dom Feliciano Belt, South Brazil: LA-ICP-MS and SHRIMP geochronology coupled to $\mathrm{Hf}$ isotopic analysis. Submitted to Precambrian Research.

Hunziker, J.C., Frey, M., Clauer, N., Dallmeyer, R.D., Friedrichsen, H., Flehmig, W., Hochstrasser, K., Roggwiler, P., Schwander, H., 1986. The evolution of illite to muscovite: mineralogical and isotopic data from the Glarus Alps, Switzerland. Contributions to Mineralogy and Petrology 92(2), 157-180.

Hurter, S.J., Pollack, H.N., 1994. Effect of the Cretaceous Serra Geral igneous event on the temperatures and heat flow of the Paraná Basin, southern Brazil. Basin Research 6, 239-244.

Irmer, G., 1985. Zum Einfluß der Apparatefunktion auf die Bestimmung von Streuquerschnitten und Lebensdauern aus optischen Phononenspektren. Experimentelle Technik der Physik 33 (6), 501506. 
Janasi, V.A., Freitas, V.A., Heaman, L.H., 2011. The onset of flood basalt volcanism, Northern Paraná Basin, Brazil: A precise U-Pb baddeleyite/zircon age for a Chapecó-type dacite. Earth and Planetary Science Letters 302, 147-153.

Janikian L., Almeida R.P., Fragoso-Cesar A.R.S., Martins V.T.S., Dantas E.L., Tohver E., Mc Reath I., D'Agrella Filho M.S, 2012. Ages (U-Pb SHRIMP and LA-ICP-MS) and stratigraphic evolution of the Neoproterozoic volcano-sedimentary successions from extensional Camaquã Basin, Southern Brazil. Gondwana Research 21, 466-482.

Jelinek, A.R., Neto, A.C.B., Poupeau, G., 2003. Análise por traços de fissão em apatitas do Distrito Fluorítico de Santa Catarina: relações entre hidrotermalismo e evolução da margem continental. Revista Brasileira de Geociências 33(3), 289-298.

Jelinek, A.R., Chemale Jr., F.C., van der Beek, P.A., Guadagnin, F., Cupertino, J.A., Viana, A., 2014. Denudation history and landscape evolution of the northern East-Brazilian continental margin from apatite fission-track thermochronology. Journal of South American Earth Sciences 54, 158181

Jessell, M.W., 1987. Grain-boundary migration microstructures in a naturally deformed quartzite. Journal of Structural Geology 9, 1007-1014.

Johnson, J.E., Flowers, R.M., Baird, G.B., Mahan, K.H., 2017. "Inverted" zircon and apatite (U-Th)/He dates from the Front Range, Colorado: High-damage zircon as a low-temperature $\left(<50{ }^{\circ} \mathrm{C}\right)$ thermochronometer. Easth and Planetary Earth Sciences 466, 80-90.

Jost, H., 1981. Geology and Metallogeny of the Santana da Boa Vista region, South Brazil. PhD thesis, University of Athens, Georgia, 208p.

Karl, M., Glasmacher, U.A., Kollenz, S., Franco-Magalhaes, A.O.B., Stockli, D.F., Hackspacher, P.C., 2013. Evolution of the South Atlantic passive continental margin in southern Brazil derived from zircon and apatite (U-Th-Sm)/He and fission-track data. Tectonophysics 604, 224-244.

Ketcham, R.A., 2005. Forward and inverse modeling of low-temperature thermochronometry data. Reviews in Mineralogy and Geochemistry 58(1), 275-314.

Ketcham, R.A., Gautheron, C., Tassan-Got, L., 2011. Accounting for long alpha-particle stopping distances in $(\mathrm{U}-\mathrm{Th}-\mathrm{Sm}) / \mathrm{He}$ geochronology: Refinement of the baseline case. Geochimica et Cosmologica Acta $75,7779-7791$.

Kilian, R., Heilbronner, R., Stünitz, H., 2011. Quartz microstructures and crystallographic preferred orientation: which shear sense do they indicate? Journal of structural geology 33(10), 1446-1466.

Kisters, A., Belcher, R., 2018. The stratigraphy and structure of the western saldania belt, south africa and geodynamic implications. In: Siegesmund, S., Oyhantçabal, P., Basei, M.A.S., Oriolo, S. (Eds.) Geology of Southwest Gondwana. Regional Geology Reviews, Springer, Heidelberg, 387-410.

Kleiman, L.E., Japas, M.S., 2009. The Choiyoi volcanic province at $34^{\circ} \mathrm{S}-36^{\circ} \mathrm{S}$ (San Rafael, Mendoza, Argentina): Implications for the Late Palaeozoic evolution of the southwestern margin of Gondwana. Tectonophysics 473, 283-299. 
Koester, E., Soliani Jr., E., Fernandes, L.A.D., Kramer, G., Tommasi, A., 1997. Geocronologia Rb/Sr e K/Ar dos granitóides sintectônicos à Zona de Cisalhamento Transcorrente Dorsal de Canguçu. Pesquisas em Geociências 24, 67-77.

Koester, E., Roisenberg, A., Fernandes, L.A.D., Soliani Jr., E., Nardi, L.V.S., Kraemer, G., 2001a. Petrologia dos granitóides sintectônicos à Zona de Cisalhamento Transcorrente Dorsal de Canguçu, Encruzilhada do Sul, RS. Revista Brasileira de Geociências, 31(2):131-140.

Koester, E., Fernandes, L.A.D., Solani Jt, E.S., Nardi, L.V.S., Kraemer, G., Roisenberg, A., 2001b. Geologia e geoquímica de granitóides sintectônicos à Zona de Cisalhamento Transcorrente Dorsal do Canguçu, Encruzilhada do Sul, RS. Revista Brasileira de Geociências 31(2), 141-154.

Koester, E., Soliani Jr., E., Leite, J.A.D., Hartmann, L.A., Fernandes, L.A.D., McNaughton, N.J., Santos, J.O.S., Oliveira, L.D., 2001c. SHRIMP U-Pb age for the emplacement of the Santana Granite and reactivation of the Porto Alegre Suture, southern Brazil. Journal of South American Earth Sciences 14, 91-99.

Koester, E., Porcher, C.C., Pimentel, M.M., Fernandes, L.A.D., Vignol-Lelarge, M.L., Oliveira, L.D., Ramos, R.C., 2016. Further evidence of $777 \mathrm{Ma}$ subduction-related continental arc magmatism in Eastern Dom Feliciano Belt, southern Brazil: the Chácara das Pedras Orthogneiss. Journal of South American Earth Sciences 68, 155-166.

Kollenz, S., 2015. Long-term landscape evolution, cooling and exhumation history of the South American passive continental margin in NE Argentina \& SW Uruguay. Phd Thesis, Ruprecht-Karls-Universität Heidelberg.

Kollenz, S., Glasmacher, U.A., Rossello, E.A., Stockli, D.F., Schad, S., Pereyra, R.E., 2016. Thermochronological constraints on the Cambrian to recent geological evolution of the Argentina passive continental margin. Tectonophysics 716, 182-203.

Konopásek, J., Kröner, S., Kitt, S.L., Passchier, C.W., Kröner, A., 2005. Oblique collision and evolution of large-scale transcurrent shear zones in the Kaoko belt, NW Namibia. Precambrian Research 136(2), 139-157.

Konopásek, J., Košler, J., Tajčmanová, L., Ulrich, S., Kitt, S. L., 2008. Neoproterozoic igneous complex emplaced along major tectonic boundary in the Kaoko Belt (NW Namibia): ion probe and LA-ICPMS dating of magmatic and metamorphic zircons. Journal of the Geological Society of London, 165(1) 153-165.

Konopásek, J., Janoušek, V., Oyhantçabal, P., Sláma, J., Ulrich, S., 2018. Did the circumrodinia subduction trigger the Neoproterozoic rifting along the Congo-Kalahari Craton margin?. International Journal of Earth Sciences, in press.

Ksienzyk, A.K., Wemmer, K., Jacobs, J., Fossen, H., Schomberg, A.C., Süssenberger, A., Lünsdorf, N.K., Bastesen, E., 2016. Post-Caledonian brittle deformation in the Bergen area,West Norway: results from K-Ar illite fault gouge dating. Norwegian Journal of Geology 96 (3), 1-25.

Kübler, B., 1967. La cristallinité de l'illite et les zones tout à fait supérieures du métamorphism. Etages Tectonique, Colloque de Neuchâtel, Neuchâtel 
Lara, P., Oyhantçabal, P., Dadd, K., 2016. Post-Collisional, Late Neoproterozoic, High-Ba-Sr Granitic Magmatism From The Dom Feliciano Belt And Its Cratonic Foreland, Uruguay. VIII Congreso uruguayo de Geología, Montevideo, Actas.

Lara, P., Oyhantçabal, P., Dadd, K., 2017. Post-collisional, Late Neoproterozoic, high-Ba-Sr granitic magmatism from the Dom Feliciano Belt and its cratonic foreland, Uruguay: Petrography, geochemistry, geochronology, and tectonic implications. Lithos 277, 178-198.

Laux, J.H., Bongiolo, E.M., Klein, C., Iglesias, C.M.F., 2012. Carta Geológica da Folha Lagoa da Meia Lua (SH.21-Z-B-VI), Escala 1:100.000. CPRM, Porto Alegre.

Leite, J.A.D., Hartmann, L.A., McNaughton, N.J., Chemale Jr., F., 1998. SHRIMP U/Pb zircon geochronology of Neoproterozoic juvenile and crustal-reworked terranes in southernmost Brazil. International Geology Review 40, 688-705.

Leite, J.A.D., Hartmann, L.A., Fernandes, L.A.D., McNaughton, N.J., Soliani Jr., E., Koester, E., Santos, J.O.S., Vasconcellos, M.A.Z., 2000. Zircon U-Pb SHRIMP dating of gneissic basement of the Dom Feliciano Belt, southernmost Brazil. Journal of South American Earth Sciences 13, 739-750.

Lena, L.O.F., Pimentel, M.M., Philipp, R.P., Armstrong, R., Sato, K., 2014. The evolution of the Neoproterozoic São Gabriel juvenile terrane, southern Brazil based on high spatial resolution U-Pb ages and 180 data from detrital zircons. Precambrian Research 247, 126-138.

Lenz, C., Fernandes, L.A.D., McNaughton, N.J., Porcher, C.C., Masquelin, H., 2011. U-Pb SHRIMP ages for the Cerro Bori Orthogneisses, Dom Feliciano Belt in Uruguay: Evidences of a 800 Ma magmatic and a 650 Ma metamorphic event. Precambrian Research 185, 149-163.

Lenz, C., Porcher, C.C., Fernandes, L.A.D., Masquelin, H., Koester, E., Conceição, R. V., 2013. Geochemistry of the Neoproterozoic (800-767 Ma) Cerro Bori orthogneisses, Dom Feliciano Belt in Uruguay: tectonic evolution of an ancient continental arc. Mineralogy and Petrology 107(5), 785806.

Lima, E.F.L., Porcher C.A., Wildner W., 1998. Granulitos da região da Várzea do Capivarita - Bloco Encruzilhada do Sul, RS. Pesquisas em Geociências 25(1), 27-33.

Lister, G.S., Hobbs, B.E., 1980. The simulation of fabric development during plastic deformation and its application to quartzite: the influence of deformation history. Journal of Structural Geology 2(3), 355-370.

Lloyd, G.E., Schmidt, N.H., Mainprice, D., Prior, D. J., 1991. Crystallographic textures. Mineralogical Magazine 55(380), 331-345.

Löbens, S., Bense, F.A., Wemmer, K., Dunkl, I., Costa, C.H., Layer, P., Siegesmund, S., 2011. Exhumation and uplift of the Sierras Pampeanas: preliminary implications from K-Ar fault gouge dating and low-T thermochronology in the Sierra de Comechingones (Argentina). International Journal of Earth Sciences 100, 671-694.

Lopes de Luchi, M.G., Dopico, C.I.M., Wemmer, K., Siegesmund, S., 2018. Untangling the NeoproterozoicEarly Paleozoic Tectonic Evolution of the Eastern Sierras Pampeanas Hidden in the Isotopical Record. In: Siegesmund, S., Oyhantçabal, P., Basei, M.A.S., Oriolo, S. (Eds.) Geology of Southwest Gondwana. Regional Geology Reviews, Springer, Heidelberg, 433-466. 
Lopes, C.G., Pimentel, M.M., Philipp, R.P., Gruber, L., Armstrong, R., Junges, S.L., 2015. Provenance of the Passo Feio Complex, São Gabriel Terrane, Dom Feliciano Belt, southern Brazil, implications for the tectonic setting of deposition, age of the São Gabriel Arc and origin of Paleoarchean detrital zircons (3.3-3.63 Ga). Journal of South American Earth Sciences 58, 9-17.

López-Gamundi, O.R., Rosello E.A., 1993. Devonian-Carboniferous unconformity in Argentina and its relation to the Eo-Hercynian orogeny in southern South America. Geologische Rundschau 82, 136147.

Lünsdorf, N.K., Lünsdorf, J.O., 2016. Evaluating Raman spectra of carbonaceous matter by automated, iterative curve-fitting. International Journal of Coal Geology 160-161, 51-62.

Luzardo, R., Fernandes, L.A.D., 1990. Análise estrutural do Lineamento do Ibaré parte I - Filitos de Ibaré greenstone belt ou cobertura cratônica deformada?. Acta Geologica Leopoldensia 30, 25-36.

Lyra, D.S., Savian, J.F., Bitencourt, M.F., Trindade, R.I., Tomé, C.R., 2017. AMS fabrics and emplacement model of Butiá Granite, an Ediacaran syntectonic peraluminous granite from southernmost Brazil. Journal of South American Earth Sciences, in press.

Mantovani, M.S.M., Shukowski, W., Basei, M.A.S., Vasconcellos, A.C.B.C., 1989. Modelos gravimétricos das principais descontinuidades crustais nos terrenos Pré-Cambrianos dos estados do Paraná e Santa Catarina. Revista Brasileira de Geociências 19 (3), 367-374.

Martil, M.M.D., Bitencourt, M.F., Nardi, L.V.S., 2011. Caracterização estrutural e petrológica do magmatismo pré-colisional do Escudo Sul-rio- grandense: os ortognaisses do Complexo Metamórfico Várzea do Capivarita. Pesquisas em Geociências 38(2),181-201.

Martil, M.M.D., Bitencourt, M.F., Nardi, L.V.S., Koester, E., Pimentel, M.M., 2017. Pre-collisional, Neoproterozoic (ca. $790 \mathrm{Ma}$ ) continental arc magmatism in southern Mantiqueira Province, Brazil: geochemical and isotopic constraints from the Várzea do Capivarita Complex. Lithos 274-275, 3952.

Martini, A., Bitencourt, M.F., Nardi, L.V.S., Florisbal, L.M., 2015. An integrated approach to the late stages of Neoproterozoicpost-collisional magmatism from Southern Brazil: Structural geology,geochemistry and geochronology of the Corre-mar Granite. Precambrian Research 261, 25-39.

Masquelin, H., Tabó, F., 1988. Memoria Explicativa de la Carta Geológica del Uruguay, Hoja Chafalote, Escala 1:100.000. DINAMIGE-Fac. de Agron.-Fac. de H. y Ciencias, 20 pp.

Masquelin, H., Sánchez-Bettucci, L., 1993. Propuesta de evolución tectono-sedimentaria para la fosa tardi-Brasliana en la región de Piriápolis, Uruguay. Revista Brasileira de Geociencias 23, 313 - 322.

Masquelin, H., 1990. Análisis estructural de las zonas de cizalla en las migmatitas de Punta del EsteUruguay. Acta Geologica Leopoldensia 30, 139-158.

Masquelin, H., Aifa, T., Muzio, R., Hallot, E., Veroslavsky, Bonnevalle, L., 2009. The Cuaró Mesozoic doleritic dyke swarm, southern Paraná basin, Uruguay: Examples of superimposed magnetic fabrics? Comptes Rendus Geoscience 341 (12), 1003-1015. 
Masquelin, H., Fernandes, L.A.D., Lenz, C., Porcher, C.C., McNaughton, N.J., 2012. The Cerro Olivo Complex: a pre-collisional neoproterozoic magmatic arc in eastern Uruguay. International Geological Review 54, 1161-1183

Masquelin, H., Lara, H.S., Betucci, L.S., Demarco, P.N., Pascual, S., Muzio, R., Peel, E., Scaglia, F., 2017. Lithologies, structure and basement-cover relationships in the schist belt of the Dom Feliciano Belt in Uruguay. Brazilian Journal of Geology 47(2), 21-42.

Matté, V., Sommer, C.A., Lima, E.F., Philipp, R.P., Basei, M.A.S., 2016. Post-collisional Ediacaran volcanism in oriental Ramada Plateau, southern Brazil. Journal of South American Earth Sciences 71, 201-222.

Meira, V.T., García-Casco, A., Juliani, C., Almeida, R.P., Schorscher, J.H.D., 2015. The role of intracontinental deformation in supercontinent assembly: insights from the Ribeira Belt, Southeastern Brazil (Neoproterozoic West Gondwana). Terra Nova 27(3), 206-217.

Meisling, K.E., Cobbold, P.R., Mount, V.S., 2001. Segmentation of an Obliquely Rifted Margin, Campos and Santos Basins, Southeastern Brazil. AAPG Bulletin 85 (11), 1903-1924.

Merriman, R.J., Frey, M., 1999. Patterns of very low-grade metamorphism in metapelitic rocks. Lowgrade metamorphism. In Frey, M., Robinson, D. (Eds.), Low-Grade Metamorphism, Blackwell Science, Oxford, 61-107.

Midot, D., 1984. Etude Geologique et diagnostic Metallogenique pour l'exploration du Secteur de Minas (Uruguay).PhD thesis, Universite Pierre et Marie Curie, Paris, 175 pp.

Milani, E., Davison, I., 1988. Basement control and transfer tectonics in the Recôncavo-Tucano-Jatobá rift, Northeast Brazil. Tectonophysics 154, 41-70.

Milani, E.J., Melo, J.H.G., Souza, P.A., Fernandes, L.A., França, A.B., 2007. Bacia do Paraná. In Milani, E.J., Rangel, H.D., Bueno, G.V., Stica, J.M., Winter, W.R., Caixeta, J.M., Pessoa Neto, O.C. (Eds.), Bacias Sedimentares Brasileiras - Cartas Estratigráficas: Boletim de Geociências da Petrobras, 15, Rio de Janeiro.

Morley, C.K., 1995. Developments in the structural geology of rifts over the last decade and their impact on hydrocarbon exploration. In: Lambiase, J., (Ed.), Hydrocarbon habitat of rift basins, Geological Society of London Special Publication 80, 1-32.

Morley, C.K., Haranya, C., Phoosongsee, W., Pongwapee, S., Kornsawan, A., Wonganan, N., 2004. Activation of rift oblique and rift parallel pre-existing fabrics during extension and their effect on deformation style: examples from the rifts of Thailand. Journal of Structural Geology 26, 18031829.

Moulin, M., Aslanian, D., Unternehr, P., 2010. A new starting point for the South and Equatorial Atlantic Ocean. Earth-Science Reviews 98 (1-2), 1-37.

Mukherjee, S., 2017. Review on symmetric structures in ductile shear zones. International Journal of Earth Sciences 106, 1453-1468.

Murray, K.E., Reiners, P.W., Thomson, S.N., 2016. Rapid Pliocene-Pleistocene erosion of the central Colorado Plateau documented by apatite thermochronology from the Henry Mountains. Geology 44(6), 483-486. 
Nardi, L.V., Bitencourt, M.F., 2009. A-type granitic rocks in post-collisional settings in southernmost Brazil: their classification and relationship with tectonics and magmatic series. The Canadias Mineralogist 47, 1493-1503.

Nardi, L.V.S., Frantz, J.C., 1995. The Cordilheira Intrusive Suite: late-Precambrian peralumious granitoids from southern Brazil. Journal of South American Earth Sciences 8, 55-64.

Nasdala, L., Wenzel, M., Vavra, G., Irmer, G., Wenzel, T., Kober, B., 2001. Metamictisation of natural zircon: accumulation versus thermal annealing of radioactivity-induced damage. Contributions to Mineral Petrology 141, 125-144.

Nuñez, P., Masquelin, E., Sánchez Bettucci, L., 2016. Estructura, estratigrafía, deformación y metamorfismo de la Formación Barriga Negra. VIII Congreso uruguayo de Geología, Montevideo, Actas.

Oliveira, C.H.E., Jelinek, A.R., 2017. História termotectônica da margem continental brasileira a partir de dados de traços de fissão em apatita. Pesquisas em Geociências 44 (3), 387-400.

Oliveira, C.H.E., Chemale Jr., F., Jelinek, A.R., Bicca, M.M., Phillip, R.P., 2014. U-Pb and Lu-Hf Isotopes applied to the evolution of the late to post-orogenic transtensional basins of the Dom Feliciano Belt, Brazil. Precambrian Research 246, 240-255.

Oliveira, C.H.E., Jelinek, A.R., Chemale Jr., Bernet, M., 2015. Evidence of post-Gondwana breakup in Southern Brazilian Shield: Insights from apatite and zircon fission track thermochronology. Tectonophysics 666, 173-187.

Oliveira, C.H.E., Jelinek, A.R., Chemale Jr., F., Bernet, M., 2016. Evidence of post-Gondwana breakup in Southern Brazilian Shield: Insights from apatite and zircon fission track thermochronology. Tectonophysics 666, 173-187.

Oliveira, D.S., Sommer, C.A., Philipp, R.P., Lima, E.F., Basei, M.A.S., 2015. Post-collisional subvolcanic rhyolites associated to the Neoproterozoic Batholith Pelotas, Southern Brazil. Journal of South American Earth Sciences 63, 84-100.

Oliveira L.D., Koester E., Soliani Jr. E., 2001. Geoquímica das rochas graníticas pós-transcorrentes da região de Porto Alegre e Viamão, RS. Geochimica Brasiliensis 15(2), 65-92.

Oliveira, S.G., Hackspacher, P.C., Neto, J.C.H., lunes, P.J., de Paulo, S.R., Ribeiro, L.F.B., Tello-Saenz, C. A., 2000. Constraints on the evolution and thermal history of the continental platform of southeast Brazil, Sao Paulo State, using apatite fission track analysis (AFTA). Revista Brasileira de Geociências 30(1), 107-109.

Oriolo, S., Oyhantçabal, P., Heidelbach, F., Wemmer, K., Siegesmund, S., 2015. Structural evolution of the Sarandí del Yí Shear Zone: kinematics, deformation conditions and tectonic significance. International Journal of Earth Sciences 104, 1759-1777.

Oriolo, S., Oyhantçabal, P., Wemmer, K., Basei, M.A.S., Benowitz, J., Pfänder, J., Hannich, F., Siegesmund S., 2016â. Timing of deformation in the Sarandí del Yí Shear Zone, Uruguay: Implications for the amalgamation of western Gondwana during the Neoproterozoic Brasiliano-Pan-African Orogeny. Tectonics 35. doi:10.1002/2015TC004052. 
Oriolo, S., Oyhantçabal, P., Wemmer, K., Heidelbach, F., Pfänder, J., Basei, M.A.S., Hueck, M., Hannich, F., Sperner, B., Siegesmund, S., 2016b. Shear zone evolution and timing of deformation in the Neoproterozoic transpressional Dom Feliciano Belt, Uruguay. Journal of Structural Geology 92, 5978

Oriolo, S., Oyhantçabal, P., Basei, M.A.S., Wemmer, K., Siegesmund, S., 2016c. The Nico Pérez Terrane (Uruguay): From Archean crustal growth and connections with the Congo Craton to late Neoproterozoic accretion to the Río de la Plata Craton. Precambrian Research 280, 147-160.

Oriolo, S., Oyhantçabal, P., Wemmer, K., Siegesmund, S., 2017. Contemporaneous assembly of Western Gondwana and final Rodinia break-up: Implications for the supercontinent cycle. Geoscience Frontiers 8(6), 1431-1445.

Oriolo, S., Hueck, M., Oyhantçabal, P., Goscombe, B., Wemmer, K., Siegesmund, S., 2018a. Shear Zones in Brasiliano-Pan-African Belts and Their Role in the Amalgamation and Break-Up of Southwest Gondwana. In: Siegesmund, S., Oyhantçabal, P., Basei, M.A.S., Oriolo, S. (Eds.) Geology of Southwest Gondwana. Regional Geology Reviews, Springer, Heidelberg, 593-613.

Oriolo, S., Wemmer, K., Oyhantçabal, P., Fossen, H., Schulz, B., Siegesmund, S., 2018b. Geochronology of shear zones - A review. Earth-Science Reviews 185, 665-683.

Orme, D.A., Guenthner, W.R., Laskowski, A.K., Reiners, P.W., 2016. Long-term tectonothermal history of Laramide basement from zircon-He age-eU correlations. Earth and Planetary Science Letters 453, 119-130.

Oyhantçabal, P., 2005. The Sierra Ballena shear zone: kinematics, timing and its significance for the geotectonic evolution of southeast Uruguay. Dissertation, Georg-August-Universität Göttingen.

Oyhantçabal, P., Sánchez Bettucci, L., Pecoits, E., Aubet, N., Preciozzi, F., Basei, M.A.S., 2005. Nueva propuesta estratigráfica para las supracorticales del Cinturón Dom Feliciano (Proterozoico, Uruguay). XII Congreso Latinoamericano de Geología, Quito, Abstracts.

Oyhantçabal, P., Siegesmund, S., Wemmer, K., Robert, F., Lyer, P., 2007. Post-collisional transition from calc-alkaline to alkaline magmatism during transcurrent deformation in the southernmost Dom Feliciano Belt (Braziliano-Pan-African, Uruguay). Lithos 98, 141-159.

Oyhantçabal, P., Siegesmund, S., Wemmer, K., Presnyakov, S., Layer, P., 2009. Geochronological constraints on the evolution of the southern Dom Feliciano Belt (Uruguay). Journal of the Geological Society of London 166, 1075-1084.

Oyhantçabal, P., Siegesmund, S., Wemmer, K., Layer, P., 2010. The Sierra Ballena Shear Zone in the southernmost Dom Feliciano Belt (Uruguay): evolution, kinematics, and deformation conditions. International Journal of Earth Sciences. doi:10.1007/s00531-009-0453-1.

Oyhantçabal, P., Siegesmund, S., Wemmer, K., Passchier, C.W., 2011a. The transpressional connection between Dom Feliciano and Kaoko Belts at 580-550 Ma. International Journal of Earth Sciences 100, 379-390.

Oyhantçabal, P., Siegesmund, S., Wemmer, K., 2011b. The Río de la Plata Craton: a review of units, boundaries, ages and isotopic signature. International Journal of Earth Sciences 100, 201-220. 
Oyhantçabal, P., Wegner-Eimer, M., Wemmer, K., Schulz, B., Frei, R., Siegesmund, S., 2012. Paleo- and Neoproterozoic magmatic and tectonometamorphic evolution of the Isla Cristalina de Rivera (Nico Pérez Terrane, Uruguay). International Journal of Earth Sciences 101, 1745-1762.

Oyhantçabal, P., Oriolo, S., Philipp, R.P., Wemmer, K., Siegesmund, S., 2018. The Nico Pérez Terrane of Uruguay and Southeastern Brazil. In: Siegesmund, S., Oyhantçabal, P., Basei, M.A.S., Oriolo, S. (Eds.) Geology of Southwest Gondwana. Regional Geology Reviews, Springer, Heidelberg, 161-188.

Paim, P.S.G., Chemale Jr., F., Lopes, C., 2000. A Bacia do Camaquã. In: Holz, M., de Ros, L.F. (Eds.), Geologia do Rio Grande do Sul, CIGO/UFRGS, Porto Alegre, 231-274.

Palenik, C.S., Nasdala, L., Ewing, R.C., 2003. Radiation damage in zircon. American Mineralogist 88 (5-6), 770-781.

Panario, D., Gutiérrez, O., Sánchez-Betucci, L., Peel, E., Oyhantçabal, P., Rabassa, J., 2014. Ancient Landscapes of Uruguay. In: Rabassa, J., Ollier, C., (Eds.), Gondwana Landscapes in southern South America. Springer.

Pángaro, F., Ramos, V.A., Pazos, P.J., 2015. The Hesperides basin: a continental-scale upper Palaeozoic to Triassic basin in southern Gondwana. Basin Research 1-27, doi: 10.1111/bre.12126

Passarelli, C.R., Basei, M.A.S., 1995. Análise dos petrotramas de eixos-c de quartzo: zona de cisalhamento Major Gercino (SC). Boletim do Instituto de Geociências da universidade de São Paulo, Série Científica 26, 99-113.

Passarelli, C.R., Basei, M.A.S., Campos Neto, M.C., 1993. Caracterização geométrica e cinemática da Zona de Cisalhamento Major Gercino e sua importância na compartimentação dos terrenos PréCambrianos de Santa Catarina. Revista Brasileira de Geociências 23, 234-241.

Passarelli, C.R., Basei, M.A.S., SigaMc Reath Jr., I., Campos Neto, M.C., 2010. Deformation and geochronology of syntectonic granitoids emplaced in the major Gercino Shear zone, southeastern south America. Gondwana Research 17, 688-703.

Passarelli, C.R., Basei, M.A.S., Wemmer, K., Siga Jr., O., Oyhantçabal, P., 2011a. Major Shear Zones of southern Brazil and Uruguay: escape tectonics in the eastern border of Rio de La Plata and Paranapanema cratons during the Western Gondwana amalgamation. International Journal of Earth Sciences (Geol.Rundsch) 100, 391-414.

Passarelli, C.R., McReath, I., Basei, M.A.S., Siga Jr, O., Campos Neto, M.C., 2011b. Heterogeneity in syntectonic granitoids emplaced in a major shear zone, southern Brazil. Journal of South American Earth Sciences 32, 369-378.

Passarelli, C.R, Basei, M.A.S., Siga Jr., O., Harara, M.M., 2018. The Luis Alves and Curitiba Terranes: Continental Fragments in the Adamastor Ocean. In: Siegesmund, S., Oyhantçabal, P., Basei, M.A.S., Oriolo, S. (Eds.) Geology of Southwest Gondwana. Regional Geology Reviews, Springer, Heidelberg, 161-188.

Passchier, C.W., Trouw, R.A.J., 2005. Microtectonics, 2nd edn. Springer, Berlin Heidelberg.

Paterson, S.R., Fowler Jr., T.K., Schmidt, K.L.,Yoshinobu, A.S., Yuan, E.S., Miller, R. B., 1998. Interpreting magmatic fabric patterns in plutons. Lithos 44, 53-82. 
Pazos, P.J., Sánchez-Bettucci, L., Tofalo, O.R., 2003. The record of the Varanger glaciation at the Río de la Plata craton, Vendian-Cambrian of Uruguay. Gondwana Research 6(1), 65-77.

Pazos, P., Rapalini, A., Sánchez Bettucci, L., Tófalo, R., 2011. The Playa Hermosa Formation, Playa Verde Basin, Uruguay. Geological Society of London Memoir 36, 547-553.

Pecoits, E., Gingras, M., Aubet, N., Konhauser, K., 2008. Ediacaran in Uruguay: palaeoclimatic and palaebiological implications. Sedimentology 55, 689-719.

Pecoits, E., Aubet, N.R., Heaman, L.M., Philippot, P., Rosière, C.A., Veroslavsky, G., Konhauser, K.O., 2016. $\mathrm{U}-\mathrm{Pb}$ detrital zircon ages from some Neoproterozoic successions of Uruguay: Provenance, stratigraphy and tectonic evolution. Journal of South American Earth Sciences 71, 108-130.

Peel, E., Muzio, R., Basei, M.A.S., 2015. U-Pb zircon ages and Sr-Nd isotopic composition of Neoproterozoic magmatism, Dionisio-Sierra de los Ríos block, NE Uruguay. Goldschmidt Abstracts 2015, 2442

Peron-Pinvidic, G.,Manatschal, G., Osmundsen, P.T., 2013. Structural comparison of archetypal Atlantic rifted margins: A review of observations and concepts. Marine and Petroleum Geology 13, 21-47.

Pertille, J., Hartmann, L.A., Philipp, R.P., 2015a. Zircon U-Pb age constraints on the Paleoproterozoic sedimentary basement of the Ediacaran Porongos Group, Sul-Riograndense Shielf, southern Brazil: Journal of South American Earth Sciences 63, 334-345.

Pertille, J., Hartmann, L.A., Philipp, R.P., Petry, T.S., Lana, C.C., 2015b. Origin of the Ediacaran Porongos Group, Dom Feliciano Belt, southern Brazilian Shield, with emphasis on whole rock and detrital zircon geochemistry and U-Pb, Lu-Hf isotopes. Journal of South American Earth Sciences 64, 69-93.

Pertille, J., Hartmann, L.A., Santos, J.O.S., McNaughton, N.J., Armstrong, R., 2017. Reconstructing the Cryogenian-Ediacaran evolution of the Porongos fold and thrust belt, Southern Brasiliano Orogen, based on Zircon U-Pb-Hf-O isotopes. International Geology Review 59(12), 1532-1560.

Peternell, M., Bitencourt, M.F., Kruhl, J.H., Stäb, C., 2010. Macro and microstructures as indicators of the development of syntectonic granitoids and host rocks in the Camboriú region, Santa Catarina, Brazil. Journal of South American Earth Sciences 29, 738-750.

Pevear, D.R., 1992. Illite age analysis, a new tool for basin thermal history analysis. In: Kharaka, Y.K., Maest, A.S. (Eds.) 7th International Symposium on Water-Rock Interaction, Balkema, Rotterdam, proceedings pp. 1251-1254

Philipp, R.P., Campos, R.S., 2004. Geologia, Petrografia e Litogeoquímica dos Gnaisses Porto Alegre, RS, Brasil: Implicações Geotectônicas. Revista Pesquisas em Geociências 31(2), 79-94.

Philipp, R.P., Machado, R., 2005. The Neoproterozoic to Cambrian granitic magmatism of the Pelotas Batholith, southern Brazil. Journal of South American Earth Science 19, 461-478.

Philipp, R.P., Mesquita, M.J.M., Gomes,M.E.B., Almeida, D.P.M., 1993. Reconhecimento estrutural e geoquímico dos granitóides brasilianos da região de Pelotas-RS. Pesquisas em Geociências 20 (1), 3-13. 
Philipp, R.P., Machado, R., Nardi, L.V.S., Lafon, J.M., 2002. O magmatismo granítico Neoproterozóico do Batólito Pelotas no sul do Brasil: novos dados e revisão de geocronologia regional. Revista Brasileira de Geociências 32(2), 277-290.

Philipp, R.P., Machado, R., Chemale Jr., F., 2003. Reavaliação e novos dados geocronológicos (Ar/Ar, $\mathrm{Rb} / \mathrm{Sr}$ e Sm/Nd) do Batólito Pelotas no Rio Grande do Sul: implicações petrogenéticas e idade de reativação das zonas de cisalhamento. Geologia USP, Série Científica 3, 71-84.

Philipp, R.P., Mallmann, G., Bitencourt, M.F., Souza, E.R., Souza, M.M.A., Liz, J.D., Wild, F., Arendt, S., Oliveira, A., Duarte, L., Rivera, C.B., Prado, M., 2004. Caracterização litológica e evolução metamórfica da porção leste do Complexo Metamórfico Brusque, Santa Catarina. Revista Brasileira de Geociências 34, 21-34.

Philipp, R.P., Lusa, M., Nardi, L.V.S., 2008. Geochemistry and petrology of dioritic, tonalitic and trondhjemitic gneisses from Encantadas Complex, Santana da Boa Vista, southernmost Brazil: a Paleoproterozoic continental-arc magmatism. Anais da Academia Brasileira de Ciências 80, 1-14.

Philipp, R.P., Massonne, H.J., de Campos, R.S., 2013. Peraluminous leucogranites of the Cordilheira Suite: A record of Neoproterozoic collision and the generation of the Pelotas Batholith, Dom Feliciano Belt, Southern Brazil. Journal of South American Earth Sciences 43, 8-24.

Philipp, R.P., Pimentel, M.M., Chemale Jr., F., 2016a. Tectonic evolution of the Dom Feliciano Belt in Southern Brazil: Geological relationships and U-Pb geochronology. Brazilian Journal of Geology 46 (1), 83-104.

Philipp, R.P., Bom, F.M., Pimentel, M.M., Junges, S.L., Zvirtes, G., 2016b. SHRIMP U-Pb age and high temperature conditions of the collisional metamorphism in the Varzea do Capivarita Complex: Implications for the origin of Pelotas Batholith, Dom Feliciano Belt, southern Brazil. Journal of South American Earth Sciences 66, 196-207.

Philipp, R.P., Pimentel, M.M., Basei, M.A.S., 2018. The Tectonic Evolution of the São Gabriel Terrane, Dom Feliciano Belt, Southern Brazil: The Closure of the Charrua Ocean. In: Siegesmund, S., Oyhantçabal, P., Basei, M.A.S., Oriolo, S. (Eds.) Geology of Southwest Gondwana. Regional Geology Reviews, Springer, Heidelberg, 243-265.

Piccirillo, E.M., Bellieni, G., Cavazzini, G., Comin-Chiaramonti, P., Petrini, R., Melfi, A.J., Pinese, J.P.P., Zantadeschi, P., De Min, A., 1990. Lower Cretaceous tholeiitic dyke swarms from the Ponta Grossa Arch (southeast Brazil): Petrology, Sr-Nd isotopes and genetic relationships with the Paraná flood volcanics. Chemical Geology 89(1-2), 19-48.

Pidgeon, R. T., 2014. Zircon radiation damage ages. Chemical Geology 367, 13-22.

Pimentel, M.M., Whitehouse, M.J., Viana, M.D.G., Fuck, R.A., Nuno, M., 1997. The Mara Rosa Arch in the Tocantins Province: further evidence for Neoproterozoic crustal accretion in Central Brazil. Precambrian Research 81(3-4), 299-310.

Pimentel, M.M., Rodrigues, J.B., DellaGiustina, M.E.S., Junges, S., Matteini, M., Armstrong, R., 2011. The tectonic evolution of the Neoproterozoic Brasília Belt, central Brazil, based on SHRIMP and LAICPMS U-Pb sedimentary provenance data: a review. Journal of South American Earth Sciences 31(4), 345-357. 
Poiré, D., Gaucher, C., 2009. Lithostratigraphy. Neoproterozoic-Cambrian evolution of the Río de la Plata Paleocontinent. Developments in Precambrian Geology 16, 87-101.

Poiré D.G., González P.D., Canalicchio, J.M., García Repetto, F., 2003. Litoestratigrafía y estromatolitos de la sucesión sedimentaria Precámbrica de la cantera Mina Verdún, Minas, Uruguay. Revista de la Sociedad Uruguaya Geologia, Publicación Especial 1, 108-123.

Porada, H., 1989. Pan-African rifting and orogenesis in southern to equatorial Africa and eastern Brazil. Precambrian Research 44, 103-136

Powell, J., Schneider, D., Stockli, D., Fallas K., 2016. Zircon (U-Th)/He thermochronology of Neoproterozoic strata from the Mackenzie Mountains, Canada: Implications for the Phanerozoic exhumation and deformation history of the northern Canadian Cordillera. Tectonics 35, 663-689

Prior, D.J., Boyle, A.P., Brenker, F., Cheadle, M.C., Day, A., Lopez, G., Peruzzo, L., Potts, G.J., Reddy, R., Spiess, R., Timms, N.E., Trimby, P., Wheeler, J., Zetterström, L., 1999. The application of electron backscatter diffraction and orientation contrast imaging in the SEM to textural problems in rocks. American Mineralogist 84(11-12), 1741-1759.

Pryer, L.L., 1993. Microstructures in feldspars from a major crustal thrust zone: the Grenville Front, Ontario, Canada. Journal of Structural Geology 15(1), 21-36.

Purdy, J.W., Jäger E., 1976. K-Ar ages on rock-forming minerals from the Central Alps. Memorie degli Istituti di Geologia e Mineralogia dell'Università di Padova 30, 1-31.

Rapalini, A.E., Tohver, E., Sánchez Bettucci, L., Lossada, A.C., Barcelona, H., Pérez, C., 2015. The late Neoproterozoic Sierra de las Ánimas Magmatic Complex and Playa Hermosa Formation, southern Uruguay, revisited: Paleogeographic implications of new paleomagnetic and precise geochronologic data. Precambrian Research 259, 143-155.

Rapela, C.W., Fanning, C.M., Casquet, C., Pankhurst, R.J., Spalletti, L., Poiré, D., Baldo, E.G., 2011. The Río de la Plata craton and the adjoining Pan-African/brasiliano terranes: their origins and incorporation into south-west Gondwana. Gondwana Research 20, 673-690.

Raposo, M.I., Drukas, C.O., Basei, M.A.S., 2014. Deformation in rocks from Itajaí basin, Southern Brazil, revealed by magnetic fabrics. Tectonophysics 629, 290-302.

Reiners P.W., Spell T.L., Nicolescu S., Zanetti K.A., 2004. Zircon (U-Th)/He thermochronometry; He diffusion and comparisons with 40Ar/39Ar dating. Geochimica et Cosmochimica Acta 68(8):18571887.

Remus, M.V.D., McNaughton, N.J., Hartmann, L.A., Koppe, J.C., Fletcher, I.R., Groves, D.I., Pinto, V.M., 1999. Gold in the Neoproterozoic juvenile Bossoroca Volcanic Arc of southernmost Brazil: isotopic constraints on timing and sources. Journal of South American Earth Sciences 12(4), 349-366.

Renne, P.R., Ernesto, M., Pacca, I.G., Coe, R.S., Glen, J.M., Prévot, M., Perrin, M., 1992. The Age of ParanJ Flood Volcanism, Rifting of Gondwanaland, and the Jurassic-Cretaceous Boundary. Science 258, 975-979.

Ribeiro, L.F.B., Hackspacher, P.C., Ribeiro, M.C.S., Hadler Neto, J.C., Tello, S.C.A., lunes, P.J., Franco, A.O.B., Godoy, D.F., 2005. Thermotectonic and fault dynamic analysis of Precambrian basement and tectonic constraints with the Parana basin. Radiation Measurements 39, 669-673. 
Riccomini, C., 1997. Arcabouço estrutural e aspectos do tectonismo gerador e deformador da Bacia Bauru no Estado de São Paulo. Revista Brasileira de Geociências 27(2), 153-162.

Riccomini, C., Sant'Anna, L.G., Ferrari, A.L., 2004. Evolução geológica do rift continental do sudeste do Brasil. In: Mantesso-Neto, V., Bartorelli, A., Carneiro, C.D.R., Brito-Neves, B.D., (Eds.), Geologia do continente Sul-Americano: evolução da obra de Fernando Flávio Marques de Almeida, Beca, São Paulo, 383-405.

Riccomini, C., Velázquez, V.F., Gomes, C.B., 2005. Tectonic controls of the Mesozoic and Cenozoic alkaline magmatism in central-southeastern Brazilian Platform. Mesozoic to Cenozoic alkaline magmatism in the Brazilian Platform 123, 31-56.

Rocha Campos, A.C., Basei, M.A.S., Nutman, A.P., dos Santos, P.R., 2007. SHRIMP U-Pb zircon geochronological calibration of the late Paleozoic supersequence, Paraná Basin, Brazil. In: 40 Simpósio Sobre Cronoestratigrafia da Bacia do Paraná, Armação de Búzios, Abstracts, 33.

Rossello, E.A., de Santa Ana, H., Veroslavsky, G., 2000. El Lineamiento Santa Lucía-Aiguá-Merín (Uruguay): Un corredor tectónico extensivo y transcurrente dextral precursor de la apertura Atlántica. Revista Brasileira de Geociências 30(4), 749-756.

Rossello, E.A., Veroslavsky, G., Masquelin, H., de Santa Ana, H., 2007. El corredor Juro-Cretácico Santa Lucía-Aiguá-Merín (Uruguay): cinemática transcurrente dextral y controles preexistentes. Revista de la Asociación Geológica Argentina 62 (1): 92-104.

Rostirolla, S.P., Alckmin, F.F., Soares, P.C., 1992. O Grupo Itajaí, Estado de Santa Catarina, Brasil, exemplo de sedimentação em uma bacia flexural de antepaís. Boletim de Geociências da Petrobrás 6(3/4), 109-122.

Rostirolla, S.P., Ahrendt, A., Soares, P.C., Carmingnani, L., 1999. Basin analysis and mineral endowment of the Proterozoic Itajaí Basin, south-east Brazil. Basin Research 11, 127-142.

Rostirolla S.P., Assine, M.L., Fernandes, L.A., Artur, P.C., 2000, Reativação de paleolineamentos durante a evolução da Bacia do Paraná - o exemplo do alto estrutural de Quatiguá. Revista Brasileira de Geociências 30(4), 639-648.

Saalmann, K., Hartmann, L.A., Remus, M.V.D., 2005. Tectonic evolution of two contrasting schist belts in southernmost Brazil, A plate tectonic model for the Brasiliano Orogeny. International Geology Review 47, 1234-1259.

Saalmann, K., Remus, M.V.D., Hartmann, L.A., 2006a. Structural evolution and tectonic setting of the Porongos belt, southern Brazil. Geological Magazine 143, 59-88.

Saalmann, K., Remus, M.V.D., Hartmann, L.A., 2006b. Tectonic evolution of the Neoproterozoic juvenile São Gabriel belt, southern Brazil - constraints on Brasiliano orogenic evolution of the La Plata Cratonic margin. Journal of South American Earth Sciences 21, 204-227.

Saalmann, K., Hartmann, L.A., Remus, M.V.D., 2007. The assembly of West Gondwana-The view from the Rio de la Plata craton. In: Linnemann, U., Nance, R.D., Kraft, P., Zulauf, G. (Eds.). The evolution of the Rheic Ocean: From Avalonian-Cadomian active margin to Alleghenian-Variscan collision. Geological Society of America Special Paper 423, 1-26. 
Saalmann, K., Gerdes, A., Lahaye, Y., Hartmann, L.A., Remus, M.V.D., Läufer, A., 2011. Multiple accretion at the eastern margin of the Rio de la Plata craton: the prolonged Brasiliano orogeny in southernmost Brazil. International Journal of Earth Sciences 100, 355-378.

Salomon E., Koehn, D., Passchier, C., Hackspacher, P.C., Glasmacher, U.A., 2015. Contrasting stress fields on correlating margins of the South Atlantic. Gondwana Research 28, 1152-1167.

Salomon, E., Passchier, C., Koehn, D., 2017. Asymmetric continental deformation during South Atlantic rifting along southern Brazil and Namibia. Gondwana Research 51, 170-176.

Sánchez Bettucci, L S., Burgueño, A.M., 1993. Análisis Sedimentológico y Faciológico de la Formación Rocha (ex-Grupo Rocha). Revista Brasilera de Geociencias 23(3), 323-329.

Sánchez Bettucci, L., Ramos, V.A., 1999. Aspectos geológicos de las rocas metavolcánicas y metasedimentarias del Grupo Lavalleja, sudeste de Uruguay. Revista Brasileira de Geociências 29(4), 557-570.

Sánchez Bettucci, L., Oyhantçabal, P., Loureiro, J., Ramos, V.A., Preciozzi, F., Basei, M.A.S., 2004. Mineralizations of the Lavalleja group (Uruguay), a probable neoproterozoic volcano-sedimentary sequence. Gondwana Research 6, 89-105.

Sánchez Bettucci, L., Peel, E., Masquelin, H., 2010. Neoproterozoic tectonic synthesis of Uruguay. International Geology Review 52(1), 51-78.

Sato, A.M., Llambías, E.J., Basei, M.A.S., Castro, C.E., 2015. Three stages in the Late Paleozoic to Triassic magmatism of southwestern Gondwana, and the relationships with the volcanogenic events in coeval basins. Journal of South American Earth Sciences 63, 48-69.

Schmid, S.M., Casey, M., 1986. Complete fabric analysis of some commonly observed quartz c-axis patterns. Geophysical Monograph Series 36, 263-286.

Schroeder, G.S., 2006. Análise tectônica da Bacia do Itajaí. Mastership dissertation. Universidade Federal do Rio Grande do Sul, Porto Alegre.

Schultz, M H., Hodges, $K$ V., Ehlers, T A., van Soest, M., Wartho, J.A., 2017. Thermochronologic constraints on the slip history of the South Tibetan detachment system in the Everest region, southern Tibet. Earth and Planetary Science Letters 459, 105-117.

Schumacher, E., 1975. Herstellung von 99.9997\% 38Ar für die 40K/40Ar Geochronologie. Geochronologia Chimica 24, 441-442.

Siegesmund, S., Oyhantçabal, P., Basei, M.A.S., Oriolo, S., 2018. Geology of Southwest Gondwana. Regional Geology Reviews, Springer, Heidelberg.

Silva, L.C., 1991. O cinturão metavulcanossedimentar Brusque e a evoluç ão policíclica das faixas dobradas proterozóicas no sul do Brasil: uma revisão. Revista Brasileira de Geociências 21, 60-73.

Silva, L.C., Hartmann, L.A., McNaughton, N.J., Fletcher, I.R., 1997. SHRIMP U/Pb zircon dating of Neoproterozoic granitic magmatism and collision in the Pelotas batholith, southernmost Brazil. International Geology Review 41, 531-551. 
Silva, L.C., Hartmann, L.A., McNaughton, N.J., Fletcher, I., 2000. Zircon U-Pb SHRIMP dating of a Neoproterozoic overprint in Paleoproterozoic granitic-gneissic terranes, southern Brazil. American Mineralogist 85, 649-667.

Silva, L.C., Armstrong, R., Pimentel, M.M., Scandolara, J., Ramgrab, G., Wildner, W., Angelim, L.A.A., Vasconcelos, A.M., Rizzoto, G., Quadros, M.L.E.S., Sander, A., Rosa, A.L.Z., 2002a. Reavaliação da evolução geológica em terrenos pré-cambrianos brasileiros com base em novos dados U-Pb SHRIMP, Parte III: Províncias Borborema, Mantiqueira Meridional e Rio Negro-Juruena. Revista Brasileira de Geociências 32(4), 529-544.

Silva, L.C., McNaughton, N.J., Santos, J.O.S., 2002b. Datações U-Pb SHRIMP do vulcanismo félsico na Bacia Brusque, Orógeno Pelotas, SC. In: Congresso Brasileiro de Geologia 41, João Pessoa, Brasil. Anais, 510

Silva, L.C., McNaughton, N.J., Hartmann, L.A., Fletcher, I.R., 2003. Contrasting zircon growth patterns in Neoproterozoic granites of Southern Brazil revealed by SHRIMP U-Pb analyses and SEM imaging: consequences for the discrimination of emplacement and inheritance ages. In: IV South American Symposium on Isotope Geology, Salvador, Bahia, Brazil. Short Papers, 687-690

Silva, L.C., McNaughton, N.J., Armstrong, R., Hartman, L.A., Fletcher, I.R., 2005a. The neoproterozoic Mantiqueira Province and its African connections: a zircon-based $\mathrm{U}-\mathrm{Pb}$ geochronologic subdivision for the Brasiliano/Pan-African systems of orogens. Precambrian Research 136: 203-240.

Silva, L.C., McNaughton, N.J., Fletcher, I.R., 2005b. Reassesment on complex zircon populations from Neoproterozoic granites in Brazil, through SEM imaging and SHRIMP analysis: consequences for discrimination of emplacement and inherited ages. Lithos 82 (3-4), 503-525

Silva, Z.C.C., Cornford, C., 1985. The kerogen type, depositional environment and maturity, of the Irati Shale, Upper Permian of Paraná Basin, Southern Brazil. Organic Geochemestry 8(6), 399-411.

Sinha, S., Alsop, G.I., Biswal, T.K., 2010. The evolution and significance of microfracturing within feldspars in low-grade granitic mylonites: A case study from the Eastern Ghats Mobile Belt, India. Journal of Structural Geology 32(10), 1417-1429.

Sommer, C.A., de Lima, E.F., Nardi, L.V.S., Figueiredo, A.M.G., Pierosan, R., 2005. Potassic and low-and high-Ti mildly alkaline volcanism in the Neoproterozoic Ramada Plateau, southernmost Brazil. Journal of South American Earth Sciences 18(3-4), 237-254.

Souza, I.V.A.F., Mendonça Filho, J.G., Menezes, T.R., 2008. Avaliação do efeito térmico das intrusivas ígneas em um horizonte potencialmente gerador da Bacia do Paraná: Formação Irati. Revista Brasileira de Geociências 38(2), 138-148.

Souza, I.V.A.F., Mendonça Filho, J.G., Menezes, T.R., 2008. Avaliação do efeito térmico das intrusivas ígneas em um horizonte potencialmente gerador da Bacia do Paraná: Formação Irati. Revista Brasileira de Geociências 38(2) 138-148.

Spiegel, C., Kohn, B., Belton, D., Berner, Z., \& Gleadow, A., 2009. Apatite (U-Th-Sm)/He thermochronology of rapidly cooled samples: the effect of He implantation. Earth and Planetary Science Letters 285(1), 105-114. 
Spoturno, J.J., Oyhantçabal, P., Loureiro, J., 2012. Mapa geológico del Departamento de Maldonado escala 1:100.000. Facultad de Ciencias (UdelaR)-Dirección Nacional de Minería y Geología (MIEM), Montevideo.

Środoń, J., Eberl, D.D., 1984. Illite. Reviews in Mineralogy and Geochemistry 13(1), 495-544.

Steenken, A., López de Luci, M.G., Dopico, C.M., Drobe, M., Wemmer,K., Siegesmund, S., 2011. The Neoproterozoic-early Paleozoic metamorphic and magmatic evolution of the Eastern Sierras Pampeanas: an overview. International Journal of Earth Sciences 100, 465-488.

Stica, J.M., Zalán, P.V., Ferrari, A.L., 2014. The evolution of rifting on the volcanic margin of the Pelotas Basin and the contextualization of the Paraná-Etendeka LIP in the separation of Gondwana in the South Atlantic. Marine and Petroleum Geology 50, 1-21.

Stipp, M., Stünitz, H., Heilbronner, R., Schmid, S.M., 2002. The eastern Tonale fault zone: a 'natural laboratory' for crystal plastic deformation of quartz over a temperature range from 250 to 700 C. Journal of Structural Geology 24(12), 1861-1884.

Streepey, M.M., Johnson, E.L., Mezger, K., Van Der Pluijm, B.A., 2001. Early history of the CarthageColton shear zone, Grenville Province, Northwest Adirondacks, New York (USA). The Journal of Geology 109(4), 479-492.

Strugale, M., Rostirolla, S.P., Mancini, F., Portela Filho, C.V., Ferreira, F.J.F., Freitas, R.C., 2007. Structural framework and Mesozoic-Cenozoic evolution of Ponta Grossa Arch, Paraná Basin, southern Brazil. Journal of South American Earth Sciences 24, 203-227.

Sueoka, S., Kohn, B.P., Tagami, T., Tsutsumi, H., Hasebe, N., Tamura, A., Arai, S., 2012. Denudation history of the Kiso Range, central Japan, and its tectonic implications: Constraints from lowtemperature thermochronology. Island Arc 21(1), 32-52.

Süssenberger, A., Wemmer, K., Schmidt, S.T., 2018. The zone of incipient 40Ar* loss-monitoring 40Ar* degassing behavior in a contact metamorphic setting. Applied Clay Science, 165, 52-63.Tagami T (2012) Thermochronological investigation of fault zones. Tectonophysics 538-540, 67-85.

Szatmari, P., Milani, E.J., 2016. Tectonic control of the oil-rich large igneous-carbonate-salt province of the South Atlantic rift. Marine And Petroleum Geolog, 77, 567-596.

Tagami, T., 2012. Thermochronological investigation of fault zones. Tectonophysics 538-540, 67-85.

Tello Saenz, C.A., Hackspacher, P.C., Hadler, N.J.C., lunes, P.J., Guedes, S., Paulo, S.R., Ribeiro, L.F.B., 2003. Recognition of cretaceous, Paleocene and Neogene tectonic reactivation, through apatite fission-track analysis in Precambrian areas of the Southeast Brazil: association with the South Atlantic Ocean Opening. Journal of South American Earth Sciences 15, 137-142.

Thiede, D.S., Vasconcelos, P.M., 2010. Parana flood basalts: rapid extrusion hypothesis confirmed by new 40Ar/39Ar results. Geology 38 (8), 747-750.

Thompson, R.N., Gibson, S.A., Mitchell, J.G., Dickin, A.P., Leonardos, O.H., Brod, J.A., Greenwood, J.C., 1998. Migrating Cretaceous-Eocene Magmatismin the Serra do Mar Alkaline Province, SE Brazil: Melts from the Deflected Trindade Mantle Plume? Journal of Petrology 39(8), 1493-1526. 
Tickyj, H., Hartmann, L.A., Vasconcellos, M.A., Philipp, R.P., Remus, M.V., 2004. Electron microprobe dating of monazite substantiates ages of major geological events in the southern Brazilian shield. Journal of South American Earth Sciences 16(8), 699-713.

Tommasi, A., Vauchez, A., Fernandes, L.A.D., Porcher, C.C., 1994. Orogen-parallel strike-slip faulting and synkinematic magmatism in the Dom Feliciano Belt, Southern Brazil. Tectonics 13, 421-437.

Torgersen, E., Viola, G., Zwingmann, H., Henderson, I.H.C., 2015. Inclined K-Ar illite age spectra in brittle fault gouges: effects of fault reactivation and wall-rock contamination. Terra Nova 27, 106-113.

Torsvik, T.H., Rousse, S., Labails, C., Smethurst, M.A., 2009. A new scheme for the opening of the South Atlantic Ocean and the dissection of an Aptian salt basin. Geophysical Journal International 177(3), 1315-1333.

Tremblay, A., Roden-Tice, M.K., Brandt, J.A., Megan, T.W., 2013. Mesozoic fault reactivation along the St. Lawrence rift system, eastern Canada: Thermochronologic evidence from apatite fi ssion-track dating. GSA Bulletin 125(5/6), 794-810.

Ullemeyer K., Braun G., Dahms M., Hruhl J.H., Olesen N.O., Siegesmund S., 2000. Texture analysis of a muscovite-bearing quartzite: a comparison of some currently used techniques. Journal of Structural Geology 22, 1541-1557.

Uriz, N.J:, Cingolani, C.A., Basei, M.A.S., Blanco, G., Abre, P., Portillo, N.S., Siccardi, A., 2016. Provenance and paleogeography of the Devonian Durazno Group, southern Paraná Basin in Uruguay. Journal of South American Earth Sciences 66, 248-267.

Valente, S.C., Corval, A., Duarte, B.P., Ellam, R.M., Fallick, A.E., Meighan, I.G., Dutra, T., 2007. Tectonic boundaries, crustal weakness zones and plume-subcontinental lithospheric mantle interactions in the Serra do Mar dyke swarm, SE Brazil. Brazilian Journal of Geology 37(1), 194-201.

Vauchez, A., Pacheco Neves, S., Tommasi, A., 1997. Transcurrent shear zones and magma emplacement in Neoproterozoic belts if Brazil. In: Bouchez, J.L., Hutton, D., Stephens, W.E. (Eds.), Granite: From segregation of melt to the emplacement fabrics. Kluwer, Dordrecht. 275-293

van der Pluijm, B.A., Mezger, K., Cosca, M.A., Essene, E.J., 1994. Determining the significance of highgrade shear zones by using temperature-time paths, with examples from the Grenville orogen. Geology 22(8), 743-746.

van der Pluijm, B.A., Hall, C.M., Vrolijk, P.J., Pevear, D.R., Covey, M.C., 2001. The dating of shallow faults in the Earth's crust. Nature 412(6843), 172.

Vedana, L.A., Philipp, R P., Basei, M.A.S., 2018. Tonian to early Cryogenian synorogenic basin of the São Gabriel Terrane, Dom Feliciano Belt, southernmost Brazil. International Geology Review 60(1), 109-133.

Vlach, S.R.F., Basei, M.A.S., Castro, N.A., 2009. Idade U-Th-Pb de monazita por microssonda eletrônica do Granito Nova Trento, Grupo Brusque, SC. In: Simpósio 45 anos de Geocronologia no Brasil, São Paulo, Brasil. Annals 325-327

von Gosen W., Buggisch, W., Dimieri, L.V., 1990. Structural and metamorphic evolution of the Sierras Australes (Buenos Aires Province / Argentina). Geologische Rundschau 79/3, 797-821. 
Wagner, G. A., van den Hute, P., 1992. Fission-track dating. Ferdinand Enke Verlag, Stuttgart, 285 p.

Wemmer, K., 1991. K/Ar-Altersdatierungsmöglichkeiten für retrograde Deformationsprozesse im spröden und duktilen Bereich - Beispiele aus der KTB Vorbohrung (Oberpfalz) und dem Bereich der Insubrichen Linie (N-Italien). Göttinger Arbeiten zur Geologie und Paläontologie 51, 1-61.

Wemmer, K., Ahrendt, H., 1997. Comparative K-Ar and Rb-Sr age determinations of retrograde processes on rocks from the KTB deep drilling project. Geologische Rundschau 86, S272.

Wildner, W., Lima, E.F., Nardi, L.V.S., Sommer, C.A., 2002. Volcanic Cycles and Setting in the Neoproterozoic III to Ordovician Camaquã Basin Succession in Southern Brazil: Characteristics of Post-Collisional Magmatism. Journal of Volcanology and Geothermal Research 118, 261-283.

Wildner, W., Ramgrab, G.E., Lopes, R.C., Iglesias, C.M.F., 2006. Mapa geologico do Estado do Rio Grande do Sul, Escala 1:750.000. CPRM, Porto Alegre

Wildner, W., Camozzato, E., Toniolo, J.A., Binotto, R.B., Iglesias, C.M.F., Laux, J.H., 2014. Geological map of the State of Santa Catarina. Scale 1:500,000. CPRM - Geological Survey of Brazil, Porto Alegre.,

Zalán, P.V., 2004. Evolução fanerozóica das bacias sedimentares brasileiras. Geologia do Continente SulAmericano: evolução da obra de Fernando Flávio Marques de Almeida. Beca, São Paulo, 595-613.

Zalán, P.V., Wolff, S., Astolfi, M.A.M., Vieira, I.S.;,Conceição, J.C.J., Appi, V.T., Santos Neto, E.V., Cerqueira, J.R., Marques, A., 1990. The Paraná Basin, Brazil. In: Leighton, M.W.,Kolata, D.R., Oltz, D.F., Eidel, J.J., (Eds.), Interior cratonic basins. American Association of Petroleum Geologists Memoir 51, 681-708.

Zanini, L.F P., Branco, P.D.M., Camozzato, E., Ramgrab, G.E.,1997. Programa levantamentos geológicos básicos do Brasil. Florianópolis-Lagoa: folha SG. 22-ZDV-folha SG. 22-ZD-VI. 1:100.000. CPRM Porto Alegre

Zerfass, H., Chemale Jr., F., Schultz, C.L., Lavina, E., 2004. Tectonics and sedimentation in Southern South America during Triassic. Sedimentary Geology 166, 265-292.

Zvirtes, G., Philipp, R.P., Camozzato, E., Guadagnin, F., 2016. Análise estrutural do Metagranito Capané, Antiforme Capané, Complexo Porongos, Cachoeira do Sul, RS. Pesquisas em Geociências 44(1), 523 . 


\section{APPENDIX A - Sample coordinates}

\section{Uruguay:}

\begin{tabular}{|c|c|c|c|c|c|c|}
\hline Sample & Stratigraphic Unit & $\begin{array}{l}\text { UTM } \\
\text { Zone }\end{array}$ & Northing & Easting & $\begin{array}{l}\text { Elevation } \\
(\mathrm{m})\end{array}$ & $\begin{array}{l}\text { Applied } \\
\text { Method }\end{array}$ \\
\hline GPS-29 & Soca Granite & $21 S$ & 624323 & 6162196 & 36 & ZHe \\
\hline U-46 & Las Animas Syenite & $21 S$ & 660292 & 6145256 & 80 & $\mathrm{ZHe}+\mathrm{AHe}$ \\
\hline U-74 & La Paz Granite & $21 S$ & 567880 & 6154691 & 50 & $\mathrm{AHe}$ \\
\hline UY-10-14 & CSZ mylonite & $21 S$ & 713342 & 6176030 & 76 & $\mathrm{ZHe}$ \\
\hline UY-23-14 & Jose Ignacio Granite & $21 S$ & 715852 & 6141437 & 19 & $\mathrm{ZHe}+\mathrm{AHe}$ \\
\hline UY-33-14 & Aiguá Granite & $21 S$ & 708914 & 6209348 & 157 & $\mathrm{ZHe}+\mathrm{AHe}$ \\
\hline UY-41-14 & $\begin{array}{l}\text { Valentines mica } \\
\text { schist/gneiss }\end{array}$ & $21 S$ & 684007 & 6316965 & 302 & $\mathrm{ZHe}$ \\
\hline UY-43-14 & $\begin{array}{l}\text { Valentines mica } \\
\text { schist/gneiss }\end{array}$ & $21 S$ & 690109 & 6316090 & 285 & $\mathrm{AHe}$ \\
\hline UY-45-14 & Maria Albina Orthogneiss & $21 S$ & 715563 & 6304524 & 142 & $\mathrm{AHe}$ \\
\hline UY-51-14 & Aiguá Batholith granite & $21 S$ & 751831 & 6359765 & 223 & $\mathrm{ZHe}+\mathrm{AHe}$ \\
\hline UY-68-14 & Florida Gneiss & $21 S$ & 629970 & 6302977 & 150 & $\mathrm{ZHe}+\mathrm{AHe}$ \\
\hline UY-1-15 & Florida Gneiss & $21 S$ & 555668 & 6290065 & 129 & $\mathrm{ZHe}+\mathrm{AHe}$ \\
\hline UY-3-15 & Florida Gneiss & $21 S$ & 584015 & 6137751 & 21 & $\mathrm{ZHe}+\mathrm{AHe}$ \\
\hline UYFG 1 & RSZ fault gouge & $21 S$ & 644497 & 6503750 & 177 & $\mathrm{~K}-\mathrm{Ar}$ in $\mathrm{FG}$ \\
\hline UYFG 2 & RSZ fault gouge & $21 S$ & 644497 & 6503750 & 177 & $\mathrm{~K}-\mathrm{Ar}$ in $\mathrm{FG}$ \\
\hline UY-21-13 & MASZ fault gouge & $21 S$ & 600099 & 6303397 & 167 & $\mathrm{~K}-\mathrm{Ar}$ in $\mathrm{FG}$ \\
\hline UY-14-14 & SBSZ Phyllonite & $21 S$ & 683975 & 6155410 & 82 & $\mathrm{~K}-\mathrm{Ar}$ in $\mathrm{FF}$ \\
\hline UY-15-14 & SBSZ fault gouge & $21 S$ & 683975 & 6155410 & 82 & $\mathrm{~K}-\mathrm{Ar}$ in $\mathrm{FG}$ \\
\hline UY-16-14 & SBSZ fault gouge & $21 S$ & 683975 & 6155410 & 82 & $\mathrm{~K}-\mathrm{Ar}$ in $\mathrm{FG}$ \\
\hline
\end{tabular}

Rio Grande do Sul:

\begin{tabular}{ccccccc} 
Sample & Stratigraphic Unit & $\begin{array}{c}\text { UTM } \\
\text { Zone }\end{array}$ & Northing & Easting & $\begin{array}{c}\text { Elevation } \\
(\mathbf{m})\end{array}$ & $\begin{array}{c}\text { Applied } \\
\text { Method }\end{array}$ \\
\hline BR-08-15 & ISZ Mylonite & $21 S$ & 6590252 & 762152 & 226 & CPO \\
\hline BR-13-15 & ISZ Mylonite & $21 S$ & 6574129 & 777068 & 348 & CPO \\
\hline BR-17-15 & Tijucas Terrane Mylonite & $22 S$ & 6585683 & 292009 & 357 & CPO \\
\hline BR-21a-15 & Tijucas Terrane Mylonite & $22 S$ & 6577141 & 291128 & 394 & CPO \\
\hline BR-31-15 & DCSZ Mylonite & $22 S$ & 6647284 & 386269 & 200 & CPO \\
\hline BR-39-15 & DCSZ Mylonite & $22 S$ & 6595342 & 341417 & 332 & CPO \\
\hline BR-54-15 & DCSZ Mylonite & $22 S$ & 6510096 & 261083 & 390 & CPO \\
\hline BR-59-15 & Tijucas Terrane Mylonite & $22 S$ & 6587782 & 292210 & 362 & CPO \\
\hline BR-12-15 & ISZ mylonite & $21 S$ & 6574129 & 777068 & 348 & K-Ar in Ms \\
\hline BR-29-15 & Cordilheira Suite Granite & $22 S$ & 6642477 & 385563 & 307 & K-Ar in Ms \\
\hline BR-30-15 & DCSZ mylonite & $22 S$ & 6647284 & 386269 & 200 & K-Ar in Ms \\
\hline BR-32-15 & DCSZ mylonite & $22 S$ & 6647284 & 386269 & 200 & K-Ar in Ms \\
\hline
\end{tabular}




\begin{tabular}{|c|c|c|c|c|c|c|}
\hline BR-64-15 & $\begin{array}{c}\text { Encantadas Complex } \\
\text { gneiss }\end{array}$ & $22 S$ & 6598036 & 304633 & 364 & $\mathrm{~K}-\mathrm{Ar}$ in $\mathrm{Ms}$ \\
\hline BR-14B-17 & ISZ metapelite & $21 S$ & 6574038 & 778910 & 350 & $\mathrm{~K}-\mathrm{Ar}$ in $\mathrm{Ms}$ \\
\hline BR-15A-17 & ISZ metapelite & $21 S$ & 6573199 & 780919 & 313 & $\mathrm{~K}-\mathrm{Ar}$ in $\mathrm{Ms}$ \\
\hline BR-16-17 & ISZ mylonite & $21 S$ & 6574136 & 777044 & 345 & $\mathrm{~K}-\mathrm{Ar}$ in $\mathrm{Ms}$ \\
\hline BR-38b-17 & $\begin{array}{l}\text { Arroio dos Ratos } \\
\text { Complex gneiss }\end{array}$ & $22 S$ & 6637896 & 391930 & 313 & $\mathrm{~K}-\mathrm{Ar}$ in $\mathrm{Ms}$ \\
\hline BR-39A-17 & DCSZ mylonite & $22 S$ & 6599342 & 344218 & 361 & $\mathrm{~K}-\mathrm{Ar}$ in $\mathrm{Ms}$ \\
\hline BR-43B-17 & Cordilheira Suite Granite & $22 S$ & 6596448 & 346406 & 350 & $\mathrm{~K}-\mathrm{Ar}$ in $\mathrm{Ms}$ \\
\hline BR-51b-17 & $\begin{array}{l}\text { Porongos Complex } \\
\text { (Capané Schist) }\end{array}$ & $22 S$ & 6638554 & 316691 & 152 & $\mathrm{~K}-\mathrm{Ar}$ in $\mathrm{Ms}$ \\
\hline BR-10-15 & ISZ Mylonite & $21 S$ & 6590252 & 762152 & 226 & $\mathrm{~K}-\mathrm{Ar}$ in $\mathrm{FF}$ \\
\hline BR-12-15 & ISZ Mylonite & $21 S$ & 6574129 & 777068 & 348 & $\mathrm{~K}-\mathrm{Ar}$ in $\mathrm{FF}$ \\
\hline BR-30-15 & DCSZ Mylonite & $22 S$ & 6647284 & 386269 & 200 & $\mathrm{~K}-\mathrm{Ar}$ in $\mathrm{FF}$ \\
\hline BR-32-15 & DCSZ Mylonite & $22 S$ & 6647284 & 386269 & 200 & $\mathrm{~K}-\mathrm{Ar}$ in $\mathrm{FF}$ \\
\hline BR-58-15 & Tijucas Terrane Mylonite & $22 S$ & 6587782 & 292210 & 362 & $\mathrm{~K}-\mathrm{Ar}$ in $\mathrm{FF}$ \\
\hline BR-60-15 & Tijucas Terrane Mylonite & $22 S$ & 6593131 & 295297 & 377 & $\mathrm{~K}-\mathrm{Ar}$ in $\mathrm{FF}$ \\
\hline BR-37-15 & Fault along DCSZ & $22 S$ & 6595342 & 341417 & 332 & $\mathrm{~K}-\mathrm{Ar}$ in $\mathrm{FG}$ \\
\hline BR-38-15 & Fault along DCSZ & $22 S$ & 6595342 & 341417 & 332 & $\mathrm{~K}-\mathrm{Ar}$ in $\mathrm{FG}$ \\
\hline BR-40-15 & Fault along DCSZ & $22 S$ & 6595342 & 341417 & 332 & $\mathrm{~K}-\mathrm{Ar}$ in $\mathrm{FG}$ \\
\hline BR-43-15 & $\begin{array}{l}\text { Fault associated with the } \\
\text { PMF }\end{array}$ & $22 S$ & 6586736 & 349760 & 127 & $\mathrm{~K}-\mathrm{Ar}$ in $\mathrm{FG}$ \\
\hline BR-45-15 & $\begin{array}{l}\text { Fault inside the Pelotas } \\
\text { batholith }\end{array}$ & $22 S$ & 6525799 & 338906 & 467 & $\mathrm{~K}-\mathrm{Ar}$ in $\mathrm{FG}$ \\
\hline BR-62-15 & $\begin{array}{c}\text { Fault inside the Tijucas } \\
\text { Terrane }\end{array}$ & $22 S$ & 6593131 & 295297 & 377 & $\mathrm{~K}-\mathrm{Ar}$ in $\mathrm{FG}$ \\
\hline BR-01-15 & $\begin{array}{c}\text { Santa Maria Chico } \\
\text { Granulite }\end{array}$ & $21 S$ & 6560679 & 739054 & 106 & $\mathrm{ZHe}+\mathrm{AHe}$ \\
\hline BR-06-15 & Saibro Granite & $21 S$ & 6572878 & 772150 & 339 & $\mathrm{ZHe}+\mathrm{AHe}$ \\
\hline BR-19-15 & $\begin{array}{c}\text { Encantadas Complex } \\
\text { gneiss }\end{array}$ & $22 S$ & 6582195 & 294508 & 238 & $\mathrm{ZHe}+\mathrm{AHe}$ \\
\hline BR-23-15 & Cambaí Complex gneiss & $22 S$ & 6572925 & 214951 & 280 & $\mathrm{ZHe}+\mathrm{AHe}$ \\
\hline BR-26-15 & $\begin{array}{l}\text { Arroio dos Ratos } \\
\text { Complex gneiss }\end{array}$ & $22 S$ & 6609855 & 349600 & 285 & $\mathrm{ZHe}+\mathrm{AHe}$ \\
\hline BR-34-15 & Quitéria Suite Granite & $22 S$ & 6636807 & 389370 & 303 & $\mathrm{ZHe}+\mathrm{AHe}$ \\
\hline BR-44-15 & $\begin{array}{c}\text { Dom Feliciano Suite } \\
\text { Granite }\end{array}$ & $22 S$ & 6554381 & 319680 & 258 & $\mathrm{ZHe}+\mathrm{AHe}$ \\
\hline BR-48-15 & $\begin{array}{l}\text { Pinheiro Machado Suite } \\
\text { Granite }\end{array}$ & $22 S$ & 6511928 & 348358 & 239 & $\mathrm{ZHe}+\mathrm{AHe}$ \\
\hline BR-52-15 & $\begin{array}{c}\text { Dom Feliciano Suite } \\
\text { Granite }\end{array}$ & $22 S$ & 6509877 & 261471 & 391 & $\mathrm{ZHe}+\mathrm{AHe}$ \\
\hline BR-55-15 & $\begin{array}{l}\text { Porongos Complex } \\
\text { (Metaconglomerate) }\end{array}$ & $22 S$ & 6510032 & 259809 & 305 & $\mathrm{ZHe}+\mathrm{AHe}$ \\
\hline BR-57-15 & $\begin{array}{l}\text { Dom Feliciano Suite } \\
\text { Granite }\end{array}$ & $22 S$ & 6487074 & 338146 & 60 & $\mathrm{ZHe}$ \\
\hline BR-63-15 & Caçapava do Sul Granite & $22 S$ & 6622094 & 263297 & 278 & $\mathrm{ZHe}+\mathrm{AHe}$ \\
\hline BR-65-15 & Dom Feliciano Granite & $22 S$ & $\begin{array}{l}6669193 \\
201\end{array}$ & 426068 & 126 & ZHe \\
\hline
\end{tabular}




\section{Santa Catarina:}

\begin{tabular}{|c|c|c|c|c|c|c|}
\hline Sample & Stratigraphic Unit & $\begin{array}{l}\text { UTM } \\
\text { Zone }\end{array}$ & Northing & Easting & $\begin{array}{c}\text { Elevation } \\
(\mathrm{m})\end{array}$ & $\begin{array}{l}\text { Applied } \\
\text { Method }\end{array}$ \\
\hline BR-92-15 & MGSZ mylonite & $22 S$ & 745412 & 6997031 & 22 & $\mathrm{CPO}$ \\
\hline DSZ-20A & MGSZ mylonite & $22 S$ & 699649 & 6963523 & 95 & $\mathrm{CPO}$ \\
\hline DSZ-25B & MGSZ mylonite & $22 S$ & 701328 & 6966600 & 72 & $\mathrm{CPO}$ \\
\hline DSZ28 & MGSZ mylonite & $22 S$ & 703847 & 6968457 & 47 & $\mathrm{CPO}$ \\
\hline DSZ-39A & MGSZ mylonite & $22 S$ & 728361 & 6980072 & 4 & $\mathrm{CPO}$ \\
\hline MTF-01B & MGSZ mylonite & $22 S$ & 705629 & 6969880 & 45 & $\mathrm{CPO}$ \\
\hline MTF-02 & MGSZ mylonite & $22 S$ & 705254 & 6969630 & 48 & $\mathrm{CPO}$ \\
\hline BR 72-15 & $\begin{array}{l}\text { Schist from the Brusque } \\
\text { Group }\end{array}$ & $22 S$ & 690257 & 6957461 & 549 & $\mathrm{~K}-\mathrm{Ar}$ in $\mathrm{Ms}$ \\
\hline BR 72-15 & $\begin{array}{l}\text { Schist from the Brusque } \\
\text { Group }\end{array}$ & $22 S$ & 690257 & 6957461 & 549 & $\mathrm{~K}-\mathrm{Ar}$ in $\mathrm{FF}$ \\
\hline BR 79-15 & MGSZ mylonite & $22 S$ & 701271 & 6966606 & 74 & $\mathrm{~K}-\mathrm{Ar}$ in $\mathrm{FF}$ \\
\hline BR $80-15$ & MGSZ mylonite & $22 S$ & 704717 & 6969022 & 38 & $\mathrm{~K}-\mathrm{Ar}$ in $\mathrm{FF}$ \\
\hline BR $82-15$ & MGSZ mylonite & $22 S$ & 705445 & 6969717 & 44 & $\mathrm{~K}-\mathrm{Ar}$ in $\mathrm{Ms}$ \\
\hline BR 83-15 & MGSZ mylonite & $22 S$ & 705445 & 6969717 & 44 & $\mathrm{~K}-\mathrm{Ar}$ in $\mathrm{Ms}$ \\
\hline BR 89-15 & São João Batista Granite & $22 S$ & 710502 & 6980924 & 39 & $\mathrm{~K}-\mathrm{Ar}$ in $\mathrm{Ms}$ \\
\hline BR-66-15 & Rolador Granite & $22 S$ & 702985 & 6955515 & 400 & $\mathrm{ZHe}+\mathrm{AHe}$ \\
\hline BR-67-15 & $\begin{array}{c}\text { São Pedro de Alcântaras } \\
\text { Granite }\end{array}$ & $22 S$ & 704627 & 6953745 & 452 & $\mathrm{ZHe}+\mathrm{AHe}$ \\
\hline BR-69-15 & $\begin{array}{c}\text { São Pedro de Alcântaras } \\
\text { Granite }\end{array}$ & $22 S$ & 697863 & 6957904 & 227 & $\mathrm{ZHe}+\mathrm{AHe}$ \\
\hline BR-70-15 & Valsungana Granite & $22 S$ & 691553 & 6963531 & 631 & $\mathrm{ZHe}+\mathrm{AHe}$ \\
\hline BR-75-15 & Fernandes Granite & $22 S$ & 700722 & 6960792 & 337 & $\mathrm{ZHe}+\mathrm{AHe}$ \\
\hline BR-76-15 & Fernandes Granite & $22 S$ & 701205 & 6964419 & 64 & $\mathrm{ZHe}+\mathrm{AHe}$ \\
\hline BR-86-15 & $\begin{array}{c}\text { São Pedro de Alcântaras } \\
\text { Granite }\end{array}$ & $22 S$ & 715699 & 6964148 & 272 & $\mathrm{ZHe}+\mathrm{AHe}$ \\
\hline BR-87-15 & $\begin{array}{c}\text { São Pedro de Alcântaras } \\
\text { Granite }\end{array}$ & $22 S$ & 719840 & 6957234 & 31 & $\mathrm{ZHe}+\mathrm{AHe}$ \\
\hline BR-88-15 & Pedras Grandes Granite & $22 S$ & 734459 & 6979928 & 19 & ZHe \\
\hline BR-90-15 & Valsungana Granite & $22 S$ & 710987 & 6992238 & 406 & $\mathrm{ZHe}+\mathrm{AHe}$ \\
\hline BR-91-15 & Nova Trento Granite & $22 S$ & 710535 & 6985468 & 141 & $\mathrm{ZHe}+\mathrm{AHe}$ \\
\hline BR-93-15 & $\begin{array}{l}\text { MGSZ Granites - Quatro } \\
\text { Ilhas Granite }\end{array}$ & $22 S$ & 744288 & 6993373 & 60 & $\mathrm{ZHe}+\mathrm{AHe}$ \\
\hline BR-94-15 & Valsungana Granite & $22 S$ & 738370 & 7011825 & 63 & $\mathrm{ZHe}+\mathrm{AHe}$ \\
\hline DSZ-24A & Valsungana Granite & $22 S$ & 698309 & 6968441 & 153 & $\mathrm{ZHe}+\mathrm{AHe}$ \\
\hline MTF-01B & MGSZ mylonite & $22 S$ & 705629 & 6969880 & 45 & $\mathrm{ZHe}+\mathrm{AHe}$ \\
\hline VSM-30 & $\begin{array}{l}\text { Granite from the Águas } \\
\text { Mornas Complex }\end{array}$ & $22 S$ & 759464 & 6958773 & 12 & $\mathrm{AHe}$ \\
\hline
\end{tabular}




\section{Observations:}

- Coordinates are in UTM system - Datum: WGS 84

- $\quad$ CPO refers to quartz crystallographic preferred orientation textural analysis in rock samples

- Ms, FF and FG refer to muscovite crystals, illite fine fractions in whole rock and illites in fault gouge, respectively

- ZHe and AHe refer to the (U-Th)/He method in zircon and apatite, respectively

- CSZ - Cordillera Shear Zone, RSZ - Rivera Shear Zone, MASZ - Maria Albina Shear Zone, SBSZ Sierra Ballena Shear Zone; DCSZ - Dorsal do Canguçu Shear Zone; ISZ - Ibaré Shear Zone; PMF Passo do Marinheiro Fault; MGSZ - Major Gercino Shear Zone 


\section{APPENDIX B - K-Ar results}

\section{Uruguay:}

\begin{tabular}{|c|c|c|c|c|c|c|c|}
\hline \multirow{2}{*}{ Sample } & \multirow{2}{*}{ Unit } & \multirow{2}{*}{$\begin{array}{c}\text { Dated } \\
\text { material }\end{array}$} & \multirow{2}{*}{$\frac{\mathrm{K}_{2} \mathrm{O}}{(\mathrm{Wt} . \%)}$} & \multicolumn{2}{|c|}{${ }^{40} \mathrm{Ar}$} & \multirow{2}{*}{$\begin{array}{c}\text { Age } \\
\text { (Ma) }\end{array}$} & \multirow{2}{*}{$\begin{array}{l}\text { Error } \\
\text { (Ma) }\end{array}$} \\
\hline & & & & (nl/g) & (\%) & & \\
\hline \multirow{3}{*}{ UY-14-14 } & \multirow{3}{*}{ SBSZ Phyllonite } & $\mathrm{FF}<0.2 \mu \mathrm{m}$ & 5.35 & 91.49 & 91.78 & 465.3 & 7.3 \\
\hline & & $\mathrm{FF}<2 \mu \mathrm{m}$ & 6.70 & 126.05 & 94.77 & 505.7 & 10.9 \\
\hline & & FF 2-6 $\mu \mathrm{m}$ & 8.17 & 163.62 & 98.54 & 533.7 & 8.3 \\
\hline \multirow{5}{*}{ UY-15-14 } & \multirow{5}{*}{ Fault along SBSZ } & \multirow{2}{*}{ FG $<0.2 \mu \mathrm{m}$} & 0.14 & 0.40 & 79.45 & 87.4 & 2.0 \\
\hline & & & 0.14 & 0.45 & 34.35 & 98.3 & 3.4 \\
\hline & & \multirow{2}{*}{$\mathrm{FG}<2 \mu \mathrm{m}$} & 0.12 & 0.62 & 75.09 & 152.8 & 3.6 \\
\hline & & & 0.12 & 0.63 & 80.18 & 155.7 & 3.6 \\
\hline & & FG 2-6 $\mu \mathrm{m}$ & 0.19 & 1.24 & 27.58 & 193.7 & 8.3 \\
\hline \multirow{4}{*}{ UY-16-14 } & \multirow{4}{*}{ Fault along SBSZ } & \multirow{2}{*}{ FG $<0.2 \mu \mathrm{m}$} & 0.09 & 0.29 & 49.32 & 92.8 & 4.0 \\
\hline & & & 0.09 & 0.27 & 44.00 & 87.7 & 3.9 \\
\hline & & $\mathrm{FG}<2 \mu \mathrm{m}$ & 0.10 & 0.25 & 45.35 & 81.3 & 1.9 \\
\hline & & FG 2-6 $\mu \mathrm{m}$ & 0.07 & 0.45 & 52.17 & 190.7 & 4.3 \\
\hline \multirow{3}{*}{ UY-21-13 } & \multirow{3}{*}{ Fault along MASZ } & $\mathrm{FG}<0.2 \mu \mathrm{m}$ & 0.73 & 3.24 & 84.41 & 132.4 & 1.6 \\
\hline & & $\mathrm{FG}<2 \mu \mathrm{m}$ & 1.14 & 6.37 & 92.49 & 165.4 & 3.1 \\
\hline & & FG 2-6 $\mu \mathrm{m}$ & 0.67 & 11.96 & 95.36 & 480.7 & 5.0 \\
\hline \multirow{3}{*}{ UYFG 1} & \multirow{3}{*}{ Fault along RSZ } & $\mathrm{FG}<0.2 \mu \mathrm{m}$ & 7.34 & 93.43 & 97.71 & 356.9 & 6.1 \\
\hline & & $\mathrm{FG}<2 \mu \mathrm{m}$ & 6.94 & 94.97 & 97.86 & 381.1 & 5.9 \\
\hline & & FG 2-6 $\mu \mathrm{m}$ & 4.70 & 75.13 & 96.40 & 437.9 & 7.0 \\
\hline \multirow{3}{*}{ UYFG 2} & \multirow{3}{*}{ Fault along RSZ } & $\mathrm{FG}<0.2 \mu \mathrm{m}$ & 7.99 & 105.45 & 98.64 & 368.8 & 9.8 \\
\hline & & $\mathrm{FG}<2 \mu \mathrm{m}$ & 7.34 & 103.62 & 99.07 & 391.9 & 5.9 \\
\hline & & FG 2-6 $\mu \mathrm{m}$ & 5.40 & 85.95 & 99.80 & 436.3 & 6.6 \\
\hline
\end{tabular}

Rio Grande do Sul:

\begin{tabular}{|c|c|c|c|c|c|c|c|}
\hline \multirow{2}{*}{ Sample } & \multirow{2}{*}{ Unit } & \multirow{2}{*}{$\begin{array}{c}\text { Dated } \\
\text { material }\end{array}$} & \multirow{2}{*}{$\begin{array}{c}\mathrm{K}_{2} \mathrm{O} \\
(\mathrm{Wt} . \%)\end{array}$} & \multicolumn{2}{|c|}{${ }^{40} \mathrm{Ar}$} & \multirow{2}{*}{$\begin{array}{c}\text { Age } \\
\text { (Ma) }\end{array}$} & \multirow{2}{*}{$\begin{array}{l}\text { Error } \\
\text { (Ma) }\end{array}$} \\
\hline & & & & (nl/g) & (\%) & & \\
\hline BR-12-15 & ISZ mylonite & Muscovite & 9.34 & 283.64 & 99.13 & 757.7 & 11.4 \\
\hline BR-29-15 & $\begin{array}{c}\text { Cordilheira Suite } \\
\text { Granite }\end{array}$ & Muscovite & 9.56 & 247.13 & 99.43 & 639.4 & 6.5 \\
\hline BR-30-15 & DCSZ mylonite & Muscovite & 9.64 & 242.47 & 99.14 & 648.0 & 6.8 \\
\hline BR-32-15 & DCSZ mylonite & Muscovite & 9.12 & 217.36 & 99.03 & 619.3 & 9.3 \\
\hline BR-64-15 & $\begin{array}{c}\text { Encantadas Complex } \\
\text { gneiss }\end{array}$ & Muscovite & 10.03 & 208.57 & 99.52 & 551.3 & 5.6 \\
\hline BR-14B-17 & ISZ metapelite & Muscovite & 9.45 & 244.11 & 99.59 & 662.7 & 7.1 \\
\hline BR-15A-17 & ISZ metapelite & Muscovite & 9.89 & 293.45 & 99.67 & 743.5 & 10.2 \\
\hline BR-16-17 & ISZ mylonite & Muscovite & 9.24 & 275.66 & 99.16 & 747.1 & 9.2 \\
\hline
\end{tabular}




\begin{tabular}{|c|c|c|c|c|c|c|c|}
\hline BR-38b-17 & $\begin{array}{l}\text { Arroio dos Ratos } \\
\text { Complex gneiss }\end{array}$ & Muscovite & 9.94 & 236.60 & 99.33 & 618.8 & 6.4 \\
\hline BR-39A-17 & DCSZ mylonite & Muscovite & 9.60 & 214.00 & 99.23 & 585.1 & 6.2 \\
\hline BR-43B-17 & $\begin{array}{c}\text { Cordilheira Suite } \\
\text { Granite }\end{array}$ & Muscovite & 9.96 & 232.41 & 99.45 & 608.2 & 7.5 \\
\hline BR-51b-17 & $\begin{array}{l}\text { Porongos Complex } \\
\text { (Capané Schist) }\end{array}$ & Muscovite & 5.88 & 123.54 & 98.34 & 556.1 & 9.5 \\
\hline \multirow{2}{*}{ BR-10-15 } & \multirow{2}{*}{ ISZ Mylonite } & $\mathrm{FF}<0.2 \mu \mathrm{m}$ & 2.76 & 61.07 & 96.60 & 581.1 & 6.3 \\
\hline & & $\mathrm{FF}<2 \mu \mathrm{m}$ & 2.97 & 63.89 & 96.14 & 567.0 & 4.9 \\
\hline \multirow{2}{*}{ BR-12-15 } & \multirow{2}{*}{ ISZ Mylonite } & $\mathrm{FF}<0.2 \mu \mathrm{m}$ & 4.07 & 86.48 & 98.31 & 561.6 & 7.2 \\
\hline & & $\mathrm{FF}<2 \mu \mathrm{m}$ & 4.36 & 92.52 & 98.36 & 560.6 & 7.3 \\
\hline \multirow{2}{*}{ BR-30-15 } & \multirow{2}{*}{ DCSZ Mylonite } & $\mathrm{FF}<0.2 \mu \mathrm{m}$ & 3.33 & 65.41 & 98.89 & 525.2 & 7.6 \\
\hline & & $\mathrm{FF}<2 \mu \mathrm{m}$ & 3.43 & 67.18 & 99.37 & 523.1 & 7.3 \\
\hline \multirow{2}{*}{ BR-32-15 } & \multirow{2}{*}{ DCSZ Mylonite } & $\mathrm{FF}<0.2 \mu \mathrm{m}$ & 2.03 & 35.05 & 95.11 & 468.8 & 6.2 \\
\hline & & $\mathrm{FF}<2 \mu \mathrm{m}$ & 2.67 & 49.21 & 98.88 & 495.9 & 7.7 \\
\hline \multirow{2}{*}{ BR-58-15 } & \multirow{2}{*}{$\begin{array}{l}\text { Tijucas Terrane } \\
\text { Mylonite }\end{array}$} & $\mathrm{FF}<0.2 \mu \mathrm{m}$ & 4.50 & 81.23 & 97.87 & 487.5 & 10.7 \\
\hline & & $\mathrm{FF}<2 \mu \mathrm{m}$ & 4.64 & 90.67 & 98.76 & 522.5 & 5.8 \\
\hline \multirow{2}{*}{ BR-60-15 } & \multirow{2}{*}{$\begin{array}{c}\text { Tijucas Terrane } \\
\text { Mylonite }\end{array}$} & $\mathrm{FF}<0.2 \mu \mathrm{m}$ & 4.40 & 80.20 & 98.94 & 492.0 & 6.8 \\
\hline & & $\mathrm{FF}<2 \mu \mathrm{m}$ & 4.37 & 84.95 & 99.26 & 520.0 & 6.4 \\
\hline \multirow{3}{*}{ BR-37-15 } & \multirow{3}{*}{ Fault along DCSZ } & $\mathrm{FG}<0.2 \mu \mathrm{m}$ & 1.47 & 31.57 & 97.42 & 568.2 & 6.1 \\
\hline & & $\mathrm{FG}<2 \mu \mathrm{m}$ & 1.72 & 32.52 & 98.30 & 506.9 & 9.1 \\
\hline & & FG 2-6 $\mu \mathrm{m}$ & 1.86 & 35.74 & 99.96 & 514.4 & 5.2 \\
\hline \multirow{3}{*}{ BR-38-15 } & \multirow{3}{*}{ Fault along DCSZ } & $\mathrm{FG}<0.2 \mu \mathrm{m}$ & 1.41 & 21.57 & 96.55 & 422.2 & 8.6 \\
\hline & & $\mathrm{FG}<2 \mu \mathrm{m}$ & 1.81 & 31.37 & 99.40 & 470.6 & 6.1 \\
\hline & & FG 2-6 $\mu \mathrm{m}$ & 3.36 & 68.91 & 99.24 & 545.0 & 5.6 \\
\hline \multirow{3}{*}{ BR-40-15 } & \multirow{3}{*}{ Fault along DCSZ } & $\mathrm{FG}<0.2 \mu \mathrm{m}$ & 3.70 & 65.80 & 96.97 & 480.8 & 8.5 \\
\hline & & $\mathrm{FG}<2 \mu \mathrm{m}$ & 3.91 & 69.32 & 99.55 & 480.1 & 4.8 \\
\hline & & FG 2-6 $\mu \mathrm{m}$ & 3.61 & 71.35 & 98.84 & 527.8 & 5.3 \\
\hline \multirow{3}{*}{ BR-43-15 } & \multirow{3}{*}{ Fault along DCSZ } & $\mathrm{FG}<0.2 \mu \mathrm{m}$ & 0.11 & 0.42 & 47.64 & 115.9 & 2.6 \\
\hline & & $\mathrm{FG}<2 \mu \mathrm{m}$ & 0.14 & 0.54 & 51.64 & 115.1 & 1.7 \\
\hline & & FG 2-6 $\mu \mathrm{m}$ & 0.41 & 1.44 & 85.84 & 107.1 & 2.6 \\
\hline \multirow{3}{*}{ BR-45-15 } & \multirow{3}{*}{ Fault along DCSZ } & $\mathrm{FG}<0.2 \mu \mathrm{m}$ & 7.65 & 103.76 & 97.42 & 377.9 & 5.2 \\
\hline & & $\mathrm{FG}<2 \mu \mathrm{m}$ & 7.29 & 108.64 & 99.49 & 411.2 & 5.8 \\
\hline & & FG 2-6 $\mu \mathrm{m}$ & 1.32 & 21.04 & 99.48 & 436.8 & 4.8 \\
\hline \multirow{3}{*}{ BR-62-15 } & \multirow{3}{*}{ Fault along DCSZ } & $\mathrm{FG}<0.2 \mu \mathrm{m}$ & 6.93 & 74.47 & 98.10 & 305.8 & 4.9 \\
\hline & & $\mathrm{FG}<2 \mu \mathrm{m}$ & 5.47 & 76.38 & 99.95 & 387.9 & 4.9 \\
\hline & & FG 2-6 $\mu \mathrm{m}$ & 1.53 & 26.89 & 99.86 & 476.1 & 5.1 \\
\hline
\end{tabular}




\section{Santa Catarina:}

\begin{tabular}{|c|c|c|c|c|c|c|c|}
\hline \multirow{2}{*}{ Sample } & \multirow{2}{*}{ Unit } & \multirow{2}{*}{$\begin{array}{c}\text { Dated } \\
\text { material }\end{array}$} & \multirow{2}{*}{$\frac{\mathrm{K}_{2} \mathrm{O}}{(\mathrm{Wt} . \%)}$} & \multicolumn{2}{|c|}{${ }^{40} \mathrm{Ar}$} & \multirow{2}{*}{$\begin{array}{l}\text { Age } \\
\text { (Ma) }\end{array}$} & \multirow{2}{*}{$\begin{array}{l}\text { Error } \\
\text { (Ma) }\end{array}$} \\
\hline & & & & (nl/g) & (\%) & & \\
\hline BR 72-15 & Brusque schist & Muscovite & 8.90 & 199.47 & 99.37 & 588.1 & 6.1 \\
\hline BR 82-15 & MGSZ mylonite & Muscovite & 7.96 & 225.81 & 98.82 & 603.9 & 6.7 \\
\hline BR 83-15 & MGSZ mylonite & Muscovite & 9.86 & 225.29 & 98.17 & 597.8 & 7.5 \\
\hline BR $89-15$ & São João Batista Granite & Muscovite & 9.48 & 207.67 & 96.71 & 576.4 & 6.3 \\
\hline \multirow{2}{*}{ BR 72-15 } & \multirow{2}{*}{ Brusque Schist } & $\mathrm{FF}<0.2 \mu \mathrm{m}$ & 1.79 & 33.06 & 98.44 & 497.4 & 3.8 \\
\hline & & $\mathrm{FF}<2 \mu \mathrm{m}$ & 2.11 & 33.53 & 98.76 & 436.3 & 6.7 \\
\hline \multirow{2}{*}{ BR 79-15 } & \multirow{2}{*}{ MGSZ mylonite } & $\mathrm{FF}<0.2 \mu \mathrm{m}$ & 3.47 & 41.45 & 92.67 & 336.8 & 4.3 \\
\hline & & $\mathrm{FF}<2 \mu \mathrm{m}$ & 3.56 & 43.68 & 92.65 & 345.2 & 4.9 \\
\hline \multirow{2}{*}{ BR $80-15$} & \multirow{2}{*}{ MGSZ mylonite } & $\mathrm{FF}<0.2 \mu \mathrm{m}$ & 2.98 & 37.46 & 90.37 & 353.3 & 5.4 \\
\hline & & $\mathrm{FF}<2 \mu \mathrm{m}$ & 2.79 & 44.73 & 93.05 & 438.9 & 4.9 \\
\hline
\end{tabular}

Observations:

- $\quad$ All age errors are $2 \sigma$

- FF and FG refer to illite fine fractions in whole rock and illites in fault gouge, respectively

- RSZ - Rivera Shear Zone, MASZ - Maria Albina Shear Zone, SBSZ - Sierra Ballena Shear Zone; DCSZ - Dorsal do Canguçu Shear Zone; ISZ - Ibaré Shear Zone; PMF - Passo do Marinheiro Fault; MGSZ - Major Gercino Shear Zone 


\section{APPENDIX C - Illite characterization of dated samples}

\begin{tabular}{|c|c|c|c|c|c|c|c|}
\hline \multirow{2}{*}{\multicolumn{2}{|c|}{ Sample }} & \multirow{2}{*}{$\begin{array}{c}\text { Size } \\
\text { fraction }\end{array}$} & \multicolumn{2}{|c|}{ Illite polytypes } & \multicolumn{2}{|c|}{ Illite crystallinity } & \multirow{2}{*}{ Metamorphic zone } \\
\hline & & & $\% 2 \mathrm{M} 1$ & error & $\mathrm{KI} \mathbf{a}$ & $\mathrm{KI} \mathrm{g}$ & \\
\hline \multirow{12}{*}{ 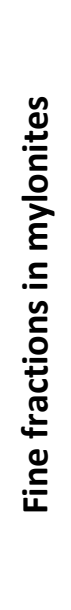 } & \multirow{2}{*}{ BR 10-15 } & $<0.2 \mu \mathrm{m}$ & 47.0 & 19.2 & 0.153 & 0.140 & Epizone \\
\hline & & $<2 \mu \mathrm{m}$ & 45.1 & 14.9 & 0.179 & 0.178 & Epizone \\
\hline & \multirow{2}{*}{ BR 12-15 } & $<0.2 \mu \mathrm{m}$ & 42.7 & 30.1 & 0.287 & 0.281 & Anchizone \\
\hline & & $<2 \mu \mathrm{m}$ & 44.8 & 32.3 & 0.395 & 0.382 & Anchizone \\
\hline & \multirow{2}{*}{ BR 30-15 } & $<0.2 \mu \mathrm{m}$ & 18.8 & 2.9 & 0.195 & 0.194 & Epizone \\
\hline & & $<2 \mu \mathrm{m}$ & 24.9 & 0.9 & 0.223 & 0.224 & Epizone \\
\hline & \multirow{2}{*}{ BR 32-15 } & $<0.2 \mu \mathrm{m}$ & 20.5 & 1.5 & 0.120 & 0.147 & Epizone \\
\hline & & $<2 \mu \mathrm{m}$ & 37.3 & 1.0 & 0.147 & 0.164 & Epizone \\
\hline & \multirow{2}{*}{ BR 58-15 } & $<0.2 \mu \mathrm{m}$ & 36.6 & 7.8 & 0.229 & 0.228 & Epizone \\
\hline & & $<2 \mu \mathrm{m}$ & 36.7 & 5.2 & 0.270 & 0.257 & Anchizone \\
\hline & \multirow{2}{*}{ BR 60-15 } & $<0.2 \mu \mathrm{m}$ & 23.8 & 2.3 & 0.195 & 0.168 & Epizone \\
\hline & & $<2 \mu \mathrm{m}$ & 25.9 & 2.2 & 0.206 & 0.200 & Epizone \\
\hline \multirow{15}{*}{ 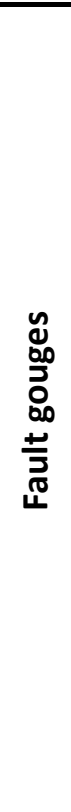 } & \multirow{3}{*}{ BR-37-15 } & $<0.2 \mu \mathrm{m}$ & 27.0 & 19.9 & 0.186 & 0.192 & Epizone \\
\hline & & $<2 \mu \mathrm{m}$ & 21.7 & 8.1 & 0.195 & 0.194 & Epizone \\
\hline & & $2-6 \mu \mathrm{m}$ & 22.8 & 3.9 & 0.161 & 0.157 & Epizone \\
\hline & \multirow{3}{*}{ BR-38-15 } & $<0.2 \mu \mathrm{m}$ & 10.5 & 1.5 & 0.466 & 0.466 & $\begin{array}{l}\text { Diagenesis/ } \\
\text { anchizone }\end{array}$ \\
\hline & & $<2 \mu \mathrm{m}$ & 10.5 & 2.5 & 0.295 & 0.299 & Anchizone \\
\hline & & $2-6 \mu \mathrm{m}$ & 34.6 & 2.3 & 0.153 & 0.158 & Epizone \\
\hline & \multirow{3}{*}{ BR-40-15 } & $<0.2 \mu \mathrm{m}$ & 20.6 & 3.7 & 0.275 & 0.277 & Anchizone \\
\hline & & $<2 \mu \mathrm{m}$ & 19.9 & 3.4 & 0.254 & 0.247 & Anchizone \\
\hline & & $2-6 \mu \mathrm{m}$ & 25.0 & 1.3 & 0.170 & 0.171 & Epizone \\
\hline & \multirow{3}{*}{ BR-45-15 } & $<0.2 \mu \mathrm{m}$ & 46.6 & 10.2 & 0.296 & 0.371 & Anchizone \\
\hline & & $<2 \mu \mathrm{m}$ & 42.5 & 6.3 & 0.382 & 0.304 & Anchizone \\
\hline & & $2-6 \mu \mathrm{m}$ & 62.1 & 6.9 & 0.240 & 0.238 & Epizone/Anchizone \\
\hline & \multirow{3}{*}{ BR-62-15 } & $<0.2 \mu \mathrm{m}$ & 38.0 & 7.5 & 0.279 & 0.343 & Anchizone \\
\hline & & $<2 \mu \mathrm{m}$ & 43.1 & 30.2 & 0.363 & 0.279 & Anchizone \\
\hline & & $2-6 \mu \mathrm{m}$ & 44.7 & 5.8 & 0.195 & 0.194 & Epizone \\
\hline
\end{tabular}

Observation:

- $\mathrm{KI} g$ and $\mathrm{KI}$ a refer to Kübler Index in $\Delta^{\circ} 2 \Theta$, measured on air-dried and ethylene-glycol-solvated samples, respectively 


\section{APPENDIX D - Individual illite polytype analyses}

Individual diagrams used for $2 \mathrm{M}_{1}$ illite polytype quantification of dated samples are presented below. Item 3.5 presents the method in detail.

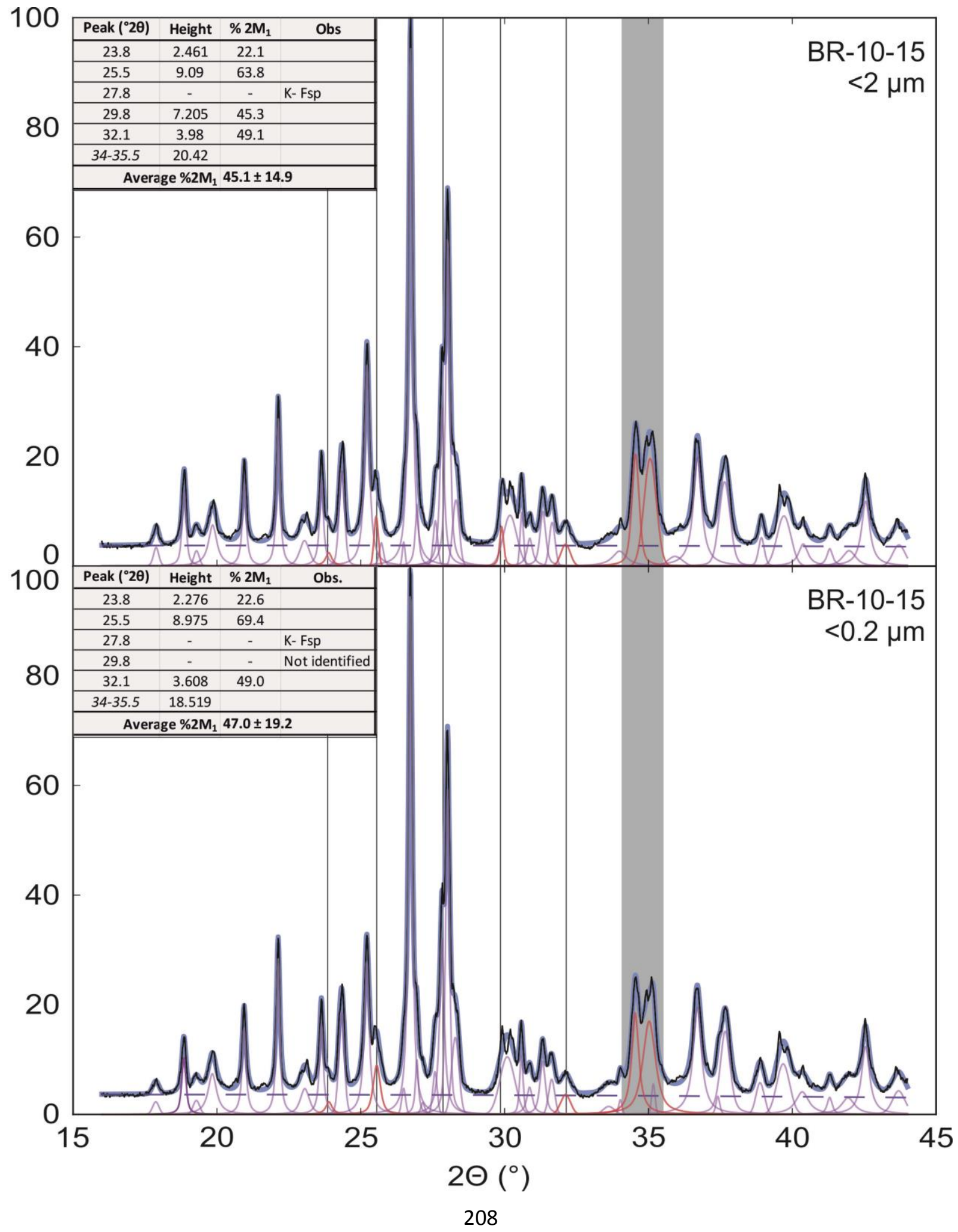




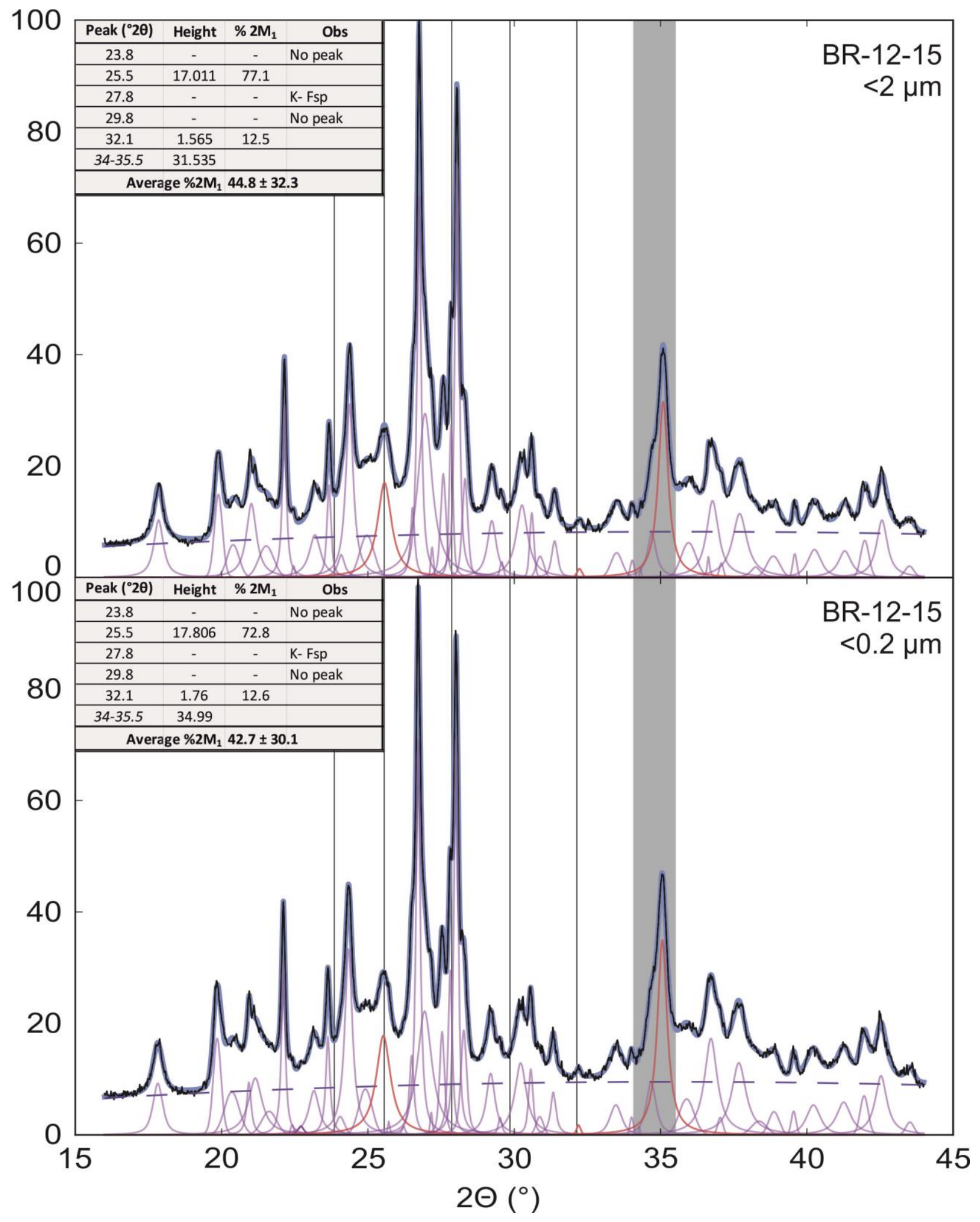




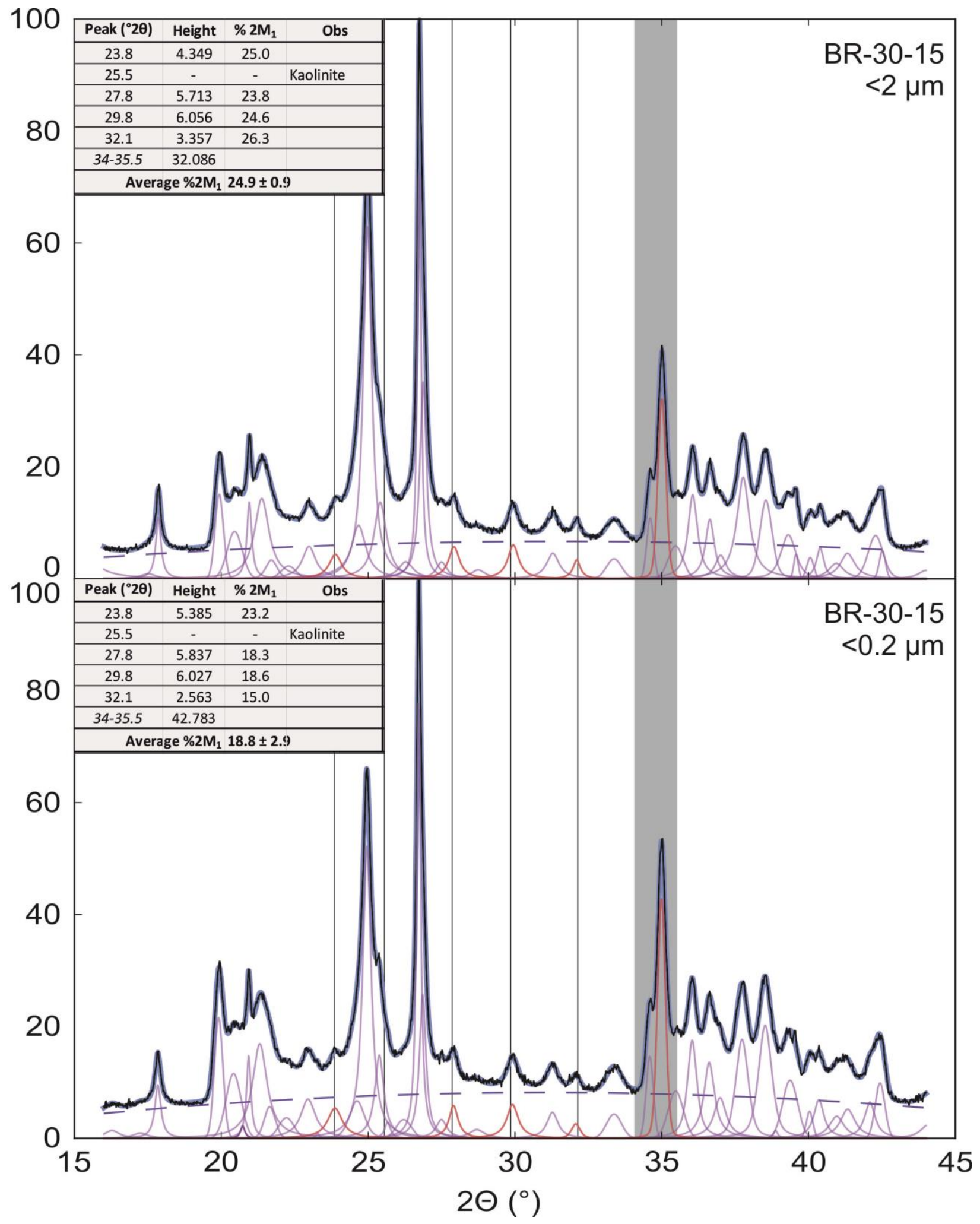




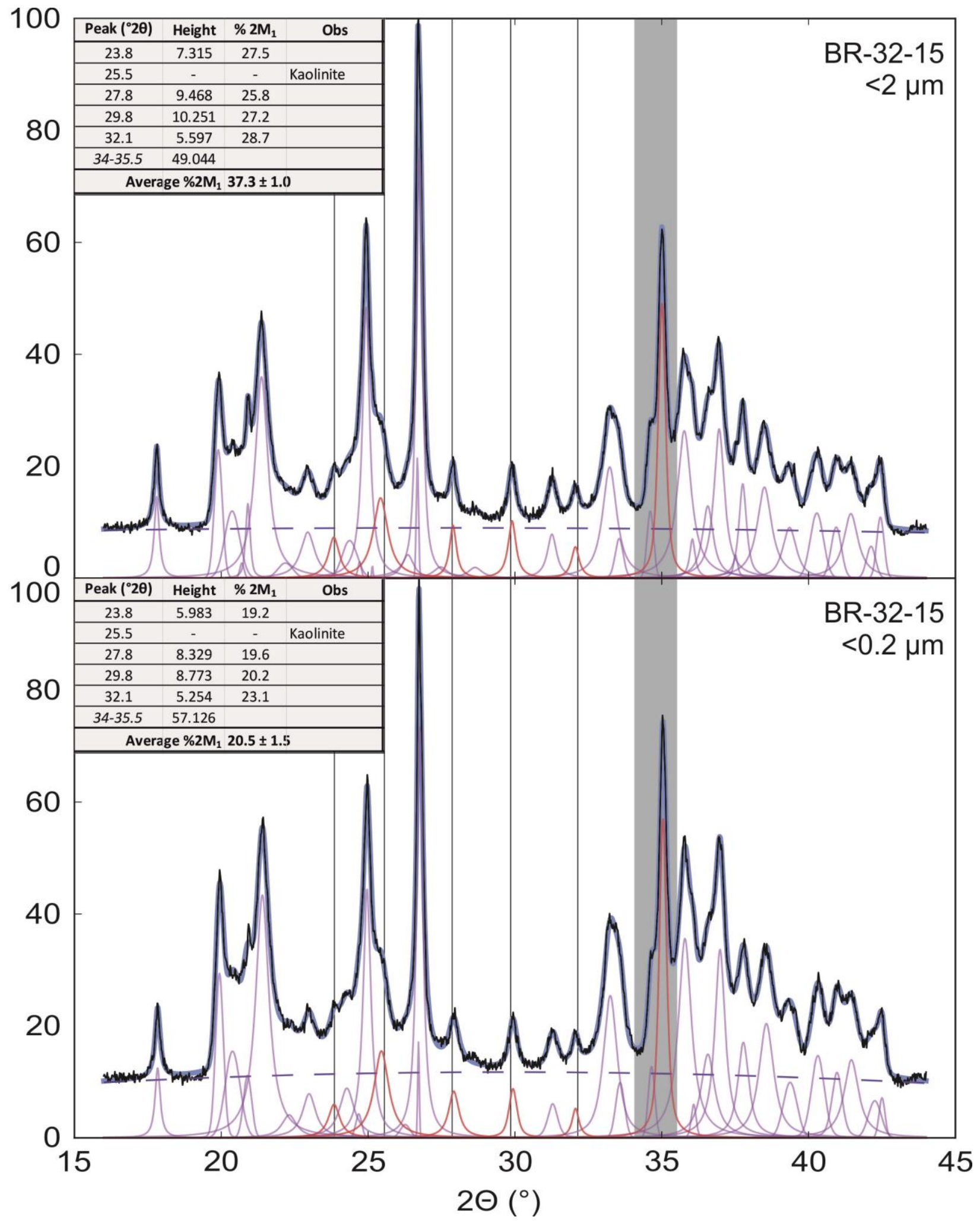




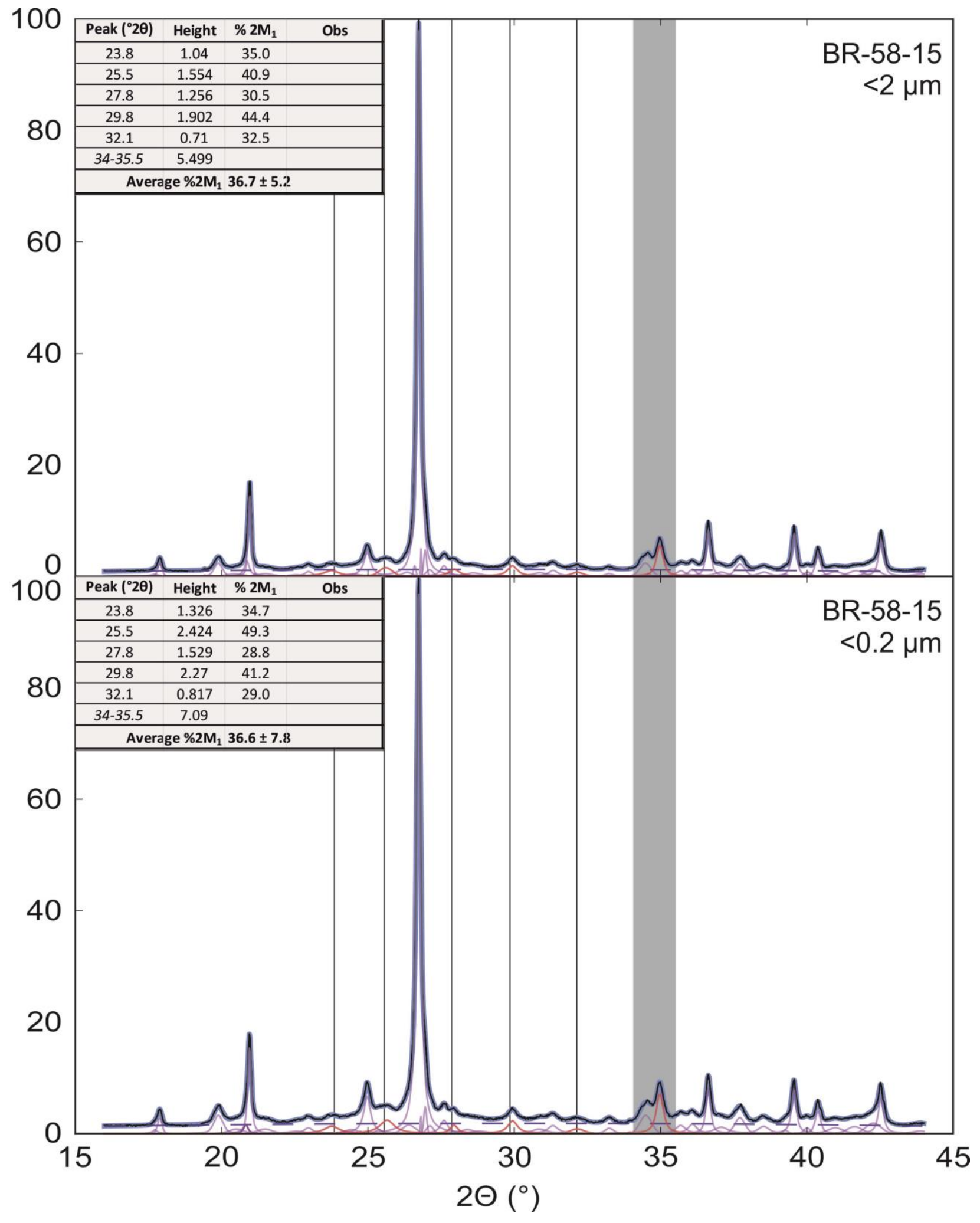




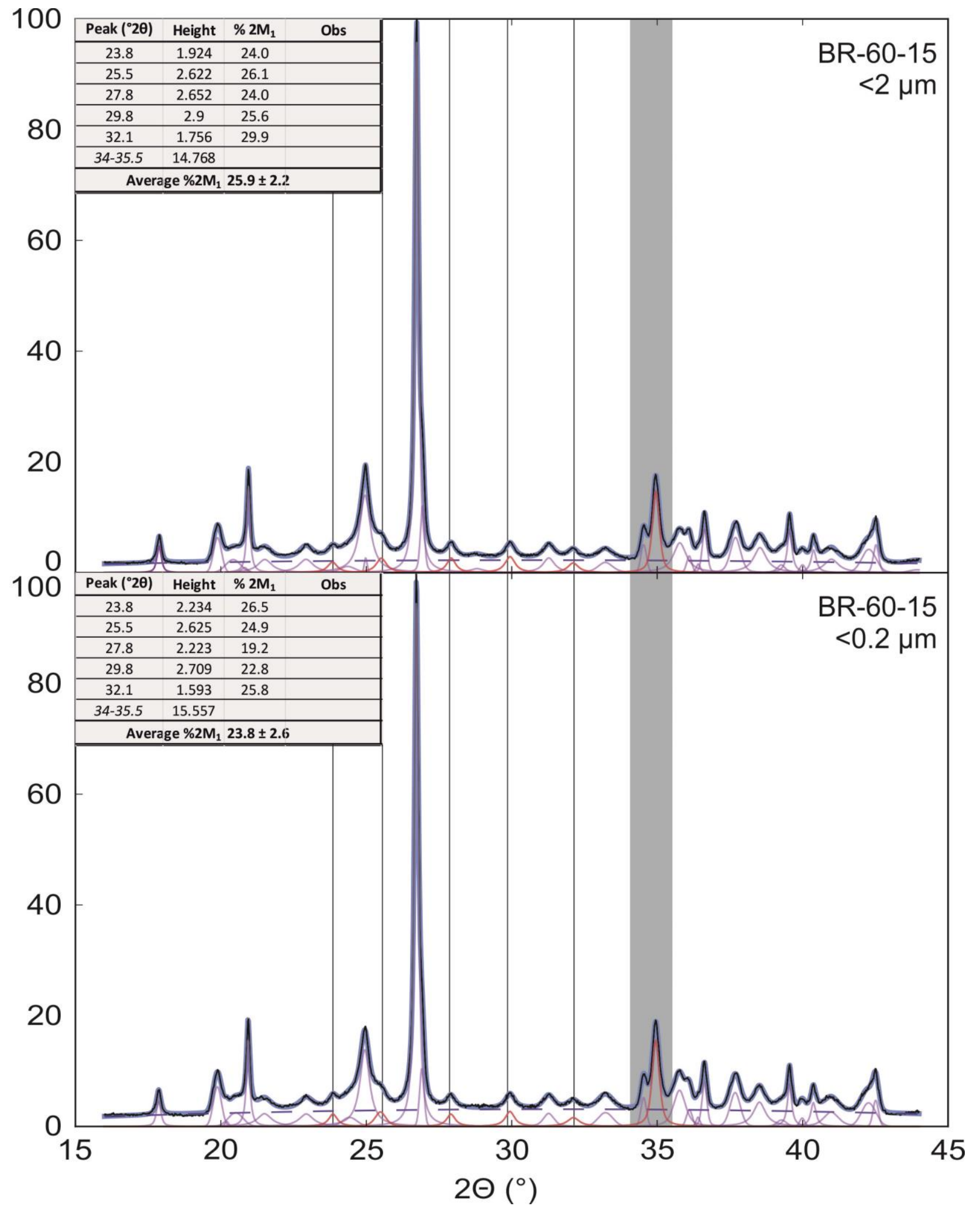




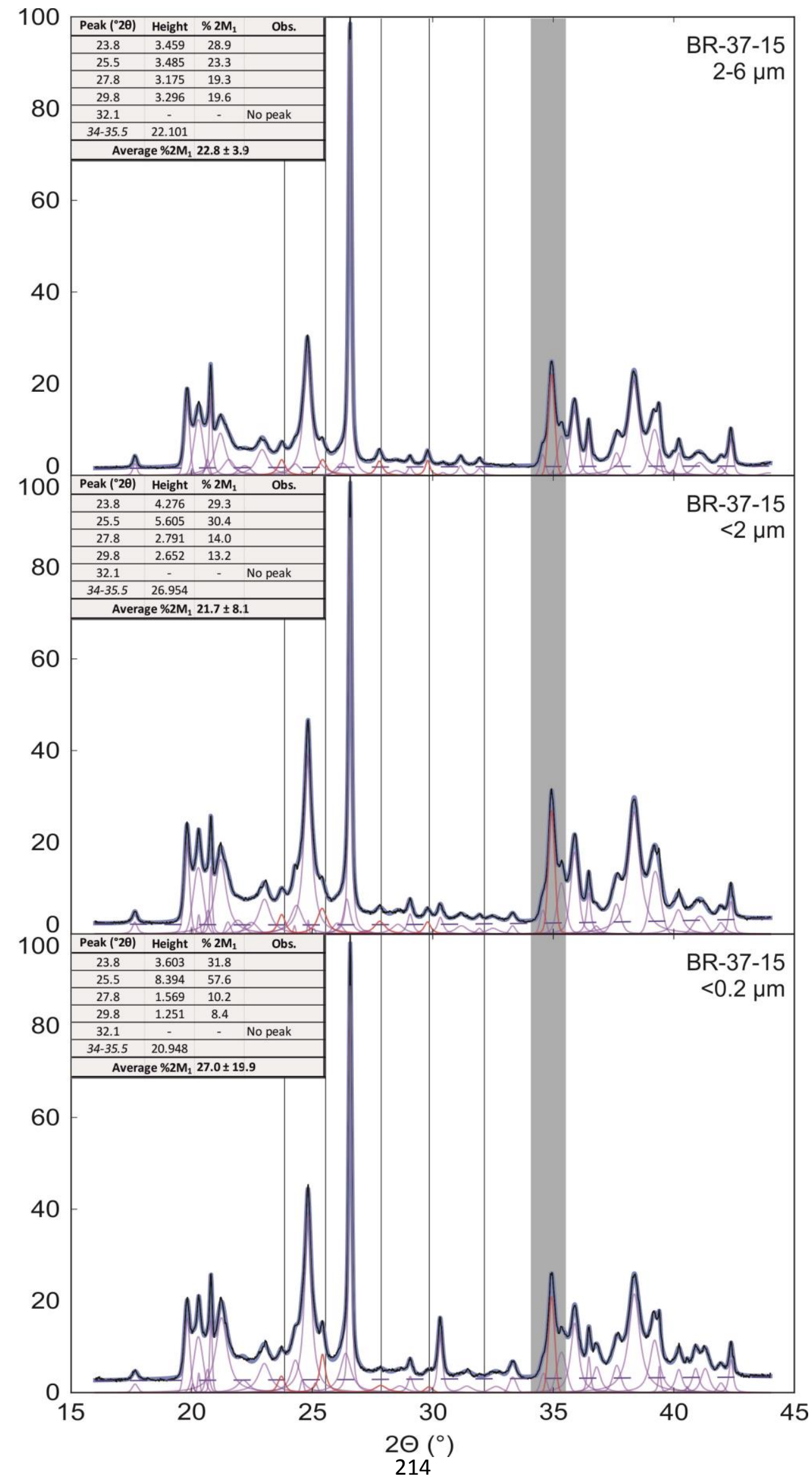




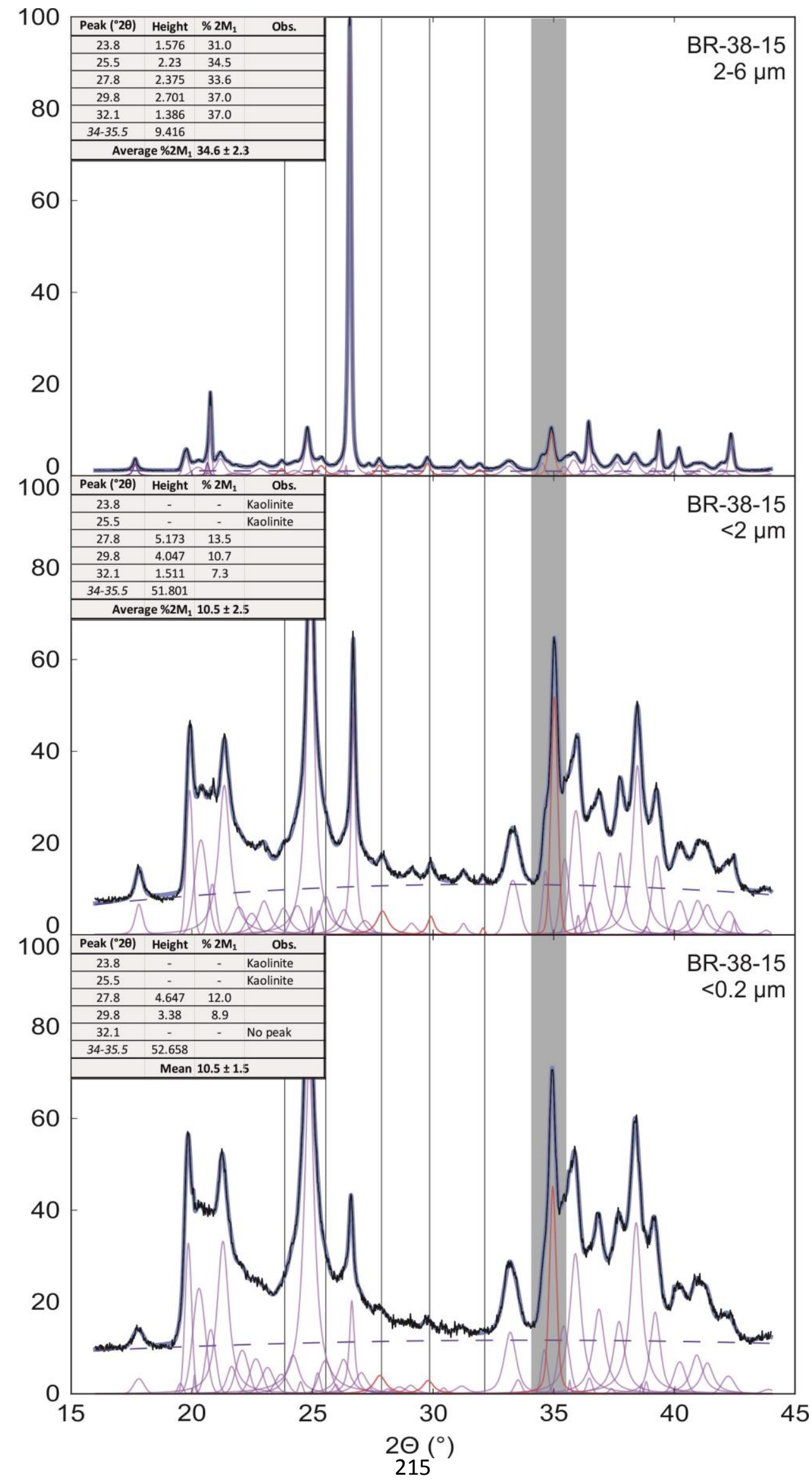




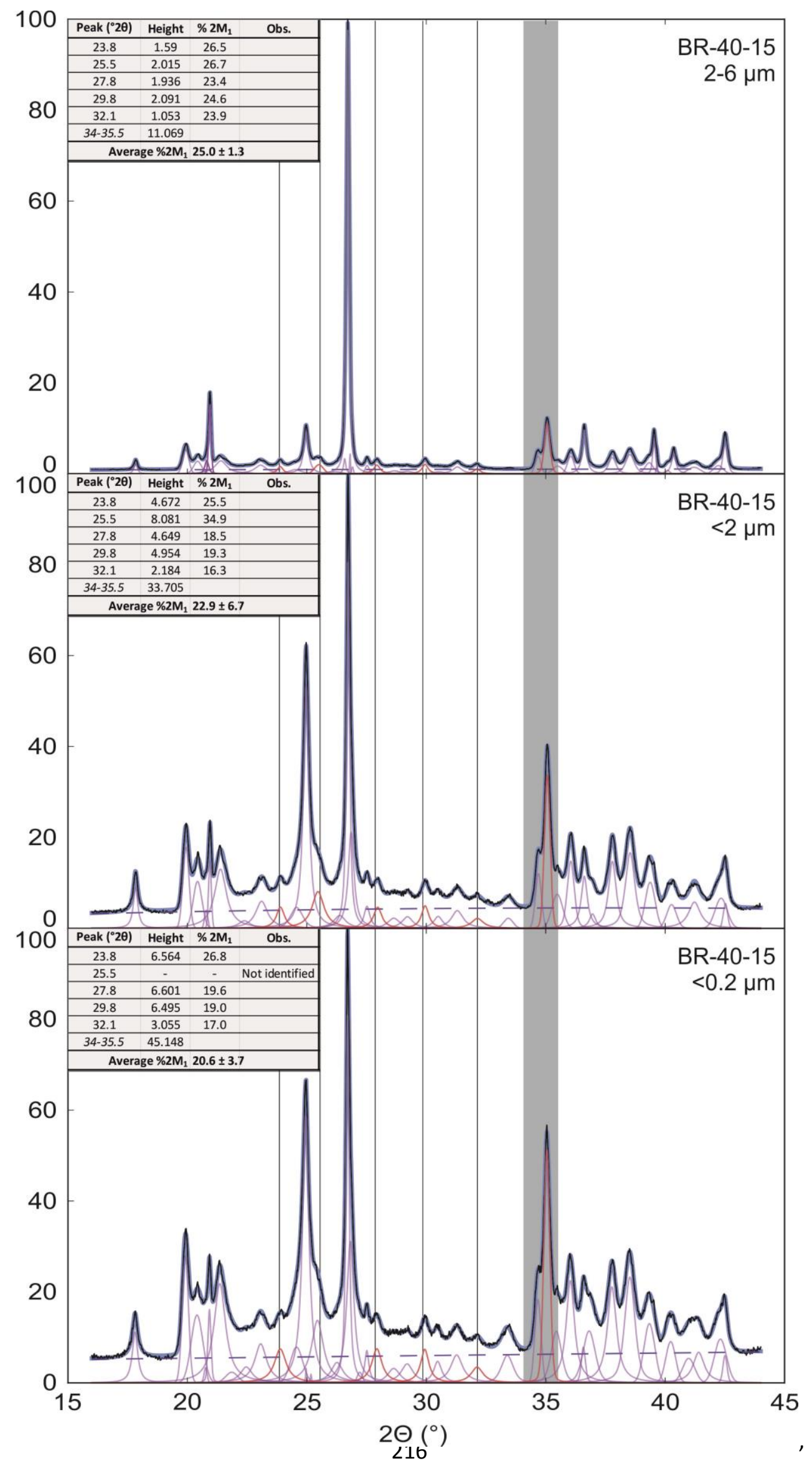




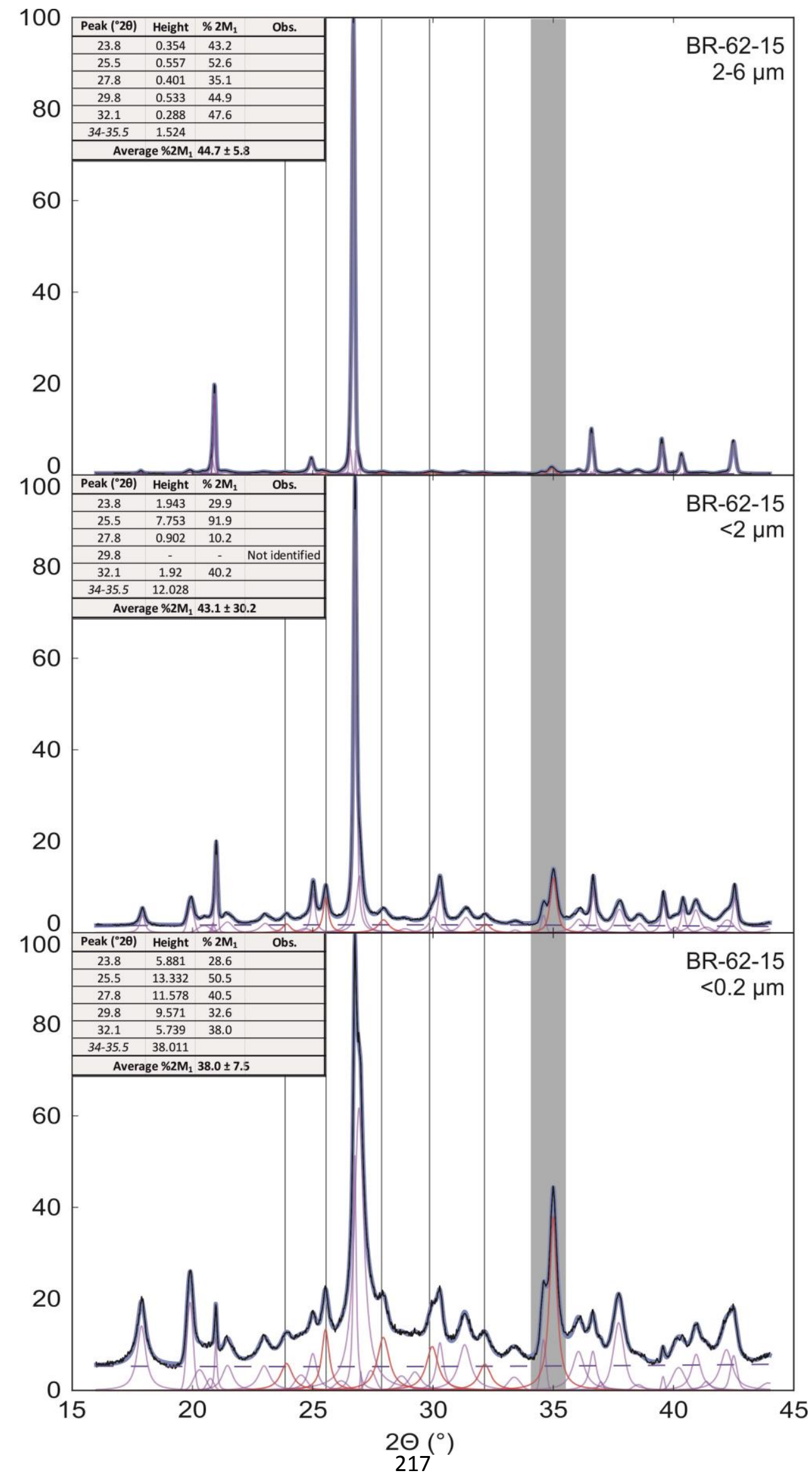




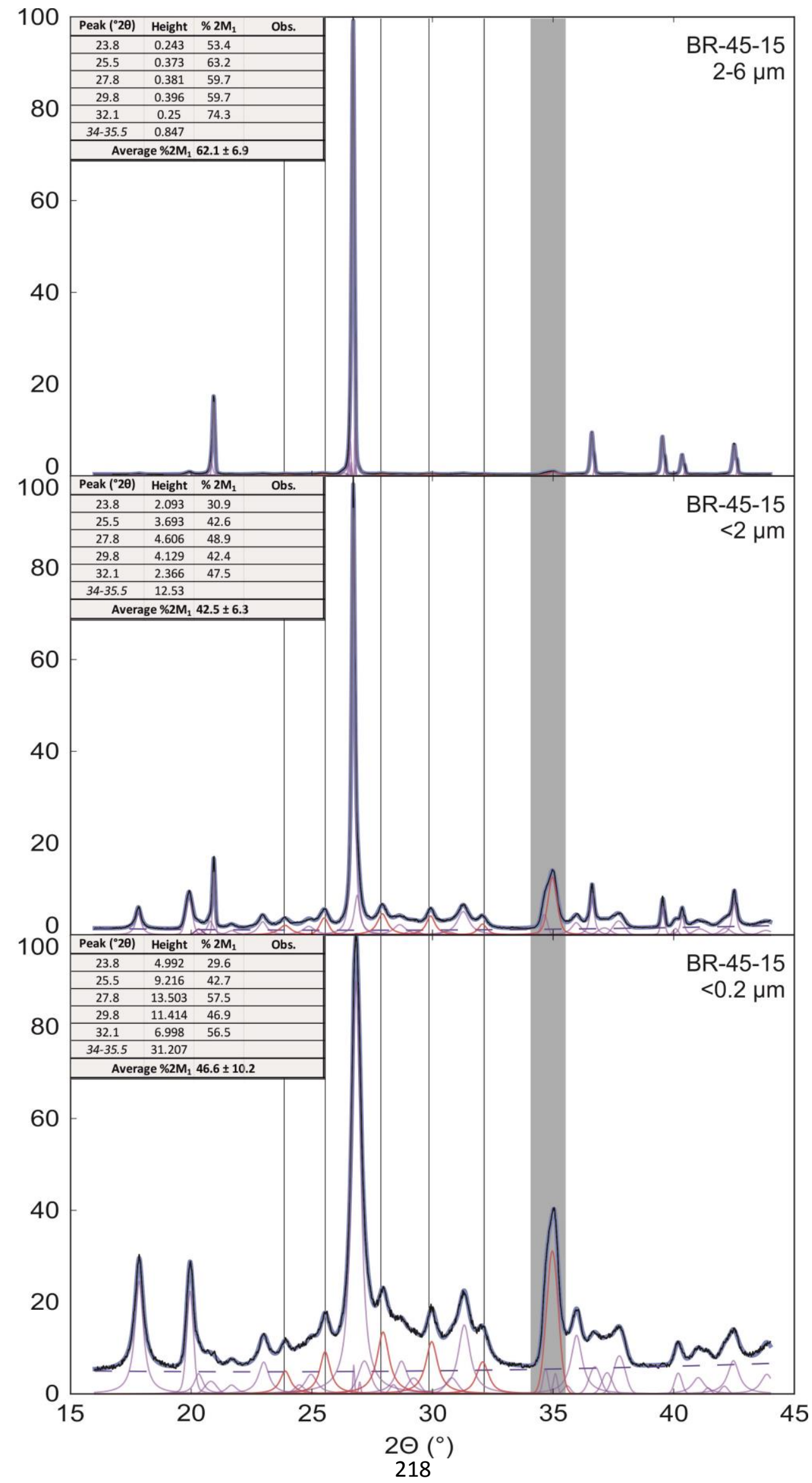




\section{APPENDIX E - (U-Th)/He results}

\section{Zircon}

Uruguay

\begin{tabular}{|c|c|c|c|c|c|c|c|c|c|c|c|c|c|c|c|c|c|c|c|}
\hline \multirow{3}{*}{ Sample } & \multirow{3}{*}{ aliq. } & \multicolumn{2}{|c|}{$\mathrm{He}$} & \multicolumn{3}{|c|}{ U238 } & \multicolumn{3}{|c|}{ Th232 } & \multirow{2}{*}{$\mathrm{Th} / \mathrm{U}$} & \multicolumn{3}{|c|}{ Sm } & \multirow{2}{*}{ eU } & \multirow{2}{*}{$\begin{array}{l}\text { Eq. } \\
\text { sphere } \\
\text { radius }\end{array}$} & \multirow{3}{*}{ FT } & \multirow{2}{*}{$\begin{array}{l}\text { Uncorr. } \\
\text { He-age }\end{array}$} & \multicolumn{2}{|c|}{ Ft-Correction } \\
\hline & & vol. & error & mass & error & conc. & mass & error & conc. & & mass & error & conc. & & & & & He-age & error \\
\hline & & [ncc] & [\%] & [ng] & [\%] & [ppm] & [ng] & [\%] & [ppm] & ratio & [ng] & [\%] & [ppm] & [ppm] & $(\mu \mathrm{m})$ & & [Ma] & [Ma] & [Ma] \\
\hline \multirow{3}{*}{ GPS-29 } & $z 1$ & 16.31 & 1.1 & 0.266 & 1.9 & 29.8 & 0.176 & 2.4 & 19.7 & 0.66 & 0.078 & 5.8 & 8.8 & 34.4 & 59 & 0.79 & 423.1 & 536.0 & 39.8 \\
\hline & z2 & 18.89 & 1.1 & 0.350 & 1.9 & 52.4 & 0.164 & 2.4 & 24.6 & 0.47 & 0.023 & 7.4 & 3.4 & 58.2 & 56 & 0.78 & 389.5 & 500.2 & 38.6 \\
\hline & 23 & 42.51 & 1.1 & 0.701 & 1.8 & 98.7 & 0.445 & 2.4 & 62.7 & 0.64 & 0.045 & 7.0 & 6.3 & 113.4 & 60 & 0.79 & 421.2 & 531.4 & 38.7 \\
\hline \multirow{3}{*}{ U-46 } & z1 & 34.92 & 1.1 & 0.620 & 1.8 & 36.6 & 0.388 & 2.4 & 22.9 & 0.63 & 0.045 & 6.4 & 2.7 & 42.0 & 70 & 0.82 & 393.0 & 478.2 & 31.4 \\
\hline & z2 & 40.05 & 1.1 & 0.598 & 1.8 & 36.9 & 0.435 & 2.4 & 26.8 & 0.73 & 0.108 & 5.3 & 6.7 & 43.2 & 74 & 0.83 & 455.0 & 547.9 & 34.7 \\
\hline & 23 & 36.46 & 1.1 & 0.607 & 1.8 & 50.3 & 0.411 & 2.4 & 34.1 & 0.68 & 0.034 & 8.9 & 2.8 & 58.3 & 69 & 0.82 & 413.8 & 505.9 & 33.7 \\
\hline \multirow{3}{*}{ UY-10-14 } & $\mathrm{z} 1^{1}$ & 50.82 & 1.1 & 0.698 & 1.8 & 189.5 & 0.421 & 2.4 & 114.2 & 0.60 & 0.006 & 13.5 & 1.8 & 216.3 & 38 & 0.68 & 505.3 & 741.5 & 76.4 \\
\hline & $z 2$ & 28.62 & 1.1 & 0.584 & 1.8 & 213.4 & 0.232 & 2.4 & 84.7 & 0.40 & 0.006 & 18.4 & 2.1 & 233.3 & 54 & 0.77 & 359.6 & 465.9 & 36.8 \\
\hline & z3 & 21.88 & 1.1 & 0.452 & 1.8 & 155.0 & 0.287 & 2.4 & 98.5 & 0.64 & 0.007 & 17.8 & 2.5 & 178.1 & 51 & 0.76 & 338.5 & 447.3 & 36.8 \\
\hline \multirow{3}{*}{ UY-23-14 } & $\mathrm{z1}$ & 36.49 & 1.1 & 0.659 & 1.8 & 171.8 & 0.429 & 2.4 & 111.9 & 0.65 & 0.009 & 15.0 & 2.3 & 198.1 & 44 & 0.72 & 384.9 & 533.7 & 49.1 \\
\hline & $z 2$ & 51.58 & 1.1 & 1.114 & 1.8 & 156.3 & 0.628 & 2.4 & 88.1 & 0.56 & 0.018 & 10.9 & 2.5 & 177.0 & 45 & 0.73 & 329.1 & 449.8 & 40.1 \\
\hline & 23 & 63.15 & 1.1 & 1.222 & 1.8 & 226.4 & 0.678 & 2.4 & 125.5 & 0.55 & 0.013 & 11.8 & 2.5 & 255.8 & 45 & 0.73 & 366.7 & 504.5 & 45.6 \\
\hline \multirow{3}{*}{ UY-33-14 } & $\mathrm{z1}$ & 98.95 & 1.1 & 1.681 & 1.8 & 218.9 & 1.109 & 2.4 & 144.4 & 0.66 & 0.019 & 9.4 & 2.5 & 252.8 & 63 & 0.80 & 407.4 & 508.2 & 35.8 \\
\hline & $z 2$ & 98.82 & 1.1 & 1.731 & 1.8 & 251.6 & 0.912 & 2.4 & 132.6 & 0.53 & 0.017 & 8.6 & 2.4 & 282.8 & 62 & 0.80 & 406.1 & 507.0 & 36.0 \\
\hline & 23 & 147.22 & 1.1 & 2.343 & 1.8 & 228.1 & 1.554 & 2.4 & 151.3 & 0.66 & 0.091 & 5.9 & 8.8 & 263.6 & 61 & 0.80 & 433.7 & 544.7 & 39.2 \\
\hline \multirow{3}{*}{ UY-41-14 } & $\mathrm{z} 1$ & 31.24 & 1.1 & 0.573 & 1.8 & 174.1 & 0.284 & 2.4 & 86.4 & 0.50 & 0.064 & 6.6 & 19.4 & 194.4 & 42 & 0.71 & 390.8 & 548.7 & 51.9 \\
\hline & z2 & 51.44 & 1.1 & 0.911 & 1.8 & 212.6 & 0.508 & 2.4 & 118.5 & 0.56 & 0.012 & 11.8 & 2.8 & 240.5 & 42 & 0.71 & 399.3 & 559.2 & 52.6 \\
\hline & $z 3$ & 49.41 & 1.1 & 0.839 & 1.8 & 184.5 & 0.522 & 2.4 & 114.8 & 0.62 & 0.042 & 6.6 & 9.2 & 211.5 & 44 & 0.72 & 410.7 & 567.2 & 51.7 \\
\hline \multirow{3}{*}{ UY-43-14 } & $\mathrm{z1}$ & 106.36 & 1.1 & 2.002 & 1.8 & 224.6 & 0.332 & 2.4 & 37.3 & 0.17 & 0.052 & 6.6 & 5.8 & 233.4 & 55 & 0.78 & 408.2 & 524.2 & 40.7 \\
\hline & $\mathrm{z2}^{1}$ & 89.45 & 1.1 & 1.350 & 1.8 & 182.9 & 0.311 & 2.4 & 42.1 & 0.23 & 0.022 & 9.2 & 3.0 & 192.8 & 52 & 0.77 & 497.6 & 649.2 & 52.3 \\
\hline & 23 & 92.04 & 1.1 & 1.876 & 1.8 & 274.4 & 0.415 & 2.4 & 60.7 & 0.22 & 0.033 & 6.6 & 4.9 & 288.6 & 55 & 0.78 & 373.6 & 480.8 & 37.4 \\
\hline
\end{tabular}




\begin{tabular}{|c|c|c|c|c|c|c|c|c|c|c|c|c|c|c|c|c|c|c|c|}
\hline & $z 1$ & 154.26 & 1.1 & 2.755 & 1.8 & 417.3 & 1.525 & 2.4 & 231.0 & 0.55 & 0.050 & 6.9 & 7.6 & 471.6 & 59 & 0.79 & 396.5 & 501.2 & 36.8 \\
\hline \multirow[t]{3}{*}{ UY-51-14 } & $z 2$ & 109.67 & 1.1 & 2.487 & 1.8 & 653.5 & 2.126 & 2.4 & 558.7 & 0.85 & 0.033 & 8.3 & 8.7 & 784.8 & 42 & 0.71 & 296.5 & 418.4 & 39.7 \\
\hline & $z 3$ & 112.40 & 1.1 & 2.111 & 1.8 & 340.8 & 1.582 & 2.4 & 255.4 & 0.75 & 0.055 & 7.5 & 8.9 & 400.8 & 49 & 0.75 & 363.5 & 484.6 & 40.6 \\
\hline & z1 & 99.29 & 1.1 & 1.751 & 1.8 & 209.7 & 0.902 & 2.4 & 108.1 & 0.52 & 0.091 & 5.3 & 10.9 & 235.1 & 60 & 0.79 & 404.4 & 509.4 & 37.1 \\
\hline \multirow[t]{3}{*}{ UY-68-14 } & $z 2$ & 38.88 & 1.1 & 0.804 & 1.8 & 185.0 & 0.348 & 2.4 & 80.1 & 0.43 & 0.056 & 6.5 & 12.8 & 203.8 & 45 & 0.73 & 352.3 & 482.5 & 43.3 \\
\hline & z3 & 167.54 & 1.1 & 3.324 & 1.8 & 353.2 & 1.771 & 2.4 & 188.2 & 0.53 & 0.202 & 4.5 & 21.4 & 397.4 & 58 & 0.79 & 359.5 & 456.7 & 34.0 \\
\hline & $z 1$ & 81.45 & 0.9 & 2.810 & 1.8 & 305.0 & 0.568 & 2.4 & 61.7 & 0.20 & 0.922 & 4.1 & 100.1 & 319.5 & 68 & 0.82 & 224.1 & 273.9 & 18.2 \\
\hline \multirow[t]{3}{*}{ UY-1-15 } & $\mathrm{z2}$ & 73.09 & 0.9 & 2.425 & 1.8 & 582.5 & 0.583 & 2.4 & 139.9 & 0.24 & 1.065 & 4.9 & 255.7 & 615.4 & 46 & 0.73 & 230.7 & 314.4 & 27.8 \\
\hline & 23 & 82.70 & 0.9 & 2.430 & 1.8 & 446.0 & 0.509 & 2.4 & 93.5 & 0.21 & 0.907 & 4.5 & 166.5 & 468.0 & 54 & 0.77 & 261.7 & 338.4 & 26.4 \\
\hline & $\mathrm{z1}$ & 29.89 & 0.9 & 2.272 & 1.8 & 1705 & 0.262 & 2.4 & 196.9 & 0.12 & 1.484 & 4.6 & 1114 & 1751 & 35 & 0.67 & 104.6 & 157.2 & 16.9 \\
\hline \multirow[t]{2}{*}{ UY-3-15 } & $\mathrm{z2}$ & 21.39 & 0.9 & 1.483 & 1.8 & 1062 & 0.184 & 2.4 & 131.8 & 0.12 & 0.798 & 5.1 & 571.2 & 1093 & 41 & 0.71 & 114.5 & 161.1 & 15.3 \\
\hline & $z 3$ & 21.08 & 0.9 & 1.320 & 1.8 & 1079 & 0.173 & 2.4 & 141.2 & 0.13 & 0.509 & 6.0 & 416.2 & 1112 & 37 & 0.68 & 126.5 & 186.5 & 19.4 \\
\hline
\end{tabular}

Rio Grande do Sul

\begin{tabular}{|c|c|c|c|c|c|c|c|c|c|c|c|c|c|c|c|c|c|c|c|}
\hline \multirow{3}{*}{ Sample } & \multirow{3}{*}{ aliq. } & \multicolumn{2}{|c|}{$\mathrm{He}$} & \multicolumn{3}{|c|}{ U238 } & \multicolumn{3}{|c|}{ Th232 } & \multirow{2}{*}{ Th/U } & \multicolumn{3}{|c|}{ Sm } & \multirow{2}{*}{ eU } & \multirow{2}{*}{$\begin{array}{l}\text { Eq. } \\
\text { sphere } \\
\text { radius }\end{array}$} & \multirow{3}{*}{ FT } & \multirow{2}{*}{$\begin{array}{l}\text { Uncorr. } \\
\text { He-age }\end{array}$} & \multicolumn{2}{|c|}{ Ft-Correction } \\
\hline & & vol. & error & mass & error & conc. & mass & error & conc. & & mass & $\begin{array}{c}1 \sigma \\
\text { error }\end{array}$ & conc. & & & & & He-age & error \\
\hline & & [ncc] & [\%] & [ng] & [\%] & [ppm] & [ng] & [\%] & [ppm] & ratio & [ng] & [\%] & [ppm] & [ppm] & $(\mu \mathrm{m})$ & & [Ma] & [Ma] & [Ma] \\
\hline \multirow{3}{*}{ BR-1-15 } & $\mathrm{z5}$ & 86.66 & 0.8 & 1.287 & 1.8 & 41.9 & 0.707 & 2.4 & 23.0 & 0.55 & 0.064 & 9.2 & 2.1 & 47.3 & 82 & 0.85 & 474.0 & 560.3 & 32.7 \\
\hline & $z 6$ & 37.78 & 0.9 & 0.636 & 1.8 & 108.4 & 0.403 & 2.4 & 68.6 & 0.63 & 0.029 & 12.0 & 4.9 & 124.5 & 54 & 0.77 & 413.2 & 534.8 & 41.3 \\
\hline & $z 8$ & 46.55 & 0.9 & 0.702 & 1.8 & 110.1 & 0.396 & 2.4 & 62.0 & 0.56 & 0.020 & 12.8 & 3.2 & 124.7 & 63 & 0.80 & 465.7 & 580.3 & 40.2 \\
\hline \multirow{3}{*}{ BR-6-15 } & $\mathrm{z} 1$ & 103.75 & 0.8 & 2.364 & 1.8 & 487.5 & 0.616 & 2.4 & 127.0 & 0.26 & 0.068 & 6.8 & 14.0 & 517.3 & 62 & 0.80 & 332.4 & 415.3 & 29.2 \\
\hline & $z 2$ & 99.61 & 0.8 & 1.806 & 1.8 & 440.2 & 1.114 & 2.4 & 271.6 & 0.62 & 0.139 & 6.3 & 33.8 & 504.0 & 51 & 0.76 & 385.6 & 509.6 & 41.3 \\
\hline & $\mathrm{z4}$ & 27.83 & 0.9 & 0.527 & 1.9 & 173.0 & 0.271 & 2.4 & 88.7 & 0.51 & 0.030 & 9.6 & 9.8 & 193.8 & 51 & 0.76 & 377.3 & 495.8 & 40.0 \\
\hline \multirow{3}{*}{ BR-19-15 } & 25 & 41.88 & 0.9 & 0.983 & 1.8 & 229.7 & 0.178 & 2.4 & 41.7 & 0.18 & 0.015 & 15.1 & 3.4 & 239.5 & 50 & 0.76 & 328.5 & 433.7 & 35.7 \\
\hline & $\mathrm{z7}$ & 60.13 & 0.8 & 1.298 & 1.8 & 344.1 & 0.583 & 2.4 & 154.5 & 0.45 & 0.054 & 8.1 & 14.4 & 380.5 & 52 & 0.76 & 337.0 & 441.5 & 35.2 \\
\hline & $z 8$ & 13.74 & 0.9 & 0.297 & 1.9 & 110.2 & 0.151 & 2.4 & 56.1 & 0.51 & 0.011 & 17.2 & 3.9 & 123.3 & 47 & 0.74 & 332.3 & 449.9 & 39.3 \\
\hline \multirow{3}{*}{ BR-23-15 } & $\mathrm{z} 2$ & 24.72 & 0.8 & 0.598 & 1.8 & 374.0 & 0.167 & 2.4 & 104.6 & 0.28 & 0.036 & 25.0 & 22.4 & 398.6 & 38 & 0.69 & 312.3 & 455.2 & 46.1 \\
\hline & $\mathrm{z3}$ & 27.77 & 1.0 & 0.590 & 1.8 & 174.0 & 0.099 & 2.5 & 29.1 & 0.17 & 0.016 & 11.4 & 4.7 & 180.9 & 41 & 0.71 & 362.7 & 512.5 & 49.3 \\
\hline & $\mathrm{z4}$ & 25.57 & 1.1 & 0.655 & 1.8 & 183.8 & 0.084 & 2.5 & 23.6 & 0.13 & 0.024 & 8.3 & 6.9 & 189.3 & 39 & 0.69 & 305.4 & 441.0 & 44.4 \\
\hline
\end{tabular}




\begin{tabular}{|c|c|c|c|c|c|c|c|c|c|c|c|c|c|c|c|c|c|c|c|}
\hline \multirow{3}{*}{ BR-26-15 } & $z 1^{2}$ & 141.37 & 0.9 & 4.051 & 1.8 & 954.4 & 2.222 & 2.4 & 523.4 & 0.55 & 4.650 & 2.2 & 1095.3 & 1077.4 & 58 & 0.79 & 248.5 & 315.7 & 23.1 \\
\hline & $z 2^{2}$ & 169.13 & 0.8 & 5.389 & 1.8 & 951.3 & 3.499 & 2.4 & 617.6 & 0.65 & 3.148 & 2.2 & 555.6 & 1096.4 & 52 & 0.76 & 220.4 & 288.7 & 22.9 \\
\hline & $z 3^{2}$ & 154.82 & 0.9 & 6.250 & 1.8 & 1138.6 & 4.567 & 2.4 & 831.9 & 0.73 & 6.259 & 2.2 & 1140.2 & 1334.0 & 50 & 0.75 & 171.3 & 227.3 & 18.6 \\
\hline \multirow{3}{*}{ BR-34-15 } & $25^{2}$ & 52.75 & 0.8 & 8.817 & 1.8 & 5902.9 & 1.281 & 2.4 & 857.7 & 0.15 & 0.069 & 2.4 & 46.3 & 6104.5 & 47 & 0.74 & 47.7 & 64.1 & 5.5 \\
\hline & $z 6^{2}$ & 97.22 & 0.9 & 3.803 & 1.8 & 1480.2 & 0.721 & 2.4 & 280.6 & 0.19 & 0.154 & 2.2 & 60.0 & 1546.1 & 49 & 0.75 & 199.1 & 265.5 & 22.3 \\
\hline & $z 8^{2}$ & 90.24 & 0.8 & 4.122 & 1.8 & 1037.9 & 0.491 & 2.4 & 123.7 & 0.12 & 0.270 & 2.2 & 67.9 & 1067.0 & 52 & 0.76 & 173.6 & 227.1 & 18.2 \\
\hline \multirow{3}{*}{ BR-44-15 } & $\mathrm{z} 1$ & 31.73 & 0.9 & 0.746 & 1.8 & 304.9 & 0.673 & 2.4 & 275.0 & 0.90 & 0.051 & 8.4 & 20.7 & 369.5 & 42 & 0.71 & 283.6 & 399.9 & 37.6 \\
\hline & z3 & 45.53 & 0.9 & 0.906 & 1.8 & 265.5 & 0.579 & 2.4 & 169.7 & 0.64 & 0.026 & 10.9 & 7.5 & 305.3 & 47 & 0.74 & 351.0 & 476.1 & 41.2 \\
\hline & $\mathrm{z4}$ & 32.18 & 0.9 & 0.788 & 1.8 & 348.3 & 0.713 & 2.4 & 315.3 & 0.91 & 0.082 & 9.9 & 36.3 & 422.4 & 46 & 0.73 & 272.4 & 372.1 & 32.6 \\
\hline \multirow{3}{*}{ BR-48-15 } & $25^{2}$ & 132.17 & 0.8 & 2.728 & 1.8 & 159.7 & 1.111 & 2.4 & 65.0 & 0.41 & 0.064 & 8.2 & 3.7 & 175.0 & 74 & 0.83 & 354.9 & 426.9 & 26.6 \\
\hline & $z 6^{2}$ & 239.29 & 0.9 & 4.751 & 1.8 & 189.9 & 1.687 & 2.4 & 67.4 & 0.36 & 0.080 & 6.9 & 3.2 & 205.7 & 71 & 0.82 & 372.5 & 452.2 & 29.2 \\
\hline & $z 8^{2}$ & 84.67 & 0.9 & 1.782 & 1.8 & 106.0 & 0.944 & 2.4 & 56.2 & 0.53 & 0.052 & 9.5 & 3.1 & 119.2 & 62 & 0.80 & 339.8 & 424.5 & 29.7 \\
\hline \multirow{3}{*}{ BR-52-15 } & $\mathrm{z} 1$ & 27.25 & 0.9 & 0.562 & 1.8 & 181.3 & 0.456 & 2.4 & 147.1 & 0.81 & 0.050 & 8.5 & 16.2 & 215.9 & 44 & 0.72 & 328.0 & 453.9 & 41.1 \\
\hline & $z$ & 93.62 & 0.9 & 2.861 & 1.8 & 534.5 & 2.830 & 2.4 & 528.7 & 0.99 & 0.359 & 5.6 & 67.0 & 658.7 & 44 & 0.72 & 215.7 & 299.3 & 27.1 \\
\hline & $\mathrm{z4}$ & 38.88 & 0.9 & 0.985 & 1.8 & 346.0 & 0.851 & 2.4 & 298.9 & 0.86 & 0.090 & 7.9 & 31.5 & 416.3 & 48 & 0.74 & 265.6 & 356.7 & 30.1 \\
\hline \multirow{2}{*}{ BR-55-15 } & $z 2$ & 22.78 & 0.9 & 0.426 & 1.9 & 409.9 & 0.668 & 2.4 & 643.7 & 1.57 & 0.015 & 2.4 & 14.8 & 561.1 & 44 & 0.72 & 315.6 & 438.1 & 39.7 \\
\hline & $\mathrm{z} 4^{2}$ & 26.74 & 0.9 & 0.565 & 1.8 & 806.0 & 0.444 & 2.4 & 634.1 & 0.79 & 0.010 & 2.4 & 14.9 & 955.0 & 44 & 0.72 & 321.9 & 446.2 & 40.6 \\
\hline \multirow{3}{*}{ BR-57-15 } & $z 6$ & 64.02 & 0.8 & 1.842 & 1.8 & 462.2 & 1.828 & 2.4 & 458.6 & 0.99 & 3.853 & 2.2 & 966.9 & 569.9 & 48 & 0.74 & 225.9 & 303.5 & 25.5 \\
\hline & 27 & 41.05 & 0.9 & 1.239 & 1.8 & 497.1 & 0.626 & 2.4 & 251.2 & 0.51 & 0.564 & 2.2 & 226.2 & 556.1 & 44 & 0.72 & 239.4 & 331.3 & 30.1 \\
\hline & $28^{2}$ & 59.72 & 0.9 & 2.171 & 1.8 & 1271.5 & 1.454 & 2.4 & 851.6 & 0.67 & 0.905 & 2.2 & 529.7 & 1471.6 & 44 & 0.72 & 193.0 & 267.0 & 24.2 \\
\hline \multirow{3}{*}{ BR-63-15 } & $z 1$ & 41.45 & 1.1 & 1.349 & 1.8 & 321.9 & 0.499 & 2.4 & 119.2 & 0.37 & 0.324 & 3.5 & 77.3 & 350.0 & 44 & 0.72 & 229.1 & 316.3 & 28.9 \\
\hline & $z 2^{2}$ & 45.50 & 1.0 & 3.739 & 1.8 & 1373.1 & 1.280 & 2.4 & 470.2 & 0.34 & 0.054 & 5.3 & 19.8 & 1483.6 & 41 & 0.71 & 92.5 & 131.1 & 12.6 \\
\hline & $z 4^{2}$ & 212.39 & 1.1 & 8.498 & 1.8 & 1041.7 & 3.508 & 2.4 & 430.1 & 0.41 & 1.105 & 3.3 & 135.5 & 1142.8 & 60 & 0.79 & 185.5 & 234.0 & 17.1 \\
\hline \multirow{3}{*}{ BR-65-15 } & $\mathrm{z} 2^{1}$ & 102.70 & 1.0 & 1.129 & 1.8 & 124.0 & 0.431 & 2.4 & 47.4 & 0.38 & 0.260 & 5.4 & 28.5 & 135.1 & 78 & 0.84 & 651.8 & 776.1 & 47.6 \\
\hline & $z 3$ & 33.93 & 1.0 & 0.669 & 1.8 & 125.4 & 0.473 & 2.4 & 88.8 & 0.71 & 0.077 & 7.1 & 14.5 & 146.3 & 56 & 0.78 & 349.2 & 449.0 & 34.3 \\
\hline & $\mathrm{z4}$ & 6.18 & 1.0 & 0.156 & 2.3 & 56.7 & 0.104 & 2.4 & 37.9 & 0.67 & 0.034 & 6.3 & 12.3 & 65.6 & 38 & 0.68 & 275.9 & 404.1 & 42.3 \\
\hline
\end{tabular}




\section{Santa Catarina}

\begin{tabular}{|c|c|c|c|c|c|c|c|c|c|c|c|c|c|c|c|c|c|c|c|}
\hline \multirow{3}{*}{ Sample } & \multirow{3}{*}{ aliq. } & \multicolumn{2}{|c|}{$\mathrm{He}$} & \multicolumn{3}{|c|}{ U238 } & \multicolumn{3}{|c|}{ Th232 } & \multirow{2}{*}{ Th/U } & \multicolumn{3}{|c|}{ Sm } & \multirow{2}{*}{ eU } & \multirow{2}{*}{$\begin{array}{c}\text { Eq. } \\
\text { sphere } \\
\text { radius }\end{array}$} & \multirow{3}{*}{ FT } & \multirow{2}{*}{$\begin{array}{l}\text { Uncorr. } \\
\text { He-age }\end{array}$} & \multicolumn{2}{|c|}{ Ft-Correction } \\
\hline & & vol. & error & mass & error & conc. & mass & error & conc. & & mass & error & conc. & & & & & He-age & error \\
\hline & & [ncc] & [\%] & [ng] & [\%] & [ppm] & [ng] & [\%] & [ppm] & ratio & [ng] & [\%] & [ppm] & [ppm] & $(\mu \mathrm{m})$ & & [Ma] & [Ma] & [Ma] \\
\hline \multirow{3}{*}{ BR-66-15 } & $z 2$ & 55.89 & 0.8 & 3.426 & 1.8 & 503.1 & 0.748 & 2.4 & 109.9 & 0.22 & 0.119 & 4.7 & 17.4 & 528.9 & 67 & 0.81 & 127.1 & 156.2 & 10.4 \\
\hline & z4 & 21.14 & 0.8 & 0.961 & 1.8 & 574.8 & 0.282 & 2.4 & 168.7 & 0.29 & 0.012 & 8.9 & 7.5 & 614.5 & 43 & 0.72 & 168.0 & 234.6 & 21.8 \\
\hline & $z 5$ & 8.95 & 0.8 & 0.546 & 1.8 & 589.7 & 0.230 & 2.4 & 248.1 & 0.42 & 0.015 & 12.5 & 16.7 & 647.9 & 38 & 0.68 & 122.3 & 178.5 & 18.1 \\
\hline \multirow{3}{*}{ BR-67-15 } & $z 3$ & 15.64 & 0.8 & 0.303 & 1.9 & 88.5 & 0.151 & 2.4 & 44.2 & 0.50 & 0.027 & 8.3 & 7.9 & 98.9 & 57 & 0.78 & 370.5 & 472.5 & 35.3 \\
\hline & z4 & 28.59 & 0.8 & 0.702 & 1.8 & 197.6 & 0.495 & 2.4 & 139.2 & 0.70 & 0.101 & 4.6 & 28.4 & 230.3 & 49 & 0.75 & 282.2 & 377.7 & 31.5 \\
\hline & $\mathrm{z} 5$ & 23.52 & 0.8 & 0.577 & 1.8 & 114.6 & 0.307 & 2.4 & 60.9 & 0.53 & 0.041 & 6.3 & 8.2 & 128.9 & 41 & 0.71 & 292.4 & 413.0 & 39.1 \\
\hline \multirow{3}{*}{ BR-69-15 } & $z 2$ & 21.51 & 0.8 & 1.304 & 1.8 & 611.5 & 0.291 & 2.4 & 136.4 & 0.22 & 0.016 & 11.2 & 7.6 & 643.6 & 45 & 0.73 & 128.4 & 175.4 & 15.5 \\
\hline & z3 & 30.69 & 0.8 & 2.203 & 1.8 & 720.4 & 0.198 & 2.4 & 64.6 & 0.09 & 0.023 & 6.5 & 7.4 & 735.6 & 44 & 0.73 & 111.9 & 153.5 & 13.8 \\
\hline & z3 & 21.04 & 0.8 & 1.433 & 1.8 & 443.9 & 0.737 & 2.6 & 228.4 & 0.51 & 0.025 & 9.8 & 7.8 & 497.6 & 53 & 0.77 & 107.5 & 139.7 & 10.8 \\
\hline \multirow{3}{*}{ BR-70-15 } & $z 1$ & 99.35 & 0.9 & 2.690 & 1.8 & 293.8 & 0.845 & 2.4 & 92.3 & 0.31 & 0.034 & 25.0 & 3.8 & 315.5 & 75 & 0.83 & 277.9 & 333.3 & 20.7 \\
\hline & $z 2$ & 42.04 & 1.0 & 1.095 & 1.8 & 243.7 & 0.305 & 2.4 & 68.0 & 0.28 & 0.018 & 10.0 & 3.9 & 259.7 & 53 & 0.77 & 290.8 & 377.7 & 29.9 \\
\hline & z3 & 72.06 & 1.1 & 1.622 & 1.8 & 202.5 & 0.699 & 2.4 & 87.3 & 0.43 & 0.052 & 6.6 & 6.4 & 223.0 & 58 & 0.79 & 324.8 & 412.1 & 30.6 \\
\hline \multirow{3}{*}{ BR-75-15 } & z1 & 24.42 & 1.1 & 0.647 & 1.8 & 126.4 & 0.262 & 2.4 & 51.1 & 0.40 & 0.021 & 5.0 & 4.1 & 138.5 & 45 & 0.73 & 278.3 & 380.8 & 34.1 \\
\hline & $z 2$ & 31.02 & 1.0 & 1.210 & 1.8 & 270.0 & 0.599 & 2.4 & 133.6 & 0.49 & 0.022 & 7.3 & 4.8 & 301.4 & 43 & 0.72 & 187.1 & 260.3 & 24.0 \\
\hline & $\mathrm{z} 5$ & 23.67 & 1.1 & 0.814 & 1.8 & 111.5 & 0.436 & 2.4 & 59.7 & 0.54 & 0.052 & 3.3 & 7.2 & 125.5 & 56 & 0.78 & 209.9 & 269.4 & 20.6 \\
\hline \multirow{3}{*}{ BR-76-15 } & z1 & 67.17 & 1.0 & 2.256 & 1.8 & 228.6 & 1.182 & 2.4 & 119.7 & 0.52 & 0.065 & 9.3 & 6.6 & 256.7 & 65 & 0.81 & 215.4 & 266.9 & 18.4 \\
\hline & $z 3$ & 38.56 & 1.1 & 1.512 & 1.8 & 243.3 & 0.559 & 2.4 & 90.0 & 0.37 & 0.034 & 9.5 & 5.5 & 264.5 & 49 & 0.75 & 191.1 & 254.4 & 21.4 \\
\hline & $\mathrm{z} 5$ & 9.90 & 1.0 & 0.523 & 1.9 & 140.7 & 0.214 & 2.4 & 57.7 & 0.41 & 0.021 & 9.2 & 5.7 & 154.3 & 42 & 0.71 & 141.1 & 198.2 & 18.8 \\
\hline \multirow{3}{*}{ BR-86-15 } & $z 1$ & 108.92 & 0.8 & 5.945 & 1.8 & 613.0 & 1.979 & 2.4 & 204.0 & 0.33 & 0.340 & 4.0 & 35.0 & 660.9 & 64 & 0.81 & 139.0 & 172.2 & 11.7 \\
\hline & $z 3$ & 41.42 & 0.8 & 2.170 & 1.8 & 552.0 & 0.989 & 2.4 & 251.6 & 0.46 & 0.107 & 3.7 & 27.3 & 611.2 & 53 & 0.77 & 141.0 & 184.0 & 14.5 \\
\hline & $\mathrm{z} 5$ & 106.00 & 0.8 & 32.439 & 1.8 & 2199.9 & 4.730 & 2.4 & 320.7 & 0.15 & 0.255 & 4.1 & 17.3 & 2275.3 & 65 & 0.81 & 26.1 & 32.3 & 2.2 \\
\hline \multirow{3}{*}{ BR-87-15 } & z1 & 32.32 & 0.8 & 1.328 & 1.8 & 263.2 & 1.267 & 2.4 & 251.0 & 0.95 & 0.059 & 8.3 & 11.7 & 322.2 & 57 & 0.78 & 162.3 & 207.5 & 15.3 \\
\hline & z4 & 34.60 & 0.8 & 1.448 & 1.8 & 430.5 & 0.870 & 2.4 & 258.6 & 0.60 & 0.053 & 25.0 & 15.7 & 491.2 & 47 & 0.74 & 170.8 & 231.5 & 20.0 \\
\hline & $z 5$ & 26.02 & 0.8 & 0.984 & 1.8 & 378.2 & 0.418 & 2.4 & 160.6 & 0.42 & 0.031 & 5.6 & 12.0 & 415.9 & 40 & 0.70 & 195.8 & 281.0 & 27.4 \\
\hline
\end{tabular}




\begin{tabular}{|c|c|c|c|c|c|c|c|c|c|c|c|c|c|c|c|c|c|c|c|}
\hline & $\mathrm{z1}$ & 60.81 & 0.8 & 16.721 & 1.8 & 4188.2 & 12.627 & 2.4 & 3162.8 & 0.76 & 0.188 & 3.6 & 47.2 & 4931.4 & 49 & 0.75 & 25.5 & 34.0 & 2.8 \\
\hline \multirow[t]{3}{*}{ BR-88-15 } & z3 & 57.35 & 0.8 & 20.240 & 1.8 & 4466.6 & 12.777 & 2.4 & 2819.7 & 0.63 & 0.223 & 3.3 & 49.3 & 5129.2 & 53 & 0.77 & 20.4 & 26.6 & 2.1 \\
\hline & $\mathrm{z} 4$ & 41.74 & 0.8 & 11.923 & 1.8 & 3309.5 & 15.010 & 2.4 & 4166.4 & 1.26 & 0.497 & 3.7 & 137.9 & 4288.6 & 54 & 0.77 & 22.3 & 29.0 & 2.2 \\
\hline & $\mathrm{z2}$ & 45.94 & 0.8 & 2.980 & 1.8 & 559.2 & 0.746 & 2.4 & 140.0 & 0.25 & 0.158 & 4.8 & 29.6 & 592.1 & 51 & 0.76 & 119.3 & 157.0 & 12.7 \\
\hline \multirow[t]{3}{*}{ BR-90-15 } & $\mathrm{z} 4$ & 40.59 & 0.8 & 1.243 & 1.8 & 367.7 & 0.603 & 2.4 & 178.5 & 0.49 & 0.056 & 4.7 & 16.5 & 409.7 & 49 & 0.75 & 237.8 & 316.2 & 26.1 \\
\hline & $\mathrm{z} 5$ & 44.22 & 0.8 & 1.936 & 1.8 & 372.6 & 0.816 & 2.4 & 157.0 & 0.42 & 0.038 & 6.4 & 7.3 & 409.5 & 54 & 0.77 & 169.5 & 219.6 & 16.9 \\
\hline & $z 1$ & 8.60 & 0.8 & 2.020 & 1.8 & 2036.0 & 0.915 & 2.4 & 921.9 & 0.45 & 0.063 & 25.0 & 63.8 & 2252.6 & 36 & 0.67 & 31.8 & 47.5 & 5.0 \\
\hline \multirow[t]{3}{*}{ BR-91-15 } & z3 & 6.65 & 0.8 & 1.263 & 1.8 & 1099.2 & 0.463 & 2.4 & 402.9 & 0.37 & 0.071 & 25.0 & 61.5 & 1193.9 & 33 & 0.64 & 40.0 & 62.2 & 7.0 \\
\hline & $\mathrm{z} 5$ & 13.13 & 1.1 & 2.573 & 1.8 & 1722.3 & 1.306 & 2.4 & 873.8 & 0.51 & 0.117 & 25.0 & 78.4 & 1927.6 & 40 & 0.70 & 37.6 & 53.9 & 5.3 \\
\hline & $z 2$ & 47.03 & 1.0 & 1.054 & 1.8 & 206.4 & 0.650 & 2.4 & 127.2 & 0.62 & 0.091 & 25.0 & 17.8 & 236.3 & 59 & 0.79 & 313.9 & 396.5 & 28.8 \\
\hline \multirow[t]{3}{*}{ BR-93-15 } & z3 & 48.25 & 1.1 & 1.205 & 1.8 & 127.4 & 0.759 & 2.4 & 80.3 & 0.63 & 0.087 & 25.0 & 9.2 & 146.3 & 62 & 0.80 & 281.7 & 352.0 & 24.9 \\
\hline & $\mathrm{z5}$ & 3.81 & 1.0 & 0.217 & 2.0 & 115.7 & 0.128 & 2.4 & 68.1 & 0.59 & 0.016 & 25.0 & 8.8 & 131.7 & 36 & 0.67 & 126.3 & 189.3 & 20.3 \\
\hline & $z 1$ & 21.07 & 1.1 & 0.723 & 1.8 & 213.3 & 0.384 & 2.4 & 113.1 & 0.53 & 0.022 & 25.0 & 6.4 & 239.9 & 49 & 0.75 & 210.6 & 281.5 & 23.8 \\
\hline \multirow[t]{3}{*}{ BR-94-15 } & $\mathrm{z2}$ & 17.21 & 1.0 & 1.008 & 1.8 & 165.7 & 0.326 & 2.4 & 53.7 & 0.32 & 0.050 & 25.0 & 8.2 & 178.3 & 49 & 0.75 & 129.9 & 172.9 & 14.5 \\
\hline & z3 & 13.77 & 1.1 & 0.942 & 1.8 & 300.6 & 0.361 & 2.4 & 115.2 & 0.38 & 0.030 & 25.0 & 9.5 & 327.7 & 52 & 0.76 & 110.0 & 144.0 & 11.6 \\
\hline & $\mathrm{z1}$ & 66.75 & 1.0 & 2.248 & 1.8 & 446.7 & 0.627 & 2.4 & 124.5 & 0.28 & 0.021 & 25.0 & 4.3 & 475.9 & 55 & 0.78 & 226.3 & 291.8 & 22.7 \\
\hline \multirow[t]{3}{*}{ DSZ-24A } & $\mathrm{z2}$ & 13.55 & 1.0 & 1.581 & 1.8 & 596.6 & 0.500 & 2.4 & 188.8 & 0.32 & 0.024 & 25.0 & 9.1 & 641.0 & 47 & 0.74 & 65.7 & 88.8 & 7.7 \\
\hline & $\mathrm{z} 4$ & 23.29 & 1.1 & 0.855 & 1.8 & 260.1 & 0.387 & 2.4 & 117.6 & 0.45 & 0.053 & 25.0 & 16.0 & 287.8 & 49 & 0.75 & 200.3 & 266.9 & 22.4 \\
\hline & $z 1$ & 46.05 & 1.0 & 2.128 & 1.8 & 782.9 & 0.159 & 2.4 & 58.6 & 0.07 & 0.019 & 25.0 & 6.9 & 796.7 & 43 & 0.72 & 173.5 & 239.8 & 22.1 \\
\hline \multirow[t]{2}{*}{ MTF-01B } & $\mathrm{z} 2$ & 95.89 & 1.1 & 2.424 & 1.8 & 583.0 & 0.327 & 2.4 & 78.6 & 0.13 & 0.028 & 25.0 & 6.8 & 601.5 & 60 & 0.80 & 308.9 & 387.8 & 28.3 \\
\hline & z3 & 204.85 & 1.0 & 4.205 & 1.8 & 379.3 & 0.461 & 2.5 & 41.6 & 0.11 & 0.055 & 25.0 & 5.0 & 389.1 & 75 & 0.83 & 380.0 & 455.5 & 28.9 \\
\hline
\end{tabular}

Observations:

- Isotope concentration errors are $1 \sigma$, and He age errors are $2 \sigma$

- FT refers to $\alpha$-ejection correction (e.g. Farley et al. 1996)

- Ages written in italic are considered unrealistic and were discarded:

${ }^{1}$ Crystal discarded: ZHe age is older than the main metamorphic event in the DFB and/or rock emplacement age

${ }^{2}$ Crystal discarded - elevated eU indicates high radiation damage 


\section{Apatite}

Uruguay

\begin{tabular}{|c|c|c|c|c|c|c|c|c|c|c|c|c|c|c|c|c|c|c|c|}
\hline \multirow{3}{*}{ Sample } & \multirow{3}{*}{ aliq. } & \multicolumn{2}{|c|}{$\mathrm{He}$} & \multicolumn{3}{|c|}{ U238 } & \multicolumn{3}{|c|}{ Th232 } & \multirow{2}{*}{ Th/U } & \multicolumn{3}{|c|}{$\mathrm{Sm}$} & \multirow{2}{*}{$\mathrm{eU}$} & \multirow{2}{*}{$\begin{array}{l}\text { Eq. } \\
\text { sphere } \\
\text { radius }\end{array}$} & \multirow{3}{*}{ FT } & \multirow{2}{*}{$\begin{array}{l}\text { Uncorr. } \\
\text { He-age }\end{array}$} & \multicolumn{2}{|c|}{ Ft-Correction } \\
\hline & & vol. & error & mass & error & conc. & mass & error & conc. & & mass & error & conc. & & & & & He-age & error \\
\hline & & [ncc] & [\%] & [ng] & [\%] & [ppm] & [ng] & [\%] & [ppm] & ratio & [ng] & [\%] & [ppm] & [ppm] & $(\mu \mathrm{m})$ & & [Ma] & [Ma] & [Ma] \\
\hline \multirow{2}{*}{ U-46 } & a1 & 0.141 & 1.6 & 0.004 & 13.0 & 5.0 & 0.021 & 2.9 & 24.9 & 4.99 & 0.502 & 6.1 & 606.0 & 10.8 & 144 & 0.93 & 88.0 & 95.1 & 9.4 \\
\hline & a2 & 0.191 & 1.4 & 0.006 & 8.9 & 3.6 & 0.052 & 2.6 & 31.4 & 8.62 & 0.891 & 6.0 & 542.3 & 11.0 & 49 & 0.67 & 61.6 & 92.1 & 10.9 \\
\hline \multirow{3}{*}{ U-74 } & $\mathrm{a} 1^{1}$ & 1.528 & 0.9 & 0.014 & 4.2 & 7.1 & 0.074 & 2.5 & 38.5 & 5.42 & 0.795 & 6.0 & 412.9 & 16.1 & 50 & 0.67 & 329.6 & 494.8 & 54.7 \\
\hline & $\mathrm{a} 2^{1}$ & 1.440 & 0.9 & 0.017 & 3.7 & 7.8 & 0.088 & 2.5 & 41.4 & 5.29 & 0.938 & 6.1 & 442.6 & 17.6 & 41 & 0.59 & 261.1 & 443.1 & 58.0 \\
\hline & a3 ${ }^{1}$ & 0.409 & 1.1 & 0.002 & 24.0 & 2.4 & 0.016 & 3.0 & 17.4 & 7.16 & 0.261 & 7.0 & 291.4 & 6.5 & 48 & 0.66 & 417.3 & 629.9 & 106.5 \\
\hline \multirow{3}{*}{ UY-23-14 } & a1 & 0.637 & 1.0 & 0.035 & 2.3 & 11.8 & 0.118 & 2.5 & 39.2 & 3.32 & 2.411 & 5.7 & 802.0 & 21.0 & 46 & 0.67 & 63.1 & 94.2 & 10.1 \\
\hline & a2 & 0.684 & 1.0 & 0.038 & 2.3 & 12.4 & 0.115 & 2.5 & 37.7 & 3.03 & 2.287 & 5.8 & 750.8 & 21.3 & 47 & 0.65 & 67.3 & 103.7 & 11.8 \\
\hline & $a 3^{2}$ & 3.609 & 0.9 & 0.029 & 2.6 & 9.0 & 0.068 & 2.5 & 20.8 & 2.32 & 1.945 & 5.7 & 595.3 & 13.8 & 54 & 0.70 & 474.6 & 681.5 & 68.9 \\
\hline \multirow{3}{*}{ UY-33-14 } & a1 & 1.678 & 0.9 & 0.072 & 2.0 & 16.2 & 0.248 & 2.4 & 56.1 & 3.47 & 0.257 & 6.5 & 58.0 & 29.4 & 55 & 0.73 & 104.1 & 142.1 & 12.4 \\
\hline & a2 & 2.774 & 0.9 & 0.109 & 1.9 & 35.2 & 0.397 & 2.4 & 128.2 & 3.64 & 0.214 & 7.2 & 69.1 & 65.4 & 63 & 0.74 & 111.4 & 150.3 & 12.8 \\
\hline & a3 & 3.179 & 0.9 & 0.103 & 1.9 & 36.4 & 0.366 & 2.4 & 129.5 & 3.56 & 0.366 & 6.7 & 129.7 & 66.8 & 53 & 0.69 & 135.6 & 195.4 & 19.1 \\
\hline \multirow{4}{*}{ UY-45-14 } & a1 & 0.065 & 7.9 & 0.006 & 9.3 & 4.8 & 0.002 & 5.8 & 1.8 & 0.38 & 0.202 & 6.7 & 164.1 & 5.2 & 37 & 0.56 & 66.7 & 120.1 & 29.5 \\
\hline & a2 & 0.073 & 2.0 & 0.007 & 7.6 & 3.6 & 0.002 & 6.6 & 1.0 & 0.29 & 0.318 & 6.7 & 160.1 & 3.8 & 42 & 0.62 & 58.7 & 94.3 & 15.2 \\
\hline & a3 & 0.228 & 1.3 & 0.018 & 3.4 & 24.9 & 0.003 & 4.1 & 4.8 & 0.19 & 0.148 & 7.9 & 201.8 & 26.1 & 37 & 0.58 & 92.2 & 158.2 & 22.3 \\
\hline & a4 & 0.484 & 1.1 & 0.015 & 3.9 & 20.9 & 0.133 & 2.5 & 182.0 & 8.72 & 0.281 & 7.0 & 385.3 & 63.7 & 33 & 0.48 & 81.4 & 169.9 & 27.7 \\
\hline \multirow{3}{*}{ UY-51-14 } & a1 & 7.137 & 0.8 & 0.101 & 1.9 & 28.9 & 0.900 & 2.4 & 258.8 & 8.95 & 0.944 & 6.0 & 271.4 & 89.8 & 47 & 0.64 & 182.1 & 285.6 & 32.9 \\
\hline & a2 & 2.836 & 0.9 & 0.038 & 2.3 & 16.9 & 0.433 & 2.4 & 191.9 & 11.37 & 0.621 & 6.3 & 275.6 & 62.0 & 50 & 0.66 & 160.0 & 241.8 & 26.4 \\
\hline & a3 & 4.517 & 0.8 & 0.061 & 2.0 & 11.4 & 0.648 & 2.4 & 121.9 & 10.66 & 0.958 & 6.0 & 180.0 & 40.1 & 57 & 0.70 & 166.8 & 240.0 & 23.9 \\
\hline \multirow{3}{*}{ UY-68-14 } & a1 & 1.629 & 0.9 & 0.041 & 2.3 & 8.3 & 0.057 & 2.6 & 11.5 & 1.39 & 0.439 & 6.3 & 89.1 & 11.0 & 53 & 0.72 & 229.9 & 317.9 & 29.1 \\
\hline & a2 & 0.840 & 1.0 & 0.031 & 2.5 & 11.2 & 0.034 & 2.7 & 12.2 & 1.09 & 0.299 & 6.7 & 107.7 & 14.0 & 53 & 0.71 & 166.1 & 235.4 & 23.1 \\
\hline & a3 & 1.012 & 1.0 & 0.026 & 2.7 & 9.2 & 0.040 & 2.6 & 14.1 & 1.53 & 0.159 & 7.4 & 55.8 & 12.5 & 49 & 0.67 & 222.3 & 329.7 & 35.4 \\
\hline \multirow{2}{*}{ UY-1-15 } & a1 & 0.245 & 2.0 & 0.009 & 7.7 & 7.6 & 0.001 & 527.0 & 0.7 & 0.09 & 0.344 & 5.7 & 274.8 & 7.7 & 48 & 0.68 & 160.1 & 235.9 & 55.5 \\
\hline & a2 & 0.641 & 1.3 & 0.024 & 3.2 & 19.8 & 0.006 & 4.3 & 4.7 & 0.24 & 0.447 & 4.9 & 369.7 & 20.9 & 36 & 0.58 & 181.0 & 313.7 & 43.9 \\
\hline
\end{tabular}




\begin{tabular}{|c|c|c|c|c|c|c|c|c|c|c|c|c|c|c|c|c|c|c|c|}
\hline & $a 3^{3}$ & 0.234 & 1.9 & 0.006 & 15.0 & 6.3 & 0.001 & 411.3 & 1.2 & 0.19 & 0.192 & 7.9 & 206.1 & 6.6 & 37 & 0.58 & 246.6 & 422.3 & 162.1 \\
\hline \multirow{3}{*}{ UY-3-15 } & a1 & 0.257 & 1.9 & 0.017 & 4.7 & 9.6 & 0.010 & 3.6 & 5.8 & 0.60 & 0.165 & 7.1 & 93.7 & 10.9 & 44 & 0.64 & 102.1 & 159.0 & 21.8 \\
\hline & $\mathrm{a} 2$ & 0.168 & 2.1 & 0.011 & 6.4 & 12.4 & 0.002 & 11.1 & 2.2 & 0.18 & 0.141 & 8.1 & 153.9 & 12.9 & 36 & 0.57 & 106.4 & 185.2 & 32.0 \\
\hline & $a 3^{3}$ & 0.066 & 2.4 & 0.005 & 22.7 & 6.7 & 0.002 & 8.0 & 3.2 & 0.48 & 0.046 & 15.6 & 66.6 & 7.5 & 30 & 0.47 & 99.2 & 210.0 & 84.5 \\
\hline
\end{tabular}

Rio Grande do Sul

\begin{tabular}{|c|c|c|c|c|c|c|c|c|c|c|c|c|c|c|c|c|c|c|c|}
\hline \multirow[b]{2}{*}{ Sample } & \multirow[b]{2}{*}{ aliq. } & \multicolumn{2}{|c|}{$\mathrm{He}$} & \multicolumn{3}{|c|}{ U238 } & \multicolumn{3}{|c|}{ Th232 } & \multirow[b]{2}{*}{$\begin{array}{l}\text { Th/U } \\
\text { ratio }\end{array}$} & \multicolumn{3}{|c|}{ Sm } & \multirow[b]{2}{*}{$\begin{array}{c}\mathrm{eU} \\
\text { [ppm] }\end{array}$} & \multirow{2}{*}{$\begin{array}{c}\text { Eq. } \\
\text { sphere } \\
\text { radius }\end{array}$} & \multirow[b]{2}{*}{ FT } & \multirow{2}{*}{$\begin{array}{c}\text { Uncorr. } \\
\text { He-age } \\
\text { [Ma] }\end{array}$} & \multicolumn{2}{|c|}{ Ft-Correction } \\
\hline & & $\begin{array}{c}\text { vol. } \\
\text { [ncc] }\end{array}$ & $\begin{array}{c}\text { error } \\
\text { [\%] }\end{array}$ & $\begin{array}{l}\text { mass } \\
\text { [ng] }\end{array}$ & $\begin{array}{c}\text { error } \\
\text { [\%] }\end{array}$ & $\begin{array}{l}\text { conc. } \\
\text { [ppm] }\end{array}$ & $\begin{array}{l}\text { mass } \\
\text { [ng] }\end{array}$ & $\begin{array}{c}\text { error } \\
\text { [\%] }\end{array}$ & $\begin{array}{l}\text { conc. } \\
\text { [ppm] }\end{array}$ & & $\begin{array}{l}\text { mass } \\
\text { [ng] }\end{array}$ & $\begin{array}{c}\text { error } \\
\text { [\%] }\end{array}$ & $\begin{array}{l}\text { conc. } \\
\text { [ppm] }\end{array}$ & & & & & $\begin{array}{c}\text { He-age } \\
\text { [Ma] }\end{array}$ & $\begin{array}{l}\text { error } \\
\text { [Ma] }\end{array}$ \\
\hline \multirow{3}{*}{ BR-1-15 } & $a 1^{3}$ & 0.009 & 6.2 & 0.001 & 152.2 & 0.4 & 0.003 & 7.4 & 1.8 & 4.42 & 0.167 & 9.1 & 95.2 & 0.8 & 38 & 0.58 & 24.7 & 42.9 & 32.9 \\
\hline & $a 2^{3}$ & 0.002 & 9.3 & 0.000 & 955.2 & 0.1 & 0.000 & 244.9 & 0.2 & 2.73 & 0.121 & 9.4 & 73.6 & 0.1 & 47 & 0.66 & 15.7 & 24.0 & 48.6 \\
\hline & $a 3^{3}$ & 0.003 & 8.6 & 0.001 & 80.8 & 0.5 & 0.002 & 35.7 & 0.7 & 1.35 & 0.182 & 8.7 & 74.7 & 0.7 & 47 & 0.67 & 8.5 & 12.8 & 8.3 \\
\hline \multirow{3}{*}{ BR-6-15 } & a1 & 0.884 & 1.1 & 0.051 & 2.1 & 23.0 & 0.056 & 2.6 & 25.0 & 1.09 & 0.661 & 3.4 & 295.1 & 28.8 & 48 & 0.67 & 103.5 & 153.8 & 16.2 \\
\hline & a2 & 0.676 & 1.1 & 0.025 & 3.3 & 13.0 & 0.039 & 2.7 & 20.0 & 1.53 & 0.380 & 5.4 & 195.1 & 17.7 & 43 & 0.63 & 147.1 & 235.3 & 29.0 \\
\hline & a3 & 2.729 & 1.0 & 0.092 & 2.0 & 18.3 & 0.150 & 2.5 & 29.9 & 1.64 & 1.274 & 8.2 & 253.4 & 25.3 & 62 & 0.74 & 162.1 & 219.3 & 18.9 \\
\hline \multirow{3}{*}{ BR-19-15 } & a1 & 1.232 & 1.1 & 0.089 & 1.9 & 33.2 & 0.014 & 3.5 & 5.3 & 0.16 & 0.441 & 5.1 & 164.8 & 34.4 & 48 & 0.68 & 105.6 & 155.9 & 16.4 \\
\hline & $\mathrm{a} 2$ & 0.242 & 1.4 & 0.016 & 4.8 & 9.5 & 0.000 & 204.9 & 0.2 & 0.02 & 0.194 & 6.5 & 117.6 & 9.6 & 42 & 0.64 & 114.4 & 179.5 & 25.4 \\
\hline & a3 & 0.318 & 1.3 & 0.026 & 3.0 & 21.5 & 0.000 & -857.6 & 0.0 & 0.00 & 0.171 & 7.8 & 141.7 & 21.5 & 38 & 0.59 & 95.6 & 162.3 & 22.4 \\
\hline \multirow{3}{*}{ BR-23-15 } & a1 & 0.330 & 1.6 & 0.019 & 8.1 & 5.1 & 0.001 & 209.8 & 0.3 & 0.06 & 0.017 & 2.2 & 4.7 & 5.2 & 43 & 0.65 & 142.9 & 219.8 & 43.2 \\
\hline & a2 & 0.127 & 1.9 & 0.011 & 14.6 & 3.2 & 0.000 & 768.5 & 0.1 & 0.03 & 0.028 & 2.2 & 8.3 & 3.2 & 38 & 0.60 & 94.0 & 156.6 & 50.8 \\
\hline & a3 & 0.070 & 2.4 & 0.010 & 14.2 & 2.8 & 0.002 & 183.4 & 0.4 & 0.15 & 0.018 & 2.2 & 4.9 & 2.8 & 40 & 0.62 & 52.5 & 84.9 & 26.5 \\
\hline \multirow{3}{*}{ BR-26-15 } & a1 & 3.306 & 1.0 & 0.146 & 1.9 & 33.1 & 0.040 & 2.7 & 9.1 & 0.27 & 1.703 & 2.9 & 387.0 & 35.2 & 59 & 0.74 & 159.9 & 216.1 & 18.6 \\
\hline & a2 & 0.839 & 1.1 & 0.054 & 2.1 & 21.1 & 0.020 & 3.1 & 8.0 & 0.38 & 0.946 & 3.4 & 369.5 & 23.0 & 51 & 0.69 & 103.4 & 149.2 & 15.0 \\
\hline & a3 & 2.969 & 1.0 & 0.097 & 1.9 & 34.0 & 0.043 & 2.7 & 15.0 & 0.44 & 1.094 & 3.4 & 382.9 & 37.5 & 53 & 0.71 & 208.1 & 295.1 & 28.3 \\
\hline \multirow{3}{*}{ BR-34-15 } & $a 1^{2}$ & 3.373 & 1.0 & 0.016 & 5.1 & 16.6 & 0.004 & 5.3 & 3.8 & 0.23 & 0.124 & 9.3 & 130.9 & 17.5 & 38 & 0.60 & 1403.2 & 2331.1 & 350.5 \\
\hline & a2 & 1.486 & 1.0 & 0.108 & 1.9 & 37.9 & 0.005 & 3.9 & 1.6 & 0.04 & 0.602 & 8.5 & 211.8 & 38.3 & 53 & 0.71 & 107.1 & 150.9 & 14.5 \\
\hline & a3 & 1.333 & 1.0 & 0.106 & 1.9 & 20.6 & 0.006 & 3.5 & 1.2 & 0.06 & 1.017 & 8.3 & 197.0 & 20.9 & 57 & 0.73 & 94.2 & 128.3 & 11.5 \\
\hline BR-44-15 & a1 & 0.461 & 1.2 & 0.031 & 3.0 & 25.7 & 0.071 & 2.5 & 59.6 & 2.32 & 0.371 & 8.5 & 311.7 & 39.7 & 48 & 0.67 & 75.4 & 111.9 & 12.1 \\
\hline
\end{tabular}




\begin{tabular}{|c|c|c|c|c|c|c|c|c|c|c|c|c|c|c|c|c|c|c|c|}
\hline & a2 & 3.118 & 1.0 & 0.102 & 2.0 & 45.5 & 0.301 & 2.4 & 133.7 & 2.94 & 1.352 & 8.2 & 600.2 & 76.9 & 48 & 0.66 & 138.4 & 209.4 & 22.6 \\
\hline & a1 & 0.312 & 1.4 & 0.028 & 3.3 & 18.2 & 0.006 & 3.5 & 3.7 & 0.21 & 0.162 & 8.8 & 106.2 & 19.1 & 44 & 0.63 & 84.4 & 133.2 & 17.0 \\
\hline \multirow[t]{3}{*}{ BR-48-15 } & a2 & 1.967 & 1.0 & 0.118 & 1.9 & 39.5 & 0.056 & 2.6 & 18.8 & 0.48 & 0.242 & 8.8 & 80.7 & 43.9 & 54 & 0.71 & 120.6 & 169.5 & 16.1 \\
\hline & a3 & 0.470 & 1.2 & 0.026 & 3.4 & 27.0 & 0.047 & 2.6 & 48.4 & 1.79 & 0.152 & 9.1 & 155.7 & 38.4 & 37 & 0.55 & 99.1 & 179.5 & 26.0 \\
\hline & $\mathrm{a} 1^{2}$ & 0.447 & 1.2 & 0.004 & 22.5 & 4.0 & 0.021 & 3.2 & 21.7 & 5.47 & 0.313 & 8.6 & 322.6 & 9.1 & 38 & 0.56 & 319.2 & 571.0 & 116.3 \\
\hline \multirow[t]{3}{*}{ BR-52-15 } & $a 2^{2}$ & 0.567 & 1.1 & 0.004 & 24.7 & 5.3 & 0.022 & 3.0 & 32.8 & 6.21 & 0.247 & 9.0 & 363.0 & 13.0 & 37 & 0.54 & 422.9 & 776.2 & 165.5 \\
\hline & $a 3^{2}$ & 2.200 & 1.0 & 0.012 & 6.4 & 13.5 & 0.086 & 2.5 & 92.6 & 6.85 & 0.629 & 8.3 & 681.5 & 35.3 & 49 & 0.67 & 469.9 & 699.6 & 79.8 \\
\hline & a1 & 0.299 & 1.3 & 0.013 & 6.5 & 14.1 & 0.026 & 2.9 & 29.4 & 2.09 & 0.428 & 8.4 & 474.5 & 21.0 & 35 & 0.53 & 109.6 & 207.3 & 33.8 \\
\hline \multirow[t]{3}{*}{ BR-55-15 } & $\mathrm{a} 2$ & 0.729 & 1.1 & 0.026 & 3.4 & 10.8 & 0.024 & 3.0 & 9.8 & 0.91 & 0.864 & 8.3 & 358.8 & 13.1 & 50 & 0.67 & 154.7 & 231.0 & 26.6 \\
\hline & a3 & 0.179 & 1.6 & 0.002 & 41.2 & 3.4 & 0.024 & 2.9 & 38.2 & 11.25 & 0.223 & 8.9 & 357.4 & 12.4 & 32 & 0.46 & 153.9 & 333.0 & 81.5 \\
\hline & a1 & 0.119 & 1.8 & 0.007 & 13.5 & 5.8 & 0.003 & 6.5 & 2.8 & 0.47 & 0.061 & 11.8 & 52.5 & 6.5 & 43 & 0.64 & 121.6 & 190.1 & 46.9 \\
\hline \multirow[t]{3}{*}{ BR-63-15 } & $a 2^{4}$ & 0.978 & 1.0 & 0.022 & 3.9 & 17.9 & 0.022 & 3.0 & 18.2 & 1.02 & 0.146 & 9.4 & 121.0 & 22.1 & 39 & 0.58 & 283.8 & 486.2 & 67.9 \\
\hline & $a 3^{4}$ & 0.341 & 1.2 & 0.007 & 13.4 & 6.6 & 0.015 & 3.4 & 14.4 & 2.18 & 0.055 & 11.1 & 54.2 & 10.0 & 43 & 0.62 & 262.5 & 423.9 & 85.4 \\
\hline & a1 & 0.320 & 1.7 & 0.052 & 3.5 & 16.0 & 0.009 & 3.3 & 2.7 & 0.17 & 0.374 & 2.2 & 115.8 & 16.6 & 33 & 0.53 & 46.5 & 87.9 & 13.9 \\
\hline \multirow[t]{2}{*}{ BR-66-15 } & a2 & 0.596 & 1.5 & 0.085 & 2.4 & 22.3 & 0.041 & 2.8 & 10.8 & 0.48 & 0.781 & 2.2 & 205.5 & 24.8 & 48 & 0.67 & 48.8 & 73.1 & 8.1 \\
\hline & a3 & 0.278 & 1.7 & 0.047 & 3.5 & 14.0 & 0.007 & 5.2 & 2.0 & 0.14 & 0.402 & 2.2 & 120.1 & 14.5 & 36 & 0.56 & 44.4 & 79.4 & 11.9 \\
\hline
\end{tabular}

\section{$\underline{\text { Santa Catarina }}$}

\begin{tabular}{|c|c|c|c|c|c|c|c|c|c|c|c|c|c|c|c|c|c|c|c|}
\hline \multirow{3}{*}{ Sample } & \multirow{3}{*}{ aliq. } & \multicolumn{2}{|c|}{$\mathrm{He}$} & \multicolumn{3}{|c|}{ U238 } & \multicolumn{3}{|c|}{ Th232 } & \multirow{2}{*}{$\mathrm{Th} / \mathrm{U}$} & \multicolumn{3}{|c|}{ Sm } & \multirow{2}{*}{ eU } & \multirow{2}{*}{$\begin{array}{l}\text { Eq. } \\
\text { sphere } \\
\text { radius }\end{array}$} & \multirow{3}{*}{ FT } & \multirow{2}{*}{$\begin{array}{l}\text { Uncorr. } \\
\text { He-age }\end{array}$} & \multicolumn{2}{|c|}{ Ft-Correction } \\
\hline & & vol. & error & mass & error & conc. & mass & error & conc. & & mass & error & conc. & & & & & He-age & error \\
\hline & & [ncc] & [\%] & [ng] & [\%] & [ppm] & [ng] & [\%] & [ppm] & ratio & [ng] & [\%] & [ppm] & [ppm] & $(\mu \mathrm{m})$ & & [Ma] & [Ma] & [Ma] \\
\hline \multirow{3}{*}{ BR-66-15 } & a1 & 0.320 & 1.7 & 0.052 & 3.5 & 16.0 & 0.009 & 3.3 & 2.7 & 0.17 & 0.374 & 2.2 & 115.8 & 16.6 & 33 & 0.53 & 46.5 & 87.9 & 13.9 \\
\hline & $\mathrm{a} 2$ & 0.596 & 1.5 & 0.085 & 2.4 & 22.3 & 0.041 & 2.8 & 10.8 & 0.48 & 0.781 & 2.2 & 205.5 & 24.8 & 48 & 0.67 & 48.8 & 73.1 & 8.1 \\
\hline & a3 & 0.278 & 1.7 & 0.047 & 3.5 & 14.0 & 0.007 & 5.2 & 2.0 & 0.14 & 0.402 & 2.2 & 120.1 & 14.5 & 36 & 0.56 & 44.4 & 79.4 & 11.9 \\
\hline \multirow{3}{*}{ BR-67-15 } & a1 & 0.384 & 1.4 & 0.030 & 2.7 & 28.7 & 0.213 & 2.4 & 205.3 & 7.14 & 1.844 & 3.3 & 1778.1 & 77.0 & 45 & 0.62 & 33.2 & 53.2 & 6.4 \\
\hline & $\mathrm{a} 2$ & 0.274 & 1.4 & 0.021 & 3.3 & 16.9 & 0.136 & 2.4 & 106.9 & 6.32 & 1.952 & 3.5 & 1537.3 & 42.0 & 46 & 0.61 & 32.5 & 52.8 & 6.5 \\
\hline & a3 & 0.113 & 2.0 & 0.010 & 6.0 & 42.7 & 0.066 & 2.4 & 270.4 & 6.33 & 0.877 & 3.4 & 3577.9 & 106.2 & 39 & 0.57 & 28.0 & 49.3 & 7.0 \\
\hline BR-69-15 & a2 & 0.182 & 1.8 & 0.022 & 3.1 & 23.3 & 0.034 & 2.7 & 35.8 & 1.54 & 0.064 & 7.5 & 66.8 & 31.7 & 42 & 0.62 & 48.8 & 78.8 & 10.1 \\
\hline
\end{tabular}




\begin{tabular}{|c|c|c|c|c|c|c|c|c|c|c|c|c|c|c|c|c|c|c|c|}
\hline & a3 & 0.579 & 1.2 & 0.077 & 2.0 & 26.9 & 0.099 & 2.5 & 34.9 & 1.30 & 0.188 & 3.5 & 66.2 & 35.1 & 55 & 0.71 & 47.0 & 66.2 & 6.3 \\
\hline & a4 & 1.231 & 1.1 & 0.131 & 1.9 & 42.4 & 0.176 & 2.4 & 56.8 & 1.34 & 0.379 & 4.0 & 122.6 & 55.7 & 64 & 0.75 & 57.8 & 77.2 & 6.5 \\
\hline \multirow{3}{*}{ BR-70-15 } & a1 & 0.185 & 1.8 & 0.026 & 6.0 & 6.3 & 0.026 & 3.0 & 6.2 & 0.99 & 1.145 & 2.2 & 280.0 & 7.8 & 51 & 0.69 & 37.0 & 53.7 & 6.6 \\
\hline & $\mathrm{a} 2$ & 0.273 & 1.7 & 0.027 & 5.5 & 6.1 & 0.032 & 3.0 & 7.2 & 1.19 & 1.299 & 2.2 & 290.1 & 7.8 & 44 & 0.64 & 49.3 & 77.0 & 10.0 \\
\hline & a3 & 0.248 & 1.7 & 0.024 & 6.4 & 6.0 & 0.033 & 2.9 & 8.4 & 1.39 & 1.137 & 2.2 & 284.4 & 8.0 & 51 & 0.68 & 49.4 & 73.2 & 9.2 \\
\hline \multirow{3}{*}{ BR-75-15 } & a1 & 2.908 & 1.3 & 0.173 & 2.0 & 40.2 & 0.018 & 3.1 & 4.1 & 0.10 & 0.267 & 2.2 & 62.0 & 41.2 & 36 & 0.57 & 132.9 & 231.8 & 31.5 \\
\hline & a2 & 0.159 & 1.9 & 0.015 & 9.8 & 4.6 & 0.080 & 2.6 & 24.2 & 5.29 & 0.786 & 2.2 & 237.8 & 10.3 & 34 & 0.47 & 32.4 & 68.5 & 12.3 \\
\hline & a3 & 0.249 & 1.8 & 0.023 & 6.4 & 7.2 & 0.141 & 2.5 & 44.9 & 6.26 & 1.163 & 2.2 & 369.5 & 17.7 & 38 & 0.55 & 31.4 & 56.8 & 8.4 \\
\hline \multirow{3}{*}{ BR-76-15 } & a1 & 0.511 & 1.5 & 0.041 & 2.6 & 13.3 & 0.259 & 2.4 & 84.5 & 6.36 & 2.103 & 6.9 & 685.6 & 33.1 & 46 & 0.64 & 35.3 & 55.1 & 6.5 \\
\hline & a2 & 0.277 & 1.7 & 0.025 & 3.7 & 7.6 & 0.117 & 2.5 & 35.7 & 4.72 & 1.403 & 6.8 & 428.2 & 15.9 & 45 & 0.63 & 35.8 & 56.5 & 6.9 \\
\hline & a3 & 0.525 & 1.5 & 0.017 & 4.9 & 7.3 & 0.086 & 2.5 & 36.3 & 4.95 & 1.023 & 6.9 & 429.6 & 15.9 & 38 & 0.56 & 93.4 & 167.2 & 24.1 \\
\hline \multirow{3}{*}{ BR-86-15 } & a2 & 0.144 & 1.8 & 0.021 & 3.3 & 22.5 & 0.008 & 3.7 & 8.0 & 0.36 & 0.279 & 3.9 & 294.6 & 24.3 & 44 & 0.65 & 47.0 & 72.7 & 9.0 \\
\hline & $\mathrm{a} 2$ & 0.378 & 1.4 & 0.044 & 2.3 & 15.5 & 0.016 & 3.1 & 5.6 & 0.36 & 0.759 & 3.7 & 267.6 & 16.8 & 94 & 0.85 & 57.7 & 67.6 & 4.3 \\
\hline & a3 & 0.724 & 1.2 & 0.031 & 2.5 & 14.5 & 0.096 & 2.5 & 44.8 & 3.08 & 0.502 & 4.7 & 234.4 & 25.1 & 56 & 0.71 & 102.8 & 145.5 & 14.2 \\
\hline \multirow{3}{*}{ BR-88-15 } & a1 & 0.042 & 2.6 & 0.005 & 18.2 & 1.4 & 0.015 & 3.3 & 4.4 & 3.03 & 0.135 & 9.0 & 39.5 & 2.5 & 36 & 0.55 & 36.0 & 65.1 & 15.2 \\
\hline & a2 & 0.055 & 2.6 & 0.007 & 12.4 & 2.0 & 0.022 & 3.1 & 6.4 & 3.26 & 0.187 & 7.4 & 55.0 & 3.5 & 43 & 0.64 & 33.7 & 52.4 & 9.0 \\
\hline & a3 & 0.124 & 1.9 & 0.010 & 8.2 & 2.7 & 0.035 & 2.8 & 9.4 & 3.49 & 0.316 & 7.4 & 83.3 & 4.9 & 44 & 0.63 & 48.5 & 77.2 & 11.1 \\
\hline \multirow{3}{*}{ BR-90-15 } & a1 & 0.687 & 1.2 & 0.088 & 1.9 & 51.7 & 0.070 & 2.5 & 41.1 & 0.80 & 1.477 & 3.7 & 863.7 & 61.4 & 40 & 0.61 & 48.4 & 79.2 & 9.7 \\
\hline & a2 & 0.309 & 1.5 & 0.040 & 2.4 & 32.2 & 0.028 & 2.7 & 22.8 & 0.71 & 0.905 & 4.2 & 732.0 & 37.6 & 44 & 0.64 & 47.2 & 73.9 & 8.7 \\
\hline & a3 & 1.085 & 1.1 & 0.138 & 1.9 & 64.9 & 0.108 & 2.5 & 51.0 & 0.79 & 1.984 & 3.6 & 935.8 & 76.9 & 49 & 0.68 & 49.9 & 73.8 & 7.7 \\
\hline \multirow{3}{*}{ BR-91-15 } & a1 & 0.131 & 1.7 & 0.013 & 5.1 & 33.2 & 0.048 & 2.5 & 123.7 & 3.72 & 0.659 & 3.9 & 1708.2 & 62.3 & 35 & 0.54 & 36.5 & 67.7 & 10.2 \\
\hline & $\mathrm{a} 2$ & 0.076 & 2.1 & 0.010 & 6.4 & 52.5 & 0.037 & 2.5 & 198.5 & 3.78 & 0.443 & 3.4 & 2363.4 & 99.2 & 32 & 0.48 & 28.3 & 58.9 & 10.1 \\
\hline & a3 & 0.215 & 1.4 & 0.007 & 12.1 & 37.0 & 0.021 & 2.6 & 114.5 & 3.10 & 0.437 & 4.5 & 2339.9 & 63.9 & 32 & 0.49 & 113.6 & 232.3 & 43.9 \\
\hline \multirow{2}{*}{ BR-93-15 } & a1 & 0.112 & 1.6 & 0.005 & 12.6 & 4.2 & 0.027 & 2.5 & 21.2 & 5.00 & 1.021 & 4.0 & 802.9 & 9.2 & 48 & 0.66 & 45.8 & 69.7 & 9.1 \\
\hline & $3 a$ & 0.075 & 2.2 & 0.005 & 16.4 & 61.7 & 0.028 & 2.5 & 358.5 & 5.81 & 0.426 & 4.6 & 5542.6 & 146.0 & 31 & 0.45 & 41.9 & 92.5 & 18.5 \\
\hline \multirow{3}{*}{ BR-94-15 } & a1 & 1.345 & 0.9 & 0.121 & 1.9 & 54.7 & 0.263 & 2.4 & 118.9 & 2.18 & 2.026 & 3.4 & 917.1 & 82.6 & 56 & 0.71 & 55.6 & 78.2 & 7.3 \\
\hline & $\mathrm{a} 2$ & 0.365 & 1.2 & 0.049 & 2.1 & 63.3 & 0.083 & 2.4 & 108.0 & 1.71 & 0.640 & 3.3 & 830.0 & 88.7 & 38 & 0.57 & 40.9 & 71.7 & 9.6 \\
\hline & a3 & 0.409 & 1.2 & 0.052 & 2.1 & 34.2 & 0.067 & 2.4 & 43.9 & 1.28 & 0.966 & 3.6 & 635.1 & 44.5 & 49 & 0.68 & 44.5 & 65.7 & 6.8 \\
\hline \multirow{3}{*}{ DSZ-24A } & a1 & 0.302 & 1.3 & 0.047 & 2.1 & 51.6 & 0.056 & 2.4 & 61.0 & 1.18 & 0.892 & 3.6 & 973.5 & 65.9 & 44 & 0.64 & 36.8 & 57.7 & 6.7 \\
\hline & a2 & 0.910 & 1.0 & 0.117 & 1.9 & 49.7 & 0.157 & 2.4 & 66.6 & 1.34 & 2.005 & 3.6 & 851.0 & 65.4 & 51 & 0.69 & 44.0 & 64.1 & 6.4 \\
\hline & a3 & 0.384 & 1.1 & 0.055 & 2.1 & 56.1 & 0.073 & 2.4 & 74.2 & 1.32 & 0.961 & 3.4 & 974.9 & 73.6 & 40 & 0.60 & 39.4 & 65.7 & 8.3 \\
\hline
\end{tabular}




\begin{tabular}{|c|c|c|c|c|c|c|c|c|c|c|c|c|c|c|c|c|c|c|c|}
\hline & a1 & 0.059 & 2.3 & 0.009 & 8.5 & 25.4 & 0.013 & 3.0 & 36.4 & 1.43 & 0.200 & 5.2 & 571.4 & 34.0 & 36 & 0.55 & 35.8 & 64.7 & 11.6 \\
\hline \multirow[t]{3}{*}{ MTF-01B } & a2 & 0.317 & 1.2 & 0.051 & 2.1 & 34.9 & 0.033 & 2.5 & 22.8 & 0.65 & 0.681 & 4.3 & 468.0 & 40.3 & 61 & 0.74 & 40.7 & 55.1 & 4.9 \\
\hline & a3 & 0.111 & 1.8 & 0.019 & 3.6 & 46.7 & 0.006 & 2.6 & 15.4 & 0.33 & 0.470 & 3.4 & 1151.9 & 50.3 & 43 & 0.63 & 37.5 & 59.1 & 7.6 \\
\hline & a1 & 1.848 & 0.9 & 0.208 & 1.8 & 116.3 & 0.097 & 2.4 & 54.1 & 0.47 & 0.522 & 4.3 & 291.5 & 129.0 & 52 & 0.70 & 64.7 & 92.7 & 9.0 \\
\hline \multirow[t]{2}{*}{ VSM-30 } & a2 & 0.303 & 1.3 & 0.042 & 2.2 & 93.4 & 0.016 & 2.9 & 35.0 & 0.38 & 0.198 & 4.3 & 437.9 & 101.6 & 42 & 0.63 & 52.4 & 83.0 & 9.9 \\
\hline & a3 & 1.327 & 0.9 & 0.150 & 1.8 & 115.9 & 0.070 & 2.4 & 54.4 & 0.47 & 0.459 & 4.0 & 354.9 & 128.7 & 54 & 0.71 & 64.2 & 90.1 & 8.4 \\
\hline
\end{tabular}

Observations:

- Isotope concentration errors are $1 \sigma$, and $\mathrm{He}$ age errors are $2 \sigma$

- FT refers to $\alpha$-ejection correction (e.g. Farley et al. 1996)

- Ages written in italic are considered unrealistic and were discarded:

${ }^{1}$ Sample discarded: AHe age implies an unrealistic cooling

${ }^{2}$ Crystal discarded: AHe age is older than the main metamorphic event in the DFB

${ }^{3}$ Crystal discarded: Isotope concentrations or AHe age are too imprecise

${ }^{4}$ Crystal discarded - AHe age is older than ZHe age in the same sample 


\section{APPENDIX F-Radiation damage analyses}

v3 (SiO4) Raman band (mean value)

\begin{tabular}{|c|c|c|c|c|c|c|c|c|c|c|}
\hline \multirow{3}{*}{ Aliquot } & \multicolumn{3}{|c|}{$\begin{array}{c}\text { v3 (SiO4) Raman band } \\
\text { (mean value) }\end{array}$} & \multicolumn{6}{|c|}{ Calculated damage density } & \multirow{3}{*}{$\begin{array}{c}\begin{array}{c}\text { Radiation } \\
\text { Damage } \\
\text { age }\end{array} \\
\text { (Ma) }\end{array}$} \\
\hline & \multirow{2}{*}{$\begin{array}{c}\text { Area } \\
\left(\mathrm{cm}^{-1}\right)^{2}\end{array}$} & \multirow{2}{*}{$\begin{array}{l}\text { FWHM } \\
\left(\mathrm{cm}^{-1}\right)\end{array}$} & \multirow{2}{*}{$\begin{array}{l}\text { Center } \\
\left(\mathrm{cm}^{-1}\right)\end{array}$} & \multicolumn{6}{|c|}{ Da (decays/g) } & \\
\hline & & & & $600 \mathrm{Ma}$ & $500 \mathrm{Ma}$ & $400 \mathrm{Ma}$ & $300 \mathrm{Ma}$ & $200 \mathrm{Ma}$ & $100 \mathrm{Ma}$ & \\
\hline BR-66-15 z2 & 2284.6 & 9.0 & 1003.8 & $1.09 \mathrm{E}+18$ & $9.00 \mathrm{E}+17$ & $7.13 \mathrm{E}+17$ & $5.30 \mathrm{E}+17$ & $3.50 \mathrm{E}+17$ & $1.73 \mathrm{E}+17$ & 299.5 \\
\hline BR-66-15 z4 & 2580.9 & 9.2 & 1000.8 & $1.27 \mathrm{E}+18$ & $1.04 \mathrm{E}+18$ & $8.28 \mathrm{E}+17$ & $6.15 \mathrm{E}+17$ & $4.06 \mathrm{E}+17$ & $2.01 \mathrm{E}+17$ & 265.5 \\
\hline BR-66-15 z5 & 2429.4 & 7.8 & 1002.8 & $1.33 \mathrm{E}+18$ & $1.10 \mathrm{E}+18$ & $8.73 E+17$ & $6.48 \mathrm{E}+17$ & $4.28 \mathrm{E}+17$ & $2.12 \mathrm{E}+17$ & 210.2 \\
\hline BR-67-15 z3 & 1576.0 & 4.1 & 1005.8 & $2.03 \mathrm{E}+17$ & $1.68 \mathrm{E}+17$ & $1.33 \mathrm{E}+17$ & $9.89 \mathrm{E}+16$ & $6.54 \mathrm{E}+16$ & $3.24 \mathrm{E}+16$ & 655.6 \\
\hline BR-67-15 z4 & 1831.2 & 5.9 & 1004.8 & $4.73 \mathrm{E}+17$ & $3.91 \mathrm{E}+17$ & $3.10 \mathrm{E}+17$ & $2.30 \mathrm{E}+17$ & $1.52 \mathrm{E}+17$ & $7.55 \mathrm{E}+16$ & 425.5 \\
\hline BR-67-15 z5 & 2267.4 & 7.6 & 1005.3 & $2.65 E+17$ & $2.19 \mathrm{E}+17$ & $1.74 \mathrm{E}+17$ & $1.29 \mathrm{E}+17$ & $8.52 E+16$ & $4.22 \mathrm{E}+16$ & 957.1 \\
\hline BR-69-15 z2 & 2020.3 & 6.1 & 1003.8 & $1.33 \mathrm{E}+18$ & $1.09 \mathrm{E}+18$ & $8.67 \mathrm{E}+17$ & $6.44 \mathrm{E}+17$ & $4.26 \mathrm{E}+17$ & $2.11 \mathrm{E}+17$ & 161.8 \\
\hline BR-69-15 z3 & 2365.6 & 7.4 & 1001.8 & $1.52 \mathrm{E}+18$ & $1.25 \mathrm{E}+18$ & $9.92 \mathrm{E}+17$ & $7.37 \mathrm{E}+17$ & $4.86 \mathrm{E}+17$ & $2.41 \mathrm{E}+17$ & 175.0 \\
\hline BR-69-15 z4 & 2979.2 & 12.3 & 1001.3 & $1.02 \mathrm{E}+18$ & $8.45 \mathrm{E}+17$ & $6.70 \mathrm{E}+17$ & $4.98 \mathrm{E}+17$ & $3.29 \mathrm{E}+17$ & $1.63 E+17$ & 456.4 \\
\hline BR-70-15 z1 & 6342.6 & 8.6 & 1003.8 & $6.50 \mathrm{E}+17$ & $5.36 \mathrm{E}+17$ & $4.25 E+17$ & $3.16 \mathrm{E}+17$ & $2.09 \mathrm{E}+17$ & $1.03 E+17$ & 468.8 \\
\hline BR-70-15 z2 & 4896.7 & 6.0 & 1003.2 & $5.35 \mathrm{E}+17$ & $4.41 \mathrm{E}+17$ & $3.50 \mathrm{E}+17$ & $2.60 E+17$ & $1.72 \mathrm{E}+17$ & $8.51 E+16$ & 382.3 \\
\hline BR-70-15 z3 & 5847.0 & 5.1 & 1003.3 & $4.59 \mathrm{E}+17$ & $3.79 \mathrm{E}+17$ & $3.00 \mathrm{E}+17$ & $2.23 E+17$ & $1.47 \mathrm{E}+17$ & $7.31 \mathrm{E}+16$ & 371.8 \\
\hline BR-75-15 z1 & 5077.1 & 3.8 & 1004.6 & $2.85 E+17$ & $2.35 E+17$ & $1.86 \mathrm{E}+17$ & $1.39 \mathrm{E}+17$ & $9.16 \mathrm{E}+16$ & $4.54 \mathrm{E}+16$ & 435.3 \\
\hline BR-75-15 z2 & 4068.1 & 7.0 & 1003.1 & $6.20 \mathrm{E}+17$ & $5.12 \mathrm{E}+17$ & $4.06 \mathrm{E}+17$ & $3.02 E+17$ & $1.99 \mathrm{E}+17$ & $9.88 \mathrm{E}+16$ & 391.1 \\
\hline BR-75-15 z5 & 4212.6 & 2.3 & 1005.7 & $2.58 \mathrm{E}+17$ & $2.13 \mathrm{E}+17$ & $1.69 \mathrm{E}+17$ & $1.26 \mathrm{E}+17$ & $8.30 \mathrm{E}+16$ & $4.11 \mathrm{E}+16$ & 286.6 \\
\hline BR-76-15 z1 & 6530.5 & 6.1 & 1003.5 & $5.28 \mathrm{E}+17$ & $4.36 \mathrm{E}+17$ & $3.46 \mathrm{E}+17$ & $2.57 E+17$ & $1.70 \mathrm{E}+17$ & $8.41 E+16$ & 396.4 \\
\hline BR-76-15 z3 & 5169.5 & 3.8 & 1004.6 & $5.45 \mathrm{E}+17$ & $4.49 \mathrm{E}+17$ & $3.56 \mathrm{E}+17$ & $2.65 \mathrm{E}+17$ & $1.75 \mathrm{E}+17$ & $8.66 \mathrm{E}+16$ & 231.6 \\
\hline BR-76-15 z5 & & 4.6 & & $3.18 \mathrm{E}+17$ & $2.62 \mathrm{E}+17$ & $2.08 \mathrm{E}+17$ & $1.54 \mathrm{E}+17$ & $1.02 \mathrm{E}+17$ & $.05 \mathrm{E}+16$ & 85.0 \\
\hline BR-86-15 z1 & 2284.6 & 7.6 & 1001.8 & $1.36 \mathrm{E}+18$ & $1.12 \mathrm{E}+18$ & $8.90 E+17$ & $6.62 E+17$ & $4.37 \mathrm{E}+17$ & $2.17 E+17$ & 200.0 \\
\hline BR-86-15 z3 & 2754.1 & 9.2 & 1002.3 & $1.26 \mathrm{E}+18$ & $1.04 \mathrm{E}+18$ & $8.23 \mathrm{E}+17$ & $6.12 E+17$ & $4.04 \mathrm{E}+17$ & $2.00 \mathrm{E}+17$ & 267.5 \\
\hline BR-86-15 z5 & 2079.8 & 12.1 & 1000.8 & $4.69 \mathrm{E}+18$ & $3.87 \mathrm{E}+18$ & $3.07 \mathrm{E}+18$ & $2.28 \mathrm{E}+18$ & $1.50 \mathrm{E}+18$ & $7.45 \mathrm{E}+17$ & 101.6 \\
\hline BR-87-15 z1 & 2018.1 & 6.2 & 1003.3 & $6.61 \mathrm{E}+17$ & $5.46 \mathrm{E}+17$ & $4.33 \mathrm{E}+17$ & $3.22 E+17$ & $2.13 \mathrm{E}+17$ & $1.06 \mathrm{E}+17$ & 323.2 \\
\hline BR-87-15 z4 & 3142.0 & 11.0 & 1001.3 & $1.01 \mathrm{E}+18$ & $8.34 \mathrm{E}+17$ & $6.61 \mathrm{E}+17$ & $4.91 \mathrm{E}+17$ & $3.25 E+17$ & $1.61 \mathrm{E}+17$ & 405.4 \\
\hline BR-87-15 z5 & 2099.4 & 6.5 & 1002.3 & $8.56 \mathrm{E}+17$ & $7.07 \mathrm{E}+17$ & $5.60 \mathrm{E}+17$ & $4.16 \mathrm{E}+17$ & $2.75 \mathrm{E}+17$ & $1.36 \mathrm{E}+17$ & 265.3 \\
\hline BR-88-15 z1 & 3694.1 & 21.7 & 991.1 & $1.01 \mathrm{E}+19$ & $8.37 E+18$ & $6.63 \mathrm{E}+18$ & $4.93 E+18$ & $3.26 \mathrm{E}+18$ & $1.62 \mathrm{E}+18$ & 106.0 \\
\hline BR-88-15 z3 & 1862.8 & 19.8 & 993.7 & $1.05 E+19$ & $8.71 \mathrm{E}+18$ & $6.90 \mathrm{E}+18$ & $5.13 E+18$ & $3.39 \mathrm{E}+18$ & $1.68 \mathrm{E}+18$ & 88.2 \\
\hline BR-88-15 z4 & 4202.6 & 20.5 & 994.2 & $8.79 \mathrm{E}+18$ & $7.26 \mathrm{E}+18$ & $5.76 \mathrm{E}+18$ & $4.29 \mathrm{E}+18$ & $2.83 \mathrm{E}+18$ & $1.41 \mathrm{E}+18$ & 110.7 \\
\hline BR-90-15 z2 & 2636.7 & 8.8 & 1003.3 & $1.22 \mathrm{E}+18$ & $1.01 \mathrm{E}+18$ & $7.98 \mathrm{E}+17$ & $5.93 \mathrm{E}+17$ & $3.92 \mathrm{E}+17$ & $1.94 \mathrm{E}+17$ & 260.7 \\
\hline BR-90-15 z4 & 1737.3 & 8.5 & 1001.3 & $8.43 E+17$ & $6.96 \mathrm{E}+17$ & $5.52 \mathrm{E}+17$ & $4.10 E+17$ & $2.71 \mathrm{E}+17$ & $1.34 \mathrm{E}+17$ & 361.5 \\
\hline BR-90-15 z5 & 2531.0 & 8.3 & 1002.3 & $8.43 \mathrm{E}+17$ & $6.96 \mathrm{E}+17$ & $5.51 \mathrm{E}+17$ & $4.10 \mathrm{E}+17$ & $2.71 \mathrm{E}+17$ & $1.34 \mathrm{E}+17$ & 351.6 \\
\hline BR-91-15 z1 & 1365.3 & 7.8 & 1003.1 & $4.64 \mathrm{E}+18$ & $3.83 \mathrm{E}+18$ & $3.03 \mathrm{E}+18$ & $2.25 \mathrm{E}+18$ & $1.49 \mathrm{E}+18$ & $7.38 \mathrm{E}+17$ & 60.8 \\
\hline BR-91-15 z3 & 1441.8 & 8.5 & 1001.3 & $2.46 \mathrm{E}+18$ & $2.03 E+18$ & $1.61 \mathrm{E}+18$ & $1.19 \mathrm{E}+18$ & $7.89 \mathrm{E}+17$ & $3.91 \mathrm{E}+17$ & 126.1 \\
\hline BR-91-15 z5 & 1590.1 & 9.2 & 1000.4 & $3.97 \mathrm{E}+18$ & $3.27 \mathrm{E}+18$ & $2.60 \mathrm{E}+18$ & $1.93 \mathrm{E}+18$ & $1.27 \mathrm{E}+18$ & $6.32 \mathrm{E}+17$ & 86.5 \\
\hline BR-93-15 z2 & 1222.7 & 6.9 & 1004.0 & $4.86 \mathrm{E}+17$ & $4.01 \mathrm{E}+17$ & $3.18 \mathrm{E}+17$ & $2.36 \mathrm{E}+17$ & $1.56 \mathrm{E}+17$ & $7.74 \mathrm{E}+16$ & 491.3 \\
\hline BR-93-15 z3 & 1304.3 & 8.3 & 1004.8 & $3.01 \mathrm{E}+17$ & $2.48 \mathrm{E}+17$ & $1.97 \mathrm{E}+17$ & $1.46 \mathrm{E}+17$ & $9.67 \mathrm{E}+16$ & $4.79 \mathrm{E}+16$ & 928.2 \\
\hline BR-93-15 z5 & 960.3 & 5.5 & 1004.8 & $2.71 \mathrm{E}+17$ & $2.24 \mathrm{E}+17$ & $1.77 \mathrm{E}+17$ & $1.32 \mathrm{E}+17$ & $8.71 \mathrm{E}+16$ & $4.32 \mathrm{E}+16$ & 666.1 \\
\hline BR-94-15 z1 & 1238.0 & 7.3 & 1004.0 & $4.93 \mathrm{E}+17$ & $4.07 \mathrm{E}+17$ & $3.23 E+17$ & $2.40 E+17$ & $1.59 \mathrm{E}+17$ & $7.86 \mathrm{E}+16$ & 508.3 \\
\hline BR-94-15 z2 & 1348.0 & 8.8 & 1005.7 & $3.67 E+17$ & $3.03 E+17$ & $2.40 E+17$ & $1.78 \mathrm{E}+17$ & $1.18 \mathrm{E}+17$ & $5.84 \mathrm{E}+16$ & 823.4 \\
\hline
\end{tabular}

Calculated damage density

Radiation

Damage

age

10.2

25.5

557.1

175.0

40.4

82.3

1.8

28.1

6.6 


\begin{tabular}{lcccccccccc}
\hline BR-94-15 z3 & 1241.9 & 7.7 & 1004.0 & $6.75 \mathrm{E}+17$ & $5.57 \mathrm{E}+17$ & $4.41 \mathrm{E}+17$ & $3.28 \mathrm{E}+17$ & $2.17 \mathrm{E}+17$ & $1.07 \mathrm{E}+17$ & 398.8 \\
\hline DSZ-24A z1 & 1603.8 & 9.2 & 1002.2 & $9.80 \mathrm{E}+17$ & $8.09 \mathrm{E}+17$ & $6.41 \mathrm{E}+17$ & $4.76 \mathrm{E}+17$ & $3.15 \mathrm{E}+17$ & $1.56 \mathrm{E}+17$ & 340.5 \\
\hline DSZ-24A z2 & 1759.2 & 10.5 & 1001.3 & $1.32 \mathrm{E}+18$ & $1.09 \mathrm{E}+18$ & $8.64 \mathrm{E}+17$ & $6.42 \mathrm{E}+17$ & $4.24 \mathrm{E}+17$ & $2.10 \mathrm{E}+17$ & 295.6 \\
\hline DSZ-24A z4 & 1371.7 & 8.0 & 1003.1 & $5.92 \mathrm{E}+17$ & $4.89 \mathrm{E}+17$ & $3.87 \mathrm{E}+17$ & $2.88 \mathrm{E}+17$ & $1.90 \mathrm{E}+17$ & $9.43 \mathrm{E}+16$ & 477.5 \\
\hline MTF-01B z1 & 1175.3 & 8.0 & 999.6 & $1.64 \mathrm{E}+18$ & $1.36 \mathrm{E}+18$ & $1.07 \mathrm{E}+18$ & $7.98 \mathrm{E}+17$ & $5.27 \mathrm{E}+17$ & $2.61 \mathrm{E}+17$ & 175.8 \\
\hline MTF-01B z2 & 1673.1 & 10.9 & 1000.4 & $1.24 \mathrm{E}+18$ & $1.02 \mathrm{E}+18$ & $8.11 \mathrm{E}+17$ & $6.02 \mathrm{E}+17$ & $3.98 \mathrm{E}+17$ & $1.97 \mathrm{E}+17$ & 329.4 \\
\hline MTF-01B z3 & 1602.2 & 10.7 & 1001.3 & $8.02 \mathrm{E}+17$ & $6.62 \mathrm{E}+17$ & $5.25 \mathrm{E}+17$ & $3.90 \mathrm{E}+17$ & $2.57 \mathrm{E}+17$ & $1.27 \mathrm{E}+17$ & 491.2
\end{tabular}

